\title{
A FUNCIONALIZAÇÃO DO CONTRATO DE FIANÇA: PROPOSTA DE REVALORIZAÇÃO DO INSTITUTO
}

Dissertação de Mestrado apresentada à Banca Examinadora da Faculdade de Direito da Universidade de São Paulo, como exigência parcial para a obtenção do título de Mestre em Direito, sob orientação do Prof. Titular Álvaro Villaça Azevedo

FACULDADE DE DIREITO DA USP

SÃO PAULO

2010 
Banca Examinadora 


\section{Agradecimentos}

A Deus e Cristo Jesus, sem os quais nada poderia fazer.

Ao meu orientador, Professor Doutor Álvaro Villaça Azevedo, pelo apoio inestimável desde o meu ingresso no mestrado e pela segura orientação.

Ao Professor Doutor José Luiz Gavião de Almeida, pela condução das aulas de mestrado e pelas críticas sempre construtivas.

Ao Professor Doutor Luiz Antônio de Souza, amigo inestimável e Professor exemplar, com quem iniciei a minha carreira acadêmica.

Ao Professor Doutor Vitor Frederico Kümpel, pelo estímulo ao estudo do direito civil e pelas discussões jurídicas travadas. 


\section{Dedicatória}

Dedico esta dissertação à memória de minha avó, Augusta Maria Ziviani Schirrmeister, a quem agradeço o estímulo inicial para cursar Direito.

Dedico também à minha mãe, Neyde Schirrmeister Segalla, pelo apoio constante e seguro ao longo de minha vida, sem o qual nada seria possível.

Dedico por fim aos três protagonistas da minha vida:

Simone, minha esposa amada, alicerce da nossa família e fonte de contínua inspiração, apoio e estímulo nos momentos de maior dificuldade;

David e Daniel, filhos amados e abençoados, que iluminam a minha vida e guiam o meu pensamento em todos os instantes. 


\section{RESUMO}

O presente trabalho analisa o contrato de fiança no Código Civil brasileiro, bem como a sua utilização na locação de imóveis urbanos. No campo das garantias contratuais a fiança representa a modalidade mais utilizada no Brasil, notadamente pelas facilidades práticas em sua constituição, bem como pelo caráter gratuito da sua prestação. No entanto, ao longo dos anos o contrato de fiança, tal como fora moldado pelo legislador, vem sendo desafiado pelos tribunais que ora suavizam as suas regras em benefício do fiador ora fortalecem a posição do credor, gerando profunda insegurança social e instabilidade jurídica. Por esta razão, neste trabalho procuramos discutir se as regras atuais relativas à fiança são adequadas à sociedade brasileira ou se estão a merecer uma profunda reforma para torná-las efetivas, funcionalizando-as de acordo com a finalidade a que se destinam: um reforço ao adimplemento em favor do credor; assim, defendemos que a confiança gerada pela promessa manifestada pelo fiador de que irá efetivamente garantir o adimplemento de um contrato deverá ser efetiva, por ser um instrumento a serviço do credor, visando pô-lo a salvo de riscos. Neste trabalho foram comparados os momentos históricos em que surgiram o Código Civil de 1916 e o de 2002, e apresentadas as origens históricas da fiança. Posteriormente, a dogmática do instituto foi apresentada com a sua análise nos planos da existência, validade e eficácia, bem como foram apresentadas as questões controvertidas envolvendo o contrato, com a apresentação de soluções que foram refletidas e julgadas adequadas, inclusive no campo da fiança à locação, posto que o instituto é de larga utilização no mercado imobiliário, tendo ainda sido analisada a Lei n. ${ }^{\circ}$ 12.112/09 que reformou a Lei do Inquilinato. Por fim, foram apresentadas propostas de alteração do perfil dogmático do contrato de fiança, na esperança de torná-lo uma segura garantia contratual da qual poderá o credor se valer como um adequado reforço ao efetivo adimplemento aguardado e que seja dotado de efetiva força vinculante.

Palavras-chave: Garantia - Fiança - Fiador - Credor - Devedor Principal - Confiança Promessa - Boa-fé - Reforço - Adimplemento - Contrato - Código Civil brasileiro - Locação - Locador - Locatário. 


\section{ABSTRACT}

This paper analyzes the contract of suretyship in the Brazilian Civil Code, and its use in the leasing of urban property. In the field of contractual guarantees suretyship is the most widely used in Brazil, especially because of the practical facilities in its constitution and by its characteristics of gratuitous guarantee of one's performance. However, over the years suretyship as it had been molded by the legislator is being challenged by the courts that sometimes soften its rules in favor of the guarantor and sometimes strengthen the position of the creditor, creating deep legal insecurity and social instability. Therefore, this paper aims to discuss whether the current rules relating to the suretyship are adequate for the Brazilian society or if they need a radical reformation to make them effective, functionalizing them according to the purpose for which they are intended: a reinforcement to the performance in favor of the creditor, so we sustain that the confidence engendered by the promise shown by the guarantor that will effectively ensure the fulfillment of a contract shall be effective as an instrument in the service of the creditor in order to keep him safe from risks. In this study we compared the historical moments that emerged in the Civil Code of 1916 and 2002, and presented the historical origins of suretyship. Subsequently, the dogmatic of the institute was presented with its analysis in the field of existence, validity and effectiveness, and controversial issues involving the contract were presented with solutions that have been thought and deemed appropriate, including in the field of suretyship of a lease, once the institute is widely used in the real estate market. We have also analyzed the Law n. 12.112/09 that reformed the Landlord and Tenant Act. Finally, proposals were made to change the dogmatic profile of suretyship, hoping to make it a secure guarantee of the contracts which the creditor may avail as a suitable reinforcement of the expected performance and to be endowed with effective binding force.

Keywords: Guarantee - Suretyship - Guarantor - Creditor - Debtor - Reliability - Promise Good Faith - Reinforcement - Performance - Contract - Brazilian Civil Code Lease - Landlord - Tenant. 


\section{SUMÁRIO}

1. INTRODUÇÃO

2. CONTEXTUALIZAÇÃO DO DIREITO BRASILEIRO

4. O CONTRATO DE FIANÇA

4.1. Introdução

4.2. A importância da distinção entre Schuld (Obrigação, Débito) e Haftung (Responsabilidade) na fiança .36

4.3. Existência, Validade e Eficácia 39

4.4. $\mathrm{O}$ conceito de fiança 44

4.4.1. Elementos do contrato de fiança 48

4.4.2. As figuras da abonação (subfiança), retrofiança e cofiança..... 56

4.4.3. A distinção entre a fiança e o aval. 59

4.4.3.1. A fiança prestada por pessoa jurídica. 61

4.4.3.1.1. Conceito de pessoa jurídica e a técnica da personificação 61

4.4.3.1.2. Estrutura: orgãos 63

4.4.3.1.3. A manifestação da vontade das pessoas jurídicas: representação ou presentação? .64

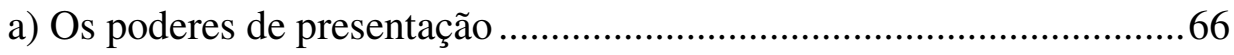

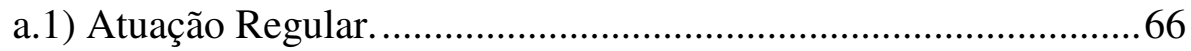

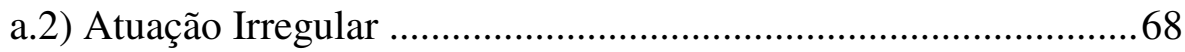

a.2.1) Atuação em desacordo com a legitimidade atribuída aos administradores no contrato social (excesso de poderes).

a.2.2) Atuação em desacordo com o contrato social, porém do conhecimento de terceiro(s) (simulação?) 
a.2.3) Utilização Indevida do Nome Empresarial (Firma) em Operações Estranhas ao Objeto Social: Teoria 'Ultra Vires'

4.5. Promessa e Contrato Preliminar de Fiança ....................................................................... 74

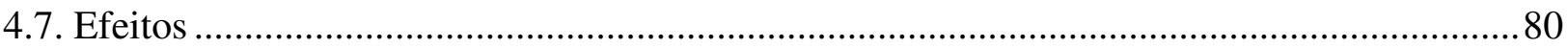

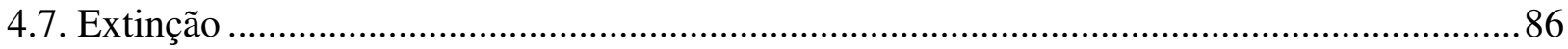

4.7.1. Diferenças entre Desobrigação e Exoneração ............................................................ 87

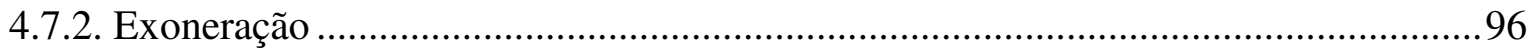

4.7.2.1. É válida a cláusula de renúncia ao direito de exoneração? .......................... 102

4.8. Os princípios da boa-fé objetiva e da função social aplicados ao contrato de fiança...........114

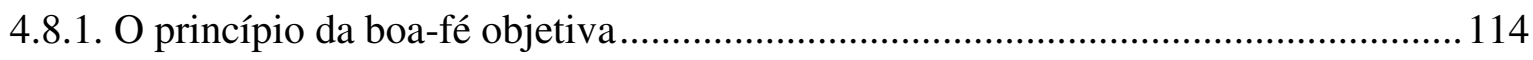

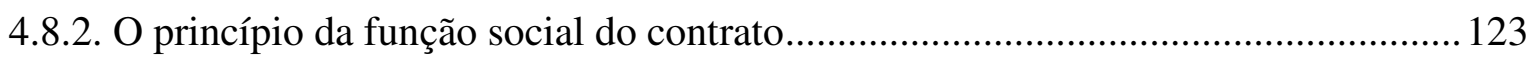

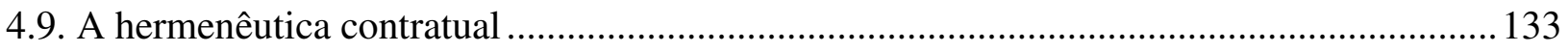

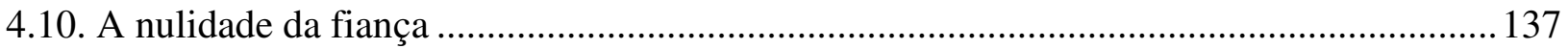

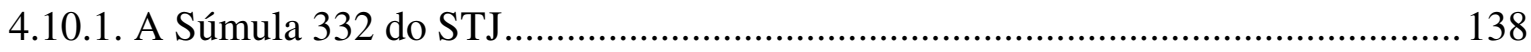

4.10.2. Análise dos artigos 1.647, III e 1.649, do Código Civil ...................................... 149

4.10.3. É possível a conversão da fiança em garantia atípica? Análise do art. 170 do

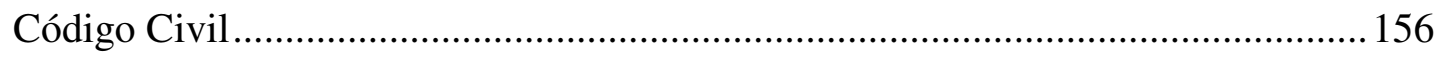

4.11. O contrato de fiança na sociedade massificada e os contratos de consumo ....................... 163

5. O CONTRATO DE FIANÇA À LOCAÇÃO............................................................. 176

5.1. A dinâmica contratual nas relações locatícias e a Lei $\mathrm{n}^{\circ} 8.245 / 91$....................................... 176

5.2. A posição do fiador em face da relação locatícia: a Súmula 268 do STJ ............................ 177

5.2.1 A majoração de aluguéis sem a participação do fiador: princípio da redução ......... 180

5.3. A possibilidade de exoneração ou desobrigação do fiador criada pela jurisprudência: a fiança prestada em favor de pessoas jurídicas

5.4. A (im)penhorabilidade do chamado bem de família na execução do contrato de fiança.

A Polêmica em Torno do Art. $6^{\circ}$, da Constituição Federal (c/ a Redação da EC n 26 ,

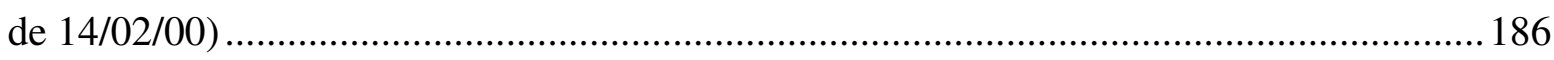

5.5. A sub-rogação da posição jurídica do fiador em face do afiançado ...................................205

5.6. Análise da Súmula ${ }^{\circ} 214$ do Superior Tribunal de Justiça ..............................................207

5.6.1. A Nova Exegese da Súmula n ${ }^{\circ} 214$ do Superior Tribunal de Justiça: Violação à

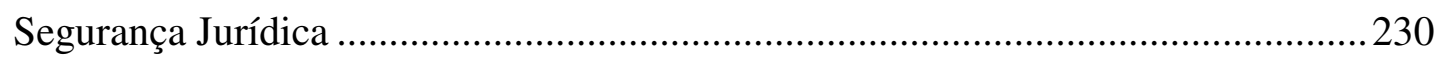

5.7. A possibilidade de utilização da ação de despejo pelo fiador do contrato de locação ........243 
5.8. É admissível que o devedor principal também figure como fiador do contrato?

6. A REFORMA DA LEI DO INQUILINATO: LEI N..$^{\circ} 12.112$, DE 9 DE DEZEMBRO DE 2009

7. PROPOSTA DE ALTERAÇÃO LEGISLATATIVA DO INSTITUTO DA FIANÇA 


\section{INTRODUÇÃO}

No Brasil, as reformas legislativas são realizadas para que tudo fique como está. Estas palavras, que foram atribuídas por Claudia Lima Marques ao insigne Pontes de Miranda, refletem, de certo modo, o trato da dogmática que foi dado ao contrato de fiança pelo legislador do Código Civil de 2002.

Com efeito, muito se falou da novel codificação antes da sua entrada em vigor. Eticidade, Socialidade e Operabilidade seriam as suas diretrizes ou princípios orientadores, o que demonstraria a preocupação do legislador em aproximar a codificação com as realidades social, econômica e cultural brasileiras.

A abstração da codificação de 1916 daria lugar ao realismo da codificação de 2002. A figura do "bom pai de família", modelo do qual se valeram as codificações oitocentistas inspiradas em um contexto de Racionalismo Jurídico, dariam lugar à figura do "homem comum", e nós dizemos, do "brasileiro comum", a do brasileiro que sofre com as agruras do dia-a-dia e que sente na prática a complexidade das leis e a lentidão do Poder Judiciário. Figura esta fruto de um período pós-moderno, de uma modernidade líquida ${ }^{2}$, que se apresenta fluída, a exigir das pessoas que contratam uma maior atenção aos vínculos que estabelecerem porque na atualidade o romântico período da reflexão, da ponderação sobre as vantagens ou desvantagens de contratar ou não, vincular-se ou não, somente existem nos livros, situações estas que não passaram despercebidas pelo espírito prático dos anglo-saxões: "law-in-the-books or law-in-action"? O mais importante é direito dos livros, dos tratados e dos textos legais ou o direito na prática, na vida das pessoas que submetem os seus conflitos, incertezas e angústias aos tribunais?

Não obstante, a normatização do contrato de fiança no Código Civil de 2002 praticamente em nada alterou o panorama legal até então em vigor, à exceção de certas mudanças pontuais nas redações dos antigos dispositivos; no mais, a novel codificação manteve intacta a estrutura dogmática do instituto da fiança, quando na verdade várias

\footnotetext{
${ }^{1}$ Segundo REALE, Miguel: "É a razão pela qual costumo declarar que o Código Civil é "a constituição do homem comum", devendo cuidar de preferência das normas gerais consagradas ao longo do tempo, ou então, de regras novas dotadas de plausível certeza e segurança, não podendo dar guarida, incontinenti, a todas as inovações ocorrentes." (In REALE, Miguel. Visão geral do projeto de Código Civil. Disponível em: <http://www.miguelreale.com.br/artigos>. Acesso em: $03 \mathrm{dez} 2008$ ) (Grifamos).

${ }^{2}$ BAUMAN, Zygmunt. Modernidade líquida. Rio de Janeiro: Zahar, 2000.
} 
alterações poderiam e deveriam ter sido feitas em um instituto tão sensível e de aplicação prática difusamente difundida entre os brasileiros.

Somente para que tenhamos uma idéia do grau de litigiosidade que o contrato de fiança apresenta nos tribunais, basta apontarmos que o Superior Tribunal de Justiça já editou até o momento 3 (três) Súmulas de Jurisprudência: $214^{3}, 268^{4}$ e $332^{5}$, cada qual abordando um aspecto específico do contrato de fiança, razão por que todas elas serão objeto de análise no decorrer do presente trabalho. Não obstante, em especial as redações das Súmulas 214 e 332 são aptas a causar confusões que colaboram para aprofundar controvérsias, antes de aclará-las.

Até mesmo o Supremo Tribunal Federal, em recente julgamento realizado pelo seu Pleno (RE 407688, Rel. Min. Cezar Peluso, Tribunal Pleno, julgado em 08/02/2006, DJ 06-10-2006), discutiu se o único imóvel de propriedade do fiador em um contrato de locação poderia ou não ser penhorado em demanda promovida pelo locador, o que também reforça a tese da ampla utilização da fiança na sociedade brasileira como garantia contratual, motivo pelo qual a estrutura legal do contrato deve ser repensada pelos operadores do direito, em especial o legislador, a fim de aparar arestas e dar solução aos problemas concretos que têm surgido e exigido a atenção dos tribunais, os quais, dada a avalanche inesgotável de demandas, quase nunca dispõem de tempo para ponderar e refletir que novas situações demandam novas soluções.

Nesse sentir, pesquisa ${ }^{6}$ do SECOVI-SP realizada no mês de outubro de 2008 no Estado de São Paulo revelou que:

"O fiador foi a modalidade mais utilizada nos contratos de locação efetuados no período pesquisado, correspondendo a 48,5\% do total dos imóveis analisados. O depósito (ou caução) respondeu por 33,5\% e o seguro-fiança foi usado em 18,5\% dos contratos locatícios. O IVL (Índice de Velocidade de Locação), que mede em quantos dias uma moradia vaga é alugada, permaneceu no mesmo patamar do mês passado, com tempo médio entre 11 e 30 dias. As casas escoaram mais rapidamente entre 10 e 27 dias, enquanto que o dos apartamentos a demora média ficou entre 17 e 36 dias."

\footnotetext{
3“O fiador na locação não responde por obrigações resultantes de aditamento ao qual não anuiu."

4“O fiador que não integrou a relação processual na ação de despejo não responde pela execução do julgado."

5، A fiança prestada sem autorização de um dos cônjuges implica a ineficácia total da garantia."

${ }^{6}$ PESQUISA mensal de locação. Disponível em:

<http://www.secovi.com.br/empty.php?local=/pesquisa/locacao/index.htm>. Acesso em: 30 nov. 2008.
} 
É por esta razão que no presente trabalho iremos defender uma profunda modificação da dogmática relativa ao contrato de fiança, a fim de tentarmos diminuir a sua litigiosidade através da elaboração de regras claras e de mais fácil operabilidade; para tanto, procuraremos identificar quais atualmente são os nós górdios do instituto e quais são os pontos que mais litígio geram, de maneira que o contrato de garantia fidejussória passe a ser dotado de ampla eficácia normativa e social, e não apenas uma "garantia de papel", nas expressivas palavras do Min. Cezar Peluso ${ }^{7}$.

No capítulo 2, abordaremos, ainda que de maneira singela, aspectos relativos à contextualização atual do direito brasileiro em um mundo em constante mutação, fazendo uma brevíssima análise do período em que vigeu o Código Civil de 1916 e aquele que se encontrava estabelecido quando da entrada em vigor do Código Civil de 2002.

No capítulo 3 apresentaremos as origens históricas do contrato de fiança.

No capítulo 4, parte central da dissertação, faremos um estudo sobre a dogmática da fiança no Código Civil de 1916 e aquela que passou a viger no Código Civil de 2002.

O capítulo 5 será dedicado a abordagem do contrato de fiança à locação de imóveis urbanos, no qual procuramos apresentar as principais dúvidas que rondam a garantia mais utilizada nessa modalidade de contrato.

O capítulo 6, a seu turno, foi dedicado a abordar as alterações promovidas pela Lei n. ${ }^{\circ} 12.112$, de 9 de dezembro de 2009, na Lei n. ${ }^{\circ} 8.245 / 91$, que modificou profundamente o regime legal da fiança locatícia e que ainda está em vacatio legis.

O último capítulo do trabalho (capítulo 7) será utilizado para que formulemos propostas de modificação do regramento legal do contrato de fiança, a fim de revalorizar o instituto para torná-lo uma garantia realmente efetiva, a fim de que sejam evitados os inúmeros entraves que passaram a tornam referido contrato uma fonte inesgotável de litígios e insegurança para credores, devedores e fiadores.

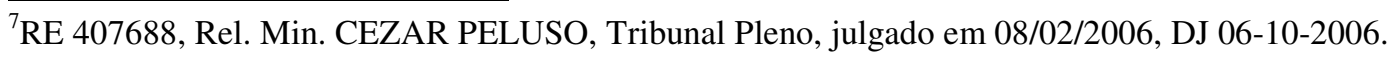




\section{CONTEXTUALIZAÇÃO DO DIREITO BRASILEIRO}

Constitui-se em verdadeiro truísmo a afirmação de que vivemos uma "época de transformações"; no entanto, referida expressão bem representa as características da sociedade brasileira, que tem sido marcada por uma crescente urbanização e por um vertiginoso desnivelamento sócio-econômico.

Em razão dessas simples constatações é que perguntamos se o modelo jurídico adotado pelo legislador do Código Civil de 2002 está a corresponder à nossa realidade sócio-econômica, apesar de estar vincado em nossas tradições, especialmente no campo dos contratos.

Será que no mundo de hoje ainda estaríamos a viver sob o signo da tão decantada autonomia da vontade? Será que as fórmulas legais genéricas e os modelos jurídicos abstratos adotados pelo Codificador de 1916 e mantidos pelo de 2002 correspondem efetivamente à necessidade de fixação de diretrizes e balizas de condutas dos sujeitos em uma sociedade em constante transformação e em permanente estado de perplexidade?

Em verdade, a perplexidade que nos abate foi traduzida há muitos anos por Orlando Gomes ${ }^{8}$ :

"No mundo instável, inseguro e volúvel de hoje, a resposta normativa não pode ser a transposição para um Código das fórmulas conceituais habilmente elaboradas no século passado, mas comprometidas com uma realidade muito distinta". (Grifamos)

A celeridade da vida não pode ser detida pelas muralhas de um direito codificado. Acontecimentos, ora na simplicidade da existência cotidiana, ora marcados pelos de maior gravidade, exigem novos comportamentos legislativos. Em conseqüência um edifício demoradamente construído, como é um Código, vê-se atingido por exigências freqüentes, necessitando de suprimentos legislativos ${ }^{9}$.

A sociedade brasileira subjacente à edição do Código Civil de 1916 era a mesma à época da apresentação do Projeto do Novo Código Civil (1970), que resultou na lei

\footnotetext{
${ }^{8}$ In GOMES, Orlando. Introdução ao direito civil. 10. ed. Rio de Janeiro: Forense, 1993. p. 71.

${ }^{9}$ PEREIRA, Caio Mário da Silva. Direito civil: alguns aspectos de sua evolução. Rio de Janeiro: Forense, 2001. p. 105.
} 
promulgada em 2002, a ponto de justificar a transposição pura e simples de vários dos seus dispositivos para a novel legislação? Com o devido respeito, é evidente que não!

É por esta razão que entendemos que o Código Civil de 2002 deverá ser adequadamente contextualizado no tempo e espaço relativos à sociedade brasileira do século XXI, a fim de não selarmos o divórcio entre a realidade socioeconômica brasileira e as regras civis, sob pena de contribuirmos ao incremento do já tão decantado déficit de efetividade que as normas jurídicas apresentam em nosso País ${ }^{10}$.

Ao contrário do que possa parecer, o nosso intuito não é o de criticar o Código Civil vigente - que reproduziu a maior parte das regras da lei revogada -, mas sim de apontar os caminhos que entendemos serem os mais coerentes com a realidade brasileira atual, de maneira a procurarmos diminuir, e até mesmo eliminar, a distância que separa as regras codificadas da vida das pessoas, em especial no contrato de fiança.

O Código é segurança, que se traduz em uma sequência ordenada de artigos. A imutabilidade é uma de suas características essenciais; não se pode alterar uma parte sem mudar o todo ${ }^{11}$. O Direito Civil codificado é auto-suficiente, não necessita de outros textos para solucionar o conflito. Pelo fato de conter uma parte geral ordenada, exporta instituições e técnicas $^{12}$. Finalmente, o Código é uma ordem racional que se propõe regular todas as épocas e latitudes ${ }^{13}$, razão pela qual Norberto Bobbio ${ }^{14}$ afirmou:

“A miragem da codificação é a completude: uma regra para cada caso. O código é para o juiz um prontuário que lhe deve servir infalivelmente e do qual não pode afastar-se. A cada grande codificação (desde a francesa de 1804 até a alemã de 1900) desenvolveu-se entre os juristas e os juízes a tendência de ater-se escrupulosamente aos códigos, atitude esta que foi chamada, com referência aos juristas franceses em relação aos códigos napoleônicos, mas que se poderia estender a cada nação com Direito codificado, de 'fetichismo da lei'. Na França, a escola jurídica que se foi impondo depois da codificação é geralmente designada com o nome de 'escola da exegese' (...) O caráter peculiar da escola da exegese é a admiração incondicional pela obra realizada pelo legislador através da codificação, uma confiança cega na suficiência das leis, a crença de que o código, uma vez promulgado, basta-se completamente a si próprio, isto é,

\footnotetext{
${ }^{10}$ Os constitucionalistas costumam apontar a distinção entre eficácia jurídica e eficácia social. Sobre o tema, aponta BULOS, Uadi Lammêgo que a eficácia normativa é a simples possibilidade de aplicação da norma constitucional, o que se dá sob o aspecto formal, enquanto eficácia social é a incidência concreta e real das normas sobre os acontecimentos da vida, razão por que norma dotada de efetividade seria aquela obedecida, seguida e aplicada, correspondendo aos fatores reais de poder que regem a sociedade. (In BULOS, Uadi Lammêgo. Curso de direito constitucional. 2. ed. São Paulo: Saraiva, 2008. p. 359-360).

${ }^{11}$ LORENZETTI, Ricardo Luis. Fundamentos de direito privado. Tradução de Vera Maria Jacob Fradera. São Paulo: Ed. Revista dos Tribunais, 1998. p. 42.

${ }^{12}$ Id. Ibid., p. 43.

${ }^{13}$ Id. Ibid., p. 45.

${ }^{14}$ BOBBIO, Norberto. Teoria do ordenamento jurídico. Brasília: UnB, 1997. p. 121.
} 
não tem lacunas: numa palavra, o dogma da completude jurídica." (Grifamos)

Ora, em uma sociedade estável, composta por pessoas adequadamente instruídas e politizadas, e que vivam de forma digna em sua plenitude (com pleno acesso à educação, à saúde, ao trabalho, à moradia, ao lazer, à segurança etc.), poder-se-ia admitir que o legislador traduzisse os comportamentos sociais em determinados modelos de condutas cujas reiterações traduzissem uma tendência social mais facilmente detectável e, por conseguinte, passível de previsão; a idéia que sempre dominou os legisladores no Estado Liberal foi a de que bastaria a positivação de regras de condutas para que estivesse garantida a sua eficácia normativa.

No entanto, José Eduardo Faria, em texto escrito antes da edição do Código Civil de 2002, já apontava que a eficácia do sistema normativo depende muito mais do que a sua simples positivação:

"a eficácia do direito depende bem menos da coerência lógico-formal de seus sistemas normativos e muito mais de um amplo universo simbólico sutilmente difundido em meio a valores culturais e sociais, onde imperaria o símbolo da "justiça", tornando-se secundária sem importância para uma eventual aplicação a casos concretos $e$ específicos ${ }^{15}$." (Grifamos)

Por conta disso, a nossa constatação é de que vivemos um momento de mudança, não só jurídica, legislativa, mas cultural e social. Os pensadores europeus estão a denominar este momento de rompimento (Umbruch), de fim de uma era e início de algo novo, ainda não identificado. É a crise da era moderna e de seus ideais concretizados na revolução francesa, que não se realizam para todos, nem são hoje considerados realmente realizáveis, onde desconfia-se de sua força e suficiência para servir de paradigma à organização das sociedades democráticas, isto atualmente em um capitalismo neoliberal bastante agressivo, com fortes efeitos de exclusão social ${ }^{16}$.

É neste contexto, pois, de quebra de paradigmas, de constantes mudanças sociais e de forte marginalização dos economicamente vulneráveis - fenômenos estes que não podem ou poderiam deixar de se relfetir no campo do Direito -, que procuraremos situar o

\footnotetext{
${ }^{15}$ FARIA, José Eduardo. Ideologia e função do modelo liberal de direito e Estado. Lua Nova, São Paulo, v. 4, n. 14, p. 82-92, abr./jun. 1988.

${ }^{16}$ MARQUES, Claudia Lima. Apresentação. In: LORENZETTI, Ricardo Luis. Fundamentos do direito privado. São Paulo: Ed. Revista dos Tribunais, 1998. p. 34.
} 
contrato de fiança, a fim de analisarmos se as regras relativas à garantia fidejussória estampadas no Codigo Civil de 2002 atendem ou não aos anseios da sociedade brasileira por justiça e segurança; justiça, pois aquele que se compromoteu a pagar determinada quantia a alguém, ou até mesmo prometeu pôr a salvo o credor das falhas do devedor, deve conhecer com exatidão a medida da sua responsabilidade, o exato valor devido e momento em que a sua responsabilidade iniciará e cessará; segurança, porque aquele que tem algo a receber deve ter a plena confiança de que o seu crédito será adimplido. Em uma sociedade em que grassa a insegurança, em que os processos judiciais são intermináveis e em que o fiador presta a garantia em um dia e no outro ingressa em juízo para extingui-la, não será possível que alcancemos um nível de respeito satisfatório aos princípios e objetivos fundamentais do sistema jurídico brasileiro: dignidade da pessoa humana $\left(\mathrm{CF}\right.$, art. $1^{\circ}$, III), valores sociais do trabalho e da livre iniciativa $\left(\mathrm{CF}\right.$, art. $1^{\circ}$, IV), solidariedade social $(\mathrm{CF}$, art. $\left.3^{\circ}, \mathrm{I}\right)$, garantia do desenvolvimento nacional $\left(\mathrm{CF}\right.$, art. $3^{\circ}$, II), erradicação da pobreza $\left(\mathrm{CF}\right.$, art. $\left.3^{\circ}, \mathrm{III}\right)$, promoção do bem estar de todos $\left(\mathrm{CF}\right.$, art. $\left.3^{\circ}, \mathrm{IV}\right)$ e segurança jurídica $\left(\mathrm{CF}\right.$, art. $1^{\circ}$, caput $)$.

Destarte, interessa à presente dissertação a análise da realidade brasileira, tão distante que se situa da de outros países, a fim de que possamos apreender o porquê de um simples contrato de garantia amplamente utilizado e difundido no Brasil ter atingido um ponto de total insegurança e inefetividade, que poderá representar o seu total declínio e desprestígio.

Em nossa análise, preferimos trilhar um caminho um pouco distinto daquele que vem sendo trilhado pela doutrina: procuramos analisar o contrato de fiança sob a ótica do credor, pois inúmeros têm sido os escritos que procuram proteger apenas o garante, considerando-o um vulnerável, relegando o credor a sua própria sorte. Por conta disso, concordamos com Flávio Tartuce ${ }^{17}$ quando afirma que "não se pode mais admitir o contrato como antes; isolado do mundo fático e jurídico, como uma bolha revestindo as partes envolvidas na avença." (Grifamos)

Assim, como o contrato não pode mais ser "isolado do mundo fático e jurídico, como uma bolha”, há que se entender a posição efetivamente ocupada pelas partes no contrato de fiança, a fim de que sejam prestigiadas as legítimas expectativas geradas a partir da contratação, de modo que a fiança volte a ocupar o papel que lhe foi reservado: o

\footnotetext{
${ }^{17}$ In TARTUCE, Flávio. Função social dos contratos: do Código do Consumidor ao Código Civil de 2002. 2. ed. São Paulo: Método, 2007. p. 186.
} 
de uma efetiva garantia, um instrumento seguro e confiável com o qual poderá contar o credor em caso de incumprimento das obrigações, porém outorgando ao fiador a exata consciência dos limites que a sua responsabilidade lhe acarretará, a fim de que tenha a exata e perfeita noção das reais consequências do risco fidejussório.

\subsection{Brasil: Do Código Civil de 1916 ao Código Civil de 2002}

Segundo Pontes de Miranda ${ }^{18}$, o Direito no Brasil, em especial o direito civil brasileiro "nasceu do galho de planta, que o colonizador português, - gente de rija têmpera, no ativo séc. XVI e naquele cansado século XVIII em que se completa o descobrimento da América, - trouxe e enxertou no novo continente."

Por sua vez, o direito português teve em suas origens o Direito Romano, o Germânico e o Canônico. Três sistemas diferentes, um, mais político do que moral e religioso, o romano; outro, mais moral do que político e religioso, o germânico; e outro, mais religioso do que político e moral, o canônico ${ }^{19}$. Por esta razão os portugueses, ao terem colonizado o Brazil, trouxeram para as bandas de cá o direito luso e, por extensão, o Direito Romano, o Germânico e o Canônico.

O direito romano primitivo só conhecera os contratos formais. Nestes, a prática das formalidades prescritas era denominada de causa civilis, a qual conferia força obrigatória ao ato. Os dois contratos formais eram o nexum e a stipulatio $^{20}$. Estes dois contratos formais do período primitivo passaram a não satisfazer às exigências do comércio romano depois das Guerras Púnicas, razão pela qual bem cedo o nexum caiu em desuso ${ }^{21}$. Somente os denominados contractus tinham à sua disposição uma actio reconhecida pelo direito quiritário para constranger o devedor a efetuar a prestação ${ }^{22}$. Ao lado do contractum o Direito Romano estruturou uma outra figura denominada pactum. Este, porém, não poderia ser defendido por uma actio que o dotasse de força cogente, uma vez que gerava tãosomente as exceptiones. Contrato e pacto eram espécies do gênero conventio. Os que os distinguia era a denominação que exteriorizava os contratos (comodato, mútuo, compra e

\footnotetext{
${ }^{18}$ In PONTES DE MIRANDA, Francisco Cavalcanti. Fontes e evolução do direito civil brasileiro. 2. ed. Rio de Janeiro: Forense, 1981. p. 27.

${ }^{19}$ In Id. Ibid., p. 28.

${ }^{20}$ Cfe. MARKY, Thomas. Curso elementar de direito romano. 8. ed. São Paulo: Saraiva, 1995. p. 119.

${ }^{21}$ Cfe. Id. Ibid., p. 120.

${ }^{22} \mathrm{Cfe}$. Id., loc. cit.
} 
venda), era a exteriorização material da forma (com exceção dos quatro consensuais: compra e venda, locação, mandato e sociedade), e era finalmente a sanção, a actio que os acompanhava; ao passo que os pacta não tinham nome especial, não revestiam forma predeterminada, e não permitiam à parte a invocação de uma ação. Todos, porém, genericamente batizados de conventiones ${ }^{23}$.

A noção romana de contractus pouco ou nada tem a ver com aquela fixada nos Códigos, hoje em crise: isto porque no Direito Romano o termo, com conotação objetiva, era utilizado para designar os acordos, reconhecidos como obrigatórios e providos de actio, discernindo-se de outros acordos, não obrigatórios e nomeados como pacta. Assim, o contractus - elipse de negotium contractus - era visualizado como um vínculo objetivo, mais propriamente servindo para designar as conseqüências do acordo, vale dizer, a vinculação obrigacional daí decorrente, e não como a manifestação de duas vontades opostas e convergentes ou a expressão da liberdade ou autodeterminação individual: nada mais distante, portanto, da concepção subjetiva ou voluntarista acolhida no primeiro código moderno, o Code Napoléon, ao qual subjazia o brocardo qui dit contractuel, dit juste, com a força de uma verdade indiscutível, colocado aí, em primeiro plano, o aspecto subjetivo do vínculo ${ }^{24}$.

Aliado a isso, o direito canônico exerceu forte influência no legislador brasileiro: para os canonistas, a palavra dada, a palavra empenhada, fruto da vontade, era elemento essencial dos contratos. A Igreja mostrou-se desde cedo favorável ao respeito da palavra dada. Textos canônicos dos séculos IV (Chromatius) e VI (Gegório, o Grande) assimilaram já a mentira ao perjúrio; era preciso tanto manter a promessa feita por simples loquela (enunciação) como a feita por juramento. De resto, a Igreja era, até o século XI, bastante hostil ao juramento e, com medo do perjúrio, exercia influência no sentido de não se fazer juramentos, não invocando em vão o nome de Deus ${ }^{25}$. No domínio dos contratos o individualismo traduz-se, sobretudo pela autonomia da vontade. Cada indivíduo, enquanto sujeito de direito, goza da liberdade de se obrigar ou não, sendo pela sua vontade consciente que ele se obriga ${ }^{26,27}$.

${ }^{23}$ Cfe. PEREIRA, Caio Mário da Silva. Instituições de direito civil. 10. ed. Rio de Janeiro: Forense, 1995. v. 3, p. 4.

${ }^{24}$ DANTAS, San Tiago. Programa de direito civil II: os contratos. Rio de Janeiro: Rio, 1978. p. 150.

${ }^{25} \mathrm{Cfe}$. GILISSEN, John. Introdução histórica ao direito (Introduction historique au droit). 2. ed. Trad. A. M. Hespanha e L. M. Macaísta Malheiros. Lisboa: Fundação Calouste Gulbenkian, 1995. p. 735.

${ }^{26}$ Id Ibid., p. 737.

${ }^{27}$ “Por seu turno, os canonistas, imbuídos do espiritualismo cristão interpretavam as normas de Direito Romano animados de uma inspiração mais elevada. No tocante ao contrato, raciocinaram que o seu 
Influenciado por estes pensamentos Clóvis Beviláqua forjou o Código Civil de 1916, no que respeita aos contratos, sob um regime voluntarista. Era o primado do individualismo $^{28}$. Segundo apontava Orlando Gomes ${ }^{29}$, a sociedade subjacente ao Código Civil de 1916 era eminentemente agrária:

“Ao tempo em que CLÓVIS BEVILÁQUA apresentou o Projeto do Código Civil brasileiro, éramos, na precisa observação de SÍLVIO ROMERO, uma nação embrionária, cuja indústria mais importante consistia em uma lavoura rudimentar, extensiva, servida ontem por dois milhões de escravos e, àquele tempo, abolida a escravatura, isto é, na última década do século XIX, por trabalhadores nacionais e algumas dezenas de milhares de colonos de procedência européia; mas eram os pobres da inércia e não os proletários no sentido socialista, porque não eram operários rurais ou fabris."

Esta situação social demonstra que à época o Código acabou por ser influenciado pela organização social do Brasil-colônia (fim do século XIX e início do século XX), de com o primitivismo patriarcal que caracterizou o estilo de vida da sociedade colonial $^{30}$.

A estrutura da sociedade colonial, dispersa, incoesa e aristocrática, criou uma forma de organização infensa à politização. A independência do Brasil não provocou mudanças significativas nesta estrutura. A sua classe política seria constituída pelas famílias que detinham a propriedade territorial e o monopólio do mando, tendo como seus representantes, embora dela distanciadas pelo pensamento, pela educação literária e pela cultura, os doutores, que agiam em defesa dos seus interesses, por tradição, por sentimento e pelo instinto conservador de todo o $\operatorname{poder}^{31}$. A mobilidade social era praticamente inexistente dada à estabilidade da estruturas sociais.

No período de elaboração do Código Civil, o divórcio entre a elite letrada e a massa inculta perdurava quase inalterado. A despeito de sua ilustração, a aristocracia de anel

descumprimento era uma quebra de compromisso equivalente à mentira; e como esta constituía peccatum, faltar ao obrigado atría as penas eternas. Não podia ser, para os jurisconsultos canonistas, predominante a sacramentalidade clássica, mas sobretudo prevalecia o valor da palavra, o próprio consentimento." (PEREIRA, Caio Mário da Silva. op. cit., v. 3, p. 8).

28، Ora, é irrecusável o caráter individualista do Código Civil de 1916, mas bem poucos cuidam de examinar e prevenir, na vida prática, os danos resultantes dessa constatação fundamental. Não se leva em conta, por exemplo, a grave injustiça decorrente da irreversibilidade dos contratos, quaisquer que sejam as condições supervenientes, rompendo a paridade ou equivalência que deve haver entre as prestações e contraprestações estipuladas, sendo os contraentes surpreendidos por alterações operadas nos parâmetros econômicos por fatores inteiramente alheios ao acordo das vontades." (REALE, Miguel. O projeto do Código Civil: situação atual e seus problemas fundamentais. São Paulo: Saraiva, 1986. p. 30).

${ }^{29}$ In GOMES, Orlando. Raizes históricas e sociológicas do Código Civil brasileiro. Salvador: Livraria Progresso, 1958. p. 39.

${ }^{30}$ Id., loc. cit.

${ }^{31}$ Cfe. Id. Ibid., p. 29. 
representava e racionalizava os interesses básicos de uma sociedade ainda patriarcal, que não perdera o seu teor privatista, nem se libertara da estreiteza do arcabouço econômico fundado na escravidão, apesar do seu sistema de produção ter sido golpeado fundamente em 1888. Natural que o Código refletisse as aspirações dessa elite e se contivesse, do mesmo passo, no círculo da realidade subjacente que cristalizara costumes, convertendo-o em instituições jurídicas tradicionais. Devido a essa contensão, o Código Civil de 1916, sem embargo de ter aproveitado frutos da experiência jurídica de outros povos, não se libertou daquela preocupação com o círculo social da família, a herança e a produção (contrato de trabalho), a filosofia e os sentimentos da classe senhorial. Suas concepções a respeito dessas instituições transfundiram-se tranqüilamente no Código. Não obstante, desenvolveu-se, à larga, a propensão da elite letrada para elaborar um Código Civil à sua imagem e semelhança, isto é, de acordo com a representação que, no seu idealismo, fazia da sociedade $\mathrm{s}^{32,33}$.

Fixadas, ainda que resumidamente, as premissas sociojurídicas que inspiraram Clóvis Beviláqua e a codificação civil de 1916, necessário se torna que procedamos a um corte epistemológico, a fim de que saltemos aproximados setenta e quatro anos e façamos uma breve comparação entre o Código revogado e o Código de Defesa do Consumidor para, ao depois, chegarmos ao Código Civil de 2002.

Transcorridos aproximados setenta e quatro anos de vigência do Código Civil de 1916, o Brasil havia sofrido uma profunda transformação social e econômica, até porque o mundo havia atravessado duas Grandes Guerras e perpassou graves Crises Econômicas que alteraram por completo o panorama mundial.

De uma população majoritariamente agrária em 1916, o Brasil no ano de 1990 já apresentava um quadro oposto: a maioria da população era urbana e o país, apesar da sua Economia de Mercado fundada na manufatura e na produção em escala, atravessava grave turbulência em razão dos altos índices de inflação que geravam profunda instabilidade social e jurídica.

\footnotetext{
${ }^{32} \mathrm{Cfe}$. GOMES, Orlando. Raizes históricas e sociológicas do Código Civil brasileiro, cit., p. 33-34.

${ }^{33}$ Outro traço marcante da sociedade brasileira à época da elaboração e promulgação do Código Civil de 1916 foi o coronelismo. Explica-o José Afonso da Silva: "O poder dos governadores, por sua vez, sustenta-se no coronelismo, fenômeno em que se transmudaram a fragmentação e a disseminação do poder durante a colônia, contido no Império pelo Poder Moderador. "O fenômeno do coronelismo tem suas leis próprias e funciona na base da coerção da força e da lei oral, bem como de favores e obrigações. Esta interdependência é fundamental: o coronel é aquele que protege, socorre, homizia e sustenta materialmente os seus agregados; por sua vez, exige deles a vida, a obediência e a fidelidade. É por isso que o coronelismo significa força política e força militar.”. (In SILVA, José Afonso da. Curso de direito constitucional positivo. 20. ed. rev. e atual. São Paulo: Malheiros Ed., 2002. p. 80).
} 
Neste contexto de profunda instabilidade e fruto da Constituição Federal de $1998^{34}$ foi editado o Código de Defesa do Consumidor (Lei $\mathrm{n}^{\circ}$ 8.078, de 11 de setembro de 1990). Ao contrário do Código Civil de 1916, o Código de Defesa do Consumidor alterou profundamente os paradigmas do direito privado: em linhas gerais, a autonomia da vontade cedeu lugar à autonomia privada; a boa-fé subjetiva foi substituída pela boa-fé objetiva; a liberdade quase que ilimitada, enfim, foi substituída pelo dirigismo contratual, a fim de proteger e salvaguardar um novo protagonista do direito privado: o consumidor.

Ainda que as disposições das matérias sejam bastante distintas nos Códigos Civil e de Defesa do Consumidor - até pela diferença temática -, na III Jornada de Direito Civil promovida pelo Centro de Estudos Judiciários - CEJ - do Conselho da Justiça Federal CJF entre os dias $1^{\circ}$ e 3 de dezembro de 2004, foi aprovado o Enunciado 167, que dispôs:

“Arts. 421 a 424: Com o advento do Código Civil de 2002, houve forte aproximação principiológica entre esse Código e o Código de Defesa do Consumidor no que respeita à regulação contratual, uma vez que ambos são incorporadores de uma nova teoria geral dos contratos." (Grifamos)

Portanto, segundo uma importante corrente doutrinária (a do Direito CivilConstitucional), apesar das críticas que podem ser dirigidas ao Código Civil de 2002, este diploma e o CDC fizeram surgir uma nova Teoria do Direito Contratual, especialmente, fundada nos princípios da autonomia privada, boa-fé objetiva e função social do contrato, princípios estes que têm por fundamento a confiança ${ }^{35}$.

É neste contexto objetivado, pois, que deverá ser analisado o contrato de fiança, a fim de que seja tutelada a confiança que as partes depositaram no vínculo contratual; em outras palavras, o direito passou a tutelar a legítima expectativa das partes de que a fiança seria de fato um contrato apto a garantir a posição jurídica do credor, e não uma simples garantia de papel, sem qualquer efetividade, pois confiar é acreditar (credere), é manter, com fé (fides) e fidelidade, a conduta, as escolhas e o meio; confiança é aparência,

\footnotetext{
${ }^{34}$ Vede Arts. $5^{\circ}$, XXXII e Art. 48, ADCT: “Art. 5 Todos são iguais perante a lei, sem distinção de qualquer natureza, garantindo-se aos brasileiros e aos estrangeiros residentes no País a inviolabilidade do direito à vida, à liberdade, à igualdade, à segurança e à propriedade, nos termos seguintes(...)XXXII - o Estado promoverá, na forma da lei, a defesa do consumidor; Art. 48: "Art. 48. O Congresso Nacional, dentro de cento e vinte dias da promulgação da Constituição, elaborará código de defesa do consumidor."

${ }^{35}$ "Precisamente, en ciertas situaciones se considera que quien genera en otro cierta confianza (reliance) o expectativa respecto de que realizará determinados actos, queda obligado por la generación de esa confianza;" (ALTERINI, Atilio Aníbal. Contratos civilis - comerciales - de consumo: teoría general. Buenos Aires: Abeledo-Perrot, 1999. p. 15). (Grifamos)
} 
informação, transparência, diligência e ética no exteriorizar vontades negociais ${ }^{36}$. Conforme doutrina Juan Carlos Rezzónico ${ }^{37}$,

"Expresado con cierta generalidad, podemos decir que el de confianza es un principio de derecho de gran contenido ético, con desenvolvimiento en el campo interindividual, de especial significación en las relaciones jurídicas patrimoniales, que impone a quienes participan en el tráfico un particular deber de honrar las expectativas despertadas en los demás, en cuanto seam legítimas y fundadas, tanto en la etapa previa a la conclusión del contrato como en su desarrollo y en el tramo poscontratual.

\section{(...)}

b) El principio de confianza se basea en un deber ético de no defraudar las expectativas suscitadas en otros. Obsérvese que hay un sujeto que ha tomado la iniciativa y son sus palabras o actos, privados o no, los que determinan ese elemento espiritual con valoración jurídica que es la confianza." (Grifamos)

A valorização da confiança ${ }^{38}$, por certo, abrirá novas perspectivas para o direito privado brasileiro. Em outras palavras, a atividade jurídica protege a conduta esperada entre os indivíduos, no âmbito negocial ou não ${ }^{39}$, pois as condutas na sociedade e no mercado de consumo, sejam atos, dados ou omissões, fazem nascer expectativas legítimas em que despertamos a confiança, os receptores das nossas informações ou dados ${ }^{40}$, o que revela a sua importância no contrato de fiança porque se o fiador prometeu garantir não poderá defraudar a legítima expectativa que a sua promessa gerou no credor. Doutrina António Menezes Cordeiro ${ }^{41}$ :

\footnotetext{
${ }^{36}$ MARQUES, Cláudia Lima. Confiança no comércio eletrônico e a proteção do consumidor. São Paulo: Ed. Revista dos Tribunais, 2004. p. 32-33.

${ }^{37}$ In REZZÓNICO, Juan Carlos. Principios fundamentales de los contratos. Buenos Aires: Astrea, 1999. p. 376-377.

${ }^{38}$ No mesmo sentir aponta DÍEZ-PICAZO, Luis: "Inicialmente, buena fe (bona fides) expressa la confianza o la esperanza en una actuación correcta de otro. Se concreta en le lealtad en los tratos y en la fidelidad en la palabra dada. Posee, sin embargo, una eficacia mucho más amplia y significa un modelo de comportamiento, no formulado legalmente y de imposible formulación legal, que vive en las creencias y en la conciencia social y al que deben ajustarse los comportamientos individuales. El principio de obrar según buena fe significa que los derechos subjetivos de naturaleza económica tienem que ser ejercitados de acurdo con la buena fe y que las obligaciones deben ser también de buena fe cumplidas." (In DÍEZPICAZO, Luis. Fundamentos del derecho civil patrimonial. 5. ed. Madrid: Tecnos, 1996. v. 1, p. 49). (Grifamos).

${ }^{39}$ Cfe. FARIAS, Cristiano Chaves de; ROSENVALD, Nelson. Direito das famílias. Rio de Janeiro: Lumen Juris, 2008, p. 65.

${ }^{40}$ Cfe. MARQUES, Cláudia Lima. Confiança no comércio eletrônico e a proteção do consumidor, cit., p. 32.

${ }^{41}$ In CORDEIRO, António Menezes. Tratado de direito civil português. 3. ed. rev. e aum. Coimbra: Almedina, 2007. v. 1, t. 1, p. 414.
} 


\begin{abstract}
"À partida, podemos considerar a confiança como um elemento imprescindível na manutenção do grupo social. Na sua falta, qualquer sociedade humana se esboroa. Em termos interpessoais, a confiança instalada coloca os protagonistas à mercê uns dos outros: o sujeito confiante abranda as suas defesas, ficando vulnerável. Seguidamente, todos os investimentos, sejam eles econômicos ou meramente pessoais, postulam a credibilidade das situações: ninguém dá hoje, para receber (apenas) amanhã, se não houver confiança nos intervenientes e nas situações. Por fim, a confiança e a sua tutela correspondem a aspirações éticas elementares. A pessoa defraudada na sua confiança é, desde logo, uma pessoa violentada na sua sensibilidade moral. Paralelamente, o agente que atinja a confiança alheia age contra um código ético imediato.
\end{abstract}

A confiança torna-se um elemento importante. O Direito não o pode ignorar: tratar um sujeito confiante pela mesma bitola dispensada a um outro não-confiante equivale a tratar o diferente de modo igual. Haveria, então, uma violação do princípio da igualdade, previsto no art. $13^{\circ}$ da Constituição.

Podemos ir mais longe. O princípio da igualdade implica a harmonia e adequação do sistema no seu conjunto. Em jogo estará, sempre, uma confiança conforme o sistema. E assim sendo, encontraremos na tutela da confiança, um modo de concretização dos valores últimos do sistema." (Grifamos)

E no momento em que o direito brasileiro passar a tutelar a confiança com maior intensidade do que a vontade, inclusive nos contratos paritários, novos horizontes se descortinarão porque no mundo atual é muito raro que as partes de determinado contrato tenham tempo para negociar e refletir acerca do contrato que estiverem a firmar, porquanto a padronização é uma característica marcante da sociedade massificada, padronização esta que no caso da fiança transformou determinadas estipulações contratuais em cláusulas de estilo encontráveis até mesmo em contratos-tipo vendidos em papelarias, nas quais as disposições já são previamente impressas, porém há espaços no instrumento que permitem a inserção de algumas e poucas disposições negociadas.

$\mathrm{Na}$ atualidade, o contrato não é valorado como um fenômeno psíquico, ancorado na vontade interna das partes, mas como um fenômeno social, sendo certo que o que conta é o valor objetivo que este fenômeno assume na sociedade em que se encontra inserido ${ }^{42,}{ }^{43}$,

\footnotetext{
${ }^{42}$ Cfe. BIANCA, C. Massimo: "Il superamento del c.d. dogma della volontà è ormai un risultato acquisito sul piano del diritto positivo. La disciplina legislativa del contratto non fa dipendere la rilevanza giuridica dell'atto dalla realtà della volontà interna della parti. Il contrato non è valutato come un fenomeno psichico ma come un fenomeno sociale, e ciò che conta è il valore obiettivo che questo fenomeno assume quale atto decisionale mediante il quale le parti constituiscono, estinguono o modificano un loro rapporto patrimoniale." (In BIANCA, Massimo C. Diritto civile: il contratto. 2. ed. Milano: Giuffrè, 2000. v. 3, p. 20).

${ }^{43}$ Em sentido semelhante escreveu AZEVEDO, Antônio Junqueira de: "O negócio jurídico é uma criação do povo. Ele é, antes de mais nada, um fato social. Não é o direito posto, o direito formalmente constituído pelo Estado legislador, que cria o negócio jurídico. Não é ele, também, uma construção teórica, doutrinária,
} 
daí defluindo a importância de ser prestigiada a confiança objetivamente criada na parte que contou com a promessa manifestada.

E esta confiança em se tratando do negócio de garantia denominado de fiança ganha relevos inquestionáveis porque a responsabilidade do garante somente será detonada se e quando o afiançado deixar de cumprir o contrato garantido, ou seja, em futuro incerto, razão por que na atualidade os credores, no momento de execução da garantia, vêm sendo surpreendidos com interpretações legais que protegem os devedores e os responsáveis fidejussórios de forma quase absoluta, enquanto os fiadores ficam à mercê de uma garantia que só existe no papel. O ordenamento protege a confiança suscitada pelo comportamento do outro e não tem outro caminho senão a de protegê-la, porque poder confiar é condição essencial para uma pacífica vida em sociedade e para que se instaure uma conduta de cooperação entre os homens. Por isso, quem frustra a confiança gerada a partir da sua própria conduta ou aquela que tiver induzido o outro a ter manifestado viola uma exigência do direito que é a de manter um mínimo de segurança interindividual ${ }^{44}$.

Em conclusão, como o Código Civil de 2002 se destinou a alterar o paradigma dos negócios jurídicos, que antes tinham apenas por fundamento a vontade das partes, passando a ser prestigiada a confiança decorrente da manifestação dos declarantes, entendemos que o contrato de fiança deverá se destinar a realmente garantir o credor das vicissitudes do crédito, prestigiando, pois, a legítima expectativa gerada a partir da promessa de garantia manifestada pelo fiador.

relizada, através de progressiva abstração, por grandes juristas; o máximo que se pode dizer é que, em determinado momento histórico, alguns estudiosos tomaram consciência de sua existência e, a partir daí, isto é, de duzentos anos para cá, começaram a teorizar sobre ele.” (In AZEVEDO, Antônio Junqueira de. Negócio jurídico e declaração negocial: noções gerais e formação da declaração negocial. São Paulo: Saraiva, 1986. p. 3).

${ }^{44}$ Cfe. LARENZ, Karl. Derecho justo: fundamentos de etica jurídica. Tradução de Luis Díez-Picazo. Madrid: Civitas, 1993. p. 91: "El ordenamiento protege la confianza suscitada por el comportamiento de otro y no tiene más remedio que protegerla, porque poder confiar, como hemos visto, es condición fundamental para una pacífica vida colectiva y una conducta de cooperación entre los hombres y, por tanto, de la paz jurídica. Quien defrauda la confiaza que ha producido o aquella a la que ha dado ocasión a otro, especialmente a la otra parte en un negocio jurídico, contraviene una exigencia que el Derecho - con independencia de cualquier mandamiento moral - tiene que ponerse a sí mismo porque la desaparición de la confianza, pensada como un modo general de comportamiento, tiene que impedir y privar de seguridad al tráfico interindividual. Aquí entre en juego la idea de una seguridad garantizada por el Derecho, que en el Derecho positivo se concreta de diferentes maneras." 


\section{ORIGENS DO CONTRATO DE FIANÇA ${ }^{45}$}

No direito romano arcaico a fiança encontra antecedentes nas figuras do vades ${ }^{46} \mathrm{e}$ do praedes $^{47}$. Ao que parece, o vades seria uma intervenção de garantia no processo, enquanto o praedes, de feição também processual, estenderia os seus efeitos para além do processo $^{48}$. Eram, pois, modalidades de garantia que um terceiro alheio ao vínculo obrigacional prestava. Mais tarde surgiriam as figuras da sponsio e da fidepromissio ${ }^{49}$, das

45، La fideiussione è un contratto formale, mediante il quale alcuno si obbliga a pagare un debito altrui nel caso che il debitore principale non paghi alla scadenza. La form è quella della stipulazione. Nel diritto antegiustinianeo esistevano varie garentie formale e civili con applicazioni ed effetti diversi: la sponsio, la fidepromissio, la fideiussio propriamente deta. La forma della fideiussio, in genere piú ampia e sicura, è lúnica che sopravviva nel diritto giustinianeo. (...) Il fideiussore è obbligato alla stessa prestazione del debitore principale. In aliam rem quam quae credita est obligari fideiussor non potest. L'obbligazione del fideiussore non può nemmeno esser più grave di quella del debitore principale, ossia non si può egli obbligare in duriorem causam. Si può invece obbligare non per non si ricavi dal debitore principale, ed abbiamo allora una fideiussio indemnitatis, il cui carattere, se sia fideiussione o stipulazione comune, è pèro dubbio." (BONFANTE, Pietro. Instituzioni di diritto romano. 10. ed. Milano: G. Giappichelli, 1949. p. 442-443).

${ }^{46}$ De acordo com BERGER, Adolf, o termo vades é plural de vas e significava "A surety which guaranteed the appearance of the defendent before de magistrate in the earliest law, in the procedure of legis actio. Origins and details are obscure(...)." (In BERGER, Adolf. Encyclopedic dictionary of roman law. Philadelphia: The American Philosophical Society, 1953. p. 641).

${ }^{47}$ Ainda de acordo com BERGER, Adolf, o termo praedes significava "In the earliest law of the Republic sureties who assumed guaranty for a person who concluded a contract with the state (e.g., a lease, a location conduction operarum, etc.)." (In BERGER, Adolf. op. cit., p. 758).

${ }^{48}$ Cfe. CORDEIRO, António Menezes. Direito das obrigações. Lisboa: A.F.D.L., 2001. v. 2, p. 510.

49"The two earliest forms of suretyship (called sponsio and fidepromissio from the formal words used) were by sptipulation, and were in most respects subject to the same rules, sponsio being however confined, as it was when used to create a principal debt, to Roman citizens. But they were both subject to several limitations and defects. They could only be used when the principal debt itself was created by stipulation; the obligation died, as did probably al primitive obligations, with the person who undertook it; it was extinguished in any case two years after it was created; and if there were several sureties for the same debt, each was liable only for for his proportionate share of the principal debt, even if one or more of his cosureties were insolvent. These last two restrictions, and some others, were the result of legislation which was evidently intended to relieve the lot of sureties. But it defeated its own purpose by making these two forms too unattractive to creditors. In the late Republic, therefore emerged a third form, fideiussio, which was also a stipulation, but was subject to none of the defects and limitations mentioned above; it could guarantee any debt, however created; it boun the heirs of the surety and was subject to no limitation period; and if there were several sureties the creditor could claim the ful debt from any of them. This last feature was indeed modified by Hadrian to the extent a surety could, if he wished, claim the privilege (beneficium divisionis) of paying only his proportionate share of the debt; buit in the calculation of the share those sureties who were insolvent at the time the action was brought were ignored. In other words, the risk of a surety's insolvency was on the other sureties, whereas in sponsio and fidepromissio it fell always on the creditor. Fideiussio was thus far more favourable to the creditor than the other two, and it alone of the three survived in the law of Justinian. We have already encountered two other, informal, mthods of effecting suretyship - by mandate and by constitum. Since both came into existence simply by agreement, and lqymen habitually do not express their agreement in legal terms, the substantial difference between the two was that in mandate the agreement must precede the creation of the principal debt an in constitutum it mus follow it. These contracts of suretyship created, of course, relationships only between creditor and surety. If there were to be any claim by the surety who paid the debt against either the debtor or his co-sureties, it must rest on some other ground. As between surety and debtor, if the surety had incurred his obligation to the creditor at the debtor's request the ground would be mandate, and if he had done so of his own accord it might be negotiorum gestio. It is significant of the early origin of sponsio that the remedy of the sponsor against the principal debtor was provided by statute. As between co-sureties the relationship would be on of 
quais se originaria a fideiussio, no séc. I a.C., muito próxima da fiança atual ${ }^{50}$. Segundo apontava Fritz Schulz ${ }^{51}$ sobre a fideiussio:

"Era ésta una tercera forma de garantía creada como la sponsio y la fidepromissio accesorias, por estipulación, pero fundamentalmente distinta de estas dos antiguas especies. La fideiussio no es de origen antiguo. Podemos fijar su aparición en la época de Labeon. Lo terminos fideiussio y fideiubere no figuran en las obras de César y Cicerón, ni en la literatura antigua. Tampoco aparecen en las leges que conocemos. Podemos pues afirmar, que la fideiussio fué creada por la jurisprudencia en el período tardío de la República o en los cominezos del Principado, probablemente por Servio Sulpicio o por Labeon. Sea de esto lo que fuera, lo cierto es que la fideiussio, constituye la forma más moderna de garantía y no puede extrañar, el hecho de que esta forma, elimoinase las otras dos más antiguas. En Derecho justinianeo sobrevive únicamente la fideiussio."

O fideiussor não prometia a mesma prestação que havia prometido o devedor principal, mas se declarava responsável pelo cumprimento da obrigação principal pelo devedor principal ${ }^{52}$. A fideiussio não foi, como as duas outras antigas formas de garantia (sponsio e fidepromissio), uma estipulação acessória de outra principal, mas sim uma obrigação que implicava em uma obrigação acessória de outra obrigação principal cuja causa podia ser distinta da stiuplatio $^{53}$. Vejamos.

1. A fideiussio não exigia uma estipulação principal que lhe antecedesse. A obrigação principal podia ter origem em uma causa que não correspondesse à da stipulatio, incluindo a de uma obrigação natural. As obrigações ex delicto não podiam ser objeto da fideiussio no Direito romano clássico em virtude do seu caráter penal ${ }^{54}$.

2. Quando a obrigação principal não existia desde o início, a fideiussio era nula ${ }^{55}$.

3. Quando a obrigação se extinguia posteriormente, cessava automaticamente a responsabilidade do fideiussor. Assim, se o credor tivesse satisfeito o seu crédito pelo devedor principal ou se efetuasse a remissão da dívida através da acceptilatio, o fideiussor estava liberado. Se a obrigação principal era extinta pela novatio ou confusio (por exemplo, o credor sucedia (herdava) o devedor principal), a responsabilidade do fideiussor

societas if they had acted in concert, but if they had no the law provided no remedy. After Hadrian's introduction of the beneficium divisionis, however, this cannot have been a matter of much importance." (NICOLAS, Barry. An introduction to roman law. New York: Oxford University Press, 1996. p. 204-205).

${ }^{50}$ Cfe. CORDEIRO, António Menezes. op. cit., p. 510.

${ }^{51}$ In SCHULZ, Fritz. Derecho romano clásico. Trad. José Santa Cruz Teigeiro. Barcelona: Bosch, 1960. p. 477.

${ }^{52} \mathrm{Cfe}$. Id., loc. cit.

${ }^{53}$ Cfe. Id. Ibid., p. 478.

${ }^{54} \mathrm{Cfe}$. Id., loc. cit.

${ }^{55}$ Cfe. Id., loc. cit. 
igualmente cessava. Se o credor demandasse o devedor principal e se extinguisse assim a obrigação principal deste (pela litis contestatio), o fideiussor estaria também livre da sua obrigação. Se o cumprimento da obrigação principal restasse impossibilitado por causa não imputável ao devedor principal (por exemplo, este deveria entregar o escravo Stico e este morrera por caso fortuito), cessava a obrigação do devedor, bem como do fideiussor. Inclusive, se o escravo morresse por dolo do fideiussor, não somente tal fato resultava na extinção da obrigação principal (porque o devedor principal não havia sido o responsável pela morte do escravo), assim como também extinguia a responsabilidade do fideiussor, porque sendo esta acessória daquela, não poderia existir sem que também houvesse a obrigação principal. Neste caso o credor titularizaria uma actio de dolo contra o fideiussor. Por outro lado, se o escravo morresse por dolus de um sponsor acessório, a obrigação principal se extinguiria porque o devedor principal não havia sido o responsável pela morte, mas a obrigação do sponsor subsistia intacta porque esta poderia existir independentemente da obrigação principal ${ }^{56}$.

4. Se o devedor principal se encontrasse protegido por uma exceptio, o fideiussor poderia se valer da mesma, independentemente do fato de que o devedor principal estivesse ou não obrigado a reembolsar o fiador ${ }^{57}$.

5. A obrigação do fiedeiussor não poderia ser mais onerosa do que a obrigação principal. Se o devedor principal estivesse a dever 100, o fideiussor poderia responder por 50 , porém nunca por mais de 100 . Neste aspecto a fideiussio não diferia da sponsio e da fidepromissio acessórias ${ }^{58}$.

6. O devedor principal e o fideiussor eram devedores solidários. O credor poderia dirigir-se primeiramente contra o fideiussor, o qual no Direito romano clássico carecia do beneficium excussionis. Este benefício foi introduzido por Justiniano. O devedor principal e o fideiussor não eram plures rei promittendi, razão pela qual entre eles a co-realidade. Se a obrigação do fideiussor havia sido objeto de novação, a obrigação principal subsistiria inalterada e se o credor demandasse o fideiussor, a litis contestatio extinguiria a obrigação deste, porém não a do devedor principal ${ }^{59}$.

7. Se o fideiussor pagasse ao credor, poderia exigir do devedor principal o reembolso do que pagou através da actio mandati ou negotiorum gestorum. O engenhoso

\footnotetext{
${ }^{56}$ Cfe. SCHULZ, Fritz. op. cit., p. $478-479$.

${ }^{57}$ Cfe. Id. Ibid., p. 480.

${ }^{58}$ Cfe. Id. Ibid., p. 478.

${ }^{59} \mathrm{Cfe}$. Id., loc. cit.
} 
expediente do beneficium cedendarum actionum não existiu com toda a segurança no Direito romano clássico ${ }^{60}$.

8. Dois ou mais fideiussores são devedores solidários e somente em caso de terem se obrigado uno actu seriam devedores co-reais. Em uma epístola de Adriano (Hadriani), os cofideiussores gozavam do beneficium divisionis, em virtude do qual o credor se via obrigado a repartir a dívida entre os fiadores que fossem solventes ao tempo da manifestação da litis contestatio. A opinião que limita este benefício aos fideiussores que se obrigaram uno actu é infundada Suponhamos que A, B e C foram cofideiussores por 60. Se todos eles eram solventes, o credor poderia reclamar 20 de cada um; porém, se $\mathrm{C}$ era insolvente A e B deveriam responder cada um por $30^{61}$.

9. Se um dos cofideiussores pagasse ao credor comum, os demais se encontravam a reembolsá-lo pro parte. O fiador que tivesse pago teria contra ele uma actio mandati, negotiorum gestorum o pro socio; o beneficium cedendarum actionum não existe no Direito Clássico. Somente a fideiussio sobrevive no Direito de Justiniano, havendo desaparecido a sponsio e a fidepromissio accesorias. Quando os compiladores inseriam em suas compilações um texto referente à sponsio ou à fidepromissio acessórias, sistematicamente substituíam estas antigas formas de fianças pela mais moderna que era a fideiussio. No geral se apresenta fácil a prova destas interpolações. Justiniano aboliu também o efeito consumativo da litis contestatio ${ }^{62}$.

Em sua origem, pois, ao que parece, os jurisconsultos romanos entendiam que a garantia pessoal se caracterizaria por ser uma obrigação acessória àquela anteriormente contraída pelo devedor principal, no sentido de que a obrigação do devedor se anexaria à do devedor principal. Por conta disso as obrigações do devedor e do garante nasciam sucessivamente e não simultaneamente ${ }^{63}$.

Por outro lado, a qualidade de obrigação acessória das garantias pessoais foi fruto de evolução, no direito romano. A princípio, o garante era o único responsável pela dívida: ela assumia a posição do devedor, de modo que, se este não cumprisse espontaneamente a obrigação, o credor somente podia acionar o garante. No direito clássico, devedor e garante são considerados co-devedores solidários, embora nesse período se vá acentuando o caráter

\footnotetext{
${ }^{60}$ Cfe. SCHULZ, Fritz. op. cit., p. 478.

${ }^{61} \mathrm{Cfe}$. Id., loc. cit.

${ }^{62} \mathrm{Cfe}$. Id., loc. cit.

${ }^{63}$ Cfe. MOREIRA ALVES, José Carlos. Direito romano. 6. ed. rev. e acresc. Rio de Janeiro: Forense, 1997. v. 2, p. 478-479.
} 
acessório da obrigação do garante. Finalmente, no direito justinianeu, reconhece-se plenamente que a obrigação do garante tem a característica de obrigação acessória com relação à do devedor, que é a principal ${ }^{64}$.

No direito romano clássico podiam ser encontradas três espécies de fiança que surgiram na seguinte ordem ${ }^{65}$ :

a) a sponsio (em que o credor pergunta ao garante: Idem mihi dari spondes? “prometes dar-me o mesmo que o devedor prometeu?", ao que responde o garante: spondeo - "prometo");

b) a fideipromissio (em que ocorriam as mesmas pergunta e resposta, mas em que, em lugar do verbo spondere se empregava fidepromittere); e

c) a fideiussio (à pergunta do devedor o garante: id fide tua esse iubes? "garantes, sob palavra, essa prestação?" -. seguia resposta do garante: fideiubeo - "garanto, sob palavra"). No direito justinianeu subsiste apenas a fideiussio $^{66}$.

A sponsio e a fidepromissio serviam apenas para garantir obrigações verbais. A sponsio era peculiar aos cidadãos romanos; a fidepromissio era acessível aos peregrinos. Em ambos os casos, ao lado do devedor principal colocava-se um devedor acessório que se obrigava também por toda a dívida (adpromissio), sem que a obrigação do garante pudesse ser de maior extensão àquela do devedor principal, sendo certo ainda que o fiador somente poderia opor ao credor todas as exceções rei cohaerentes ${ }^{67}$, mas não as pessoais do devedor, personae cohaerentes. A extinção da dívida principal iure civile acarretava ipso iure a extinção da dívida acessória. São conseqüências da acessoriedade da adpromissio. Deve-se notar ainda que as obrigações do sponsor e do fidepromissor lhes seriam pessoais,

\footnotetext{
${ }^{64}$ MOREIRA ALVES, José Carlos. op. cit., p. 479.

${ }^{65}$ All'uopo si adoperava in Roma la stipulazione. Prima di Giustiniano esistevano, l'un accanto all'altra, tre forme per la garanzia stipulata: a) La più antica era la sponsio, con le parole «idem spondes?» e questa era accessibile solo ai cittadini romani; b) Una forma posteriore, libera anche ai peregrini, era la fidepromissio, con la forma «idem fide promittis?». Queste due forme di garanzia potevano adoperarsi solo per le obbligazioni verbali. Esse erano inoltre personalissime, nel senso que non trapassavano agli eredi del garante; c) La più recente forma di garanzia fu la «fideiussio», con la formula «idem fide tua iubes?» Era libera ai prergrini. Vincolava anche gli eredi del fideiussore. Poteva aggiungersi ad obbligazioni di qualunque specie, persino future, pel caso della nascita di esse." (DERNBURG, Arrigo. Diritto delle obbligazioni. 6. ed. Tradução de Francesco Bernardino Cicala. Torino, Fratelli Bocca, 1903. p. 303-304).

${ }^{66}$ MOREIRA ALVES, José Carlos. op. cit., v. 2, p. 139.

${ }^{67}$ Segundo BERGER, Adolf (In Encyclopedic dictionary of roman law, cit., p. 461), as chamadas exceções rei cohaerentes eram espécie do gênero exceptiones personae cohaerentes, sendo que estas apenas poderiam ser opostas pelo devedor principal, mas não pelo fiador; como exemplo menciona a exceptio "quod facere possit" a que se legitimariam os pais, patrões ou sócios do devedor para o fim de fosse condenado nos limites das suas possibilidades.
} 
não passando aos herdeiros, salvo, no caso deste último, se o direito estrangeiro dispusesse de outra maneira ${ }^{68}$.

A sponsio e a fidepromissio se destinavam à garantia de débitos contraídos por stipulatio. A stipulatio era um contrato verbal por excelência e o mais importante do direito romano, graças à simplicidade e - no período clássico - à natureza de negócio jurídico abstrato, servia ela para tornar obrigatória qualquer convenção sobre coisa certa ou incerta, fato ou abstenção ${ }^{69}$.

Até o séc. III a.C. era penosa a situação do sponsor e do fidepromissor. Eles respondiam solidariamente com o devedor por todo o débito, e sendo devedores solidários podiam, a qualquer tempo, ser perseguidos judicialmente por toda a dívida. Pago o débito pelo fiador extinguia-se a dívida para o devedor e o sponsor ou o fidepromissor não tinham ação para cobrar do devedor o que por ele pagaram. E se houvesse vários fiadores, pagando um deles o débito, não dispunha de meio para cobrar dos demais as quotas proporcionais ao valor total da dívida ${ }^{70}$.

Nos séculos III e II a.C. surgem várias leis para melhorar a situação dos fiadores, uma vez que, diante do pesado ônus que representava a fiança, raro, por certo, deveria ser quem se dispusesse a garantir, como sponsor ou fidepromissor, débito alheio. Essas leis todas de data incerta, não se sabendo, até, qual a exata ordem cronológica em que surgiram - são as seguintes:

a) a lei Publilia, que determinou que o sponsor (ela não se aplicava ao fidepromissor) que pagasse o débito ao credor teria ação penal contra o devedor para obter deste, caso não o reembolsasse da quantia paga dentro de seis meses, o dobro do valor do débito $^{71}$;

b) a lei Apuleia, pela qual, se houvesse vários fiadores (sponsores ou fidepromissores) e um deles pagasse ao credor mais do que a quota a ele correspondente, poderia exigir dos demais, como se entre eles houvesse um contrato de sociedade, que o ressarcissem do que pagara em excesso ${ }^{72}$;

\footnotetext{
${ }^{68}$ Cfe. CHAMOUN, Ebert. Instituições de direito romano. 3. ed. rev. e aum. Rio de Janeiro: Forense, 1957. p. 336.

${ }^{69}$ MOREIRA ALVES, José Carlos. op. cit., v. 2, p. 60.

${ }^{70}$ Id. Ibid., p. 59-60.

${ }^{71}$ Id. Ibid., p. 61.

${ }^{72}$ Id., loc. cit.
} 
c) a lei Furia, que, aplicando-se apenas ao sponsor ou ao fidepromissor in Italia acceptus (sponsor ou fidepromissor constituídos na Itália), determinava que a garantia decorrente da fiança se extinguia no prazo de dois anos, bem como que, se houvesse vários fiadores, cada um deles responderia por quota igual à dos demais, sem se levar em consideração se um dos fiadores, por insolvência, não podia pagar sua quota ${ }^{73} ; \mathrm{e}$

d) a lei Cicereia, que dispôs que o devedor era obrigado a declarar ao que iria servir-lhe de sponsor ou de fidepromissor o objeto da obrigação a ser garantida e o número de garantes já existentes ${ }^{74}$.

Se essas leis melhoraram a situação dos sponsores e dos fidepromissores, por outro lado enfraqueceram, e muito, a garantia que a fiança representava para os credores. Por isso - e também por outros inconvenientes que a sponsio e a fidepromissio apresentavam -, nos fins da república ou início do principado, surgiu e se desenvolveu, graças à jurisprudência, a fideiussio ${ }^{75}$. A fideiussio também se fazia por stipulatio, porém destinavase a garantir qualquer obrigação, ainda que natural ou futura ${ }^{76}$. O credor perguntava ao devedor id fide tua esse iubes e este respondia fideiubeo. A obrigação do fideiussor era acessória, como as dos demais fiadores, não podendo, pois, ultrapassar a obrigação principal; diferentemente, porém da sponsio e da fidepromissio, ela se transferia aos herdeiros. Os fideiussores eram devedores solidários, porquanto a lei Furia não os alcançava ${ }^{77}$.

No direito clássico, devedor e fideiussor eram responsáveis solidários pelo débito; por isso, o credor, à sua escolha, podia exigir o pagamento de um ou de outro. Se a escolha recaísse no fideiussor, ele não tinha propriamente direito de regresso contra o devedor, mas a jurisprudência admitiu que ele se reembolsasse da quantia paga por meio ou da actio mandati contraria (se pagara a dívida a pedido do devedor), ou da actio negotiorum gestorum contraria (se a pagara espontaneamente, em lugar do devedor) ${ }^{78}$. Demais, na hipótese de haver co-fiadores garantindo a mesma dívida, foram eles beneficiados a partir

\footnotetext{
${ }^{73}$ MOREIRA ALVES, José Carlos. op. cit., v. 2, p. 61.

${ }^{74}$ Id., loc. cit.

${ }^{75}$ Id. Ibid., p. 62.

${ }^{76}$ Cfe. CHAMOUN, Ebert. op. cit., p. 337.

${ }^{77} \mathrm{Cfe}$. Id., loc. cit.

78، Tuttavia per ottenere dal debitore principale la restituzione del pagato, ossia per esercitare il diritto di regresso, il fideiussore non ha nemmeno nel nuovo diritto azione in base al contratto stesso. Egli può all'uopo ricorrere a diversi mezzi fondati sul rapporto distinto che per avventura lo leghi al debitore, e sperimentare l'actio mandati contraria in base al mandato che aveva dal debitore, .o l'actio negotiorum gestorum, se ha compiuto, pagando, una gestione utile ove concorrano tutti i requisiti della negotiorum gestio $(§ 170)$. Potrà anche farsi cedere dal creditore le sue azioni contro il debitore. Giustiniano accordó l'actio mandati anche se il fideiussore ha omesso senza dolo una eccezione o ha pagato ignorando che il debito era già stato soddisfatto dal debitore principale." (BONFANTE, Pietro. op. cit., p. 444).
} 
de Adriano $^{79}$, pelo beneficium diuisionis, em virtude do qual cada um respondia apenas pela quota do débito que lhe cabia ${ }^{80}$, quota essa que aumentava se um dos co-fiadores fosse insolvente ${ }^{81}$.

No direito justinianeu, esse panorama, se modifica. Firma-se o caráter acessório da fideiussio, pois Justiniano concede ao fideiussor o beneficium excussionis ou ordinis, pelo qual o fideiussor que pagasse em lugar do devedor se sub-rogava na ação do credor contra o devedor, para reembolsar-se da quantia paga ${ }^{82,83}$.

Portanto, em síntese, a princípio o fideiussor é responsável solidário com o devedor pelo débito; a pouco e pouco, no entanto, graças aos beneficia (diuisionis, excussionis ou ordinis, e cedendarum actionum) que lhe foram sendo atribuídos, a solidariedade desaparece ${ }^{84}$.

\footnotetext{
79،"Entre os fideiussores também não havia, a princípio, qualquer ação. Êles eram responsáveis solidàriamente, de modo que o credor podia exigir de cada um o pagamento total. Mas, a não ser que houvesse sociedade, o que pagou não podia dirigir-se contra os demais para cobrar a parte dêles na dívida: o benefício da lei Fúria, como vimos, não se aplicava à fideiussio. Essa situação iníqua foi corrigida por Adriano, que autoritzou o fideiussor, acionado para pagar tôda a dívida, a exigir que o credor dividisse a sua ação entre todos os fideiussores solventes no ato de contestação da lide (beneficium divisionis). Aliás, o benefício de cessão de ações podia servir também para facultar ao fiador que pagou o recurso contra os outros com as ações do credor." (CHAMOUN, Ebert. op. cit., p. 339).

${ }^{80}$ “La posizione del fideiussore fue più equamente regolata nel diritto imperial. Adriano per il primo concesse nel caso di più fideiussori il benficium divisionis, in virtú del cuale il fideiussore escusso poteva esigere dal creditore che dividesse la sua azione tra i vari confideiussori presenti i solventi (cfr. § 122)." (BONFANTE, Pietro. op. cit., p. 443).

${ }^{81}$ MOREIRA ALVES, José Carlos. op. cit., v. 2, p. 62.

${ }^{82}$ Id. Ibid., p. 63.

${ }^{83 ،}$ Mas per la prima volta Giustiniano accordò al fideiussore il beneficium excussionis, in virtù del quale il fideiussore convenuto può opporre al creditore che egli si rivolga prima contro il debitore principale; oramai il suo debito non è più in linea perfettamente uguale con quello del debitore principale. Con questa riforma la fideiussione assume veramente il suo tipo odierno di negozio sussidiario." (BONFANTE, Pietro. op. cit., p. 443).

${ }^{84}$ MOREIRA ALVES, José Carlos. op. cit., v. 2, p. 63.
} 


\section{O CONTRATO DE FIANÇA}

Segundo a doutrina civilista a fiança é modalidade de caução, instituto jurídico que abarcaria todas as espécies de garantias de natureza real ou pessoal ${ }^{85}$. A fiança no direito brasileiro é um contrato de garantia pessoal porque ostenta, ex vi legis, a natureza de negócio jurídico ${ }^{86}$, de modo que é a pessoa do fiador e o seu patrimônio que prometem, garantem e lastreiam o adimplemento exato e fiel do devedor principal ${ }^{87}$.

Na fiança o conteúdo da obrigação do fiador é a garantia $^{88}$ de adimplemento da obrigação principal, a partir do momento em que o garante se torna responsável pelo adimplemento alheio, sem que seja co-devedor.

E no quadro geral dos contratos, as garantias ocupam papel de destaque porquanto reforçam a possibilidade de adimplemento da obrigação, eis que induzem o devedor ao cumprimento, sob pena de sua responsabilização pessoal, com atingimento do seu patrimônio, ou ainda de terceiro, como ocorre na fiança ${ }^{89}$. Sempre que o credor teme o inadimplemento, procura garantia real ou pessoal. O devedor está sempre exposto a

85“A «cautio» romana - de «cavare», «cautum», garantir - reunia vários institutos jurídicos que tinham por finalidade assegurar e garantir o cumprimento de uma obrigação. Repetindo Windscheid, costumas os escritores dizer que as «cautiones», tendendo a essa finalidade, operavam ou de modo a estirpar de um direito qualquer dúvida, ou para assegurar a boa vontade do devedor, ou para assegurar o direito contra obstáculos de fato." (SANTOS, Moacir Amaral. Da fiança e de alguns dos benefícios do fiador. Revista dos Tribunais, São Paulo, n. 238, p. 3).

${ }^{86}$ Nesse sentido: LOPES, Miguel Maria de Serpa. Curso de direito civil. 4. ed. Rio de Janeiro: Freitas Bastos, 1993. v. 4, p. 461-462.

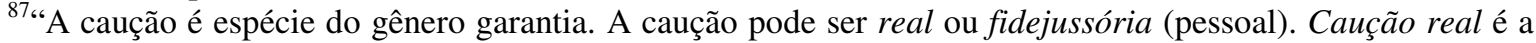
que vincula um bem móvel, imóvel ou semovente do devedor ou de terceiro pelo cumprimento da obrigação(...) Caução fidejussória ou pessoal é a dada por uma ou mais pessoas, que assumem o compromisso de pagar a obrigação, se o devedor não o fizer. A fiança é o modelo mais comum desta espécie de caução. A fiança é obrigação eminentemente pessoal. Em conseqüência, não vincula bens do fiador ao cumprimento da obrigação.” (OLIVEIRA, Lauro Laertes de. Da fiança. São Paulo: Saraiva, 1981. p. 2-3).

${ }^{88}$ Nas palavras de PONTES DE MIRANDA, Francisco Cavalcanti, “(...) prestação de segurança (Sicherheitsleistung)." "Segurança ou garantia é o reforçamento de algum direito, ordinàriamente crédito. Alguém por outrem, ou o próprio sujeito passivo da relação jurídica, com a sua promessa, ou com a dação da posse, ou do domínio, ou direito real limitado, torna mais fàcilmente executável a dívida ou mais fàcilmente exercível o direito." (In PONTES DE MIRANDA, Francisco Cavalcanti. Tratado de direito privado. 3. ed. 2. reimp. São Paulo: Ed. Revista dos Tribunais, 1984. t. 22, § 2.740, p. 299).

${ }^{89}$ Sobre o tema, OLIVEIRA, Lauro Laertes de: "É inquestionável o grande desenvolvimento trazido pelas cauções fidejussórias e reais para o desenvolvimento do crédito. A caução pessoal prestada por terceiro veio a fortalecer o adimplemento da obrigação e desenvolveu sobremaneira a realização dos negócios.(...) A fiança de uso correntio nos contratos de locações e contratos bancários jamais encontrou outra garantia similar que a substitutísse convincentemente nesses negócios. Dentre as inúmeras tentativas, máxime nos contratos locatícios, destacam-se a caução em dinheiro, o seguro de fiança ou o pagamento adiantado de aluguel. Mas nenhuma conseguiu suplantar a tradicional e costumeira caução fidejussória. Iniludivelmente é a garantia mais utilizada até nossos dias na maioria dos contratos de menor vulto. Trata-se de instituto pragmático e que substitui com êxito as garantias reais em várias hipóteses, em face das dificuldades que surgem para a prestação destas.” (In OLIVEIRA, Lauro Laertes de. op. cit., p. 3). 
eventualidades, que podem determinar insolvência e, pois, abertura de concurso de credores. Em vez de buscar devedores solidários, obtém a dívida de alguém que aceda à do devedor principal. A fiança foi, no passado, a garantia mais usual e ainda desempenha papel de relevo na vida econômica de hoje ${ }^{90}$; conforme doutrina Manuel Januário da Costa Gomes ${ }^{91}$ :

"Dentre as garantias pessoais de cumprimento avulta como estrela de primeira grandeza a fiança, desde logo porque é (...) a única das garantias pessoais regulada no capítulo do CC relativo às "garantias especiais das obrigações". Apesar de a fiança corresponder apenas a uma espécie de garantia pessoal - a garantia pessoal acessória - a sua importância ultrapassa o seu estrito campo de aplicação, já que o seu regime é de referência essencial para o estudo das garantias pessoais, maxime daquelas, como a garantia bancária autônoma, que não conhecem regulamentação legal.” (Grifamos)

A fiança sempre conheceu viva expansão, que se acentua especialmente nos períodos de incremento do tráfico jurídico. Através dela, o credor pode conseguir uma particular tranquilidade, uma vez que, ao lado do devedor, pessoa que ele pode desconhecer, surge o fiador, normalmente dele conhecido, ou de solvabilidade manifesta, respondendo pelos débitos do primeiro. É, no entanto, uma figura delicada, uma vez que, através da fiança, o fiador pode encontrar-se na situação de dever solver débitos consideráveis, de cuja constituição não colheu, inicialmente, qualquer vantagem e cujo regresso, contra o devedor é, muitas vezes, problemático ${ }^{92}$.

Assim, nos capítulos seguintes iremos apresentar o perfil dogmático desse instituto no direito brasileiro, procurando sistematizá-lo.

\subsection{Introdução}

O Código Civil de 2002 regulou o contrato de fiança nos arts. 818 a 839. Antes dele, o Código Civil de 1916 havia disciplinado o instituto nos arts. 1.481 a 1.504.

Em termos quantitativos são atualmente 21 dispositivos legais contra 23 da codificação revogada. Em termos qualitativos, porém, pouquíssimas foram as mudanças pelas quais passou este tipo contratual, à exceção de uma melhora na redação do texto

\footnotetext{
${ }^{90}$ PONTES DE MIRANDA, Francisco Cavalcanti. Tratado de direito privado. 3. ed. 2. reimp. São Paulo: Ed. Revista dos Tribunais, 1984. t. 44, § 4.78140, p. 93.

${ }^{91}$ In GOMES, Manuel Januário da Costa. Assunção fidejussória de dívida: sobre o sentido e o âmbito da vinculação como fiador. Coimbra: Almedina, 2000. p. 63.

${ }^{92}$ CORDEIRO, António Menezes. op. cit., v. 2, p. 510.
} 
legal, cuja preocupação principal do legislador foi a de emprestar uma maior clareza aos dispositivos.

Não obstante, o contrato de fiança é uma espécie dos denominados negócios de garantia $^{93}$, porém de natureza pessoal. À exceção do contrato de fiança, o Código Civil de 2002 não previu expressamente os negócios de garantia como gênero, da qual poderiam ter sido previstas outras modalidades assecuratórias de adimplemento contratual de acordo com a função a ser exercida pelas diversas modalidades contratuais. Por conta disso, a fiança continua a ser praticamente a única garantia contratual a desempenhar importante função sócio-econômica no Brasil, o que não deixa de ser criticável dada à grande insegurança jurídica que está a rondar esta modalidade contratual ${ }^{94}$.

O Código Civil de 2002, por sua vez, manteve a tradição do direito brasileiro em classificar, por gênero, as obrigações em dar, fazer ou não fazer, deixando de lado as obrigações de garantia; esta omissão do legislador brasileiro não deixa de ser criticável, na medida em que a obrigação de garantir não se exterioriza em um dar, fazer ou não fazer, mas simplesmente em um assegurar ${ }^{95}$. E as obrigações de garantia, enquanto um gênero autônomo, indicariam e reforçariam a possibilidade da formação de salvaguardas contratuais atípicas.

A doutrina civilista costuma apontar que a fiança como gênero, comportaria as espécies de fiança legal, judicial e consensual ${ }^{96}$; é desta última - a fiança consensual -, da qual nos ocupamos na presente dissertação.

Por esta razão, o presente Capítulo apresentará a dogmática relativa ao contrato de fiança, trazendo a estrutura jurídica do negócio e, quando necessário, tecendo críticas e apresentando soluções.

\footnotetext{
${ }^{93}$ Apenas a título exemplificativo, dizemos que dentre as modalidades de garantia amplamente difundidas na sociedade brasileira se encontram o penhor e a hipoteca (garantias reais), e a alienação fiduciária em garantia.

${ }^{94} \mathrm{~A}$ insegurança jurídica do contrato de fiança será desenvolvida e aprofundada em tópicos seguintes.

${ }^{95}$ Este parece ser o entedimento de Antônio Junqueira de Azevedo: "Acontece que essas duas qualificações, que, grosso modo, correspondem à divisão das obrigações em obrigações de dar e fazer (dare et facere), não esgotam todos os tipos contratuais quanto ao objeto. Antes de mais nada, por suas reminiscências romanas, em cujo direito alguns autores se referiam também às obrigações de garantia (praestare), convém lembrar contratos, como a fiança, em que a prestação - garantir - não é propriamente nem um dare nem um facere." (In AZEVEDO, Antônio Junqueira de. Estudos e pareceres de direito privado. São Paulo: Saraiva, 2004. p. 228).

${ }^{96}$ Cfe. SANTOS, Gildo dos. Fiança. São Paulo: Ed. Revista dos Tribunais, 2006. p. 44-49.
} 


\subsection{A importância da distinção entre Schuld (Obrigação, Débito) e Haftung (Responsabilidade) na fiança}

Antes de analisarmos a dogmática relativa ao contrato de fiança, cumpre que apontemos uma distinção de vital importância nos domínios do direito das obrigações, mas que revela especial importância nos contratos de garantia e em especial no contrato de fiança: a essencial distinção entre as figuras da schuld (obrigação, débito) e da haftung (responsabilidade).

Esta distinção foi fruto dos estudos desenvolvidos pelo jurista alemão Brinz, para quem schuld é o conteúdo da obrigação, o débito que poderá ser exigido pelo credor em desfavor do devedor; haftung, por sua vez, significa responsabilidade; em outras palavras, é o direito titularizado pelo credor de invadir o patrimônio do devedor para transferi-lo ao seu, dando vida à obrigação ${ }^{97,98}$.

Normalmente as figuras da schuld e da haftung incidem na pessoa do devedor; todavia, hipóteses há de titulares passivos que ostentam a haftung, mas não a schuld, como é o caso dos fiadores. Na fiança esta distinção é fundamental porque o fiador jamais será co-devedor ou titular passivo da obrigação, do débito, porém apenas será responsável ${ }^{99}$ pelo adimplemento do afiançado. Esta vem a ser a razão pela qual o fiador jamais poderá ser instado a cumprir a obrigação principal, que é a função principal do devedor, situação

\footnotetext{
${ }^{97}$ EHRLICH, Eugen: "Schuld is the Sollen of the debtor; it is that which according to the experience of life is considered the content of the obligation; liability (Haftung) is the right of the creditor to enforce his claim, a right which secures satisfaction even against the will of the debtor." (In EHRLICH, Eugen. Fundamental principals of the sociology of law. New Jersey: Transactions Publishers, 2002. p. 104-105).

${ }^{98}$ Segundo LÔBO, Paulo Luiz Netto, "Uma das mais importantes distinções do direito das obrigaçõe é a que estema a dívida da responsabilidade, de tal sorte que o devedor, pela obrigação, pode responder com seu patrimônio ou parte dele. É a teoria dualista da obrigação. Deve-se sua sistematização à doutrina alemã anterior ao respectivo Código Civil, tendo sido difundidos os termos originários de Schuld e Haftung, o primeiro consistindo no dever de prestar ou de observar determinado comportamento, e o segundo, na responsabilidade do patrimônio do devedor como garantia pelo inadimplemento, ou seja, de um estado de submissão de uma ou mais coisas. Diz Larenz que é necessário distinguir conceptualmente a responsabilidade da dívida, do dever de prestar, "mas aquela segue esta como a sombra ao corpo", de tal sorte que a "responsabilidade" que acompanha a "dívida" transmite a esta uma espécie de gravitação. Outros autores utilizam os termos latinos debitum e obligatio, com os mesmos significados da teoria dualista (em inglês: duty e liability; em francês: devoir e engagement)." (In LÔBO, Paulo Luiz Netto. Teoria geral das obrigações. São Paulo: Saraiva, 2005. p. 26-27).

${ }^{99}$ Nesse sentido doutrina LÔBO, Paulo Luiz Netto: "Mediante convenção das partes, pode ocorrer que a responsabilidade patrimonial, na execução forçada, seja de terceiro. O patrimônio de terceiro responde no lugar do patrimônio do devedor. São exemplos a responjabilidade do fiador pela dívida do devedor afiançado e as hipóteses de terceiros que garantiram com os seus bens dívidas que não eram suas, mediante hipoteca, penhor e anticrese. Também nesses casos há responsabilidade dissociada da dívida." (In LÔBO, Paulo Luiz Netto. op. cit., p. 29) (Grifamos)
} 
esta que se admissível fosse desnaturaria o caráter subsidiário da fiança. Sem a subsidiariedade o fiador não seria garantido, mas sim co-devedor ${ }^{100,101}$.

Assim, até o vencimento da obrigação a dívida deverá ser exigida do devedor, e não do fiador; este somente poderá ser responsabilizado se e quando o devedor (rectius, afiançado) não efetuar o pagamento prometido, pois desse fato é que nasce a sua responsabilidade. É por esta razão, por exemplo, que nos contratos de locação de imóveis urbanos até o vencimento os aluguéis devem ser exigidos do inquilino, mas não do fiador, cuja responsabilidade surgirá logo que a dívida vença e não seja cumprida pelo devedor principal.

É por esta razão que o devedor principal e o fiador jamais serão co-devedores, pois enquanto a dívida poderá ser exigida do primeiro, o segundo apenas será responsabilizado na hipótese de inadimplemento da obrigação. Mesmo quando o fiador se faz devedor principal, a sua principalização não o torna sujeito passivo na relação entre o credor e o devedor. Não há, na cláusula de devedor principal, assunção de dívida alheia. Por isso, é preciso ter-se todo o cuidado e toda a atenção na invocação de regras jurídicas sobre solidariedade das dívidas quando se cogita de fiador solidário. A solidariedade na fiança é atípica $^{102}$, pois que a sua única finalidade vem a ser a de pré-excluir a faculdade do garante manifestar o benefício da excussão ${ }^{103}$.

\footnotetext{
100، Também não são incomuns exemplos de responsabilidade sem débito, como no corriqueiro exemplo do fiador, que teria apenas a Haftung, permanecendo a Schuld em relação ao afiançado." (TEPEDINO, Gustavo; SCHREIBER, Anderson. Código Civil comentado. Coord. Álvaro Villaça Azevedo. São Paulo: Atlas, 2008. v. 4, p. 14).

${ }^{101} \mathrm{Em}$ sentido contrário afirmam DÍEZ-PICAZO, Luis; GULLON, Antonio: "Se dice que todas las veces en que alguien garantiza una deuda ajena, asume la responsabilidad pero que no debe. Asume una responsabilidad si el deudor no cumple simplemente. Pero en rigor el garante está también obligado, bien en grado subsidiario, bien al mismo nivel que el propio deudor (si la fianza es solidaria). El artículo 1.822 dice, refiriéndose al primer supuesto, que «por la fianza se obliga uno a pagar o cumplir por un tercero-en caso de no hacerlo» El fiador, pues, es un obligado al pago, y solo en su defecto el acreedor podrá dirigirse contra su patrimonio. (In DÍEZ-PICAZO, Luis; GULLON, Antonio. Sistema de derecho civil. 6. ed. Madrid: Tecnos, 1992. v. 2, p. 129).

${ }^{102}$ PONTES DE MIRANDA, Francisco Cavalcanti. op. cit. v. 44, § 4.783, p. 105; o mesmo autor apontava: "A solidariedade fidejussória sòmente ocorre se foi preestabelecida. Nas dívidas solidárias, há identidade do interêsse passivo dos devedores. $O$ interêsse passivo do fiador e o que possa ser vantagem para o devedor, mesmo se se trata de fiança da fiança. A ssunção de dívida solidária pode ter sido com intuito de garantia, mas, ainda assim, não se confunde com a fiança, nem muda de estrutura. Nas dívidas solidárias, o vínculo de cada devedor é independente; na fiança, depende do vínculo da dívida garantida." (In op. cit., p. 105). (Grifamos)

${ }^{103}$ Em sentido dúbio, DINIZ, Maria Helena: "Subsidiariedade, pois, devido ao seu caráter acessório, o fiador só se obrigará se o devedor principal ou afiançado não cumprir a prestação devida, a menos que se tenha estipulado a solidariedade. Nessa hipótese, assumirá a posição de co-devedor, sem que isso desfigure a fiança." (In DINIZ, Maria Helena. Curso de direito civil brasileiro: teoria das obrigações contratuais e extracontratuais. 17. ed. atual. São Paulo: Saraiva, 2002. v. 3, p. 505). (Grifamos)
} 
Em outras palavras, sem que a obrigação se torne exigível não haverá responsabilidade do fiador ao adimplemento, razão pela qual, em boa técnica, o fiador sempre será responsável sem que seja devedor. Neste sentido aponta Álvaro Villaça Azevedo ${ }^{104}$ :

"Quando a obrigação não se cumpre pela forma espontânea é que surge a responsabilidade.

\section{(...)}

Como exemplo de responsabilidade sem obrigação, menciona o caso do fiador, que é responsável, mas não é obrigado. Realmente, suponhamos que alguém se proponha a ser fiador num contrato de locação. $\mathrm{O}$ proprietário do prédio aluga-o ao inquilino, exigindo que este apresente um fiador. "A obrigação de pagar aluguel é do inquilino e não do fiador, sendo este responsável a qualquer pagamento, se o inquilino não cumprir a sua obrigação de pagar o que deve em razão desse contrato." (Grifamos)

Segundo afirmava Pontes de Miranda ${ }^{105}$,

“A obrigação resulta do dever; que é obrigado só o é porque deve.

(...)

Observe-se que não confundimos a obrigação e a executibilidade do patrimônio."

E especificamente sobre a distinção da schuld e da haftung na fiança, Pontes de Miranda ${ }^{106}$ escreveu:

“O fiador não assume a dívida afiançada. Apenas promete que o devedor adimplirá.

(...)

O fiador responde por seu patrimônio. A sua dívida não é a dívida do devedor afiançado.(...) o fiador promete - portanto, a isso se vincula - o adimplemento pelo devedor; de modo que o adimplemento, por êle, é adimplemento pelo adimplemento do devedor. Adimple a sua dívida, que é dívida do adimplemento pelo devedor principal." (Grifamos)

Dessa forma, sendo o fiador responsável pelo adimplemento da obrigação principal, porém não co-devedor, daí se conclui que do garante não poderá ser exigida a prestação,

\footnotetext{
${ }^{104}$ In AZEVEDO, Álvaro Villaça. Teoria geral das obrigações. 10. ed. São Paulo: Atlas, 2004. p. 39-40.

${ }^{105}$ In PONTES DE MIRANDA, Francisco Cavalcanti. op. cit., t. $22 \S 2.680$, p. 24.

${ }^{106}$ In Id. op. cit., t. 44, § 4.781, p. 93.
} 
razão por que será apenas e tão-somente responsabilizado, em conjunto ou separadamente com aquele, se acaso não ocorrer a entrega da prestação de acordo com os termos ajustados entre o credor e o devedor principal.

\subsection{Existência, Validade e Eficácia}

O direito se destina a regular a vida em sociedade através de um sistema de normas constituído de regras e princípios. Para tanto, se situa em uma dimensão do mundo que se ostenta abstrata ${ }^{107}$, fundada em modelos de conduta e diretrizes que tencionam ser aplicáveis a todas as situações da vida que neles se enquadrarem se e quando ocorrerem. Antes que os fatos da vida ocorram e dêem ensejo à incidência dessas normas, isto é, antes que as normas se ostentem aplicáveis às relações da vida que foram concretizadas, o mundo do direito é pura abstração, desconectado da realidade social subjacente ${ }^{108}$.

Assim, a fim de qualificarmos determinado fato da vida como jurídico ou nãojurídico, importa saber se ocorreu ou não o fenômeno da incidência; se o modelo abstrato figurado na norma caiu sobre um fato da vida, juridicizou-o, tornou-o um fato jurídico.

É a incidência, pois, que em um primeiro momento qualifica os fatos da vida como jurídicos ou não-jurídicos, permitindo que ingressem na primeira dimensão abstrata do mundo do direito, que é a do plano da existência. Portanto, serão jurídicos (plano da existência), os fatos da vida que saíram do mundo fático e ingressaram no mundo do direito. Porém, somente isto não bastará para a sobrevivência do fato no mundo jurídico.

Alguns fatos sociais - e para a presente dissertação nos interessa apenas os negociais -, a despeito de existirem no mundo do direito, não podem conter defeitos para que nele se mantenham; devem obedecer a certos requisitos que a lei prevê como suficientes para que na segunda dimensão abstrata do mundo do direito que é a do plano da validade, onde o direito fará a triagem entre o que é perfeito (que não tem qualquer vício invalidante) e o que está eivado de defeito invalidante.

\footnotetext{
${ }^{107}$ Porque opera unicamente no campo das idéias, dos gêneros, desligado da realidade sensível.

108“'Os sistemas jurídicos são sistemas lógicos, compostos de proposições que se referem a situações da vida, criadas pelos interesses mais diversos. Essas proposições, regras jurídicas, prevêem (ou vêem) que tais situações ocorrem, e incidem sôbre elas, como se as marcassem. Em verdade, para quem está no mundo em que elas operam, as regras jurídicas marcam, dizem o que se há de considerar jurídico e, por exclusão, o que se não há de considerar jurídico. Donde ser útil pensar-se em têrmos de topologia: o que entra e o que não entra no mundo jurídico." (In PONTES DE MIRANDA, Francisco Cavalcanti. Tratado de direito privado. 3. ed. 2. reimpr. São Paulo: Ed. Revista dos Tribunais, 1984. t. 1, § 4.781, p. IX).
} 
Como conseqüência da triagem realizada pelo sistema jurídico no plano da validade, se o negócio jurídico estiver conforme os requisitos previstos na lei, dir-se-á que se ostenta válido; porém, se não estiver conforme a solução do sistema decretar-se-á a sua invalidade, a qual contempla os defeitos da nulidade e da anulabilidade, demandando a sua exclusão do mundo jurídico.

Atravessadas as fronteiras dos planos da existência e da validade, cumpre ser verificado se o negócio jurídico estará ou não apto a produzir efeitos. Esta é a principal característica da última dimensão ou plano do mundo jurídico que é a da eficácia. O plano da eficácia é a parte do mundo jurídico onde os fatos jurídicos produzem os seus efeitos, criando as situações jurídicas, as relações jurídicas, com todo o seu conteúdo eficacial representado pelos direitos $\rightleftarrows$ deveres, pretensões $\rightleftarrows$ obrigações, ações e exceções, ou os extinguindo. ${ }^{109,}$

Plano da existência, plano da validade e plano da eficácia são os três planos nos quais a mente humana deve sucessivamente examinar o negócio jurídico, a fim de verificar se ele obtém plena realização ${ }^{110}$.

Ao situarmos o mundo jurídico como aquele que se estrutura em planos ou dimensões do fenômeno jurídico, cumpre apontarmos quando e quais são os elementos necessários e comuns aos vários tipos de negócios jurídicos para que sejam considerados existentes, válidos e eficazes ${ }^{111}$.

Segundo a concepção que adotamos, reproduzimos na tabela abaixo os elementos de existência, validade e eficácia dos negócios jurídicos em geral:

\footnotetext{
${ }^{109}$ MELLO, Marcos Bernardes de. Teoria do fato jurídico: plano da existência. 12. ed. São Paulo: Saraiva, 2003. p. 98.

${ }^{110}$ AZEVEDO, Antônio Junqueira de. Negócio jurídico e declaração negocial: noções gerais e formação da declaração negocial, cit., p. 24.

${ }^{111}$ As concepções aqui expostas a partir da teoria geral do direito civil não têm a pretensão de esgotar ou aprofundar o tema, mas apenas e tão-somente apresentar o nosso entedimento sobre o tema e permitir a sua aplicação ao contrato de fiança.
} 


\begin{tabular}{|c|c|c|c|}
\hline \multicolumn{2}{|c|}{ Existência } & Validade & Eficácia \\
\hline Vontade & $\begin{array}{l}\text { Seriedade } \\
\text { Finalidade Negocial }\end{array}$ & Capaz & $\begin{array}{lr}\text { Direitos, } & \text { Deveres, } \\
\text { Pretensões, } & \text { Ações, } \\
\text { Exceções; Condição, } & \text { Crmo e Encargo. }\end{array}$ \\
\hline Objeto & & $\begin{array}{lr}\text { Lícito, } & \text { Possível, } \\
\text { Determinado } & \text { ou } \\
\text { Determinável } & \end{array}$ & \\
\hline Forma & & $\begin{array}{l}\text { Prescrita e Não Defesa } \\
\text { em Lei }\end{array}$ & \\
\hline
\end{tabular}

Para que um negócio jurídico valha no mundo do direito, é preciso que exista; existindo e valendo, cumpre ao intérprete verificar se se apresenta eficaz. Superados estes três planos ou dimensões do fenômeno jurídico contratual, será possível de se dizer, que do ponto de vista lógico, a análise do negócio estaria completa.

Plano da Existência.

O primeiro elemento de existência de um negócio jurídico é a presença de um agente, quer pessoa ou sujeito de direito, pois sendo o negócio jurídico uma relação jurídica qualificada pelo elemento negocial, é mister a sua alteridade, a sua concretização entre sujeitos de direitos, determinados ou determináveis, para que ingresse no mundo jurídico e seja um negócio jurídico.

O segundo elemento de existência é a vontade ${ }^{112}$; não mais a vontade livre, soberana e quase sem peias que se apresentava como uma expressão do direito à liberdade, mas sim uma vontade qualificada como sendo a expressão de uma das exteriorizações possíveis da dignidade da pessoa humana ${ }^{113}\left(\mathrm{CF}\right.$, art. $1^{\circ}$, III). Vontade esta consistente na

\footnotetext{
${ }^{112}$ Contra a posição adotada no texto: AZEVEDO, Antônio Junqueira: “(...) procuraremos demonstrar que a vontade não é elemento necessário para a existência do negócio (plano da existência), tendo relevância somente para a sua validade e eficácia; segue-se daí que, não fazendo ela parte da existência do negócio, muito menos poderá ser elemento definidor ou caracterizador do negócio.” (AZEVEDO, Antônio Junqueira de. Negócio jurídico e declaração negocial: noções gerais e formação da declaração negocial, cit., p. 9).

${ }^{113}$ Conforme abordaremos adiante, os civilistas que na atualidade advogam a metodologia do direito civilconstitucional como a mais adequada a estes tempos pós-modernos possuem uma certa dificuldade para delimitar o conteúdo do princípio da dignidade da pessoa humana, o que acaba contribuindo para a sua utilização mais como um topos argumentativo do que como uma diretriz orientadora, o que, em certa medida, faz com que se esmaeça a necessária força do preceito; portanto, ainda que este princípio, por sua própria natureza e topografia tenha uma dimensão meta-jurídica, eis que inserido pelo legislador constitucional brasileiro como fundamento da República Federativa do Brasil, o que explica sua íntima conexão com os direitos fundamentais, mister se faz que busquemos a sua identidade jurídica, a fim de se-
} 
prerrogativa de autodeterminação consciente do indivíduo, com vistas à sua plena realização pessoal, profissional e social ${ }^{114}$. E esta vontade há que ser séria, pois dadas as consequiências que decorrem da ínsita vinculatividade dos negócios jurídicos, o sistema nega reconhecimento à manifestação imbuída de animus jocandi; e ainda deverá ser portadora de uma finalidade negocial, pois aquele que a manifestou deve necessariamente ter tido em mira vincular-se à determinada categoria contratual, a determinado tipo de negócio. Esta finalidade negocial é, segundo entendemos, um querer qualificado, posto dirigido à escolha do negócio jurídico ao qual o manifestante pretende vincular-se.

O terceiro elemento de existência dos negócios jurídicos é o objeto; todo negócio jurídico traz em seu conteúdo um acordo sobre bens da vida ou interesses que compõem o suporte fático da norma que o tipifica e o qualifica como tal. Por exemplo, o bem móvel ou imóvel é objeto necessário à existência do contrato de venda e compra; sem este não haverá contrato de venda e compra, mas poderá haver outra categoria de negócio.

O quarto elemento de existência é a forma que reveste a manifestação negocial (verbal, escrita, pelo silêncio etc.). Não há negócio jurídico sem forma, uma vez que as vontades necessitam de ser exteriorizadas, ainda que sejam simplesmente verbais ou por gestos, ou que as condutas sejam reconhecidas como geradoras de obrigações ${ }^{115}$. Todo e qualquer negócio jurídico deve ser exteriorizado, isto é, apresentar-se ao mundo para que

lhe atribuirmos efetividade. Segundo escreve MORAES, Maria Celina Bodin de: "O princípio constitucional visa garantir o respeito e a proteção da dignidade humana não apenas no sentido de assegurar um tratamento humando e não degradante, e tampouco conduz ao mero oferecimento de garantias à integridade física do ser humano. Dado o caráter normativo dos princípios constitucionais, princípios que contêm os valores ético-jurídicos fornecidos pela democracia, isto vem a significar a completa transformação do direito civil, de um direito que não mais encontra nos valores individualistas de outrora o seu fundamento axiológico. Neste ambiente de um renovado humanismo, a vulnerabilidade humana será tutelada, prioritariamente, onde quer que ela se manifeste. De modo que terão precedência os direitos e as prerrogativas de determinados grupos considerados, de uma maneira ou de outra, frágeis e que estão a exigir, por conseguinte, a especial proteção da lei. Nestes casos estão as crianças, os adolescentes, os idosos, os portadores de deficiências físicas e mentais, os não-proprietários, os consumidores, os contratantes em situação de inferioridade, as vítimas de acidentes anônimos e de atentados a direitos da personalidade, os membros da família, os membros de minorias, dentre outros. Seguramente, este é o aspecto mais visível da mencionada transmutação." (In MORAES, Maria Celina Bodin de. Princípios do direito civil contemporâneo. In: (Coord.). Rio de Janeiro: Renovar, 2006. p.15) (Grifamos)

${ }^{114} \mathrm{Na}$ realidade, a vontade é elemento de existência do negócio jurídico porque a lei a elegeu como componente do suporte fático de toda a normativa contratual. (Cfe. MELLO, Marcos Bernardes de. Teoria do fato jurídico: plano da existência. 12. ed. São Paulo: Saraiva, 2003. p. 166). A bem dizer, o elemento vontade é parte integrante dos tipos contratuais porque representa o querer do sujeito de direito necessário à sua vinculação intersubjetiva; na atualidade, ousamos afirmar que há duas manifestações dessa vontade: vontade-desejo e vontade-necessidade. Na primeira, o sujeito teria uma liberdade maior de atuação, eis que teria à sua disposição a opção de contratar ou não (liberdade de contratar) e um certo poder de ajustar o conteúdo do contrato, estipulando cláusulas e condições do negócio (liberdade contratual); na segunda, inexistira qualquer liberdade (direito de opção) seja em relação à escolha da categoria jurídica a ser estabelecida (v.g., venda e compra, locação, fiança etc.), seja em relação à delimitação das cláusulas e condições do negócio, hipótese esta da qual é exemplo frisante os denominados contratos de ou por adesão.

${ }^{115}$ LÔBO, Paulo Luiz Netto. Direito civil: parte geral. São Paulo: Saraiva, 2009. p. 245. 
seja conhecido e vincule os participantes e a sociedade ${ }^{116}$; enquanto a vontade situar-se apenas e tão-somente na mente dos figurantes do negócio ela não terá, em princípio, qualquer relevância para o direito.

Em síntese, segundo a concepção que adotamos os elementos de existência dos negócios jurídicos são: a) agente; b) vontade séria e portadora de finalidade negocial; c) objeto; d) forma.

Plano da Validade.

Ao contrário dos elementos de existência do negócio jurídico, o legislador brasileiro cuidou de estabelecer aqueles outros que para o sistema seriam considerados déficits, deficiências que maculariam a integridade jurídica do negócio, porém não afetariam a sua existência como negócios jurídicos, isto é, não impediriam o seu ingresso no mundo do direito. Tais elementos constam do art. 104 do Código Civil de 2002 e são: "I - agente capaz; II - objeto lícito, possível, determinado ou determinável; III - forma prescrita ou não defesa em lei."

O primeiro elemento ou requisito de validade dum negócio jurídico é a capacidade do agente, do sujeito de direito que pretende beneficiar-se do negócio; e capacidade é a aptidão de vincular-se juridicamente, estabelecendo direitos e deveres conforme a ordem jurídica

O segundo elemento ou requisito de validade é que o objeto seja lícito (conforme o direito), possível (material ou juridicamente), determinado ou determinável (delimitável quer em seu gênero, qualidade ou quantidade).

O terceiro elemento ou requisito de validade é o da forma prescrita ou não defesa em lei, isto é, que a forma (rectius, aparência) da qual se revestiu a manifestação de vontade esteja de acordo com o modelo imposto pelo legislador em determinado tipo de negócio (v.g., os solenes) ou pelo menos não tenha sido proibida pelo sistema (v.g., nãosolenes).

Em síntese, segundo a concepção que adotamos os elementos ou requisitos de validade dos negócios jurídicos são: a) capacidade do agente; b) licitude, possibilidade, determinação ou determinabilidade do objeto; c) prescrição ou não-proibição da forma.

\footnotetext{
${ }^{116}$ Esta vinculação da sociedade será explicada quando analisarmos o princípio da função social do contrato.
} 


\section{Plano da Eficácia.}

Por fim, os elementos de eficácia dos negócios jurídicos são as conseqüências jurídicas extraídas dos negócios jurídicos que perpassaram os planos da existência e da validade, em regra ${ }^{117}$. No plano da eficácia é que surgem os direitos, deveres, pretensões e exceções dos negócios jurídicos como resultado da incidência jurídica da norma sobre o fato da vida, razão pela como resultado da incidência os sujeitos de direito poderão modificar as conseqüências jurídicas do negócio apondo-lhe condições, termos ou encargos, alterando uma ou mais consequiências práticas etc. ${ }^{118}$.

Apresentada a estrutura geral dos negócios jurídicos, procuraremos aplicá-la ao contrato de fiança.

\section{4. $O$ conceito de fiança}

Do latim fido, fidis, fidere, fisus, fisum, tem, entre outras acepções, a de ter confiança, confiar em, fiar-se em, contar com, significando, mesmo na linguagem comum, garantir, abonar, fiar a obrigação alheia, e a própria quantia com que essa obrigação é caucionada ${ }^{119}$.

No artigo 818 do Código Civil de 2002 o legislador buscou definir o contrato de fiança nos seguintes termos, verbis:

"Art. 818. Pelo contrato de fiança, uma pessoa garante satisfazer ao credor uma obrigação assumida pelo devedor, caso este não a cumpra."

Conforme se pode perceber, o legislador da novel codificação manteve quase que a mesma redação do art. 1.481 do Código Civil de 1916:

\footnotetext{
${ }^{117}$ Dissemos “em regra: porque excepcionalmente o sistema jurídico tolera ou admite que os negócios jurídicos nulos surtam efeito (v.g., casamento nulo etc.).

118“"A eficácia jurídica é irradiação do fato jurídico; portanto, depois da incidência da regra jurídica no suporte fático, que assim, e só assim, passa a pertencer ao mundo jurídico. Incidência é prius; e a incidência supõe a regra jurídica e o suporte fáctico, sôbre o qual ela incida. A eficácia é, pois, lògicamente, posterius; o que não exclui a produção de eficácia desde antes ou até antes da incidência, ou da própria regra jurídica, ou da concepção e elaboração mesma da regra jurídica." (In PONTES DE MIRANDA, Francisco Cavalcanti. Tratado de direito privado. 3. ed. 2. reimp. São Paulo: Ed. Revista dos Tribunais, 1983. t. 5, § 505, p. 3).

${ }^{119}$ CHAVES, Antônio. Tratado de direito civil. São Paulo: Ed. Revista dos Tribunais, 1982, v. 2, t. 2, p. 1224.
} 
“Art. 1.481. Dá-se o contrato de fiança, quando uma pessoa se obriga por outra, para com seu credor, a satisfazer a obrigação, caso o devedor não a cumpra."

A definição legal do contrato de fiança baseou-se nos efeitos do contrato e não na sua estrutura. Pela definição adotada pelo legislador no art. 818 do Código Civil, é possível de se extrair que a fiança seria o contrato mediante o qual uma pessoa (o fiador) garantiria ao credor (afiançado) satisfazer a obrigação (adimplir) assumida pelo devedor, caso este não a cumpra (inadimplemento).

Portanto, à luz da dogmática atual a fiança apresentaria apenas 2 (dois) sujeitos: o credor e o fiador. No entanto, apesar de o afiançado (devedor principal) não fazer parte da fiança, é certo que a sua figura se ostenta importante porque sem a existência do afiançado não haveria causa à garantia, isto é, a função econômico-social típica da fiança que é a de garantir o adimplemento da obrigação pelo afiançado; em outras palavras, não haveria débito pelo qual se responsabilizaria o fiador.

É por esta razão que Antônio Junqueira de Azevedo aponta que o débito é a causa, ainda que pressuposta, da fiança, de modo que sem o débito não haveria responsabilidade fidejussória porque a fiança seria nula ${ }^{120}$.

Ora, a responsabilidade do garante de satisfazer aquela que não foi adimplida pelo devedor principal é uma das conseqüências que resultam da promessa fidejussória.

A grande maioria dos civilistas, por sua vez, apenas enxerga o contrato de fiança a partir da sua definição legal, considerando que pelo negócio fidejussório o fiador se obrigaria a cumprir a obrigação do devedor principal se este não o fizer, o que não é correto. Segundo Lauro Laertes de Oliveira ${ }^{121}$,

"Fiança é o contrato acessório, pelo qual uma ou mais pessoas obrigamse, perante o credor, a cumprir a obrigação do devedor, se este não o fizer no prazo e forma legais."

\footnotetext{
${ }^{120}$ In AZEVEDO, Antônio Junqueira de. Negócio jurídico: existência, validade e eficácia. São Paulo: Ed. Revista dos Tribunais, 2002. p. 159-160: "Passando, finalmente, a tratar do papel da causa nos negócios com causa pressuposta, quer-nos parecer que a causa poderá influenciá-los no plano da validade, e não mais no plano da eficácia. Assim, a solução será, quando faltar o fato justificador do negócio (a que seu elemento categorial inderrogável faz referência), considerá-lo nulo). É a "solução francesa" sobre a causa (causa como requisito de validade) Se, num mútuo, não houve a entrega da coisa, o negócio é nulo; nulo também se deverá considerar o reconhecimento do filho ilegítimo que, posteriormente, vem a saber não ser realmente filho; nula a fiança que garante débito inexistente; nula a dação em pagamento, sem débito anterior, etc." (Grifamos)

${ }^{121}$ OLIVEIRA, Lauro Laertes de. op. cit., p. 5.
} 
Esta vem a ser a mesma linha adotada, dentre outros doutrinadores, por Maria Helena Diniz ${ }^{122}$ :

\begin{abstract}
"A fiança ou caução fidejussória vem a ser a promessa, feita por uma ou mais pessoas, de garantir ou satisfazer a obrigação de um devedor, se este não a cumprir, assegurando ao credor o seu efetivo cumprimento $(\mathrm{CC}$, art. 818). Portanto, haverá contrato de fiança sempre que alguém assumir, perante o credor, a obrigação de pagar a dívida, se o devedor não o fizer."
\end{abstract}

Na realidade, a obrigação do fiador e a obrigação do devedor principal são distintas: a do fiador é de garantia, a do devedor é, normalmente, de pagar, podendo ainda ser de dar, fazer ou de não-fazer, distinção essa que já expusemos no item 4.2.

Aquele que apenas garante o adimplemento não pode ser ao mesmo tempo fiador e devedor principal ${ }^{123}$ à luz da dogmática atual, pois do contrário não seria apenas garante, mas co-devedor. E se co-devedor fosse seria também responsável principal pelo adimplemento, e não apenas subsidiário.

Portanto, como a natureza jurídica das respectivas obrigações é distinta, não se pode baralhar a situação jurídica do fiador com a do devedor principal. Enquanto a responsabilidade do devedor principal é a de adimplir a obrigação tal qual se vinculou, a obrigação do fiador é a de garantir que o adimplemento dar-se-á tal e qual se vinculou o afiançado.

O fiador não promete cumprir a obrigação do devedor principal se este não o fizer. Ao contrário, a sua eventual obrigação de pagar dívida alheia é mera conseqüência do descumprimento da obrigação principal em relação à qual se responsabiliza ${ }^{124}$.

$\mathrm{Na}$ realidade, o fiador efetua prestação de garantia, isto é, de reforço do adimplemento da obrigação principal; promete que o devedor principal adimplirá ${ }^{125}$ a sua obrigação no modo, tempo e forma combinados. Com efeito, o contrato de fiança é caso típico de promessa de fato de terceiro: o fiador garante, perante o credor, o adimplemento das obrigações assumidas pelo devedor principal ou afiançado. E segundo esclarece

\footnotetext{
${ }^{122}$ In DINIZ, Maria Helena Curso de direito civil brasileiro. 17. ed. São Paulo: Saraiva, 2002. v. 3, p. 504.

${ }^{123}$ Em tópico específico será adequadamente abordada a situação do devedor que subscreve a fiança na qualidade de "devedor principal".

${ }^{124}$ Nestes termos, GALGANO, Francesco: "Figura tipica de garanzia personale è la fideiussione: è il contratto con il quale una persona, il fideiussore, garantisce l'adempimento di una obbligazione altrui, obbliganosi personalmente verso il creditore (art. 1936 comma $1^{\circ}$ ) $\mathrm{Al}$ contratto il debitore è estraneo: la fideiussione è, anzi, efficace anche se il debitore non ne fosse neppure a conoscenza (art. 1936 comma $2^{\circ}$ )." (In GALGANO, Francesco. Diritto privato. 6. ed. Pádova: Cedam, 1990. p. 376-377).

125 "O fiador garante o adimplemento do afiançado, e firma o compromisso de solver, se o não fizer o devedor.” (PEREIRA, Caio Mário da Silva. op. cit., v. 3, p. 307). (Grifamos)
} 
Roberto Senise Lisboa ${ }^{126}$, o jurista francês Rene Demogue teria cunhado a expressão obrigação de garantia, segundo a qual o devedor se comprometeria, por força de lei, a garantir a satisfação dos interesses do credor. A fiança é uma relação jurídica de garantia, situando os sujeitos do contrato em posições jurídicas peculiares. O fiador é sujeito passivo de responsabilidade, sem ser devedor imediato; o credor, frente ao fiador, é sujeito ativo de direito expectativo eventual ${ }^{127}$.

Segundo entendemos, esta vem a ser a mais adequada visualização do negócio fidejussório, pois coloca em ordem correta a finalidade da fiança: garantir o adimplemento duma obrigação e, em consequência, satisfazê-la em caso de inadimplemento.

E isto porque o fiador, ao prestar a garantia, promete reforçar o adimplemento da obrigação, o seu cumprimento natural, razão pela qual nenhum fiador presta fiança em garantia de devedor principal já inadimplente, insolvente ou em vias de tornar-se. Pelo contrário, o fiador também confia na idoneidade do fiador principal, de maneira que leva em consideração, no ato de subscrição da garantia, o grau do risco a que estará exposto. $\mathrm{O}$ fiador crê que o devedor principal irá cumprir rigorosamente as obrigações por ele assumidas no contrato afiançado, isto é, confia, crê, se fia no adimplemento do devedor principal, pois do contrário não prestaria fiança.

Daí porque a promessa de garantia de adimplemento do fiador há que ser cercada de seriedade e reflexão, o que infelizmente não acontece na prática na imensa maioria dos contratos, pois muitos dos negócios são firmados entre amigos ou familiares, situação esta em que a negativa em prestar a fiança causaria uma situação extremamente desconfortável e penosa ao fiador, daí termos denominado as fianças de típicos negócios de constrangimento $^{128}$. Em outras palavras, podemos ainda dizer que a fiança é um típico negócio de risco ${ }^{129}$.

\footnotetext{
${ }^{126}$ In LISBOA, Roberto Senise. Manual de direito civil. 3. ed. rev., atual. e ampl. São Paulo: Ed. Revista dos Tribunais, 2004. v. 2, p. 176.

${ }^{127}$ PASQUALOTTO, Adalberto. Contratos nominados III. Coord. Miguel Reale e Judith Martins-Costa. São Paulo: Ed. Revista dos Tribunais, 2008. p. 227.

${ }^{128}$ Esta expressão - "negócios de constrangimento" - foi por nós cunhada em razão daquilo que ordinariamente acontece na origem da prestação da garantia fidejussória. Normalmente um amigo ou parente, valendo-se desse grau de amizade ou parentesco, põe à prova o fiador e a sua "lealdade" para com ele, muitas vezes valendo-se de argumentos sentimentais de que "não poderá locar o único imóvel apropriado ao seu negócio" ou de que "não poderá comprar o imóvel dos sonhos", porque estão exigindo fiador e ele - o devedor principal - não teria outra alternativa a não ser "pedir este favor", que de favor nada tem. E para não perder a amizade ou entristecer o parente, bem como para não carregar em seus ombros o peso e a culpa pelo insucesso alheio, haja vista a existência de uma situação moralmente desconfortável, embaraçosa ou vergonhosa - daí a expressão "negócios de constrangimento" - o fiador presta a garantia e se arrepende para o resto da vida...

${ }^{129} \mathrm{E}$ o que doutrina GOMES, Manuel Januário da Costa: "Dizer-se que a fiança é um negócio de risco é o mesmo que dizer que é um negócio de perigo para o fiador, maxime nas fianças de amigos, parentes ou
} 
Em nosso sentir, a fiança pode ser conceituada como o negócio jurídico unilateral, gratuito, solene, acessório e intuitu personae, por meio do qual o fiador presta em favor do credor de uma obrigação a garantia de adimplemento do afiançado ${ }^{130}$. O fiador promete que o devedor principal adimplirá, razão pela qual é devedor (rectius, responsável) de uma promessa de fato: o adimplemento de terceiro ${ }^{131}$.

\subsubsection{Elementos do contrato de fiança ${ }^{132}$}

Partes

Partindo das premissas desenvolvidas nos itens precedentes, indicamos, em primeiro lugar, que o negócio jurídico fidejussório compõe-se de duas partes (dois agentes): a) o credor; b) o fiador; ainda que em determinado negócio estejam presentes as

conhecidos prestadas por pessoas singulares, sem ligação com o exercício duma actividade profissional." (In GOMES, Manuel Januário da Costa. op. cit., p. 119).

${ }^{130} \mathrm{Na}$ visão de PONTES DE MIRANDA, Francisco Cavalcanti, com a qual concordamos, "A fiança é promessa de ato-fato jurídico ou de outro ato jurídico, porque o que se promete é o adimplemento do contrato, ou do negócio jurídico unilateral, ou de outra fonte de dívida,de que se irradiou, ou se irradia, ou vai irradiar-se a dívida de outrem." (In PONTES DE MIRANDA, Francisco Cavalcanti. op. cit. v. 44, § 4.781, p. 91).

${ }^{131}$ Ainda Segundo PONTES DE MIRANDA, Francisco Cavalcanti: "O fiador vincula-se à prática do ato de outrem, que é o devedor principal: o fiador tem de adimplir o que prometeu. Em consequiência disso, é devedor daquilo que prometeu: o ato-fato jurídico do pagamento, ou outro ato jurídico de adimplemento." (In PONTES DE MIRANDA, Francisco Cavalcanti. op. cit., t. 44, § 4.781, p. 92). Uma breve nota se faz necessária: de acordo com a doutrina pontiana relativa aos fatos jurídicos em sentido lato, os ato-fatos jurídicos são todos aqueles que necessariamente devem ser realizados pelo homem (elemento material), independentemente da vontade (elemento subjetivo). O suporte fático da norma exige para a sua concretização a intervenção humana, porém abstraindo totalmente a vontade em praticá-lo; o homem, a bem dizer, será mero instrumento material de consecução do ato-fato jurídico.

${ }^{132}$ Segundo doutrinava PEREIRA, Caio Mário da Silva, as características do contrato de fiança são: "Em nosso meio, é um contrato muito freqüente, particularmente adjeto à locação, como a contratos bancários. Além do "aval" o mais freqüente é a "fiança". Caracteres jurídicos. É um contrato: a) unilateral, porque gera obrigações somente para o fiador. Alguns escritores (Clóvis Beviláqua, M. I. Carvalho de Mendonça) o inscrevem entre os bilaterais imperfeitos, sob a justificativa de que pode surgir o direito do credor contra o afiançado para haver o que pagou e mais acessórios. 3 Não há, porém, bilateralidade eventual de obrigações, senão mera conseqüência da sub-rogação e simples repercussão dos efeitos do pagamento, o que permite ao fiador proceder contra o devedor, sem que se afetem as relações contratuais estabelecidas entre fiador e credor;4 b) gratuito, porque cria vantagens para uma só das partes, nenhum benefício auferindo o fiador. Mediante estipulação, poderá este haver do afiançado remuneração pela garantia oferecida, como compensação pelo risco assumido.5 A prática dos negócios, aliás, consagra o princípio, com a instituição freqüente de ajustes que tais, especialmente na vida bancária; c) intuitu personae, porque ajustado em função da confiança de que desfruta o fiador; d) acessório, como todo contrato de garantia, porque pressupõe sempre a existência de obrigação principal, seja esta de natureza convencional, seja de natureza legal. Como contrato acessório, e essencialmente acessório, mesmo que ajustada a solidariedade, 6 segue a sorte do principal - sequitur principale - mas não há identidade entre um e outro: se a fiança não pode ser mais onerosa (in duriorem causam), pode ser inferior ao valor da obrigação garantida, como também é possível dar fiança condicional ou a termo a uma obrigação pura e simples." (In PEREIRA, Caio Mário da Silva. op. cit., v. 3, p. 304). 
figuras do abonador ou do retrofiador ${ }^{133}$, por exemplo, ainda assim o negócio jurídico base necessariamente compõe-se dos dois agentes apontados.

Em primeiro lugar, a dogmática adotada pelo legislador do Código Civil de 2002 não deixa qualquer margem a dúvidas quanto aos figurantes necessários do contrato de fiança, na medida em que o art. 820 do Código enuncia:

"Art. 820. Pode-se estipular a fiança, ainda que sem consentimento do devedor ou contra a sua vontade." (Grifamos)

Com efeito, deflui da regra legal que se a vontade do afiançado é indiferente à configuração do negócio fidejussório, conclui-se que o devedor principal não é parte no contrato de fiança, porque não teria sentido que fosse obrigado a firmá-lo "contra a sua vontade”, como enuncia o art. 820 do Código Civil. Portanto, do pacto fidejussório não participa o devedor, pois o contrato de fiança é entre o fiador e o credor, e não entre o fiador e o afiançado ${ }^{134,135}$.

Aliás, a fiança poderá ser até mesmo convencionada contra a vontade do devedor principal $^{136}$, o que demonstra que este não faz parte do pacto fidejussório ${ }^{137}$. É o que doutrinava Pontes de Miranda ${ }^{138}$ :

\footnotetext{
${ }^{133} \mathrm{O}$ que poderá render ensejo a existência de coligação contratual; vede MARINO, Francisco Paulo De Crescenzo. Contratos coligados no direito brasileiro. São Paulo: Saraiva, 2009.

${ }^{134}$ PONTES DE MIRANDA, Francisco Cavalcanti. op. cit. v. 44, § 4.781, 4, p. 95.

${ }^{135}$ No mesmo sentido: DINIZ, Maria Helena. Código civil anotado. São Paulo: Saraiva, 1995. p. 862: “A fiança é um negócio entabulado entre credor e fiador, prescindindo da presença do devedor e podendo até mesmo ser levado a efeito sem o seu consenso, por não ser parte na relação jurídica fidejussória."; MONTEIRO, Washington de Barros et al:: "Pode-se estipular a fiança, ainda sem consentimento do devedor, ou contra a sua vontade (art. 820 do Cód. Civil de 2002). Em regra, o fiador intervém a pedido do afiançado, prestando-lhe assim um favor; contudo, pode aquele afiançar à revelia do afiançado, pois a fiança é contrato restrito a fiador e credor e em que não figura o devedor. A fiança pode, pois, ser concedida e passada na ignorância e sem o consentimento do devedor; e até mesmo contra a sua vontade." (In MONTEIRO, Washington de Barros et al. Curso de direito civil. 36. ed. São Paulo: Saraiva, 2009. 2. pte, p. 399).

136، A fiança conclui-se entre fiador e credor. O contrato principal, entre o credor e o afiançado, constitui outra relação jurídica. Se é freqüente o devedor procurar e solicitar quem lhe garanta a solvência, e se não é raro conter-se a fiança no corpo do contrato principal, como cláusula deste, não se descaracteriza subjetivamente. Pode, mesmo, ser estipulada na incidência e até contra a vontade do devedor, sem sofrer degradação e não tem o afiançado a liberdade de recusá-la sob invocação do princípio invito non datur beneficium, mesmo porque o beneficiário é o credor e não devedor. Não há, também, na fiança uma relação contratual tripartite, porém dois negócios jurídicos distintos, que se ligam pela idéia de acessoriedade. (PEREIRA, Caio Mário da Silva. op. cit., v. 3, p. 306).

137،A fiança pode ser convencionada, não só sem o consentimento do devedor, mas até contra a sua vontade ou com a sua oposição. Se na prática isto não se dará, pois a tendência dos homens é para fugurem às responsabilidades, não há jurìdicamente empecilho algum à prestação de fiança em tais condições. A razão disto está em que a fiança é uma garantia do credor e não pode negar-se-lhe o direito de tôdas as possíveis seguranças; e o devedor, que não quiser sujeitar-se a uma possível acção de regresso dum fiador, que lhe é antipático, ou que é seu inimigo, tem o fácil remédio de pagar a dívida no seu vencimento e até antes de
} 


\begin{abstract}
"O negócio jurídico bilateral é entre o fiador e o credor, que é o outorgado. Nenhuma ingerência jurídica tem, no contrato, o afiançado, dito devedor principal. De regra, o devedor principal promete a fiança, em cláusula do contrato de que se gera a dívida, ou em pacto adjecto, ou em negócio jurídico unilateral, ou bilateral, ou plurilateral, o que é quod plerumque fit se a dívida é de origem extranegocial. Não raro o devedor apenas manifesta a sua vontade de ter fiador, porém não se pode dizer, com exatidão, que aí "consinta" ou "assinta", salvo se em algum negócio jurídico foi estipulado que as fianças, obtidas pelo credor, teriam de ser concluídas com ciência e assentimento do devedor principal. No Código Civil, diz o art. 1.484: "Pode-se estipular a fiança, ainda sem consentimento do devedor". Entende-se: sem manifestação de vontade do devedor, ou mesmo contra a sua vontade. Alguém pode afiançar a dívida do desconhecido, ou ser desconhecido quem afiançou. Conforme teremos de frisar, desconhecido pode ser o próprio credor, desde que não se elidam com isso, a bilateralidade do negócio jurídico."
\end{abstract}

Em conclusão, pode-se afirmar que o contrato de fiança é negócio jurídico bilateral. Portanto, não há fiança sem que o credor aceite a fiança oferecida, ou sem que, tendo o credor oferecido que se afiançasse (dito exigido, pedido), aceite dar a fiança. Quase sempre, da parte do credor, existe invitatio ad offerendum ${ }^{139}$.

Vontade fidejussória (Animus Fideiubendi, seriedade e finalidade negocial)

Em segundo lugar, o elemento vontade nesta espécie contratual compõe-se de animus fideiubendi, seriedade e de finalidade negocial, que formam o conteúdo duma vontade qualificada em vincular-se à determinada categoria contratual, no caso ao contrato de fiança.

Ao falar-se de fiança e de obrigação fidejussória supõe-se ter havido, por parte de quem emitiu a declaração de vontade, o propósito ou a intenção de afiançar (animus fideiubendi); a existência desse animus supõe que o declarante conhece o sentido $e$ as consequências da prestação de fiança, no que à sua vinculação concerne, supondo, portanto, que o fiador sabe o que está a fazer ${ }^{140}$. A exigência de inequívoca declaração de

vencida. Doutro lado, pode a fiança ser convencionada sòmente entre o devedor e o fiador, a favor de um credor indeterminado; e êste, realizando o contrato com o devedor, ipso facto aceita aquêle fiador." (GONÇALVES, Luiz da Cunha. Tratado de direito civil. 2. ed. portuguesa, atual. e aum. e 1. ed. brasileira, anotada por Dimas Rodrigues de Alckmin. 1. ed. São Paulo: Max Limonad, 1955. v. 5, t. 1, p. 204) (Grifamos).

${ }^{138}$ PONTES DE MIRANDA, Francisco Cavalcanti. op. cit. v. 44, p. 92.

${ }^{139}$ Id. Ibid., § 4.787, p. 143-144.

${ }^{140}$ Cfe. GOMES, Manuel Januário da Costa. op. cit., p. 403-404. 
vontade do fiador é plenamente justificável, pois implicando assumir obrigação alheia, a fiança altera a regra geral da responsabilidade própria ${ }^{141}$.

Nesse sentir, enquanto a seriedade ${ }^{142}$ representa a firme promessa em afiançar ${ }^{143}$, a finalidade negocial na fiança deve necessariamente refletir a vontade livre e consciente do fiador em prometer o adimplemento do afiançado no modo, tempo e lugar estipulados no contrato garantido. Em razão da própria natureza da promessa de adimplemento, que em geral na fiança adquire contornos de gratuidade e se destina a salvaguardar os interesses de pessoas que mantêm contato próximo com o garante ${ }^{144}$, justifica-se uma salvaguarda mínima da posição jurídica do fiador, a qual, no entanto, não pode chegar ao ponto de tolher-lhe completamente a liberdade de afiançar, situação esta que representaria uma profunda violação ao princípio da dignidade da pessoa humana.

\footnotetext{
${ }^{141}$ PASQUALOTTO, Adalberto. op. cit., p. 230.

${ }^{142}$ Apenas para que seja ilustrada a nossa afirmação, a seriedade na fiança assume contornos bíblicos. Com efeito, em dez ocasiões a Bíblia Sagrada enuncia versículos que tratam diretamente da figura da fiança ou do fiador, ora demonstrando que o fiador é um garantidor ora aconselhando as pessoas dos perigos e dos riscos da fiança:

"Gênesis

44.32 Porque teu servo se deu por fiador por este moço para com o meu pai, dizendo: Se eu o não tornar a trazer-te, serei culpado para com o meu pai todos os dias.

Jó

17.3 Dá-me, pois, um penhor; sê o meu fiador para contigo mesmo; quem mais haverá que se possa comprometer comigo?

Salmos: 119.122 Sê fiador do teu servo para o bem; não permitas que os soberbos me oprimam; Provérbios: 6.1 Filho meu, se ficaste por fiador do teu companheiro e se te empenhaste ao estranho; 11.15 Quem fica por fiador de outrem sofrerá males, mas o que foge de o ser estará seguro; 17.18 O homem falto de entendimento compromete-se, ficando por fiador do seu próximo; 20.16 Tome-se a roupa àquele que fica fiador por outrem; $e$, por penhor, àquele que se obriga por estrangeiros; 22.26 Não estejas entre os que se comprometem e ficam por fiadores de dividas; 27.13 Tome-se a roupa àquele que fica fiador por outrem; e, por penhor, àquele que se obriga por mulher estranha; Hebreus: 7.22 por isso mesmo, Jesus se tem tornado fiador de superior aliança." (In SOCIEDADE BIBLICA DO BRASIL Disponível em: $<$ http://www.sbb.org.br/interna.asp?areaID=71>. Acesso em: 19 set. 2009) (Grifamos)

143“LOCAÇÃO - Imóvel comercial - Cobrança dirigida contra os fiadores - Procedência da ação - Sentença mantida - Inocorrência de cerceamento de defesa - Inexistência de elementos a autorizar a invalidação da fiança formalmente em ordem - $\mathrm{O}$ fato do locatário e de um dos fiadores estarem vinculados por relação empregatícia não os exime das obrigações avençadas no contrato de locação, tratando-se os fiadores de pessoas maiores e capazes e ausente qualquer indício de que se trata de situação especial que foge à realidade do "homem médio" a indicar vício de consentimento - Anulação que deve ser pleiteada em ação própria - Fiança prestada, sem limitação da garantia, estando incluídas as obrigações principais e acessórias - Recurso não provido." (TJSP - Apelação Cível n. 992.05.087992-7 - Jundiaí - 35ª Câmara de Direito Privado - Relator: Manoel Justino Bezerra Filho - 21.09.09 - V.U. - Voto n. 7.957) (Grifamos)

144،Quem afiança, em princípio, sòmente o faz por amizade, altruísmo ou solidariedade humana." (PONTES DE MIRANDA, Francisco Cavalcanti. op. cit., t. 44, § 4.785, p. 115).
} 


\section{Objeto}

Em terceiro lugar, o elemento objeto na fiança é a promessa, manifestada pelo fiador, de que o devedor principal adimplirá a sua obrigação ${ }^{145}$, podendo recair sobre o adimplemento de dívidas futuras ou presentes ${ }^{146}$.

Com relação às dívidas futuras, algumas palavras se fazem necessárias. O art. 821 do Código Civil enuncia que as dívidas futuras podem ser objeto de fiança. Como já apontamos, o objeto na fiança não é a dívida do afiançado que porventura poderá surgir, mas sim a promessa de adimplemento do afiançado. A dívida do afiançado representa, no contrato de fiança, a sua causa pressuposta.

Não obstante, quando esta promessa tiver por finalidade garantir o adimplemento de dívidas futuras ${ }^{147}$, estas deverão ser entendidas como toda e qualquer obrigação cuja existência estiver submetida a uma condição suspensiva no ato de outorga da garantia, obrigação esta que porventura poderá surgir em face do devedor principal em decorrência do contrato sobrejacente à fiança. Ora, essa vem a ser, segundo entendemos, a única exegese viável, porque, por definição, o fiador garante o adimplemento de todas as obrigações imputáveis ao afiançado de forma ilimitada ${ }^{148}$, incluindo nestas as que surgirem após a outorga da garantia; assim, todas as obrigações surgidas após a outorga da garantia se apresentarão como futuras ${ }^{149}$, razão pela qual não teria qualquer sentido se o legislador

\footnotetext{
145“'Objeto da dívida fidejussória é o que há de prestar o fiador, o que o credor quer obter com a vinculação do fiador.(...) O objeto da fiança simples (fiança à dívida) e o objeto da subfiança ou fiança à fiança (fiança ao fiador) são diferentes. O que o fiador de regresso ou retrofiador promete é o que o devedor principal (ou o fiador afiançado) deva, em via de regresso, ao fiador (ou ao subfiador)." (PONTES DE MIRANDA, Francisco Cavalcanti. op. cit. v. 44, § 4.781, p. 96).

${ }^{146}$ Código Civil: "Art. 821. As dívidas futuras podem ser objeto de fiança; mas o fiador, neste caso, não será demandado senão depois que se fizer certa e líquida a obrigação do principal devedor."; Contrario sensu, em regra o objeto recai sobre dívidas presentes.

147،FIANÇA - PRESTAÇÃO PARA GARANTIR DÍVIDA FUTURA - ARTIGO 1.485 DO CÓDIGO CIVIL - NOVAÇÃO INEXISTENTE - EXIGIBILIDADE DO DÉBITO QUANDO CONSTITUÍDO COM A ANUÊNCIA DO FIADOR - APELAÇÃO NÃO PROVIDA - Do incontestável caráter acessório da fiança, resulta claro que, quando se refere à obrigação futura, só passa a vigorar depois de fixada a principal. Tal requisito ocorre "depois que não houver mais dúvida sobre a existência dessa obrigação que se ache fixada a importância devida". No caso em foco, a fiança não se vincula à nota promissória e esta cártula não traduz a fixação da obrigação principal vislumbrada na carta, mesmo porque dessa pretensa constituição de dívida não participaram os fiadores. Evidentemente, se a fiança concerne à dívida futura e esta fica estabelecida sem participação dos fiadores, não há como lhes imputar responsabilidade." $\left(1^{\circ}\right.$ TACIVIL - 4 ${ }^{\text {a }}$ Câm.; Ap. n 345.576-SP; rel. Juiz Amauri Ielo; j. 06.11.1985; v.u.). BAASP, 1427/99, de 23.04.1986.

${ }^{148}$ Código Civil: “Art. 822. Não sendo limitada, a fiança compreenderá todos os acessórios da dívida principal, inclusive as despesas judiciais, desde a citação do fiador."

${ }^{149}$ “A fiança de dívida futura é uma fiança anterior à dívida; significa que o fiador obriga-se a garantir a execução, no caso em que venha a existir. Tal é a hipótese da fiança a um crédito aberto; obriga até o limite do crédito ou o limite inferior declarado, desde que a pessoa, em cujo favor é aberto, usa do crédito, recebendo quantias por conta dêle, isto é, tornando-se devedora. Por isso mesmo a fiança de dívida futura não é exigível, senão depois que se faz certa e líquida a obrigação afiançada: certa, quanto à sua existência
} 
tivesse enunciado o óbvio, uma verdadeira petição de princípio. Logo, deve-se entender por dividas futuras apenas aquelas obrigações submetidas a uma condição suspensiva.

\section{Forma}

Em quarto lugar, o elemento forma na fiança representa aquele de que se deve revestir a manifestação contratual fidejussória, vale dizer, a exteriorização da manifestação de vontade; no caso, a fiança é contrato solene porque deverá adotar a forma escrita ${ }^{150}$. A forma substancial tem por objetivo obrigar as pessoas a refletir sobre as consequências daquele negócio jurídico, a facilitar o reconhecimento do negócio jurídico por terceiros e quando se impuser maior segurança ${ }^{151}$.

Vistos os elementos de existência, cumpre apontarmos os requisitos de validade da fiança.

\section{Plano da Validade}

Os elementos de validade do contrato de fiança, por sua vez, são os mesmos de todo e qualquer negócio jurídico e se encontram previstos no art. 104 do Código Civil:

a) agente capaz; em regra, poderão ser fiadoras as pessoas que tenham a livre disposição dos seus bens ${ }^{152}$. Nesse sentir, poderá ser fiador todo aquele que detiver capacidade genérica para praticar os atos da vida civil, isto é, capacidade de administrar bens e aliená-los, como também legitimidade para afiançar ${ }^{153}$; o fiador tem de ter capacidade jurídica.

Porém, há restricões. Umas de ordem legal, envolvendo certas pessoas em razão de ofício ou função (e. g., agentes fiscais, tesoureiros, leiloeiros, tutores e curadores pelos pupilos e curatelados), ou atingindo as entidades públicas - e. g., o governador não pode prestar fiança sem autorização da Assembléia Legislativa; as autarquias não podem ser fiadoras, salvo as instituições de previdência social na locação de casa ocupada pelos seus

e líquida, quanto à sua importância." (ALVES, João Luiz. Código Civil da República dos Estados Unidos do Brasil anotado. 3. ed. Rio de Janeiro: Borsoi, 1958. v. 5, p. 146-147).

${ }^{150}$ Código Civil: “Art. 819. A fiança dar-se-á por escrito, e não admite interpretação extensiva.”.

${ }^{151}$ LÔBO, Paulo Luiz Netto. Direito civil: parte geral, cit., p. 255.

${ }^{152} \mathrm{Cfe}$. MONTEIRO, Washington de Barros et al. op. cit., p. 396; de acordo com o mesmo autor: "Se analfabeto o fiador, nula será a fiança prestada em seu nome, desde que se não apresente procuração por instrumento público outorgada por ele próprio." (In Id. Ibid., p. 397).

${ }^{153}$ Cfe. DINIZ, Maria Helena. Curso de direito civil brasileiro: teoria das obrigações contratuais e extracontratuais, cit., v. 3, p. 506. 
associados (Decreto-lei $\mathrm{n}^{\circ}$ 1.308, de 31 de maio de 1939); ou as unidades militares em favor dos oficiais e praças que as compõem. Outras, de ordem convencional, mediante ajuste expresso, como nos contratos constitutivos de sociedade, ao interdizerem aos seus gerentes e administradores assumir esta responsabilidade em negócios estranhos aos interesses sociais. No mútuo feito a menor, a fiança dada a este é inválida, e não é lícito ao credor recobrar o empréstimo do fiador (Código Civil, art. 588) ${ }^{154}$.

Ainda no plano da validade, cumpre perquirir: seria válida a fiança prestada por analfabetos, deficientes auditivos e visuais?

Sim, responde a doutrina, desde que atendidos certos requisitos.

Segundo Sílvio de Salvo Venosa ${ }^{155}$, o analfabeto e o cego não estariam impedidos de afiançarem, porém para a validade da manifestação da garantia seriam necessárias escritura pública ou procuração por instrumento público, nos termos dos artigos 819 e 1661, II e IV, do Código Civil. Lauro Laertes de Oliveira ${ }^{156}$, por sua vez, comunga do mesmo entendimento, apenas tendo acrescentado que na procuração outorgada devem constar "poderes expressos e especiais para afiançar". Pontes de Miranda ${ }^{157}$ também entende que, "O fiador analfabeto ou que não pode escrever é que só o pode ser por instrumento público." 158 A posição sustentada pela doutrina demonstra os cuidados que devem ser tomados para que validamente os analfabetos, deficientes auditivos e visuais prestem fiança.

b) objeto lícito, possível, determinado ou determinável; neste tópico, duas questões relativas à validade da fiança, segundo entendemos, se apresentam relevantes:

\footnotetext{
${ }^{154}$ PEREIRA, Caio Mário da Silva. Instituições de direito civil. 11. ed. Rio de Janeiro: Forense, 2003. v. 3, p. 305.

${ }^{155}$ In VENOSA, Sílvio de Salvo. Direito civil. 2. ed. São Paulo: Atlas, 2002. v. 3, p. 416.

${ }^{156}$ In OLIVEIRA, Lauro Laertes de. op. cit., p. 30-31.

${ }^{157}$ In PONTES DE MIRANDA, Francisco Cavalcanti. op. cit., v. 44, § 4.786, p. 128.

158“"FIADOR ANALFABETO - INTERESSE COLETIVO. Não tem eficácia a fiança prestada por pessoa analfabeta ou que não saiba ler ou escrever. A liberdade dos contratantes sobre a criação ou a estipulação de vínculos obrigacionais está subordinada às normas jurídicas e ao interesse coletivo." (2. ${ }^{\circ}$ TACivSP, Ap. 604551-0/9, rel. Juiz Irineu Pedrotti, 10. ${ }^{\text {a }}$ Câm., j. 25.04.2001, v.u.); "FIANÇA PRESTADA POR ANALFABETO - Pessoa sem nenhum estofo econômico, incapaz de despertar em quem quer que seja a convicção de que poderia honrar, de favor, compromissos para terceiros que nem conhece. Nulidade da fiança por ausência de vontade substancial e formalmente declarada. Provimento do recurso para julgar procedentes os embargos e extinguir a execução por falta de título." (TJSP, Ap. 1044103-0/, rel. Des. Rosa Maria de Andrade Nery, 34. ${ }^{a}$ Câm., j. 12.12.2007, v.u.); "FIANÇA PRESTADA POR ANALFABETO - O analfabeto só poderá prestar fiança pessoalmente por instrumento público, ou por instrumento particular se for representado no ato por procurador legalmente constituído.” (2. 'TACivSP, Ap. 465811, rel. Juiz José

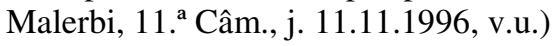


(b.1) ocorrerá a nulidade da fiança todas as vezes que o contrato subjacente à garantia for nulo, nos termos do art. $824,1 .^{a}$ parte, do Código Civil ${ }^{159}$, tendo em vista a acessoriedade do contrato de garantia;

(b.2) não ocorrerá a nulidade da fiança se o contrato subjacente à garantia for nulo em decorrência de incapacidade pessoal do devedor, nos termos do art. 824, 2. ${ }^{\text {a }}$ parte, do Código Civil ${ }^{160}$.

Por primeiro, com relação à premissa estabelecida no item (b.1), extraímos o princípio segundo o qual inexistente ou nulo o contrato garantido, inexistente ou nula será a fiança. Esta inexistência ou nulidade decorre do caráter acessório da fiança, porquanto as suas existência e validade jurídicas somente ocorrerão se e enquanto também se mantiverem estas mesmas características dos contratos garantidos. Por conseguinte, a nulidade da fiança não implicará na nulidade do contrato garantido, conclusão esta que decorre do caráter acessório da garantia (o acessório segue a sorte do principal).

Da mesma forma ocorre com as denominadas obrigações naturais, não sendo estas afiançáveis. E isto porque a ausência de eficácia ou de exigibilidade da pretensão representaria, na expressiva locução de Pontes de Miranda ${ }^{161}$, a existência de "direitos mutilados”, que nada mais são do que aqueles carentes de pretensão, do poder de exigir, razão pela qual não teria sentido garantir uma obrigação inexigível ${ }^{162}$.

Por segundo, com relação à premissa estabelecida item (b.2), destacamos que a única exceção à nulidade apontada se encontra na hipótese prevista no parágrafo único, do art. 824 do Código Civil, segundo o qual se a obrigação garantida for nula em decorrência da incapacidade do devedor afiançado, esta incapacidade não contaminará a

\footnotetext{
${ }^{159}$ Civill Art. 824. As obrigações nulas não são suscetíveis de fiança (...)."

${ }^{160}$ Código Civil Art. 824. As obrigações nulas não são suscetíveis de fiança, exceto se a nulidade resultar apenas de incapacidade pessoal do devedor." (Grifamos)

161 "Há direitos que não têm ou perderam pretensão ou ação. Circunstâncias históricas deram ao fato nome impróprio, pois ao complexo "direito, pretensão e ação", tirando-se a ação, ou a ação e a pretensão, ficaria direito. Em verdade, trata-se de direitos desprovidos de pretensões ou da ação, ou de direitos mutilados." (In PONTES DE MIRANDA, Francisco Cavalcanti. Tratado de direito privado. 4. ed. São Paulo: Ed. Revista dos Tribunais, 1983. t. 6, § 640, p. 40).

${ }^{162}$ Nesse sentido doutrinam GODOY, Claudio Luiz Bueno de: "Quanto as obrigações naturais, desde que decorrentes de dívia ou aposta, vige a regra prevista no art. $818, \S 1 .^{\circ}(\ldots)$. No que toca às obrigações prescritas, por isso que igualmente despidas de ação, prevalece o entendimento de que não são afiançáveis, porquanto uma forma de dotar de exigibilidade uma dívida que não a possui, mercê de obrigação acessória que não se pode dissociar da principal(...)."(In GODOY, Claudio Luiz Bueno de. Código civil comentado: doutrina e jurisprudência. Coord. Cezar Peluso. 3. ed. rev. e atual. Barueri: Manole, 2009. p. 811); VENOSA, Sílvio de Salvo: "É ineficaz a fiança de obrigação natural, pois, por ser inexigível, não pode ser cobrado o fiador". (In VENOSA, Sílvio de Salvo. Direito civil, cit., v. 3, p. 415).
} 
fiança, ainda que vier a ser anulada a obrigação principal ${ }^{163}$. No entanto, o parágrafo único do artigo 824 e o artigo $588^{164}$, do Código Civil, enunciam preceitos específicos que proíbem a concessão de fiança nas hipóteses de mútuos concedidos a menores, "quando este não tiver sido previamente autorizado pelo respectivo representante legal: neste caso, determina a lei, a dívida não poderá ser exigida de ninguém (art. 588). ${ }^{165 ",}$

c) forma prescrita ou não defesa em lei ${ }^{166}$; no contrato de fiança a forma do negócio foi erigida pelo legislador como elemento de validade ${ }^{167}$, a qual não é meramente ad proabationem, mas sim ad substantiam (ad solemnitatem) ${ }^{168}$. É da substância da própria fiança que o contrato adote a forma escrita. Se a fiança tiver sido, v.g., manifestada verbalmente, totalmente nula será a própria fiança que não poderá vir a ser demonstrada por qualquer outro meio.

\subsubsection{As figuras da abonação (subfiança ${ }^{169}$ ), retrofiança e cofiança}

Ao lado da fiança encontram-se outras figuras de pouca utilização no Brasil, mas que ainda são citadas pela doutrina. São elas a abonação (subfiança) e a retrofiança; a cofiança, por sua vez, é a mais comum das três, razão pela qual trataremos em conjunto as figuras.

\footnotetext{
${ }^{163}$ Cfe. NERY JUNIOR, Nelson; NERY, Rosa Maria de Andrade. Código Civil comentado. 7. ed. rev. atual. e ampl. São Paulo: Ed. Revista dos Tribunais, 2009. p. 739.

${ }^{164}$ Código Civil: "Art. 588. O mútuo feito a pessoa menor, sem prévia autorização daquele sob cuja guarda estiver, não pode ser reavido nem do mutuário, nem de seus fiadores."

${ }^{165}$ NORONHA, Fernando. Direito das obrigações. São Paulo: Saraiva, 2003. v. 1, p. 252. Esclarece ainda o citado autor que: "Como se vê, os empréstimos feitos a menores são objeto de um regime jurídico especialmente restritivo, que proíbe que eles sejam afiançáveis. A razão da severidade da lei nesta matéria, proibindo a fiança, tem apenas uma justificativa histórica, que já vem do Direito Romano: ela deriva do senatusconsultus Macedonianum (Dig., 14, 16, 1, pr.), que visava punir os mutuantes, para coibir a exploração da inexperiência de menores. Os senatusconsulta eram, como o próprio nome indica, respostas a consultas feitas ao Senado romano, que tinham força igual à das leis." (In ob. cit., p. 252).

${ }^{166}$ De acordo com a doutrina de THEODORO JÚNIOR, Humberto, "Embora a tendência moderna esteja voltada para o rumo da liberalização das formas, a lei ainda exige maiores solenidades para determinados negócios jurídicos, a respeito dos quais entende deva haver maior cuidado com a autenticidade da declaração, com a garantia da livre manifestação da vontade das partes, e com o rigor na prova do negócio." (In THEODORO JÚNIOR, Humberto. Comentários ao novo Código Civil. Coord. Sálvio de Figueiredo Teixeira. 3. ed. Rio de Janeiro: Forense, 2005. p. 381).

${ }^{167}$ Código Civil: "Art. 819. A fiança dar-se-á por escrito, e não admite interpretação extensiva.".

${ }^{168}$ Estas são da substância do ato ou negócio, "que só se completaria e se aperfeiçoaria quando revestido de tais formas.” (RODRIGUES, Silvio. Direito civil: parte geral. 34. ed. atual. 6. tir. São Paulo: Saraiva, 2007. p. 177). (Grifamos)

${ }^{169}$ Explica DINIZ, Maria Helena que a subfiança é "Aquela fiança que tinha por objeto uma outra. Era o contrato pelo qual alguém afiançava a obrigação do fiador. Todavia, urge lembrar que alguns autores ainda a admitem como contrato atípico." (In DINIZ, Maria Helena. Dicionário jurídico. 3. ed. rev. atual. e aum. São Paulo: Saraiva, 2007. p. 225).
} 
Abonação (Subfiança) é uma fiança prestada por uma pessoa ao próprio fiador, sendo que aquele que a presta é chamado de abonador, que vem a ser o fiador do fiador. A abonação é "uma garantia acessória da fiança, que já era acessório da dívida principal." ${ }^{170,171} \mathrm{Na}$ fiança da fiança há um contrato pelo qual o fiador do fiador se obriga para com o credor a satisfazer a dívida do fiador, caso este não a cumpra. Quer dizer: o fiador abonado ou afiançado está para o fiador do fiador, como o verdadeiro devedor principal para o credor $^{172}$. Conforme doutrinava Pontes de Miranda ${ }^{173}$,

\begin{abstract}
"A subfiança é a fiança a fiador; afiança-se a dívida a que o fiador, com a sua promessa, assumiu. O fiador prometeu que o devedor principal adimpliria; o subfiador promete que o fiador adimplirá o que prometeu: o adimplemento pelo devedor principal. A subfiança é afiançável, o que estabelece a possibilidade de subfianças a subfianças. Nada obsta a que a subfiança seja anterior à fiança, uma vez que se preveja a sua dação. Assim como se pode afiançar a dívida futura, afiançável é a futura fiança. As circunstâncias podem sugerir ou exigir que se preste a subfiança antes de se ter concluído o contrato de fiança.

(...)

A fiança da fiança garante o adimplemento pelo fiador: o credor tem ação contra o fiador do fiador, como fiador do segundo grau. O subfiador que paga sub-roga-se nos direitos do credor a quem pagou e pode ir contra o fiador ou contra o devedor.

O fiador do fiador sòmente tem de adimplir se o fiador não adimple. Não importa se incapaz o fiador afiançado, ou o devedor, ou ambos. O fiador do fiador tem por si o benefício da excussão, se não se fêz fiador solidário do fiador."
\end{abstract}

A retrofiança, ao contrário, é um contrato realizado entre o fiador e o retrofiador, pelo qual este se obriga a garantir e assegurar o direito de regresso e reembolso daquele contra o devedor principal. Nessa relação jurídica, o devedor, por quem o retrofiador se obriga, é o mesmo devedor principal; e o credor do retrofiador é o fiador, e não o credor da obrigação principal, que não aparece na relação. Desse modo, o retrofiador está para o fiador, como este está para o credor $^{174}{ }^{175}$; enquanto a subfiança é fiança da fiança, a

\footnotetext{
${ }^{170}$ GONÇALVES, Luiz da Cunha. op. cit., v. 5, t. 1, p. 193.

171، Assim o abonador ou fiador do fiador, pagando, integralmente, a dívida, fica subrogado, de acôrdo com o estatuido no art. 1495, 1a parte, do código civil, nos direitos do credor contra o fiador abonado ou afiançado, seu devedor principal, e pode, por conseguinte, cobrá-la dêle por inteiro." (NETO, Soriano. Pareceres. Separata da: Revista Acadêmica da Faculdade de Direito do Recife, Recife, v. 2, p. 57, 1947).

${ }^{172}$ Cfe. Id. Ibid., p. 58.

${ }^{173}$ In PONTES DE MIRANDA, Francisco Cavalcanti. op. cit., t. 44, 2. ed. 3.impr., § 4.784, p. 106-107.

${ }^{174}$ Cfe. NETO, Soriano. op. cit., p. 58.

${ }^{175}$ Segundo DINIZ, Maria Helena, a retrofiança é "Aquela em que há uma relação com o credor sub-rogado, pois o retrofiador garante o devedor perante o fiador que exerce o direito de crédito no qual se sub-rogou." (In DINIZ, Maria Helena. Dicionário jurídico, cit., p. 225).
} 
retrofiança se apresenta como fiança à fiança ${ }^{176}$. Conforme doutrinava Pontes de Miranda $^{177}$,

\begin{abstract}
"A retrofiança (Rückbürgschaft) é a fiança para o caso de regresso do fiador contra o devedor principal, de jeito que se promete ao fiador que o devedor principal atenderá à pretensão de regresso. Os princípios sobre a fiança são sempre invocáveis. Alguém, que preste a fiança, se expõe a que o devedor principal, que deixou de adimplir, também não tenha meios ou dificulte a prestação de regresso. Daí a conveniência prática da retrofiança. Pode dar-se que sejam simultâneas, ou que a própria retrofiança seja prestada, para que o futuro fiador se vincule pelo contrato de fiança. O retrofiador tem exceção de ação prévia de que cogita o art. 1.491 do Código Civil (beneficium excussionis)."
\end{abstract}

Em síntese: a fiança pode ter por objeto outra fiança. Chama-se subfiança o contrato pelo qual alguém afiança a obrigação do fiador. $\mathrm{O}$ fiador do fiador denomina-se abonador. Se o fiador exige do devedor outro fiador para o caso que venha a exercer seu direito regressivo, diz-se que há retrofiança ${ }^{178}$.

Já a figura da cofiança pressupõe uma pluralidade de fiadores que se responsabilizam pelo adimplemento de uma obrigação de forma própria ou comum, como esclareceu Pontes de Miranda ${ }^{179}$. Cofiadores próprios são aqueles que se vincularam separadamente, talvez mesmo sem se conhecerem, enquanto cofiadores comuns são aqueles que se vincularam conjuntamente sobre a mesma obrigação ${ }^{180}$.

Ao nosso sentir, a principal distinção entre a cofiança própria e a comum reside nas consequências relativas ao eventual pagamento do débito e à nulidade da garantia. Na cofiança própria, se cada cofiador se responsabilizou independentemente do outro, o cofiador que pagar a dívida não terá ação de regresso contra os demais, mas apenas poderá voltar-se contra o devedor principal, pois cada cofiança é considera independente das demais. Já na cofiança comum, incidirá o artigo 829 do Código Civil, de maneira que entre os cofiadores será estabelecido ex lege um vínculo de solidariedade entre, de modo que a nulidade da fiança ou a eventual insolvência de um dos fiadores será disciplinada pelos

\footnotetext{
${ }^{176}$ Cfe. PONTES DE MIRANDA, Francisco Cavalcanti. op. cit. v. 44, § 4.781, p. 107.

${ }^{177}$ In Id. Ibid., $\$ 4.784$, p. 108.

${ }^{178}$ GOMES, Orlando. Contratos. 18. ed. Rio de Janeiro: Forense, 1998. p. 437.

${ }^{179}$ In PONTES DE MIRANDA, Francisco Cavalcanti. op. cit. v. 44, § 4.784, p. 108.

${ }^{180} \mathrm{Cfe}$. Id. Ibid., p. 108-109.
} 
artigos $184^{181}$ e $283^{182}$ do Código Civil, o que demonstra a importância da exata distinção entre as espécies de cofiança.

Por fim registre-se que nas cofianças solidárias ex lege ou nas fianças solidárias ex voluntate, incide o artigo 204, $\S 1 .^{\circ}$, do Código Civil $^{183}$, de modo que o curso da prescrição de uma pretensão eventualmente exercitável contra os co-obrigados solidários, se acaso for interrompida em face de apenas um deles estará automaticamente interrompida em face dos demais, o que demonstra, em nosso sentir, que perante o credor os devedores solidários se apresentam como se fossem uma só pessoa.

\subsubsection{A distinção entre a fiança e o aval}

A fiança e o aval são modalidades de garantia que não se confundem, apesar da similaridade entre ambas ${ }^{184}$.

No direito brasileiro a fiança é garantia pessoal de natureza contratual; há entre fiador e o credor um negócio jurídico bilateral. O aval, por sua vez, é também uma garantia pessoal, porém de natureza cambial; há entre o avalista e o credor um negócio jurídico unilateral. Enquanto o fiador garante o adimplemento daquele que figura como devedor em um contrato, o avalista se torna garantidor do adimplemento de um título de crédito ${ }^{185}$.

Outra semelhança entre os institutos é que o artigo 1.647, III, do Código Civil passou a exigir, como condição de validade do aval a ser prestado por pessoa casada, da

\footnotetext{
${ }^{181}$ Código Civil: “Art. 184. Respeitada a intenção das partes, a invalidade parcial de um negócio jurídico não o prejudicará na parte válida, se esta for separável; a invalidade da obrigação principal implica a das obrigações acessórias, mas a destas não induz a da obrigação principal."

${ }^{182}$ Código Civil: "Art. 283. O devedor que satisfez a dívida por inteiro tem direito a exigir de cada um dos codevedores a sua quota, dividindo-se igualmente por todos a do insolvente, se o houver, presumindo-se iguais, no débito, as partes de todos os co-devedores."

${ }^{183}$ Código Civil: "Art. 204. A interrupção da prescrição por um credor não aproveita aos outros; semelhantemente, a interrupção operada contra o co-devedor, ou seu herdeiro, não prejudica aos demais coobrigados.

$\S 1^{\circ}$ A interrupção por um dos credores solidários aproveita aos outros; assim como a interrupção efetuada contra o devedor solidário envolve os demais e seus herdeiros."

184 "Não há confundir fiança e aval. Ambos são tipos de garantia pessoal, mas, enquanto a fiança é uma garantia fidejussória ampla, e hábil a aceder a qualquer espécie de obrigação, convencional, legal ou judicial, o aval é restrito aos débitos submetidos aos princípios cambiários. Em razão da velocidade dos títulos desta espécie, não está o aval sujeito às restrições de que padece a fiança, no tocante à outorga do outro cônjuge. E nos seus efeitos também difere, gerando o aval responsabilidade sempre solidária, ao contrário da fiança, que pode sê-lo, ou não.” (PEREIRA, Caio Mário da Silva. op. cit., v. 3, p. 304).

${ }^{185}$ Cfe. MARTINS, Fran. Títulos de crédito. 9. ed. Rio de Janeiro: Forense, 1994. v. 1, p. 208-209.
} 
mesma forma que já era exigido para a prestação de fiança, a autorização expressa do outro cônjuge, exceto no regime da separação absoluta de bens.

Da mesma forma que ocorre com a fiança, o avalista é um terceiro dentro das obrigações cambiais, pela posição singular que ocupa no título ${ }^{186}$.

Entretanto, e como diferença maior, o avalista garante obrigação constante da letra da mesma maneira que o avalizado. Tal quer dizer que as obrigações assumidas pelo avalizado e pelo avalista são equiparadas, donde, muitas vezes, proclamar-se que o avalista é um co-sacador, um co-endossante, um co-aceitante, conforme a pessoa a quem avalize. Sendo as suas obrigações equiparadas, o credor poderá acionar a qualquer um deles e, no caso de fazer em relação ao avalista, esse não pode requerer que, em primeiro lugar, seja acionado o avalizado, já que a obrigação que ele assumiu é autônoma e independente apesar de ser do mesmo grau da do avalizado ${ }^{187}$; a independência ou autonomia é absoluta $^{188}$. Na fiança, porém, não há autonomia, mas sim acessoriedade; o fiador, se assim o permitir o contrato, poderá exercer o chamado benefício da excussão, a fim de que antes dele seja executado o afiançado, tal como previsto no artigo 827 do Código Civil.

Em razão da autonomia do aval em face da obrigação avalizada, se esta for nula nada acontecerá com a avalizada, já que há a necessidade de salvaguardar a circulabilidade do crédito e salvaguardar os terceiros de boa-fé, nos termos do artigo 899, § 2. ${ }^{\circ}$, do Código Civil. Já com relação à fiança, o seu caráter será sempre acessório, ainda que o fiador a tenha subscrito como devedor solidário e principal pagador, daí decorrendo o enunciado segundo o qual nulo o contrato, nula a fiança, nos termos do artigo 824, do Código Civil.

O aval, segundo enuncia o artigo 898, do Código Civil, deve ser lançado no verso ou no anverso do próprio título, pois assim o exige o princípio da cartularidade, enquanto a fiança poderá ser prestada no corpo do próprio contrato garantido ou até mesmo em instrumento separado.

A obrigação que resulta do aval opera a solidariedade entre o avalista e o avalizado, enquanto a fiança prestada somente operará a solidariedade se for prestada em comum por dois ou mais fiadores a um só débito, a teor do artigo 829, do Código Civil, ou

\footnotetext{
${ }^{186}$ Segundo MARTINS, Fran: “O aval é uma obrigação de garantia própria do títulos cambiários ou dos a ele equiparados. Assim sendo, não se confunde com as demais garantias do direito comum, se bem que, com algumas, como a fiança, tenha muitos pontos de contato. Igualmente, não tem a mesma natureza jurídica das demais garantias oferecidas ao portador pelos que participam da letra de câmbio, tais como o sacador, os endossantes e o aceitante." (In MARTINS, Fran. op. cit., v. 1, p. 208-209).

${ }^{187}$ Cfe. MARTINS, Fran. op. cit., v. 1, p. 210-211.

${ }^{188}$ Cfe. BORGES, João Eunápio. Títulos de crédito. 2. ed. Rio de Janeiro: Forense, 1975. p. 84.
} 
se decorrer de expressa estipulação contratual; caso contrário, a fiança será própria e não importará na solidariedade passiva entre os cofiadores, conforme expusemos no item 4.4.2, desta dissertação.

\subsubsection{A fiança prestada por pessoa jurídica}

E a fiança prestada pela pessoa jurídica mesmo havendo cláusula vedatória expressa em seus estatutos: seria válida ou não?

Antes de respondermos à indagação, mister se fazem breves esclarecimentos sobre como opera a manifestação de vontade das pessoas jurídicas.

\subsection{Conceito de pessoa jurídica e a técnica da personificação}

De maneira geral, a doutrina civilista clássica conceitua as pessoas jurídicas como o “conjunto de pessoas ou de bens, dotado de personalidade jurídica própria e constituído na forma da lei, para a consecução de fins comuns ${ }^{189}$."

Entendemos que este conceito deixa de destacar a principal diferença existente entre as pessoas jurídicas e as pessoas naturais: a ausência de humanidade naquelas, mas que nestas se torna elemento caracterizador indispensável.

Humanidade, por sua vez, é o elemento psicofísico a entrelaçar corpo, mente e espírito em uma unidade orgânica que lhe permite uma autodeterminação consciente; ainda que para o Direito a condição de ser pessoa dependa de concessão do ordenamento jurídico, cujo sistema trabalha com realidades próprias ${ }^{190}$; dada a humanidade, em nosso entendimento seria vedado ao legislador negar o reconhecimento desta condição [a de ser

\footnotetext{
${ }^{189}$ GONÇALVES, Carlos Roberto. Direito civil brasileiro: parte geral. São Paulo: Saraiva, 2003. v. 1, p. 182.

190، O direito cria as suas próprias realidades. E ao criá-las pode mesmo contrariar a ordem natural. Por isso, ao arrebanhar coisas e seres do mundo fenomênico, o direito os reelabora, emprestando-lhes um significado próprio do mundo jurídico, isto é, transforma-os em seres lógicos, destinados a atuarem exclusivamente no universo do direito. Tal a pessoa jurídica, um conceito do mundo jurídico, criação trabalhada do direito, sem que caibam aqui digressões sobre as teorias que a respeito de sua natureza jurídica foram engendradas (teoria da ficção, teoria da equiparação, teoria orgânica ou da realidade objetiva, teoria da realidade jurídica) (...), bastando, tão-somente, para os nossos propósitos, a indicação de que a pessoa jurídica, como criação do direito, "é tão real como a pessoa física", agindo por meio de seus órgão, que não a representam, mas são ela própria (presentação)" (LUCENA, José Waldecy. Das sociedades limitadas. 6. ed. atual. Rio de Janeiro: Renovar, 2005. p. 398).
} 
pessoa] às pessoas humanas ou naturais, por força do princípio constitucional da dignidade da pessoa humana $\left(\mathrm{CF}\right.$, art. $1^{\circ}$, III), que pré-exclui qualquer tentativa em coisificar o ser humano, reconhecida a sua condição existencial própria de sujeito, mas nunca de objeto.

Todavia, em nossa opinião nada impediria que o legislador deixasse de atribuir esta condição às denominadas pessoas jurídicas - a de ser pessoa -, que são apenas instrumentos de técnica legislativa voltados a facilitar o desempenho de determinadas finalidades econômicas lucrativas (sociedades empresárias) ou não-lucrativas (associações e fundações). Logo, defendemos que o ser ou não pessoa jurídica em nada interferiria nas relações jurídico-sociais entabuladas por este sujeito de direito, pois bastaria ao ordenamento jurídico atribuir-lhe patrimônio próprio e legitimidade para agir ${ }^{191}$.

Não obstante, atualmente a técnica de atribuição de capacidade às pessoas jurídicas é denominada de personificação, que é o processo destinado a atribuir-lhes personalidade e tornar-lhes pessoas para que seja determinada a completa separação patrimonial entre as mesmas e os seus sócios, como bem aponta Fábio Ulhoa Coelho ${ }^{192}$ :

"As pessoas jurídicas são sempre personalizadas, ou seja, são pessoas distintas dos sócios, titularizam seus próprios direitos e obrigações(...)"

Em remate sobre este ponto, entendemos que o paradigma da personificação ${ }^{193}$ adotado pelo legislador do Código Civil de 2002 em relação às pessoas jurídicas encontrase atualmente superado, pois, em nossa concepção, indevida se torna a equiparação, ainda que no plano do Direito, das pessoas jurídicas às pessoas humanas ( $\mathrm{CF}$, art. $1^{\circ}$, III); para tanto, bastaria ter o legislador considerado estas últimas como sujeitos despersonificados não-humanos ${ }^{194}$, sugestão esta aqui colocada de lege ferenda.

\footnotetext{
191“"A second key feature of the modern corporation that has its roots in early trading practices is the separation of the property that belongs to the corporation from the personal property of its members." (SWEDBERG, Richard. Max Weber and the idea of economic sociology. New Jersey: Princeton University, p. 16).

${ }^{192}$ In COELHO, Fábio Ulhoa. Curso de direito comercial. 6. ed. rev. e atual. São Paulo, 2003. v. 2, p. 7.

${ }^{193}$ Para FÁBIO ULHOA COELHO, "personalizaçãoo".

${ }^{194}$ Vede, por todos, COELHO, Fábio Ulhoa. Curso de direito civil. São Paulo: Saraiva, 2003. v. 1, p. 152 e ss.
} 


\subsection{Estrutura: orgãos}

Em que pese ter o direito brasileiro adotado a teoria da realidade técnica é indiscutível que a Lei $n^{\circ}$ 6.404/76 (v.g., arts. 138 e 139) adotou, pelo menos no que diz respeito à estruturação administrativa das Sociedade Anônimas, a denominada Teoria Orgânica através da qual se enxerga a pessoa jurídica como uma realidade do direito, de modo que a sua constituição deverá obedecer a critérios técnico-legais de organização (ordenação) da sua estrutura administrativa, razão pela qual alguns centros de manifestação de interesses da pessoa jurídica são denominados de órgãos ${ }^{195}$. Por isso, entendemos que nada impede a utilização do termo órgão para as demais espécies societárias, uma vez que se trata de forma de organização da estrutura interna da pessoa jurídica com o fim de facilitar o exercício das suas atividades.

Os órgãos, por sua vez, podem ser conceituados como centros de imputação de direitos e obrigações das pessoas jurídicas, que fazem parte integrante da sua estrutura administrativa, aos quais a lei atribui funções específicas para permitir a consecução da sua finalidade social (vontade social). Na realidade, os órgãos das pessoas jurídicas são as pessoas dos sócios ou administradores aos quais a lei atribuiu a legitimidade de manifestarem as finalidades da sociedade, vinculando a pessoa jurídica perante o mercado e a sociedade em geral.

Com efeito, dada a natureza técnica ${ }^{196}$ das pessoas jurídicas a manifestação da sua vontade somente será possível, por óbvio, através das pessoas dos sócios ou administradores que as compõem; são esses sócios, que ao dirigi-las, tornam dela a vontade deles através de um processo de abstração total das vontades, as quais, ao se fundirem como uma única vontade - a da pessoa jurídica, deverão se circunscrever à finalidade social - objeto da sociedade -, que se encontra expressada em seus atos constitutivos.

\footnotetext{
${ }^{195}$ Anote-se uma divergência doutrinária: enquanto para AMARAL, Francisco a teoria orgância ou da realidade objetiva poderia ser chamada de pré-normativista, "à medida que reduz o papel do Estado a mero conhecedor de realidades já existentes, desprovidos de maior poder criador" (AMARAL, Francisco. Direito civil: introdução. 6. ed. rev. atual. e aum. Rio de Janeiro: Renovar, 2006. p. 281-282), COELHO, Fábio Ulhoa entende que a teoria orgânica é uma "doutrina estreitamente ligada à superação das concepções pré-normativistas das pessoas jurídicas, (...) tomando-se por premissa a constatação de que a pessoa jurídica não existe fora do direito positivo(...)" (COELHO, Fábio Ulhoa. Curso de direito comercial, cit., v. 6, p. 193).

196،"Pessoas jurídicas, quaisquer que sejam, criam-se. É o homem que as cria;" (PONTES DE MIRANDA, Francisco Cavalcanti. op. cit., p. 281.
} 
Quem melhor abordou esta questão no direito brasileiro foi Pontes de Miranda ${ }^{197}$, que assim escreveu, verbis:

\begin{abstract}
"Quem pratica os seus atos [os da pessoa jurídica] é o órgão, ou são os órgãos, se em caso de distribuição de funções; porque os órgãos são parte dela, como o braço, a bôca, o ouvido, são os órgão da pessoa física."
\end{abstract}

Daí a importância de se apontar o modo pelo qual a manifestação dos sócios se apresenta como a enunciação de vontade da própria pessoa jurídica, e qual teria sido o instrumento criado pelo ordenamento jurídico para permitir a exteriorização, a manifestação, para conhecimento de terceiros, das deliberações interna corporis da sociedade, o que faremos nos itens que seguem.

\title{
4.4.3.1.3. A manifestação da vontade das pessoas jurídicas: representação ou presentação?
}

Por tradição do direito brasileiro costuma-se dizer que os órgãos das pessoas jurídicas (sócios ou administradores) seriam os seus representantes; entretanto, "A representação, em sentido amplo, é um fato jurídico pelo qual um sujeito atua na vida jurídica, em lugar da outra pessoa"198, razão pela qual o órgão não pode ser representante, pois atua como se a pessoa jurídica fosse. (Cfe. arts. 115 a 120 do Código Civil)

$\mathrm{Na}$ verdade, pode-se afirmar que o órgão é, em dado momento, a própria pessoa jurídica; assim, mais correto será, pois, dizer que os órgão sociais não representam, mas sim presentam a pessoa jurídica, pois tornam presente a vontade social no momento em que manifestam-na, isto é, fazem presente a própria pessoa jurídica no momento em que praticam um ato ou negócio jurídico.

Diante disso, a razão parecia e ainda parece estar como Pontes de Miranda ${ }^{199}$, para quem:

"O órgão não representa; presenta. A pessoa jurídica é que assina o título de crédito, ou qualquer título circulável, ou o instrumento público ou particular de contrato, ou qualquer ato jurídico, negocial ou não, pôsto que a mão que escreve seja a do órgão da sociedade, uma vez que

\footnotetext{
197،Pessoas jurídicas, quaisquer que sejam, criam-se. É o homem que as cria;” (Id. Ibid., p. 282).

${ }^{198}$ DE MATTIA, Fábio Maria. Aparência de representação. São Paulo: Ed. CID, 1999. p. 1.

${ }^{199}$ In PONTES DE MIRANDA, Francisco Cavalcanti. Tratado de direito privado. São Paulo: Ed. Revista dos Tribunais, 1984. t. 47, p 113.
} 
o nome de quem materialmente assina integre a assinatura. A pessoa jurídica pode outorgar podêres de representação. Mas o órgão tem outros podêres, que resultam da sua investidura, na conformidade do ato constitutivo ou dos estatutos, ou da lei. $\mathrm{O}$ representante figura em nome do representado; o órgão não é figurante: quem figura é a pessoa jurídica: ela se vincula em seu próprio nome." (Grifamos)

Decorre daí que os órgãos não substituem a vontade da sociedade, mas a expressam $^{200}$. De fato, o administrador é órgão social executivo da sociedade, com a função de fazer a sociedade presente perante terceiros e desenvolver a sua atividade relacionada com o objeto social delimitado no contrato ${ }^{201}$.

O mesmo entendimento era compartilhado por Carlos Fulgêncio da Cunha Peixoto $^{202}$, que assim se posicionava sobre o tema:

"Pela maneira por que se define, o mandato menos se ajusta aos administradores das sociedades, pois se com êle é que uma pessoa pratica um ato jurídico em nome de outra, há aí a existência de duas pessoas distintas: o representante e o representado.

Ora, os administradores não agem em nome da sociedade, mas apenas por intermédio seu é que ela manifesta a sua vontade.

A administração constitui, assim, elemento essencial na existência da própria sociedade, que segundo Boistel: (...)

Quando a sociedade age por intermédio de seus administradores, é ela mesma quem pratica o ato jurídico; os gerentes, frente a terceiros, são a própria sociedade. Ora, se os administradores constituem parte integrante da sociedade - ou ela própria - evidentemente não se pode falar na figura da representação, visto como não há duas pessoas, mas apenas uma. (...)

Por sua vez, FEINE ensina que "la sociedad obra y vive en sus organes, cuya voluntad, conocimiento o ignorancia de hechos, buena o mala fé, error, declaraciones, actos y juramentos, le son imputables a ella misma, como actos suyos y personales".

A lei francesa, a seu turno, confere aos gerentes, em quaisquer circunstâncias, poderes para agir em nome da sociedade, estabelecendo, inclusive, ser nula tôda a limitação contratual dêsses poderes em relação a terceiros.

As leis brasileiras normativas da espécie mostram que adotaram êstes princípios. $\mathrm{O}$ art. 302 do Cód. do Comércio, aplicável às limitadas ex vi do art. $2^{\circ}$ do dec. n. $^{\circ} 3.708$, estipula, como elemento essencial ao contrato social, a nomeação daqueles que vão gerir a sociedade. e, para mostrar que não é possível a existência do contrato social sem administração expressa, supre a omissão contratual, tornando gerentes, nesta hipótese,

${ }^{200}$ COELHO, Fábio Ulhoa. Curso de direito comercial, cit., v. 2, p. 193.

${ }^{201}$ Cfe. WALD, Arnoldo. Comentários ao novo Código Civil. Rio de Janeiro: Forense, 2005. v. 14, p. 204.

${ }^{202}$ In PEIXOTO, Carlos Fulgêncio da Cunha. A sociedade por cotas de responsabilidade limitada. Rio de Janeiro: Forense, 1958. p. 293 e ss. 
todos os sócios. E a lei de Sociedade Anônima deixou claro haver-se filiado a esta doutrina, ao dispor, no $\S 5^{\circ}$ do art. 116, que é lícito aos diretores constituir, em nome da sociedade, mandatários ou procuradores." (Grifamos)

Em face do exposto, entendemos ser neste sentido a disposição do art. 1.022 do Código Civil, verbis:

"Art. 1.022. A sociedade adquire direitos, assume obrigações e procede judicialmente, por meio de administradores com poderes especiais, ou, não os havendo, por intermédio de qualquer administrador."

A redação do dispositivo em apreço deixa claro que o artigo se encontra em uma perspectiva externa, isto é, numa visão da sociedade perante terceiros ${ }^{203}$, sendo importante, pois, delimitar em que situações estas manifestações, ao se desviarem da finalidade social para as quais deveriam contribuir, são eivadas de algum vício capaz de negar-lhes validade ou eficácia, quer internamente, na relação de sócio/administrador perante sócio, quer externamente, na relação sócio/administrador perante terceiros.

\section{a) Os poderes de presentação}

Consideram-se poderes de presentação todos aqueles a que a lei ou o ato constitutivo da pessoa jurídica atribuem a um ou alguns dos seus orgãos com o objetivo de permitir o atingimento das finalidade sociais e vão desde a faculdade de praticarem atos e negócios jurídicos corriqueiros (v.g., adquirir insumos, efetuar pagamentos) aos mais complexos (v.g., fazê-la presente em processos judiciais, participar de licitações).

Nesse contexto calha apontarmos as hipóteses nas quais a atuação dos órgãos sociais se dará regular ou irregularmente, e quais os efeitos decorrentes de ambas as situações.

\section{a.1) Atuação Regular}

Como regra, desde que regulares, isto é, de acordo ou nos limites dos poderes definidos no ato constitutivo da sociedade, os atos praticados pelo(s) órgão(s) sociais

$\overline{{ }^{203} \text { Cfe. WALD, Arnoldo. op. cit., p. } 204 .}$ 
vinculam a pessoa jurídica e obrigam-na a cumpri-los. É o que se extrai da redação do art. 47 do Código Civil:

"Art. 47. Obrigam a pessoa jurídica os atos dos administradores, exercidos nos limites de seus poderes definidos no ato constitutivo."

Portanto, segundo o critério preconizado no Código Civil a regularidade dos atos e negócios praticados pelos administradores da pessoa jurídica deverá ser aferida à luz "de seus poderes definidos no ato constitutivo”.

Apesar da lógica subjacente ao art. 47 do Código Civil, entendemos que o referido dispositivo é apto a causar situações inusitadas, na medida em que desconsidera a dinâmica intrínseca da atividade empresarial, porque vincula a regularidade dos atos práticados à definição expressa de poderes em seu ato constitutivo; todavia, há negócios corriqueiros que são praticados pelas pessoas jurídicas e que muitas vezes não se encontram presentes expressamente em seu ato de constituição e tornam impossível a verificação da sua regularidade por terceiros (v.g., aquisição de alguns insumos de menor monta).

Nesses casos melhor seria que o legislador tivesse feito a distinção entre as atividades-meio e as atividades-fim. Atividade-fim é aquele definida no objeto social da pessoa jurídica (v.g., construção civil). Assim, seria vedado ao administrador desta sociedade [a de construção civil] passar a praticar, com reiteração, atividades estranhas ao objeto social, como, por exemplo, a venda e compra de computadores. Já as atividadesmeio são aquelas cuja prática se apresenta como indispensável ao atingimento das finalidades sociais de qualquer pessoa jurídica (v.g., o pagamento da conta de consumo de serviços públicos, a aquisição de papel para o escritório ou a locação de imóveis para a instalação de sedes, filiais ou escritórios).

Portanto, se o administrador praticar ato relativo a atividade-meio necessário ao exercício da empresa, ainda que não expresso em seu contrato social, haverá vinculatividade da sociedade, ao passo em que se se tratar de atividade-fim, a mesma deverá encontrar-se expressamentre prevista, sob pena de invalidade da determinação, salvo os casos em que ocorrer a aplicação da teoria da aparência. 


\section{a.2) Atuação Irregular}

Por seu turno, ao interpretarmos o art. 47 do Código Civil de modo contrario sensu, chegaremos à conclusão de que irregulares serão os atos praticados pelos órgão da pessoa jurídica que estiverem em desacordo ou extravasarem os limites dos poderes dos administradores definidos no ato constitutivo da sociedade, de modo que, pelos menos em tese, não teriam o condão de vincular a pessoa jurídica.

Entretanto, ainda que tenham sido praticados de forma irregular, os atos manifestados pelo(s) órgão(s) sociais poderão ou não vinculá-la. É a hipótese denominada de abuso do poder de presentação, figura essa prevista no art. 1.015 do Código Civil, verbis:

\footnotetext{
"Art. 1.015. No silêncio do contrato, os administradores podem praticar todos os atos pertinentes à gestão da sociedade; não constituindo objeto social, a oneração ou a venda de bens imóveis depende do que a maioria dos sócios decidir.

Parágrafo único. $O$ excesso por parte dos administradores somente pode ser oposto a terceiros se ocorrer pelo menos uma das seguintes hipóteses:

I - se a limitação de poderes estiver inscrita ou averbada no registro próprio da sociedade;

II - provando-se que era conhecida do terceiro;

III - tratando-se de operação evidentemente estranha aos negócios da sociedade." (Grifamos)
}

Sobre o tema, Arnoldo Wald ${ }^{204}$ aponta:

"561. Esta posição legislativa contraria a posição doutrinária e jurisprudencial já firmada sobre o tema, conforme salienta RUBENS REQUIÃO:

"O Projeto, como se percebe, abandonou a construção doutrinária e jurisprudencial, elaborada por nossos juristas e pelos tribunais, para se inspirar na lei italiana (...) é exigir demais que no âmbito do comércio, onde as operações se realizam em massa, avessas ao formalismo, que, a todo instante, o terceiro que contrata com uma sociedade solicite desta a exibição do contrato social, para verificação dos poderes do gerente. A doutrina que dá validade a tal cláusula é evidentemente contrária às tendências e espírito do direito comercial." (...)

"Em face do exposto, esperamos que o legislador se mantenha fiel à jurisprudência do Supremo Tribunal Federal, à lição predominante dos doutrinadores pátrios e à realidade das atividades comerciais em nosso

${ }^{204}$ WALD, Arnoldo. op. cit., p. 187-188. 
País, que não devem estar sujeitas às delongas de comprovações, nem sempre fáceis, dos poderes gerenciais, devido ao distanciamento entre as diversas regiões nacionais."

563. Em seguida, sugere a seguinte redação: "Os administradores podem praticar todos os atos pertinentes à gestão social, dependendo, entretanto, de deliberação da maioria dos associados ou sócios a oneração de imóveis ou a sua alienação, quando esta não constitua objeto social. Parágrafo único. Os administradores respondem perante a sociedade pelo excesso que praticaram, ou pelas operações estranhas ao objeto social, não sendo oponíveis a terceiros de boa-fé as limitações de seus poderes."

564. Pertinente é a crítica de RUBENS REQUIÃO. Esperamos que a jurisprudência e a doutrina se posicionem perante a nova disciplina, interpretando-se de forma razoável e sempre tendo em vista a aplicação do princípio da boa-fé, para não premiar a atuação fraudulenta e de máfé, esquivando a sociedade das obrigações contraídas por seus administradores, mas sem poderes específicos para tanto. Isto poderá ser alcançado, mediante a aplicação da teoria da aparência e invocando-se um conceito ampliado do princípio constitucional da boa-fé objetiva, considerando como um princípio-chave do Código Civil.

565. Ademais, caso a sociedade venha a ser responsabilizada pelos atos do administrador praticados com excesso de poder ou contrários ao contrato social, ela terá direito de regresso contra ele, salvo se os sócios sabiam e concordaram com a atuação irregular".(Grifamos)

De fato, ainda que a letra do art. 1.015 do Código Civil pareça limitar a responsabilidade da pessoa jurídicas nas hipóteses em que houver abuso de presentação, entendemos que a razão estava e permanece com Rubens Requião, pois se revela de impossível cumprimento a exigência, ainda que implícita, de terceiros terem de compulsar o contrato social da pessoa jurídica para aferirem se os órgão de presentação estaria ou não autorizado à prática de determinado ato. Com o devido respeito, tal exigência contraria a lógica e a dinâmica da vida empresarial, de maneira que a regra legal possui um potencial de causar mais prejuízos do que benefícios nas situações reais do dia-a-dia.

$\mathrm{Na}$ realidade, se o órgão da pessoa jurídica agiu com excesso de poderes a pessoa jurídica deveria permanecer vinculada ao cumprimento do negócio, em benefício de terceiros, desde que tenham agido com boa-fé, devendo o orgão social ser responsabilizado interna corporis perante a sociedade. Dessa forma, prestigia-se a segurança necessária à prática de atos e negócios jurídicos, impondo uma fiscalização constante dos demais sócios aos administradores da sociedade. 
Em princípio, a atuação com excesso de poderes não obriga a sociedade, ressalvados os caso de aplicação da teoria da aparência ${ }^{205}$ Eis aí a grande questão, pois trata de dois interesses antagônicos que merecem tutela do ordenamento ${ }^{206}$ :

a) $O$ interesse da sociedade, que as regras restritivas dos poderes dos administradores sejam obedecidas e os atos de gestão somente as vinculem quando praticados de acordo com o estabelecido no contrato social;

b) O interesse dos terceiros, credores de boa-fé que travam relações com a sociedade.

Em face do exposto, passaremos a analisar as hipóteses previstas nos três incisos que compõem o art. 1.015 do Código Civil, bem como a situação por nós visualizada e que não recebeu tratamento expresso por parte do legislador: a do desvio de finalidade, e qual a sua relação com a prestação de fiança pela pessoa jurídica.

\section{a.2.1) Atuação em desacordo com a legitimidade atribuída aos administradores no contrato social (excesso de poderes)}

Hipótese do art. 1.015, p. único, inciso I, do Código Civil de 2002. Exemplo: no contrato social da pessoa jurídica consta limitação expressa de que determinadas operações sociais, como a prestação de fiança, só poderão ser realizadas mediante a assinatura de 2 (dois) ou mais sócios, porém apenas 1 (um) deles pratica o ato e contrai obrigação ou responsabilidade em face da sociedade. Neste caso, o terceiro com quem se contratou não tinha conhecimento da limitação aos poderes de presentação, pois não houve consulta ao contrato social.

Em casos que tais, além da distinção entre atividade-meio e atividade-fim que fizemos no item a.1, entendemos que a solução da situação sob análise deverá ainda pautar-se pela natureza do ato praticado pelo órgão social, a fim de proteger a atuação regular de terceiros. Com efeito, se determinado ato ou negócio tiver sido praticado pelo órgão com excesso de poderes, há que se verificar se a natureza daqueles estaria a exigir do terceiro uma atuação com formalidade ou informalidade.

Assim, se se tratar de venda e compra de imóvel ou prestação de fiança, por exemplo, dada a formalidade intrínseca que afeta a própria validade do negócio se acaso vier a ser desrespeitada (arts. 108 e 819 do Código Civil), não poderá terceiro alegar que

\footnotetext{
${ }^{205}$ WALD, Arnoldo. op. cit., p. 185.

${ }^{206}$ Id. Ibid., p. 186.
} 
desconhecia a limitação imposta no contrato social da pessoa jurídica, porque a natureza do negócio impunha a consulta aos seus atos constitutivos; ademais, a prestação de fiança é ato extraordinário de administração, pois implica na responsabilidade por débito alheio, sendo um negócio de risco que poderá causar grandes prejuízos à pessoa jurídica.

Todavia, tratando-se de negócio corriqueiro, como, por exemplo, a venda e compra de insumos, o pagamento de funcionários, dentre outros, a própria natureza destes atos não exige maiores formalidades para a sua efetivação, de modo que qualquer exigência contrária à dinâmica destes negócios seria, em nosso sentir, indevida por ser contrária a própria natureza da atividade desenvolvida; desse modo, o negócio porventura praticado nas condições descritas efetivamente vincularia a pessoa jurídica, salvo se restasse demonstrado que o terceiro agira de má-fé porque conhecia a limitação existente, que vem a ser justamente a hipótese descrita no inciso II, do art. 1.015 do Código Civil.

\section{a.2.2) Atuação em desacordo com o contrato social, porém do conhecimento de terceiro(s) (simulação?)}

Hipótese do art. 1.015, p. único, inciso II, do Código Civil de 2002. Exemplo: o administrador, presentando a sociedade, afiança obrigação para favorecer terceiro que, apesar de consultar o contrato social e ter conhecimento da limitação dos poderes de presentação, mesmo assim assume o risco do negócio.

Haveria neste caso simulação ou para a configuração de tal espécie de vício social se faz necessária a ocorrência de dolo bilateral? (v. art. 167, § $2^{\circ}$ do Código Civil)

Segundo entendemos, se aquele que estabeleceu um negócio jurídico com o orgão social tinha conhecimento da limitação à atuação desse órgão, mas mesmo assim decidu concretizá-lo, nesta hipótese não haverá vinculatividade da pessoa jurídica, não se podendo falar em simulação porque a finalidade das partes não foi a de prejudicar terceiros, uma vez que o negócio foi efetivamente realizado entre as próprias partes. Portanto, a prestação da fiança nesta hipótese causará a sua invalidade e inoponibilidade em face da pessoa jurídica.

Já se aquele que estabeleceu um negócio jurídico com o orgão social tinha conhecimento da limitação à atuação do órgão, mas a finalidade era de prejudicar terceiros, e não a de beneficiar a si próprio, entendemos que o caso também será de nulidade absoluta do negócio, por se tratar de simulação nocente (art. 167, do Código 
Civil), de modo que a ocorrência de nulidade absoluta também impediria a vinulação da pessoa jurídica ao cumprimento do negócio nessa hipótese.

\section{a.2.3) Utilização Indevida do Nome Empresarial (Firma) em Operações Estranhas ao Objeto Social: Teoria 'Ultra Vires' ${ }^{, 207}$}

Hipótese do art. 1.015, p. único, inciso III, do Código Civil de 2002. Exemplo: os administradores de uma sociedade contraem empréstimos em seus próprios benefícios e empregam o nome empresarial na prestação de fiança dessa operação particular, de forma completamente estranha ao objeto social, sob a alegação de que o empréstimo visou antecipar parcela de rendimentos futuros que seriam distribuídos aos administradores pela própria pessoa jurídica fiadora. Em tese, pois, uma operação aparentemente regular.

Entendemos que esta hipótese também poderá causar inúmeras dificuldades práticas, na medida em que o legislador incluiu o advérbio evidentemente na regra legal, de maneira que, pelo menos em princípio, somente haveria espaço para a aplicação da teoria ultra vires quando a operação efetivada pelo órgão social se apresentasse em manifesta estraneidade aos negócios da sociedade.

Ora, a verificação do que é manifestamente estranho ou não ao objeto social não é tão simples, na medida em que determinados atos são aparentemente estranhos à finalidade da pessoa jurídica, porém na verdade estão indiretamente vinculados ao regular atingimento do objeto social da empresa, razão pela qual, segundo entendemos, apenas, a análise casuística desta hipótese permitirá a sua correta aplicação, como bem aponta Arnoldo Wald ${ }^{208}$ :

\footnotetext{
"Em resumo, os gestores podem praticar todos os atos relacionados com o objeto social, devendo observar, entretanto, as eventuais especificações, restrições ou requisitos estabelecidos no contrato social para a prática de determinado ato.

550. Dentro da complexidade da vida de uma sociedade e dos seus negócios, pode-se dizer que os "atos pertinentes à gestão da sociedade" são aqueles necessários para o desenvolver a atividade relacionada com o

207“Com a vigência do Código Civil de 2002, porém, o direito nacional passa a contemplar, no capítulo atinente às sociedades simples, norma claramente inspirada na ultra vires doctrine, de acordo com a qual a prática de operação evidentemente estranha aos negócios da sociedade pode ser oposta ao credor como excesso de poderes do administrador (art. 1.015, parágrafo único, III) (...) Em conseqüência, quando a sociedade limitada tem por diploma de regência supletiva o capítulo do Código Civil de 2002 referente às sociedades simples, a vinculação da pessoa jurídica a atos praticados em seu nome não se verifica em operações evidentemente estranhas ao objeto social." (COELHO, Fábio Ulhoa. Curso de direito comercial, cit., v. 2, p. 449). (Grifamos)

${ }^{208}$ WALD, Arnoldo. op. cit., p. 182-183.
} 
objeto social, abrangendo todos aqueles que se apresentam como meio para se atingir o objeto especificado no objeto social.

551. Na lição de GIUSEPPE FERRI, a noção de atos de gestão somente pode ser vista na hipótese concreta e não no plano abstrato, pois não se pode distinguir a priori um ato relacionado com o objeto social e os que não se enquadram nele. Apenas diante do caso concreto é possível verificar, de acordo com as circunstâncias, se o ato é pertinente ou, ao contrário, se houve excesso por parte do administrador.

552. Esta impossibilidade de analisar a questão em abstrato decorre da falta de rigidez da atividade econômica desenvolvida e pelo fato de existirem atos que indiretamente estão relacionados com o objeto social. Por exemplo, a realização de contrato de locação de um conjunto comercial na cidade de São Paulo, com o objetivo de estabelecer a sede administrativa, não tem relação direta com a sociedade, que tem por objeto a produção de soja no interior do Estado. Ainda assim, não é possível afirmar que o referido contrato de locação não está dentro do objeto social, pois, em princípio, pode ter relação indireta com a atividade social."

Como se pode perceber, portanto, e também com base na distinção entre atividademeio e atividade-fim que fizemos no item a.1, entendemos que o correto preenchimento do conteúdo do inciso III, do art. 1.015 do Código Civil não poderá prescindir da análise casuística do ato ou negócio praticado, pois há operações aparentemente estranhas ao objeto social, mas que indiretamente servem à sua finalidade, bem como há operações aparentemente conformes ao objeto social, o que demonstra a dificuldade de soluções apriorísticas.

Em remate, ainda aduziu Pontes de Miranda que duas seriam as situações in casu: a da fiança prestada por pessoa em seu próprio nome, mas que o estatuto da pessoa jurídica a impedia de fazê-lo e a da pessoa que prestou a fiança como órgão da pessoa jurídica, como o seu presentante, apesar da vedação expressa em seus estatutos.

Sobre as duas hipóteses escreveu Pontes de Miranda ${ }^{209}$ :

"O fiador tem de ter capacidade jurídica. Pode acontecer que faça parte de alguma emprêsa, de cujos estatutos constem prö̈bição de afiançar. Tal cláusula estatutária de modo nenhum faz incapaz a pessoa. Apenas a fiança, que fôr examinada pelo fiador, em seu nome, será ineficaz contra a emprêsa. Os credores da emprêsa são pagos pela parte que toca à pessoa no fundo da emprêsa antes dos credores do fiador. Em todo o caso, o direito à parte que toca ao fiador pode ser penhorado, para que se possa atribuir ao credor principal a que se deu a fiança.

Tratando-se de fiança prestada pelo sócio como órgão, é inexistente, porque o sócio, a que se proïbiu dar fiança como órgão, assumiu o que

\footnotetext{
${ }^{209}$ In PONTES DE MIRANDA, Francisco Cavalcanti. op. cit., t. 44, 2. ed. 3.impr., § 4.786, p. 127.
} 
não podia assumir. Pôsto que se trate de presentação, e não de representação, tem de se atender aos interêsses dos terceiros de boa fé."

Em conclusão, como regra geral a fiança a ser prestada por pessoa jurídica nas hipóteses previstas no art. 1.015 e incisos do Código Civil será estéril, nula em face da sociedade, porém devendo cada situação vir a ser casuísticamente avaliada, a fim de ser verificado se havia ou não interesse da pessoa jurídica à prestação de fiança.

\subsection{Promessa e Contrato Preliminar de Fiança}

A fiança, contrato unilateral ${ }^{210}$ que é, em regra, pode ser formalizada mediante contrato preliminar ${ }^{211}$, que chamaremos de promessa de fiança. $\mathrm{O}$ maior problema da promessa de fiança é comum a todas as promessas relativas às liberalidades ${ }^{212}$, como a doação: qual seria a sua eficácia jurídica, na medida em que grande parte dos civilistas nega-se-lhe validade porque não se poderia constranger alguém a prestar, contra a sua vontade, uma liberalidade, uma vantagem a que não corresponderia uma obrigação contrária $^{213}$.

Entretanto, pensamos que o tema está a merecer uma maior reflexão. Na atualidade, muito mais importante do que a vontade manifestada na seara contratual se apresenta a

\footnotetext{
${ }^{210}$ Constitui exemplo frisante de contrato unilateral em relação ao qual a doutrina majoritária rejeita possa ser viabilizado mediante contrato preliminar é o de doação, doutrina essa que, acaso aceita, também inviabilizaria a sua estipulação na fiança. Sobre o tema, aponta SANSEVERINO, Paulo de Tarso: "Parte da doutrina nega validade e eficácia a esse pacto. Sustentam a necessidade de o animus donandi estar também presente no momento da celebração do contrato definitivo. Se houver arrependimento posterior, não haverá doação. Não há igualmente possibilidade de execução do pacto na hipótese de descumprimento por ser incompatível com a noção de liberalidade inerente às doações, assim como não haverá obrigação de indenizar. Filiam-se a essa corrente Serpa Lopes (p. 391), Sílvio Rodrigues (p. 200), Caio Mário da Silva Pereira (p. 161), Agostinho Alvim (p. 42).” (In PASQUALOTTO, Adalberto. op. cit., p. 77).

${ }^{211}$ Nesse sentido: GOMES, Orlando: "O pré-contrato deve obedecer à mesma forma do contrato." (In GOMES, Orlando. Contratos, cit., p. 437).

${ }^{212}$ Liberalidade, na fiança, é "ação altruística e desinteressada" de garantir em favor do credor o exato e fiel adimplemento do devedor. Segundo anota LÔBO, Paulo Luiz Netto: "Liberalidade não se confunde com doação, porque esta exige que a vantagem implique enriquecimento do donatário, isto é, que aumente o seu patrimônio, e ao aumento do patrimônio corressponda uma diminuição do patrimônio do doador. Há liberalidades que têm escopos próprios distintos da doação. (...) A fiança que alguém dá à dívida de outrem não enriquece este e, portanto, não é doação."(In LÔBO, Paulo Luiz Netto. Comentários ao Código Civil. Coord. Antonio Junqueira de Azevedo. São Paulo: Saraiva, 2003. v. 6, p. 282). (Grifamos).

${ }^{213}$ Neste sentido, ao ter discorrido sobre as promessas de doções puras, Caio Mário da Silva Pereira afirmava que a determinação coativa da doação (pela via judicial) não se coadunaria com as liberalidades, pois aquele que se comprometeu a prestar um ato de benemerência não poderia ser compelido a prestar contra a sua vontade (In PEREIRA, Caio Mário da Silva. op. cit., v. 3, p. 161) O mesmo raciocínio pode ser utilizado no caso da promessa de fiança, posto também tratar-de, em regra dada a sua gratuidade, de uma liberalidade.
} 
confiança ${ }^{214}$ que a promessa manifestada gera na contraparte; a confiança de que a palavra será cumprida tal qual fora veiculada. $\mathrm{O}$ direito deve proteger a legítima expectativa daquele que confiou na promessa de cumprimento da obrigação, porém teve a sua expectativa frustrada pela outra parte.

Ainda que os argumentos contrários à exigência judicial de cumprimento de uma liberalidade sejam razoáveis, o direito brasileiro deve, antes de tudo, prestigiar o princípio da auto-responsabilidade ${ }^{215}$ : toda e qualquer manifestação de vontade deve necessariamente vincular juridicamente o sujeito que a manifestou, pois a liberdade de agir, ínsita especialmente em contratos paritários, pressupõe a responsabilidade e, por conseguinte, a vinculatividade do sujeito que, com a sua anterior conduta, gerou no alter a expectativa de que iria cumprir a promessa. Na realidade, no Brasil há que se começar a prestigiar a seriedade das manifestações, abandonando antigos e superados dogmas para que seja tutelada a confiança despertada pelas condutas praticadas na sociedade. Dessa forma, desloca-se o foco da questão da liberalidade para o da confiança na promessa empenhada.

Assim, entendemos que a promessa de fiança é gênero da qual são espécies $a$ promessa de afiançar e a promessa de dar fiador. É o compromisso quer por parte do fiador quer por parte do devedor principal, de que futuramente prestará a fiança em favor do afiançado (no primeiro caso) ou de que futuramente apresentará fiador idôneo ao credor (no segundo caso). Quando a promessa é manifestada pelo próprio fiador, está-se diante de uma promessa de fiança; já quando for manifestada pelo devedor principal a obrigação recebe o nome de promessa de dar fiador, que é espécie de promessa de fato de terceiro ${ }^{216}$.

\footnotetext{
214“A b base de tôdas as transacções humanas humanas é a confiança, o crédito, derivando de uma presunção de probidade e da solvabilidade do devedor. E, como qualquer pessoa pode contrair obrigações com diversas pessoas, e tôdas essas obrigações são fundadas na mesma confiança, resukta daí o princípio jurídico de que "o patrimônio do devedor é a garantia dos seus credores" (...)." (GONÇALVES, Luiz da Cunha. op. cit., v. 5, t. 1, p. 188).

${ }^{215}$ Conforme anota BIANCA, C. Massimo: "In definitiva, secondo il nostro diritto positivo ha valore negoziale l'atto imputabile al soggeto ed obiettivamente valutabile come atto di autonomia privata, cioè come atto decisionale del soggetto in ordine alla sua sfera giuridica. Questa nozione comporta che il soggetto può restare impegnato per un atto che egli non ha realmente voluto. Al riguardo si parla di un principio di autoresponsabilità. Tale principio esprime la soluzione normativa nel senso che chi immette o dà causa all'immissione di dichiarazioni negoziali nel traffico giuridico è assoggettato alle conseguenze di esse secondo il loro obiettivo significato. De questa nozione di auto responsabilitá esula ogni idea di una sanzione a carico del dichiarante per uno suo comportamento negligente.(..) Il principio dell'autoresponsabilità assegna a carico del dichiarante il rischio di una dichiarazione non conforme alla colontà reale e, oltre, di una dichiarazione non voluta." (In BIANCA, Massimo C. op. cit., v. 3, p. 21).

${ }^{216}$ Código Civil: "Art. 439. Aquele que tiver prometido fato de terceiro responderá por perdas e danos, quando este o não executar.”.
} 
Segundo Lauro Laertes de Oliveira ${ }^{217}$,

"Por um contrato preliminar, também denominado promessa de contrato, compromisso preparatório, contrato precursor, pacto de contrahendo ou pré-contrato, pode a fiança ser prometida pela própria pessoa que deva ser fiador. Ela promete que prestará fiança a determinada pessoa a favor do credor em tempo oportuno.

Não se confunde pré-contrato de fiança com promessa de dar fiador. Nesta o devedor promete perante o credor providenciar oportunamente fiador. É promessa do devedor.

Naquela a promessa é da pessoa que há de ser fiador.

No pré-contrato se o obrigado não prestar a fiança no tempo hábil e na forma contratada ficará sujeito a: a) ser condenado a emitir declaração de vontade (fiança); e $b$ ) responder por eventuais perdas e danos."

E na doutrina de Pontes de Miranda ${ }^{218}$, também se ostentaria jurídico o pré-contrato de fiança:

"Quando o pré-contrato de fiança é feito entre o credor e o futuro fiador, não há qualquer dúvida sôbre se se trata de pré-contrato. A preparatoriedade do pré-contrato de fiança entre futuro fiador e devedor não justifica que se distingam duas espécies: o pré-contrato preliminar, que seria o pré-contrato com o credor, e o pré-contrato preparatório, se com o devedor (...), tanto mais quanto êsse pré-contrato pode ser posterior ao contrato de devedor com o credor.

Os juristas que afastavam os pré-contratos de fiança porque não admitem promessa de doação não tinham qualquer razão. Os dois précontratos podem existir.

Pode-se prometer a fiança prestada por terceiro. Aí, promete-se negócio jurídico de outrem. O terceiro há de ser determinado ou determinável a certo momento, ou terceiro que satisfaça as exigências do art. 1.489 do Código Civil e outras, que no negócio jurídico se apontem." (Grifamos)

Apresentadas estas considerações, dizemos que a promessa de fiança pode se apresentar de três maneiras: a) o próprio fiador promete ao credor que afiançará o devedor principal; b) o próprio fiador promete ao devedor principal que prestará a garantia por ele solicitada em favor do credor; c) o devedor principal promete ao credor que apresentará fiador idôneo.

No primeiro caso (a), quando o próprio fiador prometer ao credor que afiançará o devedor principal e também no segundo (b), quando o próprio fiador prometer ao devedor principal que prestará a garantia por ele solicitada em favor do credor, defendemos que o

${ }^{217}$ In OLIVEIRA, Lauro Laertes de. op. cit., p. 3-4.

${ }^{218}$ In PONTES DE MIRANDA, Francisco Cavalcanti. op. cit., t. 44, 3. ed. § 4.783, p. 105-106. 
garante poderá ser compelido a prestar a garantia caso se recuse a fazê-lo, uma vez que a sua promessa gerou no credor da obrigação ou no devedor principal a confiança de que seria salvaguardado, não podendo o direito tolerar a violação duma legítima expectativa. Com efeito, ainda que a fiança se constitua em uma liberalidade, há que se responsabilizar o garante descuidado que prometeu afiançar sem qualquer ponderação ou reflexão e que, com a sua conduta, veio a frustrar a legítima expectativa gerada. Não podemos esquecer que a boa-fé objetiva representa um modelo de conduta ou standard jurídico que deve ser obedecido tanto pelo credor como pelo devedor, sendo que in casu o fiador seria o devedor da promessa.

No terceiro caso (c), quando o devedor principal prometer ao credor que apresentará fiador idôneo, a situação é totalmente diferente das anteriores. O art. 825 do Código Civil enuncia:

"Art. 825. Quando alguém houver de oferecer fiador, o credor não pode ser obrigado a aceitá-lo se não for pessoa idônea, domiciliada no município onde tenha de prestar a fiança, e não possua bens suficientes para cumprir a obrigação."

A leitura do dispositivo legal deverá ser a seguinte:

“Art. 825. Quando alguém houver de oferecer fiador, o credor será obrigado a aceitá-lo se for pessoa idônea, domiciliada no município onde tenha de prestar a fiança, e possuir bens suficientes para cumprir a obrigação." (Grifamos)

O credor do devedor principal que porventura tiver a obrigação de apresentar fiador para a garantia de um contrato de que participará não possui uma prerrogativa absoluta de vetar ou de não-aceitar o fiador apresentado pelo devedor ${ }^{219}$; sendo o fiador idôneo - e aqui se trata de idoneidade financeira - será ilícita a recusa do credor em aceitar o garante; neste caso, haveria uma exceção à regra geral de que ninguém será obrigado a contratar contra sua vontade. Ao ter sopesado os interesses em jogo o legislador pré-excluiu do

\footnotetext{
${ }^{219}$ Dispõe o art. 187 do Código Civil: “Art. 187. Também comete ato ilícito o titular de um direito que, ao exercê-lo, excede manifestamente os limites impostos pelo seu fim econômico ou social, pela boa-fé ou pelos bons costumes." Diante do expresso dispositivo legal que criou uma nova categoria de ilicitude (a decorrente do ato abusivo), vedou-se, no campo contratual, as recusas ou negativas injustificadas de um contratante em desfavor do outro, a prática de atos emulativos, desprovidos que são de qualquer vantagem para o agente, o que reforça a importância do papel do juiz que deverá atuar ativamente e com profunda sensibilidade para se colocar nas mesmas posições do contratantes e avaliar se agiram sem qualqur justificativa jurídica, econômica ou moral, nesta incluída a religiosa, eis que a liberdade de culto e, por conseguinte, de atuar de acordo com o código ou tábua de valores relativos à sua crença constitui-se de um direito fundamental, nos termos do art. 5. ${ }^{\circ}$, VI, da Constituição Federal.
} 
sistema a licitude da recusa injustificada do credor. E a justificativa do credor em recusar o fiador apresentado pelo devedor poderá ser passível de reavaliação judicial, podendo o magistrado superar a recusa e proferir sentença que a supra. Segundo apontava Silvio Rodrigues $^{220}$ em comentários ao artigo 825 do Código Civil,

"O problema relevante que essa regra suscita, nem sempre desenvolvidos nos livros de doutrina, é o que diz respeito ao critério para julgar a idoneidade do fiador. Quem decide se o fiador é, ou não, idôneo?

Em princípio, tal decisão compete ao credor. Mas não pode ele, abusivamente, recusar qualquer pessoa indicada pelo devedor, sob o pretexto de não ser moral ou financeiramente idônea. Quando sua alegação for insustentável, o juiz deve julgá-la abusiva e ordenar a aceitação do fiador, a despeito da recusa do credor.

É evidente que o falido, insolvente, ou o incapaz não podem ser fiadores.

Tendo ainda em vista a proteção do credor, confere-lhe a lei a prerrogativa de exigir do devedor a substituição do fiador, quando este, após o contrato, tornar-se insolvente ou incapaz. Cumpre, nesse caso, ao credor, fazer a prova do alegado.

Em suma: antes do contrato pode o credor recusar o fiador indicado, devendo o devedor provar a idoneidade do mesmo, se quiser obter que o juiz ordene sua aceitação. Após o contrato, pode o credor demandar a substituição do fiador, mas terá de provar que este se tornou incapaz ou insolvente. O ônus da prova varia conforme o caso." (Grifamos).

Uma vez atendidas às exigências do artigo 825, do Código Civil, além de outras que sejam pertinentes em face de circunstâncias concretas, o credor não poderá recusar o garante apresentado pelo devedor, porque estar-lhe-ia impondo embaraço incompatível com o espírito de lealdade e cooperação exigido pela boa-fé, além de exercer abusivamente o seu direito à garantia ${ }^{221}$.

Nestes casos, os arts. 826 a 838 do Código de Processo Civil se destinam a superar o impasse. Enuncia o art. 829 do Código de Processo Civil:

\footnotetext{
“Art. 829. Aquele que for obrigado a dar caução requererá a citação da pessoa a favor de quem tiver de ser prestada, indicando na petição inicial:

I - o valor a caucionar;

II - o modo pelo qual a caução vai ser prestada;

III - a estimativa dos bens;

IV - a prova da suficiência da caução ou da idoneidade do fiador."
}

\footnotetext{
${ }^{220}$ In RODRIGUES, Silvio. Direito civil: dos contratos e das declarações unilaterais de vontade. 30 . ed. atual. São Paulo: Saraiva, 2007. p. 360.

${ }^{221}$ Cfe. PASQUALOTTO, Adalberto. op. cit., p. 246.
} 
Em brevíssima síntese, dizemos que o devedor principal deverá promover contra o credor uma demanda cautelar de caução, que de cautelar nada tem por se tratar de demanda satisfativa; na realidade, é uma demanda de conhecimento sob as vestes do procedimento cautelar.

Provada a suficiência da caução ou demonstrada à idoneidade do fiador, o juiz deverá julgar procedente o pedido e determinar o prazo em que a fiança deverá ser prestada, nos termos do art. 834 do Código de Processo Civil:

\footnotetext{
“Art. 834. Julgando procedente o pedido, o juiz determinará a caução e assinará o prazo em que deve ser prestada, cumprindo-se as diligências que forem determinadas.

Parágrafo único. Se o requerido não cumprir a sentença no prazo estabelecido, o juiz declarará:

I - no caso do art. 829, não prestada a caução;

II - no caso do art. 830, efetivada a sanção que cominou."
}

A sentença de procedência da ação cautelar de caução tem natureza executiva lato sensu, a qual permite a sua efetivação independentemente da colaboração do vencido, mas necessitará da intervenção do fiador que deverá subscrever a fiança no prazo assinalado na decisão judicial.

A promessa de fiança, ao contrário do que possa parecer, é muito comum na prática, especialmente em contratos de alienação de quotas sociais, mormente envolvendo sociedade limitadas de médio e pequeno portes. Destarte, é muito comum em contratos deste tipo a seguinte cláusula contratual:

"Os adquirentes das quotas (cessionários) prometem apresentar fiador idôneo ao locador do prédio ocupado pela sociedade XXX, no prazo de 60 (sessenta) dias, razão pela qual isentam os atuais fiadores de quaisquer responsabilidades pelas dívidas surgidas após a data de assinatura do presente contrato."

Neste casos, a promessa de fiança - in casu de apresentar fiador idôneo - não apresenta qualquer eficácia perante o credor; é pacto completamente inidôneo a obrigá-lo porque apenas o credor é que titulariza a prerrogativa de exonerar o fiador mediante declaração unilateral de vontade ou resilição nas hipóteses não contempladas nos arts. 835, 838 ou $844, \S 1^{\circ}$, do Código Civil, hipóteses estas que atingem as partes contratantes ex vi legis e, pois, independentemente de qualquer vontade. 


\subsection{Efeitos}

Os efeitos do contrato de fiança são objeto dos arts. 827 a 836 do Código Civil, bem como de outros dispositivos. O art. 839 da mesma lei, por seu turno, apesar de disciplinar um dos aspectos do benefício de ordem foi incluído pelo legislador no capítulo relativo à extinção da fiança e será objeto de análise no momento oportuno. Da mesma forma, o art. 835 que versa sobre o direito de exoneração do fiador, dada a sua enorme importância, será abordado em tópico específico.

Basicamente, os dispositivos em comento versam sobre as figuras jurídicas dos benefício de ordem, benefício da divisão e sub-rogação.

Benefício de Ordem.

Em primeiro lugar encontra-se o art. 827 do Código Civil a versar sobre a figura do benefício de ordem:

“Art. 827. O fiador demandado pelo pagamento da dívida tem direito a exigir, até a contestação da lide, que sejam primeiro executados os bens do devedor.

Parágrafo único. O fiador que alegar o benefício de ordem, a que se refere este artigo, deve nomear bens do devedor, sitos no mesmo município, livres e desembargados, quantos bastem para solver o débito."

Benefício de ordem é a exceção deferida ao fiador demandado para pagamento da dívida do devedor principal para que obtenha a paralisação momentânea da demanda até que sejam excutidos, por primeiro, os bens do devedor principal. Trata-se de exceção dilatória autônoma, que permite ao fiador "recusar o pagamento enquanto o credor não haja proposto contra o devedor, sem êxito bom e completo, a execução contra o devedor principal. Como exceção que é, o benefício da excussão ou de ordem constitui matéria de defesa $a^{222}$. O limite temporal para o exercício da exceção é o do prazo para a apresentação de contestação ou embargos ${ }^{223}$, sob pena de preclusão.

$\mathrm{O}$ art. 828 do Código Civil foi destinado a limitar a alegação do benefício de ordem:

\footnotetext{
${ }^{222}$ Cfe. PASQUALOTTO, Adalberto. op. cit., p. 248-249.

223“A razão de impor a lei este momento processual é evitar que já ao fim do processo venha o fiador a socorrer-se da aludida exceção, com maior prejuízo ainda para o credor. Se o credor não opuser tempestivamente a referida exceção, a consequiência será presumir-se a sua renúncia. Todavia, essa presunção deve ser interpretada tendo em vista a atitude do fiador, isto é, se com essa abstenção pretendeu efetivamente renunciar ou não ao citado benefício.” (LOPES, Miguel Maria de Serpa. op. cit., v. 4, p. 486).
} 
“Art. 828. Não aproveita este benefício ao fiador:

I - se ele o renunciou expressamente;

II - se se obrigou como principal pagador, ou devedor solidário;

III - se o devedor for insolvente, ou falido."

A leitura do dispositivo em comento indica que nas quatro situações versadas o fiador estaria impedido de excepcionar com base no benefício de ordem.

A primeira delas, a renúncia ${ }^{224}$, é um ato abdicativo de direito através do qual o fiador se despe da faculdade de excepcionar em face do credor.

A segunda, na realidade contempla duas situações: se o fiador também se obrigou perante o credor como principal pagador das obrigações do devedor principal ou se obrigou como devedor solidário; nestas hipóteses, independentemente de ter ou não manifestado renúncia, estará impedido de excepcionar o benefício de ordem. Ressalte-se que a eventual clausulação das hipóteses em questão não torna o fiador co-devedor, pois a sua única finalidade vem a ser a de pré-excluir a faculdade do garante manejar o benefício de ordem.

A terceira e última situação está ligada à eventual insolvência ou falência do devedor principal, o que, em ambos os casos, impediria o exercício da exceção; com efeito, se a obrigação do fiador é precipuamente de garantia, o legislador obstou ao garante o acesso à exceção neste caso, pois com a insolvência ou falência do devedor principal instalar-se-ia uma execução coletiva da qual participariam todos os credores do devedor insolvente, razão por que a garantia do credor se esvaziaria profundamente e comprometeria o adimplemento da obrigação prometida.

\section{Benefício da Divisão.}

Em segundo lugar, o Código Civil trata do benefício da divisão nos arts. 829 a 830:

“Art. 829. A fiança conjuntamente prestada a um só débito por mais de uma pessoa importa o compromisso de solidariedade entre elas, se declaradamente não se reservarem o benefício de divisão.

Parágrafo único. Estipulado este benefício, cada fiador responde unicamente pela parte que, em proporção, lhe couber no pagamento.

\footnotetext{
${ }^{224} \mathrm{Cfe}$. CAVALCANTI, José Paulo: "É o ato pelo qual o sujeito - à semelhança do suicida, com relação à vida animal - voluntàriamente acaba com seu direito." (In CAVALCANTI, José Paulo. Da renúncia no direito civil. Rio de Janeiro: Forense, 1958. p. 13).
} 
Art. 830. Cada fiador pode fixar no contrato a parte da dívida que toma sob sua responsabilidade, caso em que não será por mais obrigado."

O benefício da divisão vem a ser a exceção ${ }^{225}$, nos casos em que concorrem vários fiadores à garantia de obrigações, deferida aos co-fiadores, a fim de que a responsabilidade dos garantes seja fracionada perante o credor, devendo cada qual responder, apenas e tãosomente, pela parte (ou fração) da dívida pela qual se vinculou. Trata-se de exceção pouco usual na prática jurídica, porque normalmente os credores exigem que a garantia seja prestada sob o selo da solidariedade, de maneira que a dívida toda possa ser exigida de um, alguns ou de todos os fiadores, em conjunto ou não com o devedor principal.

Aliás, os próprios arts. 829 e 830 do Código Civil trataram de apontar que a manifestação do benefício da divisão é de caráter dispositivo, a depender do exercício da autonomia privada; na ausência de qualquer estipulação contratual a respeito, incide a solidariedade entre os co-fiadores.

Em terceiro lugar, o instituto da sub-rogação vem enunciado no art. 831 do Código Civil:

“Art. 831. O fiador que pagar integralmente a dívida fica sub-rogado nos direitos do credor; mas só poderá demandar a cada um dos outros fiadores pela respectiva quota.

Parágrafo único. A parte do fiador insolvente distribuir-se-á pelos outros."

A sub-rogação é a substituição de um sujeito (o devedor) por outro (o fiador) tendo por fundamento o adimplemento feito por pessoa diversa da do devedor, sem extinção da dívida. Não há extinção da dívida, porque o devedor continua ligado porque deve adimplir a quem adimpliu ${ }^{226}$.

Neste caso, há satisfação do credor, que recebe o seu crédito, e que é substituído pelo fiador que adimpliu e que passa a ostentá-lo perante o devedor principal.

Segundo a regra do art. 349 do Código Civil, "A sub-rogação transfere ao novo credor todos os direitos, ações, privilégios e garantias do primitivo, em relação à dívida, contra o devedor principal e os fiadores." (Grifamos)

\footnotetext{
${ }^{225}$ “É a exceção dos devedores solidários frente ao credor, de natureza premptória, conquanto parcial(...)" (PASQUALOTTO, Adalberto. op. cit., p. 254).

${ }^{226}$ Cfe. MARTINS-COSTA, Judith. Comentários ao novo Código Civil. Coord. Sálvio de Figueiredo Teixeira. Rio de Janeiro: Forense, 2003. v. 5, t. 1, p. 427.
} 
Portanto, o fiador que adimple assume a posição do credor originário com "todos os direitos, ações, privilégios e garantias”, podendo exercê-los contra o devedor principal e os respectivos fiadores da mesma forma que o faria o credor. A sub-rogação legal oriunda do adimplemento realizado pelo fiador em razão de contrato de locação será abordada em capítulo próprio quando discorrermos sobre a garantia e as relações locatícias.

Em quarto lugar, o legislador contemplou no campo dos efeitos da fiança os arts. 832 e 833 do Código Civil, que enunciam o princípio de que o afiançado é o responsável por todos os danos que o fiador vier a sofrer em razão da fiança:

"Art. 832. O devedor responde também perante o fiador por todas as perdas e danos que este pagar, e pelos que sofrer em razão da fiança.

Art. 833. O fiador tem direito aos juros do desembolso pela taxa estipulada na obrigação principal, e, não havendo taxa convencionada, aos juros legais da mora."

Na realidade, os dispositivos retratam uma especialização do princípio geral que foi adotado na codificação civil de que "todo dano oriundo de um ilícito contratual deverá ser indenizado”, por força da incidência do art. 389 do Código Civil, que tem aplicação específica às hipóteses de inadimplementos contratuais. E sendo a fiança uma garantia contratual, algumas considerações devem ser feitas acerca da extensão do dever de indenizar que é imputado ao devedor principal.

Por primeiro, sob a expressão “perdas e danos” contida no art. 832 do Código Civil, não há dúvidas de que se encontram os danos materiais (danos emergentes e lucros cessantes) sofridos pelo fiador, notadamente oriundos da desmobilização do capital necessário para fazer frente às suas obrigações de garante ${ }^{227}$.

Por segundo, doutrina e jurisprudência não admitem, como regra, que o inadimplemento de um contrato possa gerar dano moral ${ }^{228},{ }^{229}$. Assim, à luz da posição

\footnotetext{
${ }^{227}$ Nesse sentido: PASQUALOTTO, Adalberto. op. cit., p. 259.

${ }^{228}$ Vede, por todos, CAVALIERI FILHO, Sergio. Programa de responsabilidade civil. 8. ed. rev. e ampl. São Paulo: Atlas, 2008. p. 83-85. Segundo o autor, o seu posicionamento se justificaria porque o dano moral seria uma agressão à dignidade da pessoa humana; por conta disto, o mero inadimplemento contratual, mora ou prejuízo econômico ficaram absorvidos pelos danos material porque não agridiriam a dignidade humana, "salvo se os efeitos do inadimplemento contratual, por sua natureza ou gravidade, exorbitarem o aborrecimento normalmente decorrente de uma perda patriomonial e também repercutirem na esfera da dignidade da vítima, quando, então, configurarão o dano moral.” (p. 84). Em outras palavras, o citado autor indicou que será a casuística que irá determinar se os danos extrapatrimoniais oriundos de descumprimento contratual irão ou não ser compensados.
} 
doutrinário-jurisprudencial que se apresenta majoritária, se o fiador pretender demandar o devedor principal para pleitear indenização por dano moral deverá demonstrar, além do inadimplemento contratual do afiançado, que este decorreu de uma situação específica que lhe ofendeu a dignidade e acarretou-lhe um sofrimento ou aborrecimento que destoaram de um simples descumprimento do contrato ${ }^{230}$.

Em quinto lugar, o art. 834 do Código Civil representa uma especialização da vedação ao abuso de direito previsto no art. 187 do Código da Parte Geral:

“Art. 834. Quando o credor, sem justa causa, demorar a execução iniciada contra o devedor, poderá o fiador promover-lhe o andamento."

Ao comentar o art. 834 do Código Civil, José Augusto Delgado ${ }^{231}$ encampou a posição que havíamos defendido em artigo doutrinário ${ }^{232}$, qual seja, a de se interpretar a regra legal não apenas como concessiva de legitimação ativa extraordinária ao fiador para dar andamento a uma execução já iniciada, como também a de permitir ao garante que ajuíze ação de despejo por falta de pagamento quando o locador não o fizer e restar configurado o abuso do direito. Voltaremos ao tema em capítulo específico sobre a fiança e locação.

Ainda nesta tópico, nas situações que o contrato sobrejacente à fiança não for o de locação, entendemos ser possível ao fiador ajuizar as medidas necessárias a buscar o

\footnotetext{
${ }^{229} \mathrm{Na}$ jurisprudência do STJ, confira-se: "1. O inadimplemento de contrato, por si só, não acarreta dano moral, que pressupõe ofensa anormal à personalidade. É certo que a inobservância de cláusulas contratuais pode gerar frustração na parte inocente, mas não se apresenta como suficiente para produzir dano na esfera íntima do indivíduo, até porque o descumprimento de obrigações contratuais não é de todo imprevisível." (REsp 876.527/RJ, Rel. Ministro JOÃO OTÁVIO DE NORONHA, 4. a Turma, julgado em 01/04/2008, DJe 28/04/2008); "I - Como anotado em precedente (REsp 202.504-SP, DJ 1.10.2001), "o inadimplemento do contrato, por si só, pode acarretar danos materiais e indenização por perdas e danos, mas, em regra, não dá margem ao dano moral, que pressupõe ofensa anormal à personalidade.

Embora a inobservância das cláusulas contratuais por uma das partes possa trazer desconforto ao outro contratante - e normalmente o traz - trata-se, em princípio, do desconforto a que todos podem estar sujeitos, pela própria vida em sociedade"” (REsp 338162/MG, Rel. Ministro SÁLVIO DE FIGUEIREDO TEIXEIRA, 4. ${ }^{\text {a }}$ Turma, julgado em 20/11/2001, DJ 18/02/2002 p. 459); "O inadimplemento contratual implica a obrigação de indenizar os danos patrimoniais; não, danos morais, cujo reconhecimento implica mais do que os dissabores de um negócio frustrado. Recurso especial não conhecido.

(REsp 201414/PA, Rel. Ministro WALDEMAR ZVEITER, Rel. p/ Acórdão Ministro ARI PARGENDLER, 3. ${ }^{\text {a }}$ Turma, julgado em 20/06/2000, DJ 05/02/2001 p. 100).

${ }^{230}$ A título de exemplo, podemos citar uma situação, não tão incomum, em que credor e afiançado firmaram um conluio para prejudicar o fiador: muitas vezes, sendo um imóvel de difícil locação, o credor permite ao devedor principal que ocupe o imóvel por meses ou até anos sem pagar, pois sabe que o fiador irá adimplir em virtude do seu patrimônio.

${ }^{231}$ In DELGADO, José Augusto. Comentários ao novo Código Civil. Coord. Sálvio de Figueiredo Teixeira. Rio de Janeiro: Forense, 2004. v. 11, t. 2, p. 255-265.

${ }^{232}$ SEGALLA, Alessandro Schirrmeister. Da possibilidade de utilização da ação de despejo pelo fiador do contrato de locação. Revista Jurídica, Porto Alegre, v. 48, n. 279, p. 22-41, jan. 2001.
} 
adimplemento do devedor principal, porque se o credor se omitir em buscar o seu crédito, não se ostenta razoável fazer com que o fiador assista a tudo sem nada poder fazer. Ainda que a sua obrigação seja a de garantia do adimplemento de outra, não faz sentido pensarmos que o legislador tivesse tolerado o abuso do direito ${ }^{233}$ do credor, sendo que uma das pilastras da novel codificação foi a da eticidade, de modo que a boa-fé objetiva não admitiria que o credor arruinasse o garante, podendo ser utilizada in casu a doutrina do "duty to mitigate the loss", que será por nós abordada no momento oportuno

Não obstante, o Código Civil de 1916 contemplava expressamente uma regra que não foi reproduzida no Código Civil de 2002: a do art. 1.499, que enunciava:

"Art. 1.499. O fiador, ainda antes de haver pago, pode exigir que o devedor satisfaça a obrigação, ou o exonere da fiança desde que a dívida se torne exigível, ou tenha decorrido o prazo dentro no qual o devedor se obrigou a desonerá-lo."

Este artigo foi objeto de duras críticas doutrinárias, porque se entendia que o mesmo permitiria ao fiador ser muito mais rigoroso do que o credor da obrigação. Nas palavras de Caio Mário da Silva Pereira ${ }^{234}$,

"O princípio tem sido criticado como excessivo, em razão de colocar nas mãos do fiador uma arma que o habilita a ser mais severo do que o credor, antecipando-se a este na exigência, e forçando um desfecho danoso ao afiançado, em contraste com a tolerância do credor. Conciliando o interesse do fiador, que não deseja permanecer na perspectiva indefinida de ter de pagar, e do afiançado que não pretende ser compelido a fazê-lo na falta de exigência do credor cordato, será conveniente um meio-termo razoável como faz o novo Código italiano (art. 1.593), que abre ao fiador a faculdade de agir contra o devedor, para que este lhe dê a liberação, ou forneça as garantias necessárias a assegurar-lhe a satisfação no caso de proceder regressivamente."

A bem dizer, a segunda parte do art. 1.499 do Código Civil de 1916 sempre se apresentou despida de eficácia, sendo o contrato de fiança firmado entre fiador e credor, apenas, de nenhuma valia se apresentava o ato manifestado pelo devedor principal de que estaria a exonerar o garante. Ineficaz, pois, porque não tinha o condão de desvincular a fiança da pessoa do credor.

\footnotetext{
233،O dispositivo serve especialmente para prevenir qualquer conluio que possa haver entre credor e devedor em prejuízo do fiador, o que é presumível quando a demora processual seja causada pelo credor sem justa causa. Naturalmente, caberá ao fiador a prova da demora injustificada, o que deverá demonstrar na petição em que requerer a sua admissão no processo." (PASQUALOTTO, Adalberto. op. cit., p. 261).

${ }^{234}$ In PEREIRA, Caio Mário da Silva. Instituições de direito civil. 10. ed. Rio de Janeiro: Forense, 1995. v. 3 , p. 333.
} 
Em sexto lugar, embora a fiança seja um contrato intuitu personae, porque firmado na confiança que o credor deposita na pessoa do fiador ${ }^{235}$, especialmente na capacidade patrimonial do garante em assegurar o adimplemento da obrigação principal, o art. 836 do Código Civil indica que as obrigações porventura exigíveis do fiador antes da sua morte transmitem-se aos seus herdeiros, obrigações estas, porém limitadas às "forças da herança", isto é, ao valor dos bens que compõem o acervo hereditário; assim, se o valor devido pelo fiador pré-morto superar o do acervo hereditário, o excesso não poderá ser exigido dos herdeiros:

"Art. 836. A obrigação do fiador passa aos herdeiros; mas a responsabilidade da fiança se limita ao tempo decorrido até a morte do fiador, e não pode ultrapassar as forças da herança."

Assim, a exigibilidade da parte que sobejar "as força da herança" será ineficaz perante os herdeiros e deles não poderá ser cobrada. Nesse sentir, afirma-se que a morte do fiador extingue a fiança. Sem fiador não há fiança. Se o fiador falecido era casado, e sua mulher assinou como fiadora conjunta - mais do que simples anuente -, subsiste a obrigação por ela assumida, não se extinguindo a fiança. Nessa hipótese o credor não terá direito de exigir novo fiador, a não ser que possa alegar insuficiência dos bens que couberem à viúva. Neste caso, entretanto, o fundamento será a diminuição da garantia e não a morte do fiador ${ }^{236}$.

\subsection{Extinção}

Os arts. 835, 837, 838 e 839 do Código Civil versam sobre as hipóteses de extinção da fiança; porém, tratam de duas situações distintas: as de desobrigação da garantia e a de exoneração. $\mathrm{O}$ art. 839 já foi objeto de análise juntamente com o benefício de ordem (excussão). A desobrigação e a exoneração geram diferentes conseqüências para o contrato de fiança, o que procuraremos demonstrar em seguida.

\footnotetext{
${ }^{235}$ PEREIRA, Caio Mário da Silva. op. cit., v. 3, p., 1995, p. 328.

${ }^{236}$ Cfe. BARROS, Francisco Carlos Rocha de. Comentários à lei do inquilinato. São Paulo: Saraiva, 1995. p. 174-175.
} 


\subsubsection{Diferenças entre Desobrigação e Exoneração ${ }^{237}$}

O contrato de fiança, negócio jurídico que é, se submete às mesmas vicissitudes de qualquer contrato $^{238}$; todavia, dada a sua característica de contrato unilateral o legislador brasileiro acabou por privilegiar a figura da resilição, tendo outorgado ao fiador um direito potestativo $^{239}$ para que encerrasse o vínculo de garantia estabelecido em favor do credor.

Este direito potestativo de resilição recebeu uma denominação específica na fiança, que foi a de exoneração; em outras palavras, exoneração é sinônimo de resilição, denúncia.

No âmbito do contrato de fiança identificamos duas espécies de exoneração outorgados ao garante, a que denominaremos de exoneração ativa e de exoneração passiva.

A principal diferença entre ambas reside na forma pela qual poderão ser arguidas pelo fiador; na exoneração ativa, é necessário que o fiador atue extra ou judicialmente para obter a sua liberação. São os casos da exoneração extrajudicial prevista no artigo 835, do Código Civil, exoneração por ato amigável e exoneração judicial a ser obtida mediante sentença, hipóteses previstas no artigo 1.500, do Código Civil de 1916. Nestas, o direito potestativo exige que o fiador promova ativamente os atos necessários à sua exoneração,

\footnotetext{
${ }^{237}$ Ao ter comparado as hipóteses legais de desobrigação do fiador previstas no art. 1.503 do Código Civil de 1916 com o direito à exoneração do garante previsto no art. 1.500 do mesmo Código, advertiu, com precisão, BARROS, Francisco Carlos Rocha de: “12. Não se confunda exoneração (CC, art. 1.500) com as hipóteses em que o fiador poderá se considerar desobrigado (CC, art. 1.503). Aquela só produz efeitos se reconhecida amigável ou judicialmente. As hipóteses de desobrigação poderão ser invocadas pelo fiador se e quando for cobrado pelo locador. Para ficar livre da obrigação de pagar, poderá argumentar com moratória concedida pelo locador ao inquilino; fato praticado pelo locador que impossibilite a sub-rogação do fiador nos direitos e preferências daquele; aceitação pelo locador, em pagamento da dívida pelo locatário, de bem que venha a perder depois por evicção. Acrescente-se, ainda, a regra do art. 1.006 do Código Civil, que libera o fiador quando o locador, à sua revelia, ajusta novação com o locatário." (In BARROS, Francisco Carlos Rocha de. op. cit., p. 179-180).

${ }^{238}$ Podendo ser invalidado por defeitos (erro, dolo, coação etc.) ou causas de anulabilidade em geral.

${ }^{239}$ A noção de direito potestativo passou a receber um tratamento mais detalhado pela doutrina civilista brasileira a partir da edição do Código Civil de 2002, e representa um instrumento de vital importância no campo da fiança. Sobre o tema doutrinam, AMARAL, Francisco: "Direito potestativo é o poder que a pessoa tem de influir na esfera jurídica de outrem, sem que este possa fazer algo que não se sujeitar. Consiste em um poder de produzir efeitos jurídicos mediante declaração unilateral de vontade, ou decisão judicial, constituindo, modificando ou extinguindo relações jurídicas. Opera na esfera jurídica de outrem, sem que este tenha algum dever a cumprir. O direito potestativo não exige um determinado Comportamento de outrem nem é suscetível de violação." (In AMARAL, Francisco. op. cit., p. 200-201); NORONHA, Fernando: "Potestativos são os direitos que permitem a uma pessoa, por simples manifestação de vontade (isto é, sem necessidade de concurso de qualquer outra pessoa), modificar ou extinguir uma relação jurídica preexistente, que é de seu interesse. As pessoas sujeitas a direitos deste tipo não têm propriamente uma obrigação, estão em posição puramente passiva, chamada de sujeição ou estado de sujeição." (In NORONHA, Fernando. op. cit., v. 1, p. 56-57); no Código Civil são exemplos de direito potestativo a resilição prevista no artigo 473 e a resolução, no artigo 475.
} 
de modo que se o garante resolver exercer o seu direito apenas em sede de eventual defesa (v.g., contestação), a sua liberação não será obtida porque se ostentará ineficaz. A participação ativa do fiador visando a sua liberação se mostra indispensável.

Já nos casos de exoneração passiva, que na realidade são situações legais de desobrigação, o fiador estará livre do vínculo de garantia a partir do momento que os eventos configuradores vierem a ocorrer, sem que haja a necessidade de o fiador agir para ser liberado, hipóteses estas previstas no artigo 838, do Código Civil. In casu o fiador poderá também aguardar eventual demanda do credor para que fundamente a sua defesa, porém nada impede que o garante se antecipe à eventual ação e ele próprio ajuíze demanda contra o credor fundado nos casos de desobrigação.

Destarte, as hipóteses legais de desobrigação são exceções de direito material $^{240}$, que têm por finalidade extinguir a pretensão do credor em face do fiador. São meios de defesa legais, dos quais poderá se valer o garante se assim o quiser; caso delas não se valha quando acionado judicialmente, opera-se a preclusão. Muito embora as hipóteses de desobrigação possam ser tecnicamente conceituadas como exceções de direito material, ou seja, meios de defesa, repita-se, não vislumbramos qualquer empecilho em que venham a fundamentar demanda judicial do fiador contra o devedor principal pela via da ação declaratória. Quando o art. $4^{\circ}$, I, do Código de Processo Civil enuncia ser cabível a demanda declaratória para a certificação da existência ou inexistência de relação jurídica, também aponta para a possibilidade de seu ajuizamento visando à certificação da existência ou inexistência dos efeitos de relação jurídica.

A exoneração, por seu turno, especialmente diante da nova disciplina introduzida pelo legislador do Código Civil de 2002 em seu artigo 835, é o direito potestativo do fiador exercido para desvinculá-lo da fiança, pressupondo a sua atuação para tal mister mediante notificação endereçada ao credor.

Outro ponto importante: enquanto a manifestação das exceções relativas à desobrigação do fiador gera uma decisão judicial com eficácia ex tunc, dada a sua carga predominantemente declaratória, o exercício do direito potestativo de exoneração possui

\footnotetext{
${ }^{240}$ Nas palavras de Miguel Maria de Serpa Lopes, as exceções de direto material, por ele denominadas de exceções substanciais, seriam classificadas em dilatórias e peremptórias. As dilatórias suspenderiam a eficácia do direito ou pretensão do autor, sem no entanto extinguí-la; já as peremptórias, não apenas paralisariam a eficácia como também extinguiriam a pretensão ou direito do autor. (In LOPES, Miguel Maria de Serpa. Exceções substanciais: exceção de contrato não cumprido. Rio de Janeiro: Freitas Bastos, 1959. p. 103-104)
} 
eficácia ex nunc, salvo a hipótese do artigo 835, do Código Civil, que independe de decisão judicial para surtir efeitos.

Analisemos, pois, os arts. 837 a 839, do Código Civil, que tratam das hipóteses de desobrigação da garantia.

"Art. 837. O fiador pode opor ao credor as exceções que lhe forem pessoais, e as extintivas da obrigação que competem ao devedor principal, se não provierem simplesmente de incapacidade pessoal, salvo o caso do mútuo feito a pessoa menor.

$\mathrm{O}$ art. 837 do Código Civil enuncia que o fiador poderá opor ao credor as exceções que lhe forem pessoais, uma vez que, sendo o negócio de garantia firmado entre as pessoas do credor e fiador, as eventuais vicissitudes do negócio jurídico fidejussório representam um meio de defesa disponibilizado ao garante.

Segundo apontava Pontes de Miranda ${ }^{241}$,

"A dívida do fiador é acessória, porque êle deve o adimplemento pelo devedor. Não há identidade das dívidas, porque prometeu que outrem faça a cêrca não é prometer fazer a cêrca. Se o fiador não pudesse opor o que o devedor poderia opor, a divida do fiador seria mais dura do que a do fiador. Por isso, tem-se de atribuir ao fiador a oponibilidade de tôdas as objeções e exceções que o devedor poderia opor. Tais objeções e exceções existem para os dois devedores, independentemente, porque quem promete que outrem faça a cêrca não promete mais do que a pessoa encarregada teria de fazer."

A exceção à alegabilidade, enuncia o mesmo dispositivo, haverá se as defesas tiverem origem na incapacidade pessoal do devedor principal, o que representa uma hipótese específica de vedação à alegação da própria torpeza, ressurgida com a cláusulageral da boa-fé objetiva (art. 422, Código Civil), sob as vestes da venire contra factum proprium. Se o fiador prestou a garantia sabendo que o devedor principal se apresentava incapaz, não poderá valer-se desta incapacidade para se desobrigar perante o credor. Se a incapacidade pessoal do devedor principal não obstou a outorga da garantia, por idêntica razão não deve obstar a sua exigibilidade pelo credor, exceto se o negócio jurídico sobrejacente à fiança for o de mútuo feito a pessoa menor ${ }^{242}$, ante a disciplina estatuída no

\footnotetext{
${ }^{241}$ PONTES DE MIRANDA, Francisco Cavalcanti. Tratado de direito privado. 3. ed. Rio de Janeiro: Borsoi, 1972. t. 44, § 4.790, p. 180-181. (Grifamos)

${ }^{242}$ E menor, no texto da lei, significa o relativamente incapaz. (Cfe. ALVES, Jones Figueirêdo. Novo Código Civil comentado. Coord. Ricardo Fiuza. 3. ed. atual. São Paulo: Saraiva, 2004. p. 535); em sentido aparentemente contrário encontram-se ANDRIGHI, Nancy et al., para os quais menor designaria os relativa
} 
art. 588 do Código Civil $^{243}$, que veda a exigibilidade do mútuo tanto do mutuário menor, quanto de seus fiadores.

A norma do art. 588 do Código Civil representa exceção aos efeitos da invalidade (nulidade ou anulabilidade) dos negócios jurídicos, que ordinariamente determinam, ante o seu reconhecimento, o retorno das partes aos estado anterior ao da contratação, nos termos do art. 182 do Código Civil ${ }^{244}$.

$\mathrm{O}$ art. 838 do Código Civil contempla algumas hipóteses específicas de desobrigação do fiador, as quais são complementadas pelo art. 366 relativo à novação, pelo art. $844, \S 12^{\circ}$, relativo à transação e pelo artigo 371, relativo à compensação. Trata-se de situações específicas que extinguem a garantia fidejussória e representam, em nosso sentir, o princípio geral de vedação ao abuso de direito (art. 187, do Código Civil). Vejamos cada uma delas:

“Art. 838. O fiador, ainda que solidário, ficará desobrigado:

I - se, sem consentimento seu, o credor conceder moratória ao devedor;"

A primeira hipótese legal diz respeito à concessão de moratória pelo credor ao devedor principal, situação esta que agravaria a situação do garante em total afronta à natureza da liberalidade manifestada e ao princípio da interpretação restritiva da fiança. Moratória é a concessão de prazo ao devedor para resgate da dívida.

Doutrina e jurisprudência, no entanto, firmaram o entendimento de que não seria qualquer concessão de prazo feita ao devedor pelo credor que desobrigaria o fiador, mas apenas aquela que teria o condão de causar prejuízo ao garante. Além disso, o entendimento que se formou ao tempo de vigência do Código Civil de 1916 asseverava, de forma praticamente uníssona, que para configuração da moratória exigir-se-ia forma expressa (rectius, escrita) ${ }^{245}$ veiculando a extensão do prazo para pagamento, razão pela

e os absolutamente incapazes (In ANDRIGHI, Nancy et al. Comentários ao novo Código Civil. Coord. Sálvio de Figueiredo Teixeira. Rio de Janeiro: Forense, 2008. v. 9, p. 140-146).

${ }^{243}$ Código Civil: "Art. 588. O mútuo feito a pessoa menor, sem prévia autorização daquele sob cuja guarda estiver, não pode ser reavido nem do mutuário, nem de seus fiadores."

${ }^{244}$ Código Civil: "Art. 182. Anulado o negócio jurídico, restituir-se-ão as partes ao estado em que antes dele se achavam, e, não sendo possível restituí-las, serão indenizadas com o equivalente.”; anulado no texto, segundo a concepção que adotamos, tem o sentido de desconstituído por nulidade ou anulabilidade.

${ }^{245}$ Segundo Pontes de Miranda: "Se o credor espera, sem se vincular a não pedir dentro de prazo, há tolerância e não moratória. O acôrdo de espera, o pactum de non petendo in tempus, entra no mundo jurídico, é negócio jurídico bilateral, e pode haver declaração unilateral de vontade do credor que lhe crie a vinculação de não pedir dentro de determinado prazo, ou até a algum acontecimento. $\mathrm{O}$ ato de tolerância não entra no mundo jurídico; permanece no mundo fáctico: a relação jurídica entre o credor e o devedor, 
qual a inércia do credor em exigir a sua obrigação ou até mesmo a sua mera tolerância ${ }^{246}$ não configuraria o favor legal. Segundo apontou Lauro Laertes de Oliveira ${ }^{247}$,

"Não se deve confundir mera tolerância ou inércia do credor com a moratória. Esta extingue a fiança. Aquelas não. A moratória ingressa na órbita jurídica. A tolerância ou inércia do credor não ingressa na ordem jurídica, mas apenas no mundo fático.

(...)

Dessa forma, meros acordos verbais de tolerância não vislumbram moratória. Nem pedido de suspensão da ação judicial revela caráter moratório. Mas concessão de prazo na ação de despejo por falta de pagamento à revelia do fiador pode caracterizar moratória, pois está causando prejuízo ao fiador; quanto mais a ação de despejo prolongar-se, maior será o débito a responsabilidade do fiador."

Não obstante, na teoria e na prática torna-se bastante sutil o discrimen entre o que seria moratória e o que seria ato de tolerância. Ademais, com o devido respeito, não nos parece acertada a opinião de que a moratória deveria se dar por escrito, ainda mais nas épocas atuais em que muitos negócios, apesar dos riscos que apresentam, serem realizados verbalmente e sem as formalidades de que se revestem outros tipos, tais como o compromisso de venda e compra de imóvel. Nem sempre o credor e o fiador se encontram para que seja subscrito o ato da moratória e mesmo se se encontrassem, tal fato dificilmente chegaria ao conhecimento do fiador, até porque o credor, o que sói acontecer na prática dos negócios, até poderá pretender auxiliar o devedor no adimplemento, porém se se despir da garantia fidejussória. E foi com base nestas dificuldades que formulamos as idéias de que ao fiador fosse outorgada legitimidade ativa para pleitear a exigibilidade do crédito ou até mesmo o despejo do imóvel locado do devedor.

Por estas razões, entendemos que a concessão de prazo ao devedor principal para pagar a sua dívida não necessita de formalização por escrito para que venha a ser considerada, porém a análise do caso específico é que irá demonstrar se in concreto

quanto a êsse acôrdo, ou quanto ao ato unilateral de tolerância, é de ordem moral, ou de ordem econômica, ou política, não de ordem jurídica (....) A prorrogação do prazo ou qualquer adiamento, que entre no direito, tem de ser escrito." (In PONTES DE MIRANDA, Francisco Cavalcanti. Tratado de direito privado. 3. ed. Rio de Janeiro: Borsoi, 1972. t. 38, § 4.798, p. 219-220.

246“"CIVIL - ALUGUÉIS EM ATRASO - FIANÇA - Não se tendo como extinta a fiança (art. 1.503 do Código Civil), responde o fiador do locatário pelos aluguéis em atraso, não se podendo considerar como havendo moratória a mera tolerância de maior prazo no recebimento dos aluguéis. Não conhecimento pela letra "a" do art. 119, III, da Constituição Federal. E não é, igualmente, de admitir-se o recurso pela letra "d" se o acórdão trazido a confronto não oferece questão idêntica ou semelhante àquela objeto do apelo excepcional." (STF - 2 ${ }^{\mathrm{a}}$ T.; RE no 76.965-2-RJ; rel. Min. Aldir Passarinho; j. 07.06.1985; v.u.; DJU, 27.09.1985; p. 16.612, ementa.) BAASP, 1402/267, de 30.10.1985.

${ }^{247}$ In OLIVEIRA, Lauro Laertes de. op. cit., p. 86-87. 
ocorreu ou não prejuízos ao fiador que não estariam abrangidos nos riscos inerentes à fiança. De todo o modo, o dispositivo, em nosso sentir, estaria a merecer reforma legislativa, a fim de que fosse introduzido um prazo dentro do qual o credor estaria autorizado a conceder ao devedor para que este procurasse cumprir a sua obrigação com uma maior facilidade, a fim de que fosse evitado o prolongamento indefinido de uma situação extremamente desvantajosa ao garante.

A segunda hipótese legal diz respeito ao fato do credor, isto é, o agir ou omitir do credor que impedem o fiador de sub-rogar-se em seus direitos. Sob este dispositivo legal enquadram-se todas as situações em que o credor vier a favorecer outros garantidores das mesmas obrigações em detrimento do fiador ou até mesmo se omitir em tomar providências contra o devedor principal:

II - se, por fato do credor, for impossível a sub-rogação nos seus direitos e preferências;

Conforme apontava Silvio Rodrigues ${ }^{248}$,

"Assim, se o crédito era garantido por fiança e penhor, e o credor abriu mão da garantia pignoratícia, extingue-se igualmente a fiança, pois ao fiador que resgatasse a dívida não mais seriam transferidos os direitos reais decorrentes do penhor, e com os quais aquele, legitimamente, podia contar."

O credor deve abster-se de praticar qualquer ato capaz de prejudicar a efetividade da sub-rogação do fiador, assim como deve agir com prudência e zelo na conservação dos seus próprios direitos relativos ao crédito, consciente de que os mesmos poderão vir a ser exercitados futuramente pelo fiador. São deveres de boa-fé e lealdade que permeiam o contrato de fiança ${ }^{249}$.

A terceira hipótese legal indica que se o credor receber objeto diverso daquele a que estaria obrigado devedor principal, a dação em pagamento extinguirá a fiança, ainda que o bem entregue venha a ser retirado do patrimônio do credor em virtude de evicção:

III - se o credor, em pagamento da dívida, aceitar amigavelmente do devedor objeto diverso do que este era obrigado a lhe dar, ainda que depois venha a perdê-lo por evicção."

\footnotetext{
${ }^{248}$ In RODRIGUES, Silvio. Direito civil: dos contratos e das declarações unilaterais de vontade, cit., p. 376377.

${ }^{249}$ PASQUALOTTO, Adalberto. op. cit., p. 271.
} 
Segundo apontou Clóvis Beviláqua ${ }^{250}$, se da coisa dada em pagamento vier o credor a ser privado em virtude da ocorrência de evicção, não obstante a obrigação originária venha a se restaurar ${ }^{251}$, a fiança já terá sido e permanecerá extinta,

"porque o fiador apenas assegurou o pagamento, não assumiu a responsabilidade pela evicção, que constitue outra relação de direito. Se, expressamente, assumir essa responsabilidade, decorrerá ella do estipulado, e não da fiança." (Grifamos)

A quarta hipótese de desobrigação do fiador foi prevista no art. 366 do Código Civil:

“Art. 366. Importa exoneração do fiador a novação feita sem seu consenso com o devedor principal."

A novação constitui modalidade de extinção de uma obrigação que vem ocupar o lugar da primeira. É uma forma de pagamento indireto que, ao mesmo tempo em que extingue o débito anterior, produz um novo débito, em um ato único, de modo que não apenas se assume nova dívida: se assume uma nova dívida em lugar de outra, que se extingue. Este é o mais relevante traço da novação, sem cuja compreensão é impossível a apreensão do instituto, da sua funcionalidade e da sua eficácia, que é a de criar e extinguir relação jurídica por efeito do mesmo ato jurídico ${ }^{252,253}$.

Portanto, a novação implica na assunção de nova obrigação visando a automática extinção da anterior. É, na verdade, a substituição de uma dívida por outra, substituição essa que implica na extinção da obrigação sucedida pela sucessora, a qual poderá vir a ser exigida do devedor pelo credor na data do seu vencimento. A obrigação sucedida desaparece, razão pela qual o único vínculo que passa a unir credor e devedor é o da

\footnotetext{
${ }^{250}$ In BEVILÁQUA, Clóvis. Código Civil dos Estados Unidos do Brasil. Rio de Janeiro: Francisco Alves, 1919. v. 5, t. 2, p. 258 e 259. (Grifamos)

${ }^{251}$ Código Civil: “Art. 359. Se o credor for evicto da coisa recebida em pagamento, restabelecer-se-á a obrigação primitiva, ficando sem efeito a quitação dada, ressalvados os direitos de terceiros.”

${ }^{252}$ MARTINS-COSTA, Judith. op. cit., v. 5, t. 1, p. 504.

253، A novação corresponde a meio liberatório singular, a modo especial de extinguir-se a obrigação. Chegase a compará-la a um pagamento fictício. Define-se como "a conversãode uma dívida em outra para extinguir a primeira". É a substituição de uma dívida por outra, eliminando-se a precedente. Desaparece a primeira, e, em seu lugar, surge nova. Esse o seu conteúdo essencial, aliás duplo: um extintivo, referente à obrigação antiga; outro gerador, relativo à obrigação nova. Não existe, pois, tão-somente, uma transformação; o fenômeno é mais complexo, abrangendo a criação de nova obrigação, que se substituiu à antiga." (MONTEIRO, Washington de Barros; MALUF, Carlos Alberto Dabus; SILVA, Regina Beatriz Tavares da. Direito das obrigações: 1. parte. 34. ed. São Paulo: Saraiva, 2009. p. 320).
} 
obrigação nova, qual seja, a sucessora. É o que se extrai do artigo 360, inciso I, do Código Civil.

Desta forma, uma vez que a novação faz desaparecer a obrigação novada, a fiança, dado o seu caráter acessório, também é extinta. Não bastasse este princípio $^{254}$ e a disposição do art. 366, o Código Civil de 2002 ainda contemplou a hipótese do art. 364:

"Art. 364. A novação extingue os acessórios e garantias da dívida, sempre que não houver estipulação em contrário. Não aproveitará, contudo, ao credor ressalvar o penhor, a hipoteca ou a anticrese, se os bens dados em garantia pertencerem a terceiro que não foi parte na novação."

Nesse sentir, aponta Judith Martins-Costa ${ }^{255}$, com base na doutrina de Pontes de Miranda, que o dispositivo em comento contempla o "princípio da inclusão da parte no todo", que embora formulado para o regime de bens, constituiria princípio lógico que poderia ser excepcionado. Na hipótese contemplada no art. 364 do Código Civil a desobrigação do fiador ocorre ex vi legis, de maneira que o garante não precisará manejar qualquer demanda judicial. Muito embora no art. 366 o legislador tenha se valido do termo exonerado, na realidade se trata de hipótese de desobrigação, uma vez que a exoneração, no sentido empregado na presente dissertação, é direito potestativo conferido ao fiador, enquanto as hipóteses de desobrigação da garantia representariam exceções de direito material. Daí por que, havendo alteração do negócio anterior quanto às garantias, não poderem as fianças ou hipotecas dadas por terceiros, aderir ao novo negócio, sem a manifestação expressa dos terceiros garantes ${ }^{256}$.

A quinta hipótese de desobrigação legal foi prevista pelo legislador no art. 839 do Código Civil e se relaciona diretamente ao benefício de ordem, o qual já abordamos:

“Art. 839. Se for invocado o benefício da excussão e o devedor, retardando-se a execução, cair em insolvência, ficará exonerado o fiador que o invocou, se provar que os bens por ele indicados eram, ao tempo da penhora, suficientes para a solução da dívida afiançada."

\footnotetext{
${ }^{254} \mathrm{O}$ que pode atualmente ser extraído do art. 92 do Código Civil de 2002 (“Art. 92. Principal é o bem que existe sobre si, abstrata ou concretamente; acessório, aquele cuja existência supõe a do principal.), uma vez que o legislador não manteve expressamente na nova codificação a disposição constante do art. 59 do Código Civil de 1916 (“Art. 59. Salvo disposição especial em contrário, a coisa acessória segue a principal.").

${ }^{255}$ In MARTINS-COSTA, Judith. Comentários ao novo Código Civil. Coord. Sálvio de Figueiredo Teixeira. Rio de Janeiro: Forense, 2003. v. 5, t. 1, p. 552.

${ }^{256}$ VIANA, Rui Geraldo Camargo. A novação. São Paulo: Ed. Revista dos Tribunais, 1979. p. 61. (Grifamos)
} 
O dispositivo em comento, dentre outros já analisados, representa para nós mais um reflexo da vedação ao comportamento contraditório; se a execução tiver se retardado por desídia do credor $^{257}$, este não poderá valer-se da própria torpeza para prejudicar a situação jurídica do fiador, de modo que o garante estará automaticamente exonerado (rectius, desobrigado) se provar que os bens do devedor principal que foram indicados ao tempo da penhora eram suficientes para solver a obrigação.

A sexta hipótese de desobrigação legal foi prevista pelo legislador no art. $844, \S$ 1. ${ }^{\circ}$, do Código Civil no capítulo relativo ao negócio jurídico da transação:

“Art. 844. A transação não aproveita, nem prejudica senão aos que nela intervierem, ainda que diga respeito a coisa indivisível.

$\S 1^{\underline{o}}$ Se for concluída entre o credor e o devedor, desobrigará o fiador."

A transação não aproveita, nem prejudica senão aos que nela intervierem, ainda que diga respeito a coisa indivisível (art. 844, do Código Civil). Os efeitos dela não podem atingir os que não transigiram ${ }^{258}$. Em relação às pessoas que nela não intervieram, é res inter alios; conseqüentemente, não aproveita nem prejudica. A transação só produz efeito entre as próprias partes e quanto à relação de direito entre elas existente. Ela dá origem a uma exceção (exceptio litis per transactionem finitae), anàloga à da coisa julgada ${ }^{259}$.

Assim, havendo fiança, o fiador se desobrigará se celebrada transação entre o credor e o devedor. Nesse ponto, aplica-se a regra de que, extinta a obrigação principal, extingue-se, de igual forma, a acessória ${ }^{260,261}$.

Por fim, a sétima e última hipótese a ser relacionada aos efeitos da fiança encontrase no artigo 371, do Código Civil, e diz respeito à compensação:

"Art. 371. O devedor somente pode compensar com o credor o que este lhe dever; mas o fiador pode compensar sua dívida com a de seu credor ao afiançado."

\footnotetext{
${ }^{257}$ Cfe. PASQUALOTTO, Adalberto. op. cit., p. 273.

${ }^{258}$ Ainda que esta afirmação seja tecnicamente correta à luz do princípio da relatividade dos efeitos dos contratos, dado o caráter acessório da fiança a extinção da obrigação transacionada beneficia o fiador da obrigação extinta, razão pela qual os transatores não poderão manifestar qualquer direito ou pretensão do garante.

${ }^{259}$ Cfe. MONTEIRO, Washington de Barros; MALUF, Carlos Alberto Dabus; SILVA, Regina Beatriz Tavares da. Direito das obrigações. 2. parte. 36. ed. São Paulo: Saraiva, 2009, p. 422.

${ }^{260}$ TEPEDINO, Gustavo; BARBOZA, Heloisa Helena; MORAES, Maria Celina Bodin de. Código Civil interpretado. Rio de Janeiro: Renovar, 2006. v. 2, p. 662.

${ }^{261}$ No mesmo sentido: MALUF, Carlos Alberto Dabus. A transação no direito civil e no processo civil. 2. ed. rev. e aum. São Paulo: Saraiva, 1999. p. 160-161.
} 
A primeira parte do dispositivo não é inovadora, pois somente se poderá falar em compensação (art. 368) quando as duas pessoas forem simultaneamente credor e devedor uma da outra. A segunda parte, porém, permite ao fiador que obtenha a compensação do crédito do afiançado contra o seu credor. Assim, em uma mesma relação jurídica, ao ser ajuizada a cobrança pelo credor em face do devedor afiançado, ele não pode apresentar um crédito de seu fiador em relação ao credor para compensá-lo. No entanto, se o fiador é executado, poderá postular a compensação do valor devido pelo credor ao devedor afiançado, porque isso lhe é permitido pelo presente artigo ${ }^{262}$. A norma pretende trazer desafogo ao fiador ${ }^{263}$.

A compensação impõe-se independentemente da anuência de ambas as partes da relação obrigacional. Assim, ao invocar a compensação frente ao credor, o fiador não está fazendo mais que recordar o encontro de dívidas e créditos pessoalmente recíprocos entre credor e afiançado. Claro que tal invocação se dá em benefício próprio do fiador, já que evita a cobrança de dívida contra ele, mas nenhuma alteração se tem aí à disciplina da compensação ${ }^{264}$.

Além da compensação entre credor e devedor-afiançado, o fiador pode, obviamente, invocar a compensação pessoal, isto é, a compensação da dívida do afiançado pela qual vier a ser demandado com a dívida detida pelo credor em face do próprio fiador. Também aqui a afirmativa não traz surpresa, atentando-se à verificação automática da compensação no direito brasileiro, dependendo apenas o seu reconhecimento de invocação pelo devedor $^{265}$.

\subsubsection{Exoneração}

Sob a égide do Código Civil de 1916 o exercício do direito à exoneração da fiança pelo garante foi objeto de intermináveis discussões doutrinário-jurisprudenciais, até pela redação do art. 1.500 que colocava o fiador em uma situação absolutamente desconfortável:

\footnotetext{
${ }^{262}$ BDINE JR., Hamid Charaf. Código civil comentado: doutrina e jurisprudência. Coord. Cezar Peluso. 3. ed. rev. e atual. Barueri: Manole, 2009. p. 811.

${ }^{263}$ TEPEDINO, Gustavo; BARBOZA, Heloisa Helena; MORAES, Maria Celina Bodin de. op. cit., v. 2, p. 676.

${ }^{264}$ TEPEDINO, Gustavo; SCHREIBER, Anderson. op. cit., v. 4, p. 311.

${ }^{265}$ Id., loc. cit.
} 
"Art. 1.500. O fiador poderá exonerar-se da fiança que tiver assinado sem limitação de tempo, sempre que lhe convier, ficando, porém, obrigado por todos os efeitos da fiança, anteriores ao ato amigável, ou à sentença que o exonerar."

À luz do Código revogado, a exoneração do fiador, quando a garantia tivesse sido prestada sem tempo determinado ${ }^{266}$, ficava na dependência do ajuizamento de uma demanda judicial ${ }^{267}$ pelo garante e da procedência do pedido ou da liberação amigável fornecida pelo credor, que na verdade era uma quimera. Na prática, em grande parte das vezes o exercício do direito à exoneração se mostrava inócuo porque o art. 1.500 dispunha que o fiador somente seria liberado após a sentença que o exonerasse. Nesta medida, como a sentença apenas detonava a sua eficácia plena após o seu trânsito em julgado e como as demandas se eternizavam e ultrapassavam facilmente o prazo contratual fixado pelas partes, o fiador não conseguia se desvincular da obrigação; em conseqüência, alguns doutrinadores passaram a defender uma exegese que flexibilizasse a regra legal, a fim de permitir a efetividade do direito concedido ao garante. À época da vigência do Código Civil de 1916, Caio Mário da Silva Pereira fez duras críticas ao dispositivo em comento e passou a defender que o fiador ficasse livre da garantia a partir da citação do credor, para tanto devendo os efeitos da sentença retroagir até a data da sua realização ${ }^{268}$ :

\footnotetext{
${ }^{266}$ Em conhecida passagem de sua obra, Clóvis Beviláqua apontava: "Pode a fiança não ter limitação de tempo e adherir a uma obrigação, que também o não tenha. A fiança, acto benefico, desinteressado, não pode ser uma tunica de Nessus. Assim como o fiador, livremente, a tomou sobre si, livremente, lhe sacode o jugo, quando lhe convier; pois, não tendo promettido conserva-la por tempo certo, contra a sua vontade, não poderá permanecer indefinidamente obrigado." (In BEVILÁQUA, Clóvis. op. cit., v. 5, t. 2, p. 253 ).

267"ILEGITIMIDADE “Ad Causam” - Ação de cobrança - Contrato bancário - Avença firmada pelos apelantes na qualidade de fiadores da devedora principal - Afirmação de notificação ao credor de exoneração da obrigação assumida - Insuficiência - Fiança prestada sob a égide no antigo Código Civil que deve respeitar suas regras - Existência de acordo de vontades ou sentença judicial que os desobrigassem, de acordo com o art. 1.500 do antigo CC - Necessidade - Alegada novação inocorrente - Legitimidade passiva - Reconhecimento - Recurso parcialmente provido, com determinação, na parte conhecida." (Apelação Cível n. 7.081.291-6 - São Joaquim da Barra - 22a Câmara de Direito Privado - Relator: Campos Mello - 06.05.09 - V.U. - Voto n. 19779); "LOCAÇÃO - Fiança - Exoneração - Faculdade não exercida - Responsabilidade do fiador - Reconhecimento - Diante do caráter gratuito da fiança, operada a prorrogação legal ou convencional da locação e passando ela a vigorar por prazo indeterminado, é lícito ao fiador pleitear a sua exoneração, nos termos do art. 1.500 do $\mathrm{CC}$ revogado, se o contrato tiver sido celebrado na sua vigência, ou do art. 835 do CC atual, se o contrato foi ajustado após sua entrada em vigor Esse raciocínio não implica ofensa à Súmula 214 do STJ porque ela cuida de aditamento contratual e não da hipótese de prorrogação do contrato locatício por tempo indeterminado - Recurso não provido" (Apelação Cível n. 1.098.360-0/0 - São Paulo - 26a Câmara de Direito Privado - Relator: Renato Sartorelli 16.06.08 - V.U. - Voto n.13.542).

${ }^{268}$ In PEREIRA, Caio Mário da Silva. Instituições de direito civil. 10. ed. Rio de Janeiro: Forense, 1995. v. 3, p. 334: "Mas a solução do Código Civil não é a melhor, pois que libera o fiador somente a partir da sentença, se o credor não anuir em desonerá-lo. Justo será que o fiador fique livre a partir da citação, retroagindo os efeitos da sentença até a sua data. Em caso contrário, o credor que maliciosamente procrastinar o andamento do feito estenderá no tempo os efeitos da garantia, e tirará proveito da própria
} 
"Em contrário, o credor que maliciosamente procrastinar o andamento do feito estenderá no tempo os efeitos da garantia e tirará proveito da própria má-fé, o que é contra moral e o direito. Em qualquer caso, porém, o fiador exonerado responde pelos débitos existentes até a data da sua liberação."

Até mesmo Clóvis Beviláqua criticava a dureza da regra legal, sob o argumento de que se o fiador tinha o direito à exoneração da fiança, não deveria o Código Civil sujeitá-lo aos caprichos do credor. Assim, dizia que a sentença de exoneração poderia fixar o momento em que cessaram os efeitos da fiança, evitando-se a oneração demasiada do garante $^{269}$. Apesar das críticas, as decisões judiciais, com raríssimas exceções, seguiam a orientação diversa, no sentido de que a exoneração do fiador ficava na dependência do trânsito em julgado da sentença liberatória.

Foi por esta razão que o legislador introduziu uma das maiores inovações no Código Civil de 2002, pois passou a permitir, de acordo com a regra constante do seu art. 835, que o direito do fiador à exoneração do vínculo se daria independentemente de demanda judicial:

“Art. 835. O fiador poderá exonerar-se da fiança que tiver assinado sem limitação de tempo, sempre que lhe convier, ficando obrigado por todos os efeitos da fiança, durante sessenta dias após a notificação do credor."

Diante da nova disciplina introduzida pelo legislador, afirma-se que a exoneração é o direito potestativo do fiador exercido para desvinculá-lo da fiança, pressupondo a sua atuação para tal mister mediante notificação endereçada ao credor.

O direito potestativo poderá ser exercido extra ou judicialmente mediante simples comunicado ou ação cautelar de notificação, uma vez tratar-se de manifestação receptícia de $\operatorname{vontade}^{270}$, pois a sua eficácia exoneratória estará vinculada à efetivação da comunicação do credor como corolário do princípio da boa-fé objetiva. A notificação exoneratória que não chegar ao conhecimento do credor será ineficaz e não terá o condão de extinguir a fiança, porque tratando-se a fiança de um negócio jurídico de garantia,

má-fé, o que é contra a moral e o direito. Em qualquer caso, porém, o fiador exonerado responde pelos débitos existentes até a data da liberação."

${ }^{269}$ In BEVILÁQUA, Clóvis. op. cit., v. 5, t. 2, p. 253. (Grifamos)

${ }^{270}$ Conforme a doutrina de DíEZ-PICAZO, Luis, os negócios jurídicos unilaterais, dentre os quais se enquadra a notificação exoneratória $e x$ artigo 835 do Código Civil, "Pueden ser «recepticios» e «no recepticios». Los primeros son aquellos en los cuales la declaración de voluntad emitida por el autor del negocio, para ser eficaz, tiene que ser recibida por otra u otras personas." (In DÍEZ-PICAZO, Luis. op. cit., v. 1, p. 75). 
cumpre ao fiador informar ao credor a partir de qual data não mais afiançará o negócio, a fim de permitir a sua substituição, evitando que a fiança sofra solução de continuidade e coloque em risco a garantia de adimplemento exato e fiel da prestação devida.

Em que pese a boa inovação legislativa, os doutrinadores que passaram a escrever sobre o Código Civil não se aprofundaram na análise do tema e passaram a repetir, quase em uníssono, que o direito à exoneração poderia se dar sem que fosse ajuizada demanda judicial $^{271}$.

Não obstante, uma importante questão relativa ao direito de exoneração do fiador com base no artigo 835 do Código Civil não pode ser esquecida: o exercício do direito de exoneração comportaria algum limite objetivo ou apenas estaria vinculado ao limite subjetivo consistente na manifestação de vontade do garante?

Para nós, o exercício da exoneração sofre uma limitação, que vem a ser a mora ou inadimplemento do devedor principal. Expliquemos melhor.

A notificação exoneratória do art. 835 do Código Civil é espécie do gênero causas de extinção do contrato supervenientes à sua formação; é, na verdade, uma resilição (rectius, denúncia) do vínculo sob a forma de um direito potestativo ${ }^{272}$.

E este direito potestativo à exoneração existe para proteger o fiador que assegurou o adimplemento de um afiançado não-inadimplente, isto é, aquele cujas obrigações encontram-se em dia, pois as obrigações assumidas devem ser fielmente executadas ${ }^{273}, \mathrm{o}$ que representa o ponto de equilíbrio do sistema jurídico contratual; se pelo contrato de fiança o fiador garante que o devedor principal adimplirá a sua obrigação, o não-

\footnotetext{
${ }^{271}$ Nesse sentido: DELGADO, José Augusto. op. cit., v. 11, t. 2, p. 266; PASQUALOTTO, Adalberto. op. cit., p. 261; SANTOS, Gildo dos. op. cit., p. 109-116; ALVES, Jones Figueirêdo. op. cit., p. 766: "Nesse ponto, o novo Código Civil traz mudanças significativas, que merecem ser ressaltadas: a um, porque admite a exoneração por simples comunicação (notificação) ao credor, independentemente de anuência deste ou do devedor principal, ou mesmo de sentença judicial; a dois, porquanto, pelo prazo de sessenta dias, contados da notificação ao credor, o fiador continuará vinculado por todas as obrigações assumidas pelo devedor, produzindo, daí, efeitos ex nunc, voltados apenas para o futuro.”; RODRIGUES, Silvio. Direito civil: dos contratos e das declarações unilaterais de vontade, cit., v. 3, p. 363: "A lei defere ao fiador o direito de alforriar-se mediante mera manifestação da sua vontade. $O$ assunto não comporta maiores debates, porque isso raramente ocorre na prática, em que a responsabilidade do fiador é, em geral, exigida e assumida, enquanto perdurar a obrigação do afiançado. Aliás, quando o credor aceita fiador na hipótese figurada no art. 835 do Código Civil, age imprudentemente e ameaça a seu crédito, resultante da deserção do fiador, decorre de sua própria culpa." (Grifamos)

272 "A "denúncia" é a denominação que se dá ao exercício do direito formativo-extintivo de desfazimento das obrigações duradouras, contra a sua renovação ou continuação, independentemente do inadimplemento da outra parte, nos casos permitidos na lei ou no contrato (v.g., arts. $6 .^{\circ}, 46, \S 2 .^{\circ}$, e 57 da Lei ${ }^{\circ} 8.245$, de 18/10/91, sobre locação de imóveis urbanos)." (AGUIAR JÚNIOR, Ruy Rosado de. op. cit., p. 72). (Grifamos)

${ }^{273}$ ALVIM, Agostinho. Da inexecução das obrigações e suas consequiências. 2. ed. São Paulo: Saraiva, 1955. p. 17. (Grifamos)
} 
cumprimento (mora ou inadimplemento absoluto) da obrigação principal tem o efeito de atingi-lo e também torná-lo "inadimplente" perante o credor principal, principalmente se tiver subscrito a fiança na condição de principal pagador ou devedor solidário, pois, como já dissemos, o fiador, ao prometer fato de terceiro, é responsável por dívida alheia, e se a dívida alheia não for paga, isto significará que a sua promessa falhou.

Assim, não teria sentido permitir que o fiador se exonerasse da fiança tão-logo o devedor principal - a pessoa em quem depositou confiança, isto é, a pessoa que o fiador confiou que iria adimplir -, deixasse de cumprir o contrato sobrejacente à garantia. Ao admitir-se tal exegese estar-se-ia transformando a fiança em garantia de papel, como bem restou decidido pelo Supremo Tribunal Federal ao ter julgado o RE 407.688 (j. em 08/02/2006), no qual o Relator, Exmo. Sr. Min. Cesar Peluso, manifestou um duro ataque aos fiadores que expressamente manifestam a sua vontade fidejussória no contrato de garantia para ao depois, quando cobrados pela inadimplência do devedor principal, recorrerem ao Poder Judiciário alegando o direito à exoneração ${ }^{274}$ :

"O SENHOR MINISTRO CEZAR PELUSO (RELATOR) - Ministro, ele [o fiador] é um fraudador: declara que pode garantir, mas, na verdade, não pode, pois não tem nada para garantir."

Com efeito, ainda que a regra jurídica que veda ao inadimplente o acesso ao mecanismo da extinção do contrato diga respeito ao instituto da resolução previsto no art. 475 do Código Civil, o mesmo raciocínio deve ser aplicado, por uma interpretação sistemática, ao instituto da exoneração previsto no art. 835 do Código Civil. Da mesma forma que o art. 475 do Código Civil enuncia que apenas ao lesado cabe a ação de resolução: “A parte lesada pelo inadimplemento...”, a exoneração do fiador somente se viabilizará se o afiançado não estiver em uma situação de mora ou inadimplência, mormente se o garante tiver subscrito a garantia como devedor principal ou solidário. Segundo defendemos, a leitura do art. 835 do Código Civil deverá ser a seguinte:

"Art. 835. O fiador poderá exonerar-se da fiança que tiver assinado sem limitação de tempo, sempre que lhe convier, [e desde que as obrigações garantidas estiverem sendo fielmente cumpridas], ficando obrigado por

\footnotetext{
274،"Entre tantas expressões derivadas do princípio da boa-fé pode ser destacado o dever de não agir contra o ato próprio. Significa dizer que a ninguém é dado valer-se de determinado ato, quando lhe for conveniente e vantajoso, e depois voltar-se contra ele quando não mais lhe interessar. Esse comportamento contraditório denota intensa má-fé, ainda que revestido de aparência de legalidade ou de exercício regular de direito. Nas obrigações revela-se, em muitos casos, como aproveitamento da própria torpeza, mas a incidência desse dever não exige o requisito da intencionalidade" (LÔBO, Paulo Luiz Netto. Teoria geral das obrigações, cit., p. 88) (Grifamos).
} 
todos os efeitos da fiança, durante sessenta dias após a notificação do credor." (Grifamos)

E isto porque a parte lesada pelo inadimplemento da obrigação principal é o credor, razão pela qual o fiador não poderá se exonerar da garantia se no momento da notificação veiculada de acordo com o artigo 835 do Código Civil o devedor principal já estiver inadimplente, ainda que o contrato sobrejacente estiver a viger por tempo indeterminado, o que sói acontecer nas locações de imóveis urbanos. Não teria sentido, pois, que o fiador permanecesse vinculado ao contrato somente se o devedor principal adimplisse; se assim o fosse, não haveria a necessidade de prestação de fiança, a qual se consubstancia em um reforço ao adimplemento.

Para bem esclarecer, a mora ou inadimplemento do afiançado não impede a notificação exoneratória ex art. 835, do Código Civil, mas a sua eficácia somente será detonada se vier a ser cumprida a obrigação garantida. Cumprida fielmente a obrigação e detonada a eficácia da exoneração, o fiador somente permanecerá responsável pelo prazo de 60 (sessenta) dias. Esta vem a ser a melhor exegese de acordo com o princípio da boa-fé objetiva. O fiador que pretender exonerar-se da fiança através do exercício do direito potestativo previsto no artigo 835 do Código Civil deverá se apresentar "with clean hands”, isto é, “com mão limpas” porque a exoneração não poderá ser interpretada como um instrumento de defraudação da garantia, permitindo que o fiador se livre de um afiançado indesejado tão-logo este apresente sinais de que não continuará a cumprir a prestação principal $^{275}$ ou até mesmo já tiver deixado de fazê-lo. Uma interpretação do art. 835 do Código Civiel conforme à boa-fé objetiva não permite outra conclusão, pois esta diretriz deverá balizar a conduta de todos os figurantes dos negócios e não ser usada como um escudo do garante para esvaziar o conteúdo da promessa fidejussória. Aquele que se comprometeu a afiançar deverá cumprir fielmente a sua promessa.

Com efeito, não teria sentido garantir ao fiador o acesso ao exercício do direito potestativo de extinção da fiança ex artigo 835 do Código Civil justamente no momento em

\footnotetext{
275“ A boa-fé paralisa o direito a invocar a exceptio non adimpleti contractus nas hipóteses em que se configura a representação refletida no adágio turpitudinem suam allegans non auditur ou equity must come with clean hands, como expressa lapidarmente o direito inglês. Este vem amparado na chamada teoria dos atos próprios, segundo a qual se entende que a ninguém é lícito fazer valer um direito em contradição com a sua anterior conduta interpretada objetivamente segundo a lei, segundo os bons costumes e a boa-fé, ou quando o exercício posterior se choque com a lei, os bons costumes e a boa-fé. O seu efeito primordial é impedir que a parte que tenha violado deveres contratuais exija o cumprimento pela outra parte, ou valhase do seu próprio incumprimento para beneficiar-se de disposição contratual ou legal." (MARTINSCOSTA, Judith. A boa-fé no direito privado. São Paulo: Ed. Revista dos Tribunais, 1999. p. 460).
} 
que o credor estaria mais vulnerável, que é o do incumprimento da obrigação. Por isso, iniciado o incumprimento da obrigação o fiador estará impedido de pôr fim à fiança através da notificação ao credor, situação esta que apenas será possível se as obrigações garantidas estiverem sendo fielmente cumpridas.

Isto não impede, porém, que o fiador notifique o credor de que deixará de garantir a fiança, mas a eficácia da exoneração somente ocorrerá quando as obrigações afiançadas forem efetivadas adimplidas, porque a partir de então a mora terá sido purgada.

\subsubsection{1. É válida a cláusula de renúncia ao direito de exoneração?}

Há profunda divergência na doutrina e jurisprudência quanto à possibilidade do fiador duma locação se libertar do encargo prestado na hipótese em que o contrato tiver passado a viger por tempo indeterminado.

Para alguns, ainda que o contrato de locação passasse a viger por tempo indeterminado ao fiador seria impossível libertar-se do vínculo se, quando da assinatura do contrato, tivesse renunciado à faculdade de exoneração prevista no artigo 1.500 do Código Civil de $1916^{276}$, inclusive por conta do disposto no artigo 39 da Lei $n^{\circ} 8.245 / 91$, o qual determina que a fiança prestada na locação vigerá, salvo estipulação contratual em contrário, "até a entrega das chaves". A renúncia à exoneração seria um direito disponível. Assim, a renúncia antecipada à faculdade de exoneração somada a vigência da garantia até a devolução do imóvel impediriam a liberação do garante. Nesse sentido ${ }^{277}$ :

\footnotetext{
${ }^{276}$ Equivalente, em parte, ao artigo 835 do Código Civil de 2002.

${ }^{277}$ Ap. Sum. 165.405-00/4 - 5a Câm. - Rel. Juiz MENEZES GOMES - J. 30.11.83; Ap. 166.606-00/5 - $9^{\mathrm{a}}$ Câm. - Rel. Juiz MARCELLO MOTTA - J. 4.4.84; Ap. c/ Rev. 222.610-00/1 - $4^{\text {a }}$ Câm. - Rel. Juiz TELLES CORRÊA - J.14.6.88; Ap. c/ Rev. 396.599-00/0 - $2^{\mathrm{a}}$ Câm. - Rel. Juiz DIOGO DE SALLES - J. 4.4.94; Ap. s/ Rev. 407.904-00/1 - 9a Câm. - Rel. Juiz CLARET DE ALMEIDA - J. 3.8.94; Ap. s/ Rev. 406.597-00/5 $3^{\mathrm{a}}$ Câm. - Rel. Juiz TEIXEIRA DE ANDRADE - J. 8.11.94; Ap. s/ Rev. 491.956-00/9 - $1^{\text {a }}$ Câm. - Rel. Juiz LAERTE CARRAMENHA - J. 18.8.97; Ap. c/ Rev. 509.004-00/3 - $2^{\text {a }}$ Câm. - Rel. Juiz FELIPE FERREIRA - J. 6.4.98; Ap. c/ Rev. 540.015-00/3 - $2^{\text {a }}$ Câm. - Rel. Juiz FELIPE FERREIRA - J. 15.3.99; Ap. c/ Rev. 552.437-00/1 - $8^{\mathrm{a}}$ Câm. - Rel. Juiz KIOITSI CHICUTA - J. 2.9.99; AI 606.376-00/8 - $11^{\text {a }}$ Câm. - Rel. Juiz MENDES GOMES - J. 20.12.99; Ap. c/ Rev. 592.220-00/0 - $11^{\text {a }}$ Câm. - Rel. Juiz MENDES GOMES - J. 27.11.2000; Ap. c/ Rev. 674.867-00/2 - $3^{\text {a }}$ Câm. - Rel. Juiz MILTON SANSEVERINO - J. 17.4.2001; Ap. c/ Rev. 606.457-00/8 - 10a Câm. - Rel. Juiz IRINEU PEDROTTI - J. 16.5.2001; Ap. c/ Rev. 605.084-00/2 - 11 ${ }^{\mathrm{a}}$ Câm. - Rel. Juiz MENDES GOMES - J. 14.5.2001; Ap. c/ Rev. 608.306-00/9 - $10^{\mathrm{a}}$ Câm. - Rel. Juiz SOARES LEVADA - J. 23.5.2001; Ap. c/ Rev. 608.819-00/1 - $8^{\mathrm{a}}$ Câm. - Rel. Juiz RENZO LEONARDI - J. 7.6.2001; Ap. c/ Rev. 611.275-00/4 - $2^{\mathrm{a}}$ Câm. - Rel. Juiz ANDREATTA RIZZO -

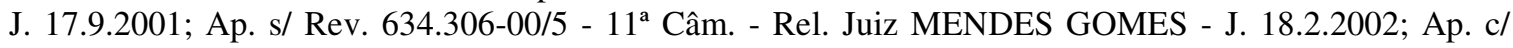
Rev. 635.758-00/3 - $11^{\mathrm{a}}$ Câm. - Rel. Juiz MENDES GOMES - J. 27.5.2002; Ap. c/ Rev. 624.166-00/4 - $3^{\mathrm{a}}$ Câm. - Rel. Juiz FERRAZ FELISARDO - J. 3.9.2002; Ap. c/ Rev. 635.347-00/3 - $3^{\text {a }}$ Câm. - Rel. Juíza REGINA CAPISTRANO - J. 11.6.2002; EI 619.318-01/6 - $3^{\text {a }}$ Câm. - Rel. Juiz RIBEIRO PINTO - J. 18.3.2003.
} 


\section{"FIANÇA - EXONERAÇÃO (ARTIGO 1500 DO CÓDIGO CIVIL) - RENÚNCIA - VALIDADE - RECONHECIMENTO}

É hígida a cláusula em que fiador renuncia direito à exoneração da fiança, que tampouco resulta da inadimplência da afiançada ou do rompimento da relação trabalhista que ela mantinha com os fiadores. Com o advento do Código Civil de 2002, porém, tornou-se bizantina a questão. (Ap. c/ Rev. 687.676-00/9 - 4a Câm. - Rel. Juiz CELSO PIMENTEL - J. 23.11.2004)".

Colhem-se os seguintes fundamentos do v. acórdão:

"O preceito do artigo 1.500 do Código Civil de 1916 trata de tema de natureza privada, não pública. Quer dizer, constitui regra não cogente, cuja disponibilidade harmoniza-se com a renúncia à exoneração da fiança manifestada, no caso, pelos fiadores, em cláusula que nada tem de nula e que lhes veda a pretendida exoneração, bem repelida na r. sentença."

E seguem a mesma linha outros julgados emanados da mesma Corte:

"E porque a obrigação eternizou-se, à falta de um termo fatal para o contrato é que os apelantes entendem ter inteira aplicação o ad. 1500 do Código Civil, para verem-se desonerados da responsabilidade que assumiram. Acrescente-se a isto o fato de a situação financeira dos fiadores ter sofrido modificação, e para pior, além de não mais existir izade entre eles, fiadores e afiançado, justamente pelo fato de nteriormente, o inquilino ter deixado de pagar locativos, obriga o os garantes a saldarem a dívida.

A r. sentença guerreada desacolheu a pretensão dos apelantes, tendo em vista que, no contrato que firmaram, renunciaram expressamente a faculdade prevista no art. 1500 do Código substantivo.

E bem andou o magistrado "a quo" julgando improcedente a ação. Realmente, pela cláusula $14^{\mathrm{a}}$ do contrato, os autores deixaram consignado expressamente que "sua responsabilidade continuará até a entrega real das chaves à Locadora", além do que renunciavam "a qualquer eventual direito no sentido de restringir somente ao prazo ora ajustado, a garantia de sua fiança”" (v. fI. 06).

Assim contratando, outra coisa não fizeram os fiadores que renunciará aplicação do artigo 1500 do Código Civil.

A questão é saber se aos apelantes era ou não lícito renunciarem.

E forçoso é reconhecer ter sido lícita tal renúncia, pois essa norma, além de não proibir a renúncia ao poder que confere, dirige-se aos contratos de Direito Privado, como o é o próprio instituto da fiança.

Lembre-se que somente não é lícito às partes contratantes disporem de maneira diversa se as normas ampararem interesses sociais, os chamados interesses de ordem pública. 'O art. 1500 é norma de conduta dispositiva que deixa ao destinatário o direito de dispor de maneira diversa, até de renúncia às faculdades que confere. A todo o direito está ínsita a faculdade de disposição e, por conseguinte, se a isto não se opõe motivo 
de ordem pública, persiste o poder de abandono ou de abdicação do próprio direito (Ap. 170.268 - SP, declaração de voto eminente juiz Mello Junqueira)" (Ap.186.498-7 - 5 Câm. - rel. juiz ISIDORO CARMONA j. 11.12.85).

Sendo lícito renunciarem à aplicação do art. 1500 do Código Civil, incompreensível que os próprios renunciantes venham a juízo, agora, pleitear a exoneração da fiança que livremente pactuaram, ao argumento de que a garantia subsistiu somente durante o prazo inicialmente estipulado no contrato.

Também a jurisprudência desta Corte já assentou que "é perfeitamente legítima a cláusula contratual de renúncia ao direito de exoneração da fiança, posto que o preceito do art. 1500 do C.C. não tem caráter dispositivo de ordem pública" (RT 612/147).

Em resumo: os apelantes somente poderiam ver-se desobrigados da fiança se não tivesse havido renúncia à faculdade de exoneração. E como renunciaram, sua responsabilidade deve perdurar até a efetiva entrega das chaves, como pactuado.

Irrepreensível a r. sentença hostilizada, que deve ser mantida por seus próprios fundamentos."

"Os autores são fiadores em contrato de locação de bem imóvel para fim não residencial, e, do que consta do instrumento contratual, renunciaram expressamente à faculdade conferida pelo art. 1.500 do Código Civil (cf. cláusula n. ${ }^{\circ} 15$, parágrafo único - fl. 11). Isto é, abriram mão da possibilidade de se exonerarem da obrigação acessória de fiança (garantia fidejussória). $\mathrm{O}$ ato jurídico é válido porque o da manifestação livre e desembaraçada dos contratantes, res itando se, outrossim, o disposto no art. 82 do Código Civil e, nesse compasso, o princípio da vinculação das avenças (pacta sunt servanda). Significa, pois, que a vigência do pacto de fiança dar-se-á até a efetiva entrega das chaves, corno consta da referida cláusula contratual n. ${ }^{\circ} 15$, parágrafo único (fl. 11)." ${ }^{, 279}$

Para outros, a faculdade de exoneração instituída em favor do fiador seria de ordem pública, e, portanto, cogente, o que impediria a sua renúncia antecipada que, se acaso ocorrente, seria leonina ou abusiva. Nesse sentido ${ }^{280}$ :

\footnotetext{
${ }^{278}$ Ap. c/ Rev. 605.084-00/2 - $11{ }^{\text {a }}$ Câm. - Rel. Juiz MENDES GOMES - J. 14.5.2001.

${ }^{279}$ Emb. Infring. 619.318-01/6 - $3^{\text {a }}$ Câm. - Rel. Juiz RIBEIRO PINTO - J. 18.3.2003.

${ }^{280}$ EI 194.764-01/1 - $7^{\mathrm{a}}$ Câm. - Rel. Juiz GILDO DOS SANTOS - J. 30.3.87; Ap. s/ Rev. 275.967-00/1 - $8^{\mathrm{a}}$ Câm. - Rel. Juiz MARTINS COSTA - J. 30.8.90; EI c/ Rev. 328.380-01/5 - $3^{\text {a }}$ Câm. - Rel. Juiz FRANCISCO BARROS - J. 8.2.94; Ap. c/ Rev. 361.888-00/4 - $7^{\text {a }}$ Câm. - Rel. Juiz ANTONIO MARCATO - J. 8.2.94; Ap. c/ Rev. 386.924-00/4 - $3^{\text {a }}$ Câm. - Rel. Juiz FRANCISCO BARROS - J. 1.3.94; Ap. c/ Rev. 382.102-00/9 - $3^{\text {a } ~ C a ̂ m . ~-~ R e l . ~ J u i z ~ F R A N C I S C O ~ B A R R O S ~-~ J . ~ 15.3 .94 ; ~ A p . ~ c / ~ R e v . ~ 414.450-00 / 0 ~-~} 6^{\text {a }}$ Câm. - Rel. Juiz PAULO HUNGRIA - J. 14.12.94; Ap. s/ Rev. 425.541-00/9 - $2^{\mathrm{a}}$ Câm. - Rel. Juiz FÁBIO GOUVÊA - J. 3.4.95; Ap. c/ Rev. 429.535-00/4 - $3^{\text {a } ~ C a ̂ m . ~-~ R e l . ~ J u i z ~ F R A N C I S C O ~ B A R R O S ~-~ J . ~ 30.5 .95 ; ~}$ Ap. c/ Rev. 437.306-00/8 - $6^{\mathrm{a}}$ Câm. - Rel. Juiz PAULO HUNGRIA - J. 20.9.95; Ap. s/ Rev. 444.800-00/1 $1^{\text {a }}$ Câm. - Rel. Juiz MAGNO ARAÚJO - J. 18.12.95; Ap. s/ Rev. 449.789-00/7 - $9^{\text {a }}$ Câm. - Rel. Juiz RADISLAU LAMOTTA - J. 31.1.96; Ap. c/ Rev. 456.524-00/9 - $6^{\text {a }}$ Câm. - Rel. Juiz PAULO HUNGRIA -

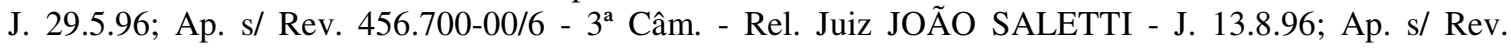
463.942-00/0 - $9^{\text {a }}$ Câm. - Rel. Juiz EROS PICELI - J. 4.9.96; Ap. c/ Rev. 457.565-00/7 - 12 ${ }^{\text {a }}$ Câm. - Rel. Juiz LUÍS DE CARVALHO - J. 26.9.96; Ap. c/ Rev. 467.537-00/8 - 4a Câm. - Rel. Juiz CELSO
} 
"FIANÇA - EXONERAÇÃO (ARTIGO 1500 DO CÓDIGO CIVIL) LOCAÇÃO - RESPONSABILIDADE ATÉ ENTREGA DAS CHAVES - CONTRATO PRORROGADO - CLÁUSULA DE RENÚNCIA IRRELEVÂNCIA - CABIMENTO

À vista dos pesados ônus que naturalmente sobrecarregam a fiadora solidária, pode ela, uma vez prorrogada a avença locatícia por prazo indeterminado, sempre que lhe convier, exonerar-se da fiança que tiver assinado sem limitação de tempo, neste conceito compreendida aquela prestada até a entrega das chaves, sendo-lhe inoperante, porque já e então insuportavelmente onerosa, a renúncia eventualmente manifestada em relação ao benefício de exoneração." ${ }^{281}$

"Resolveram os fiadores desligar-se da fiança prestada através de contatos amigáveis, inclusive com notificação extrajudicial. Contudo, a tentativa resultou frustada. Pretendem, com a presente ação a declaração judicial de sua exoneração, o que mostra-se possível na hipótese em que já vencido e indeterminado o contrato original.

A jurisprudência de nossos Tribunais tem considerado abusiva cláusula de renúncia à exoneração prevista no art. 1.500 do Código Civil, desde que prorrogada a avença locatícia por prazo indeterminado. Não há ofensa ao art. 39 da Lei $\mathrm{n}^{\circ}$ 8.245/91, uma vez que por direito próprio podem os fiadores pleitear a exoneração.

Inviável interpretação no sentido de que ficariam eles atados à garantia prestada, posto que seria o mesmo que admitir ficar o garante ligado perpetuamente a obrigação à obrigação, sujeita no tempo, ao arbítrio de terceiro, o que afronta o art. 115 do Código Civil que veda cláusula potestativa.,282

Como se pôde perceber, sempre reinou profunda divergênica no âmbito do extinto $2^{\circ}$ TACivSP no que dizia respeito à validade ou eficácia da renúncia antecipada, pelo

PIMENTEL - J. 12.11.96; Ap. c/ Rev. 472.376-00/7 - 10ª Câm. - Rel. Juiz EUCLIDES DE OLIVEIRA - J. 19.2.97; Ap. c/ Rev. 474.519-00/4 - 5 Câm. - Rel. Juiz PEREIRA CALÇAS - J. 26.2.97; Ap. c/ Rev. 511.035-00/7 - 6 Câm. - Rel. Juiz PAULO HUNGRIA - J. 30.4.98; Ap. c/ Rev. 512.237-00/1 - 4ª Câm. Rel. Juiz MOURA RIBEIRO - J. 26.5.98; Ap. c/ Rev. 518.315-00/9 - 5a Câm. Rel. Juiz FRANCISCO THOMAZ - J. 27.5.98; Ap. c/ Rev. 523.755-00/4 - $1^{\text {a }}$ Câm. - Rel. Juiz MAGNO ARAÚJO - J. 14.9.98; Ap. c/ Rev. 529.889-00/6 - 12 ${ }^{\mathrm{a}}$ Câm. - Rel. Juiz ARANTES THEODORO - J. 8.4.99; Ap. c/ Rev. 544.616-00/5 - $12^{\mathrm{a}}$ Câm. - Rel. Juiz ARANTES THEODORO - J. 8.4.99; Ap. c/ Rev. 547.067-00/8 - $5^{\mathrm{a}}$ Câm. - Rel. Juiz LUÍS DE CARVALHO - J. 14.9.99; Ap. c/ Rev. 560.118-00/4 - 7ª Câm. - Rel. Juiz AMÉRICO ANGÉLICO - J. 9.11.99; Ap. c/ Rev. 618.866-00/0 - 5a Câm. - Rel. Juiz S. OSCAR FELTRIN - J. 28.11.2001; Ap. c/ Rev. 623.909-00/5 - $4^{\text {a } ~ C a ̂ m . ~-~ R e l . ~ J u i z ~ A M A R A L ~ V I E I R A ~-~ J . ~ 19.12 .2001 ; ~ A p . ~ c / ~ R e v . ~}$ 626.069-00/2 - $4^{\mathrm{a}}$ Câm. - Rel. Juiz NEVES AMORIM - J. 12.3.2002; Ap. c/ Rev. 632.787-00/4 - $8^{\mathrm{a}}$ Câm. Rel. Juiz WALTER ZENI - J. 23.5.2002; Ap. c/ Rev. 635.220-00/3 - $11^{a}$ Câm. - Rel. Juiz EGIDIO GIACOIA - J. 12.8.2002; Ap. c/ Rev. 640.354-00/2 - 2 ${ }^{\mathrm{a}}$ Câm. - Rel. Juiz GILBERTO DOS SANTOS - J. 16.9.2002; Ap. c/ Rev. 643.418-00/3 - $7^{\mathrm{a}}$ Câm. - Rel. Juiz PAULO AYROSA - J. 15.10.2002; Ap. c/ Rev. 726.518-00/1 - 6 Câm. - Rel. Juiz LINO MACHADO - J. 13.11.2002; Ap. c/ Rev. 648.109-00/8 - $11^{\text {a }}$ Câm. - Rel. Juiz ARTUR MARQUES - J. 24.2.2003; Ap. c/ Rev. 674.220-00/6 - $4^{\mathrm{a}}$ Câm. - Rel. Juiz JÚLIO VIDAL - J. 21.9.2004.

${ }^{281}$ Ap. c/ Rev. 669.092-00/9 - 12a Câm. - Rel. Juiz PALMA BISSON - J. 13.5.2004.

${ }^{282}$ Ap. c/ Rev. 635.220-00/3 - $11^{\text {a }}$ Câm. - Rel. Juiz EGIDIO GIACOIA - J. 12.8.2002. 
fiador de contrato de locação, à faculdade de exoneração dantes prevista no artigo 1.500 do Código Civil de $1916^{283}$, ora estatuída no artigo 835 do Código Civil de 2002.

Nesse sentir, percebe-se que longe de se encontrar pacificada tal questão, a mesma ainda é apta a gerar profunda divergência entre os operadores do direito, o que contribui para o clima de insegurança que baliza tão tormentoso tema.

Sobre o tema, Milton Sanseverino ${ }^{284}$ escreveu e apontou que a tese que defendia a irrenunciabilidade do direito à exoneração seria antiga e não corresponderia à visão perfilhada pela jurisprudência do extinto $2 .^{\circ}$ TACivSP:

"É imperativo assinalar, a bem da verdade, que esse último entendimento: irrenunciabilidade do direito de obter exoneração da fiança, ainda que por declaração expressa de vontade contida em cláusula contratual especifica a propósito desse assunto e vigorando a garantia fidejussória por tempo indeterminado, corresponde, na verdade, a entendimento antigo, de todo superado na atualidade e francamente minoritário na jurisprudência deste Tribunal, como mostra singela pesquisa em tomo do tema. Basta atentar, com efeito, para a copiosa quantidade de julgados em contrário anotados não só pelos Relatores de inúmeros acórdãos divergentes, que comungam daquele primeiro entendimento, como exposto em seus substanciosos votos, proferidos num sem-número de casos semelhantes, como pela Comissão de Jurisprudência desta Corte nos vv. arestos insertos in JTACSP (LEX) 147/391-392, rel. o ilustre Juiz Cunha Cintra; JTACSP (RT) 128/241, rel. o eminente Juiz Sebastião Amorim; JTACSP (RT) 124/270, desta C.

\footnotetext{
${ }^{283}$ Sobre o tema, assinala VENOSA, Sílvio de Salvo: "Consoante o dispositivo legal de 1916, havia duas modalidades de exoneração, quais sejam, pelo distrato, com a aquiescência do afiançado e do credor, se fosse o caso, e por sentença judicial. A lei fazia referência expressa à sentença. Por esta dicção, não havia como deslocar a exoneração do fiador para momento anterior, como a citação. Havia, portanto, a necessidade de ação judicial para obtenção desse desiderato pelo fiador, não sendo suficiente mera notificação ou outro ato unilateral. Embora a menção à sentença desapareça no mais recente estatuto civil, é evidente que, pelo princípio geral, a sentença pode rescindir ou tornar ineficaz qualquer negócio jurídico. Quanto aos efeitos, surgirá a dúvida se os efeitos da exoneração retroagirão à citação ou gerarão efeitos a partir da sentença. Qualquer dessas soluções traz dificuldades na prática, embora o problema fique minimizado em razão da possibilidade de notificação, ou seja, resilição unilateral por parte do fiador. Era aconselhável que o legislador mantivesse o texto e expressamente determinasse a sentença como termo inicial dos efeitos, na hipótese de ser necessário o procedimento judicial. Por outro lado, há de se convir que, se o fiador aguardar a sentença ou o trânsito em julgado de um processo de exoneração de fianác, terá que esperar talvez anos para obter o desiderato, o que exlcui de todo efeito a possibilidade facultada pelo legislador. A matéria é complexa e o atual texto do art. 835 não dirime aparentemente todas as dúvidas. Lembre-se de que existe toda uma problemática no direito do inquilinato nesse tema de exoneração do fiador. O art. 39 da Lei $\mathrm{n}^{\circ}$ 8.245/91 dispõe: "Salvo disposição contratual em contrário, qualquer das garantias da locação se estende até a efetiva devolução do imóvel.” Portanto, pelo microssistema do inquilinato, em interpretação literal, não há possibilidade de exoneração do fiador antes da entrega do imóvel locado. No entanto, nota-se que o Superior Tribunal de Justiça tem acolhido pretensões nesse sentido, aplicando a regra geral da fiança e não a lei especial, o que motiva uma reviravolta no sentido da lei locatícia e, em princípio, coloca em risco esse segmento social. Esses julgados levam em conta expressamente o interesse social do contrato, antes mesmo que vigorasse o novo princípio estampado no atual Código, no art. 421.”(In VENOSA, Sílvio de Salvo. Direito civil: contratos em espécie. 8. ed. São Paulo: Atlas, 2008. v. 3, p. 403-404).

${ }^{284}$ SANSEVERINO, Milton. Renunciabilidade do direito à exoneração da fiança. Disponível em: <http://bdjur.stj.gov.br/>. Acesso em: 25 maio 2009.
} 
Terceira Câmara - rel. o ilustre Juiz Corrêa Vianna e revisor o eminente Juiz Oswaldo Breviglieri; JTACSP (RT) 117/257-258, rel. o insigne Juiz Ferreira Conti; JTACSP 111/438-439, rel. o ilustre Juiz José Telles Corrêa; JTACSP (RT), 106/368, rel. o ínclito Juiz Soares Lima; JTACSP 103/301, em particular itens 6 e 7 - rel. o emérito Juiz Isidoro Carmona; JTACSP 98/234-236, rel. o insigne Juiz Martins Costa; JTACSP (RT) 95/258-259, rel. o eminente Juiz Mauro Silveira; Ap. c/rev. n 396.599-0, 2a Câm., j. em 4-4-94, v.u., rel. o ilustre Juiz Diogo de SaBes; etc. v. tb. RT 482/162 e 5811155-156. Em contrapartida, a favor do entendimento perfilhado pela segunda corrente não se contam mais que uns poucos julgados, francamente minoritários, como demonstram as resenhas apresentadas nos vv. arestos mencionados acima, em particular nos três primeiros, v. tb. RT 463/134-135; 466/130-131; e JTACSP 46178.

\section{(...)}

Ora, havendo cláusula expressa, pela qual o(s) fiador(es) renuncia(m) ao direito de obter exoneração da fiança, não se justifica enjeitar simplistamente, data maxima venia, tão ampla declaração de vontade, quando livre e validamente formalizada, sob pena de pôr em risco a segurança dos negócios jurídicos privados e a estabilidade dos direitos. A não ser assim, bastará, com efeito, que a parte num dado momento empenhe sua palavra, assinando como fiador e renunciando explicitamente ao benefício do art. 1.500 do Código Civil, e, depois, candidamente volte atrás, dando o dito por não dito pura e simplesmente, com o beneplácito do Poder Judiciário. Pois bem. Não pode ser este, a meu ver, o destino de uma obrigação livremente assumida, nem o de uma renúncia validamente progressivamente para o caos jurídico e social. Nada há, de fato, que impeça a renúncia a um direito que, em essência, é disponível, por isso que de índole exclusivamente patrimonial. De fato: cuida-se, na hipótese, de típica matéria obrigacional e, dessa forma, de cunho estritamente patrimonial, não estando em litígio, conseqüentemente, direito indisponível, já que não há interesse público em jogo, mas mero interesse pessoal ou particular da parte interessada. Até porque, se não fosse assim, no processo onde discutida a validade e/ou a eficácia da renúncia à exoneração da fiança deveria intervir, obrigatoriamente, o Ministério Público, como fiscal da lei, sob pena de nulidade, de conformidade com os arts. 82, 111, 84 e 246 do CPC."

Em que pese tal fato, não podemos perder de vista que, na prática, a quase totalidade dos contratos de locação contém cláusula expressa de renúncia à faculdade de exoneração do fiador, situação essa que não se mostra negociável: ou o fiador assina o contrato nesses termos ou o inquilino não toma posse do imóvel. A renúncia à exoneração deixou de ser uma cláusula manifestada com fundamento na vontade livremente manifestada pelo fiador e se tornou uma cláusula de estilo, encontrada até mesmo em 
contratos de papelaria ${ }^{285}$. Diante disso, pergunta-se: há o exercício efetivo de uma livre e soberana manifestação da autonomia privada? Entendemos que não.

E assim sendo, como cabe ao locador a escolha da modalidade de garantia contratual que melhor lhe aprouver, aliada à cultura disseminada de que a fiança seria a melhor delas, ou o candidato a locatário arruma alguém para afiançar-lhe o contrato ou não aluga o imóvel desejado. E diante das dificuldades em se encontrar um garante disposto a enfrentar a gravidade das consequências que cercam a assunção do encargo, na absoluta maioria das vezes a escolha do fiador recai sobre um amigo próximo ou parente, por serem esses os únicos a demonstrarem (con)fiança na pessoa do afiançado ou, também, os únicos a se sentirem constrangidos diante do pedido que lhes é apresentado. Tal assertiva vem a ser confirmada pela análise dos julgados que abordaram a questão da exoneração do fiador, segundo os quais em nenhum deles os fiadores eram pessoas estranhas ao afiançado, mas, ao revés disso, eram pais, avós, tios ou amigos de longa data.

A nossa posição sobre o tema é a de não ser admitida a renúncia antecipada ao direito de exoneração, atualmente previsto no artigo 835 do Código Civil, pelas razões que seguem. Vejamos.

A exoneração é o único meio disposto ao fiador para fazer extinguir o contrato de garantia $^{286}$. Se se admitisse a renúncia antecipada à faculdade (rectius, direito potestativo)

\footnotetext{
${ }^{285}$ Sintetiza o tema José Fernando Lutz Coelho: "Embora se trate de direito disponível, o que, de regra, enseja a possibilidade de renunciar à faculdade de liberação, há que se convir que deve ser assegurado ao fiador de não mais permanecer vinculado ao contrato da fiança perpétua e indefinidamente, configurando imposição insuportável e incompatível ao seu direito propiciado por lei, sem contar que estaria sempre à mercê de garantir com o seu único imóvel, pois está em situação desfavorável, em virtude de uma cláusula firmada, que, diga-se de passagem, em quase todos os contratos de locação de imóvel urbano, existe cláusula expressa e timbrada, onde o fiador renuncia ao direito de exoneração, e por efeito, o fiador não poderá se utilizar da significativa mudança do novo Código Civil, que admite a exoneração por simples comunicação ao credor, instrumentalizada via notificação." (In COELHO, José Fernando Lutz. Locação: questões atuais e polêmicas. Curitiba: Juruá, 2005. p. 36).

${ }^{286}$ Com efeito, conforme já expusemos no item 5.7.2, a exoneração prevista no artigo 835 do Código Civil é o poder conferido pela lei ao fiador de provocar a extinção de um contrato em curso por tempo indeterminado, prevista como gênero no artigo 473 do Código Civil sob o nome de resilição unilateral; da mesma forma que a resolução prevista no artigo 475 do Código Civil, ambas as figuras são direitos potestativos que poderão ser exercidos pelos figurantes de um negócio jurídico; a resilição é mecanismo que poderá ser utilizado por qualquer das partes, já que representa denúncia do vínculo contratual nãofundada em alegação de justa causa, enquanto a resolução é remédio atribuído apenas e tão-somente ao lesado pelo inadimplemento, na expressa dicção do artigo 475 do Código Civil. Ao escrever sobre o tema da renúncia à resolução dos contratos, Araken de Assis aponta a doutrina de Carvalho Santos, para quem o direito à resolução seria renunciável por não versar acerca de um interesse de ordem pública. Todavia, aquele autor obtempera o caráter disponível da resolução sob o seguinte enfoque: "Não obstante, $a$ renúncia prévia pode implicar sérias conseqüências, na esfera do parceiro fiel à relação contratual, ou alterar, profundamente, a lógica do seu programa. Exemplo: a coisa, que se deveria prestar, sofreu grave deterioração culposa, inutilizando-a para o fim desejado. Não se descarta, ademais, o risco de a situação patriominal do inadimplente fazer a demanda de cumprimento inútil, muito difícil ou desinteressante em comparação ao resultado do efeito restituitório da resolução. Em todas essas situações, todavia submetidas
} 
de exoneração ao fiador jamais seria possível libertar-se do encargo, até mesmo nas hipóteses em que o contrato sobrejacente estivesse a vigorar por tempo indeterminado ${ }^{287}$. Portanto, até mesmo estaria frustrada a nova dinâmica da exoneração ex artigo 835, do Código Civil, pois a cláusula "sempre que lhe convier" seria estéril, o que não se mostraria razoável. Por qual motivo teria sido simplificado o procedimento legal da exoneração se esta pudesse vir a ser renunciada? Data venia, não teria sido uma mudança oca, pois tudo ficaria como já está!!!

Neste caso, o vínculo se eternizaria ${ }^{288}$ porque, não havendo data assinalada para a extinção do contrato principal, a permanência do ajuste fidejussório dependeria apenas da vontade exclusiva do credor e do afiançado, o que não se ostenta razoável até mesmo se resultasse do exercício da autonomia privada, porque ambos estipulariam se e quando a responsabilidade do fiador haveria de cessar, por força do exercício do direito à resilição previsto no art. 473 do Código Civil ${ }^{289}$, que no campo da garantia fidejussória é denominado de exoneração. Ora, veja-se o absurdo: a fiança poderá ser contratada até mesmo contra a vontade do afiançado, porém o desfazimento da garantia dependeria da vontade do devedor principal! Com o devido respeito, o raciocínio é ilógico!

E mais: a fiança, contrato acessório que é, acarretaria consequências muito mais graves do que o contrato garantido, dito principal, especialmente porque o credor, sabendo de antemão que dispunha de um fiador com amplo patrimônio, poderia perder o interesse em agir contra o afiançado para receber o seu crédito, de maneira que o garante ficaria sine die vinculado aos humores do afiançado e do credor.

à liberdade - onde ela existe! - contratual das partes, o prejuízo ao escopo do resolutório se ostenta evidente." (In ASSIS, Araken de. Resolução do contrato por inadimplemento. 3. ed. rev. e atual. São Paulo: Ed. Revista dos Tribunais, 1999. p. 31). (Grifamos).

${ }^{287}$ Com fundamento semelhante: "FIANÇA - EXONERAÇÃO - CONTRATO DE LOCAÇÃO - PRAZO INDETERMINADO - RENÚNCIA - "É ineficaz a renúncia prévia à faculdade de exonerar-se o fiador quando inserta em contrato de locação com prazo determinado porque manifestada antes da formação do direito que só se PERFECTIBILIZA ao tornar-se prorrogada por prazo indeterminado, sendo inadmissível a perpetuidade de garantia dada pelo fiador, sobretudo por ser ato benéfico e desinteressado; todavia, responde por seus efeitos até o ato liberatório ou a sentença que o exonerar (artigo 1.500 do CC)". (TAMG - Ap. Cível 2.0000.00.319819-4/000(1) - 1ª Câm. - Rel. ALVIM SOARES - J. 26.09.2000).

288 "O fiador não poderia, contra a sua vontade, ficar indefinidamente sujeito à responsabilidade da fiança, que, pelo próprio caráter de que se reveste, não admite interpretação diferente. Assim, deve entender-se que a fiança outorgada sem limitação de tempo é estipulada, quanto à sua duração, sempre em benefício do fiador, que poderá retirá-la a qualquer tempo, ou seja quando lhe convenha.” (SANTOS, J. M. Carvalho. Código Civil brasileiro interpretado. 2. ed. Rio de Janeiro: Freitas Bastos, 1938. v. 19, p. 483).

${ }^{289}$ Código Civil: "Art. 473. A resilição unilateral, nos casos em que a lei expressa ou implicitamente o permita, opera mediante denúncia notificada à outra parte.

Parágrafo único. Se, porém, dada a natureza do contrato, uma das partes houver feito investimentos consideráveis para a sua execução, a denúncia unilateral só produzirá efeito depois de transcorrido prazo compatível com a natureza e o vulto dos investimentos." 
Ora, se o fiador é o responsável pelo adimplemento da prestação sem ser o seu devedor, fere a lógica do sistema arredar-lhe o direito à exoneração da fiança, tratando-o de forma mais severa do que o devedor principal. Em outras palavras, o devedor poderia desvincular-se do contrato garantido, porém o mesmo direito não seria reconhecido ao fiador, que é um responsável subsidiário e acessório. Neste caso, o principal seguiria a sorte do acessório, invertendo a lógica do sistema.

Outrossim, a função social do contrato de fiança é a de assegurar o adimplemento das obrigações assumidas pelo devedor principal, porém sem que a garantia seja eternizada e fique na exclusiva dependência da atuação do credor ou do afiançado, argumento este que é reforçado pela disposição contida no art. 2.035 do Código Civil:

“Art. 2.035. A validade dos negócios e demais atos jurídicos, constituídos antes da entrada em vigor deste Código, obedece ao disposto nas leis anteriores, referidas no art. 2.045, mas os seus efeitos, produzidos após a vigência deste Código, aos preceitos dele se subordinam, salvo se houver sido prevista pelas partes determinada forma de execução.

Parágrafo único. Nenhuma convenção prevalecerá se contrariar preceitos de ordem pública, tais como os estabelecidos por este Código para assegurar a função social da propriedade e dos contratos."

Por conta disso, não se nos afigura razoável tornar a fiança, contrato subsidiário e acessório que é, um pacto muito mais gravoso do que o contrato garantido.

Nesta exata medida, não nos parece relevante a discussão que sempre balizou o tema da renúncia à exoneração, no sentido de se discutir se a faculdade de exoneração seria dispositiva ou cogente.

$\mathrm{Na}$ verdade, segundo entendemos e defendemos, importa também saber nesta hipótese se o fiador poderia renunciar a um direito inexistente ${ }^{290}$, porque o direito potestativo de exoneração previsto no artigo 835 do Código Civil apenas surge quando o contrato garantido passa a viger por tempo indeterminado. Antes disso não há, não existe direito à exoneração, razão pela qual o garante não poderia manifestar a renúncia à um direito inexistente. A renúncia à um direito inexistente, inexistente é, podendo até mesmo

\footnotetext{
${ }^{290}$ Em sentido semelhante: VENOSA, Súlvio de Salvo: "Não há que se admitir a renúncia prévia ao direito de exonerar-se o fiador da garantia, pois ninguém pode renunciar previamente a um direito potestativo. $\mathrm{Na}$ fiança comercial por prazo indeterminado, o fiador poderia exonerar-se quando lhe conviesse, conforme o art. 262 do Código Comercial, em dispositivo análogo do estatuto civil. Fixada a sentença como termo final da responsabilidade do fiador, não há como estendê-lo para o trânsito em julgado, porque a lei é expressa (RT 462/164). A decisão judicial pode reconhecer fato jurígeno de exoneração da fiança em momento diverso, até mesmo antes da citação, matéria objeto da força declaratória da sentença. (In VENOSA, Sílvio de Salvo. op. cit., v. 3, p. 404). (Grifamos)
} 
vir a ser declarada por sentença, com fundamento no artigo $4 .^{\circ}, \mathrm{I}$, do Código de Processo Civil.

Outrossim, sendo a exoneração um direito potestativo, Moreira Alves ${ }^{291}$, indicando o Relatório da Comissão Revisora do então Projeto do Código Civil, aponta que tal modalidade de direito não se submeteria à prescrição, mas somente à decadência:

\begin{abstract}
"A decadência só se aplica a direitos potestativos, que são direitos sem pretensão, e, portanto, insusceptíveis de violação. Assim sendo, somente quando, para o exercício do direito potestativo, é preciso usar de ação judicial, é que se vai a Juízo (para, por exemplo, exercer o direito de anular negócio jurídico). Ora, o simples ajuizamento da ação, que é o instrumento do exercício desse direito potestativo, significa que a parte está exercendo o seu direito."
\end{abstract}

Pois bem. O Código Civil, por sua vez, não previu nenhum prazo para que o fiador exercitasse o direito de exoneração previsto em seu artigo 835, o que permite a conclusão de que o garante poderá dele se valer a qualquer momento, quando lhe convier e desde que o contrato garantido esteja a viger por tempo indeterminado, em regra. Assim sendo, se o legislador não circunscreveu o exercício do direito potestativo de exoneração a qualquer limite temporal, não seria razoável admitir-se a renúncia a tal direito porque burlaria a finalidade da exoneração, bem como o seu caráter nitidamente protetivo da posição jurídica do garante, já que não se submete a prescrição ou a decadência.

Logo, se o artigo 209 do Código Civil enuncia ser "nula a renúncia à decadência fixada em lei”, entendemos também ser nula a renúncia prévia a um direito potestativo cujo exercício o legislador não submeteu à decadência, posto não representar uma simples faculdade, mas sim um verdadeiro poder ou prerrogativa jurídica que não sofre os efeitos do tempo.

Assim, em termos práticos, a renúncia ao direito potestativo de exoneração equivaleria à consumação da decadência in casu, porquanto o fiador estaria impedido de exercê-lo, tal como se daria se a decadência tivesse ocorrido.

Esta vem a ser a razão pela qual entendemos que se o próprio legislador pré-excluiu a incidência de decadência ao direito potestativo de exoneração ex artigo 835 do Código Civil, não é possível a estipulação de renúncia por meio de imposição contratual, porque representaria burla à finalidade protetiva de dispositivo expresso de lei.

\footnotetext{
${ }^{291}$ MOREIRA ALVES, José Carlos. A parte geral do projeto de Código Civil brasileiro. 2. ed. aum. São Paulo: Saraiva, 2003. p. 163.
} 
Nesta linha de argumentação, uma vez manifestada a exoneração da fiança poderá o credor exigir do devedor-afiançado a apresentação de novo garante, até porque o fiador permanecerá vinculado ao contrato garantido por até 60 (sessenta dias) após a notificação do credor, tempo este mais do que suficiente para que nova garantia seja apresentada.

No mesmo sentido defendido na presente dissertação, porém com fundamentação diversa relativa à Lei do Inquilinato, se encontra a doutrina de Luiz Antonio Scavone Junior $^{292}$ :

\begin{abstract}
"Ainda que o assunto seja polêmico, havendo quem sustente a possibilidade de renúncia ao direito de pedir exoneração, entendemos, inclusive com suporte no art. 45, que o novel inciso $\mathrm{X}$ encerra norma cogente e não comporta renúncia prévia no contrato.

Pensar o contrário significa tornar a renúncia uma cláusula de estilo apta a afastar completamente a intenção da lei, que é de proteger o fiador quando da prorrogação automática do contrato, notadamente em razão da possibilidade de o locador exigir nova garantia do locatário, sob pena de infração contratual e despejo.

Em reforço à impossibilidade de renúncia prévia ao direito de o fiador pedir exoneração, é preciso observar que a maioria dos contratos de locação amoldam-se à idéia de contrato de adesão, posto que são apresentados prontos, em regra pelo locador.

(...)

Neste caso, aplica-se o art. 424 do Código Civil, segundo o qual, "nos contratos de adesão, são nulas as cláusulas que estipule a renúncia antecipada do aderente a direito resultante da natureza do negócio".

Posta desta maneira a questão, a fiança deve ser interpretada restritivamente (Código Civil, art. 819), de tal sorte que é da sua natureza possibilitar ao fiador a exoneração ao final do prazo contratado, cuja renúncia prévia implica limitação de direito resultante da natureza do negócio jurídico e não deve ser admitida."
\end{abstract}

Em face do exposto, entendemos que a renúncia previa ao direito potestativo de exoneração do fiador não pode ser admitida, ainda que no instrumento contratual subscrito pelo garante conste expressa cláusula contratual prevendo-a, eis que neste caso seria inexistente e desprovida de eficácia porque, repita-se, o direito potestativo de exoneração previsto no artigo 835 do Código Civil apenas surge quando o contrato garantido passa a viger por tempo indeterminado. Antes disso não há, não existe direito à exoneração, razão pela qual o garante não poderia manifestar a renúncia à um direito

\footnotetext{
${ }^{292}$ In SCAVONE JUNIOR, Luiz Antonio. Reforma da lei do inquilinato. São Paulo: Ed. Revista dos Tribunais, 2010. p. 46-47.
} 
inexistente. A renúncia a um direito inexistente, inexistente é, podendo até mesmo vir a ser declarada por sentença.

Não obstante, registramos um precedente recente oriundo do Superior Tribunal de Justiça, no qual a turma julgadora considerou nula - e não inexistente - a cláusula de renúncia antecipada à garantia:

“(...) 5. É nula a cláusula contratual mediante a qual o fiador renuncia ao direito de exonerar-se da obrigação, nas hipóteses em que a locação vige por prazo indeterminado. Precedentes. (...) Recurso especial conhecido e improvido". (REsp 884917/PR, Rel. Ministro ARNALDO ESTEVES LIMA, 5. ${ }^{\text {a }}$ TURMA, julgado em 17/04/2007, DJ 14/05/2007 p. 393)

E no corpo do referido acórdão o Exmo. Min.-Relator escreveu:

“Também não há falar em malferimento ao art. 1.500 do Código Civil, tendo em vista que esta Corte de Justiça firmou a compreensão de que é nula a cláusula contratual mediante a qual o fiador renuncia ao direito de exonerar-se da obrigação, nas hipóteses em que a locação vige por prazo indeterminado.

Nesse mesmo sentido:

LOCAÇÃO. FIANÇA. EXONERAÇÃO. RENÚNCIA. ARTIGO 1.500 DO CÓDIGO CIVIL/1916. IRRELEVÂNCIA. FIADOR OBRIGADO SOMENTE AO PACTO ORIGINÁRIO COM O QUAL ANUIU.

É defeso ao fiador exonerar-se da fiança, eis ser de ordem pública a norma contida no artigo 1.500 da Lei Substancial Civil.

Não pode o fiador ficar vinculado ao pacto locatício por tempo indeterminado, visto que deve ser conferida a respectivo contrato acessório, interpretação restritiva e benéfica, vale dizer, a responsabilidade do garante fica delimitada a encargos originariamente estabelecidos.

O termo a quo da exoneração deve ser fixado desde a citação, haja vista possuir tal decisão natureza declaratória, operando efeitos ex tunc.

Recurso especial improvido. (REsp 598.647/SP, Rel. Min. PAULO MEDINA, Sexta Turma, DJ 29/3/04)

Vale observar que a solução dada à controvérsia é consonante com a jurisprudência deste Superior Tribunal, senão vejamos:

LOCAÇÃO. FIANÇA. EXONERAÇÃO DOS FIADORES. GARANTIA PRESTADA EM RAZÃO DA AMIZADE OU PARENTESCO COM OS SÓCIOS. RETIRADA DOS SÓCIOS. NOTIFICAÇÃO EXTRAJUDICIAL DA VONTADE DE EXONERAÇÃO DA FIANÇA.

Fiança é contrato de natureza intuitu personae e se interpreta estritamente.

Malgrado distinga-se a pessoa dos sócios da pessoa jurídica, é possível a exoneração da garantia prestada à sociedade após a retirada dos sócios em 
função dos quais se deu essa garantia substituídos por estranhos à fidúcia original.

Recurso conhecido e provido. (REsp 299.036/MG, Rel. p/ Acórdão Min. JOSÉ ARNALDO DA FONSECA, Quinta Turma, DJ 8/10/01)

RECURSO ESPECIAL. EXONERAÇÃO DE FIANÇA APÓS A RETIRADA DOS SÓCIOS AFIANÇADOS. POSSIBILIDADE À VISTA DA NATUREZA INTUITU PERSONAE DO CONTRATO.

A garantia destinava-se mais à pessoa dos sócios que então integravam a sociedade.

A eventual renúncia ao direito assegurado no art. 1.500, do Código Civil e o fato de a fidúcia ser por prazo limitado são irrelevantes no caso.

Recurso conhecido e provido para declarar a exoneração da fiança. (REsp 236.671/RJ, Rel. Min. JOSÉ ARNALDO DA FONSECA, Quinta Turma, DJ 17/4/00)"

Não obstante, muito embora discordemos da fundamentação do acórdão porque, conforme já expusemos, o direito de exoneração na atualidade não nos parece de ordem pública, a consequiência será a mesma: permitir a exoneração do fiador, ainda que no contrato de garantia conste cláusula expressa de renúncia ao direito potestativo.

\subsection{Os princípios da boa-fé objetiva e da função social aplicados ao contrato de fiança}

\subsubsection{O princípio da boa-fé objetiva}

A partir da entrada em vigor do Código Civil de 2002 o direito civil brasileiro contemplou expressamente duas novas diretrizes orientadoras que passaram a exercer grande influência sobre a doutrina e jurisprudência brasileiras: a primeira, a da boa-fé objetiva, vem prevista no artigo 421 do Código Civil; a segunda, a da função social do contrato, encontra-se no artigo 422 do Código Civil.

Entretanto, apesar da decisiva importância destes novos princípios contratuais, os quais passaram a ser objeto de intensa atividade doutrinária, ousamos apontar que nunca se falou e escreveu tanto sobre boa-fé objetiva e função social do contrato, porém contraditoriamente nunca se desrespeitou tanto referidos princípios, que mais têm sido utilizados como parâmetros argumentativos para justificar vários e reiterados 
descumprimentos contratuais ${ }^{293}$, do que para buscar balizar e valorar a correta conduta dos contratantes, a fim de serem encontrados os necessários modelos de conduta que deveriam guiar os operadores de direito na análise das várias situações da vida geradoras de conflitos.

A ausência da intenção de prejudicar alguém e do conhecimento ou da consciência sobre a existência de um vício ou obstáculo à aquisição de um direito compõem o núcleo essencial da chamada boa-fé subjetiva. Diz-se 'subjetiva' justamente porque, para a sua aplicação, deve o intérprete considerar a intenção do sujeito da relação jurídica, o seu estado psicológico ou íntima convicção. Antitética à boa-fé subjetiva está a má-fé, também vista subjetivamente como a intenção de lesar a outrem ${ }^{294}$. Nestes casos, se em uma determinada relação jurídica um dos sujeitos teve a intenção de prejudicar o outro ou tinha conhecimento de que determinado objeto não poderia ser transferido ao comprador, eis que eivado de vícios redibitórios, por exemplo, diz-se que a parte agiu de má-fé ou sem boa-fé subjetiva. Em outras palavras, podemos dizer que a boa-fé subjetiva está no sujeito ${ }^{295}$.

A boa-fé contratual [objetiva] é uma regra de comportamento ético-jurídica, que se situa no mesmo plano da lei, vale dizer, adquire função de norma dispositiva, integrando, suprindo e corrigindo o conteúdo do contrato, numa função interpretativa. Daí a sua natureza objetiva, que não está baseada na vontade das partes, "mas na adequação dessa

\footnotetext{
${ }^{293}$ A bem dizer, a boa-fé objetiva é uma via de mão dupla pela qual deverão trafegar credor, devedor e fiador. Não se justifica que no direito brasileiro atual apenas o devedor seja protegido, enquanto os ônus dos negócios seriam apenas do credor. A boa-fé objetiva não tem por finalidade suprimir da vida econômicojurídica o caráter especulativo dos negócios, a perseguição dos lucros e a manutenção de situações de vantagem; muito pelo contrário, a boa-fé objetiva tem em mira induzir que os participantes de um negócio atuem de forma clara e aberta, de maneira a garantirem que o outro, que o alter possa conduzir-se de forma consciente, de modo a conhecer todas as nuances do negócio do qual participará. Em sentido semelhante apontam Gustavo Tepedino e Anderson Schreiber: "Justamente por não exigir a proteção aos interesses íntimos e privados da contraparte, mas somente a colaboração para aqueles interesses objetivamente extraídos da própria realização do negócio, a boa-fé objetiva não importa em sacrifício de posições contratuais de vantagem. Em outras palavras, as partes, na prática, concorrem - e o direito não veda, em relações paritárias, que concorram - entre si na aquisição e manutenção de posições prevalentes e de proteção, o que é da essência das relações negociais. O comprador deseja o menor preço, o vendedor o maior, e não há como esperar que renunciem a tais interesses, que são da lógica do negócio. A boa-fé, seja por meio da imposição positiva de deveres anexos, seja por meio da proibição de exercer abusivamente (em contrariedade aos deveres anexos) os direitos contratuais, não implica renúncia a tais direitos ou às situações de preponderância que possam vir a ocorrer no curso da relação obrigacional.(...) Sustentar o contrário traduz puro romantismo, ao qual as relações patrimoniais e a prática contratual não podem se adaptar. A concorrência por posições prevalentes e um certo grau de disputa em prol de interesses contrapostos é inerente a qualquer negócio jurídico." (In: TEPEDINO, Gustavo; SCHREIBER, Anderson. A boa-fé objetiva no Código de Defesa do Consumidor e no novo Código Civil. In: FARIAS, Cristiano Chaves (Org.). Leituras complementares de direito civil: o direito civil-constitucional em concreto. Salvador: Podivm, 2007, p. 218-219). (Grifamos)

${ }^{294}$ MARTINS-COSTA, Judith. A boa-fé no direito privado, cit., p. 411. (Grifamos)

${ }^{295}$ No direito brasileiro atual a boa-fé subjetiva ainda mantém a sua importância no campo dos direitos reais, especialmente no que atina à posse e à usucapião.
} 
vontade ao princípio que inspira e fundamenta o vínculo negocial”. Donde fica clara a sua distinção da boa-fé subjetiva: enquanto a boa-fé objetiva atua sobre o conteúdo da relação jurídica, nascida da obrigação, em particular, ou do negócio, em geral, a boa-fé subjetiva incide sobre o sujeito dessa relação ${ }^{296}$.

Um modelo de conduta considerada ideal à luz de determinada situação concreta, de acordo com uma legítima expectativa pré-concebida pelo intérprete em vista dos princípios e valores que permeiam o ordenamento jurídico representa a denominada boa-fé objetiva. Objetiva porque não guarda nenhuma relação com eventual estado anímico do sujeito, com a sua consciência sobre o que seria certo ou errado, legal ou ilegal, mas apenas com a sua conduta, conduta esta que é avaliada a partir de um modelo que se situa em zona exterior ao sujeito e que é construído a partir da idéia de conduta esperada em determinada situação concreta. Nestes casos, o modelo de conduta esperada é construído pelo intérprete a partir da seguinte premissa: o que se poderia esperar de um determinado contratante, homem comum, em face de uma determinada situação concreta e nas mesmas condições? Como teria atuado um contratante honesto, probo, leal e diligente naquela situação? $?^{297}$ Por este modelo objetivo de conduta levam-se em consideração os fatores concretos do caso, tais como o status pessoal e cultural dos envolvidos, não se admitindo uma aplicação mecânica do standard, de tipo meramente subsuntivo ${ }^{298}$. Em outras palavras, podemos dizer que a boa-fé objetiva está fora do sujeito.

Destarte, a boa-fé objetiva é um 'standard jurídico', isto é, um modelo optimizado de conduta imposto pelo ordenamento jurídico às partes de uma determinada relação contratual. E esse modelo de conduta tem por conteúdo os deveres de colaboração, solidariedade, honestidade, retidão, coerência, fidelidade, cooperação, a fim de que ambos os contraentes possam atingir o 'porto seguro da suas expectativas', que vem a ser o cumprimento do contrato ${ }^{299}$.

\footnotetext{
${ }^{296}$ ZANELLATO, Marco Antonio. Da boa fé no direito privado. 2002. Dissertação (Mestrado) - Faculdade de Direito, Universidade de São Paulo, São Paulo, 2002. p. 77.

297،A boa-fé objetiva é dever de conduta dos indivíduos nas relações jurídicas obrigacionais, especialmente no contrato. Interessam as repercussões de certos comportamentos na confiança que as pessoas neles normalmente neles depositam. Confia-se no significado comum, usual, objetivo da conduta ou comportamento reconhecível no mundo social. A boa-fé objetiva importa conduta honesta, leal, correta. É a boa-fé de conduta." (LÔBO, Paulo Luiz Netto. Teoria geral das obrigações, cit., p. 81).

${ }^{298}$ MARTINS-COSTA, Judith. A boa-fé no direito privado, cit., p. 411. (Grifamos)

${ }^{299}$ “Antes já se registrou que a boa-fé objetiva consiste no comportamento leal, correto e transparente que as partes devem adotar na relação obrigacional. Diferentemente do que ocorre na análise da função social da obrigação, onde se analisa o negócio, ao apreciar a boa-fé objetiva foca-se no comportamento da parte, no seu proceder, objetivamente analisado,para aferir se ele é adequado. Afinal, o ordenamento jurídico deseja que as partes atuem da melhor forma possível, com o máximo de correção. O comportamento em
} 
Assim, pode-se afirmar que em cada modelo ou tipo contratual também haverá um modelo ou tipo de conduta a ser esperada dos contratantes, tendo em vistas regras e princípios específicos de um determinado contrato. Várias, pois, serão as "boas-fés objetivas" porque vários são os contratos contemplados no ordenamento.

E no caso do contrato de fiança, pois, qual seria o modelo de conduta ideal a ser adotado pelos contratantes - credor e fiador? Em outras palavras, o que se pode esperar, como regra, do credor e do fiador? Vejamos ${ }^{300}$.

Por primeiro, analisemos a postura que vem a ser esperada do credor.

a) O credor garantido pela fiança deverá atuar para evitar o agravamento do próprio prejuízo $^{301}$, situação esta que na atualidade é deficientemente regrada pelo artigo 834 do Código Civil ${ }^{302}$. Assim, não se admite, por violar a boa-fé objetiva, que o credor deixe de exigir o cumprimento da prestação do devedor-afiançado em prazo razoável, tolerando o aumento da dívida ante a existência de garantia fidejussória.

$\mathrm{Na}$ grande maioria dos casos, em especial nos campos da locação de imóveis urbanos, o credor permite que o inquilino permaneça no imóvel por longo período de

conformidade com a boa-fé objetiva impõe a uma das partes o dever de atuar lealmente, a fim de garantir a satisfação da prestação oferecida. Impõe-se a transferência da plena informação e na garantia da correção da conduta. Logo se vê que o princípio da boa-fé representa um conceito aberto e geral, que visa a estimular e proteger a conduta adequada." (NEVES, José Roberto de Castro. Direito das obrigações. Rio de Janeiro: GZ Editora, 2009, p. 83).

${ }^{300}$ Os Enunciados do CJF oriundos das Jornadas de Direito Civil representam um valiosos auxílio no campo da criação de modelos contratuais fundados na boa-fé objetiva:

"Enunciado n. 24 da I Jornada de Direito Civil do CJF: Em virtude do princípio da boa-fé, positivado no art. 422 do novo Código Civil, a violação dos deveres anexos constitui espécie de inadimplemento, independentemente de culpa."

"Enunciado n. 26 da I Jornada de Direito Civil do CJF: A cláusula geral contida no art. 422 do novo Código Civil impõe ao juiz interpretar e, quando necessário, suprir e corrigir o contrato segundo a boa-fé objetiva, entendida como a exigência de comportamento leal dos contratantes."

"Enunciado n. 27 da I Jornada de Direito Civil do CJF: Na interpretação da cláusula geral da boa-fé, devese levar em conta o sistema do Código Civil e as conexões sistemáticas com outros estatutos normativos e fatores metajurídicos."

"Enunciado n. 167 da III Jornada de Direito Civil do CJF: Com o advento do Código Civil de 2002, houve forte aproximação principiológica entre esse Código e o Código de Defesa do Consumidor, no que respeita à regulação contratual, uma vez que ambos são incorporadores de uma nova teoria geral dos contratos."

"Enunciado n. 168 da III Jornada de Direito Civil do CJF: O princípio da boa-fé objetiva importa no reconhecimento de um direito a cumprir em favor do titular passivo da obrigação."

"Enunciado n. 169 da III Jornada de Direito Civil do CJF: O princípio da boa-fé objetiva deve levar o credor a evitar o agravamento do próprio prejuízo."

"Enunciado n. 362 da IV Jornada de Direito Civil do CJF: A vedação do comportamento contraditório(venire contra factum proprium) funda-se na proteção da confiança, tal como se extrai dos arts. 187 e 422 do Código Civil."

"Enunciado n. 363 da IV Jornada de Direito Civil do CJF: Os princípios da probidade e da confiança são de ordem pública, estando a parte lesada somente obrigada a demonstrar a existência da violação.”

${ }^{301}$ Enunciado n. 169 da III Jornada de Direito Civil do CJF.

302، Art. 834. Quando o credor, sem justa causa, demorar a execução iniciada contra o devedor, poderá o fiador promover-lhe o andamento." 
tempo e somente após vários meses ou até anos promove o despejo do imóvel; já nos contratos bancários, as instituições financeiras fingem que estão a negociar a solução da dívida enquanto está é majorada pelos juros que elas próprias praticam, situação esta que é piorada quando se admite a incidência da malsinada comissão de permanência. Tal postura, que é aparentemente lícita, na realidade é gravíssima e denota violação à conduta que se pode legitimamente esperar de um credor honesto, probo e leal e que vem a ser a plena satisfação do seu crédito. Assim, segundo pensamos, o credor que tolera a inadimplência do devedor tão-somente porque o contrato é garantido por fiança descumpre a boa-fé objetiva, pois a sua conduta concreta (a de não exigir a prestação do devedor) se afasta do modelo de conduta que era de se esperar de um credor na mesma situação (a de prontamente agir para recuperar o seu crédito) ${ }^{303}$, pois o fiador, por ser apenas garantidor do adimplemento alheio, não poderá ser transformado em devedor principal por ato do credor, o que de fato acontece porque o credor se "esquece" do verdadeiro obrigado ao adimplemento, pois sabe que o fiador possui forças para suportar a execução da garantia.

b) Nas situações em que ocorrer a inadimplência do devedor-afiançado ou se der a prorrogação legal de determinado contrato deverá o credor cientificar o fiador acerca do incumprimento da obrigação, a fim de que este possa agir para minorar o seu prejuízo, bem como deverá obter o consentimento do fiador para a manutenção da garantia fidejussória durante o período de prorrogação legal do contrato ${ }^{304,} 305$.

Como já apontamos anteriormente, o fiador é responsável pela dívida, porém sem que seja devedor. Assim, apesar da sua peculiar situação o fiador nunca é notificado do inadimplemento do devedor-afiançado, de modo que somente vem a ser informado da situação ou quando o seu nome já se encontra nos cadastros de proteção ao crédito ou

\footnotetext{
${ }^{303}$ A mesma situação ocorre em sede de contratos bancários. As instituições financeiras, remuneradas por juros altíssimos, ocorrida a inadimplência do cliente deixam de exigir a dívida de pronto sob as vestes de uma tolerância solidária, vale dizer, sob o argumento de que concederam um tempo para que o devedor pudesse realizar a prestação amigavelmente. Todavia, enquanto o cliente permanece em default, enquanto o cliente não paga incidem, ao mesmo tempo, juros moratórios, remuneratórios, comissão de permanência, dentre outras taxas, que elevam a dívida em progressão geométrica e impedem qualquer possibilidade de adimplemento. Desta forma, apenas quando a dívida atingiu um patamar insustentável para o devedor, porém interessante para a instituição financeira, esta ingressa em juízo e passa a exigir a prestação. Claramente, esta situação contribui para aumentar a dívida do devedor e causar enorme prejuízo ao fiador que é o responsável pelo adimplemento.

${ }^{304}$ Esta segunda hipótese de prorrogação legal do contrato, notadamente prevista na Lei n. ${ }^{\circ} 8.245 / 91$, está em vias de sofrer uma profunda alteração em relação à manutenção da fiança durante o período que passar a viger por prazo indeterminado por força do Projeto de Lei n. ${ }^{\circ} 71 / 2007$ que foi recentemente aprovado pelo Senado Federal e que está prestes a ser sancionado ou vetado pelo Exmo. Sr. Presidente da República. Em tópico específico desta dissertação iremos analisar os pontos do projeto que afetam o contrato de fiança.

${ }^{305}$ Estas premissas decorrem especialmente dos Enunciados n. 26 da I Jornada de Direito Civil, n. 168 da III Jornada de Direito Civil do CJF, n. 362 e 363 da IV Jornada de Direito Civil do CJF.
} 
quando vem a ser demandado judicialmente e, desta forma, citado para a demanda. Entretanto, quem primeiro toma conhecimento do incumprimento do contrato pelo devedor é o credor que não recebeu a sua prestação no modo, tempo e local convencionados. Em casos que tais, ainda que o garante não figure como parte no contrato gerador do débito não honrado pelo afiançado, ele é o responsável pelo adimplemento, de maneira que deverá ser informado sobre a conduta do afiançado para que possa fiscalizá-la.

Em casos que tais, em uma interpretação construtiva do princípio da boa-fé objetiva defendemos que o fiador deverá ser mantido informado pelo credor sobre a situação do contrato afiançado, mesmo porque garantiu o adimplemento do devedor principal e, desta forma, possui nítido interesse jurídico em acompanhar e ser informado sobre a situação subjacente, até porque irá ser responsabilizado se o devedor não efetuar a prestação.

A premissa é simples: como o fiador poderá ser responsabilizado pelo débito do afiançado se não lhe foi permitido que tomasse conhecimento sobre a real situação do crédito garantido? Desta forma, uma vez informado da situação do devedor o fiador poderá agir para solucionar o problema, por exemplo, quer efetuando o pagamento da prestação quer exigindo que o afiançado cumpra a sua obrigação. O que se quer evitar em hipóteses semelhantes é o efeito surpresa em face do garante: ao ter assentido em garantir o adimplemento de prestação alheia o fiador deverá ser informado acerca do comportamento do devedor, pois do contrário não terá como agir para evitar o seu próprio prejuízo, bem como para evitar o incumprimento do contrato.

E esta comunicação poderia ser realizada por qualquer meio idôneo que permitisse o conhecimento do fiador, bastando, segundo defendemos, que o comunicado fosse enviado para o endereço fornecido pelo garante para que o dever de informação fosse satisfeito $^{306}$.

Por segundo, analisemos a postura que vem a ser esperada do fiador.

a) O fiador não poderá agir como se fiança não houvesse, atuando em desfavor do credor como se o contrato de garantia tivesse sido firmado com total ausência de seriedade; outrossim, veda-se ao garante postular a sua invalidade apenas sob a alegação de vícios formais ou contrariando a legítima expectativa criada pelo credor a partir da própria promessa manifestada pelo garante.

\footnotetext{
${ }^{306}$ Nesta hipótese, como ordinariamente as correspondências chegam aos domicílios dos destinatários, caberia ao fiador demonstrar que não foi adequadamente informado pelo credor da situação de incumprimento contratual por parte do devedor. Daí por que o credor diligente cuidaria de notificar o fiador por telegrama ou correspondência com aviso de recebimento.
} 
Nos contratos de locação garantidos por fiança é prática usual que o locador exija do fiador, de plano, a demonstração da sua idoneidade financeira, principalmente através da exibição de título de propriedade de determinado imóvel. E em conjunto com a demonstração de idoneidade o fiador declara que não irá alienar referido imóvel apresentado como prova de seu cabedal financeiro enquanto perdurar o contrato de garantia e estiver vinculado ao credor. Todavia, referida declaração manifestada em face do credor se submete ao princípio da relatividade dos contratos, não atingido terceiro de boa-fé que porventura venha a adquirir o imóvel do fiador em regular negociação; nestes casos, apesar da declaração do fiador esta poderá ser facilmente burlada pelo garante quando transferir o imóvel objeto do pacto de non alienando, uma vez que o descumprimento contratual, pelo menos em regra, não poderá ser oposto contra o terceiro de boa-fé.

Desta forma, fácil é perceber que a declaração manifestada pelo fiador de que não irá alienar o imóvel indicado ao credor se ostenta eficaz apenas contra este, porém não contra o terceiro de boa-fé, principalmente por ausência total de publicidade que permitisse a presunção de conhecimento erga omnes ante a falta de registro hábil a tal finalidade. Em situações iguais a narrada, em muitas ocasiões o fiador não apenas descumpre a sua promessa de não alienar o imóvel indicado, como também reduz o seu patrimônio de modo a esvaziar por completo a garantia dantes prometida. Na prática, o fiador atua contra a promessa por ele manifestada de garantir a obrigação, violando a legítima expectativa criada em favor do credor $^{307}$. E este descumprimento impede que o credor receba o seu crédito porque o fiador esvazia a garantia ao dispor do seu patrimônio em favor de terceiro e em detrimento do credor.

Esta hipótese é exemplo típico de violação ao princípio da boa-fé sob as vestes da teoria denominada de venire contra factum propium $^{308}$. No Brasil, Ruy Rosado de Aguiar

\footnotetext{
${ }^{307}$ Esta situação será objeto de proposta por nós formulada ao final do trabalho visando emprestar ao contrato de fiança publicidade plena e, por conseguinte, eficácia erga omnes. Ainda que o princípio da relatividade dos efeitos dos contratos seja uma diretriz considerada fudamental pela doutrina civilista em matéria de contrato, não podemos admitir que em pleno século XXI e em plena era da globalização e da internete o legislador ainda não tenha criado um mecânismo jurídico idôneo a permitir que o contrato de fiança seja conhecido pelos terceiros que contratarem com o fiador, porque a garantia repercute não apenas nas esferas particulares dos credor e fiador como também atinge terceiros que na imensa maioria das vezes não tinham como saber a fiança existia. Assim, a fim de evitar que ocorra mais uma hipótese que obstaculiza senão impede o recebimento do crédito, iremos propor a oponibilidade erga omenes da fiança.

308،Entre tantas expressões derivadas do princípio da boa-fé pode ser destacado o dever de não agir contra o ato próprio. Significa dizer que a ninguém é dado valer-se de determinado ato, quando lhe for conveniente $e$ vantajoso, e depois voltar-se contra ele quando não mais lhe interessar. Esse comportamento contraditório denota intensa má-fé, ainda que revestido de aparência de legalidade ou de exercício regular de direito. Nas obrigações revela-se, em muitos casos, como aproveitamento da própria torpeza, mas a incidência desse dever não exige o requisito da intencionalidade" (LÔBO, Paulo Luiz Netto. Teoria geral das obrigações, cit., p. 88) (Grifamos).
} 
Júnior $^{309}$ bem apontou a importância que o mecanismo repressor do comportamento contraditório (venire contra factum proprium) ostenta no âmbito das relações contratuais:

“A teoria dos atos próprios, ou a proibição de venire contra factum proprium protege uma parte contra aquela que pretenda exercer uma posição jurídica em contradição com o comportamento assumido anteriormente. Depois de criar certa expectativa, em razão de conduta seguramente indicativa de determinado comportamento futuro, há quebra dos princípios de lealdade e de confiança se vier a ser praticado ato contrário ao previsto, com surpresa e prejuízo à contraparte. Aquele que vende um estabelecimento comercial e auxilia, por alguns dias, o novo comerciante, inclusive preenchendo pedidos e novas encomendas, fornecendo o seu próprio número de inscrição fiscal, não pode depois cancelar tais pedidos, sob alegação de uso indevido de sua inscrição. $\mathrm{O}$ credor que concordou, durante a execução do contrato de prestações periódicas, com o pagamento em lugar ou tempo diverso do convencionado, não pode surpreender o devedor com a exigência literal do contrato. Para o reconhecimento da proibição é preciso que haja univocidade de comportamento do credor e real consciência do devedor quanto à conduta esperada." (Grifamos)

A teoria dos atos próprios, fundada na boa-fé objetiva ${ }^{310}$, renova e oxigena o vínculo contratual estabelecido entre as partes ao impedir a atuação desleal de um dos contratantes que criara na contraparte, através de uma conduta anterior, a legítima expectativa de que atuaria em determinado sentido quando isto o beneficiava, para logo em seguida desconsiderar, mediante conduta posterior, a confiança gerada, passando a atuar de forma completamente incoerente ${ }^{311}$.

b) $\mathrm{O}$ fiador encontra-se impedido de postular a sua exoneração extrajudicial $e x$ artigo 835 do Código Civil quando o afiançado já estiver em default (mora ou inadimplemento absoluto), de modo a buscar frustrar a garantia prometida ao credor

\footnotetext{
${ }^{309}$ In AGUIAR JÚNIOR, Ruy Rosado de. A extinção dos contratos por incumprimento do devedor. 1. ed. Rio de Janeiro: Aide, 1991. p. 240 e ss.

310“"A cláusula geral de boa-fé objetiva obriga as partes a não agirem em contradição com atos e comportamentos anteriores, praticados antes da conclusão do contrato, durante a execução ou depois de exaurido o objeto do contrato. Em outras palavras, a parte não pode venire contra factum proprium. A proibição incide objetiva e unilateralmente, independentemente do comportamento ou da atitude da contraparte, porque é dever de conduta de cada um dos contratantes isoladamente considerado." (NERY JUNIOR, Nelson; NERY, Rosa Maria de Andrade. op. cit., p. 537).

${ }^{311}$ Como bem aponta Anderson Schreiber em obra específica sobre o tema: "De fato, a proibição do comportamento contraditório não tem por fim a manutenção da coerência por si só, mas afigura-se razoável apenas quando e na medida em que a incoerência, a contradição aos próprios atos, possa violar expectativas despertadas em outrem e assim causar-lhes prejuízos. Mais que contra a simples coerência, atenta o venire contra factum proprium à confiança despertada na outra parte, ou em terceiros, de que o sentido objetivo daquele comportamento inicial seria mantido e não contrariado." (In SCHREIBER, Anderson. A proibição de comportamento contraditório: tutela da confiança e venire contra factum proprium. Rio de Janeiro: Renovar, 2005. p. 90).
} 
mediante a alegação de uma aparente pretensão formalmente legal de interesse na extinção do vínculo.

No Brasil, como sói acontecer em várias modalidades contratuais, as partes estabelecem vínculos já antevendo formas de não cumprir os contratos. No caso das fianças, tão-logo se inicia a situação de incumprimento contratual por parte do devedorafiançado o garante se apressa em tentar desvencilhar-se da garantia como se nenhuma responsabilidade pelo débito tivesse. Nestas hipóteses, se se admitisse a exoneração extrajudicial do fiador estar-se-ia permitindo que o garante esvaziasse completamente a fiança porque a sua responsabilidade seria limitada ao período de 60 (sessenta) dias que seriam contados a partir da notificação recebida pelo credor.

E uma vez transcorrido o prazo fixado no artigo 835 do Código Civil, o fiador estaria exonerado, porém ao credor não restaria mais nenhuma garantia ante a total impossibilidade de que alguém viesse a assumir as pesadas responsabilidades de uma fiança em face de um afiançado que na data da contratação da garantia já estivesse a dever. Por conta disso, a visualização do direito potestativo à exoneração à luz do princípio da boa-fé objetiva permite vedar ao garante que arredasse a garantia se enquanto se mantivesse o incumprimento contratual do afiançado. Assim, uma vez efetuado o pagamento da prestação ou purgada a mora do afiançado poderia o fiador buscar, se o caso, a exoneração extrajudicial da garantia através do exercício do seu direito potestativo com fundamento no artigo 835 do Código Civil, pois estaria a agir "de mãos limpas”.

Em casos que tais, a boa-fé paralisa o direito de o fiador invocar a exoneração prevista no artigo 835 do Código Civil porque o afiançado já se encontrava em default quando o garante tencionou fazê-lo, bem como porque já iniciada a fase da responsabilização do fiador. Se fosse admitida a invocação ao pretenso direito potestativo de exoneração, seria o mesmo que se admitir que a responsabilidade do fiador estaria limitada por apenas 60 (sessenta) dias quando o contrato estivesse a viger por tempo indeterminado, o que não se afigura razoável. Aquele que não cumpriu a sua obrigação contratual, bem como aquele que se responsabilizou pelo adimplemento alheio, deve garantir ao credor o cumprimento exato e fiel da obrigação. A principal finalidade da obrigação é proporcionar ao credor o adimplemento da obrigação nos exatos termos $\operatorname{ajustados}^{312}$, de maneira que não poderá o fiador agir como se fiança não tivesse havido,

\footnotetext{
${ }^{312}$ Aliás, os precisos termos dos artigos 313 e 314 do Código Civil enunciam expressamente que o direito do credor é limitado pela obrigação assumida pelo devedor ou responsável:
} 
vale dizer, apenas garantir o adimplemento enquanto o afiançado estivesse a cumprir as suas obrigações, pois dessa forma não se trataria de garantia, mas sim de garantia apenas aparente.

\subsubsection{O princípio da função social do contrato}

O artigo 421 do Código Civil inovou o direito civil brasileiro ao ter enunciado o princípio da função social do contrato como razão e limite da liberdade de contratar, o qual recebeu a crítica de Álvaro Villaça Azevedo e Antônio Junqueira de Azevedo ${ }^{313}$ para quem a redação equivocada do dispositivo torná-lo-ia fonte de constante insegurança, posto que liberdade contratual estaria limitada pela função social do contrato, mas não seria a sua razão de ser.

Não obstante, a função social do contrato é apontada por muitos doutrinadores ${ }^{314}$ como sinal dos novos tempos pelos quais o direito privado brasileiro estaria a atravessar,

“Art. 313. O credor não é obrigado a receber prestação diversa da que lhe é devida, ainda que mais valiosa. Art. 314. Ainda que a obrigação tenha por objeto prestação divisível, não pode o credor ser obrigado a receber, nem o devedor a pagar, por partes, se assim não se ajustou."

313“19. Art. 421: A alteração proposta, atendendo a sugestão dos professores ÁLVARO VILLAÇA AZEVEDO e ANTÔNIO JUNQUEIRA AZEVEDO, objetiva inicialmente substituir a expressão "liberdade de contratar" por "liberdade contratual". Liberdade de contratar a pessoa tem, desde que capaz de realizar o contrato. Já a liberdade contratual é a de poder livremente discutir as cláusulas do contrato. Também procedeu-se à supressão da expressão "em razão". A liberdade contratual está limitada pela função social do contrato, mas não é a sua razão de ser." (CÂMARA DOS DEPUTADOS. Projeto de Lei 6.960/2002. Disponível em: <http://www2.camara.gov.br/proposicoes>. Acesso em: 17 ago. 2008).

${ }^{314}$ Cfe. GONÇALVES, Carlos Roberto: “A concepção social do contrato apresenta-se, modernamente, como um dos pilares da teoria contratual. Por identidade dialética guarda intimidade com o "princípio da função social da propriedade" previsto na Constituição Federal. Tem por escopo promover a realização de uma justiça comutativa, aplainando as desigualdades substanciais entre os contratantes." (In GONÇALVES, Carlos Roberto. Direito civil brasileiro. São Paulo: Saraiva, 2004. v. 3, p. 5) (Grifamos); AZEVEDO, Álvaro Villaça: "Pelos contratos, os homens devem compreender-se e respeitar-se, para que encontrem um meio de entendimento e de negociação sadia de seus interesses e não um meio de opressão. Para que esse espírito de fraternidade nos contratos se preserve, no âmbito do direito interno, têm os Estados modernos lançado mão de normas cogentes, interferindo nas contratações, com sua vontade soberana, para evitar lesões. A intervenção do Estado, no âmbito contratual, abriu as portas de um novo tempo, em que se mitigaram os malefícios do liberalismo jurídico, com a proteção social aos mais fracos." (Contratos: disposições gerais, princípios e extinção. In: AZEVEDO, Álvaro Villaça. Contratos: disposições gerais, princípios e extinção. In: AZEVEDO, Antonio Junqueira; TÔRRES, Heleno Taveira; CARBONE, Paolo (Coords.). Princípios do novo Código Civil brasileiro e outras temas em homenagem a Tullio Ascarelli. São Paulo: Quartier Latin, 2008. p. 52) (Grifamos); NEGREIROS, Teresa: "Nesta sua acepção, o princípio da função social do contrato encontra fundamento constitucional no princípio da solidariedade, a exigir que os contratantes e os terceiros colaborem entre si, respeitando as situações jurídicas anteriormente consolidadas, ainda que as mesmas não sejam dotadas de eficácia real, mas desde que a sua prévia existência seja conhecida pelas pessoas implicadas." (In NEGREIROS, Teresa. Teoria do contrato: novos paradigmas. Rio de Janeiro: Renovar, 2003. p. 207) (Grifamos); LISBOA, Roberto Senise: “A consagração da dignidade da pessoa como princípio fundamental inerente a todas as relações jurídicas públicas e privadas, assim como da solidariedade social como objetivo a ser alcançado, nos termos do que conceitua a 
especialmente porque demonstraria a mudança do paradigma liberal que fora adotado pelo legislador no Código Civil de 1916 para o paradigma social que teria sido o mote do Código Civil de 2002. Neste cenário, a autonomia da vontade teria sido mitigada pela solidariedade social prevista no art. $3^{\circ}$, I, da Constituição Federal, de modo que a vontade manifestada somente seria prestigiada se estivesse de acordo com a solidariedade social contemplada no texto constitucional ${ }^{315}$.

Todavia, o princípio da função social que tem sido cantado em verso e prosa pela doutrina civil contemporânea está longe de ostentar utilidade prática maior por faltar-lhe densidade normativa: o que vem a ser a função social do contrato? ${ }^{316}$ Apesar dos esforços

constituição vigente, viabilizam o preenchimento do conteúdo da expressão função social, permitindo-se sua aplicabilidade em consonância com o direito pós-moderno. (In LISBOA, Roberto Senise. Manual de direito civil. 4. ed. reform. São Paulo: Saraiva, 2009. v. 3, p. 64) (Grifamos); NEVES, José Roberto de Castro: "Nem sempre o que duas partes contratam é o mais justo, assim entendido como o que seja razoável, correto, ético e eqüitativo. Não raro, uma parte tira proveito da outra, seja porque detém mais informação, seja pela posição superior que ocupa. Nesses cassos, o acordo contém um conteúdo injusto. Não é certo privilegiar a "esperteza" de alguém, ou legitimar a vantagem decorrente de uma posição de poder que exista de uma pessoa em relação à outra, ainda que não tenha havido vilação direta da letra da lei. O Direito anseia por garantir um contéudo ético nas relações." (In NEVES, José Roberto de Castro. Direito das obrigações. Rio de Janeiro: GZ Ed., 2009. p. 77-78). (Grifamos)

${ }^{315}$ É o que pensa LÔBO, Paulo: "A função social é princípio autônomo que deriva do macroprincípio da solidariedade. Significa que o exercício de qualquer direito deve estar em conformidade com o interesse social da comunidade onde se insere. Em outras palavras, o interesse individual não pode prevalecer sobre o interesse social." (In LÔBO, Paulo Luiz Netto. Direito civil: parte geral, cit., p. 96). (Grifamos) No mesmo sentido aponta BIANCA, Massimo C.: "L'autonomia privata rappresenta ancora un aspetto ineliminable della libertà della persona, e cioè la libertà negoziale (n. 14). Ma l'idea secondo la quale solo ed esclusivamente l'individuo può essere giudice dei suoi interessi non ha più riscontro nella società del nostro tempo. Il riconoscimento della libertà del singolo s'inserisce ormai in una concezione dell'ordinamento che s'ispira al prevalente valore della solidarietà sociale, qual valore di fondo della nostra Constituizone." (In BIANCA, Massimo C. op. cit., v. 3, p. 32). Logo em seguida o autor italiano, ao indicar que a "prima espressione" do princípio da solidariedade seria o princípio da igualdade de fato que faria parte integrante do princípio da igualdade jurídica, de modo a ser reconhecida a efetiva igualdade entre as partes de um contrato, e não meramente a igualdade formal. (In op. cit., p. 32-33). Todavia, o próprio autor italiano reconhece as dificuldades em se indicar qual seria o conteúdo do princípio da solidariedade social: "È difficile dire in che misura il principio di solidarietà incida direttamente sull'autonomia privata. È un dato di fatto che la nostra giurisprudenza appare poco propensa ad esercitare un controllo sui contratti applicando il principio di solidarietà o norme del codice che ad esso possono ricondursi, come la nuorma sulla boa fede. È anche certo però che il principio di solidarietà giustifica e anzi impone l'intervento della legge là dove il principio dell'autonomia privata non è sufficiente as assicurare giusti rapporti." (In op. cit., p. 33)

${ }^{316}$ Os Enunciados do CJF oriundos das Jornadas de Direito Civil indicam alguns dos rumos que a doutrina tem apontado na interpretação da função social do contrato:

"Enunciado n. 360 da IV Jornada de Direito Civil do CJF: O princípio da função social dos contratos também pode ter eficácia interna entre as partes contratantes."

Enunciado n. 361 da IV Jornada de Direito Civil do CJF: O adimplemento substancial decorre dos princípios gerais contratuais, de modo a fazer preponderar a função social do contrato e o princípio da boafé objetiva, balizando a aplicação do art. 475."

"Enunciado n. 21 da I Jornada de Direito Civil do CJF: A função social do contrato, prevista no art. 421 do novo Código Civil, constitui cláusula geral a impor a revisão do princípio da relatividade dos efeitos do contrato em relação a terceiros, implicando a tutela externa do crédito."

"Enunciado n. 22 da I Jornada de Direito Civil do CJF: A função social do contrato, prevista no art. 421 do novo Código Civil, constitui cláusula geral que reforça o princípio de conservação do contrato, assegurando trocas úteis e justas." 
doutrinários pouco se sabe até o momento em razão da generalidade das explicações doutrinárias e da retórica constitucional dos comentadores, cujas análises partiram da premissa de que o contrato, instrumento principal de circulação de riquezas, viesse a ser transformado em instrumento principal de realização de justiça social, uma vez que a partir da promulgação do Código Civil de 2002 credor e devedor passariam a se preocupar mais detidamente com o interesse alheio e menos com o interesse próprio; passariam a atuar de "mãos dadas", cooperando entre si como protagonistas de uma mesma finalidade, e jamais como antagonistas ${ }^{317}$.

Com o devido respeito, a doutrina que vem se formando a partir da entrada em vigor do Código Civil de 2002 acabou por construir um conteúdo tão amplo da função social do contrato que "já não se reconheça a sua utilidade. Em nome da função social, passar-se-ia a fundamentar certos improvisos, que não se mostrariam resistentes a um exame mais prudente, ou concreções supérfluas, uma vez que já fundamentadas por outros caminhos. Em especial, a consagração da função social do contrato como sumo princípio da teoria contratual, como chave para uma compreensão mais humanista do fenômeno

"Enunciado n. 23 da I Jornada de Direito Civil do CJF: A função social do contrato, prevista no art. 421 do novo Código Civil, não elimina o princípio da autonomia contratual, mas atenua ou reduz o alcance desse princípio quando presentes interesses metaindividuais ou interesse individual relativo à dignidade da pessoa humana."

"Enunciado n. 166 da III Jornada de Direito Civil do CJF: A frustração do fim do contrato, como hipótese que não se confunde com a impossibilidade da prestação ou com a excessiva onerosidade, tem guarida no Direito brasileiro pela aplicação do art. 421 do Código Civil."

"Enunciado n. 167 da III Jornada de Direito Civil do CJF: Com o advento do Código Civil de 2002, houve forte aproximação principiológica entre esse Código e o Código de Defesa do Consumidor, no que respeita à regulação contratual, uma vez que ambos são incorporadores de uma nova teoria geral dos contratos."

${ }^{317}$ “Em segundo lugar, não se pode interpretar a função social do contrato de modo a exigir dos contraentes um comportamento altruístico, a impor que eles procurem realizar, antes de seus interesses, os interesses dos outros. Na realidade, a perspectiva funcional do direito contratual desloca o fundamento das situações subjetivas, antes ancorado na vontade do indivíduo, para os interesses e valores da coletividade. Porém, isto não quer dizer que as pessoas não possam mais se servir de seus direitos para satisfazer os seus interesses. Ao contrário, o que se pode entender é que a própria razão que justifica que essa pessoa possa exercer os seus direitos em seu benefício e uma razão do ordenamento. Com efeito, há um interesse social a ser atendido quando se tutela o interesse individual de cada pessoa, assim como há quando se tutela a satisfação de interesses difusos ou coletivos que estejam eventualmente envolvidos na realização daquele contrato. Na realidade, não raro a tutela de um interesse coletivo se confunde com a de um interesse individual; por exemplo, o interesse coletivo em promover o acesso à habitação se revela na tutela individual do inquilino.

Nesse sentido, é de se tomar com cuidado a proposta daqueles que defendem a funcionalização da relação contratual como decorrência do princípio da função social, mas disso inferem que se deva, em nome da função social, imputar às partes deveres positivos que teriam por escopo assegurar que o contrato esteja a efetivar interesses sociais relevantes (meio ambiente, geração de empregos etc.). Além do mais, mostrar-seia difícil efetuar o controle quanto à observância desses deveres positivos. Quando muito, é o Estado que estaria obrigado a prever em seus contratos administrativos esses deveres promocionais, o que reduziria significativamente a pretendida eficácia do princípio da função social." (RENTERÍA, Pablo. Considerações acerca do atual debate sobre o princípio da função social do contrato. In: MORAES, Maria Celina Bodin de (Coord.). Princípios do direito civil contemporâneo. Rio de Janeiro: Renovar, 2006. p. 305-306). 
contratual, pode ter o efeito reverso de transformá-la num antiquado princípio geral de direito, de cuja aplicação direta não se cuidaria muito. „318

Em artigo escrito após o primeiro biênio da vigência do Código Civil de 2002, Rodrigo Xavier Leonardo ${ }^{319}$ identificou na jurisprudência de alguns dos tribunais brasileiros quatro orientações sobre a função social do contrato, a saber:

"As quatro principais orientações seriam as seguintes: a) relativização dos princípios clássicos do direito dos contratos; b) controle de cláusulas iníquas ou abusivas; c) controle da conduta das partes contratantes; d) ponderação entre os valores econômicos e a justidade dos contratos."

A relativização dos princípios clássicos do direito dos contratos em favor de outros princípios e de outros valores albergados pela ordem jurídica é retratada como uma constante nos precedentes jurisprudenciais analisados e adiante citados.

Efetivamente, pela manifestação praticamente uníssona verificada na recente jurisprudência, parece não mais existir lugar para as tentativas de justificação da eficácia contratual, única e exclusivamente, na exteriorização da vontade pelos contratantes.

(...)

A aplicação da função social do contrato é mais expressiva no controle de cláusulas contratuais abusivas. Cite-se, neste sentido, o repúdio às cláusulas que determinam a perda das prestações adimplidas por um mutuário nos contratos de financiamento; a revisão de cláusulas penais que impõem ônus desproporcionais para uma das partes; a redução nos contratos de financiamento, entre outros.

Outro grupo de acórdãos busca fundamento na função social do contrato como mecanismo para coibição de comportamentos contratuais abusivos. Neste sentido, por exemplo, a função social do contrato é indicada como fundamento para evitar o desfazimento da relação contratual nas situações em que se verifica um adimplemento substancial sensivelmente superior a um pequeno inadimplemento, permitindo prevalecer à manutenção da relação contratual ante o poder de resolução do contrato por inadimplemento.

Nestes casos, a função social do contrato propicia um controle sobre a conduta dos contratantes segundo posicionamento teórico conhecido como doutrina da substancial performance.

Em alguns acórdãos, por fim, percebe-se algo mais. Por meio da função social do contrato, abre-se espaço para um juízo de proporcionalidade entre os bens jurídicos tutelados para cada uma das partes ante a necessidade de decisão sobre um específico conflito de interesses interior ao desenvolvimento das relações contratuais."

\footnotetext{
${ }^{318}$ RENTERÍA, Pablo. op. cit., p. 284. (Grifamos).

${ }^{319}$ A função social dos contratos: ponderações após o primeiro biênio de vigência do Código Civil. In: CANEZIN, Claude. Arte jurídica. Curitiba: Juruá, 2005. v. 2.
} 
E após ter sustentado que as três primeiras orientações jurisprudenciais apontavam para a incidência conjunta da função social do contrato e da boa-fé objetiva, o que em tese - sustentamos - impediria a correta apreensão da hipótese de incidência do primeiro, Rodrigo Xavier Leonardo ${ }^{320}$ aponta que a quarta orientação jurisprudencial indicaria o verdadeiro papel da diretriz normativa:

"O quarto grupo de julgados e a correspectiva orientação deles extraída, todavia, apontam para algo de novo. Todos os casos citados fundamentavam-se em silogismos nos quais a premissa menor não foi extraída das cláusulas contratuais nem tampouco do comportamento das partes.

Ao invés de fornecer soluções absolutas sobre a invalidade ou ineficácia das cláusulas contratuais e ao invés de se avaliar a conduta dos contratantes, nestes julgados foram analisadas as circunstâncias concretas da operação econômica para a realização de uma ponderação entre expectativas contratuais igualmente tuteláveis abstratamente que precisam ceder no caso concreto pela necessária predominância de alguns valores no ordenamento jurídico brasileiro.

Se nos três primeiros grupos de julgados utiliza-se a função social do contrato como uma nova fundamentação adicional para construções doutrinárias e jurisprudenciais de certo modo já consolidadas, no último grupo de julgados pode-se verificar algo de inovador que talvez aponte para um sentido autônomo da cláusula geral da função social do contrato.

A função social dos contratos, nesta perspectiva, apresenta-se como a cláusula geral por meio do qual se permite que as circunstâncias concretas presentes em um conflito surgido numa relação contratual integrem o processo de decisão judicial servindo de sustentação para uma ponderação entre os interesses e expectativas contratuais conforme valores reconhecidos no ordenamento jurídico brasileiro.

Na medida em que esses valores, por sua vez, aparecem na jurisprudência brasileira como justificação para a ponderação de o sistema jurídico e consolidam-se linhas de entendimento que, com o passar do tempo, podem se tornar mais definidas e, assim, promover a justiça contratual sem prejuízo da segurança no tráfico econômico.

Mesmo sujeitando-se à enorme dificuldade de se circunscrever o sentido da palavra função, se partirmos da definição de Luciano Camargo Penteado de que "a idéia de função, em direito, vincula-se à relação existente entre exercício de poder e interesses outros que não os do titular do poder, ou ao menos, que não os exclusivos deste titular", pode-se extrair desses exemplos (sobretudo dos últimos) a indicação de que a sustentação da eficácia jurídica do contrato e do exercício de alguns poderes contratuais deixa de ser circunscrita à manifestação de vontade das partes para encontrar embasamento em valores superiores do que aqueles pertinentes exclusivamente à parte que exerce um poder contratual." (Grifamos)

\footnotetext{
${ }^{320} \mathrm{~A}$ função social dos contratos: ponderações após o primeiro biênio de vigência do Código Civil. In: CANEZIN, Claude. op. cit., v. 2.
} 
Como se vê, os tribunais têm se valido do princípio da função social do contrato para as mais variadas finalidades, muitas vezes contraditórias, o que gera ainda mais insegurança na utilização do princípio ${ }^{321}$.

“Nesse sentido”, lembra ainda Pablo Rentería, “o aparente consenso na doutrina em torno da conexão entre o princípio da solidariedade e a função social do contrato, antes de resolver o debate, põe as bases para o seu desenvolvimento. Afinal, em torno da solidariedade, procura-se construir toda a teoria contratual, de tal maneira que essa conexão, posto que extremamente importante para balizar os contornos da função social do contrato, não serve para identificar suas notas características que poderiam, inclusive, melhor aclarar a sua relação (contigüidades e distinções) com os outros princípios contratuais que igualmente orbitam em torno da solidariedade social (e.g., boa-fé objetiva)." 322

Como se vê, a doutrina acabou por construir um conceito tão amplo de função social, que acabou, em nosso sentir, se transformando em um fator de perturbação do vínculo contratual. Ora, quando dois ou mais sujeitos estabelecem um contrato - e não estamos aqui a escrever sobre o contrato de adesão - levam em consideração, no momento da contratação, os prós e contras que aquela relação surtirá em face de cada um.

É certo, porém, que nos dias atuais esta “consideração” é quase inexistente quando nos deparamos com o fenômeno da contratação despersonalizada, também conhecida como contratação por adesão; porém, quando falamos de contratação paritária, essa consideração

\footnotetext{
${ }^{321}$ Vejamos, v.g., duas decisões recentes do Superior Tribunal de Justiça: “(...)- O fato do comprador obter maior margem de lucro na revenda, decorrente da majoração do preço do produto no mercado após a celebração do negócio, não indica a existência de má-fé, improbidade ou tentativa de desvio da função social do contrato. - A função social infligida ao contrato não pode desconsiderar seu papel primário e natural, que é o econômico. Ao assegurar a venda de sua colheita futura, é de se esperar que o produtor inclua nos seus cálculos todos os custos em que poderá incorrer, tanto os decorrentes dos próprios termos do contrato, como aqueles derivados das condições da lavoura. - A boa-fé objetiva se apresenta como uma exigência de lealdade, modelo objetivo de conduta, arquétipo social pelo qual impõe o poder-dever de que cada pessoa ajuste a própria conduta a esse modelo, agindo como agiria uma pessoa honesta, escorreita e leal. Não tendo o comprador agido de forma contrária a tais princípios, não há como inquinar seu comportamento de violador da boa-fé objetiva. Recurso especial conhecido e provido. (REsp 803.481/GO, Rel. Ministra NANCY ANDRIGHI, 3. ${ }^{\text {a }}$ TURMA, julgado em 28/06/2007, DJ 01/08/2007 p. 462) (Grifamos); “(...)- O exame da função social do contrato é um convite ao Poder Judiciário, para que ele construa soluções justas, rente à realidade da vida, prestigiando prestações jurisdicionais intermediárias, razoáveis, harmonizadoras e que, sendo encontradas caso a caso, não cheguem a aniquilar nenhum dos outros valores que orientam o ordenamento jurídico, como a autonomia da vontade. - Não se deve admitir que a função social do contrato, princípio aberto que é, seja utilizada como pretexto para manter duas sociedades empresárias ligadas por vínculo contratual durante um longo e indefinido período. Na hipótese vertente a medida liminar foi deferida aos 18.08.2003, e, por isto, há mais de 5 anos as partes estão obrigadas a estarem contratadas.(...)"(REsp 972.436/BA, Rel. Ministra NANCY ANDRIGHI, 3. ${ }^{a}$ TURMA, julgado em 17/03/2009, DJe 12/06/2009) (Grifamos)

${ }^{322}$ RENTERÍA, Pablo. op. cit., p. 285. (Grifamos).
} 
existe, até porque os sujeitos mensuram as razões pelas quais os levaram a contratar e a vincularem-se.

Em outras palavras, enquanto nas contratações despersonalizadas a proteção é voltada precipuamente à garantia de que a oferta de um dos contratantes atenderá à legítima expectativa que aquela gerou nos aderentes ${ }^{323}$, nas contratações paritárias deve ser garantido às partes que a finalidade por elas perseguida em um determinado negócio venha a ser protegida, pois as categorias contratuais são escolhidas pelas partes a fim de que certas consequências jurídicas nelas previstas possa ser alcançadas. Em toda a contração existe um fim prático que é a razão de ser da contratação. E neste caso estamos a falar da causa dos contratos ${ }^{324}$. A causa permite, portanto, que se qualifique o negócio jurídico. Desta forma, ainda que o elemento causal, como requisito do contrato, não esteja expresso no ditado do Código Civil, ele lhe é inerente uma vez que "a causa é a função que o sistema jurídico reconhece a determinado tipo de ato jurídico, função que o situa no mundo jurídico, traçando-lhe e precisando-lhe a eficácia." ${ }^{325}$ Nesta perspectiva, sendo a causa elemento inderrogável do negócio, e considerando, por outro lado, que não pode existir negócio que, em abstrato, no seu esquema típico, não tenha efeitos, entende-se que todo e qualquer negócio tenha uma causa e que esta é, precisamente, a síntese dos seus efeitos jurídicos essenciais. Os efeitos jurídicos essenciais, em sua síntese, constituem a “mínima unidade de efeitos” que o negócio está juridicamente apto a produzir ${ }^{326}$.

Segundo entendemos, pois, a função social dos contratos prevista no artigo 421 do Código Civil está vinculada à idéia de causa do contratos. Como se sabe, o controvertido instituto da causa comporta a sua análise sob dois prismas diversos: o subjetivo e o objetivo.

Sob o aspecto subjetivo, a causa seria o motivo, as razões íntimas que levaram as partes à contratação: beneficiar um amigo, presentear a mulher, agraciar um filho etc. Sob

\footnotetext{
${ }^{323}$ De que é exemplo o artigo 30 da Lei n. ${ }^{\circ} 8.078 / 90$.

${ }^{324} \mathrm{Em}$ sentido análogo ao defendido nesta dissertação encontra-se a posição de NORONHA, Fernando: "Os termos aqui expostos são aqueles em que o interesse do credor, considerado nos limites da "função social do contrato", permite o controle do conteúdo deste. Entendido assim, ele desempenhará, na relação obrigacional, papel semelhante ao da causa dos sistemas jurídicos francês e italiano, e sobretudo deste, onde prevalece o entendimento de que a "causa" é a função econômico-social do contrato." (In NORONHA, Fernando. op. cit., v. 1, p. 35). (Grifamos)

${ }^{325}$ MORAES, Maria Celina Bodin de. A causa dos contratos. Revista Trimestral de Direito Civil, Rio de Janeiro, v. 21, p. 98, jan./mar 2005.

${ }^{326}$ Id. Ibid., p. 108.
} 
o aspecto objetivo, a causa seria a função sócio-econômica ${ }^{327}$ que as partes sempre buscam em uma determinada categoria contratual ${ }^{328}$; assim, a causa na compra e venda seria a transferência da propriedade mediante o pagamento do preço; a causa não locação de imóveis urbanos seria a cessão temporária do uso de determinado imóvel mediante uma remuneração denominada de aluguel. Assim posta a questão, a causa consistiria na síntese dos efeitos essenciais de cada contrato. Em princípio, se um sujeito pretende adquirir e se tornar o proprietário de determinado bem titularizado por outrem, deverá com este firmar um contrato de compra e venda; se pretender utilizar imóvel alheio por tempo certo e determinado, sendo-lhe conveniente pagar ao seu titular uma remuneração (rectius, mensal), deverá firmar contrato de locação etc., sendo certo que assim ocorrerá em todas as espécies contratuais. Como sustenta Humberto Theodoro Júnior ${ }^{329}$,

"O fim jurídico dentro da estrutura negocial é, nessa ordem de idéias, sua causa. Isto é: a transferência da propriedade é a causa da compra e venda, como a transferência da posse é a causa da locação, e como a realização da obra é a causa da empreitada. No plano do direito, cada contrato se justifica pelo efeito que lhe é próprio e que se individualiza na declaração de vontade. Mesmo nos negócios atípicos, a declaração de vontade ao criar a identidade da relação contratual indicará, in concreto, a base negocial, seu objeto e o efeito jurídico perseguido, definindo, dessa maneira, a respectiva causa.

A causa do negócio entrelaça-se com a economia do contrato, seus sujeitos, sua base estrutural, e tudo o que condiciona, como razão determinante, o efeito jurídico programado. Há, outrossim, efeitos que decorrem naturalmente do tipo jurídico e há aqueles que decorrem de cláusulas e condições acidentais inseridas pela vontade negocial dos contratantes, integrandom também, o objeto do contrato." (Grifamos)

Portanto, quando o legislador fixou no artigo 421 do Código Civil a idéia de função social do contrato, a bem dizer passou a tutelar - ainda que esta não tenha sido a sua intenção -a causa de todas as espécies contratuais, de modo a evitar que as finalidades

\footnotetext{
${ }^{327}$ Como anota AMARAL, Francisco: "Conforme opinião dominante na doutrina contemporânea, ela [a causa] tem uma função econômico-social, figurando como justificação da autonomia privada.”(...) exercendo "uma função de proteção à parte que acreditou na sua existência." (In AMARAL, Francisco. op. cit., p. 425); no mesmo sentido PONTES DE MIRANDA, Franciso Cavalcanti: "A causa é a função, que o sistema reconhece a determinado tipo de ato jurídico, função que o situa no mundo jurídico, traçando-lhe e precisando-lhe a eficácia. A causa fixa, na vida jurídica, o ato." PONTES DE MIRANDA, Francisco Cavalcanti. Tratado de direito privado. 3. ed. Rio de Janeiro: Borsoi, 1972. t. 3, § 262, p. 78).

${ }^{328}$ Conforme doutrina BIANCA, C. Massimo: "La causa è la ragione pratica del contratto, cioè l'interesse che l'operazione contratttuale è direttta a soddisfare.(...) La causa si distingue rispetto sll'oggetto del contratoo. L'oggetto indica il programma, ossia il contenuto dell' accordo delle parti, mentre la causa indica l'interesse che tale programma è volto a soddisfare.(...) La causa constituisce fondamento della rilevanza giuridica del contratto. (In BIANCA, Massimo C. op. cit., v. 3, p. 447-448).

${ }^{329}$ In THEODORO JÚNIOR, Humberto. Comentários ao novo Código Civil. Coord. Sálvio de Figueiredo Teixeira. Rio de Janeiro: Forense, 2003. v. 3, t. 2, p. 87-88. (Grifamos)
} 
essenciais buscadas pelas partes através da contratação pudessem ser desviadas ou defraudadas em detrimento da função sócio-econômica do negócio.

Posta a questão nestes termos, fácil será perceber que o contrato de compra e venda eventualmente firmado entre dois sujeitos deverá ser hábil a permitir que o comprador adquira a propriedade da coisa alienada e o vendedor receba o preço exigido como contraprestação; se, no entanto, da leitura dos termos deste contrato de compra e venda o intérprete extrair que a sua causa sofreu um desvio ilegal por parte do vendedor, por exemplo, de maneira que o comprador jamais se tornará titular da res alienada, mas apenas o seu usuário, nítido estará que o contrato não atenderá a sua função social, sua função jurídica (rectius, sócio-econômica), o fim prático que é inerente a todos os contratos da mesma espécie, da mesma categoria. Neste caso hipotético, as partes firmaram uma locação sob as vestes de uma compra e venda, de maneira que a função social do negócio sofreu um desvio insanável que redundará na sua nulidade, nos termos do artigo 2.035 do Código Civil.

E no contrato de fiança, qual seria, em essência, a sua função social? Qual seria o fim prático buscado pelas partes? Na fiança, a função por ela exercida na vida das pessoas que a contratam é a de servir de garantia do adimplemento do devedor principal, de modo a responsabilizá-lo em conjunto com o fiador nas hipóteses de incumprimento da prestação prometida ${ }^{330}$. Em sentido semelhante encontra-se a doutrina de Alejandro Borda $^{331}$ :

"La teoría de la causa, en la actualidad, responde al llamado
neocausalismo, el cual ha dado origen a tres tesis: la subjetiva, la objetiva
y la dualista. Para la tesis subjetiva la causa es el motivo determiante que
al declararse exteriorizarse se vuelve común, es decir, se ubica en el
ámbito de la pura voluntad. Para le tesis objetiva, la causa es la función
económica y social que el negocio juridico es idóneo para realizar por sí y
en todos los casos. La tesis dualista abarca ambos criterios. A esta
posición ha adherido antes de haora. Como consecuencia de lo expuesto hasta aquí, debe afirmarse que uno de los elementos esenciales del contrato de fianza es la causa. Y esta causa

\footnotetext{
${ }^{330}$ É por esta razão que LORENZETTI, Ricardo Luis afirma que as causas do contrato da fiança e da própria fiança são diferentes: "Existiendo una causa-fuente distinta que origina las obligaciones del deudor y del fiador, puede afirmarse que ambas están relacionadas por dos principios: accesoriedad y subsidiariedad, que examinaremos más adelante.” (In LORENZETTI, Ricardo Luis. Tratado de los contratos. Santa Fe: Rubinzal-Culzoni, 2000. t. 3, p. 487). Em outro ponto da sua obra o autor argentino afirma: "El contrato de fianza presenta los siguientes caracteres: - Accesorio: la garantía presupone la existencia de una obligación principal a la que accede, y en virtud de este carácter se contamina de la nulidad del contrato principal, o de su extinción, o de su cesibilidad (arts. 524 y 525, Cód. Civ.).” (In ob. cit., p. 487) (Grifamos)

${ }^{331}$ In BORDA, Alejandro. El contrato de fianza: límites de la responsabilidad del fiador. Buenos Aires: La Ley, 2009. p. 101.
} 
responde a dos aspectos diferenciables. Por un lado la dimensión objetiva, que a mi juicio está dada por la función económica que cumple la fianza facilitando el giro comercial, con un ingrediente social em muchos casos remarcable. Por otro lado, la faz subjetiva constituida por la liberalidad del fiador, quien se obriga por diversas razones, las que en su mayoría se fundam en lazos familiares o de amistad, sin desconocer otros motivos como son los que pueden perseguir las personas jurídicas. Pero, si el fiador probare que su obligacion carece de causa, o ella fuese ilícita, la fianza será nula."

Nesse contexto, entendemos que a função social do contrato prevista no artigo 421 do Código Civil está vinculada ao instituto da causa das obrigações, causa esta porém em sua feição objetiva que é sinônimo de função econômico-social do contrato.

E na fiança a verificação da sua causa ou da sua função-social se revela de extrema importância dada a sua natureza acessória: o contrato de garantia estará sempre vinculado à sorte do contrato garantido, princípio este extraído do artigo 824 do Código Civil, razão pela qual acessório não poderá se tornar mais oneroso do que o contrato principal, assim como do fiador não poderá ser exigido o cumprimento da prestação principal.

Outrossim, a análise da função social do contrato sob o prisma da causa permite visualizá-lo sob dois prismas que se completam: o da eficácia entre as partes (tutela interna do crédito) e o da eficácia perante terceiros (tutela externa do crédito).

Com relação à tutela interna do crédito, todas as vezes que a causa da fiança vier a ser alterada ou modificada pelas partes que figurarem no contrato garantido e isto vier a agravar abusivamente a posição do fiador (v.g., caso do locador que deixa de postular o despejo do imóvel locado visando aumentar o seu crédito para exigi-lo apenas do fiador), a função social do contrato incidirá para salvaguardar a posição jurídica do garante, quer liberando-o da garantia por força do abuso do credor quer permitindo ao garante tomar as medidas que o credor deixou de tomar contra o devedor principal.

Já com relação à tutela externa do crédito, a função social do contrato incide para salvaguardar a posição jurídica do fiador contra atos ilícitos praticados por terceiros alheios ao vínculo da garantia, porque "os terceiros não podem comportar-se como se o contrato [de fiança] não existisse" ${ }^{332}$, de modo que há uma flexibilização do princípio da relatividade dos efeitos contratuais para que os terceiros que contribuíram para o

\footnotetext{
${ }^{332}$ AZEVEDO, Antonio Junqueira de. Os princípios do atual direito contratual e a desregulamentação do mercado. Direito de exclusividade nas relações contratuais de fornecimento. Função social do contrato e responsabilidade aquiliana do terceiro que contribuiu para o inadimplemento contratual. In: AZEVEDO, Antônio Junqueira de. Estudos e pareceres de direito privado, cit., p. 142.
} 
inadimplemento de um contrato do qual não participaram possam ser responsabilizados (v.g., caso do terceiro que, conhecedor de uma fiança prestada por um garante que titulariza apenas um imóvel, convence-o a vendê-lo para si por um preço de ocasião, esvaziando a garantia fidejussória) ${ }^{333,334}$.

Em remate, acrescentamos que os princípios da boa-fé objetiva e da função social dos contratos não são espada e escudo de proteção de inadimplentes, mas sim instrumentos de defesa dos comportamentos leais, probos e honestos de todos os figurantes de negócios, razão por que a sua estatura não permite que sejam transformados em meros fundamentos ocos e estéreis de justificação de incumprimentos contratuais.

Não obstante, analisado o contrato de fiança sob o aspecto da sua função de garantir o adimplemento do devedor e outorgar segurança ao credor é que entendemos que a fiança nula poderá ser convertida em garantia atípica ex artigo 170 do Código Civil, o que abordaremos no item 4.10.3 desta dissertação.

\subsection{A hermenêutica contratual}

A interpretação tem por fito fixar o sentido, alcance e efeitos do negócio jurídico. O intérprete deve pautar-se em critérios emanados do sistema jurídico, evitando o senso comum ou razões de ordem meramente empírica. "Interpretar ato jurídico é revelar quais os elementos do suporte fático que entraram no mundo jurídico e quais os efeitos que, em virtude disso, produz. A regra fundamental de interpretação do negócio jurídico volitivo está exposta no art. 112 do Código Civil, relativamente às declarações de vontade: prevalece a intenção nelas consubstanciada, e não o sentido literal da linguagem. $O$ que

\footnotetext{
${ }^{333}$ Cfe. doutrina MIRAGEM, Bruno: "Já a função social dos contratos tem sido reconhecida entre nós, como fonte para o reconhecimento de novos efeitos aos contratos. E naquilo que se distingue da boa-fé, vai se revelar sobretudo pela geração de efeitos a outros sujeitos que não os contratantes (eficácia perante terceiros), tese que remonta ao direito francês, e que no Brasil teve a sua divulgação a partir de um conhecido parecer do professor Antônio Junqueira de Azevedo, cujo resultado determina a flexibilização do clássico princípio da relatividade dos efeitos dos contratos." (MIRAGEM, Bruno. Diretrizes interpretativas da função social do contrato. Revista de Direito do Consumidor, São Paulo, v. 56, p. 30, 2005).

${ }^{334}$ Em situação análoga: "EMBARGOS DE TERCEIRO - Fraude à execução - Reconhecimento - Doação de pai (fiador executado) para filho - Reconhecimento da fraude à execução, ainda que a citação dos executados para a ação de execução tenha sido posterior à doação ou mesmo antes de ajuizada a execução Teleologia do inciso II do artigo 593 do Código de Processo Civil - Sendo a doação feita pelo pai fiador em favor do filho, não pode este donatário alegar desconhecimento da situação de insolvência de seu pai, independentemente de haver ou não execução já ajuizada - Ajuizamento de ação específica Desnecessidade - Recurso não provido.” (TJSP - Apelação Cível n. 992.05.135797-5 - Campinas - 35 Câmara de Direito Privado - Relator: Manoel Justino Bezerra Filho - 05.10.09 - V.U. - Voto n. 7996).
} 
interessa é a intenção exteriorizada, e não o pensamento íntimo do declarante. Essa regra é apenas aplicável ao negócio jurídico volitivo, como expressão da autonomia privada; não pode ser aproveitada nos negócios jurídicos de tráfico jurídico massificado e nas condições gerais dos contratos, em virtude da abstração da vontade ${ }^{335}$.

O contrato de fiança é classificado pela doutrina civilista como gratuito, uma vez que na grande maioria das situações apenas o fiador sacrifica o seu patrimônio em favor do credor e em benefício do devedor-afiançado.Como já escrevemos em outro tópico, o fiador titulariza uma responsabilidade pela dívida (haftung), sem no entanto dela ser devedor (schuld).

Diante desta situação o legislador brasileiro acolheu nos artigos 114 e 819, do Código Civil, uma diretriz normativa de interpretação na fiança: a de que os negócios fidejussórios, por serem em regra benéficos (gratuitos) não admitem interpretação extensiva. Em outras palavras, é vedado ao intérprete proceder a uma exegese do contrato de modo a nele incluir obrigações que não foram expressamente previstas pelas partes ${ }^{336}$.

É a hipótese mencionada por Lauro Laertes de Oliveira ${ }^{337}$ de fiança aos aluguéis e fiança à locação:

\begin{abstract}
"Na primeira hipótese, se constar do texto do contrato de fiança que o fiador se responsabiliza pela locação, há de se compreender tudo aquilo que engloba a locação, como aluguel, encargos legais e contratuais, danos no imóvel, responsabilidade por incêndio (CC, art. 1.208) e multa contratual.

Na segunda alternativa, se consta da fiança que o fiador se responsabiliza pelos aluguéis do imóvel tal, locado a Fulano, a garantia cinge-se somente aos aluguéis. Nem os encargos legais ou contratuais incidirão na responsabilidade do fiador."
\end{abstract}

Dessa forma, eventuais obrigações que deveriam ter sido atribuídas ao fiador, mas que não o foram não poderão ser incluídas no ajuste. Portanto, diante da hipótese descrita ocorrerá a inexistência de responsabilidade do fiador, inexistência esta que até mesmo poderá vir a ser declarada por sentença, nos termos do artigo $4 .^{\circ}$, I, do Código de Processo Civil.

\footnotetext{
${ }^{335}$ Cfe. LÔBO, Paulo Luiz Netto. Direito civil: parte geral, cit., p. 252-253.

336“Para prevalecerem devem ser expressas as disposições de que resulte fiança ou garantia, renúncia, cessão, transação, e interpretam-se restritivamente como os contratos benéficos." (MAXIMILIANO, Carlos. Hermenêutica e aplicação do direito. 15. ed. Rio de Janeiro: Forense, 1995. p. 350). (Grifamos)

${ }^{337}$ In OLIVEIRA, Lauro Laertes de. op. cit., p. 93.
} 
O intérprete há que partir da declaração exteriorizada pelo fiador, a fim de apreender se a sua intenção foi a de limitar ou ampliar a sua responsabilidade em favor do afiançado; deve se partir do texto do negócio, como apoio no contexto em que fora firmada a garantia, a fim de que seja correta e adequadamente apreendida a vontade fidejussória ${ }^{338}$.

Assim, se o fiador se responsabilizou a garantir o adimplemento do devedor até certa data, vedado se encontra estender a sua responsabilidade além do prazo fixado em contrato, sendo vedada a extensão da responsabilidade do garante pela via da interpretação da sua vontade pressuposta; da mesma forma, se o fiador se responsabilizou apenas pelo aluguéis de um prédio, não poderá ser responsabilizado pelos danos a ele causados pelo inquilino-devedor.

A diretriz de interpretação restritiva do contrato de fiança representa verdadeira salvaguarda outorgada pelo legislador ao garante, a fim de impedir que venha a ser surpreendido com a sua responsabilização por débitos que não foram incluídos de forma expressa na garantia, dada a principal finalidade de beneficiar o devedor ${ }^{339}$ Assim, se o fiador prometeu garantir o credor até determinado valor, não poderá responder pelo excesso; da mesma forma se a sua promessa se dirigiu a determinado período de tempo ou até mesmo se não se responsabilizou expressamente pelas eventuais perdas e danos causadas ao credor pelo afiançado, responsabilização esta que deverá ser expressamente pactuada por não fazer parte das obrigações que ordinariamente incidem sobre o garante . $^{340}$.

\footnotetext{
338، O dado cognoscível é sempre a declaração, por si só ou através dela na pesquisa da intenção das partes, desde que exteriorizada. O negócio jurídico é texto e principalmente contexto. A vontade, o querido, há de estar contida na declaração. O que não foi declarado não entra no mundo jurídico. A intenção que não se declarou não pode servir à interpretação.(...) Ou seja, o objeto da interpretação não é a vontade interna, quando permaneça oculta, mas a declaração ou comportamento enquadrados no marco das circunstâncias que lhes conferem valor e significado. Não é o fato da vida interior, mas a declaração como ato que comporta sentido." (LÔBO, Paulo Luiz Netto. Direito civil: parte geral, cit., p. 253).

${ }^{339}$ Segundo anota LÔBO, Paulo: "Os negócios jurídicos benéficos recebem regra de interpretação espcífica, dadas suas peculiaridades. Nessas hipóteses, a interpretação é sempre restritiva, de modo a não agravar a situação de quem os praticou em benefício de terceiros. É o exemplo do contrato de fiança, pelo qual uma pessoa garante ao credor satisfazer a obrigação do devedor se este não a cumprir; a interpretação não pode ser extensiva em desfavor do fiador." (In LÔBO, Paulo Luiz Netto. Direito civil: parte geral, cit., p. 255).

${ }^{340}$ Sob a égide do Código Civil de 1916 o Ministro João Luiz Alves apontava em doutrina que mantém-se atual: "A fiança não se presume. Deve ser provada por escrito, do qual constará a sua sua extenção e a sua modalidade. Não pode ser estendida por interpretação: se é prestada, pura e simplesmente, considera-se ilimitada e abrange tôda a dívida e seus acessórios (art. 1.4860; se condicional ou a têrmo, só pode ser entendido de acôrdo com a condição ou têrmo; se refere-se a uma pessoa, não se estende a outra; se a uma dívida, não é garantia de outra, etc.

A regra de interpretação, que deve ser sempre no sentido mais favorável ao fiador, é que a fiança non extenditur de re ad rem, de persona ad personam, de tempore ad tempus. (Huc, Comm. Cod. Civ., vol. XII, n. ${ }^{\circ} 182$ ).

Assim, a fiança pelo aluguel não se estende à responsabilidade pelos danos da coisa locada, a do capital não compreende os juros; a fiança de uma dívida não se estende à sua novação; a fiança para um certo número de meses de aluguel não se estende a outros meses devidos; etc." (In ALVES, João Luiz. op. cit., v. 5, p. $145)$.
} 
Nesse sentir doutrinava Luiz da Cunha Gonçalves ${ }^{341}$ acerca do direito português, porém igualmente aplicável ao direito brasileiro:

“- Em qualquer dos casos, a fiança deve ser claramente convencionada. Não há para isso fórmulas sacramentais; mas, devem evitar-se frases equívocas. $\mathrm{O}$ legislador sòmente a respeito da abonação diz, no art. 828, que ela deve ser dada em têrmos claros, expressos e positivos, sendo certo que também a fiança deve ser assim estipulada, como aliás todos os contratos. "Ainda que a fiança se possa fazer por uma carta missiva, ou mesmo verbalmente, - diz Pothier, - é preciso, contudo, ter grande atenção em não tomar por fiança o que diz ou escreve uma pessoa, se não mostrar uma intenção bem clara de afiançar”. Assim, não é fiador quem escreve que uma pessoa é honrada ou solvável.; nem quem acompanha um amigo a um estabelecimento comercial a fim de o apresentar ao respectivo proprietário; nem quem se limita a solicitar uma abertura de crédito a favor de terceiro, mas sem assumir a responsabilidade pelos respectivos pagamentos. Com idêntica razão, quem pagou uma parte da dívida de outrem, por exemplo, dum filho, dum amigo, dum protegido, duma amante, não se obriga a pagar o resto.

Escusado parece dizer que sòmente a obrigação do fiador ou abonador deve ser contraída em têrmos positivos. O consentimento do credor pode ser tácito. Por exemplo, quando alguém escreve a um comerciante: "queira vender-lhe os gêneros de que êle necessite; e eu respondo por êle", o credor que faz as vendas, ipso facto, concorda com esta fiança. Além disto, no art. 828, o legislador quis também frisar que é necessário ficar bem esclarecido que o abonador quis ser fiador do fiador e não segundo fiador do devedor."

É no mesmo sentido a doutrina de Francesco Galgano ${ }^{342}$, também integralmente aplicável ao direito brasileiro:

"La volontà di assumere una obbligazioni fideiussoria deve essere espressa (art. 1937). Non basta, cioè, la semplice presentazione del debitore al creditore, accompagnata da giudizi o da previsioni sulla solvibilità del primo; né basta l'invito o la calda raccomandazione a fargli credito. Comportamenti di questo genere, tuttavia, ove il debitore non paghi, possono essere fonte di responsabilità, se non contrattuale (a titolo de fideiussone), extracontrattuale (per fato illecito [19.1.])."

Entretanto, advertimos que a imposição de uma interpretação restritiva da fiança não significa a irresponsabilidade do fiador pelos acessórios da obrigação, quer de natureza material quer de natureza processual ${ }^{343}$. Inexistindo ressalva expressa que limite a fiança, há que se entender que o fiador prestou a garantia sobre toda a dívida e assumiu a responsabilidade pelo pagamento de multas, juros, correção monetária e honorários

\footnotetext{
${ }^{341}$ In GONÇALVES, Luiz da Cunha. op. cit., v. 5, t. 1, p. 205.

${ }^{342}$ In GALGANO, Francesco. Diritto privato. 6. ed. Pádova: Cedam, 1990. p. 377.

${ }^{343}$ Cfe. GODOY, Claudio Luiz Bueno de. op. cit., p. 809.
} 
advocatícios, nos termos dos artigos 389 e 408 do Código Civil, na medida em que representam mera consequência, no plano da eficácia, do descumprimento contratual do afiançado $^{344}$, a teor do artigo 822, do Código Civil ${ }^{345}$. E assim o é porque todo e qualquer descumprimento contratual, salvo a hipótese de multa (rectius, cláusula penal) que deverá ser expressamente pactuada, exporá o devedor às consequências previstas no artigo 389 do Código Civil; logo, se o fiador prometeu que o afiançado adimpliria a obrigação principal e este veio a falhar, significa dizer que o garante também não cumpriu a prestação prometida $^{346}$, razão pela qual a sua responsabilidade pelos acessórios da dívida se apresenta de rigor.

Em remate, entendemos que a diretriz normativa que impõe a interpretação restritiva da fiança terá plena aplicação ante a existência de uma lacuna contratual que impeça ao intérprete apreender de plano qual teria sido a real intenção dos contratantes no momento da contratação da garantia; se o garante prestou fiança até a entrega das chaves, este será o limite da responsabilização do fiador, sem que incida nesta hipótese de clausulação expressa o princípio da interpretação restritiva.

\subsection{A nulidade da fiança}

As hipóteses de nulidade da fiança são de extrema importância prático-jurídica, porquanto o reconhecimento da invalidade da garantia implicará na ausência de responsabilização do garante e, por conseguinte, não permitira que os débitos porventura gerados pelo devedor sejam exigidos do fiador. Afinal, a nulidade da garantia impede a exigibilidade dos débitos.

E no direito brasileiro, atualmente três são as hipóteses de nulidade contempladas pelo legislador acerca do contrato de fiança:

a) nulidade da garantia em decorrência da nulidade do contrato garantido, hipótese esta já estudada;

b) nulidade da garantia por defeito de forma, hipótese esta a ser estudada no item 4.10.3;

\footnotetext{
${ }^{344}$ No mesmo sentido: GODOY, Claudio Luiz Bueno de et al. op. cit., p. 811.

345 “Art. 822. Não sendo limitada, a fiança compreenderá todos os acessórios da dívida principal, inclusive as despesas judiciais, desde a citação do fiador."

${ }^{346} \mathrm{O}$ fato do adimplemento.
} 
c) nulidade decorrente da ausência de outorga uxória, nos casos em que a fiança foi apenas prestada por um dos cônjuges ou um dos companheiros, hipótese esta que acabou sendo consolidada no verbete da Súmula 332 do STJ e que será abordada no tópico seguinte (4.10.1).

\subsubsection{A Súmula 332 do STJ}

A Súmula 332 do STJ foi publicada em 13/03/2008 e contém a seguinte redação, verbis:

"A fiança prestada sem autorização de um dos cônjuges implica a ineficácia total da garantia."

Por primeiro, apontamos que a redação da súmula não foi das mais felizes, pois a utilização do termo ineficácia dá margem a dúvidas, mormente porque no direito brasileiro ineficácia não é sinônimo de nulidade, bem como há hipótese de nulidade que gera efeitos (v.g. casamento putativo); assim, a fiança poderá ser nula e ineficaz (regra geral), nula e eficaz (se aceita for a hipótese de conversão do negócio jurídico fidejussório), como também poderá ser ineficaz sem ser nula (submetida a termo ou condição).

Por segundo, dizemos que o termo cônjuge utilizado na redação da súmula, que denota uma situação jurídica decorrente do casamento, há que ser interpretado de forma a abranger tanto a situação dos companheiros, quer decorra de união estável quer decorra de união homoafetiva, em face do princípio da isonomia previsto no art. 5. $^{\circ}$, I, da Constituição Federal, porque estas situações são aptas a gerar uma família, e como tal devem receber a mesma proteção jurídica.

Por terceiro, o fundamento legal que deu origem à Súmula 332 do STJ se encontra no artigo 1.647, III, do Código Civil de 2002, segundo o qual:

“Art. 1.647. Ressalvado o disposto no art. 1.648, nenhum dos cônjuges pode, sem autorização do outro, exceto no regime da separação absoluta:

(...)

III - prestar fiança ou aval;" 
E o artigo 1.649, do Código Civil, enunciou que a conseqüência da inexistência de outorga, consentimento ou suprimento “(...) tornará anulável o ato praticado, podendo o outro cônjuge pleitear-lhe a anulação, até dois anos depois de terminada a sociedade conjugal.” (Grifamos)

Neste ponto, o Código Civil de 2002 alterou a diretriz normativa que era adotada no Código Civil de 1916, pois sob a égide da codificação revogada o artigo 252 impunha a nulidade da fiança prestada pelo marido sem o consentimento da mulher ${ }^{347,348}$. Portanto, o

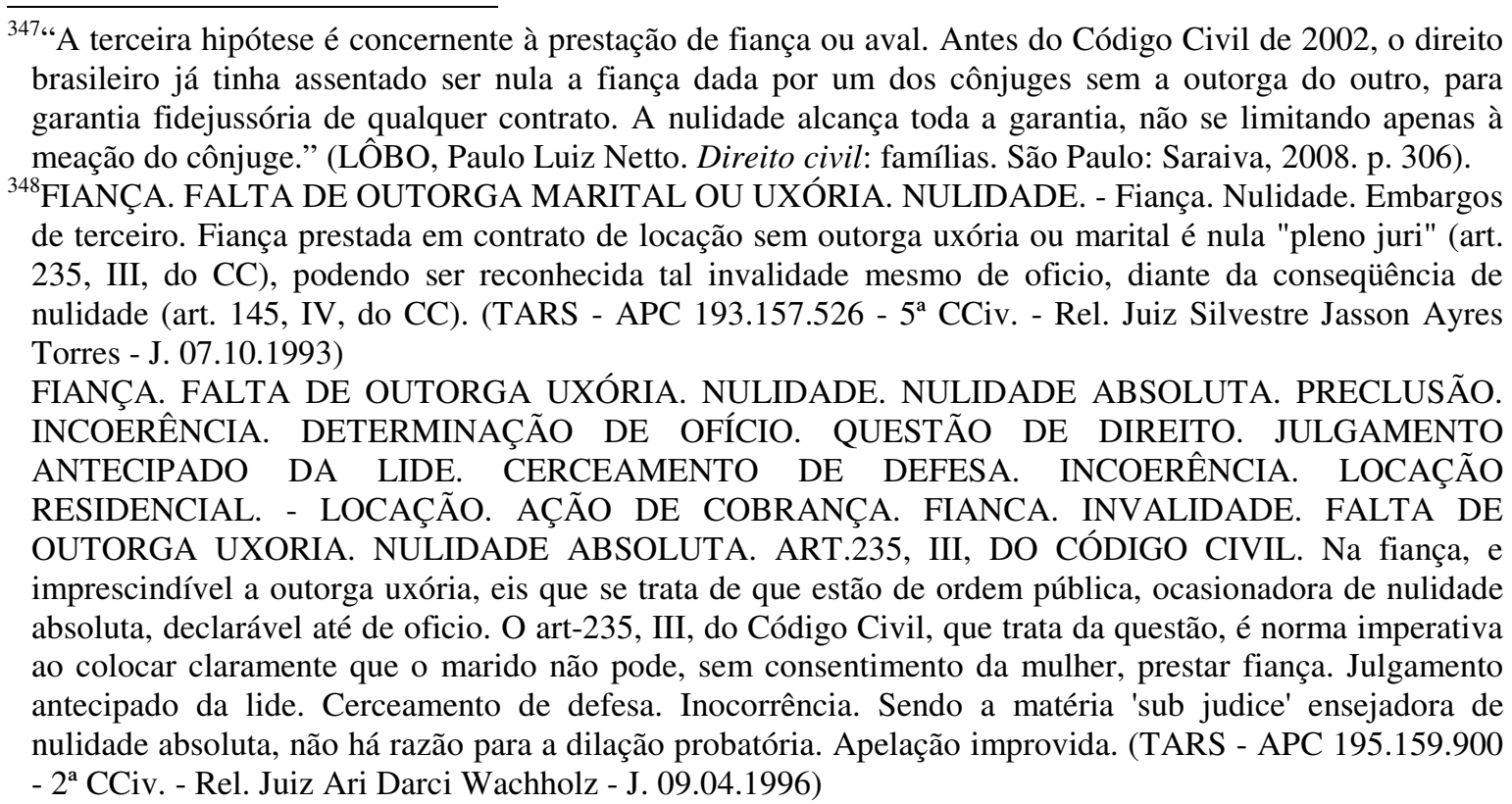

FIANÇA. INTERPRETAÇÃO EXTENSIVA. DESCABIMENTO. 2. HERMENEUTICA. INTERPRETAÇÃO. 3. FIANÇA. FALTA DE OUTORGA UXÓRIA. NULIDADE. - Execução. Fiança. Não há aval fora de título cambiário. A Fiança não admite INTERPRETAÇÃO extensiva. Hermenêutica. Princípio da igualdade. Igualdade não é tratar igualmente os desiguais, mas desigualmente os desiguais na medida em que se desigualam. Logo, pode-se exigir mais de quem pode mais e menos de quem pode menos. Elaboração de contratos: cautelas. Pode-se exigir de entidades financeiras que, diante de tormentosa, atinga e, ainda, não solucionada questão jurídica - Como a validade da Fiança sem outorga uxória - Acautelem-se na elaboração dos contratos, de forma a não macular a certeza do título executivo. Fiança: falta de outorga uxória. A pior solução para tema não tormentoso e dogmática. Considerando-se que todas as posições trazem excelentes razões jurídicas, as peculiaridades do caso concreto dirão se a Fiança e válida, válida em parte ou nula. Precedente jurisprudencial. (TARS - APC 194.252.359 - 4ª CCiv. - Rel. Juiz Rui Portanova - J. 09.02.1995)

FIANÇA. LOCAÇÃO. FALTA DE OUTORGA UXÓRIA. INEFICÁCIA. ANULABILIDADE. GERA EFEITOS ATÉ ANULAÇÃO. LEGITIMAÇÃO ATIVA. MULHER OU HERDEIROS. - Ação declaratória de nulidade. Fiança em contrato de locação, ausente outorga uxória. A falta de consentimento uxório não constitui nulidade de pleno direito, implicando apenas em ineficácia relativa em relação ao cônjuge não anuente. Recurso provido. (TARS - APC 195.197.868 - $8^{\text {a }}$ CCiv. - Rel. Juiz Luiz Ari Azambuja Ramos - J. 27.02.1996)

FIANÇA. RESPONSABILIDADE SOLIDÁRIA. FALTA DE OUTORGA UXÓRIA. ANULABILIDADE. LEGITIMAÇÃO ATIVA. - Fianca. Solidariedade. Falta de outorga uxória. Anulabilidade. Da solidariedade entre os co-fiadores decorre a responsabilidade pela dívida comum, mas autoriza o credor exigir a prestação de um ou de todos, no todo ou em parte e lhe faculta a busca do valor pro-rata entre os co-fiadores, sem ofender o disposto no art. 1.031, par. 3, do Código Civil. A fianca prestada pelo marido sem outorga uxória constitui ato anulável e não nulo, já que somente a mulher e seus herdeiros tem legitimidade para invalida-la e, no caso, não se trata de demanda em que prevalece norma de proteção da família, onde haveria interesse público, mas disputa de interesse patrimonial, eminentemente 
que era nulo passou a ser anulável, situação esta que modificou totalmente o panorama legislativo até então vigente ${ }^{349}$. Nesta hipótese, à luz dos artigos 235, III $^{350}$ e $263, \mathrm{X}^{351}$, do Código Civil de 1916, a nulidade da fiança deveria ser concedida, “a fim de que não fiquem responsáveis pela fiança, não só os bens dos casal, inclusive a meação do marido, como também os bens próprios dêste". Nasce ao credor o direito regressivo contra o marido ou seus herdeiros, como dívida do marido incomunicável. Por isso, enquanto subsiste a comunhão de bens, não pode ser executada a meação do marido. "352

A nulidade da fiança, que era absoluta no regime do Código Civil de 1916, de fato impunha por conseqüência a ineficácia da garantia, porque do absolutamente nulo, em regra não podiam e não podem surtir efeitos; do contrário, a anulabilidade da fiança prestada sem a outorga uxória prevista no Código Civil é válida e eficaz se e enquanto não for reconhecida e decretada por sentença, nos termos do artigo 177 do Código Civil ${ }^{353}$.

Por primeiro, a fim de que possamos entender a Súmula 332 do STJ, iremos apontar qual era a posição da doutrina à luz do Código Civil de 1916: a nulidade prevista no artigo 252 era relativa (anulabilidade) ou absoluta?

privado. Apelo improvido, sem discrepância. (TARS - APC 194.207.890 - 2a CCiv. - Rel. Juiz João Pedro Freire - J. 02.03.1995)

FIANÇA - OUTORGA UXÓRIA - AUSÊNCIA - NULIDADE DA GARANTIA - APLICAÇÃO DO ARTIGO 235, III DO CÓDIGO CIVIL - A fiança dada pelo marido sem a anuência da mulher é absolutamente nula (e não simplesmente anulável), por infração a preceito de natureza cogente (ou seja, de observância obrigatória ou imperativa) contido no artigo 235, III, do Código Civil, c/c o seu artigo 145, IV. ( $2^{\circ}$ TACivSP - Ap. c/ Rev. 454.332 - $3^{\text {a }}$ C. - Rel. Juiz Milton Sanseverino- J. 21.05.96)

FIANÇA. FALTA DE OUTORGA UXÓRIA. NULIDADE. - Fiança Civil e Comercial - É irrelevante a distinção para anular a fiança concedida pelo marido sem o expresso consentimento da mulher. Ineficácia total da fiança anulada pela mulher. Embargos declaratórios acolhidos. Fiança e aval - Se o acórdão expressa a concomitância das garantias, uma em contrato e a outra em cártulas, e evidente que explicitou que a execução se funda em dois títulos. Alegado equivoco sobre a Sucumbência não autoriza embargos declaratórios, principalmente quando engano não houve. Embargos declaratórios rejeitados. (TARS - EMD 25.593 - $3^{a}$ CCiv. - Rel. Juiz Ernani Graeff - J. 07.10.1981)

${ }^{349}$ Segundo o escólio de Pontes de Miranda, a falta de outorga marital acarretaria apenas a anulabilidade do ato praticado por força do artigo 252 do Código Civil de 1916: "A falta de assentimento direto ou suprimental, por isso que deixa a mulher casada sem o adminículo da vontade do marido, invalida o ato que ela praticar (Código Civil, art. 252). Não se trata de nulidade, nem de ato inexistente, mas de anulabilidade, cabendo sanar-se pela ratificação. Não pode ser invocada a invalidade senão por aquêle em cujo favor foi estabelecida, e dentro de certo prazo." (In PONTES DE MIRANDA, Francisco Cavalcanti. Tratado de direito privado. 3. ed. reimpr. Rio de Janeiro: Borsoi, 1971.§ 865, 1. p. 201)

${ }^{350}$ Código Civil de 1916: "Art. 235. O marido não pode, sem consentimento da mulher, qualquer que seja o regime de bens: (...) III - prestar fiança (arts. 178, § 9, I, b, e 263, X);”

${ }^{351}$ Código Civil de 1916: “Art. 263. São excluídos da comunhão: (...)X - a fiança prestada pelo marido sem outorga da mulher (arts. 178, $\S 9^{\circ}$, I, b, e 235, III); ”

${ }^{352}$ PONTES DE MIRANDA, Francisco Cavalcanti. op. cit., 1971, § 855, 18, p. 155-156.) (Grifamos)

${ }^{353}$ Código Civil de 2002: “Art. 177. A anulabilidade não tem efeito antes de julgada por sentença, nem se pronuncia de ofício; só os interessados a podem alegar, e aproveita exclusivamente aos que a alegarem, salvo o caso de solidariedade ou indivisibilidade." 
Segundo aponta Milton Paulo de Carvalho Filho ${ }^{354}$,

"O Superior Tribunal de Justiça editou recentemente a Súmula n. 332 com o seguinte teor: "A fiança prestada sem a autorização de um dos cônjuges implica a ineficácia total da garantia". O entendimento inserto nos acórdãos - de casos anteriores à vigência do atual Código Civil que deram origem a Súmula, na verdade, define e realça a impossibilidade da subsistência de parte da fiança (invalidade total da garantia) quando conferida se a autorização de um dos cônjuges. Daí porque talvez não se atentou para a utilização do termo correto, pois, sob a égide da lei anterior implica nulidade, enquanto para o Código Civil vigente, a ausência de autorização para a concessão da garantia importa anulabilidade, não se justificando o direcionamento para o campo da ineficácia." (Grifamos)

Sob a égide do Código Civil de 1916 a fiança prestada pelo marido sem a outorga uxória era nula.

Assim, concluímos que a Súmula 332 do STJ se ostenta atualmente contra legem, não se justificando a manutenção do regime da nulidade absoluta (consoante o Código Civil de 1916) em detrimento do regime da anulabilidade (de acordo com o Código Civil de 2002).

E em matéria de garantia contratual a confusão ${ }^{355}$ gerada pelo equivocado posicionamento do Superior Tribunal de Justiça contribuiu ainda mais para a insegurança

\footnotetext{
${ }^{354}$ In CARVALHO FILHO, Milton Paulo de. Código Civil comentado: doutrina e jurisprudência. Coord. Cezar Peluso. 3. ed. rev. e atual. Barueri: Manole, 2009. p. 1787.

355“O ano de 2005 foi sem dúvida um ano repleto de decisões judiciais interessantes, pois o Código Civil começa a receber a interpretação jurisprudencial e, portanto, tudo o que a doutrina escreveu começa a ser confirmado ou desmentido pelos Tribunais.

Num ano como este, poderíamos escrever em nossas colunas de novembro e dezembro sobre decisões inovadoras a respeito do Código Civil. Entretanto, as decisões serão objeto de artigos no início de 2006.

A reflexão que pretendemos fazer concerne o instituto da velha FIANÇA, mormente quando prestada como garantia em contrato de locação de imóvel urbano (L.8245/91).

$\mathrm{O}$ instituto da fiança vem sofrendo sistematicamente ataques por parte dos Tribunais, notadamente o Superior Tribunal de Justiça, motivo de preocupação para os advogados e locadores.

A questão que não quer calar é a seguinte: a fiança locatícia sobreviverá ao novo Código Civil e a seus princípios, bem como aos princípios decorrentes do Direito Civil Constitucional? É exatamente esta nossa reflexão no presente artigo.

Já de início, observamos que a fiança é, em regra, um contrato gratuito pelo qual o fiador nada recebe para garantir o pagamento de dívida alheia. A dívida não lhe trará qualquer benefício, apesar o ônus de garantir eventual inadimplemento. Em razão de seu caráter gratuito, a lei determina que a interpretação da fiança dar-se-á restritivamente, e jamais de maneira a ampliar os deveres do fiador (CC, art. 819).

Sempre nos perguntamos (e também verbalizo esta inquietude com os nossos alunos) os motivos que levam determinada pessoa a concordar em ser fiador. Nunca me explicaram o porquê. Só podemos acreditar que se trata realmente de um favor que geralmente é feito entre pessoas de uma mesma família e decorre exclusivamente da CONFIANÇA. Da certeza de que o devedor honrará o compromisso assumido.

Em razão disto, quando do inadimplemento do devedor o fiador recebe com surpresa a notícia de que ele, geralmente pessoa honrada e cumpridora de seus deveres, também está devendo quantia vultosa.

$\mathrm{Na}$ fiança locatícia os fatos narrados são corriqueiros e se multiplicam aos milhares.

Tribunais, sensíveis à situação desoladora do fiador, já se posicionavam, antes mesmo da vigência do Código Civil de 2002, de maneira claramente favorável à redução desta responsabilidade (Haftung sem Schuld) dos fiadores de imóveis urbanos.
} 
De início, já está pacificado o entendimento pelo qual o fiador apenas responde pelas dívidas do inquilino que surgirem no prazo de duração do contrato de locação. Em caso de prorrogação do contrato, o fiador está exonerado de qualquer responsabilidade, ainda que haja cláusula contratual prevendo a responsabilidade até a efetiva entrega de chaves:

- Na fiança, o garante só pode ser responsabilizado pelos valores previstos no contrato a que se vinculou, sendo irrelevante, na hipótese, para se delimitar a duração da garantia, cláusula contratual prevendo a obrigação do fiador até a entrega das chaves (Precedentes desta Corte) (REsp 697470 / SP ; RECURSO ESPECIAL 2004/0158470-1)

- O contrato de fiança deve ser interpretado restritivamente, pelo que é inadmissível a responsabilização do fiador por obrigações locativas resultantes de prorrogação do contrato de locação sem a anuência daquele, sendo irrelevante a existência de cláusula estendendo a obrigação fidejussória até a entrega das chaves (REsp 754329 / SP ; RECURSO ESPECIAL 2005/0088101-0)

Por outro lado, em ocorrendo ausência de vênia conjugal por parte do cônjuge do fiador, o Superior Tribunal de Justiça corretamente entende que a fiança é NULA como um todo e não há que se falar apenas em preservação de fiação do cônjuge que não anuiu:

- A ausência de consentimento da esposa em fiança prestada pelo marido invalida o ato por inteiro. Nula a garantia, portanto. Certo, ainda, que não se pode limitar o efeito dessa nulidade apenas à meação da mulher (REsp 631262 / MG ; RECURSO ESPECIAL 2004/0023956-0)

- O entendimento deste Superior Tribunal de Justiça é pacífico no sentido que a ausência da outorga uxória nulifica integralmente o pacto de fiança. O contrato de fiança não admite interpretação extensiva, consoante determinava o art. 1483 do Código Civil de 1916. Com base nessa premissa, inclinou-se a jurisprudência no sentido de que o fiador não responde pelos aditamentos ao contrato original a que não tenha anuído (REsp 619814 / RJ ; RECURSO ESPECIAL 2003/0238648-9)

- O Superior Tribunal de Justiça possui jurisprudência uniforme no sentido de que é nula a fiança prestada sem a necessária outorga uxória, não havendo como se considerá-la parcialmente eficaz para constranger a meação do cônjuge varão (AgRg no Ag 595895/SP ; AGRAVO REGIMENTAL NO AGRAVO DE INSTRUMENTO 2004/0063468-0).

Mas o golpe fatal contra a fiança locatícia estava por vir. Quando menos se esperava, ocorreu a promulgação, em fevereiro de 2000 , da emenda Constitucional $n^{\circ} 26$ pela qual o direito à moradia passou a ser considerada direito social do cidadão, alterando-se o art. $6^{\circ}$ da Carta Magna.

Com a emenda, julgados surgiram no sentido de que a norma em questão era meramente programática e não alterava em nada a possibilidade de penhora do bem de família do fiador, concluindo-se que "a inclusão da moradia entre esses direitos não implica em qualquer alteração à legislação infra-constitucional que regula a propriedade de bens imóveis" (2 TAC, Ap. s/ Rev. 801.745-00/7 - $6^{\text {a }}$ Câm. - Rel. Juiz SOUZA MOREIRA - J. 17.3.2004)

Entretanto, mesmo com a forte resistência dos locadores, não foi esta a interpretação que prevaleceu. Recentemente os Tribunais Superiores começaram a se manifestar com relação à impossibilidade de o fiador ter os benefícios decorrentes da impenhorabilidade do bem de família, nos termos da Lei 8.009/90. Em decisão monocrática pioneira, o Ministro Carlos Velloso considerou não recepcionado pelo sistema o artigo $3^{\circ}$, inciso VII da mencionada lei, a partir da vigência da Emenda 26, e, portanto, concluiu pela IMPENHORABILIDADE DO BEM DE FAMÍLIA DO FIADOR EM FIANÇA LOCATÍCIA (RE 352940SP e RE 349.370SP publicados em 1305/2005).

Meses depois, também o Superior Tribunal de Justiça acolheu a tese da impenhorabilidade do bem de família:

- Com respaldo em recente julgado proferido pelo Pretório Excelso, é impenhorável bem de família pertencente a fiador em contrato de locação, porquanto o art. $3^{\circ}$, VII, da Lei $\mathrm{n}^{\circ}$ 8.009/90 não foi recepcionado pelo art. $6^{\circ}$ da Constituição Federal (redação dada pela Emenda Constitucional $n^{\circ}$ 26/2000) (REsp 631262 / MG; RECURSO ESPECIAL 2004/0023956-0)

Em, conclusão, a fiança locatícia está sangrando e prenunciamos que não sobreviverá! Os mais pessimistas dizem que sem ela estaremos diante do fim do mercado imobiliário, pois os locatários mais humildes dificilmente encontrarão outra forma de garantia e acabarão dormindo ao relento. Entretanto, estes pessimistas se esquecem que, se não fosse a interpretação restritiva de um contrato benéfico, quem acabaria dormindo ao relento seria o fiador, nas hipóteses de inadimplemento do inquilino!

Por fim, dizer que se ele assinou o contrato, o problema é dele (em termos jurídicos é a alegação do vetusto princípio pacta sunt servanda) é ignorar a realidade brasileira e demonstrar evidente insensibilidade.

Cabe a nós, portanto, pensarmos em novas formas de garantias, principalmente em novas modalidades de caução. Bem, mas isto já é assunto para outro momento" (SIMÃO, José Fernado. Crônica de uma morte anunciada: a fiança locatícia. <http://www.flaviotartuce.adv.br/secoes/verartigoc.asp?art=162>. Acesso em: 17 ago. 2009). 
jurídica em tema de vital importância, porque fiança anulável não é a mesma coisa que fiança nula!

Dessa forma, ainda que o credor tenha se cercado de todo o cuidado necessário à contratação de uma fiança e ainda que a garantia tenha sido redigida de forma clara e isenta de dúvidas, mesmo assim poderá o fiador tornar-se irresponsável em detrimento do credor pela falha cometida pelo Superior Tribunal de Justiça que desconsiderou a exata medida de um termo técnico de comum utilização na praxe forense (anulabilidade) para emprestar-lhe um figurino para o qual não foi talhado (o da nulidade) $)^{356}$.

Com efeito, as hipóteses de nulidade e de anulabilidade podem ser agrupadas sob uma mesma categoria jurídica denominada de invalidade. E invalidade é a inaptidão atribuível a determinado ato ou negócio jurídico de produzir consequências ou efeitos jurídicos, isto é, de tornar-se exigível e oponível às partes. Em regra, pois, no plano da validade o que é nulo não produzirá efeitos, enquanto aquilo que for anulável será eficaz e produzirá efeitos até o momento em que o defeito causador da anulabilidade vier a ser

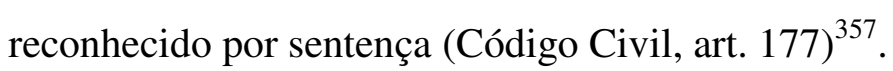

A despeito do equívoco na redação e aplicação da súmula 332 pelo STJ, entendemos ser possível que três situações semelhantes, porém distintas se encontrariam sob a égide do posicionamento jurisprudencial consolidado:

a) as hipóteses envolvendo homem e mulher vivendo sob o vínculo do casamento;

b) as hipóteses envolvendo homem e mulher vivendo sob o vínculo da união estável.

c) as hipóteses envolvendo parceiros do mesmo sexo vivendo sob o vínculo de uma união ou parceria homoafetiva.

Tratando-se de situações fáticas enquadradas na hipótese (a), a existência do casamento é demonstrada única e exclusivamente pelo registro do ato no cartório

\footnotetext{
356،2. É pacífico neste Superior Tribunal de Justiça o entendimento de que a falta da outorga uxória invalida a fiança por inteiro." (REsp 832.669/SP, Rel. Ministra MARIA THEREZA DE ASSIS MOURA, SEXTA TURMA, julgado em 17/05/2007, DJ 04/06/2007 p. 437); “1. É pacífica a jurisprudência do Superior Tribunal de Justiça no sentido de que é nula a fiança prestada sem a necessária outorga uxória, não havendo considerá-la parcialmente eficaz para constranger a meação do cônjuge varão.” (REsp 772419/SP, Rel. Ministro ARNALDO ESTEVES LIMA, QUINTA TURMA, julgado em 16/03/2006, DJ 24/04/2006 p. 453).

357 “Se o cônjuge que deveria ter dado o seu consentimento considerar-se prejudicado, d qualquer forma, poderá pleitear, em dois anos, a anulabilidade do negócio, a contar do término da sociedade conjugal, por qualquer das formas previstas no art. 1.571 do Código Civil: morte, nulidade ou anulação do casamento, separação judicial ou divórcio." (CHINELATO, Silmara Juny. Comentários ao código civil. Coord. Antônio Junqueira de Azevedo. São Paulo: Saraiva, 2004. v. 18, p. 312).
} 
competente, pois o matrimônio acarreta a mudança do estado civil da pessoa e acarreta também, por conseguinte, a alteração em seu registro.

Todavia, tratando-se de situações fáticas subsumíveis nas hipóteses (b) e (c), a solução se altera radicalmente: como o credor poderá saber, sem o auxílio efetivo do fiador, que este vive com alguém em união estável ou parceria homoafetiva? Como poderá vir a ser decretada a invalidade da garantia fidejussória se o credor não possuía qualquer condição de vir a tomar conhecimento da união ou parceria mantida pelo fiador?

A união estável e a parceria homoafetiva, a despeito dos profundos reflexos fáticos e jurídicos que gera na vida das pessoas, quer dos próprios companheiros, conviventes ou parceiros quer de terceiros que com estes contratam, muitas vezes não permite a sua demonstração, eis que as pessoas envolvidas nos relacionamentos poderão não ostentar a aparência ou a posse do estado de companheiros, conviventes ou parceiros.

Neste caso, qual solução seria a mais razoável ou legítima, à luz da boa-fé objetiva?:

a) permitir a invalidação da garantia ex artigo 1.647, III e 1.649 do Código Civil, ante a equiparação dos efeitos da união estável e da parceria homoafetiva ao casamento? ${ }^{358}$, ou

b) manter a garantia ante a impossibilidade fática de o credor vir a conhecer a real situação pessoal do fiador, com isso sacrificando a posição jurídica do companheiro(a) ou parceiro (a) que não manifestou a sua outorga?

Aparentemente, a solução mais simples seria a de se considerar inválida a fiança em face daquele companheiro ou parceiro que não manifestou a sua outorga em relação à garantia prestada, situação esta que teria por fundamento o clássico princípio da relatividade dos efeitos dos contratos: aquele que não figurou no contrato não poderia ter a sua situação jurídica atingida em virtude de um contrato do qual não participou.

Todavia, a realidade da vida e dos negócios jurídicos clama por uma solução que assegure de fato a função social da fiança, a boa-fé objetiva e um mínimo de segurança jurídica em tema tão sensível como o das garantias contratuais.

\footnotetext{
358،Enunciado n. 114 da I Jornada de Direito Civil do CJF: O aval não pode ser anulado por falta de vênia conjugal, de modo que o inc. III do art. 1.647 apenas caracteriza a inoponibilidade do título ao cônjuge que não assentiu."
} 
Como se sabe, o casamento é demonstrável através da respectiva certidão, pois o ato da sua celebração é registrado no Cartório de Registro Civil competente, nos termos do artigo 29, II, da Lei n. ${ }^{\circ} 6.015 / 73$ e gera eficácia erga omnes. Portanto, em regra a simples pesquisa e verificação do credor poderão permitir o conhecimento da real situação jurídica do garante: se casado for, exigir-se-á a outorga da mulher ou do marido, se ambos não subscreverem a fiança como fiadores, o que será abordado no item seguinte.

Neste caso, se o credor, estando ciente de que o garante é casado, deixa de exigir a outorga do respectivo cônjuge, assumiu o risco de celebrar uma garantia inválida, de maneira que a fiança assim firmada não poderá responsabilizar o cônjuge que não manifestou a outorga, nos termos do artigo 1.647, III, do Código Civil. Se o credor agiu com culpa e assumiu um risco que não deveria ter assumido, os ônus respectivos ser-lhe-ão carreados.

Todavia, segundo entendemos, diferente se apresentará a solução se o garante não for casado, mas viver em união estável ${ }^{359}$ ou parceria homoafetiva. Nestas duas últimas hipóteses, impossível será ao credor tomar conhecimento da real situação jurídica do fiador sem o auxílio deste, vale dizer, sem que ocorra a efetiva cooperação do garante o credor estará absolutamente impossibilitado de exigir a manifestação da outorga marital ou uxória porque a sua real situação não poderá ser descortinada.

Assim, a solução que propomos busca atribuir um mínimo de segurança ao negócio jurídico de garantia e prestigiar a necessária boa-fé que deve presidir a manifestação da fiança. Com efeito, o companheiro ou o parceiro que omite, não divulga ou não informa ao credor que vive em união estável ou parceria homoafetiva atua sem a necessária boa-fé, de maneira que não seria razoável punir o credor diligente e beneficiar o fiador que atuou de modo a violar o direito de informação daquele, razão pela qual o patrimônio do companheiro ou do parceiro poderão ser alcançados pelo credor, mesmo que não tenham manifestado outorga à fiança. Se o fiador praticou um ato ilícito ${ }^{360}$ violador do direito de

\footnotetext{
359“A situação de convivência em união estável exige prova segura para que se reconheça sua existência e se concedam os direitos assegurados aos companheiros." (OLIVEIRA, Euclides de. União estável: do concubinato ao casamento. 6. ed. atual. e ampl. São Paulo: Método, 2003. p. 149); “A união estável é um fato jurídico que nasce, perdura por um tempo e muitas vezes acaba. Constitui-se e extingue-se sem a chancela estatal, ao contrário do que ocorre com o casamento. Solvida a união estável, se os conviventes retornam à vida em comum, o arrependimento dispõe dos mesmos efeitos da reconciliação (CC 1.577)." (DIAS, Maria Berenice. Manual de direito das famílias. 5. ed. rev. atual. e ampl. São Paulo: Ed. Revista dso Tribunais, 2009. p. 179).

${ }^{360}$ Código Penal, artigo 299: "Falsidade ideológica
} 
informação do credor, o seu companheiro ou parceiro serão responsáveis perante o credor, porque ostentarão a situação jurídica de co-responsáveis ao adimplemento. Esta será uma hipótese de responsabilidade sem culpa por ato de outrem $^{361}$, com fundamento, segundo defendemos, no artigo 932, V, do Código Civil.

Nesta hipótese, tendo o fiador praticado um ato ilícito omissivo em detrimento do credor, o patrimônio do companheiro ou parceiro responderá pela dívida porventura exigível, porém outorgará a estes o direito de regresso contra o fiador ou até mesmo permitirá a futura compensação das meações se acaso ocorrer o desfazimento da união estável ou da parceria homoafetiva. Ora, na atualidade não faz sentido prestigiar-se absolutamente o fiador e o seu companheiro/parceiro e desprestigiar-se absolutamente o credor. Na verdade, há que ser prestigiada a atuação conforme à boa-fé objetiva.

Com efeito, se protegido for absolutamente o companheiro ou parceiro do fiador, desprotegido absolutamente restará o garante; se protegido for absolutamente o garante, absolutamente restará protegido o companheiro ou parceiro do fiador. Por conta dessa situação, uma solução equânime e razoável há que ser buscada a fim de que sejam reequilibradas as posições jurídicas das partes.

Ora, se a doutrina tem apontado que as obrigações são um processo de cooperação entre credor e devedor, não faz sentido que justamente aquele que não cooperou seja beneficiado! Na atualidade, e em especial no Brasil, é cada vez mais difícil exigir do devedor que cumpra as suas obrigações e do fiador que se responsabilize pela fiança prestada tamanhos os obstáculos que devem ser superados. Por conta disso é que temos defendido que a prestação de fiança seja cercada de responsabilidade: uma vez prestada a garantia, a promessa do fiador gera no credor a legítima expectativa de que o adimplemento exato e fiel da obrigação foi assegurado e será cumprido, de modo que não

\footnotetext{
Art. 299 - Omitir, em documento público ou particular, declaração que dele devia constar, ou nele inserir ou fazer inserir declaração falsa ou diversa da que devia ser escrita, com o fim de prejudicar direito, criar obrigação ou alterar a verdade sobre fato juridicamente relevante:

Pena - reclusão, de um a cinco anos, e multa, se o documento é público, e reclusão de um a três anos, e multa, se o documento é particular."

361 "DESPEJO - Falta de pagamento - A exigência da citação pessoal, em casos como o dos autos (em que foi recebida por funcionário do condomínio), tem sido mitigada por construção pretoriana - A petição inicial é apta, porquanto há pedido e causa de pedir, cuja narração dos fatos decorre logicamente a conclusão, que é juridicamente possível - Não há se falar em nulidade da fiança, porque o fiador ao ser qualificado no contrato não declarou que vivia em união estável com terceira pessoa, de modo que a fiança subsiste Mora "ex re": juros e atualização monetária a partir do vencimento de cada parcela - Inadmissível a cobrança da multa compensatória no caso em apreço - Recurso não provido. (TJSP, Apelação Cível n. 992.06.061003-3 - São Paulo - 25 a Câmara de Direito Privado - Relator: Antonio Benedito Ribeiro Pinto 17.09.09 - V.U. - Voto n. 16.007)"
} 
se ostenta legítimo desguarnecer o credor ante um ilícito, até mesmo penal, cometido pelo fiador que deixou de informar que vivia em união estável ou parceria homoafetiva.

De outra banda e em remate, o direito brasileiro já protege de longa data o patrimônio das famílias através do instituto do bem de família ex Lei n. ${ }^{\circ}$ 8.009/90, cuja interpretação e aplicação às novas formas de entidades familiares têm sido prestigiadas pela jurisprudência, em especial do Superior Tribunal de Justiça, que editou a Súmula n. ${ }^{\circ}$ $364^{362}$ e tem apontado a impenhorabilidade da residência de solteiros, viúvas e famílias monoparentais ${ }^{363,364}$, em claro avanço protetivo da dignidade mínima do devedor.

Destarte, se a cada direito corresponderia um respectivo dever, defendemos que o companheiro ou parceiro também se responsabilizassem perante o credor, de maneira a torná-los reciprocamente responsáveis pelos atos praticado pelo outro, pois se o companheiro ou o parceiros ostentam o direito de serem protegidos contra a penhorabilidade do único imóvel titularizado pelo fiador, também deverão ser responsabilizados no caso da prestação de fiança em violação ao direito de informação do credor. Ou o direito brasileiro avança para tornar as pessoas responsáveis pelos seus atos, ou continuaremos a agir de forma a protegermos tanto aqueles merecedores de tutela como aqueles não merecedores de proteção. Aqui no Brasil fala-se muito em proteção e dignidade, mas muito pouco em cumprimento de promessas e assunção de responsabilidades, de tal modo que os devedores muitas vezes são considerados incapazes

\footnotetext{
362، $O$ conceito de impenhorabilidade de bem de família abrange também o imóvel pertencente a pessoas solteiras, separadas e viúvas." (DJe 03/11/2008).

363“PROCESSUAL - EXECUÇÃO - IMPENHORABILIDADE - IMÓVEL - RESIDÊNCIA - DEVEDOR SOLTEIRO E SOLITÁRIO - LEI 8.009/90. - A interpretação teleológica do Art. $1^{\text {o }}$, da Lei 8.009/90, revela que a norma não se limita ao resguardo da família. Seu escopo definitivo é a proteção de um direito fundamental da pessoa humana: o direito à moradia. Se assim ocorre, não faz sentido proteger quem vive em grupo e abandonar o indivíduo que sofre o mais doloroso dos sentimentos: a solidão. - É impenhorável, por efeito do preceito contido no Art. $1^{\circ}$ da Lei 8.009/90, o imóvel em que reside, sozinho, o devedor celibatário." (EREsp 182223/SP, Rel. Ministro SÁLVIO DE FIGUEIREDO TEIXEIRA, Rel. p/ Acórdão Ministro HUMBERTO GOMES DE BARROS, CORTE ESPECIAL, julgado em 06/02/2002, DJ 07/04/2003 p. 209)

364،"PROCESSUAL CIVIL. EXECUÇÃO FISCAL. VIOLAÇÃO DO ART. 557 DO CPC SUPERADA PELO JULGAMENTO DO ÓRGÃO COLEGIADO. PENHORA DE BEM DE FAMÍLIA. MORADOR SOLITÁRIO. NÃO-INCIDÊNCIA DA CONSTRIÇÃO JUDICIAL. INEXISTÊNCIA DE OBRIGATORIEDADE DE RECAIR EM OUTRO BEM IMÓVEL PASSÍVEL DE PENHORA. RECURSO ESPECIAL NÃO-PROVIDO. 1. Considera-se superada a violação ao art. 557 do CPC quando ocorre o julgamento do agravo interno pelo competente órgão colegiado da Corte regional. 2. A interpretação do art. $1^{\circ}$ da Lei n. 8.009/90 não se limita ao resguardo da família, mas sim, ao direito fundamental de moradia previsto na Constituição da República, baseado no princípio da dignidade da pessoa humana. Caso concreto em que se pretende que a penhora recaia sobre imóvel habitado por pessoa viúva, mesmo havendo outro imóvel que lhe pertence e que pode ser objeto da constrição. 4. Recurso especial não-provido." (REsp 980.300/PE, Rel. Ministro MAURO CAMPBELL MARQUES, 2. ' Turma, julgado em 21/10/2008, DJe 21/11/2008)
} 
quando a dívida lhes é exigida, porém plenamente capazes quando a mesma dívida é contraída...

Este vem a ser o correto entendimento de Cristiano Chaves de Faria e Nelson Rosenvald $^{365}$, o qual adotamos:

"De fato considerando que a união estável é uma união de fato, se a necessidade de registros públicos, não há como vincular terceiros, motivo pelo qual a outorga não pode ser exigida em nome da proteção do adquirente de boa-fé, resolvendo-se o problema entre os companheiros, através da responsabilidade civil. A única hipótese em que o terceiro adquirente pode ser acionado, em nosso pensar, ocorrerá se ele tiver ciência de que o alienante vive em união estável, participando de um negócio fraudulento e propiciando a anulabilidade. Essa desnecessidade de outorga na união estável se justifica por diferentes razões. Primus, porque se tratando de regra restritiva à disposição de direitos, submete-se a uma interpretação restritiva, dependendo de expressa previsão legal. Secundus, pois a união estável é uma união fática, não produzindo efeitos em relação a terceiros. Tertius, e principalmente, em face da premente necessidade de proteção do terceiro adquirente de boa-fé, que veio a adquirir um imóvel sem ter ciência (e não há como se exigir dele) que o alienante havia adquirido o imóvel na constância de uma união estável. Por tudo isso, se um dos companheiros aliena (ou onera) imóvel que pertence ao casal, mas que está registrado somente em seu nome, sem o consentimento de seu parceiro, o terceiro adquirente, de boa-fé (subjetiva) está protegido, não sendo possível anular o negócio jurídico. No caso, o companheiro preterido poderá reclamar a sua meação através de ação dirigida contra o seu comunheiro/alienante, mas nada podendo reclamar do terceiro.

Exigir, destarte, a anuência do companheiro para a prática de atos por pessoas que vivem em união estável é desproteger, por completo, o terceiro de boa-fé. Assim, estando o bem registrado em nome apenas de um dos companheiros, lhe será possível aliená-lo ou onerá-lo, independentemente da outorga do outro companheiro. Neste caso, fica assegurado ao companheiro prejudicado o direito de regresso contra o convivente que dilapidou o patrimônio comum.

Também se reconhece ao companheiro, nestas circunstâncias, o direito de promover medidas cautelares inominadas para obstar a prática do negócio que lhe será desfavorável.

O ideal, sem dúvida, é que as pessoas que vivem em união estável tomem o cuidado de registrar o patrimônio adquirido, na constância da convivência, em nome de ambos, evitando, assim, dissabores e problemas futuros e garantindo a divisão do bem, quando da dissolução da entidade familiar." (Grifamos)

\footnotetext{
${ }^{365}$ In FARIA, Cristiano Chaves de; ROSENVALD, Nelson. Direito das famílias. Rio de Janeiro: Lumen Juris, 2008. p. 243-244.
} 
No mesmo sentido doutrina Euclides de Oliveira ${ }^{366}$, esclarecendo que os negócios jurídicos realizados pelos companheiros não se submeteriam às restrições do artigo 1.647, III, do Código Civil:

\begin{abstract}
“A pessoa que efetuar negócio jurídico com homem e mulher sob união estável, especialmente havendo interesse na aquisição de bens imóveis adquiridos durante o tempo da vida em comum, haverá de se perguntar sobre o modus procedendi e as formalidades que seriam exigíveis em tais casos, no que respeita à necessidade ou não da anuência de ambos os companheiros na prática dos atos de alienação. Qual a segurança jurídica do terceiro a contratar em tais condições?

O NOVO CÓDIGO CIVIL não estabelece para os companheiros a exigência de consentimento para os atos de alienação de bens, diversamente do que se dá em relação aos cônjuges no regime comunitário. Afigura-se de toda conveniência, entretanto, que se obtenha o comparecimento e a anuência do companheiro na escritura de venda procedida pelo outro, para evitar futuros litígios decorrentes da reclamação de direitos de participação no bem. Faz-se necessário, na qualificação do alienante, constar seu estado civil, aí se compreendendo a eventual situação do companheiro, para ciência do companheiro. A este se assegura a regularidade do ato negocial se estiver contratando de boa-fé." (Grifamos)
\end{abstract}

Assim, se o companheiro ou parceiro vierem a omitir a sua condição ao terceiro que com eles contratar uma fiança, a inexistência de boa-fé objetiva não poderá prejudicar o credor, devendo aquele que não manifestou a outorga e restou prejudicado valer-se dos mecanismos de responsabilização civil em face do companheiro ou parceiro ímprobo.

\title{
4.10.2. Análise dos artigos 1.647, III e 1.649, do Código Civil
}

O artigo 1.647, III, combinado com o artigo 1.649, do Código Civil, enunciam ser vedado aos cônjuges prestar fiança sem o consentimento de um ou outro (manifestando outorga uxória ou marital), salvo no regime da separação absoluta de bens, sob pena de tornar "anulável o ato praticado, podendo o outro cônjuge pleitear-lhe a anulação, até dois anos depois de terminada a sociedade conjugal." (Grifamos)

Na realidade dos negócios é praticamente inexistente que uma fiança prestada por um homem ou mulher casados se ultime sem que ambos assinem o instrumento contratual como fiadores, mas apenas como assentidores ou consentidores. Normalmente a fiança é

\footnotetext{
${ }^{366}$ In OLIVEIRA, Euclides de Oliveira União estável: do concubinato ao casamento. 6. ed. atual. e ampl. São Paulo: Método, 2003. p. 157-158.
} 
prestada pelo casal, marido e mulher que assumem a condição de fiadores. Já apontamos, inclusive, que a fiança prestada por um só dos cônjuges sem o consentimento do outro é apenas anulável e não nula.

E nesse contexto importa saber qual será a situação jurídica do cônjuge que consente - através de outorga uxória ou marital - que o outro subscreva a fiança: será ele fiador ou um mero consentidor? Sobre o tema, aponta Gildo dos Santos ${ }^{367}$ :

"Em outras palavras, se a fiança for prestada por pessoa casada, duas situações devem ser examinadas. Se o marido é o fiador, com consentimento da mulher, apenas ele é o garante, de modo que, falecendo, a mulher não é fiadora do devedor, porque apenas deu autorização para que o seu marido fosse garantidor das obrigações. Se a mulher não deu o seu consentimento, porém, mais do que isso, é também fiadora, como acontece quando o contrato dispõe que "Fulano de tal e sua mulher Beltrana são fiadores...", a responsabilidade da mulher subsiste como fiadora, mesmo após a morte do marido, embora a do espólio do marido e a dos herdeiros cesse com a morte do cônjuge varão. Afinal, "a mulher que com o marido assina na qualidade de fiadora não é mera figurante, mas fiadora, e sua obrigação persiste mesmo após a morte do marido, desnecessária, nessa hipótese, a apresentação de novo fiador".

Portanto, o cônjuge que não subscreve a fiança como fiador, mas apenas como autorizador da garantia prestada pelo outro não ostentará o figurino de fiador ${ }^{368,369}$

Nesta hipótese, qual seria a responsabilidade do cônjuge que assinou a fiança como autorizador? Poderia ele vir a sofrer a penhora da sua meação ou bens particulares em eventual demanda movida pelo credor?

Segundo apontam Pablo Malheiros da Cunha Frota e Fábio Viana Fernandes da Silveira $^{370}$, o autorizador ou anuente da fiança do outro cônjuge ex artigos 1.647, III e 1.649, do Código Civil, não seriam responsabilizados pela fiança prestada pelo outro cônjuge porque garantidores não seriam, de modo que não teriam figurado no negócio

\footnotetext{
${ }^{367}$ In SANTOS, Gildo dos. Fiança. São Paulo: Ed. Revista dos Tribunais, 2006. p. 120.

368، Os contratos de fiança, muitas vezes, não trazem com clareza, explicitado, se as assinaturas de ambos os cônjuges corresponde à fiança prestada por um, acompanhada da outorga do outro, ou se ambos são, conjuntamente, fiadores. Se um cônjuge pré-morre ao outro, e este é também fiador do negócio, apenas com relação ao falecido se limita a fiança. Contudo, para se admitirem os efeitos previstos na hipótese do CC 829, é necessário que exista explícita referência à qualidade de fiador do outro cônjuge. Na ausência de expressa referência a essa situação, presume-se que a participação do outro cônjuge tem a mera natureza de outorga conjugal.” (NERY JUNIOR, Nelson; NERY, Rosa Maria de Andrade. op. cit., p. 740).

369" A esposa do fiador que se limita a dar outorga uxória à fiança prestada por seu marido, em atendimento à exigência legal, não adquire a condição de fiadora. O acordo realizado entre locadora e locatário, com o qual não consentiu a esposa do fiador, não pode ser executado em relação a esta." (RT 778/319)

${ }^{370}$ In FROTA, Pablo Malheiros da Cunha; SILVEIRA, Fábio Viana Fernandes da. Famílias no direito contemporâneo: estudos em homenagem à Paulo Luiz Netto Lôbo. Salvador: Juspodivm, 2010. p. 538.
} 
fidejussório. De acordo com o entendimento que manifestaram, a outorga uxória ou marital teria apenas a finalidade de servir como elemento de validade da garantia prestada pelo outro cônjuge:

\begin{abstract}
"A subsidiariedade do contrato de fiança não abona que os efeitos deste atinjam os bens do cônjuge ou do companheiro, visto que a mencionada característica se refere ao benefício de ordem ou excussão do fiador (CC/02, art. 827), para que o credor execute primeiramente os bens do devedor. Percebe-se, destarte, que o cônjuge ou companheiro anuente, além de não deter solidariedade com o consorte ou companheiro que afiançou, não é co-responsável pelo adimplemento da fiança, afastando quaisquer hipóteses de ofensa ao patrimônio comum do casal ou dos conviventes, bem como aos particulares do outorgante na constância do casamento ou da união estável e após o rompimento de uma ou outra.

Percebe-se, por conseguinte, que a outorga não cria vínculo obrigacional para o anuente. Serve só como fator de validade do contrato realizado entre credor elou devedor e o fiador, a afastar a constrição de bens do outorgante." (Grifamos)
\end{abstract}

Em remate, referidos autores aduzem que o cônjuge que simplesmente autoriza a prestação de fiança pelo outro seria terceiro, de modo que este não poderia ser responsabilizado pela fiança sem que fosse garantidor, sob pena de violação ao princípio da função social do contrato ${ }^{371}$ :

“À parte isto, o ataque aos bens do cônjuge ou do companheiro que anuiu fere a eficácia externa do princípio da função social do contrato, mitigadora do princípio da relatividade dos efeitos contratuais, a comprovar a eficácia, no mínimo, indireta de qualquer contrato perante terceiros. No caso em comento, o pacto feriu direito de terceiro, pois não houve a assunção de dívida pelo anuente, que não é obrigado, responsável ou co-responsável solidariamente ou subsidiariamente pela dívida constituída pelo devedor e garantida pelo fiador, seu cônjuge ou companheiro."

Pois bem. A finalidade da vedação contida no artigo 1.647, III, do Código Civil, no sentido de evitar que o cônjuge pratique determinados atos ou negócios sem o consentimento do outro é a de garantir o patrimônio da família, “cuja situação econômica pode ser prejudica com a prática dêsses atos. Daí querer o Código que a mulher [rectius, cônjuge] intervenha nêles, contribuindo com a sua fiscalização, a fim de evitar, justamente, conseqüências danosas à família." 372

\footnotetext{
${ }^{371}$ In FROTA, Pablo Malheiros da Cunha; SILVEIRA, Fábio Viana Fernandes da. op. cit., p. 539.

${ }^{372}$ PONTES DE MIRANDA, Francisco Cavalcanti. op. cit., 1971, p. 155) (Grifamos)
} 
Assim, qual seria o sentido do artigo 1.647, III, do Código Civil, se de um dos cônjuges fosse exigida a autorização para que o outro prestasse fiança, e uma vez manifestada a autorização não fosse responsabilizado pelo ato praticado? Com efeito, não há solidariedade entre o cônjuge fiador e o prestador de autorização porque o artigo 829, do Código Civil, impõe o regime da solidariedade passiva quando a fiança for conjuntamente prestada a um só débito por mais de uma pessoa, o que não é o caso. Assim posta a questão, dizer que não há solidariedade entre marido e mulher in casu não é o mesmo que dizer que entre ambos não há co-responsabilidade.

Nesse sentir, a necessidade de autorização dos cônjuges para que o outro preste fiança impõe, a nosso ver, a responsabilização subsidiária do autorizador, permitindo que a sua meação e bens particulares venham a ser atingidos apenas e tão-somente se os bens do cônjuge-fiador se mostrarem insuficientes. Ora, se o legislador exige a autorização quernos parecer que dessa autorização há que emanar alguma eficácia jurídica em favor do credor, até porque a finalidade da exigência seria a de permitir que o outro cônjuge fiscalizasse um negócio que poderia vir a ser extremamente prejudicial ao patrimônio familiar, e não ao patrimônio apenas do fiador.

$\mathrm{Na}$ atualidade, a doutrina se cala diante dessa situação, de tão escassa que é a sua ocorrência prática, porque na vida de relação se exige a assinatura de ambos os cônjuges na prestação de fiança em lugar de se exigir apenas a outorga uxória ou marital. Em outras palavras, ambos os cônjuges são fiadores.

Segundo um precedente do Superior Tribunal de Justiça, "Devendo a fiança ser interpretada restritivamente, a outorga uxória exigida legalmente para dar validade à garantia prestada pelo cônjuge varão não implica a solidariedade de que trata o art. 1.493 do Código Civil [de 1916]. "373 Neste caso específico, a fundamentação do acórdão apenas afastou a existência de solidariedade entre o fiador e a cônjuge que apenas autorizou a prestação da garantia, uma vez que esta não se torna fiadora quando manifesta a outorga uxória; no corpo do referido acórdão foi feita remissão a outro acórdão do mesmo tribunal, acórdão este no qual o tribunal assestou:

"Sendo a fiança contrato que não admite interpretação extensiva, por ter caráter benéfico, e constando no contrato de locação o marido como fiador, a que a mulher apenas concedeu anuência para atender a exigência

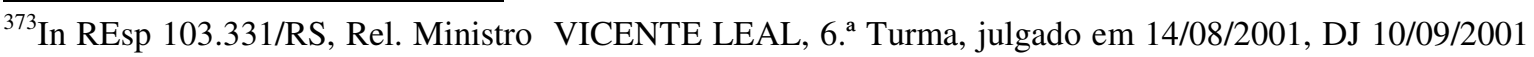
p. 417.
} 
legal (art. 235, III, CC); não há cogitar de solidariedade, de que trata o art. 1.493, do CC [de 1916]." 374

Como se percebe, restou estabelecido - e com razão - que o cônjuge autorizador da prestação de fiança pelo outro não seria responsável solidário pela dívida, até porque tanto o Código Civil de 1916 dispunha, quanto o de 2002 dispõe que a solidariedade não se presume, decorrendo da lei ou da vontade das partes, nos termos do artigo 265, do Código Civil.

No entanto, o Superior Tribunal de Justiça estatuiu que a inexistência de solidariedade não implicaria na irresponsabilidade da cônjuge do fiador, mas que subsistiria a responsabilidade da autorizadora até a morte do marido.

Neste caso específico, o Superior Tribunal de Justiça estava com a razão. Destarte, quando um dos cônjuges assina a fiança apenas como autorizador, ele não se torna fiador mas apenas co-responsável subsidiário, porque a sua autorização vincula o seu patrimônio ao adimplemento exato e fiel da obrigação afiançada. Se da sua autorização não decorresse nenhuma consequência jurídica, a necessidade de autorização se ostentaria inócua. Em hipóteses que tais, o outro cônjuge autorizaria para quê e por quê? ? $^{375}$

Maria Berenice Dias, por exemplo, parece entender que uma vez autorizada a prestação de fiança pelo outro cônjuge o ato de autorização resultaria no comprometimento do patrimônio comum, sob a presunção de que teria sido firmada em benefício do casal:

\footnotetext{
${ }^{374}$ In REsp 163477/SP, Rel. Ministro JOSÉ ARNALDO DA FONSECA, 5. ${ }^{a}$ Turma, julgado em 28/04/1998, DJ 15/06/1998 p. 153.

${ }^{375} \mathrm{Um}$ dos raros autores a escreverem sobre o assunto, Nelson Godoy Bassil Dower indica que: "Portanto, é vedada a prestação de fiança sem a outorga conjugal. Não será demais reiterar que, para a sua validade, necessária é essa outorga. Contudo, o consentimento do cônjuge pode ser suprido judicialmente na hipótese de recusa injusta, mas não atingirá os bens próprios desse cônjuge. O consentimento do cônjuge autorizando a fiança significa que não há fiança de ambos. Ou seja, um cônjuge afiança e o outro simplesmente autoriza. Mas os cônjuges podem afiançar em conjunto. Quando apenas um deles é fiador, somente seus bens podem ser constrangidos." (In DOWER, Nelson Godoy Bassil. Curso moderno de direito civil. 4. ed. São Paulo: Nelpa, 2009. p. 384). (Grifamos) Como se vê, o autor entende que aquele que apenas autoriza a prestação de fiança pelo outro não sofrerá qualquer investida contra os seus bens. Em face do exposto, renovamos a indagação: por qual motivo, então, exige-se que o outro cônjuge manifeste autorização in casu se não será responsabilizado? É no mesmo sentido a doutrina de VENOSA, Sílvio de Salvo: "Quanto ao consentimento, este não se confunde com a fiança conjunta. O cônjuge pode autorizar a fiança. Preenche-se desse modo a exigência legal, mas não há fiança de ambos: um cônjuge afiança e o outro simplesmente autoriza, não se convertendo em fiador. Os cônjuges podem, por outro lado, afiançar conjuntamente. Assim fazendo, ambos se colocam como fiadores. Quando apenas um dos cônjuges é fiador, unicamente seus bens dentro do regime respectivo podem ser constrangidos. Desse modo, sendo apenas fiador o marido, com mero assentimento da mulher, os bens reservados desta, por exemplo, bem como os incomunicáveis, não podem ser atingidos pela fiança." (In VENOSA, Sílvio de Salvo Direito civil, cit., v. 3, p. 418).
} 
"Nenhum dos cônjuges pode prestar aval ou fiança sem o consentimento do outro (CC 1.647 III). Como, de um modo geral, são garantias de favor, que não trazem benefício à família, não há como comprometer o patrimônio comum. Esta é a explicação. Diz a lei que o ato é anulável (CC 1.649).

\section{(...)}

Em sede de responsabilidade civil dos cônjuges, mister atentar que ao menos um artigo do Estatuto da Mulher Casada não se encontra revogado (EMC 3. ${ }^{\circ}$ ): pelos títulos de dívida de qualquer natureza, firmados por um só dos cônjuges, ainda que casados pelo regime da comunhão universal, somente responderão os bens particulares do signatário e os comuns até o limite da sua meação. Essa norma permanece no sistema jurídico, nunca foi revogada, pois jamais outra lei dispôs sobre o mesmo tema. Inclusive sua vigência é referendada na lei civil, ao afirmar, ainda que de forma pouco clara, no mesmo sentido (CC $\left.1.663 \S 10^{\circ}\right)$ : as dividas contraídas no exercício da administração obrigam os bens comuns e particulares do cônjuge que os administra, $e$ os do outro na razão do proveito que houver auferido.

Em se tratando de dívida de qualquer natureza assumida por um dos cônjuges, cabe ao outro a prova da ausência de benefício, pois é do casal a responsabilidade pelos encargos da família (CC 1.565) e presume-se que as dívidas são contraídas para tal fim. Ao depois, para o credor é praticamente impossível a comprovação em sentido contrário. Pelas dívidas contraídas por qualquer um dos cônjuges responde o patrimônio comum. Na hipótese da dívida ser somente de um, cabe a penhora somente da meação do devedor. Em se tratando de bem indivisível, a meação é preservada sobre o produto da alienação do bem (CPC 655-B)."

Conforme já tivemos a oportunidade de expor, o fiador é responsável pela dívida alheia, sem que seja devedor principal, uma vez que a sua responsabilidade será sempre subsidiária. Assim, ao contrário do que afirmou Maria Berenice Dias ${ }^{376}$, o cônjuge que subscreve a fiança sem a autorização do outro não contrai ou assume dívida de qualquer natureza, mas se torna garantidor do adimplemento do afiançado. E como responsável o cônjuge que prestou a fiança sem a autorização do outro poderá ter o seu patrimônio (rectius, meação ou bens particulares) sacrificado se não demandar a anulação da garantia.

Como já vimos, a necessidade de autorização objetiva permitir que o cônjuge do fiador possa fiscalizar e acompanhar o ato que será praticado pelo outro porque será coresponsabilizado, ainda que subsidiariamente, pela fiança prestada pelo outro ${ }^{377}$, razão

\footnotetext{
${ }^{376}$ Em outras palavras, sobre o fiador recai a responsabilidade (haftung) sem que lhe recaía o débito (schuld); portanto, os dispositivos legais invocados pela doutrinadora somente teriam incidência se o fiador fosse também co-devedor, o que não ocorre atualmente, razão pela qual o cônjuge que apenas autoriza a prestação de fiança pelo outro será co-responsável subsidiário e não co-devedor.

${ }^{377}$ Ao ter comentado o artigo 263, X, do Código Civil de 1916, o Min. João Luiz Alves, ao que parece, comungava do entedimento de que a ausência de outorga uxória não autorizaria fossem atingidos os bens comuns e os particulares da mulher, o que, a contrario sensu, permitiria a conclusão de que a existência de
} 
pela qual a responsabilidade do autorizador se estende apenas até a morte do fiador ou até que ocorra um fato que desobrigue o garante, de modo que responsabilidade do autorizador não se transmitirá aos seus herdeiros, bem como cessará tão-logo a responsabilidade do fiador se extinga ${ }^{378}$.

Desta maneira, a responsabilidade do autorizador será apenas e tão-somente subsidiária e não solidária, posto que a manifestação de outorga uxória ou marital nos termos do artigo 1.647, III, do Código Civil, não transforma o autorizador em fiador e responsável solidário. Assim, uma vez manifestada a outorga uxória ou marital ficará o cônjuge que manifestou a autorização para que o outro prestasse fiança vinculado subsidiariamente ao adimplemento e suportará o ataque aos seus bens se não demandar a invalidação (rectius, anulação) da garantia nos termos do artigo 1.649 do Código Civil e o patromônio do fiador se mostrar insuficiente ao cumprimento da finalidade de garantir.

Outra questão a envolver fiança e casamento foi aventada por Francisco Carlos Rocha de Barros ${ }^{379}$ e envolve a seguinte situação: se a fiança tiver sido prestada quando ainda o fiador era solteiro o que ocorrerá com a garantia se ocorrer o casamento superveniente do garante? Em tese, sustentamos com fundamento no princípio da boa-fé objetiva que a celebração do casamento deverá ser informada pelo fiador ao credor, a fim de que este colha a autorização do outro cônjuge ou exija a sua subscrição como fiador ou fiadora, a fim de garantir a higidez da garantia. Caso o fiador omita o seu casamento

autorização obrigaria os bens comuns e até os bens próprios da mulher: "Faltando a outorga uxória, embora suprida, a fiança do marido não obriga os bens comuns (art. 263, n. ${ }^{\circ} \mathrm{X}$ ) e menos obriga os próprios da mulher (art. 238)." (In Código civil da república dos Estados Unidos do Brasil anotado. 3. ed. 5. Vol. Rio de Janeiro: Borsoi, 1958, p. 144).

${ }^{378}$ Segundo expunha BETTI, Emilio, a autorização "envolve a assunção das consequências onerosas doa cto autorizado ou aprovado nas esfera do autorizante e, removendo um obstáculo que impede a legitimação alheia, serve para tornar legítimo, no que respeita ao interessado, um acto de disposição dos seus direitos praticado por outros ou, de um modo geral, uma ingerência anormal na sua esfera jurídica (\$ 73). Embora podendo ser coordenada com uma finalidade gestória, a autorização ou aprovação não tem, como tal, uma função positiva, mas apenas negativa: a de excluir o torto, a ilicitude no acto alheio em si mesmo, eventualmente lesivos dos interesses do aquiescente." (In BETTI, Emilio. Teoria geral do negócio jurídico. Trad. de Fernando Miranda. Coimbra: Coimbra Ed., 1970. t. 3, p. 263-264) (Grifamos)

${ }^{379}$ In BARROS, Francisco Carlos Rocha de. op. cit., p. 535. Os comentários escritos pelo autor citado se referiam à hipótese de garantia prestada nos autos de ação renovatória de contrato de locação, mas que podem ser aplicadas, mediante um processo de generalização, a situações análogas: "Questão interessante poderá surgir quando, após ter manifestado a aceitação da fiança, a pessoa, que era solteira, vier a se casar. A rigor, tal fato deveria ser noticiado nos autos, completando-se a aceitação com a anuência do cônjuge. Todavia, se a ação prosseguir sem essa providência, e sentença julgar procedente o pedido renovatório, será válida a fiança? Deve-se responder afirmativamente. A sentença é de natureza constitutiva, produzindo, no caso, efeitos ex tunc. A decisão que determina a renovação, fixando prazo, aluguel e demais condições envolve a fiança. Quem aceitou ser fiador, será considerado como tal a partir do termo inicial do novo contrato proclamado pela sentença. A situação assemlha-se àquela em que a pessoa solteira firma contrato de fiança, vindo a se casar depois. O casamento posterior não repercute na validade da fiança, por ela antes prestada." (Grifamos) 
superveniente do credor, responderá perante este por perdas e danos, caso o seu patrimônio se revele insuficiente a garantir.

Nesta hipótese específica, no entanto, não será possível responsabilizar o cônjuge do outrora fiador, notadamente porque a garantia foi manifestada antes do casamento, de maneira que a sua boa-fé deverá ser presumida para que seja afastada a sua responsabilização.

Outra situação relativa ao casamento foi ventilada por Carlos Alberto Dabus Maluf, notadamante acerca de cônjuges separados de fato. Os cônjuges separados de fato poderão prestar fiança isoladamente? Nesta hipótese, para evitar futuros problemas, o locador deve exigir que o cônjuge assine também a garantia. Se não obtiver êxito, então é melhor encontrar outro fiador ${ }^{380}$.

\subsection{3. É possível a conversão da fiança em garantia atípica? ${ }^{381}$ Análise do art. 170 do Código Civil}

O artigo 169 do Código Civil enuncia regra tradicional no direito brasileiro, segundo a qual "O negócio jurídico nulo não é suscetível de confirmação, nem convalesce pelo decurso do tempo”. (Grifamos) A clareza da regra legal permite que o intérprete enuncie que a nulidade absoluta poderá ser arguida pelo interessado a qualquer momento, pois o decurso do tempo não terá o condão de afetá-la, bem como que as partes dum negócio nulo não poderão saná-lo ou confirmá-lo porque esta modalidade de invalidade se situa fora dos domínios da autonomia privada. Assim, o absolutamente nulo sempre conservará esta qualidade ainda que as partes tolerem a invalidade.

\footnotetext{
${ }^{380}$ In MALUF, Carlos Alberto Dabus. Comentários à lei de locação de imóveis urbanos. Coord. Juarez de Oliveira. São Paulo: Saraiva, 1992. p. 270.

${ }^{381}$ Em Portugal, o tema da garantia atípica é suscitado pela doutrina de GOMES, Manuel Januário da Costa, que aponta: "Apesar de não ter sido delineada como garantia, é de admitir, mas não sem reservas, que os intervenientes na operação de crédito, naturalmente por impulsos do credor, a "utilizem" como alternativa v.g. à fiança, caso em que, no dizer expressivo de Heck, o credor fica na posição de um "pachá jurídico", atenta a posição confortável em que fica investido. Verifica-se, de facto, na praxis ligada sobretudo à actividade dos bancos, que estes, amiúde, "fazem entrar" terceiros, normalmente o cônjuge ou familiares próximos do candidato à obtenção do crédito, na própria relação de mútuo ou de abertura do crédito, como devedores solidários, sendo legítimo questionar se os bancos têm "liberdade de escolha" entre a solidariedade passiva e a fiança, figura que, a priori, seria mais adequada para a vinculação do terceiro." (In GOMES, Manuel Januário da Costa. op. cit., p. 101); ainda sobre a denominada garantia bancária autónoma, vede TELLES, Inocêncio Galvão. Manual dos contratos em geral. 4. ed. Coimbra: Coimbra Ed., 2002. p. 503-518.
} 
No entanto, o citado dispositivo relativo à nulidade absoluta dos negócios jurídicos veio a ser temperado pelo artigo 170 do Código Civil de 2002 que introduziu no direito brasileiro o instituto da conversão judicial do negócio jurídico ${ }^{382}$, importante instrumento legal que tem com base o princípio da conservação dos contratos. Com isso, ainda que determinado negócio jurídico seja absolutamente nulo, pode sobreviver apesar da nulidade, quando contiver os requisitos de outro e se comprovar que as partes realizariam o segundo contrato se tivessem conhecimento da invalidade que atingiria o primeiro. Em casos que tais a vontade hipotética ou conjuntural das partes do negócio deve ser considerada, a fim de que a nulidade possa ser suprida por decisão judicial ${ }^{383}$. Assim se poderá conservar útil a atividade negocial, sob outra roupagem jurídica, mas com fidelidade aos mesmos desígnio práticos ${ }^{384}$.

E qual seria o fundamento da conversão? Segundo Pontes de Miranda ${ }^{385}$,

"O fundamento da conversão está em que, nas relações da vida, mais se há de atender aos propósitos de cada um, econômicos ou não, do que à coincidência entre tudo que se quis e a regra jurídica em que se pensou, querendo-se determinada categoria jurídica. Mais à vida que à rigidez das normas em que se atentara, explicitamente ou, apenas, implicitamente pela pré-escolha do negócio jurídico. Com isso não se sacrificam as normas, não se tornam menos incidentes do que deveriam ser certas regras jurídicas: há a incidência da regra jurídica que faz negócio jurídico válido o que corresponde aos elementos fácticos que integram o mínimo de vontade que a deixaria de pé.".

Para Humberto Theodoro Júnior ${ }^{386}$, o principal fundamento da conversão seria a preservação do "fim prático" perseguido pelas partes no negócio nulo:

\footnotetext{
382 "É o princípio da convertibilidade, segundo o qual, na determinação das categorias jurídicas, se atende ao mínimo suficiente e, na interpretação da vontade negocial, se lhe salva o máximo possível. Nesse salvamento, de certo modo se deixa de atende a parte de vontade; pois que, compndo-se o negócio jurídico suficiente, se afasta a vontade manifestada, naquilo em que quis o negócio jurídico nulo. Não se pode dizer que se abstraia da vontade; abstrai-se de parte dela, exatamente para se lhe reter o máximo possível.(...) A nulidade pode ser quanto à forma do negócio jurídico, que se quis com tôda a vontade; e a conversão aproveita essa vontade no que enche negócio jurídico para o qual o elemento de forma bastaria ao suporte fáctico. A nulidade pode ser quanto à capacidade de um ou de mais de um dos figurantes; e então a conversão aproveita aquilo que êle ou êles poderiam ter querido. A nulidade pode ser quanto a algum outro elemento (= "requisito", art. 145, V), que a lei repute essencial à validade do negócio jurídico; e a conversão há de consistir em se selecionar suporte fáctico que baste à constituição de negócio jurídico que prescinda dêsse elemento." (PONTES DE MIRANDA, Francisco Cavalcanti. op. cit., t. 4, 3. ed. § 374, p. 62-63).

${ }^{383}$ Cfe. LÔBO, Paulo Luiz Netto. Direito civil: parte geral, cit., p. 209.

${ }^{384}$ THEODORO JÚNIOR, Humberto. Comentários ao novo Código Civil, cit., v. 3, t. 2 (Arts. 185 a 232), p. 533.

${ }^{385}$ In PONTES DE MIRANDA, Francisco Cavalcanti. op. cit., t. 4, 3. ed., § 2374, p. 64-65.

${ }^{386}$ THEODORO JÚNIOR, Humberto. Comentários ao novo Código Civil, cit., v. 3, t. 2, p. 533. (Arts. 185 a 232). (Grifamos)
} 
"É a partir das "intenções práticas" e das "valorações reconhecíveis de interesses das partes" que se pode fixar a "vontade hipotética" justificadora da conversão. Completa-se a operação com a averiguação sobre a adequação do negócio substitutivo para efetivar os fins práticos determinantes do negócio substituído. É assim que se fundamenta a substituição do negócio jurídico, para atender-se à sistematização que lhe deu o direito positivo." (Grifamos)

Portanto, antes de se preocupar com a vontade das partes, deve o intérprete buscar a finalidade do negócio firmado, o fim prático que foi perseguido pelas partes, de modo a buscar salvaguardar a confiança despertada nos contraentes e a legítima expectativa que foi neles gerada, as quais deverão ser objetivamente consideradas.

Para Paulo Lôbo seriam dois os requisitos necessários à ocorrência da conversão: o primeiro, consiste em que o negócio nulo contenha todos os elementos necessários à sua conversão no negócio não-nulo; o segundo, consistente na presunção de que as partes teriam querido o novo negócio se tivessem previsto a nulidade, em virtude dos fins que pretenderam atingir com o negócio originário ${ }^{387}$.

Para a teoria subjetiva, somente se admitiria a conversão se as partes tivessem atuado de boa-fé subjetiva quando estabeleceram o negócio nulo, sendo vedado o seu aproveitamento em caso de fraude ou má-fé; já para a teoria objetiva ${ }^{388}$ o que realmente importa para a conversão seria o suporte fático do negócio que resultaria da conversão: se a estrutura do negócio jurídico nulo (primeiro) contivesse os elementos de existência do negócio jurídico para o qual ocorreria a conversão (segundo) ${ }^{389}$, a incidência do artigo 170 do Código Civil se apresentaria possível ${ }^{390}$.

\footnotetext{
${ }^{387}$ In LÔBO, Paulo Luiz Netto. Direito civil: parte geral, cit., p. 209. O mesmo autor cita três exemplos bastante claros e elucidativos de hipóteses em que a conversão se apresenta como um instrumento de extrema importância: "Exemplos: contrato de compra e venda de imóvel mediante documento particular (negócio jurídico nulo, por defeito insanável de forma), que pode ser convertido em promessa de compra e venda; título de crédito nulo, que pode ser convertido em recibo; testamento cerrado que não foi aprovado por tabelião (art. 1.868 do Código Civil), por isso nulo, que pode ser convertido em testamento particular."

${ }^{388}$ Enunciado n. 13 da I Jornada de Direito Civil do CJF: "O aspecto objetivo da convenção requer a existência do suporte fático no negócio a converter-se."

${ }^{389}$ Cfe. DEL NERO, João Alberto Schützer. Conversão do negócio jurídico. Rio de Janeiro: Renovar, 2001, p. 229.

${ }^{390}$ Segundo Marcos Bernardes de Mello, em casos de ilicitude, imoralidade ou impossibilidade do objeto, hipóteses denominadas pelo autor como de nulidades irremovíveis, a conversão não seria admissível. "Só é admissível a conversão, portanto, em casos de incapacidade do agente ou de forma." (In MELLO, Marcos Bernardes de. Teoria do fato jurídico: plano da validade. 7. ed. rev. e atual. São Paulo: Saraiva, 2006. p. 259); "Diversa, contudo, é a situação do contrato em que a forma é da substância do negócio. Sua inobservância conduzirá à nulidade, mas se for possível aproveitar a declaração para validá-la como outro negócio não formal, o caso será realmente de substituição substancial.” THEODORO JÚNIOR, Humberto. Comentários ao novo Código Civil, cit., v. 3, t. 2, p. 538, (Arts. 185 a 232). (Grifamos)
} 
Segundo entendemos, a teoria objetiva da conversão atende melhor aos anseios de justiça e segurança jurídica, além de se encontrar mais afinada ao princípio da boa-fé objetiva previsto no artigo 422 do Código Civil, que no campo contratual deslocou-se da intenção dos sujeitos para os seus comportamentos a serem valorados de acordo com um padrão de conduta (rectius, modelo) que poderia ser esperado de qualquer pessoa no mesmo contexto.

Com efeito, independentemente da intenção dos sujeitos, segundo entendemos a conversão do negócio nulo deverá ser determinada pelo juiz que vier a dele conhecer por uma questão de segurança jurídica, até mesmo para se evitar que o eventual conluio das partes venha a prejudicar terceiros e causar situações de extrema injustiça ou perplexidade.

Assim, partindo da premissa de que a conversão prevista no artigo 170 do Código Civil independe da vontade dos contratantes $^{391}$, a pergunta que se coloca nesta oportunidade é a seguinte: a fiança, por se um contrato em que não se admite interpretação extensiva, se acaso for nula permitirá a sua conversão em contrato de garantia atípico, a fim de manter o fiador (após a conversão, garante) ainda responsável pelo adimplemento do afiançado (após a conversão, garantido)?

Apesar da importância que o tema desperta, pois, quando ainda não havia disposição legal expressa acerca da possibilidade de conversão dos negócios jurídicos nulos, a decretação de nulidade da fiança deixava o credor sem qualquer garantia patrimonial de satisfação do seu crédito, a doutrina que tem sido produzida após a entrada em vigor do Código Civil de 2002 não se atentou ou se preocupou em debater o tema, cujas considerações faremos a seguir.

A jurisprudência tem reconhecido na figura do "garante solidário" a existência de uma garantia pessoal que não é fiança nem aval. O prestador da garantia anui em assegurar o pagamento de dívida alheia como devedor solidário. Assim: STJ, 4. ${ }^{\text {a }}$ Turma, REsp 3.238/MG e REsp 6.268, Rel. Min. Sálvio de Figueiredo Teixeira, julgados, respectivamente, em 23/10/1990 e em 15/04/1991, ambos unânimes. No mesmo sentido:

\footnotetext{
${ }^{391}$ Conforme aponta THEODORO JÚNIOR, Humberto: "O fenômeno da conversão é uma das modalidades da qualificação jurídica do ato negocial. No momento em que o juízo de subsunção reconhece a falta de algum elemento indispensável à sua conformação com o padrão definido no ordenamento jurídico, o resultado seria a negação à eficácia da declaração de vontade para produzir o efeito jurídico visado. $\mathrm{O}$ ato de vontade não consegue penetrar no mundo dos negócios jurídicos, ou seja, dos negócios tutelados pelo direito. A operação de subsunção é negativa. Nem sempre, porém, deve encerrar-se nesse primeiro estágio, pois é possível salvar-se o negócio programado convertendo-o em outro que, embora diverso do arquitetado pelas partes, pode, de alguma maneira, atingir seus objetivos práticos, se não inteiramente, pelo menos em parte." (In THEODORO JÚNIOR, Humberto. Comentários ao novo Código Civil, cit., v. 3, t. 2, p. 536 (Arts. 185 a 232). (Grifamos)
} 
REsp 538.832/RS, STJ, 3. ${ }^{a}$ Turma, Rel. Min. Carlos Alberto Menezes Direito, 10/02/2004, unânime ${ }^{392}$, este último com a seguinte conclusão, verbis:

"1. Na forma de precedentes da Corte, o "interveniente garantidor solidário" não se confunde com o avalista nem com o fiador, sendo inaplicável, portanto, a disciplina positiva sobre a fiança, com o que se afasta a necessidade de outorga uxória (REsp $\mathrm{n}^{\circ}$ 6.268/MG, julgado em sessão de 15/4/91; no mesmo sentido, do mesmo Relator: REsp $\mathrm{n}^{\circ}$ 3.238/MG, DJ de 19/11/90)."

E em seu voto o Min. Carlos Alberto Menezes Direito reproduziu os argumentos que haviam sido expendidos no REsp 6.268 pelo Min. Sálvio de Figueiredo Teixeira, tendo concluído que a figura do "interveniente garantidor solidário" ou apenas "garantidor solidário" seria uma figura jurídica distinta do fiador e do avalista, verbis:

"Em face de tais premissas, seria de indagar-se como situar a figura do rotulado 'garante solidário', para o qual se invocam os arts. 896 e 904 do Código Civil.

Fiador, a meu sentir, não seria. Não, ressalve-se, por faltar, muitas vezes, a assinatura da mulher, uma vez que sem a impugnação dessa a obrigação subsistiria; mas pela circunstância de que, nos termos do art. 1.483 do Código Civil, a fiança não admite interpretação extensiva, 'jamais se presume', segundo salienta Washington de Barros Monteiro ('Curso', Saraiva, 20ªd., 1985).

Existiria uma nova modalidade de garante, ao lado do avalista e do fiador? Pode o aval ter ampliação com simples declaração em pacto adjeto, em cláusula contratual?

Vejo a problemática sob outro prisma, dentro de uma exegese na qual os institutos de um mesmo sistema não podem atritar-se, impondo-se interpretação que os harmonize.

Assim, vê-se que a execução, no sistema processual civil brasileiro, a exemplo do que ocorre hoje no melhor direito comparado, se assenta em títulos executivos judiciais e extrajudiciais. Outrossim, ao elencar, em numerus clausus, os títulos extrajudiciais, proclama o inciso II do art. 585 do Código de Processo Civil ter eficácia executiva 'o documento público, ou o particular assinado pelo devedor e subscrito por duas testemunhas, do qual conste a obrigação de pagar quantia determinada, ou de entregar coisa fungivel'.

Ora, se o contrato está devidamente formalizado, nos termos do art. 585, II, CPC, constitui título executivo o documento particular através do qual alguém se responsabiliza por um determinado débito, não podendo constituir-se em óbice a circunstância do valor não estar expresso em cruzeiros no documento, mesmo porque, em anômalo regime inflacionário como o nosso, já assentou esta Corte da validade de títulos lançados não em nosso padrão monetário-cruzeiro, mas em outros padrões, formulados e oficializados pelo próprio sistema econômico, e

${ }^{392}$ Cfe. PASQUALOTTO, Adalberto. op. cit., p. 223-224 (nota de rodapé 4). 
como indiscutíveis o conhecimento e a aceitação dos mesmos pelo mercado financeiro e pela própria comunidade.

Ademais, impende aduzir que eventual imprecisão no rotular essa obrigação repercussão alguma pode ter na esfera jurídica, inclusive por força do disposto no art. 85 do Código Civil, segundo o qual 'nas declarações de vontade se atenderá mais à sua intenção que ao sentido literal da linguagem'.

Por fim, é de acrescentar-se que, não obstante as cautelas de que precisa munir-se o Judiciário para evitar que os mais poderosos esmaguem ou enfraqueçam ainda mais os hipossuficientes, especialmente na área econômica, não menos certo também é que o Direito, 'cette toujours et jeune chanson', não pode omitir-se ante uma realidade que reclama novas formas de proteção jurídica, sob pena de deixar de cumprir sua missão normativa de disciplinar a vida social.

Do exposto, chega-se à conclusão que, na real verdade, o pretenso 'garante solidário' não passa de um devedor (CPC, art. 568, I) e como tal obrigado, e de forma ainda mais ampla que o fiador, quer por dispensar a anuência do cônjuge (embora incidente a Lei 4.121/62), quer por não dispor do benefício de ordem, com o qual é contemplado o fiador por força de lei (CPC, art. 595; CC, art. 1.491)"”".

Assim, segundo já apontaram os citados precedentes do Superior Tribunal de Justiça, o tribunal tem admitido a existência no sistema de 3 (três) negócios jurídicos de garantia distintos: aval, fiança e garantia solidária.

O aval, conforme já escrevemos, é garantia de natureza cambial; fiança é negócio jurídico que poderá incidir em todo e quaisquer contratos, especialmente nos bilaterais; já a denominada garantia solidária também possui natureza negocial, mas difere substancialmente da fiança porque desde o início da avença o garantidor assume a obrigação de efetuar a prestação prometida ao credor, por ser ele co-devedor, enquanto o fiador, dada a natureza subsidiária desta espécie negocial, será sempre responsável pelo adimplemento de terceiro, mas não co-devedor.

Porém, ainda que sob o aspecto estrutural a fiança e a garantia solidária sejam distintas, entendemos que ambas exercem no sistema a mesma função, qual seja, a de garantir o adimplemento da obrigação, reforçando a possibilidade de o credor vir a ser integralmente satisfeito; assim, tendo em vista a nítida função de garantia de ambos os negócios, entendemos que a fiança nula poderá vir a ser convertida em negócio de garantia atípico, pois a boa-fé objetiva que deve conduzir as partes nas conclusões e execuções dos negócios permite a suposição de que o fim prático a que visavam as partes ao terem concluído o negócio fidejussório teria sido o de garantir, de forma firme e séria, o 
adimplemento do afiançado, razão pela qual se tivessem previsto a nulidade da fiança certamente teriam adotado as cautelas necessárias para obviar as consequências da invalidade ou até mesmo teriam pactuado uma garantia diversa da fiança.

Com efeito, não admitimos que um contrato de grande utilização e importância no Brasil - a fiança - seja utilizado de forma contrária à sua função, que vem a ser a de pôr a salvo o credor dos riscos de sofrer as maléficas consequências do inadimplemento do devedor. Ou quem afiança garante de forma idônea o adimplemento do afiançado, ou melhor seria que fosse excluído tal modelo contratual do sistema por incumprimento da sua função típica.

A bem dizer, o garante que assume a responsabilidade pelo adimplemento alheio o faz independentemente de qualquer nulidade, pois do contrário seria de se admitir que o fiador, ao ter assumido esta condição, prometeu garantir com o seu patrimônio o que já sabia de antemão que jamais poderia fazê-lo, situação esta que estaria a violar um dos pilares do edifício contratual sobre o qual se erigiu o Código Civil de 2002 - o da boa-fé objetiva -, e também por violar uma das principais diretrizes da novel codificação - a da eticidade ${ }^{393}$.

Em conclusão, se em determinado negócio jurídico tiver sido oferecida garantia fidejussória em caráter solidário, a eventual nulidade da avença não beneficiará o fiador porque ocorrerá a conversão da fiança em garantia solidária atípica, passando o fiador a figurar na avença como garantidor solidário; porém, em razão da extinção da fiança estarão extintos os privilégios que acompanhavam a garantia fidejussória, da qual vem a ser o maior exemplo a vedação a formulação de exceção de impenhorabilidade do único imóvel residencial do fiador, por força do disposto no art. 3. ${ }^{\circ}$, VII, da Lei n. ${ }^{\circ} 8.009 / 90^{394}$.

Tendo ocorrido a conversão da fiança em garantia solidária atípica, o credor não mais poderá se valer da penhorabilidade do bem de família do fiador, porque este deixou de ser garantidor fidejussório e assumiu a figura de garantidor solidário.

\footnotetext{
${ }^{393}$ Neste caso, poderia ser admitida, ainda que de lege ferenda, a juridicidade de uma fiança verbal, isto é, não-escrita e formalizada com defeito de forma, uma vez que a conversão do negócio visa proteger a legítima expectativa das partes: "A nulidade em razão de infringência de forma substancial não deve prevalecer quando as circunstâncias qualificadoras da situação recomendarem a conservação do negócio, em razão da confiança despertada em terceiros, e quando ficar caracterizada a boa-fé. Igualmente, quando a nulidade for pleiteada com flagrante abuso do direito, principalmente por uma das partes interessadas, que antes se aproveitou da ausência da forma." (LÔBO, Paulo Luiz Netto. Direito civil: parte geral, cit., p. 251). 394“"Art. $3^{\circ}$ A impenhorabilidade é oponível em qualquer processo de execução civil, fiscal, previdenciária, trabalhista ou de outra natureza, salvo se movido:

(...)

VII - por obrigação decorrente de fiança concedida em contrato de locação." (Grifamos)
} 
Neste caso, se as partes quiseram firmar o negócio com desvio de causa, o negócio dissimulado não poderá ser convertido em outro hipoteticamente querido; já se uma das partes agiu de boa-fé e com desconhecimento da nulidade, enquanto a outra tencionou obter vantagem ilegal, protege-se a boa-fé de um dos contratantes e sanciona-se o contrato por nulo, repondo as partes ao status quo ante. Entretanto, se ambos os contratantes agiram de boa-fé, o ordenamento permite a manutenção do vínculo através do instituto da conversão dos negócios jurídicos previsto no artigo 170 do Código Civil.

\subsection{O contrato de fiança na sociedade massificada e os contratos de consumo}

O método de contratação a que chamamos de despersonalizado é uma realidade inseparável do mundo atual. Se no passado a invitação ao contrato por meio da ofertaaceitação ocorria entre pessoas determinadas, na atualidade o convite à contratação - pelo menos como regra - se dá entre um fornecedor e o mercado, sendo correto dizer que neste caso a aceitação nos moldes clássicos, fundada na manifestação da vontade, não ocorre.

Esta vem a ser a razão pela qual a doutrina costuma denominar a sociedade em que vivemos atualmente de massificada; massificada porque não se considera a individualidade própria dos elementos (rectius, pessoas) que a compõem, mas sim sobreleva notar os elementos em seu conjunto, como se formassem uma massa indivisível, na qual os aspectos particulares de cada um dos seus membros são desconsiderados em prol da suposta homogeneidade desse mesmo conjunto ${ }^{395}$.

"Na sociedade de consumo”, escreve Cláudia Lima Marques 396 , “com seu sistema de produção e distribuição em grande quantidade, o comércio jurídico se despersonalizou e

\footnotetext{
395،IV. A ideia de tráfego negocial de massas permite entender, de modo impressivo, o aumento da actividade jurídica. As pessoas celebram, no seu dia-a-dia, inúmeros negócios de que dependem para uma coexistência inteiramente desprovida de particulares imprevistos. As empresas, por seu turno, concretizam as funções económicas que desenvolvem através de um fluxo contínuo de actos cuja eficácia é a sua própria atividade. Em termos psicológicos, sociológicos ou culturais, seria deslocado pretender encontrar, na antecâmara de cada um dos incontáveis negócios concretizados em cada momento, todo um processo de formação minimamente desenvolvido. A realidade decorre de um modo diferente: os negócios formam-se e executam-se a um ritmo de todo incompatível com um esquema negocial que faculte aos intervenientes um consciente exercício das suas liberdades de celebração e de estipulação. V. Pode considerar-se que as modernas sociedades técnicas assentam num táfego negocial de massas. Este, por seu turno, provoca a erosão dos esquemas negociais(...): as pessoas desenvolvem uma actividade jurídica em que se limitam a aceitar ou recusar certos esquemas que lhes são propostos(...)." (CORDEIRO, António Menezes. Tratado de direito civil português, cit., v. 1, t. 1, p. 595).

${ }^{396}$ In MARQUES, Cláudia Lima. Contratos no Código de Defesa do Consumidor. 5. ed. rev. atual. e ampl. São Paulo: Ed. Revista dos Tribunais, 2005. p. 65.
} 
se desmaterializou. Os métodos de contratação em massa, ou estandardizados, predominam em quase todas as relações contratuais entre empresas e consumidores."

Assim, os novos atores sociais - os empresários - não se preocupam há muito tempo com as necessidades individuais dos consumidores, mas com as do mercado, que por sua vez e contraditoriamente é formado por pessoas! É por esta razão que dizemos que a tônica na sociedade atual é a da contratação despersonalizada estabelecida entre o fornecedor e o mercado. Por isso, o modelo clássico de contrato (fundado na oferta e aceitação pessoais) não sobreviveu à nova feição da sociedade massificada, razão pela qual aos industriais de outrora (ora denominados de empresários) interessava forjar um novo instrumento contratual que lhes permitisse estabelecer um sem-número de relações com um sem-número de contratantes: surgiu o denominado contrato de adesão, o qual representa, sem sombra de dúvidas, a forma mais corriqueira de contratação no mundo atual. E nesse contexto de despersonalização no qual a manifestação de vontade é desconsiderada em prol de uma rapidez maior nas contratações e de uma eficiência ótima que objetiva a redução dos custos empresariais, como ficaria a posição do garante que adere a um contrato massificado (rectius, de adesão)? Haveria nesta hipótese uma real manifestação de vontade fidejussória? Cremos que não.

Destarte, por conta da ausência de qualquer "margem de liberdade” nas contratações massificadas hodiernas, pelo menos sob o ângulo do aderente ${ }^{397}$, é que entendemos que o fundamento jurídico da contratação massificada vem a ser o exercício do poder contratual fático ou jurídico pelo predisponente, geralmente uma sociedade organizada e com poder econômico.

Escrevemos "geralmente" porque o exercício do poder contratual independe do potentado econômico que estiver a ostentar o predisponente: basta que, de fato, em uma determinada situação, uma das partes esteja em condições de, unilateralmente, impor ao aderente as balizas da contratação massificada. Cumpre verificar se na espécie o aderente

\footnotetext{
397،Eles são apenas livres de aderir ao modelo, padrão ou norma que lhes é oferecida, ou de a rejeitar, não de discutirem ou alterarem o conteúdo da proposta. Não há aqui, por conseguinte, a livre discussão entre as duas partes, que salutarmente costumava preceder a fixação do conteúdo do contrato e da qual nascia a seiva ético-jurídico do negócio bilateral. Daí exatamente o nome de contrato de adesão, dado a esse tipo de convenções, que entre nós têm os seus exemplos mais vulgarizados, como vimos, nas várias modalidades do contrato de seguro, em algumas variantes do contrato de transporte (aéreo, marítimo ou terrestre), de fornecimento (de água, energia ou gás), em certas operações bancárias e nas promessas de compra e venda de imóveis." (VARELLA, João de Matos Antunes. Das obrigações em geral. 8. ed. Coimbra: Almedina, v. 1, p. 261 e ss.).
} 
será ou não um vulnerável, isto é, aquele que não titulariza um bargain power (poder de barganha).

Para Jorge Mosset Iturraspe ${ }^{398}$, o homem não é livre para contratar:

"El hombre nos es libre para contratar. Salvo que elija el suicidio. Debe hacerlo para satisfacer necesidades, a diario, mal que le pese." (Grifamos)

No entanto, a maioria dos civilistas pátrios enquadra o fenômeno da contratação massificada na categoria de negócio jurídico. Segundo apontava Orlando Gomes sobre o contrato de adesão ${ }^{399}$,

"É, primeiramente, um negócio jurídico bilateral. Forma-se pelo concurso de vontades destinado à jurisformização do intento empírico das partes, apresentando-se como expressão da autonomia privada."

No mesmo sentir, Pontes de Miranda ${ }^{400}$ doutrinava,

"O fato de alguns contratos perfazerem-se conforme fórmulas rígidas e tarifas não lhes retira a bilateralidade das manifestações de vontade, mesmo quando a lei estabelece a coerção ou constrição a contratar (Kontrakierungszwang).”

Na realidade, Pontes de Miranda, e com ele a maior parte dos doutrinadores, jamais concebeu a contratação massificada fora dos parâmetros clássicos, uma vez que o aderente manifestaria a sua vontade em aderir ou haveria abastração do consentimento; em uma outra situação, como a do menor de dezesseis anos que contrata, a vontade manifestada não seria a dele, mas sim a da pessoa que lhe deu o dinheiro, pois

"a ordem jurídica supõe que alguém que deu o dinheiro queria que o menor incapaz quisesse; portanto, alguém quis ${ }^{401}$.” (Grifamos)

Ao contrário do pensamento pontiano, situa-se a doutrina de Paulo Luiz Netto Lôbo $^{402}$. Em linhas gerais, Paulo Lôbo prega a “não-essencialidade da vontade” nos contratos massificados; a bem dizer, o ordenamento jurídico apanha determinados

\footnotetext{
${ }^{398}$ In MOSSET ITURRASPE, Jorge Mosset. Como contratar en una economia de mercado. Santa Fe: Rubnizal-Culzoni Editores, 1996. p. 178.

${ }^{399}$ In GOMES, Orlando. Contrato de adesão: condições gerais dos contratos. São Paulo: Ed. Revista dos Tribunais, 1972. p. 3.

${ }^{400}$ In PONTES DE MIRANDA, Francisco Cavalcanti. op. cit., t. 38, p. 34.

${ }^{401}$ In Id., loc. cit.

${ }^{402}$ In LÔBO, Paulo Luiz Netto. O contrato: exigências e concepções atuais. São Paulo: Saraiva, 1986. p. 40.
} 
comportamentos sociais fazendo abstração completa da vontade e da capacidade das pessoas que lhes manifestaram. Destarte, dizemos nós, seria contraproducente se o legislador exigisse a manifestação duma vontade livre e soberana em uma seara em que apenas o predisponente manifesta unilateralmente o seu poder contratual. Este excerto de uma das obras de Paulo Lôbo ${ }^{403}$ demonstra a irrelevância da vontade, tomada esta em seus termos clássicos:

\begin{abstract}
"A necessidade de enquadrar os complexos fatos da vida a rígidos e abstratos esquemas conceptuais leva a situações curiosas. Assim, a utilização de transporte pelo menor de dezesseis anos ou pelo louco seria feita com o consentimento dos pais, tutores curadores ou do Estado, mesmo que se trate de menores abandonados ou de órfãos. E mais: se a oferta foi dirigida ao público, quem a aceitaria não é a criança, ou o louco, ou o surdo-mudo que não poderia exprimir a sua vontade. Ou a criança teria pai ou mãe, titular do pátrio poder, ou tutor, ou curador, e esse a deixaria em situação de praticar o ato, que entraria no mundo jurídico como ato-fato jurídico, ou não teria pai ou mãe, nem tutor ou curador, e o serviço ao público ou a oferta ao público implicaria que o Estado permitiu, ou deixou que praticasse.

Convenhamos que é levar às últimas conseqüências o consensualismo: o consentimento tem de existir, mas se não há? Cria-se uma vontade abstrata, etérea, que transcende as pessoas: do agente a seu representante, desde a vontade geral ou presumida do Estado. E se vivêssemos em outras épocas, quem sabe, poderíamos chegar à vontade de Deus (!) à falta de outras."
\end{abstract}

Costumamos dizer que na contratação massificada o legislador não atua visando garantir a manifestação duma "bilateralidade consciente" das partes, para garantir a "manifestação livre e soberana do aderente ao conteúdo contratual imposto pelo predisponente"; na verdade, o legislador atua para "conter os abusos" do predisponente, a fim de garantir as "legítimas expectativas" do aderente, que se consubstanciam na confiança criada em seu favor de que a oferta (rectius, promessa) do predisponente será cumprida tal como veiculada.

A "adesão" da parte não configura exteriorização consciente de vontade, mas submissão às condições preestabelecidas ${ }^{404}$.

Seja como for, ainda que se considere o contrato de adesão como um negócio jurídico, mister se faz que os princípios clássicos do direito civil contratual cedam espaço às novas formulações que se afeiçoem à sociedade em que vivemos: urbana, desigual e

\footnotetext{
${ }^{403}$ In LÔBO, Paulo Luiz Netto. $O$ contrato: exigências e concepções atuais, cit., p. 40.

${ }^{404} \mathrm{Cfe}$. Id. Direito civil: parte geral, cit., p. 241.
} 
despersonalizada, com a predominância dos interesses do mercado sobre o das pessoas individualmente consideradas.

Com tal viragem metodológica, garante-se a continuidade do exercício do poder contratual (corolário da princípio da livre iniciativa, art. 170, caput, CF), inafastável das sociedades modernas, porém sem perder de vista a proteção do aderente, forte no princípio da dignidade da pessoa humana ( $\mathrm{CF}$, art. $1^{\circ}$, III); ora, se o legislador, nos contratos massificados, reduz (nos contratos civis) ou extirpa (nos contratos de consumo ${ }^{405}$ ) o poder da vontade, é indiscutível que o novo edifício do contrato se assenta em novas bases.

Pois bem. O Código Civil de 2002 acarretou a unificação do direito obrigacional privado: as obrigações não-comerciais e as comerciais - hoje rotuladas "de empresa" foram agrupadas sob um mesmo regime, o das obrigações civis.

Assim, cuidou o legislador de 2002 de forjar tipos contratuais que tanto pudessem ser utilizados pelos não-empresários como pelos empresários. E na categoria dos nãoempresários se enquadram tanto as pessoas comuns como os chamados consumidores: aqueles a estabeleceram relações jurídicas gerais entre particulares, pessoas nãoconsumidoras em dada situação casuística; estes a firmarem relações jurídicas especiais denominadas "de consumo" por envolveram, basicamente, um profissional (o fornecedor, o empresário) e um não-profissional (os consumidores).

Esta vem a ser a razão pela qual na atualidade o "contrato são os contratos ${ }^{406 ": ~}$ ainda que os tipos contratuais básicos sejam os mesmos tanto nas relações civis como nas de consumo, terão tratamento jurídico distinto a depender da natureza da relação jurídica subjacente:

(a) Relações Jurídicas de Consumo: incidência da Lei $n^{\circ}$ 8.078/90 (lei especial), principalmente, e subsidiariamente do Código Civil (lei geral).

(b) Relações Jurídicas Civis ou Empresariais: Código Civil (lei geral), principalmente, e subsidiariamente a Lei $\mathrm{n}^{\circ}$ 8.078/90 (lei especial).

Esta aplicação conjunta dos diplomas legais destinados a reger relações jurídicas com finalidades diversas está a indicar que na atualidade a sociedade, pelo menos no

\footnotetext{
${ }^{405}$ Nesse sentido o art. $1^{\circ}$ do Código de Defesa do Consumidor aos estabelecer a natureza cogente das regras e princípios nele previstas.

${ }^{406}$ MARTINS-COSTA, Judith. O método de concreção e a interpretação dos contratos: primeiras notas de uma leitura suscitada pelo Código Civil. In: DELGADO, Mário Luiz; ALVES, Jones Figueirêdo (Coords.). Questões controvertidas no direito das obrigações e dos contratos. São Paulo: Método, 2005. v. 4, p. 133.
} 
campo das práticas contratuais massificadas, caminha para uma padronização: a mesma clásusula contratual porventura considerada abusiva na Lei $n^{\circ}$ 8.078/90 também poderá sê-lo por aplicação extensiva do diploma consumerista às relações civis.

E isto se explica porque na contratação massificada não há espaço para reflexão, negociação, discussão prévia: dada a uniformização das práticas contratuais, fruto da já apontada exigência do mercado, o mesmo contrato imposto às relações interempresariais é também imposto às relações civis ou de consumo.

Não haverá contaminação do direito civil pelo de consumo, ou do direito de consumo pelo civil: a tendência é do diálogo das fontes, técnica tão decantada pela jurista Cláudia Lima Marques ${ }^{407}$, pois os sub-sistemas jurídicos se manterão em constante comunicação, em constante diálogo, pois provocarão constantes influências recíprocas.

E este sistema de constantes influências recíprocas faz lembrar a visão autopoiética do direito, na qual o intérprete passa a exercer um papel de extremada importância. Nesse sistema a função do intérprete seria de vital importância, pois a ele caberia a manipulação da linguagem técnico-argumentativa que permitiria a aplicação da lei a um caso nela não previsto inicialmente, de modo que a completude do sistema restaria preservada. Segundo aponta o jurista alemão Karl-Heinz Ladeur ${ }^{408}$, enquanto o sistema jurídico na visão tradicional $^{409}$ teria por pressuposto lógico a sua unidade sistemática, que levaria a uma constante preocupação em se preservar o conteúdo das regras estabelecidas, o seu conceito autopoiético baseia-se, de maneira geral, na suposição de que haveria dentro do sistema uma necessária continuação ${ }^{410}$, no sentido de que os elementos de um sistema se autoreproduziriam $^{411}$ em um contínuo processo que ligaria evento a evento, operação a operação, em um modo de diferenciação, razão pela qual nesta abordagem o sistema jurídico se diferenciaria do ambiente em que estivesse inserido, bem como de outros sistemas (p. ex. econômico, social etc.) pelos eventos e operações internos de autoreprodução dos seus elementos. Como se percebe, na visão autopoiética cada um dos

\footnotetext{
${ }^{407}$ In MARQUES, Cláudia Lima. Manual de direito do consumidor. São Paulo: Ed.Revista dos Tribunais, 2008. p. 87 e ss..

${ }^{408}$ In LADEAUR, Karl-Heinz. The theory of autopoiesis as an approach to a better understanding of postmodern law: from the hierarchy of norms to the heterarchy of changing patterns of legal interrelationships, Fiesole, European University Institute, EUI Working Paper on Lau n. 99/3.

${ }^{409}$ Um conjunto de regras, princípios e decisões judiciais.

410 “necessary continuation" (In art. cit., p. 9).

411 “a self-production of a system (...) on a process linking event to event - operation to operation - in a differential mode." (In art. cit., p. 10).
} 
sistemas sociais seria funcionalmente diferenciado, cada um contendo uma finalidade distinta, porém complementar a do outro.

E é em razão das influências sistemáticas recíprocas, em nosso sentir também denominada como técnica de diálogo das fontes, que entendemos ter natureza autopoiética, parece ser a tendência atual do Superior Tribunal de Justiça, que tem mitigado a distinção dos regimes legais havidos entre os contratos submetidos ao Código Civil e ao Código de Defesa do Consumidor, os tendo aglutinado sob uma nota específica: a da vulnerabilidade.

Com isso, a um contrato que seria submetido apenas ao regime da igualdade formal do Código Civil, aplicar-se-iam também as regras do Código de Defesa do Consumidor, fundado na igualdade material, se um dos contratantes fosse qualificado pelo signo da vulnerabilidade. Sobre o tema em pauta, cumpre transcrever parcialmente a fundamentação exposta no acórdão proferido pela $3^{a}$ Turma do STJ nos autos do REsp $n^{\circ}$ 687.322-RJ, relatados pelo Min. Carlos Alberto Menezes Direito, j. 27/09/06, verbis:

"O critério fundamental, sem dúvida, para a melhor identificação da existência de relação de consumo é o da vulnerabilidade, nas suas diversas projeções, porque permite enlaçar o Código de Defesa do Consumidor com a teoria moderna dos contratos que finca raízes mais fortes na boa-fé e na destinação social. Não é por outra razão que o Código Civil de 2002, diferentemente do anterior, consagra as duas primeiras normas ao tema, dispondo no art. 421 que a "liberdade de contratar será exercida em razão e nos limites da função social do contrato", e, no art. 422, que os "contratantes são obrigados a guardar, assim na conclusão do contrato, como em sua execução, os princípios de probidade e boa-fé" e, ainda, no art. 423 , que a existência de cláusulas ambíguas ou contraditórias em contratos de adesão conduz a uma interpretação mais favorável ao aderente, o que também está previsto no art. 47 do Código de Defesa do Consumidor.

Isso quer dizer que o novo Código Civil pôs a disciplina dos contratos também sob a égide de princípios que estão entranhados no Código de Defesa do Consumidor para proteger o consumidor. Modernamente, portanto, seja no regime do Código Civil seja no regime do Código de Defesa do Consumidor, há proteção específica para assegurar o necessário equilíbrio contratual partindo-se do pressuposto de que o contrato não pode ser instrumento de proteção a uma das partes contratantes em detrimento da outra. Dessa forma, poder-se-á considerar no exame dos contratos sob o ângulo do Código Civil aquelas regras estabelecidas no art. 51 do Código de Defesa do Consumidor que cuida das cláusulas abusivas, sem perder de vista o conceito de vulnerabilidade como base para a identificação da relação de consumo, com menor peso, portanto, para o conceito de destinatário final, levandose em conta o que dispõe o art. 29 do Código de Defesa do Consumidor.

Nessa direção, veja-se mais uma vez a lição de Cláudia Lima Marques:

"Certo é que a 'vulnerabilidade', no dizer de Antônio Hermann Benjamin, é a 'peça fundamental' do direito do consumidor, é o 'ponto de 
partida' de toda sua aplicação aos contratos. Em se tratando de vulnerabilidade fática, o sistema do CDC a presume para o consumidor não-profissional (o advogado que assina um contrato de locação abusivo porque necessita de uma casa para a sua família perto do colégio dos filhos), mas não a presume para o profissional (o mesmo advogado que assina o contrato de locação comercial abusivo, para localizar o seu escritório mais próximo do fórum), nem a presume para o consumidor pessoa jurídica (veja art. 51, I, in fine, do CDC). Isto não significa que o Judiciário não possa tratar o profissional de maneira 'equivalente' ao consumidor, se o profissional efetivamente provar a sua vulnerabilidade, que levou ao desequilíbrio contratual" (cit., pág. 335).

A prevalência há de ser, portanto, um adequado balanceamento entre os conceitos de vulnerabilidade e de destinatário final, aquele sempre dependente da prova existente e o fato de não ser possível ampliar sem lastro a aplicação do Código de Defesa do Consumidor. De fato, assim deve ser pela só razão de que o direito civil geral, ou seja, aquele que está subordinado ao Código Civil, e o direito civil especial, assim, aquele que está ao alcance do Código de Defesa do Consumidor, devem ser preservados para garantir a pureza da relação de consumo, já agora considerando que aquele que não pode ser configurado como consumidor encontra no Código Civil de 2002 uma proteção contratual que tem ampla conexão com o Código de Defesa do Consumidor. Diria, até mesmo com risco de exagero, que o direito civil geral moderno está inspirado na cláusula geral de boa-fé que o Código de Defesa do Consumidor elegeu como fonte imperativa para a identificação das cláusulas abusivas. Há, portanto, um ingrediente de excepcional relevância para a sociedade moderna que é o encontro dos contratos no mesmo leito da proteção do contratante mais fraco na relação, mas, ao mesmo tempo, porque a noção de boa-fé não é unilateral, protegidas as partes contratantes sempre por esse salutar principio que deve estar na raiz de todas as relações humanas. A diferença substancial reside na circunstância de que o direito civil geral já agora parte do pressuposto de que a liberdade de contratar tem limite na função do contrato e na interpretação mais favorável ao aderente quando se trate de contrato de adesão diante de cláusulas ambíguas e contraditórias. Não se diga que há distância entre o conceito de cláusula abusiva, consagrado no art. 51 do Código de Defesa do Consumidor, e este de cláusula ambígua ou contraditória. E isso pela só razão de que, tecnicamente, a disposição do Código Civil é mais ampla, mas, em contrapartida, não é causa de nulidade, facultando, apenas, a interpretação mais favorável ao aderente, enquanto no art. 51, caracterizada a cláusula abusiva em contratos relativos ao fornecimento de produtos e serviços, torna-se imperativo reconhecer a nulidade. Ocorre que em ambas as situações a finalidade da regra é garantir a igualdade de contratar e, por conseqüência, o equilíbrio das partes na relação contratual. Em certa medida, essa circunstância benfazeja de pôr o direito civil geral no rumo mais moderno da relação contratual, isto é, que os contratos estarão protegidos contra a disparidade das partes contratantes, estabilizados por sua função social e pela cláusula da boa-fé, que está presente também como critério para a interpretação dos negócios jurídicos (art. 113 do Código Civil). Nessa matéria, considerando a confluência entre o Código de Defesa do Consumidor e o Código Civil de 2002, é necessário ter presente que o primeiro, em matéria contratual, como mostra Cláudia Lima Marques, "representa a evolução do pensamento jurídico para uma teoria 
contratual que entende o contrato em termos de sua função social", sendo que "o problema é o desequilíbrio de forças dos contratantes.

Uma das partes é vulnerável (art. $4^{\circ}$, I) é o pólo mais fraco da relação, pois não pode discutir o conteúdo do contrato ou a informação recebida; mesmo que saiba que determinada cláusula é abusiva, só tem uma opção, 'pegar ou largar', aceitar o contrato nas condições que lhe oferece o fornecedor ou não aceitar e procurar outro fornecedor.

Sua situação é estruturalmente e faticamente diferente da do profissional que oferece o contrato. Este equilíbrio fático de forças nas relações de consumo é a justificativa para um tratamento desequilibrado e desigual dos co-contratantes, protegendo o direito daquele que está na posição mais fraca, o vulnerável, o que é desigual fática e juridicamente" (Cláudia Lima Marques, Antonio Hermann V. Benjamin e Bruno Miragem, Comentários ao Código de Defesa do Consumidor, RT, $2^{\mathrm{a}}$ ed., 2006, págs. 85/86).

Extrai-se aqui, pelo menos na minha convicção, que o tratamento das relações contratuais a partir do Código Civil de 2002 está bem harmonioso seja no campo especial do consumo seja no campo geral das práticas negociais em geral.Tanto em um como em outro, a proteção à parte vulnerável está presente, havendo, sem dúvida, distinções em muitos aspectos como, por exemplo, no das presunções sobre a vulnerabilidade. Mas o que é importante salientar é que a interpretação dos contratos não necessita mais buscar o abrigo do Código de Defesa do Consumidor para proteger o equilíbrio de forças entre as partes contratantes, porquanto o Código Civil tem suficiente instrumento técnico para calçar as decisões judiciais que ao longo do tempo foram construídas com esse sentido e alcance.” (Grifamos)

Portanto, o contrato de fiança porventura subscrito no bojo de um contrato de adesão será regido em conjunto pelo Código Civil e pelo Código de Defesa do Consumidor, pois o fiador neste caso seria um vulnerável por excelência: prometeu que o devedor principal adimpliria, sem ter recebido nada em troca. O fiador titularizaria a haftung sem que titularizasse a schuld.

Dessa forma, demonstrada a vulnerabilidade do fiador em determinado contrato massificado, bem como se acaso for decretada a nulidade ou vier a ser desnaturada alguma das cláusulas do contrato, o fiador haverá de ser beneficiado, por força inclusive do caráter acessório da garantia fidejussória. Portanto, a contrato de fiança nesta espécie de contratação em massa representa um risco muito grande para o credor, em face da posição adotada nesta dissertação, que considera o garante um vulnerável por excelência nos contratos de adesão.

Por fim, ainda que o fiador não se enquadre no conceito de consumidor descrito no artigo $2^{\circ}$, do CDC (consumidro stricto sensu), certamente a ela seria aplicável o conceito 
de consumidor previsto no artigo 29 (consumidor lato sensu ou equiparado), do mesmo diploma legal. Trata-se atualmente da mais importante norma extensiva do campo de aplicação do Código de Defesa do Consumidor às relações civis stricto sensu, regidas que são basicamente pelo Código Civil $^{412}$ :

"Art. 29. Para os fins deste Capítulo e do seguinte, equiparam-se aos consumidores todas as pessoas determináveis ou não, expostos às práticas nele previstas".

Com efeito, o dispositivo legal em questão sempre gerou inúmeras controvérsias, dado o seu amplo espectro de incidência: todas as pessoas expostas a uma das práticas nele previstas estariam sob o manto protetor do CDC.

Para alguns doutrinadores, o dispositivo legal teria dito mais do que tencionava, pois pretendia apenas reforçar a proteção do consumidor no campo contratual, das práticas comerciais e da publicidade.

Todavia, em que pesem as considerações em contrário, entendemos que o artigo 29, do Código de Defesa do Consumidor está a representar verdadeira regra de sobredireito, alcançando até os contratos interempresariais; é, na verdade, uma regra de extensão da Lei n. ${ }^{\circ} 8.078 / 90$ às situações que apenas seriam regidas, em tese, pelo Código Civil.

Em primeiro lugar, porque o artigo 29, do CDC, ao ter veiculado a equiparação legal de consumidor apenas restringiu a incidência da Lei n. ${ }^{\circ}$ 8.078/90 aos capítulos nele indicados. Com efeito, essa é a única restrição existente.

Em segundo lugar, o artigo 29, do Código de Defesa do Consumidor, conforme entendemos, teve por finalidade inserir no direito privado a moderna noção do direito obrigacional $^{413}$, a qual tem por objeto manter o equilíbrio e a proporcionalidade dos pactos privados. E foi justamente isso que ocorreu: o artigo 29 buscou humanizar e flexibilizar os

\footnotetext{
${ }^{412}$ MARQUES, Cláudia Lima. Contratos no Código de Defesa do Consumidor. 3. ed. São Paulo: Ed. Revista dos Tribunais, 1998. p. 157.

${ }^{413}$ Desde os anos 50, com juristas como Karl Larenz, vêm-se trazendo novas noções acerca do direito das obrigações. Larenz dizia que "o direito dos contratos não surge exclusivamente dos princípios da autodeterminação e da autovinculação, como posto no liberalismo; agregam-se a estes, os transformando, os princípios da equivalência objetiva e da proporcionalidade medida, os quais funcionam, no aspecto positivo, para conformar o 'direito legal' que integra o contrato (aí incidindo os princípios básicos da tutela à boa-fé a rejeição ao abuso) e, no aspecto negativo, para impor limites ao próprio conteúdo contratual, infletindo nas hipóteses extremas - e todavia, não excepcionais - da laesio enormis e do desequilíbrio provocado pelas 'condições gerais dos negócios', tornando possível a revisão judicial do contrato para o restabelecimento da comutatividade, ou relação de equivalência originariamente fixada." (JUDITH H. MARTINS COSTA, Apud CASADO, Márcio Mello. O leasing e a variação cambial. Revista dos Tribunais, São Paulo, n. 763, p. 87, 1999).
} 
princípios seculares do direito privado clássico, consentâneo aos princípios vigorantes no direito contratual moderno: autonomia privada, boa-fé objetiva e função social do contrato.

Nesse sentir o pensamento de Antonio Janyr Dall'Agnol Junior ${ }^{414}$ :

"Noticia Antonio Benjamin, incansável batalhador pela causa do "consumerismo" e jurista experimentado, que "o conceito do art. 29 integrava, a princípio, o corpo do art. $2^{\circ}$. Como consequiência de lobby empresarial que queria eliminá-lo por completo, foi transportado, por sugestão minha, para o Capítulo V".

"Não houve qualquer prejuízo - prossegue o eminente autor. Mantém-se, não obstante a fragmentação do conceito, a abrangência da redação primitiva. O consumidor é, então, não apenas aquele que 'adquire ou utiliza produto ou serviço' (art. $2^{\circ}$ ), mas igualmente as pessoas expostas às práticas previstas no Código (art. 29). Vale dizer: pode ser visto concretamente (art. $2^{\circ}$ ) ou abstratamente (art. 29). No primeiro caso, impõe-se que haja ou esteja por haver aquisição ou utilização. Diversamente, no segundo, o que se exige é a simples exposição à prática, mesmo que não se consiga apontar, concretamente, um consumidor que esteja em via de adquirir ou utilizar o produto ou o serviço"

Em outros termos, estende-se a rede protetiva àquele que se encontra em situação de vulnerabilidade - de modo restrito, pois limitada ao conjunto de regras que compreendem os capítulos V e VI-, pouco relevando que não haja relação estritamente de consumo.

Esta tem sido a tendência jurisprudencial dos tribunais gaúchos, conforme se observa, para lembrar apenas os primeiros, de julgamentos publicados na Revista de Direito do Consumidor, em seus números 6 e 9. Em ambos os casos, cuidava-se de negócio jurídico de financiamento, figurando, de uma lado, instituição financeira, e, de outro, pequena empresa; nos dois julgamentos foram invalidadas, por abusivas, cláusulas contratuais, invocado o art. 51 do CDC; as cláusulas previam, em contrato de mera adesão, possibilidade de variação da taxa de juros pela predisponente." ${ }^{, 415}$ (Grifamos)

Como se vê, a técnica de equiparação de determinadas pessoas a consumidores adotada pelo Código de Defesa do Consumidor em seu artigo 29 permite a sua aplicação até mesmo às hipóteses em que não haja uma relação de consumo propriamente dita aquisição ou utilização de produtos ou serviços na condição de destinatário final -, o que representa grande avanço no direito pátrio, eis que visa inibir a utilização do instrumento contratual, máxime os contratos de adesão, como forma de prepotência, de pressão, de abuso da parte econômica e tecnicamente mais forte contra aquela que não se encontra no

\footnotetext{
${ }^{414}$ In DALL'AGNOL JUNIOR, Antonio Janyr. Direito do consumidor e serviços bancários e fnanceiros aplicação do CDC nas atividades bancárias - Revista de Direito do Consumidor, São Paulo, n. 17, p. 12, 1998.

${ }^{415}$ Id. Ibid., p. 13 e ss..
} 
mesmo pé de igualdade, afastando o denominado take it or leave it basis, ou seja, na base de pegar ou largar!

O art. 29 supera, portanto, os estritos limites da definição jurídica de consumidor para imprimir uma definição de política-legislativa! Parece-nos que, para harmonizar os interesses presentes no mercado de consumo, para reprimir eficazmente os abusos do poder econômico, para proteger os interesses econômicos dos consumidores-finais, o legislador concedeu um poderoso instrumento nas mãos daquelas pessoas (mesmo agentes econômicos) expostas às práticas abusivas. Estas, mesmo não sendo "consumidores stricto sensu”, poderão utilizar das normas especiais do CDC, de seus princípios, de sua ética de responsabilidade social no mercado, de sua nova ordem pública, para combater as práticas comerciais abusivas! ${ }^{416}$

Assim, qualquer pessoa exposta a uma prática comercial estabelecida no Código de Defesa do Consumidor, tais como oferta, publicidade, práticas abusivas, cobrança de dívidas e bancos de dados e cadastros de consumidores, bem como qualquer pessoa que faça um contrato portador de cláusulas abusivas ou que se submeta à aceitação de um contrato de adesão, é considerada consumidor e, portanto, está apta a agir como tal, fazendo uso das normas do CDC para defender seus direitos. ${ }^{417}$

No mesmo sentido é a doutrina Nelson Nery Júnior ${ }^{418}$ :

"Muitos dos preceitos agora positivados pelo Código de Defesa do Consumidor já se encontravam no ordenamento jurídico, sob a forma de princípios gerais de direito, como, por exemplo, a cláusula geral de boafé, o princípio da boa-fé, o princípio da interpretação mais favorável ao aderente (interpretatio contra stipulatorem) etc.

$\mathrm{Na}$ verdade, o CDC veio consolidar muitas das teses já sufragada pela nossa doutrina e nossa jurisprudência. De outro lado, as regras gerais sobre contratos de consumo estatuídas no CDC são de sobredireito, aplicáveis, portanto, a todos os ramos do Direito Privado, ainda que não se trate de relação de consumo em sentido estrito.

Num contrato civil seria válida cláusula que deixasse apenas a um dos contratantes, unilateralmente, a fixação do preço ou do reajuste das prestações? A respostas é negativa. Essa cláusula é inválida em qualquer contrato, independentemente de ser ou não relação de consumo.

Destarte, a teoria geral dos contratos criada pelo capítulo da proteção contratual do Código de Defesa do Consumidor, porque encerra regras

\footnotetext{
${ }^{416}$ MARQUES, Cláudia Lima. Contratos no Código de Defesa do Consumidor, cit., p. 157.

${ }^{417}$ NOVAIS, Alline Arquette Leite. A teoria contratual e o código de defesa do consumidor. São Paulo: Ed. Revista dos Tribunais, 2001. p. 142.

${ }^{418}$ NERY JUNIOR, Nelson. Código brasileiro de defesa do consumidor. 6. ed. rev. atual. e ampl. Rio de Janeiro: Forense Universitária, 1999. p. 470-471.
} 
de sobredireito, deve ser aplicada a toda e qualquer relação jurídica de Direito Privado, seja civil, comercial ou de consumo.

Aliás, a tendência mundial é toda nesse sentido, como se pode ver na lei alemã sobre condições gerais dos contratos (AGB-Gesetz, de 9.12.76), que incide sobre todos os contratos celebrados naquele país e não apenas nas relações de consumo." (Grifamos)

Em conclusão, as fianças prestadas em contratos de consumo, especialmente se forem de adesão, deverão ser casuisticamente ponderadas a fim de serem afastados os abusos eventualmente praticados pelos credores, uma vez que o caráter benéfico e intuitu personae da fiança colocam o garante em uma posição de total vulnerabilidade nas contratações despersonalizadas. 


\section{O CONTRATO DE FIANÇA À LOCAÇÃO}

No Brasil o contrato de fiança possui ampla utilização nas locações de imóveis urbanos regidas na Lei $n .^{\circ} 8.245 / 91$, diploma este que veio a sofrer profunda reforma pela Lei n. ${ }^{\circ}$ 12.112, de 9 de dezembro de 2009, que será analisada no item 7 desta dissertação.

E em razão da ampla utilização da fiança como garantia contratual de locações urbanas, o fio condutor das idéias expostas e defendidas no presente capítulo foi o de buscar apontar os problemas que cercam várias situações comumente enfrentadas pelos operadores de direito nas demandas judiciais e que ainda não receberam da doutrina o devido sopesamento, pois os manuais que se dedicam ao estudo da fiança no Código Civil de 2002 ainda analisam as regras pertinentes a este negócio neste diploma à luz da experiência haurida nos longos anos em que vigeu o Código Civil de 1916, metodologia esta que não pode desprezar a profunda alteração a que a sociedade brasileira vem sendo submetida ao longo dos anos e que causa distorções interpretativas ainda não apreendidas pelos operadores do sistema normativo.

\subsection{A dinâmica contratual nas relações locatícias e a Lei $^{\circ} \mathbf{8 . 2 4 5 / 9 1}$}

O artigo 37 da Lei n. ${ }^{\circ} 8.245 / 91$ prevê 4 (quatro) modalidades de garantia que poderão ser exigidas pelo locador do inquilino de imóvel urbano:

a) caução; b) fiança; c) seguro de fiança locatícia; d) cessão fiduciária de quotas de fundo de investimento.

Das modalidades previstas a fiança ainda vem a ser a mais exigida pelos locadores, quer pelo prestígio que sempre desfrutou na sociedade brasileira, inclusive porque na maior parte das vezes o custo da sua outorga é inexistente: os negócios fidejussórios são geralmente gratuitos, pois neles quase sempre figuram familiares próximos ou amigos de longa data.

Apesar do prestígio que ainda goza entre os locadores, a fiança tem se mostrado um contrato de altíssimo risco tanto para credores quanto para fiadores, principalmente pela insegurança jurídica que tem grassado nesse campo, haja vista as abruptas mudanças de 
orientação que a jurisprudência, especialmente do Superior Tribunal de Justiça sofreu de forma abrupta e em um campo tão sensível.

$\mathrm{Na}$ atualidade a fiança é um risco muito alto para ser assumido, até pela ausência de decisões judiciais que poderiam nortear e balizar a atuação das partes em questões de extrema importância; uma delas, segundo pensamos, vem a ser a dos limites de exoneração do fiador fundado no artigo 835 do Código Civil de 2002, hipótese esta cuja posição já apresentamos.

No presente Capítulo procuraremos apresentar as questões mais sensíveis e tormentosas relativas à fiança prestada em contrato de locação de imóvel urbano, indicando as posições interpretativas consolidadas e apontando o seu eventual acerto ou desacerto.

\subsection{A posição do fiador em face da relação locatícia: a Súmula 268 do STJ}

A súmula 268 do STJ foi publicada em 29/05/2002 e contém a seguinte redação, verbis:

"O fiador que não integrou a relação processual na ação de despejo não responde pela execução do julgado."

Em outras palavras, a súmula 268 contém o seguinte enunciado: o fiador que não figurou na demanda de despejo ou outra qualquer como réu não poderá sofrer a execução da sentença por ser terceiro que não se submete à eficácia da coisa julgada porventura a vincular locador e inquilino.

A razão de ser da súmula em comento foi a de evitar que a figura da cientificação, bastante difundida em sede de demandas de despejo por falta de pagamento, fosse equiparada à citação, ato inicial de comunicação processual dirigido ao réu para informá-lo do ajuizamento de uma demanda contra si.

Com efeito, a figura da cientificação foi prevista no artigo $59, \S 2 .^{\circ}$ da Lei $\mathrm{n} .^{\circ}$ $8.245 / 91^{419}$, e teve por finalidade levar ao conhecimento de eventuais sublocatários do imóvel locado pelo sublocador que uma demanda de despejo fora contra este ajuizada.

\footnotetext{
419، § $2^{\circ}$ Qualquer que seja o fundamento da ação dar-se-á ciência do pedido aos sublocatários, que poderão intervir no processo como assistentes."
} 
Assim, como o sublocatário não figura como parte na relação locatícia originária o legislador entendeu por bem criar figura diversa da citação, cuja finalidade principal vem a ser a de permitir que o réu ou interessado duma demanda possa dela tomar conhecimento formal e vir a integrá-la ${ }^{420}$ se assim o quiser.

E de acordo com a diretriz adotada na Lei n. ${ }^{\circ}$ 8.245/91, em face da ação de despejo os sublocatários, apesar de claramente terem assumido a condição de terceiros interessados $^{421}$, dela não seriam réus porque não participaram do contrato de locação firmado entre locador e locatário, in casu também sublocador.

Todavia, sendo nítido o prejuízo que os sublocatários sofreriam com a eventual decretação de despejo do imóvel locado e por eles sublocado, entendeu por bem o legislador garantir-lhes o acesso aos autos a partir da sua cientificação da demanda, de maneira que poderiam, se assim quisessem, assumir a condição de assistentes.

Frise-se, por oportuno, que ante a inadimplência do inquilino (sublocador) perante o locador os sublocatários não assumiriam a condição de co-devedores ou responsáveis pela obrigação não-cumprida, de modo que a sua esfera jurídica neste caso não seria atingida. Entretanto, os sublocatários certamente serão atingidos pela eficácia jurídica da sentença que vier a decretar o despejo, pois a ordem de desocupação contida na sentença se presta a ser executada em relação ao imóvel e não à pessoa do inquilino ${ }^{422}$. Esta vem a ser a razão pela qual os sublocatários não assumem a condição de co-devedores solidários ou até mesmo subsidiários das dívidas havidas entre o inquilino e o locador, a este título nada podendo thes ser exigido pelo credor.

Portanto, a figura da cientificação apenas dirigir-se-ia aos sublocatários e jamais aos fiadores, sendo figura específica e restrita de comunicação processual.

Mesmo assim, em inúmeras ações de despejo por falta de pagamento a tramitarem pelos foros brasileiros os locadores demandam única e exclusivamente contra os

\footnotetext{
${ }^{420}$ Código de Processo Civil: “Art. 213. Citação é o ato pelo qual se chama a juízo o réu ou o interessado a fim de se defender."

${ }^{421}$ Em comentários ao artigo 304 do Código Civil doutrinam Gustavo Tepedino e Anderson Schreiber: "É preciso que o terceiro possa sofrer, com o inadimplemento, os ônus da relação obrigacional ou algum efeito negativo sobre situação jurídica de que seja titular." (In TEPEDINO, Gustavo; SCHREIBER, Anderson. Código Civil comentado, cit., v. 4, 198).

${ }^{422}$ É muito comum ovirmos a afirmação de que determinada pessoa foi despeja do imóvel ou até mesmo sofreu o despejo; entretanto, a bem dizer, a sentença que decreta o despejo tem por finalidade autorizar que o imóvel locado seja desocupado e entregue ao locador livre de quaisquer pessoas e coisas; se a ordem de despejo fosse dirigida às pessoas que ocupavam o imóvel - isto é, se ocorresse o despejo da pessoa do inquilino -, necessário seria que todas elas, independentemente de terem figurado ou não no contrato de locação, fossem citadas da demanda, pois eventual ordem de desocupação a elas seria dirigida.
} 
inquilinos, porém requerem que os fiadores sejam cientificados da demanda. Esta figura esdrúxula de comunicação processual acabou por resultar na edição da súmula 268 do STJ, porque na própria Lei $n .^{\circ} 8.245 / 91$ o legislador autorizou que os pedidos de despejo por falta de pagamento e de cobrança de aluguel fossem cumulados e dirigidos contra locatário e fiadores, com as seguintes peculiaridades que se afastaram completamente do sistema adotado pelo Código de Processo Civil em seu artigo $292^{423}$ :

a) enquanto o pedido de despejo é dirigido apenas contra o inquilino, o pedido de cobrança de aluguéis é dirigido contra este e os fiadores, razão por que a sentença que vier a acolher ambas as pretensões será composta por dois capítulos ${ }^{424}$ claros e precisos: enquanto o despejo atingirá apenas o inquilino e as pessoas a ele vinculadas (familiares ou eventuais moradores do imóvel), a condenação ao pagamento dos aluguéis vencidos e vincendos até a desocupação do imóvel será executada contra o inquilino (mas neste caso não contra os seus familiares ou eventuais moradores do imóvel) e os fiadores.

b) proferida a sentença que decretou o despejo do imóvel contra o inquilino e condenou este e os fiadores ao pagamento dos aluguéis e encargos vencidos e vincendos, se acaso apenas os fiadores manifestarem recurso contra a sentença, deixando o inquilino de fazê-lo, o capítulo relativo ao despejo transitará em julgado; nesta hipótese, se o locador não agir para instaurar a execução provisória do despejo do imóvel, com o nítido interesse de se locupletar às custas dos garantes, estarão os fiadores autorizados a promoverem o despejo provisório do imóvel, notadamente porque no direito civil contemporâneo não se tolera o abuso do direito, a teor do artigo 187 do Código Civil de 2002, quer porque o artigo 834 do Código Civil de 2002 outorga, segundo entendemos, legitimidade ativa extraordinária para que os fiadores atuem na omissão abusiva dos locadores ${ }^{425}$, bem como porque o credor deve agir para mitigar o próprio prejuízo.

\footnotetext{
${ }^{423}$ Código de Processo Civil: “Art. 292. É permitida a cumulação, num único processo, contra o mesmo réu, de vários pedidos, ainda que entre eles não haja conexão.

$\S 1^{\circ}$ São requisitos de admissibilidade da cumulação:

I - que os pedidos sejam compatíveis entre si;

II - que seja competente para conhecer deles o mesmo juízo;

III - que seja adequado para todos os pedidos o tipo de procedimento.

$\S 2^{\mathrm{o}}$ Quando, para cada pedido, corresponder tipo diverso de procedimento, admitir-se-á a cumulação, se o autor empregar o procedimento ordinário." (Grifamos) No sistema do Código de Processo Civil a cumulação de pedidos diversos somente é autorizada quando for dirigida a um mesmo réu, porém não a réus diversos, situação esta que foi excepcionada expressamente pelo artigo 62, I, da Lei n. ${ }^{\circ}$ 8.245/91.

${ }^{424}$ Conceituam-se estes como as partes em que ideologicamente se decompõe o decisório de uma sentença ou acórdão, cada uma delas contendo o julgamento de uma pretensão distinta. (Cfe. DINAMARCO, Cândido Rangel. Instituições de direito processual civil. São Paulo: Malheiros Ed., 2001. v. 3, p. 663).

${ }^{425}$ Compartilha do nosso entendimento José Maria Tesneiner: “Ação de despejo proposta pelo fiador do inquilino e ação de consignação em pagamento de alugueres, proposta contra a imobiliária, seriam
} 
c) cientificação de fiadores em ação de despejo é medida esdrúxula e sem qualquer eficácia jurídica, posto que a figura da cientificação apenas se dirige aos eventuais sublocatários que estejam a ocupar o imóvel locado, por força do artigo $59, \S 2 .^{\circ}$ da Lei n. ${ }^{\circ}$ $8.245 / 91$.

\subsubsection{A majoração de aluguéis sem a participação do fiador: princípio da redução}

Outro tema que está vinculado ao da ausência de participação do fiador na demanda promovida contra o devedor, objeto de preocupação da já comentada Súmula 268 do Superior Tribunal de Justiça, é o de se saber se a eventual majoração de aluguéis em sede de ação revisional $e x$ arts. 68 a 70 da Lei n. ${ }^{\circ} 8.245 / 91$ sem a participação do garante teria o condão de excluir a responsabilidade do fiador sobre todo o aluguel estabelecido no processo ou reduzir a sua responsabilidade ao montante originariamente garantido com a exclusão ou extirpação do excesso decorrente da majoração. Em nosso sentir, o artigo 823 do Código Civil veicula o princípio da reduzibilidade, o qual permite restringir as obrigações decorrentes de uma fiança que porventura se tornou mais onerosa do que a dívida afiançada aos limites originariamente assumidos pelo fiador. Assim sendo, a fiança agravada não será nula, mas apenas o excesso decorrente da oneração será ineficaz (o Código Civil menciona equivocadamente nulidade) ${ }^{426}$, razão pela qual o débito que se manteve nos limites da garantia fidejussória poderá ser exigido do fiador.

exemplos possíveis de falta de legitimação para a causa, pois locador e locatário são ordinariamente os legitimados para as ações relativas à locação. Mas cuidado! Pode haver surpresas. Assim, Alessandro Schirrmeister Segalla sustenta, com bons argumentos, a possibilidade de a ação de despejo ser proposta pelo fiador do inquilino, na qualidade de substituto processual do locador, para o que invoca o disposto no artigo 1.498 do Código Civil: "Quando o credor, sem justa causa, demorar a execução iniciado contra o devedor, poderá o fiador, ou o abonador (art. 1.482), promover-lhe o andamento" (SEGALLA, Alessandro Schirrmeister. Da possibilidade de utilização da ação de despejo pelo fiador do contrato de locação, cit., p. 22-41). Recordo-me, por outro lado, de haver admitido ação de consignação em pagamento proposta contra imobiliária, dado ter sido ela apontada, no contrato de locação, como a pessoa a quem deveriam ser pagos os alugueres; um bom exemplo de substituição processual no pólo passivo da relação processual. A legitimidade pode eventualmente ser negada, em ambas as hipóteses. Mas pode ser também afirmada. Resta apenas a certeza da incerteza." (In SEGALLA, Alessandro Schirrmeister. Legimitação extraordinária e relações de locação. Disponível em: <http://www.tex.pro.br/>. Acesso em: 24 ago. 2009).

${ }^{426}$ Conforme sustenta PASQUALOTTO, Adalberto, "Se acontecer, ou se o fiador se obrigar em condições mais onerosas que o devedor, o excedente da fiança será ineficaz, mantendo-se a eficácia na parte coincidente com a obrigação principal. Apesar de o texto do art. 823 afirmar que a fiança excedente "não valerá senão até o limite da obrigação principal”, não se trata de invalidade, mas de simples ineficácia, sendo desnecessária qualquer adaptação contratual." (In PASQUALOTTO, Adalberto. op. cit., p. 243). (Grifamos) 
Segundo doutrinava Pontes de Miranda ${ }^{427}$,

"Se a fiança vai além do quanto da dívida e seus acessórios, há o princípio da reduzibilidade: o excesso está fora da garantia fidejussória. Todavia, se a extensão objetiva da fiança era precisamente igual à da dívida e essa diminuiu, devido a circunstâncias objetivas ou subjetivas, há a redução."

Como sustenta Claudio Luiz Bueno de Godoy $^{428}$,

"Ou seja, nada impede que, para uma obrigação de cem, se contra uma fiança limitada a cinqüienta.(...) A rigor, o contrário é que a lei proíbe, impedindo que a fiança seja mais onerosa que a obrigação garantida.(...) Se isto ocorrer, vale dizer, se a fiança for pactuada de forma mais onerosa - quanto a valor, modo, lugar, tempo, condição ou encargos - que a obrigação principal, a despeito de inocorrer causa de invalidade, ela será reduzida aos limites quantitativos e qualitativos daquela divida afiançada."

E é nesse sentido a jurisprudência do Superior Tribunal de Justiça, a qual confirma que o excesso que porventura estiver a onerar a fiança não tornará nula ou anulável a garantia, mas apenas ineficaz a parte que sobejar aquela que fora originariamente contratada $^{429}$. A solução apontada pelo artigo 823 do Código Civil está em consonância como o princípio da conservação dos contratos, porque não determina a nulidade da fiança, mas apenas a desconsideração do excedente, mantendo, desta forma, o pacto firmado livremente entre as partes ${ }^{430}$.

\footnotetext{
${ }_{427}$ In PONTES DE MIRANDA, Francisco Cavalcanti. op. cit., t. 44, 3. ed. 2. reimp., § 4.787, p. 143.

${ }^{428}$ In GODOY, Claudio Luiz Bueno de. op. cit., p. 813.

429،"FIADOR - CONTRATO DE LOCAÇÃO - ARTIGO 1.483 DO CÓDIGO CIVIL - Sendo a fiança contrato benéfico, que não admite interpretação extensiva, não poder ser o fiador responsabilizado por majorações de alugueres, avençadas entre o locador e locatário, em pacto adicional a que não anui. $\mathrm{O}$ fiador só responde pelas majorações previstas no contrato a que se vinculou. Recurso especial em parte conhecido e provido." (STJ - $4^{\mathrm{a}}$ T.; Rec. Esp. no 10.987-0-RS; rel. Min. Athos Carneiro; j. 16.06.1992; v.u.; DJU, Seção I, 03.08.1992, p. 11.322, ementa.) BAASP, 1762/372, de 30.09.1992; "2. É firme a jurisprudência do Superior Tribunal de Justiça no sentido de que, "Não tendo o fiador integrado a ação revisional, não pode ser demandado pelos valores que por ela forem acrescidos ao antes contratado, sendo, na espécie, de todo irrelevante a previsão de responsabilização até a entrega das chaves, dessarte, notória a sua ilegitimidade passiva para a ação que executa título judicial emanado daquela ação revisora do locativo" (EREsp 154.845/SP, Rel. Min. GILSON DIPP, Terceira Seção, DJ 16/11/1999, p. 179). 3. Recurso especial conhecido e provido. (REsp 672.615/RS, Rel. Ministro ARNALDO ESTEVES LIMA, QUINTA TURMA, julgado em 01/03/2007, DJ 19/03/2007 p. 383)" (Grifamos)

${ }^{430}$ Cfe. TEPEDINO, Gustavo; BARBOZA, Heloisa Helena; MORAES, Maria Celina Bodin de. op. cit., v. 2, p. 638.
} 


\subsection{A possibilidade de exoneração ou desobrigação do fiador criada pela jurisprudência: a fiança prestada em favor de pessoas jurídicas}

Quando o contrato de locação for firmado por pessoa jurídica, poderá o fiador que nele figurar pleitear a sua exoneração judicial se acaso ocorrer a alteração do quadro social da sociedade em virtude da confiança que mantinham nos sócios que se retiraram?

Esta hipótese que não é contemplada no Código Civil, tampouco na Lei n. ${ }^{\circ}$ 8.245/91, passou a ser admitida pela jurisprudência do Superior Tribunal de Justiça que construiu o entendimento de que, "1. É cabível a exoneração da garantia fidejussória prestada à sociedade após a retirada da sócia-fiadora, em face da quebra da affectio societatis. 2. Tendo a sócia fiadora e seu cônjuge notificado o locador de sua pretensão de exoneração do pacto fidejussório, em razão da sua retirada da sociedade que afiançaram, direito lhes assiste de se verem exonerados da obrigação, uma vez que o contrato fidejussório é intuitu personae, sendo irrelevante, no caso, que o contrato locatício tenha sido estipulado por prazo determinado e ainda esteja em vigor. 3. Em se cuidando de contrato de natureza complexa em que a fiança pactuada o é enquanto preservado o contrato societário, faz-se evidente que a resolução de qualquer dos contratos implica a resolução do remanescente, mormente se a essência complexa do contrato foi aceita pelo locador, na exata medida em que locou o imóvel à pessoa jurídica, sendo fiadora uma de suas sócias. "431

No mesmo sentido: RESP 285.280/MG, Rel. Ministro JORGE SCARTEZZINI, 5 a Turma, julgado em 21.02.2002, DJ 20.05.2002 p. 175 ${ }^{432}$; RESP 373.671/MG, Rel. Ministro FELIX FISCHER, $5^{\text {a }}$ Turma, julgado em 19.02.2002, DJ 11.03.2002 p. $274^{433}$;

\footnotetext{
${ }^{431}$ In RESP 285.821/SP, Rel. Ministro HAMILTON CARVALHIDO, 6. ${ }^{\text {a } T u r m a, ~ j u l g a d o ~ e m ~ 19.09 .2002, ~ D J ~}$ 05.05.2003 p. 325.

432، 2 - Esta Corte de Uniformização vem firmando entendimento no sentido de não se admitir interpretação extensiva à fiança, não podendo o fiador ser responsabilizado perpetuamente por obrigações futuras, resultantes da prorrogação do contrato por prazo determinado, ex vi lege, do qual não anuiu concretamente. No caso concreto, tendo o sócio-fiador vendido suas cotas da pessoa jurídica afiançada-locatária, renunciou expressamente a fiança, sendo certo que a inadimplência ora cobrada, somente começou a ocorrer 01 (um) ano após sua saída da referida sociedade. Incidência da Súmula 214/STJ. 3 - Precedentes (REsp n's 299.036/MG e 246.809/PR). 4 - Recurso conhecido, nos termos acima expostos e, neste aspecto, provido para, reformando o v. acórdão de origem, julgar improcedente a ação em relação aos fiadores, declarandoos desonerados da fiança, invertendo-se eventuais ônus sucumbenciais já fixados."

433،LOCAÇÃO. FIANÇA. PESSOA JURÍDICA EXONERAÇÃO DOS FIADORES. SAÍDA DE SÓCIOS. É assente neste Tribunal o entendimento de que o instituto da fiança não comporta interpretação extensiva, obedecendo, assim, disposição expressa do artigo 1.483 do Código Civil. Não obstante distinção entre a pessoa do sócio e a pessoa jurídica, é possível a exoneração da garantia prestada à sociedade após a retirada dos sócios aos quais se deu a garantia originalmente. Recurso não conhecido.”
} 
RESP 299.036/MG, Rel. Ministro EDSON VIDIGAL, Rel. p/ Acórdão Ministro JOSÉ ARNALDO DA FONSECA, $5{ }^{\text {a }}$ Turma, julgado em 10.04.2001, DJ 08.10.2001 p. $242^{434}$; REsp 419128/ES, Rel. Ministro ALDIR PASSARINHO JUNIOR, $4{ }^{\text {a }}$ Turma, julgado em 06/03/2003, DJ 19/05/2003 p. 235 ${ }^{435}$; REsp 651.412/DF, Rel. Ministro HUMBERTO GOMES DE BARROS, 3. ${ }^{\text {a } T u r m a, ~ j u l g a d o ~ e m ~ 17 / 08 / 2004, ~ D J ~ 06 / 09 / 2004 ~ p . ~} 260^{436}$.

O fundamento principal dos julgados tem sido o de que a fiança se apresenta como um negócio jurídico de garantia que é firmado intuitu personae ${ }^{437}$, de maneira que o fiador, ao assumir a responsabilidade pelo adimplemento do afiançado, leva em consideração a pessoa do afiançado e as suas qualidades individuais, da mesma forma que o credor leva em consideração a pessoa do fiador e as suas qualidades individuais.

\footnotetext{
434“LOCAÇÃO. FIANÇA. EXONERAÇÃO DOS FIADORES. GARANTIA PRESTADA EM RAZÃO DA AMIZADE OU PARENTESCO COM OS SÓCIOS. RETIRADA DOS SÓCIOS. NOTIFICAÇÃO EXTRAJUDICIAL DA VONTADE DE EXONERAÇÃO DA FIANÇA. Fiança é contrato de natureza intuitu personae e se interpreta estritamente. Malgrado distinga-se a pessoa dos sócios da pessoa jurídica, é possível a exoneração da garantia prestada à sociedade após a retirada dos sócios em função dos quais se deu essa garantia substituídos por estranhos à fidúcia original. Recurso conhecido e provido."

435“"CIVIL. FIANÇA DADA A PESSOA JURÍDICA. CONTRATO DE FORNECIMENTO DE PASSAGENS AÉREAS. TRANSFERÊNCIA DE PROPRIEDADE DA EMPRESA. SAÍDA DOS SÓCIOS GARANTIDOS. DESAPARECIMENTO DO ELEMENTO FIDÚCIA. COMUNICAÇÃO FORMAL À AUTORA. DÍVIDA SURGIDA A POSTERIORI, DURANTE A NOVA GESTÃO. EXONERAÇÃO DOS FIADORES. CC, ARTS. 1.006, 1.491, 1.500 E 1.503. I. A fiança é dada em caráter personalíssimo, de sorte que mesmo em caso de garantia dada a favor de pessoa jurídica, tal elemento sofre afetação quando há transferência de titularidade na empresa, fazendo desaparecer a razão essencial daquele ato. II. Destarte, vendidas as cotas sociais e comunicada a autora de que isso ocorrera, bem como que a fiança antes celebrada deixava de existir, improcede a pretensão da credora de considerar perene a garantia, ainda que novos sócios, desconhecidos dos garantes, houvessem passado a gerir os negócios e assumido dívidas posteriores àquela comunicação. III. A cláusula de renúncia prevista no art. 1.500 do Código Civil não prevalece indefinidamente. IV. Recurso especial não conhecido."

436“FIANÇA - PESSOA JURÍDICA - SUCESSÃO SOCIETÁRIA - EXONERAÇÃO DA GARANTIA. Havendo sucessão societária e a constituição de novo mútuo, os antigos sócios-fiadores libertam-se da fiança."

${ }^{437}$ Em sentido contrário, PASQUALOTTO, Adalberto, que entende que a fiança não ostenta a característica de garnatia intuitu personae: "Ao contrário do que sugere a noção intuitiva da fiança, o negócio jurídico de fiança não pressupõe uma relação de confiança entre devedor e fiador, pois entre eles não há vínculo jurídico imediato - somente haverá em eventual ação de regresso do fiador. Tal noção intuitiva não é desprezível, pois nas relações sociais, em plano ainda pré-jurídico, é comum que o devedor e o fiador sejam pessoas de afinidade. O fiador acede ao pedido confiando que o devedor honrará as suas obrigações e presta a garantia como por mera formalidade, com significado mais moral do que jurídico, sentindo-se traído se é chamado à responsabilidade assumida(...) Em todas essas situações, o que é relevante na fiança é o motivo pelo qual foi prestada. Os fiadores podem resguardar-se e efetivamente verem extinta a fiança explicitando o motivo no contrato, que assim passa a ter força de causa.”. (In PASQUALOTTO, Adalberto. op. cit., p. 248-249). (Grifamos)
} 
Assim, a jurisprudência do Superior Tribunal de Justiça e de outros tribunais ${ }^{438,439}$ têm entendido que no momento em que o garantidor presta a fiança em favor de uma pessoa jurídica, a bem dizer leva em consideração os sócios que a compõem, de modo que a garantia é prestada não para beneficiar a sociedade, mas sim as pessoas que nela figuram. Daí o caráter personalíssimo da fiança.

A bem dizer, entendemos que o orientação jurisprudencial encontra-se correta, razão pela qual deveria ser positivada em texto expresso de lei para que pudesse orientar os figurantes do negócio, dando-lhes um norte seguro de como deveriam proceder na contratação da garantia.

Destarte, pode-se dizer que nenhum fiador busca prestar uma fiança para beneficiar apenas uma pessoa jurídica; esta é beneficiada, por certo, em atenção aos sócios que dela participam e em favor dos quais a garantia fidejussória é manifestada, situação esta que é extraída da realidade da vida e dos negócios.

Por conta disso, não raras vezes o quadro social da pessoa jurídica vem a ser alterado - mormente através da cessão de quotas sociais -, com a saída do ou dos sócios "afiançados de fato" - em favor dos quais se dirigiu a motivação do negócio, motivação

\footnotetext{
438،“LOCAÇÃO - EMBARGOS À EXECUÇÃO - TÍTULO EXECUTIVO JUDICIAL - LEGITIMIDADE PASSIVA DO FIADOR - ALTERAÇÃO DA TITULARIDADE DO PONTO COMERCIAL - CASO CONCRETO - MATÉRIA DE FATO. - A fiança é contrato de natureza intuitu personae e se interpreta estritamente. Embora a pessoa dos sócios seja distinta da pessoa jurídica, é possível a exoneração da garantia prestada à sociedade após a retirada dos sócios em função dos quais se deu a garantia. Apelo provido.” (TJRS - 15 ${ }^{\text {a }}$ Câm. Cível; ACi no 70013783394-Santa Maria-RS; Rel. Des. Vicente Barroco de Vasconcellos; j. 8/3/2006; v.u.) BAASP, 2510/1320-e, de 12.2.2007); "LOCAÇÃO - Comercial - Fiança Garantia prestada à pessoa jurídica da qual eram sócios os fiadores - Alteração societária - Quebra da relação de confiança - Pedido de exoneração - Cabimento - Sentença confirmada - Recurso improvido (Apelação Cível n. 1.122.070-0/7 - Guarulhos - 26 Câmara de Direito Privado - Relator: Andreatta Rizzo -27.08 .07 - v.u. - Voto n. 18012).

${ }^{439} \mathrm{Em}$ sentido contrário: "FIANÇA - LOCAÇÃO - RESPONSABILIDADE - PESSOA JURÍDICA ALTERAÇÃO SOCIETÁRIA - IRRELEVÂNCIA - SUBSISTÊNCIA DA GARANTIA - Sendo afiançada a pessoa jurídica, a mudança em sua composição societária é irrelevante, não sendo fato idôneo a desconstituir o contrato de fiança, salvo se provida, oportunamente, pelo fiador a exoneração da garantia. ( $2^{\circ}$ TACIVIL - $2^{a}$ Câm.; AP c/ Revisão no 580.183-00/2-SP; Rel. Juiz Peçanha de Moraes; j. 7/8/2000; v.u.; JTACSP 185/477.) BAASP, 2249/503-e, de 4.2.2002; "LOCAÇÃO - FIANÇA - LIMITES - A prorrogação da avença locatícia a prazo indeterminado não exonera o fiador quanto à garantia prestada, quando esta foi convencionada até a data da efetiva devolução do bem locado. A substituição dos primitivos sócios da empresa afiançada por outros, bem assim a alteração do nome desta, também não é caso de exoneração da garantia, pois que tais alterações não implicam extinção da firma locatária." (TJDF - $3^{\mathrm{a}} \mathrm{T}$.; Ag. de Instr. ${ }^{\circ}$ 1998002000221-2-Brasília-DF; Rel. Des. Vasquez Cruxên; j. 13.04.1998; v.u.; ementa.) BAASP, 2092/177-e, de 01.02.1999); "FIANÇA - Fiador - Exoneração - Garantia prestada "intuito personae", enquanto o autor integrava o quadro societário da afiançada - Possibilidade de desoneração, após retirada do quadro societário - Hipótese, contudo, em que assumiu idêntico encargo, após sua saída da empresa e antes da comunicação do fato ao credor - Prevalecimento da fiança prestada nesses termos, até o vencimento do contrato - Ação de exoneração parcialmente procedente - Recursos não providos. (Apelação Cível n. 7.213.347-4 - Diadema - 14 Câmara de Direito Privado - Relator: Melo Colombi - 06.08.08 v.u.).
} 
esta que, em nosso sentir, é elevada em fundamento principal (rectius, causa) da prestação da garantia.

Antes que o Superior Tribunal de Justiça tivesse passado a se orientar no sentido de admitir a exoneração do fiador ante a alteração do contrato social da pessoa jurídica afiançada, Francisco Carlos Rocha de $\operatorname{Barros}^{440}$ já defendia tal tese:

"Na hipótese de extinção da pessoa jurídica - locatária afiançada -, pelas mesmas razões deve ser considerada extinta a fiança.

É comum, por outro lado, quando se trata de sociedade por cotas de responsabilidade limitada, não a extinção, mas a alteração do contrato social, com a substituição dos sócios originais.

Claro que o fiador, ainda que se responsabilizando por pessoa jurídica, levou em consideração a confiança que lhe mereciam os sócios originais. Com a alteração, desaparecem os motivos que o levaram a prestar fiança. Esta não se considera extinta com a alteração, mas entendemos que o fiador poderá pleitear, judicialmente, sua exoneração. Ainda que a pessoa jurídica permaneça, tem o fiador motivos para postular a extinção da fiança, na medida em que a fidúcia justificador já não subsiste. Exemplo absurdo, apenas para escancarar: suponha-se que os novos sócios da pessoa jurídica afiançada sejam inimigos pessoais do fiador... Fiança é contrato gratuito e benéfico, como se sabe. No exemplo, seria insustentável negar ao fiador o direito de desvincular-se de contrato que, além de gratuito, beneficia pessoas que lhe são hostis."

E esta vem a ser a razão pela qual em hipóteses que tais não se justifica a manutenção da garantia, razão pela qual o Superior Tribunal de Justiça tem admitido a exoneração do fiador tão-logo ocorra a alteração do quadro social da pessoa jurídica afiançada, a qual poderá ocorrer esteja o contrato sobrejacente à fiança a viger por tempo determinado ou indeterminado.

Todavia, esta exoneração não tem sido automática e tem exigido uma postura ativa do fiador em prol da segurança jurídica e da boa-fé objetiva. O Superior Tribunal de Justiça tem indicado que necessário será que a partir da mudança dos sócios da pessoa jurídica afiançada o fiador notifique o credor $^{441}$ para informá-lo acerca do término da

\footnotetext{
${ }^{440}$ In BARROS, Francisco Carlos Rocha de. op. cit., p. 171.

${ }^{441}$ Nesse sentido foi a fundamentação do acórdão indicado na nota de rodapé anterior (214), verbis: "No caso dos autos, como relatado no acórdão, logo após a venda da empresa os antigos titulares comunicaram à Varig a transferência da propriedade e o fim da fiança, sem que a autora houvesse, à época, sequer a respeito se manifestado, para somente após três anos, em face da inadimplência dos novos donos, ajuizar a ação contra os garantes. Inquestionável, assim, de um lado o procedimento escorreito dos ex-sócios, e, de outro, que dado o caráter personalíssimo dessa espécie de garantia, não se pode entender que deveria ela perdurar ad infinitum, também durante o período da nova gestão. E, por isso mesmo, em tais condições, não prevalece a cláusula de renúncia, já que está atrelada à própria avença, que desapareceu por inteiro.
} 
vontade fidejussória (rectius, intenção de garantir); a notificação, por sua vez, segundo defendemos, já se ostentará como o veículo hábil à manifestação da exoneração pretendida, sendo desnecessária a propositura de demanda judicial desconstitutiva.

Posta a questão nestes termos, é importante indicar que a exoneração do fiador nas hipóteses envolvendo a mudança de sócios duma pessoa jurídica afiançada não se submeterá ao prazo de 120 (cento e vinte) dias previsto no artigo 40, X, da Lei n. ${ }^{\circ}$ $8.245 / 91$, com a redação que lhe conferiu a Lei n. ${ }^{\circ} 12.112$, de 9 de dezembro de $2009^{442}$, mas ocorrerá tão-logo se concretize a efetiva comunicação do credores, por se tratar de manifestação de vontade receptícia e como tal mais consentânea à necessidade de segurança jurídica do tráfego negocial e da boa-fé objetiva como norma de conduta que deve pautar a atuação dos parceiros contratuais.

\subsection{A (im)penhorabilidade do chamado bem de família na execução do contrato de fiança. A Polêmica em Torno do Art. $6^{\circ}$, da Constituição Federal (c/ a Redação da $\mathrm{EC} \mathrm{n}^{\circ} 26$, de 14/02/00)}

De acordo com a letra do artigo 391, do Código Civil, "Pelo inadimplemento das obrigações respondem todos os bens do devedor." (Grifamos); no mesmo sentido enuncia o artigo 591, do Código de Processo Civil: “O devedor responde, para o cumprimento de suas obrigações, com todos os seus bens presentes e futuros, salvo as restrições estabelecidas em lei." (Grifamos)

A simples leitura de ambos os dispositivos permite a conclusão de que se complementam, na medida em que indicam que o patrimônio do devedor (rectius, responsável) é a garantia do credor, patrimônio este composto dos bens presentes e

Frisa-se que as dívidas surgiram depois da comunicação sobre a venda das cotas e do término da intenção de garantir, de modo que se cuidou de dívida contraída pelos titulares subseqüentes a descoberto de fiança.

Ante o exposto, não conheço do recurso especial." (Grifamos)

${ }^{442} \mathrm{E}$ isto porque o fundamento da exoneração do fiador neste caso não será o da prorrogação do contrato de locação por tempo indeterminado, mas sim o da substituição total ou parcial dos sócios da pessoa jurídica afiançada em virtude dos quais - e apenas e tão-somente por isso - a garantia foi prestada, o que põe em relevo a natureza intuitu personae. 
futuros $^{443}$, salvo - como fora bem realçado na expressão de encerramento do dispositivo legal da lei processual - as restrições estabelecidas em lei.

Todavia, no direito brasileiro a regra enunciada como geral (pelo inadimplemento respondem todos os bens do devedor) acabou por se transformar em exceção (salvo as restrições estabelecidas em lei); em outras palavras, o patrimônio do devedor somente será invadido pelo credor se os seus os bens estiverem livres, desembargados e disponíveis para penhora, situação esta cada vez mais rara de ocorrer, notadamente por conta do catálogo de impenhorabilidades que os artigos 648, 649 e 650 do Código de Processo Civil apresentam.

Pois bem. A Lei n. ${ }^{\circ}$ 8.009/90, de 29/03/1990 instituiu no Brasil mais uma espécie ou modalidade de bem impenhorável, qual seja, o chamado bem de família legal que, segundo o seu artigo $1 .^{\circ}$, é o imóvel residencial próprio do casal, ou da entidade familiar, que se ostenta impenhorável e não responde por qualquer tipo de dívida civil, comercial, fiscal, previdenciária ou de outra natureza, contraída pelos cônjuges ou pelos pais ou filhos que sejam seus proprietários e nele residam, salvo nas hipóteses previstas naquela lei.

Assim sendo, tendo em vista a natureza cogente da Lei n. ${ }^{\circ}$ 8.009/90, o único imóvel do devedor não poderia ser penhorado para pagamento de dívidas, o que permite a afirmação de que, em regra, o bem de família legal encontra-se fora do poder de disposição de quaisquer contratantes, situando-se fora da zona de influência da autonomia privada.

E no caso da fiança, contrato de garantia que é, em 2005 surgiu uma importante questão - fruto de uma decisão do Supremo Tribunal Federal - que passou a receber a atenção dos contratantes e do Poder Judiciário: se da fiança prestada em contrato de locação poderia decorrer responsabilidade ao fiador ao ponto de se permitir a penhora do único bem imóvel por ele titularizado, a fim de que o credor pudesse executar a garantia e receber o seu crédito.

Antes de discorrermos sobre as duas teses que se confrontaram no Supremo Tribunal Federal - e que ainda são alvo de intensos debates na doutrina -, apresentaremos

\footnotetext{
${ }^{443}$ Sobre o tema: "Aparentemente, o legislador, ao formular o preceito, fixou-se, não no marco temporal da constituição da obrigação, e sim no estabelecido pelo início do processo executivo, para dizer: respondem pela dívida os bens constantes do patrimônio do devedor neste momento (em que se pede a tutela do Estado) bem como os que, daqui em diante, forem a ele incorporados. É a inteligência que melhor conforma o dispositivo com o princípio geral, realçado na doutrina, segundo o qual "o devedor responde por suas obrigações com os bens que se encontram em seu patrimônio no momento da execução". (ZAVASCKI, Teori Albino. Comentários ao código de processo civil. Coord. Ovídio Araújo Baptista da Silva. São Paulo: Ed. Revista dos Tribunais, 2000. v. 8, p. 261).
} 
abaixo um quadro comparativo entre as mesmas, a fim de facilitar a compreensão da discussão:

\begin{tabular}{|c|c|}
\hline & STF \\
\hline $\begin{array}{l}\text { "CONSTITUCIONAL. CIVIL. FIADOR: BEM } \\
\text { DE FAMÍLIA: IMÓVEL RESIDENCIAL DO } \\
\text { CASAL OU DE ENTIDADE FAMILIAR: } \\
\text { IMPENHORABILIDADE. Lei n }{ }^{\circ} \text { 8.009/90, arts. } \\
1^{\circ} \text { e } 3^{\circ} \text {. Lei } 8.245 \text {, de } 1991 \text {, que acrescentou o } \\
\text { inciso VII, ao art. } 3^{\circ} \text {, ressalvando a penhora "por } \\
\text { obrigação decorrente de fiança concedida em } \\
\text { contrato de locação": sua não- recepção pelo art. } \\
6^{\circ} \text {, C.F., com a redação da EC } 26 / 2000 . \\
\text { Aplicabilidade do princípio isonômico e do } \\
\text { princípio de hermenêutica: ubi eadem ratio, ibi } \\
\text { eadem legis dispositio: onde existe a mesma razão } \\
\text { fundamental, prevalece a mesma regra de Direito. } \\
\text { Recurso extraordinário conhecido e provido". } \\
\text { (STF, RE 352.940-4-SP, rel. Carlos Velloso, } 2^{\mathrm{a}} \\
\text { Turma, j. 25.04.2005, DJU 09.05.2005, p. 00106). }\end{array}$ & $\begin{array}{l}\text { "FIADOR. Locação. Ação de despejo. Sentença de } \\
\text { procedência. Execução. Responsabilidade solidária } \\
\text { pelos débitos do afiançado. Penhora de seu imóvel } \\
\text { residencial. Bem de família. Admissibilidade. } \\
\text { Inexistência de afronta ao direito de moradia, } \\
\text { previsto no art. } 6^{\circ} \text { da CF. Constitucionalidade do } \\
\text { art.3, inc. VII, da Lei no } 8.009 / 90 \text {, com a redação } \\
\text { da Lei no 8.245/91. Recurso extraordinário } \\
\text { desprovido. Votos vencidos. A penhorabilidade do } \\
\text { bem de família do fiador do contrato de locação, } \\
\text { objeto do art. } 3^{\circ} \text {, inc. VII, da Lei }{ }^{\circ} 8.009 \text {, de } 23 \text { de } \\
\text { março de 1990, com a redação da Lei } n^{\circ} 8.245 \text {, de } \\
15 \text { de outubro de 1991, não ofende o art. } 6^{\circ} \text { da } \\
\text { Constituição da República." (STF, RE } 407.688- \\
\text { SP, rel. Min. Cezar Peluso, Tribunal Pleno, j. } \\
\text { 08.02.2006, DJU 06.10.2006, p. 00033). } \\
\text { (Grifamos) }\end{array}$ \\
\hline
\end{tabular}

Com efeito, em 2005 o Supremo Tribunal Federal, através da decisão monocrática proferida pelo Min. Carlos Velloso nos autos do Recurso Extraordinário 352.940-4-SP, da 2. ${ }^{a}$ Turma, iniciou a discussão sobre a penhorabilidade ou não de um único bem imóvel da propriedade de um fiador de contrato de locação, discussão esta provocada por uma caso oriundo do Estado de São Paulo; naquela oportunidade o Min. Carlos Velloso considerou impenhorável o bem de família titularizado pelo fiador em contrato de locação, em decisão que segue transcrita:

"EMENTA: CONSTITUCIONAL. CIVIL. FIADOR: BEM DE FAMÍLIA: IMÓVEL RESIDENCIAL DO CASAL OU DE ENTIDADE FAMILIAR: IMPENHORABILIDADE. Lei $n^{\circ} 8.009 / 90$, arts. $1^{\circ}$ e $3^{\circ}$. Lei 8.245 , de 1991, que acrescentou o inciso VII, ao art. $3^{\circ}$, ressalvando a penhora "por obrigação decorrente de fiança concedida em contrato de locação": sua não- recepção pelo art. $6^{\circ}$, C.F., com a redação da EC 26/2000. Aplicabilidade do princípio isonômico e do princípio de hermenêutica: ubi eadem ratio, ibi eadem legis dispositio: onde existe a mesma razão fundamental, prevalece a mesma regra de Direito. Recurso extraordinário conhecido e provido. DECISÃO: - Vistos. O acórdão recorrido, em embargos à execução, proferido pela Quarta Câmara do Eg. Segundo Tribunal de Alçada Civil do Estado de São Paulo, está assim ementado: "A norma constitucional que inclui o direito à moradia entre os sociais (artigo $6^{\circ}$ do Estatuto Político da República, texto conforme a Emenda 26, de 14 de fevereiro de 2000) não é imediatamente aplicável, persistindo, portanto, a penhorabilidade do bem de família de fiador de 
contrato de locação imobiliária urbana. A imposição constitucional, sem distinção ou condicionamento, de obediência ao direito adquirido, ao ato jurídico perfeito e à coisa julgada é inarredável, ainda que se cuide, a regra eventualmente transgressora, de norma de alcance social e de ordem pública." (Fl. 81) Daí o RE, interposto por ERNESTO GRADELLA NETO e GISELDA DE FÁTIMA GALVES GRADELLA, fundado no art. 102, III, a, da Constituição Federal, sustentando, em síntese, o seguinte: a) impenhorabilidade do bem de família do fiador em contrato de locação, dado que o art. $6^{\circ}$ da Constituição Federal, que se configura como auto-aplicável, assegura o direito à moradia, o que elidiria a aplicação do disposto no art. $3^{\circ}$, VII, da Lei 8.009/90, redação da Lei $8.245 / 91$; b) inexistência de direito adquirido contra a ordem pública, porquanto "(...) a norma constitucional apanha situações existentes sob sua égide, ainda que iniciadas no regime antecedente" (fl. 88). Admitido o recurso, subiram os autos. A Procuradoria-Geral da República, em parecer lavrado pela ilustre Subprocuradora-Geral da República, Dra Maria Caetana Cintra Santos, opinou pelo não-conhecimento do recurso. Autos conclusos em 15.10.2004. Decido. A Lei 8.009, de 1990, art. $1^{\circ}$, estabelece a impenhorabilidade do imóvel residencial do casal ou da entidade familiar e determina que não responde o referido imóvel por qualquer tipo de dívida, salvo nas hipóteses previstas na mesma lei, art. $3^{\circ}$, inciso I a VI. Acontece que a Lei 8.245, de 18.10.91, acrescentou o inciso VII, a ressalvar a penhora "por obrigação decorrente de fiança concedida em contrato de locação." É dizer, o bem de família de um fiador em contrato de locação teria sido excluído da impenhorabilidade. Acontece que o art. $6^{\circ}$ da C.F., com a redação da $E C n^{\circ} 26$, de 2000, ficou assim redigido: "Art. $6^{\circ}$. São direitos sociais a educação, a saúde, o trabalho, a moradia, a segurança a previdência social, a proteção à maternidade e à infância, a assistência aos desamparados, na forma desta Constituição." Em trabalho doutrinário que escrevi - "Dos Direitos Sociais na Constituição do Brasil", texto básico de palestra que proferi na Universidade de Carlos III, em Madri, Espanha, no Congresso Internacional de Direito do Trabalho, sob o patrocínio da Universidade Carlos III e da ANAMATRA, em 10.3.2003 - registrei que o direito à moradia, estabelecido no art. $6^{\circ}$, C.F., é um direito fundamental de $2^{\mathrm{a}}$ geração - direito social - que veio a ser reconhecido pela EC 26, de 2000. O bem de família - a moradia do homem e sua família - justifica a existência de sua impenhorabilidade: Lei 8.009/90, art. $1^{\circ}$. Essa impenhorabilidade decorre de constituir a moradia um direito fundamental. Posto isso, veja-se a contradição: a Lei 8.245, de 1991, excepcionando o bem de família do fiador, sujeitou o seu imóvel residencial, imóvel residencial próprio do casal, ou da entidade familiar, à penhora. Não há dúvida que ressalva trazida pela Lei 8.245, de 1991, inciso VII do art. $3^{\circ}$ - feriu de morte o princípio isonômico, tratando desigualmente situações iguais, esquecendo-se do velho brocardo latino: ubi eadem ratio, ibi eadem legis dispositio, ou em vernáculo: onde existe a mesma razão fundamental, prevalece a mesma regra de Direito. Isto quer dizer que, tendo em vista o princípio isonômico, o citado dispositivo - inciso VII do art. $3^{\circ}$, acrescentado pela Lei 8.245/91, não foi recebido pela EC 26, de 2000. Essa não recepção mais se acentua diante do fato de a EC 26, de 2000, ter estampado, expressamente, no art. $6^{\circ}$, C.F., o direito à moradia como direito fundamental de $2^{\mathrm{a}}$ geração, direito social. Ora, o bem de família $3 / 4$ Lei $8.009 / 90$, art. $1^{\circ}$ - encontra justificativa, foi dito linha atrás, no constituir o direito à moradia um direito fundamental que deve ser protegido e por isso mesmo encontra garantia na Constituição. 
Em síntese, o inciso VII do art. $3^{\circ}$ da Lei 8.009, de 1990, introduzido pela Lei 8.245 , de 1991 , não foi recebido pela $\mathrm{CF}$, art. $6^{\circ}$, redação da EC 26/2000. Do exposto, conheço do recurso e dou-lhe provimento, invertidos os ônus da sucumbência. Publique-se.” Brasília, 25 de abril de 2005. Ministro CARLOS VELLOSO - Relator -(RE 352940, Relator(a): Min. CARLOS VELLOSO, julgado em 25/04/2005, publicado em DJ 09/05/2005 PP-00106)

Em linhas gerais, dois foram os fundamentos que guiaram o entendimento exposado na decisão monocrática:

(a) o artigo $3 .^{\circ}$, VII, da Lei n. ${ }^{\circ}$ 8.009/90, violaria o princípio constitucional $d a$ isonomia, porque trataria a mesma situação jurídica a que estariam vinculados os devedores e os fiadores de maneira distinta;

(b) em virtude do princípio da isonomia, o inciso VII do art. $3^{\circ}$, acrescentado pela Lei 8.245/91, não teria sido recepcionado pela EC 26, de 2000. Essa não-recepção mais se acentuaria diante do fato de a EC 26, de 2000, ter estampado, expressamente, no art. $6^{\circ}$, $\mathrm{CF}$, o direito à moradia como direito fundamental de $2^{\mathrm{a}}$ geração, direito social. Ora, o bem de família - Lei 8.009/90, art. $1^{\circ}$ - encontra justificativa no constituir o direito à moradia um direito fundamental que deve ser protegido e por isso mesmo encontra garantia na Constituição.

Posteriormente, o Supremo Tribunal Federal decidiu a questão pelo seu pleno e afastou a tese da impenhorabilidade por força do voto-condutor proferido pelo Min. Cezar Peluso, nos autos do Recurso Extraordinário n. ${ }^{\circ}$ 407.688-8, também oriundo de São Paulo. No julgamento, votaram a favor da tese da penhorabilidade os Ministros Cezar Peluso, Joaquim Barbosa, Gilmar Mendes, Nelson Jobim e Sepúlveda Pertence; votaram contra a tese da penhorabilidade os Ministros Eros Grau, Carlos Brito e Celso de Mello.

Dois foram os fundamentos que guiaram a tese vencedora exposada no acórdão:

(a) o direito à moradia introduzido no sistema pela EC 26, de 2000, e que modificou o art. $6^{\circ}, \mathrm{CF}$, não se confundiria com o direito de propriedade imobiliária, razão pela qual teria um espectro de incidência sobre os locadores (proprietários de imóveis para moradia) e sobre os inquilinos (sujeitos que postulariam acesso à moradia); dessa forma, se acaso fosse vedada a penhora do único imóvel do fiador em contrato de locação, isto "romperia equilíbrio do mercado, despertando exigência sistemática de garantias 
mais custosas para as locações residenciais, com conseqüente desfalque do campo de abrangência do próprio direito constitucional à moradia." (Grifamos)

(b) o inciso VII do art. $3^{\circ}$, acrescentado pela Lei 8.245/91, ao ter pré-excluído do campo da impenhorabilidade o imóvel do fiador que poderia ser considerado bem de família não teria violado o princípio da isonomia porque "se patenteia diversidade de situações factuais e de vocações normativas - a expropriabilidade do bem do fiador tende, posto que por via oblíqua, também proteger o direito social de moradia, protegendo direito inerente à condição de locador, não um qualquer direito de crédito”. (Grifamos)

Por sua vez, a tese vencida que foi esposada no voto-condutor do Min. Eros Grau, considerou inconstitucional o inciso VII do art. $3^{\circ}$, acrescentado pela Lei 8.245/91, porque:

(a) haveria evidente afronta ao princípio da isonomia, pois "Se o benefício da impenhorabilidade viesse a ser ressalvado quanto ao fiador em uma relação de locação, poderíamos chegar a uma situação absurda: o locatário que não cumprisse a obrigação de pagar aluguéis, com o fito de poupar para pagar prestações devidas em razão de aquisição de casa própria, gozaria da proteção da impenhorabilidade. Gozaria dela mesmo em caso de execução procedida pelo fiador cujo imóvel resultou penhorado por conta do inadimplemento das suas obrigações, dele, locatário.

Quer dizer, sou fiador; aquele a quem prestei fiança não paga o aluguel, porque está poupando para pagar a prestação da casa própria, e tem o benefício da impenhorabilidade; eu não tenho o benefício da impenhorabilidade.” (Grifamos)

(b) haveria também violação do direito social à moradia do fiador, de maneira que não mais poderia viver com a sua família no espaço por ele escolhido para que pudesse desenvolver a sua personalidade e habitar com dignidade ${ }^{444}$.

Na votação que acolheu a tese da penhorabilidade do bem de família do fiador, dois outros votos merecem destaque: o do Min. Joaquim Barbosa e o do Min. Celso de Mello.

\footnotetext{
${ }^{444}$ Segundo apontam PINHEIRO, Rosalice Fidalgo e ISAGUIRRE, Katya: "Como manifestação do princípio da democracia econômica e social, o direito à moradia deriva do princípio da dignidade da pessoa humana. Trata-se, porém, de uma fundamentação comum a todos os direitos fundamentais. Os direitos fundamentais sociais encontram em sue fundamento na igualdade substancial e na liberdade material, objetivando a proteção das pessoas junto às suas necessidades materiais, garantindo sua existência com dignidade. Ser e habitar acham-se estritamente ligados, pois morar faz parte da existência humana. Portanto, o direito à moradia constitui-se não apenas no direito de ocupar um espaço, mas de fazê-lo, em conformidade com as condições que tornam esse espaço, um local de moradia. Por outras palavras, o direito à moradia remete-se à existência humana, traduzida em condições mínimas de dignidade." (PINHEIRO, Rosalice Fidalgo; ISAGUIRRE, Katya. O direito à moradia e o STF: um estudo de caso acerca da impenhorabilidade do bem de família do fiador. In: TEPEDINO, Gustavo; FACHIN, Luiz Edson (Orgs.). Diálogos sobre direito civil. Rio de Janeiro: Renovar, 2008. v. 2, p. 153).
} 
No voto que proferiu o Min. Joaquim Barbosa - favorável à tese da penhorabilidade - ressaltou que naquele julgamento estariam em rota de colisão dois direitos fundamentais: o direito à moradia e o direito à liberdade de agir, considerado como emanador da autonomia da vontade:

"Senhor Presidente, aparentemente, a questão posta nos presentes autos centra-se no embate entre dois direitos fundamentais: de uma lado, o direito à moradia (art. $6^{\circ}$ da Constituição Federal), que é direito social constitucionalmente assegurado e, em princípio, exige uma prestação do Estado; de outro, o direito à liberdade, em sua mais pura expressão, ou seja, o da autonomia da vontade, exteriorizada, no caso concreto, na faculdade que tem cada um de obrigar-se contratualmente e, por consequiência, de suportar os ônus dessa livre manifestação de vontade.

Ambos os direitos merecem igual tutela em nossa Constituição, de modo que é tarefa complexa estabelecer os parâmetros e limites de sua aplicação, em especial neste tema da penhorabilidade do bem de família do fiador nos contratos de locação.

Mas a singularidade do presente caso reside no fato de que a suposta violação de um direito fundamental não se dá no bojo de uma típica relação jurídica que se estabelece entre o titular de um direito e o órgão estatal, mas, sim, numa relação entre particulares, tipicamente de direito privado.

Nessa linha de pensamento, entendo que a questão posta neste recurso extraordinário implicam inicialmente saber se são impositivas ao cidadão comum, ou melhor, se são aplicáveis às relações privadas, com o mesmo peso e o mesmo rigor, as limitações e obrigações impostas ao Estado em virtude da previsão, na Constituição, de um catálogo de direitos fundamentais. Noutras palavras, a questão é saber se esses direitos se impõem, com a mesma força e o mesmo alcance, às relações travadas ao largo de qualquer manifestação estatal. Em seguida, cumpre decidir, em juízo de ponderação, qual dos direitos deve preponderar.

Sou dos que entendem que, em princípio e em certas circunstâncias, os direitos fundamentais se aplicam igualmente nas relações privadas.

(...)

É precisamente essa cautela que preconizei ao proferir o voto no caso mencionado, essa opção pelo exame casuístico, que norteará meu voto no presente recurso extraordinário.

(...)

A norma é muito clara: o fiador que oferece o único imóvel de sua propriedade para garantir contrato de locação de terceiro pode ter o bem penhorado em caso de descumprimento da obrigação principal pelo locatário.

Sustenta-se que essa penhora seria contrária ao disposto na Constituição Federal, sobretudo após a Emenda Constitucional 26, que incluiu o direito à moradia no rol dos direitos sociais descritos no art. $6^{\circ}$ da Constituição.

Entendo, porém, que esse não deve ser o desenlace da questão. Como todos sabemos, os direitos fundamentais não têm caráter absoluto. Em 
determinadas situações, nada impede que um direito fundamental ceda passo em prol da afirmação de outro, também em jogo numa relação jurídica concreta.

É precisamente o que está em jogo no presente caso. A decisão de prestar fiança, como já se disse, é expressão da liberdade, do direito à livre contratação. Ao fazer uso dessa franquia constitucional, o cidadão, por livre e espontânea vontade, põe em risco a incolumidade de um direito fundamental social que lhe é assegurado na Constituição. E o faz, repito, por vontade própria.

Por via de conseqüência, entendo que não há incompatibilidade entre o art. $3^{\circ}$, VII, da Lei 8.009/90, inserido pela Lei 8.245/1991, que prevê a possibilidade de penhora do bem de família em caso de fiança em contrato de locação, e a Constituição Federal.

No caso, o acórdão recorrido deu por legítima a penhora de um bem de família do fiador em contrato de locação."

A seu turno, o Min. Celso de Mello - favorável à tese da impenhorabilidade destacou em seu voto que o direito à moradia qualificar-se-ia como um dos mais expressivos porque teria em mira proclamar a "intangibilidade do espaço doméstico em que o ser humano vive com a sua família”:

“A Constituição brasileira, ao positivar a declaração de direitos, proclamou, dentre aqueles impregnados de caráter social, o direito à moradia, assim qualificado pela $\mathrm{EX} \mathrm{n}^{\circ} 26$, de 14/02/2000.

Cabe assinalar, neste ponto, por relevante, que o direito à moradia - que representa prerrogativa constitucional deferida a todos $\left(\mathrm{CF}\right.$, art. $\left.6^{\circ}\right)-$ qualifica-se como um dos direitos sociais mais expressivos, subsumindose à noção dos direitos de segunda geração (RSTJ 164/158-161).

A essencialidade desse direito é também proclamada por declarações internacionais que o Brasil subscreveu ou a que o nosso País aderiu, valendo referir, dentre elas, a Declaração Universal dos Direitos da Pessoa Humana (art. 25) e o Pacto Internacional dos Direitos Econômicos, Sociais e Culturais (art. 11), que dispõem sobre o reconhecimento do direito à moradia como expressão de um direito fundamental que assiste a toda e qualquer pessoa.

Dentro do contexto pertinente ao direito à moradia, torna-se relevante observar, na linha de reflexão feita pelo eminente Professor LUIZ EDSON FACHIN ("Estatuto Jurídico do Patrimônio Mínimo", 2001, Renovar), que se impõe, ao Estado, dispensar tutela efetiva às pessoas em geral, notadamente àquelas postas à margem das grandes conquistas sociais, assegurando-lhes, mediante adoção de medidas apropriadas, a proteção do patrimônio mínimo fundada em postulados inderrogáveis, como o princípio da dignidade da pessoa humana, que representa enquanto um dos fundamentos da República (CF, art. $1^{\circ}$, III) - valor revestido de centralidade em nosso sistema constitucional. 
Esse princípio fundamental, valorizado pela fiel observância da exigência ético-jurídica da solidariedade social - que traduz um dos objetivos fundamentais do Estado Social de Direito (CF, art. 3. $\left.{ }^{\circ}, \mathrm{I}\right)$ - permite legitimar interpretações que objetivem destacar, em referido contexto, o necessário respeito ao indivíduo, superando-se, desse modo, em prol da subsistência digna das pessoas, restrições que possam injustamente frustrar a eficácia de um direito tão essencial, como o da intangibilidade do espaço doméstico em que o ser humano vive com a sua família.

(...)

A "ratio" subjacente a esse entendimento prende-se ao fato de que o bem de família do devedor principal - que é o locatário - não pode ser penhorado, muito embora o fiador - que se qualifica como garante meramente subsidiário ( $\mathrm{CC}$, art. 827) - possa sofrer a penhora de seu único imóvel residencial, daí resultando um paradoxo absolutamente inaceitável, pois, presente tal contexto, falecer-lhe-á a possibilidade de, em regresso, uma vez paga, por ele, a obrigação principal, fazer incidir essa mesma constrição judicial sobre o único imóvel residencial eventualmente pertencente ao inquilino.

(...)

A moradia representa, efetivamente, uma necessidade básica da pessoa. É preciso, desse modo, que o Poder Público dê conseqüência ao que a nossa Lei Fundamental proclama, notadamente quando põe em destaque essa garantia asseguradas às pessoas em geral, como se vê, por exemplo, da norma inscrita no inciso XXVI do art. $5^{\circ}$ da Constituição da República, que impede a penhora da pequena propriedade rural, desde que trabalhada pela família."

Por ora, tendo em vista que a decisão tomada por maioria foi proferida pelo Supremo Tribunal Federal em sede de controle difuso de constitucionalidade (tratava-se do julgamento de um recurso extraordinário), a decisão não ostentou eficácia erga omnes, mas apenas inter partes, o que permite afirmar que a questão relativa à penhorabilidade ou não do único imóvel da propriedade do fiador poderá no futuro voltar à pauta da Suprema Corte.

Não obstante a posição sustentada pelos defensores da tese da impenhorabilidade do bem de família do fiador por afronta ao texto constitucional, entendemos que a da penhorabilidade é a mais correta.

Nos dias atuais é praticamente impossível cobrar uma simples dívida no Brasil tais são os entraves e obstáculos enfrentados pelos credores. Ser credor passou a portar uma conotação negativa, sem se falar no completo déficit de efetividade da tutela jurisdicional, que faz com que uma simples cobrança de dívida acabe se tornando uma questão constitucional sob o argumento de que estaria a ocorrer violação à cláusula constitucional 
da dignidade da pessoa humana! Na atualidade há uma completa inversão de valores: cobrar uma dívida se tornou sinônimo de abuso, enquanto ser devedor passou a ser uma situação digna de tutela e proteção para resguardar os direitos fundamentais do devedor. Com o devido respeito, o exagero parece-nos evidente!

Nesse contexto, o devedor não paga a dívida porque lhe deve ser garantido um patrimônio mínimo, de modo a garantir-lhe a subsistência, enquanto o credor, tão ou mais vulnerável que o devedor, nada recebe porque deve garantir a manutenção do devedor em patamares dignos! Ora, e a dignidade do credor, quem protege?! O Estado, que não cumpre os seus deveres básicos, mas exige qua a sociedade cumpra os dela? O devedor, que muitas vezes não paga porque não pode, mas que também em outras tantas vezes não paga porque não quer? A premissa encontra-se completamente equivocada: a cláusula constitucional da dignidade da pessoa humana é invocável tanto pelo credor quanto pelo devedor e fiador, porque todos têm direito a uma existência digna. Assim, se retiro do credor para transferir ao devedor, certamente alguém irá perder; em outras palavras, alguém sempre perde, razão por que a melhorar solução é tentar o equilíbrio das posições jurídicas em confronte, sem nos esquecermos do princípio da auto-responsabilidade; em face do exposto, pergunta-se: a hipótese seria isonômica ou credor e devedor e o seu responsável estariam a ser tratados de forma desigual?

Quando se advoga a tese de que ao devedor deve ser garantido um patrimônio mínimo, olvida-se que a sua proteção se dá em detrimento do patrimônio mínimo do credor; se o princípio é o da isonomia, porque a posição jurídica do devedor ou do responsável pela dívida terão prevalência sobre o direito do credor? Qual seria a justificativa? Se ambos são pessoas humanas, ambos são titulares de dignidade. Em outras palavras: por qual razão proteger a dignidade apenas do devedor? A quem isto beneficia?

Todavia, a questão que se coloca, ao nosso sentir, é a seguinte: é razoável que alguém tenha subscrito um contrato de garantia ciente de que poderia vir a perder o seu único imóvel se acaso o devedor não pagasse a sua dívida decorrente de um contrato de locação, tenha assumido o risco por confiar na solvência do afiançado, porém se negue a ser responsabilizado sob a alegação de que iria perder a sua moradia? Com o devido respeito, é evidente que não! Alguém se oferece para ser fiador, ciente de que não tem condições de afiançar! ${ }^{445}$ Esta vem a ser a razão pela qual o risco fidejussório deve incidir

445“Relativamente ao inc. VII, acrescentado ao art. $3 .^{\circ}$ da Lei $8.009 / 1990$, pelo art. 82 da Lei 8.245 , de 18.10.1991, que regula a locação de imóveis urbanos, o foi com a seguinte redação: "por obrigação 
sobre o fiador, e não sobre o credor, a não ser nos casos em que este aceitou a garantia ciente de que o garante não possuíria lastro patrimonial.

Ainda que a Constituição Federal assegure, como direito social, o direito à moradia, a mesma Carta Política também garante a dignidade da pessoa humana como um dos fundamentos da República Federativa do Brasil, garantindo também o direito de propriedade. E o que representaria ser digno no contexto narrado? Em outras palavras, qual seria o conteúdo jurídico do princípio da dignidade da pessoa humana que protegeria absolutamente o fiador e não protegeria na mesma extensão o locador? Porque o fiador seria tolhido em seu direito de optar pela prestação ou não da garantia, arcando com as consequências daí decorrentes?

decorrente de fiança concedida em contrato de locação", e não há exceção de impenhorabilidade. Tal exceção, como posta, poderia parecer verdadeira incongruência; pois, tendo o inquilino como impenhoráveis os bens que guarnecem sua residência, poderia seu fiador sofrer execução de seu bem de família, sua residência. Assistimos, nesse caso, à execução do patrimônio do fiador, sem possibilidade de exercer o benefício de ordem; a execução do acessório sem a possibilidade de executar o principal. Acresce, ainda, que tal preceito leva a que seja executado o responsável (fiador), sem a possibilidade de execução do devedor (o locatário, afiançado); e, mais, que, sendo executado o primeiro, não possa ele exercer seu direito de regresso contra o segundo. Escudado nesse entendimento o então Tribunal de Alçada Civil de São Paulo, por sua $4^{\mathrm{a}}$ Câm., sendo relator à época, o Juiz Neves Amorim, decidiu pela possibilidade de penhora do imóvel residencial do fiador, em razão de fiança em contrato locatício. Tudo parece incrível ante o instituto da fiança, como garantia fidejussória, de natureza pessoal, sem vincular bem específico do fiador. Nesse caso, realmente, não poderia existir penhora, a não ser em bem disponível; jamais sobre bem de família. Todavia, a fiança locatícia apresenta natureza jurídica diversa, pois estabelece a vinculação de um bem específico, oferecido em garantia. Esse bem fica gravado, por um contrato real de penhor ou de verdadeira hipoteca, pois o art. 38 da Lei do Inquilinato, 8. 245/91, exige, em seu $\S 1 .^{\circ}$, que: "A caução em bens móveis deverá ser registrada em Cartório de Títulos e Documentos; a em bens imóveis deverá ser averbada à margem da respectiva matrícula." Com todas essas providências registrais, como visto, não se cuida de mera garantia fidejussória, que vincula, mais, a pessoa do garantidor. Trata-se de direito real sobre coisa alheia. $\mathrm{O}$ locador tem direito de executar o bem específico dado em penhor. Assim, como existe um contrato em que o bem do fiador se torna penhorado ou hipotecado, quer se trate, respectivamente, de um bem móvel ou imóvel, dado em garantia, esse ato jurídico perfeito, cuja validade se estende a terceiros, é erga omnes; não há que se falar em sua desconstituição por ser bem de família. Aliás, tal exceção existe, também, no caso do oferecimento do imóvel em hipoteca, pelo próprio casal ou entidade familiar, como previsto no inc. $\mathrm{V}$ do art. $3 .^{\circ}$ sob exame. Nesse caso, entretanto, cuida-se do instituto da hipoteca, como vem regulado pelo Código Civil, com todas as formalidades ali exigidas. No caso específico do inc. VII sob análise, o legislador concedeu benefício equivalente ao do direito real de hipoteca, quando o imóvel é dado em garantia da locação; cuida da matéria como se fiança fosse (garantia fidejussória), autoriza registro para valer contra terceiros, por mera indicação de bem imóvel pelos fiadores, em garantia de locação. O mesmo acontece com a fiança mobiliária ofertada, que se transmuda em verdadeiro penhor. Desse modo, não seria lógico nem jurídico que, por força de contrato real de penhor ou de hipoteca, o bem objeto dessa contratação pudesse ser libertado do ônus, por lei, em quebra do direito adquirido do contratante credor da garantia, e do ato jurídico perfeito. Todavia, como visto, não basta que a aludida fiança se mostre somente fidejussória; é preciso que adquira natureza de direito real sobre bem dado em garantia. Daí a necessidade do registro do ato de garantia, nos apontados Cartório de Títulos e Documentos ou Registro Imobiliário, conforme seja móvel ou imóvel o objeto onerado. Também seria procedimento de alta má-fé que o proprietário de um bem o conferisse em garantia de uma relação jurídica, para não cumprir o avençado ou já sabendo da impossibilidade de fazê-lo. $O$ direito não pode suportar procedimento de má-fé, ou de quem alegue nulidade a que tenha dado causa. Quem viola a norma não pode invocá-la em seu benefício (nemo auditur turpitudinem suam allegans)." (AZEVEDO, Álvaro Villaça. Bem de família: penhora em fiança locatícia e direito à moradia. In: NERY, Rosa Maria de Andrade. DONNINI, Rogério (Coords.). Responsabilidade civil: estudos em homenagem ao professor Rui Geraldo Camargo Viana. São Paulo: Ed. Revista dos Tribunais, 2009. p. 71-72). (Grifamos) 
Qual seria o direito fundamental violado quando alguém optasse por ou, dadas as circunstâncias da vida, fosse impelido a prestar fiança?

Com efeito, a ausência de parâmetros claros e objetivos acabaram por tornar o princípio da dignidade da pessoa humana - uma importante conquista social - em uma topos argumentativo vazio de sentido e conteúdo, pois tudo pode ser justificado à luz da cláusula de dignidade ${ }^{446}$. Na realidade, uma das emanações que decorrem do princípio da dignidade da pessoa humana $\left(\mathrm{CF}\right.$, art. $\left.1 .^{\circ}, \mathrm{III}\right)$ é a de proteger a autodeterminação das pessoas, a fim de que possam escolher os seus próprios caminhos e optar pelas decisões que melhor reflitam os seus interesses. Ora, qual abuso haveria nesta situação?

E no campo dos direitos fundamentais este direito de escolha recebe o nomem juris de direito à liberdade, que é considerado nesta dissertação como gênero, do qual seria espécie a liberdade de contratar. O catálogo dos direitos fundamentais na Constituição consagra liberdades variadas e procura garanti-las por meio de diversas normas. Liberdade e igualdade formam dois elementos essenciais do conceito de dignidade da pessoa humana, que o constituinte erigiu à condição de fundamento do Estado Democrático de Direito e vértice do sistema dos direitos fundamentais. As liberdades são proclamadas partindo-se da perspectiva da pessoa humana como ser em busca da auto-realização, responsável pela escolha dos meios aptos para realizar as suas potencialidades. O Estado

\footnotetext{
${ }^{446}$ Conforme temos abordado, os civilistas que na atualidade advogam a metodologia do direito civilconstitucional como a mais adequada a estes tempos pós-modernos possuem uma certa dificuldade para delimitar o conteúdo do princípio da dignidade da pessoa humana, o que acaba contribuindo para a sua utilização mais como um topos argumentativo do que como uma diretriz orientadora, o que, em certa medida, faz com que se esmaeça a necessária força do preceito; portanto, ainda que este princípio, por sua própria natureza e topografia, tenha uma dimensão meta-jurídica, eis que inserido pelo legislador constitucional brasileiro como fundamento da República Federativa do Brasil, o que explica sua íntima conexão com os direitos fundamentais, mister se faz que busquemos a sua identidade jurídica, a fim de selhe atribuirmos efetividade. Segundo escreve Maria Celina Bodin de Moraes, "O princípio constitucional visa garantir o respeito e a proteção da dignidade humana não apenas no sentido de assegurar um tratamento humano e não degradante, e tampouco conduz ao mero oferecimento de garantias à integridade física do ser humano. Dado o caráter normativo dos princípios constitucionais, princípios que contêm os valores ético-jurídicos fornecidos pela democracia, isto vem a significar a completa transformação do direito civil, de um direito que não mais encontra nos valores individualistas de outrora o seu fundamento axiológico. Neste ambiente de um renovado humanismo, a vulnerabilidade humana será tutelada, prioritariamente, onde quer que ela se manifeste. De modo que terão precedência os direitos e as prerrogativas de determinados grupos considerados, de uma maneira ou de outra, frágeis e que estão a exigir, por conseguinte, a especial proteção da lei. Nestes casos estão as crianças, os adolescentes, os idosos, os portadores de deficiências físicas e mentais, os não-proprietários, os consumidores, os contratantes em situação de inferioridade, as vítimas de acidentes anônimos e de atentados a direitos da personalidade, os membros da família, os membros de minorias, dentre outros. Seguramente, este é o aspecto mais visível da mencionada transmutação." (In MORAES, Maria Celina Bodin de. Princípios do direito civil contemporâneo, cit., p. 15) (Grifamos)
} 
democrático se justifica, também, como instância de solução de conflitos entre pretensões colidentes resultantes dessas liberdades ${ }^{447}$.

De fato, se é dado à pessoa o poder de autodeterminação, é correlato a este a assunção das consequências que dos comportamentos assumidos para realização dos seus interesses resultem ${ }^{448,449}$. Repetimos: enquanto não exigirmos no Brasil que as pessoas assumam as responsabilidades por seu atos, não haverá solução possível, quer reformem todas as leis ou Códigos! De nada adiantam as reformas legislativas se as próprias pessoas humanas não se transformarem em sujeitos responsáveis e cumpridores das legítimas expectativas!

E mais: partindo da premissa de que o direito social à moradia teria de prevalecer frente ao direito à liberdade, não se poderia admitir um desvirtuamento na fruição do direito fundamental, a ponto de se permitir que a utilização abusiva de uma posição jurídica (o direito à moradia) seria tolerada até mesmo se o locatário resolvesse não mais pagar aluguel e morar de graça, pois o direito à moradia seria superior ao direito de credor do locador; é razoável tal premissa?

Exageremos mais um pouco: se o direito à saúde é mais importante do que o direito patrimonial do dono da farmácia, por qual razão não toleramos o não-pagamento dos medicamentos adquiridos na farmácia? Se o direito à moradia é mais importante do que o direito de propriedade, por que não se permite que o condôminio que porventura perdeu a sua unidade por não pagar condomínio possa exigir do seu vizinho que este tolere a sua mudança para aquela unidade, já que o dever de solidariedade se sobreporia ao interesse individual do proprietário? São razoáveis as hipóteses narradas?

De acordo com o pensamento de George Marmelstein ${ }^{450}$ - a que aderimos -, a fruição de qualquer direito fundamental é incompatível com a idéia de abuso:

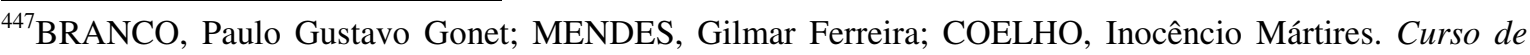
direito constitucional. 4. ed. rev. e atual. São Paulo: Saraiva, 2009, p. 402).

${ }^{448}$ MEIRELES, Rose Melo Venceslau. Autonomia privada e dignidade humana. Rio de Janeiro: Renovar, 2009. p. 266.

${ }^{449}$ "La obligatoriedad del contrato encuentra su fundamento en la idea misma de persona. Si la persona es un ser de fines cuya dignidad, derivada de su naturaleza racional, el ordenamiento juridico no puede dejar de reconocer, no cabe duda ninguna que debe reconocerse a la persona un ambito de autosoberania para reglamentar sus propias situaciones juridicas y a traves de ellas dar cauce a sus fines, intereses $y$ aspiraciones. El contrato es asi un cauce de realizacion de la persona en la vida social. A esta idea de poder de autogobierno de los propios fines nosotros la hemos denominado «autonomia privada». El contrato tiene pues su fundamento mas hondo en el principio de autonomia privada." (DÍEZ-PICAZO, Luis. op. cit., v. 1, p. 126). (Grifamos)

${ }^{450}$ In MARMELSTEIN, George. Curso de direitos fundamentais. São Paulo: Atlas, 2008. p. 423-424.
} 
"Em diversas declarações de direito pelo mundo afora, há expressa menção ao princípio da proibição de abuso de direito fundamental. Em linhas gerais, esse princípio estabelece que nenhum direito fundamental deve ser autorizado no sentido de autorizar a prática de atividades que visem à destruição de outros direitos ou liberdades. Em outras palavras: $O$ exercício de direitos fundamentais não pode ser abusivo a ponto de acobertar práticas ilícitas/criminosas cometidas em detrimento de outros direitos fundamentais ou de valores constitucionais relevantes.

(...)

Aqui no Brasil, não há uma norma constitucional expressa acolhendo o princípio da proibição de abuso de direito fundamental. Mas ele está latente no sistema constitucional brasileiro.

Basta ver inúmeras normas da própria Constituição que possibilitam a limitação ou até mesmo a perda total de direitos fundamentais quando existe abuso no seu exercício.

(...)

Analisando todas essas normas, o que se conclui é que os direitos fundamentais não podem ser utilizados para fins ilícitos, até porque eles existem para promover o bem-estar e a dignidade do ser-humano e não para acobertar a prática de maldades que possa ameaçar esses valores. Indo mais além, pode-se dizer que o exercício de direitos fundamentais não pode gerar uma situação de injustiça, nem pode servir de desculpa para a prática de atos moralmente injustificáveis ou para violar direitos de terceiros." (Grifamos)

Desta forma, e com o devido respeito àqueles que advogam uma visão distinta, já é chegada a hora de haver um maior respeito à prerrogativa de autodeterminação das pessoas, a fim de que possam ser responsabilizadas pelas decisões que vierem a tomar ${ }^{451} . A$ todo direito corresponde um dever: se alguém presta fiança de forma absolutamente consciente e livre de quaisquer máculas ou induzimentos e assume o risco do contrato firmado e da promessa realizada em favor do credor $^{452}$, deverá suportar os acertos e erros dessa decisão, pois todas as vezes que se procura proteger alguém em termos absolutos, na

\footnotetext{
${ }^{451}$ Segundo aponta MARMELSTEIN, George: "Há, ainda, dentro do art. 5, uma proteção implícita à autonomia da vontade, aqui entendida como a faculdade que o indivíduo possui para tomar decisões na sua esfera particular de acordo com os seus próprios interesses e preferências. Isso significa basicamente o reconhecimento do direito individual de fazer tudo aquilo que se tem vontade, desde que não prejudique os interesses de outras pessoas. Cada um deve ser senhor de si, agindo como um ser responsável por suas próprias escolhas pessoais, especialmente por aquelas que não interferem na liberdade alheia. A proteção da auotonomia da vontade tem como objetivo conferir ao indivíduo o direito de autodeterminação, ou seja, de determinar autonomamente o seu próprio destino, fazendo escolhas que digam respeito a sua vida e ao seu desenvlvimento humano, como a decisão de casar-se, de ter filhos ou não, de definir sua orientação sexual etc." (In MARMELSTEIN, George. op. cit., p. 94-95).

452،"Em suma: renunciar e até mesmo negociar a direitos fundamentais é algo que ocorre com bastante frequência. Na verdade, não permitir que uma pessoa, com plena capacidade de discernimento, negocie ou renuncie a direitos fundamentais é violar um dos mais básicos atributos da dignidade humana, que é a autonomia da vontade. A autonomia da vontade, conforme já dito, nada mais é do que a faculdade que o indivíduo possui para tomar decisões em sua esfera particular de acordo com os seus próprios interesses e preferências. Em outras palavras: por força da autonomia da vontade, o indivíduo pode, em princípio, fazer tudo aquilo que desejar, desde que não prejudique outras pessoas.” (In Id. Ibid., p. 438-439).
} 
mesma medida se desprotege outrem também em termos absolutos. Se o caminho a ser trilhado é o razoabilidade e da proporcionalidade, os absolutismos devem ser afastados.

De mais a mais, até mesmo à luz do princípio da unidade da Constituição ${ }^{453,454}$ não se poderia falar que o direito fundamental à moradia teria uma importância maior do que o direito fundamental de liberdade no ordenamento. Em outras palavras, a existência de um direito fundamental não é uma justificativa para desrespeitar outro direito fundamental: não é razoável que alguém não pague aluguel e prive o locador do seu crédito, ao argumento de que a sua saída do imóvel violaria a sua dignidade, bem como impediria a fruição de seu direito à moradia.

Segundo George Marmelstein ${ }^{455}$, esta situação hipotética, porém muito comum no Brasil, configuraria uma situação a ser combatida através do já citado princípio da proibição de abuso de direitos fundamentais ${ }^{456}$ :

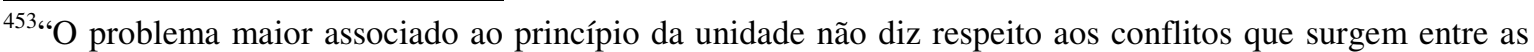
normas infraconstitucionais. O princípio da unidade é uma especificação da interpretação sistemática, impondo ao intérprete o dever de harmonizar as tensões e contradições entre as normas jurídicas. A superior hierarquia das normas constitucionais impõe-se na determinação de sentido de todas as normas do sistema. O problema maior associado ao princípio da unidade não diz respeito aos conflitos que surgem entre as normas infraconstitucionais ou entre estas e a Constituição, mas sim às tensões que se estabelecem dentro da própria Constituição. De fato, a Constituição é um documento dialético, fruto do debate e interesses contrapostos. A livre iniciativa é um princípio que entra em rota de colisão, por exemplo, com a proteção do consumidor ou com restrições ao capital estrangeiro. Desenvolvimento pode confrontar-se com proteção ao meio ambiente. Direitos fundamentais interferem entre si, por vezes em casos extremos, como ocorre no choque entre liberdade religiosa e direito à vida ou na hipótese de recusa de certos tratamentos médicos, como transfusões de sangue, sustentada pelos fiéis de determinadas confissões. Nesses casos, como intuitivo, a solução das colisões entre normas não pode beneficiar-se, de maneira significativa, dos critérios tradicionais. Em primeiro lugar, e acima de tudo, porque inexiste hierarquia entre normas constitucionais. Embora se possa cogitar de certa hierarquia axiológica, tendo em vista determinados valores que seriam, em tese, mais elevados - como a dignidade da pessoa humana ou o direito à vida - a Constituição contém previsões de privação da liberdade (art. $5^{\circ}, X L V I$, a) e até de pena de morte (art. 5०, XLVII, a). Não é possível, no entanto, afirmar a inconstitucionalidade dessas disposições, frutos da mesma vontade constituinte originária. Por essa razão, uma norma constitucional não pode ser inconstitucional em face de outra." (BARROSO, Luís Roberto. Curso de direito constitucional contemporâneo. São Paulo: Saraiva, 2009. p. 302-302) (Grifamos)

454"Segundo essa regra de interpretação, as normas constitucionais devem ser vistas não como normas isoladas, mas como preceitos integrados num sistema unitário de regras e princípios, que é instituído na e pela própria Constituição. Em conseqüência, a Constituição só pode ser compreendida e interpretada corretamente se nós a entendermos como unidade, do que resulta, por outro lado, que em nenhuma hipótese devemos separar uma norma do conjunto em que ela se integra, até porque - relembre-se o círculo hermenêutico - o sentido da parte e o sentido do todo são interdependentes." (BRANCO, Paulo Gustavo Gonet; MENDES, Gilmar Ferreira; COELHO, Inocêncio Mártires. op. cit., p. 114).

${ }^{455}$ In MARMELSTEIN, George. Análise econômica dos direitos fundamentais. Disponível em: $<$ http://direitosfundamentais.net/2007/12/14/>. Acesso em: 22 set. 2007.

${ }^{456}$ Com fundamento no Pacto de San Jose da Costa Rica, de 22 de novembro de 1969 e ratificado pelo Brasil em 25 de setembro de 1992:

"Artigo 29 - Normas de interpretação

Nenhuma disposição da presente Convenção pode ser interpretada no sentido de:

1. permitir a qualquer dos Estados-partes, grupo ou indivíduo, suprimir o gozo e o exercício dos direitos e liberdades reconhecidos na Convenção ou limitá-los em maior medida do que a nela prevista; 
"Por outro lado, o desrespeito aos contratos também não pode ser a regra. Há que haver um meio termo entre a proteção aos contratos (que, em última análise, significa respeitar a autonomia privada, que também é um direito fundamental) e a proteção ao sistema de valores que emana dos direitos fundamentais.

Nesse ponto, a teoria dos direitos fundamentais fornece um princípio bastante interessante que, apesar de ser uma ferramenta importantíssima, tem sido pouco utilizado pelos juízes: o princípio da proibição de abuso de direitos fundamentais. Os direitos fundamentais não devem servir para acobertar práticas ilícitas. Trazendo esse raciocínio para os direitos sociais, pode-se dizer que os direitos sociais não podem servir de desculpa para a prática de atos moralmente injustificáveis ou para burlar a lei.

Sobre o assunto, já tive a oportunidade de julgar um processo em que consignei o seguinte: "O direito fundamental à habitação, cujos fundamentos são tão nobres, não pode servir de escudo ao locupletamento sem causa, nem pode ser invocado ao ponto de garantir o direito de se morar em prédio de ótima localização sem que se pague nada por isso. Atitudes como a da ré somente fazem aumentar a crise do Sistema Financeiro da Habitação, pois retira a oportunidade de pessoas de boa-fé habitarem no imóvel”. (Grifamos)

E ainda neste contexto, seria o caso de se declarar a inconstitucionalidade da Lei $\mathrm{n} .^{\circ}$ $8.245 / 91$, pois se o direito social à moradia deveria prevalecer em face do eventual interesse patrimonial do locador em receber aluguéis pela cessão temporária do uso de um bem imóvel, como se poderia admitir a cobrança de uma aluguel pela fruição de um direito social fundamental de tamanha magnitude? Não seria inconstitucional a previsão legal da demanda de despejo por falta de pagamento? Ora, se o direito social à moradia não se confunde com o direito fundamental de propriedade, portanto morar estaria acima de todo e qualquer interesse patrimonial... Como se percebe, a alegação não se sustenta!

Em síntese, não há direitos fundamentais absolutos, tampouco se admite que as liberdades públicas sejam exercidas de modo a se aniquilarem reciprocamente ${ }^{457}$ :

"o estatuto constitucional das liberdades públicas, ao delinear o regime jurídico a que estas estão sujeitas - e considerado o substrato ético que as informa - permite que sobre elas incidam limitações de ordem jurídica, destinadas, de um lado, a proteger a integridade do interesse social e, de outro, a assegurar a coexistência harmoniosa das liberdades, pois nenhum

2. limitar o gozo e exercício de qualquer direito ou liberdade que possam ser reconhecidos em virtude de leis de qualquer dos Estados-partes ou em virtude de Convenções em que seja parte um dos referidos Estados;

3. excluir outros direitos e garantias que são inerentes ao ser humano ou que decorrem da forma democrática representativa de governo;

4. excluir ou limitar o efeito que possam produzir a Declaração Americana dos Direitos e Deveres do Homem e outros atos internacionais da mesma natureza". (Grifamos)

${ }^{457}$ STF, MS 23.452-RJ, Rel. Min. Celso de Mello, j. 16/9/1999. 
direito ou garantia pode ser exercido em detrimento da ordem pública ou com desrespeito aos direitos e garantias de terceiros."

Segundo ainda aponta Uadi Lammêgo Bulos, o STF, embasado no princípio da convivência entre liberdades, concluiu que nenhuma prerrogativa pode ser exercida de modo danoso à ordem pública e aos direitos e garantias fundamentais, as quais sofrem limitações de ordem ético-jurídicas. Essas limitações visam, de um lado, tutelar a integridade do interesse social e, de outro, assegurar a convivência harmônica das liberdades, para que não haja colisões ou atritos entre elas. Evita-se, assim, que um direito ou garantia seja exercido em detrimento da ordem pública ou com desrespeito aos direitos e garantias de terceiros ${ }^{458}$. No mesmo sentido doutrina Gilmar Ferreira Mendes, para quem, em princípio, não há que se falar em direitos absolutos, pois tantos outros direitos fundamentais como outros valores com sede constitucional podem limitá-los ${ }^{459}$.

E é justamente o que está a ocorrer na atualidade: a insegurança ${ }^{460}$ em ser fiador é tão grande que muitos locadores preferem deixar o imóvel fechado a locar para alguém sem garantia. E nem se diga que tal pensamento se curvaria à lógica do mercado, porque o que realmente importa é atribuir um mínimo de segurança jurídica e estabilidade ao jogo contratual, segurança esta que favorece ambos os contratantes, quer ostentem a condição de credores ou devedores.

$\mathrm{Na}$ atualidade há certo exagero na utilização de normas constitucionais como parâmetro argumentativo e justificador da tão decantada constitucionalização do direito civil. Não há dúvidas de que a Constituição Federal é a norma fundante do ordenamento, sendo aquela que lhe dá coerência, consistência e unidade. No entanto, a tipicidade aberta de vários dispositivos constitucionais permite que o intérprete neles enquadre qualquer situação fático-jurídica, sem que tenha a menor preocupação em procurar justificar o

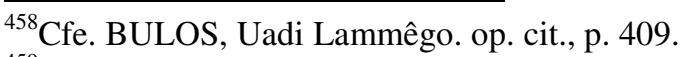

${ }^{459}$ Cfe. Curso de Direito Constitucional. 3. ${ }^{\text {a }}$ ed. rev. e atual. São Paulo: RT, 2008, p. 241.

${ }^{460}$ Sobre o tema doutrina SILVA FILHO, Artur Marques da: "Importante, porém, é não se descuidar que um julgamento constitui forma de lição pública sobre determinado "conflito de interesses" e sua solução pode ter repercussão na realidade nacional, gerando conseqüências, às vezes, imprevisíveis. E, na atualidade, ante a falta de credibilidade de nossas instituições, é visivelmente sentida na consciência de todos que as decisões judiciais não podem ser "lotéricas", exigindo-se do Poder Judiciário uniformidade nas interpretações judiciárias para oferecer segurança jurídica, sobretudo pelo informe da igualdade substancial." (SILVA FILHO, Artur Marques da. Direito à moradia e fiança locatícia. In: NANNI, Giovanni Ettore (Coord.). Temas relevantes de direito civil contemporâneo. São Paulo: Atlas, 2008. p. 567569). (Grifamos)
} 
porquê da opção manejada pela operador do sistema. Este exagero e as suas consequências foram bem delineados por Luís Roberto Barroso $^{461}$ :

"Um sentido da locução constitucionalização do Direito identifica a vinda para a Constituição de normas dos diversos ramos do direito infraconstitucional que nela viram consignados institutos, princípios e regras a eles atinentes. Outro sentido possível, que foi explorado no presente capítulo, traduz a ida da Constituição, com seus valores e fins, aos diferentes ramos do direito infraconstitucional. Mas constitucionalizar uma matéria significa retirá-la da política cotidiana, do debate legislativo. Isso dificulta o governo da maioria, que não pode manifestar-se através do processo legislativo ordinário - que exige maioria simples ou, no máximo, absoluta -, precisando alcançar, com frequiência, o quórum qualificado das emendas constitucionais. Como a Constituição brasileira já padece do excesso de constitucionalização, na primeira acepção, não se deve alargar além do limite razoável a constitucionalização por via interpretativa, sob pena de se embaraçar, pelo excesso de rigidez, o governo da maioria, componente importante do Estado democrático.

De outra parte, é indispensável que juízes e tribunais adotem certo rigor dogmático e assumam o ônus argumentativo da aplicação de regras que contenham conceitos jurídicos indeterminados ou princípios de conteúdo fluido. $O$ uso abusivo da discricionariedade judicial na solução de casos difíceis pode ser extremamente problemático para a tutela de valores como segurança e justiça, além de poder comprometer a legitimidade democrática da função judicial. Princípios como dignidade da pessoa humana, razoabilidade e solidariedade não são cheques em branco para o exercício de escolhas pessoais e idiossincráticas. Os parâmetros da atuação judicial, mesmo quando colhidos fora do sistema estritamente normativo, devem corresponde ao sentimento social e estar sujeitos a um controle intersubjetivo de racionalidade e legitimidade.

(...)

A Constituição não pode pretender ocupar todo o espaço jurídico em um Estado democrático de direito. Respeitadas as regras constitucionais e dentro das possibilidades de sentido dos princípios constitucionais, o Legislativo está livre para fazer escolhas que lhe pareçam melhores e mais consistentes com o anseios da população que o elegeu. $O$ reconhecimento de que juízes e tribunais podem atuar criativamente em determinadas situações não lhes dá autorização para se sobreporem ao legislador, a menos que este tenha incorrido em inconstitucionalidade. Vale dizer: havendo lei válida a respeito, é ela que deve prevalecer. A preferência da lei concretiza os princípios da separação de Poderes, da segurança jurídicas e da isonomia." (Grifamos)

O que não pode ocorrer, segundo pensamos, é a alteração da lógica do sistema de forma abrupta, de modo a atingir todas os figurantes de contratos de fiança sem que se atentasse para a peculiaridade de cada um; desse modo, seria mais coerente com o caráter protetivo da interpretação que considera impenhorável o único imóvel do fiador, a vedação

\footnotetext{
${ }^{461}$ In BARROSO, Luís Roberto. op. cit., p. 392.
} 
pura e simples de assumir a responsabilidade de uma fiança daquele que é proprietário de um único imóvel. Em outras palavras, quem fosse o proprietário de um único imóvel não poderia ser fiador, situação esta que seria pré-excluída pelo sistema e impediria discussões intermináveis sobre se haveria ou não haveria colisão de direitos fundamentais na espécie.

Mas em lugar disso preferimos discussões intermináveis à soluções...

$\mathrm{Na}$ atualidade, se tivesse saído vencedora do julgamento realizado no Supremo Tribunal Federal a tese que advogava a impenhorabilidade do imóvel do fiador, na prática teria sido sinalizado ao mercado que não se mostraria mais viável que o proprietário de um único imóvel se apresentasse como fiador. Talvez seja esta a melhor solução para a questão, a fim de se evitar que discussões intermináveis impeçam a realização da função social do contrato de fiança.

Por fim, apontamos que Pablo Stolze Gagliano e Rodolfo Pamplona Filho favoráveis à tese da impenhorabilidade - , entendem que a penhora violaria o princípio constitucional da isonomia, porque de uma mesma base negocial decorreria tratamento desigual entre fiador e locatário, muito embora as obrigações de ambos tivessem a mesma causa jurídica - o contrato de locação ${ }^{462,463}$.

Não comungamos desse entendimento, até porque as obrigações do locatário e do fiador decorrem de causas distintas. Enquanto o locatário é obrigado por força do contrato

\footnotetext{
462،Em outras palavras: se o fiador for demandado pelo locador, visando à cobrança dos aluguéis atrasados, poderá o seu único imóvel residencial ser executado, para a satisfação do débito do inquilino. Não ignorando que o fiador possa se obrigar solidariamente, o fato é que, nas sua essência, a fiança é um contrato meramente acessório pelo qual um terceiro (fiador) assume a obrigação de pagar a dívida, se o devedor principal não o fizer. Mas seria razoável garantir o cumprimento desta obrigação (essencialmente acessória) do fiador com o seu único bem de família? Seria tal norma constitucional? Partindo da premissa de que as obrigações do locatário e do fiador têm a mesma base jurídica - contrato de locação -, não é justo que o garantidor responda com o seu bem de família, quando a mesma exigência não é feita para o locatário. Isto é, se o inquilino, fugindo de suas obrigações, viajar para o interior da Bahia, e comprar um único imóvel residencial, este seu bem será impenhorável, ao passo que o fiador continuará respondendo com o seu próprio bem de família perante o locador que não foi pago. À luz do Direito Civil Constitucional - pois não há outra forma de pensar modernamento o Direito Civil - parece-me forçoso concluir que este dispositivo de lei viola o princípio da isonomia insculpido no art. $5 .^{\circ}$, da $\mathrm{CF}$, uma vez que trata de forma desigual locatário e fiador, embora as obrigações de ambos tenham a mesma causa jurídica: o contrato de locação." (In GAGLIANO, Pablo Stolze; PAMPLONA FILHO, Rodolfo. Novo curso de direito civil: parte geral. 8. ed. rev., atual. e reform. São Paulo: Saraiva, 2006. v. 1, p. 284-285).

${ }^{463}$ No mesmo sentido é a doutrina de SANTOS, Gildo: "Por outro ângulo, há importante tema relativo à impenhorabilidade, porque, como já se disse, o fiador teria ficado injustiçado com essa alteração da Lei 8.009/90, uma vez que o afiançado continuava e continua beneficiado pela impenhorabilidade do seu bem de família, enquanto o garante ficou sem essa proteção ao seu único bem residencial. A dívida pela qual responde o bem de família do fiador e a mesma pela qual não pode ser penhorado o bem de família do locatário afiançado. Isto, embora decorrente da Lei do Inquilinato, chocava muitas opiniões abalizadas, pelo tratamento desigual, do ponto de vista jurídico legal, que se dava à responsabilidade do locatário e à do fiador pela mesma dívida decorrente do mesmo contrato de locação." (In SANTOS, Gildo dos. op. cit., p. 125). (Grifamos)
} 
de locação, o fiador é responsável por força do contrato de fiança. Portanto, as causas dos deveres jurídicos são distintas, de maneira que distintas também serão as respectivas consequências $^{464}$. O fiador é o responsável pela dívida, sem ser também devedor principal, quando o locatário é o responsável pela dívida, sendo o seu principal e único devedor.

Portanto, se locatário e fiador participam de contratos diversos, não há que se falar em violação à isonomia no caso, porque ambos se encontram sob situações fático-jurídicas diversas. O fiador, é bom que se lembre, é o responsável pelo adimplemento do afiançado, é o sujeito que prometeu fato de terceiro, enquanto o inquilino se vinculou a uma obrigação de pagar, hipóteses estas substancialmente distintas, razão por que a alegação de violação ao princípio da isonomia não nos convence.

\subsection{A sub-rogação da posição jurídica do fiador em face do afiançado}

Sub-rogação é a transferência dos direitos do credor para o terceiro que solveu a obrigação ou emprestou o necessário para o devedor solvê-la. A obrigação pelo pagamento se extingue, porém em virtude da sub-rogação a dívida, que foi extinta para o credor originário, subsiste para o devedor que passa a ter por credor o terceiro que efetuou o pagamento em seu lugar ou lhe emprestou o necessário ao adimplemento. Nesta hipótese, o terceiro que pagou fica investido nas mesmas garantias e privilégios do credor originário $^{465}$.

O Código Civil, por sua vez, admite que o pagamento seja efetuado por duas espécies de terceiro: o interessado e o não interessado. $\mathrm{O}$ terceiro interessado é aquele que possui interesse jurídico na extinção da dívida, por estar a ela vinculado (o fiador disposto a pagar a dívida do afiançado, o avalista de um título de crédito, outro credor do devedor etc.) e o não interessado será o terceiro que possui um interesse não jurídico, mas apenas moral, benemérito, sentimental (o pai que cumpre a obrigação do filho, o patrão que paga a dívida do empregado, a namorada que quita o débito do namorado etc. $)^{466}$.

\footnotetext{
${ }^{464} \mathrm{Cfe}$. já expusemos no item 4.2. desta dissertação.

${ }^{465}$ Cfe. BEVILÁQUA, Clovis. Código Civil dos Estados Unidos do Brasil comentado. Rio de Janeiro: Francisco Alves, 1917. p. 144.

${ }^{466}$ GREGÓRIO, Ricardo Algarve. Comentários ao código civil: artigo por artigo. Carlos Eduardo Nicoletti Camillo et al. [coord.] São Paulo: RT, 2006, p. 345).
} 
Nesse sentir, por força do disposto no artigo 831, do Código Civil, o fiador que pagar integralmente a dívida ficará sub-rogado nos direitos do credor e assumirá integralmente o crédito originário com todas as suas qualidades e vicissitudes. Da forma como a sub-rogação opera na atualidade o mecanismo acaba sendo, na grande maioria das vezes, completamente inútil ao fiador porque não lhe garante pleno ressarcimento, situação esta que apenas beneficia o afiançado e incentiva a postura abusiva e irresponsável do devedor, razão pela qual defendemos a alteração do instituto da sub-rogação para torná-lo realmente eficaz à luz daquilo que diuturnamente ocorre na sociedade.

Com efeito, os tribunais brasileiros já sedimentaram o entendimento de que o fiador que paga a dívida do afiançado e se sub-roga na posição jurídica do credor originário assume o crédito tal como ele se apresentaria se o próprio credor originário demandasse o devedor principal.

Assim, se o credor originário demandasse o devedor principal pela obrigação nãocumprida em contrato de locação, por exemplo ${ }^{467}$, não poderia penhorar e levar à hasta 0 seu único imóvel, na medida em que incidiria a proteção conferida pela Lei n. ${ }^{\circ}$ 8.009/90 ao bem de família em cujo texto não foi contemplada nenhuma exceção em favor do credor. Neste caso, se a obrigação não-cumprida estivesse garantida por fiança, e o garante viesse a ser demandado pelo credor originário, o único imóvel do fiador poderia vir a ser demandado e levado à hasta pública porque a proteção legal conferida ao bem de família não se estenderia ao fiador, ex vi do seu artigo $3 .^{\circ}, \mathrm{VII}^{468}$.

\footnotetext{
${ }^{467}$ Sobre o tema, é importante esclarecer que o bem de família do fiador somente poderá ser vulnerado e atingido se a fiança tiver sido "concedida em contrato de locação", tal como se encontra enunciado no art. 3. ${ }^{\circ}$, VII, da Lei n. ${ }^{\circ} 8.009 / 90$. Como se trata de uma regra restritiva do direito do fiador, a sua interpretação também deverá ser restritiva, de modo a circunscrevê-la apenas às garantias prestadas em contrato de locação; tirante esta hipótese, em todo e qualquer outr contrato que não o de locação o patrimônio do fiador será invulnerável às pretensões dos credores.

${ }^{468}$ Nesse sentido: "LOCAÇÃO. EMBARGOS À EXECUÇÃO EM CARÁTER REGRESSIVO. OUTORGA UXÓRIA EM FIANÇA. FALTA DE PREQUESTIONAMENTO. SUB-ROGAÇÃO DO FIADOR QUE PAGA A DÍVIDA ORIUNDA DE DÉBITOS LOCATÍCIOS. IMPENHORABILIDADE DO BEM DE FAMÍLIA DO LOCATÁRIO - A nova Lei do Inquilinato restringiu o alcance do regime de impenhorabilidade dos bens patrimoniais residenciais instituído pela Lei $n^{\circ} 8.009 / 90$, considerando passível de constrição judicial o bem familiar dado em garantia por obrigação decorrente de fiança concedida em contrato locatício. - Com o pagamento da dívida pelo fiador da relação locatícia, fica este sub-rogado em todas as ações, privilégios e garantias que tinha o locador-credor em relação ao locatário-devedor, nos termos do Código Civil, art. 988. - A jurisprudência já pacificou entendimento no sentido de ser vedada a penhora de bem de família do locatário, em execução proposta pelo locador a fim de solver dívida advinda da relação locatícia. - Se ao locador-credor não é possibilitado constringir judicialmente o imóvel do locatário, e a sub-rogação transmite os direitos e ações que possuía o credor, conseqüência lógica é que ao fiador tal privilégio não pode ser assegurado, de vez que não existia para o credor primitivo. - Recurso especial conhecido e provido." (REsp 263.114/SP, Rel. Ministro VICENTE LEAL, 6. ${ }^{\text {a Turma, julgado em }}$ 10/04/2001, DJ 28/05/2001 p. 217)
} 
Entretanto, o fiador que pagasse a dívida do devedor principal visando salvaguardar o seu patrimônio não poderia, em demanda de regresso, penhorar e levar à hasta o único bem imóvel do devedor porventura existente, uma vez que a condição legal de bem de família impediria tanto que o credor como fiador atingissem o patrimônio do devedor principal. Ora, esta disciplina legal viola a lógica do sistema porque o fiador é o responsável pela adimplemento, mas não é obrigado pela dívida, enquanto o devedor principal é o responsável pelo débito e o obrigado pela dívida, o que demonstra que a situação jurídica do fiador é muito mais grave do que a do devedor principal!

Com efeito, este incongruência demonstra que o legislador brasileiro intervém no sistema normativo sem qualquer critério ou consistência, atuando de afogadilho apenas na vã tentativa de tentar resolver situações pontuais; todavia, a bem dizer, acaba, por remendar o tecido normativo e cria mais problemas do que soluções.

É por esta razão que urge seja realizada a completa reforma do instituto da fiança, de maneira a tornar a garantia realmente efetiva em benefício do credor, além de também torná-la um instrumento de responsabilidade do fiador. Portanto, ainda que façamos um análise de lege ferenda, porque de lege lata o direito positivo atual não permitiria conclusão outra, a possibilidade de atingimento de eventual bem de família do devedor principal há que ser garantida ao garante, de modo tornar o devedor principal realmente responsável pelos débitos que a sua conduta houver gerado. Na atualidade, como o devedor principal não tem nada a perder, o ônus recai totalmente sobre o garante.

Como a tendência natural dos homens é a de fugir às suas responsabilidades ${ }^{469}$, o legislador deveria atuar para induzir que o próprio devedor principal cumprisse as suas obrigações, e que fosse efetivamente responsabilizado pelos débitos por ele contraídos, de maneira a tornar o eventual inadimplemento das suas obrigações muito mais desvantajoso do que seu adimplemento.

\subsection{Análise da Súmula ${ }^{\circ} 214$ do Superior Tribunal de Justiça}

A imensa maioria dos contratos de locação contém cláusula que responsabiliza os fiadores pelo débito do inquilino até que este devolva as chaves do imóvel locado em mãos do locador. De prática tão comum que é, até mesmo os contratos de locação cujos

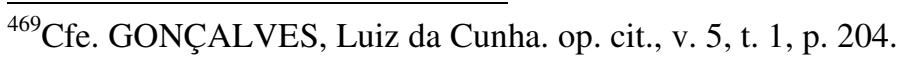


impressos podem ser adquiridos em papelarias consignam tal cláusula, razão pela qual Luís Camargo Pinto de Carvalho anotou em um artigo ${ }^{470}$, que "fica evidente o arraigamento na consciência jurídica pátria da validade da cláusula contratual que impõe ao fiador responder pela fiança até a efetiva entrega das chaves do imóvel ou entrega do prédio."

Tal cláusula, na verdade, é a transposição literal para o contrato da regra prevista no artigo 39 da Lei do Inquilinato, que é assim redigido:

"Art. 39 - Salvo disposição contratual em contrário, qualquer das garantias da locação se estende até a efétiva devolução do imóvel." (Grifamos)

Ao adotarem tal cláusula os locadores visam manter o fiador atrelado ao contrato de locação se, após o seu vencimento, vier o inquilino a continuar na posse do imóvel alugado por mais de trinta dias sem oposição ${ }^{471}$, hipótese essa que gera a chamada prorrogação da locação por tempo indeterminado, "mantidas as demais cláusulas e condições do contrato", isto é, ante a letra da lei mantido será o negócio jurídico sem que seja fixado tempo certo e determinado para encerrá-lo, como expressamente prevê o $\S 1^{\circ}$, do artigo 46, da Lei do Inquilinato $^{472}$.

E a maioria dos tribunais da federação vinha entendendo, de forma praticamente pacífica, que o vencimento do contrato de locação com a conseqüente manutenção dos inquilinos no imóvel locado por mais de trinta dias sem oposição do senhorio prorrogaria a locação por tempo indeterminado sem que isso afetasse a responsabilidade dos fiadores, a qual se estenderia até a efetiva devolução do imóvel locado, haja vista que tal prorrogação ocorreria por força de lei, e também porque seriam mantidas todas as demais cláusulas e condições do contrato, exceto, por óbvio, a relativa ao seu tempo de duração, a qual já se encontraria vencida.

No entanto, a partir de 1998 o que era pacífico deixou de sê-lo por força da nova orientação adotada pelo Superior Tribunal de Justiça que em 23 de outubro daquele ano

\footnotetext{
${ }^{470}$ In CARVALHO, Luís Camargo Pinto de. Da extinção da responsabilidade do fiadores em contrato de locação. Disponível em: <http\l:www.saraivajur.com.br>.Acesso em: 21 jun. 2005.

${ }^{471}$ Quer do locador, quer do locatário, o que se dá mediante denúncia do vínculo.

${ }^{472}$ Eis a redação do dispositivo: “Art. 46 - Nas locações ajustadas por escrito e por prazo igual ou superior a trinta meses, a resolução do contrato ocorrerá findo o prazo estipulado, independentemente dc notificação ou aviso. $\S 1^{\circ}$ - Findo o prazo ajustado, se o locatário continuar na posse do imóvel alugado por mais de trinta dias sem oposição do locador, presumir-se-á prorrogada a locação por prazo indeterminado, mantidas as demais cláusulas e condições do contrato".
} 
publicou $^{473}$ a Súmula 214 que consolida(va) a jurisprudência daquele tribunal sobre a limitação da responsabilização do fiador. A referida súmula foi assim redigida:

"O fiador não responde por obrigações resultantes de aditamento ao qual não anuiu." (Grifamos)

Uma primeira e apressada leitura da Súmula 214 do STJ levou os intérpretes a uma conclusão que, aparentemente, apresentar-se-ia óbvia sobre o seu verdadeiro alcance: $a$ de que o fiador não responderia pela dívida decorrente de "aditamento" contratual ao qual não teria se vinculado.

Tomada apenas em seu aspecto gramatical, a Súmula 214 não teria trazido nenhuma inovação ao ordenamento jurídico brasileiro, na medida em que se basearia em princípio secular do direito dos contratos - o da relatividade dos seus efeitos -, porque o aditamento contratual firmado sem a participação do garante seria res inter alios acta e, assim, inoponível ao fiador. Quanto a essa interpretação, entendo não pairarem quaisquer dúvidas.

Todavia, em que pese a literalidade da Súmula 214 do Superior Tribunal de Justiça, uma análise dos julgados que eram proferidos por esta Corte mostrou-se-nos que "A leira mata e o espírito vivifica." 474

Com efeito, apesar da letra em que fora redigida a súmula em questão, o seu espírito vinha sendo diuturnarnente revelado pela interpretação consagrada pelo Superior Tribunal de Justiça, que podia ser aferida a partir da leitura de alguns julgados que bem espelhavam a orientação daquela Corte sobre um tema de capital importância no Brasil, por dizer respeito a uma das modalidades de garantia mais utilizadas em contratos de locação.

Por exemplo, vejamos o que restou decidido pela $6^{\text {a }}$ Turma do Superior Tribunal de Justiça, em 25.09.01, nos autos do REsp n. ${ }^{\circ}$ 254.409-MG, relatados pelo Ministro Vicente Leal:

"LOCAÇÃO E PROCESSUAL CIVIL. NULIDADE E INEFICÁCIA DA SENTENÇA. INOCORRÊNCIA. FIANÇA. INTERPRETAÇÃO RESTRITIVA. PRORROGAÇÃO DO CONTRATO SEM ANUÊNCIA DOS FIADORES. IMPOSSIBILIDADE. SÚMULA 214/STJ.

\footnotetext{
${ }^{473}$ DJU, p. 250.

${ }^{474}$ II Coríntios 3:6: "O qual nos fez também capazes de ser ministros de um novo testamento, não da letra, mas do espírito; porque a letra mata e o espírito vivifica".
} 
- É cediço o entendimento de que o juiz não está obrigado a responder todas alegações das partes, quando já tenha encontrado motivos suficientes para fundamentar a decisão, nem está obrigado a ater-se aos fundamentos indicados por ela e tampouco a responder um ou todos os seus argumentos.

- Não ocorre nulidade da sentença, por falta de fundamentação, na hipótese em que afastada, ainda que indiretamente, a alegação de que não restara comprovado que os fiadores anuiram à prorrogação do contrato por prazo indeterminado porquanto proclamado o entendimento de que a responsabilidade dos fiadores estende-se até a efetiva entrega das chaves.

- Descabida a alegação de ineficácia da sentença em face da ausência de citação válida de um dos listiconsortes necessários porque, tendo os demais fiadores a oportunidade de argüir a ausência de citação de um dos garantes, em diversos momentos processuais, quedaram-se inertes.

- A jurisprudência assentada nesta Corte construiu o pensamento de que, devendo ser o contrato de fiança interpretado restritivamente, não se pode admitir a responsabilização do fiador por encargos locaticios decorrentes de contrato de locação prorrogado sem a sua anuência, ainda que exista cláusula estendendo sua obrigação até a entrega das chaves.

- Recurso especial parcialmente conhecido e, nesta extensão, provido." (Grifamos)

Colhe-se do acórdão acima referido o seguinte entendimento:

"Ora, responsabilizar os fiadores pelos aluguéis e demais encargos vencidos após o prazo de expiração da avença locatícia originária implica conferir à garantia fidejussória interpretação extensiva, ainda que exista cláusula contratual que estenda a obrigação até a efetiva entrega das chaves".

E neste mesmo sentido vários outros julgados vinham sendo diariamente proferidos pelo STJ, de modo a fazerem não mais pairarem quaisquer dúvidas com relação ao campo de incidência da Súmula 214: conquanto os contratos de locação possam ser portadores de cláusula estendendo a garantia fidejussória "até a entrega das chaves”, a prorrogação da locação por força de lei vinha sendo considerada como aditamento contratual a exigir, para a sua eficácia perante o fiador, anuência expressa deste quando da sua ocorrência.

Em que pese a clareza do posicionamento que vinha sendo adotado pelo STJ, a exegese meramente literal da súmula em comento fazia com que muitos tribunais afastassem a sua aplicação em inúmeros casos concretos, principalmente nas demandas oriundas da Lei do Inquilinato (Lei ${ }^{\circ}$ 8.245/91), situação essa que se colocava em frontal 
dissídio à jurisprudência dominante ${ }^{475}$ do Superior Tribunal de Justiça, a quem cabe, por força de preceito constitucional, unificar a interpretação da lei federal.

É o que vinha acontecendo, por exemplo, com a jurisprudência dominante do extinto $2^{\circ}$ Tribunal de Alçada Civil de São Paulo ${ }^{476}$, hoje incorporado ao Tribunal de Justiça por força da Emenda Constitucional $n^{\circ} 45^{477}$; a resistência ao posicionamento adotado pelo STJ pelos juízos ordinários foi bem apontada pelo Desembargador Luís Camargo Pinto de Carvalho no artigo doutrinário ${ }^{478}$ dantes mencionado:

"Aliás, a inoportunidade e a ilegalidade da interpretação dada pelo STJ a essa Súmula n. 214 têm feito que tanto os juizes de primeiro grau como os Tribunais, na sua generalidade, ignorem o alcance que essa corte the tem dado."

Com efeito, apesar das ótimas decisões em matéria de locação que sempre proferiu, o que o colocou em situação de destaque e vanguarda nesse campo, parece-nos que no que dizia respeito ao árido tema objeto da Súmula 214 a jurisprudência predominante do extinto Segundo Tribunal de Alçada Civil de São Paulo entrava em rota de colisão com as decisões proferidas pelo Superior Tribunal de Justiça, posto proceder a interpretação meramente literal da súmula, o que causava apreensão entre os aplicadores do direito, pois casos idênticos poderiam receber solução diversa, causando perplexidade e gerando instabilidade entre os jurisdicionados, que muitas vezes deixavam de ter atendidos os seus reclamos por não terem conseguido remetê-los, via recurso especial, à apreciação do Tribunal Superior, seja por ausência de prequestionamento ou por alguma outra deficiência técnica.

Nesse sentir, pode-se afirmar, em linhas gerais, que da $25^{\mathrm{a}}$ a $36^{\mathrm{a}}$ Câmaras de Direito Privado do Tribunal de Justiça de São Paulo, as quais compete julgar recursos que tenham por matéria questões envolvendo locação, sempre entenderam que $a$ responsabilização dos fiadores deveria perdurar até que ocorresse a efetiva desocupação do imóvel locado, não obstante o posicionamento adotado pelo Superior Tribunal de Justiça.

\footnotetext{
475، "Quando urna linha jurisprudencial está erigida em súmula, isso em princípio significa que ela é largamente dominante no tribunal". (DINAMARCO, Cândido Rangel. A reforma da reforma. 2. ed. São Paulo: Malheiros Ed., 2002. p. 187).

${ }^{476}$ Atualmente, o $2^{\circ}$ Tribunal de Alçada Civil de São Paulo, ao ter sido incorporado à estrutura administrativa do Tribunal de Justiça de São Paulo, converteu-se nas Câmaras $25^{\circ}$ a $36^{\circ}$ da Seção de Direito Privado deste Tribunal, de acordo com o Provimento $n^{\circ}$ 66/2005 do TJSP.

${ }^{477}$ Publicada no DOU de 31/12/2004.

${ }^{478}$ In art. cit.
} 
Foi o que decidiu, por exemplo, a $2^{\mathrm{a}}$ Câmara do extinto $2^{\circ}$ TACivSP, em 24.11.03, nos autos da apelação com revisão n. ${ }^{\circ} 808.159-00 / 8$ relatados pelo ilustre Desembargador Andreatta Rizzo em acórdão bem redigido, razão por que seus termos bem sintetizam per se a posição majoritária do Tribunal:

"FIANÇA - RESPONSABILIDADE DO FIADOR - LOCAÇÃO CONTRATO PRORROGADO - SUBSISTÊNCIA ATÉ A EFETIVA DEVOLUÇÃO DO IMÓVEL - RECONHECIMENTO - APLICAÇÃO DO ARTIGO 39 DA LEI 8245/91

A prorrogação da locação sem a anuência dos fiadores não desonera a garantia. Permanecem eles obrigados pelos encargos do afiançado, mesmo após o vencimento do contrato escrito, mormente, quando há cláusula contratual expressa nesse sentido."

Colhem-se do v. aresto os seguintes fundamentos:

"De fato, segundo disposto na Cláusula $11^{a}$ do Contrato de Locação, os fiadores tornaram-se solidariarnente responsáveis com a locatária por todas as obrigações decorrentes da avença, cuja responsabilidade haveria de perdurar até "a devolução das chaves" (fls. 13 dos autos em apenso).

Ora, sendo assim, a prorrogação do ajuste não engendrou a desoneração da garantia, permanecendo, os fiadores, obrigados até a entrega do imóvel ao locador, responsáveis, mesmo após o vencimento do contrato escrito, pelos encargos do afiançado, exceção feita à hipótese de aditamento acertado entre locador e locatário, estabelecendo nova pactuação, sem a anuência deles.

Com isso, longe de se dar interpretação extensiva à fiança, mas, sim, medir a exata responsabilidade dos fiadores, tal como subscreveu a garantia.

Sem embargo da orientação já firmada pelo Colendo Superior Tribunal de Justiça, no sentido da limitação da fiança ao prazo contratado, esta Turma Julgadora e este Tribunal, em casos assemelhados, têm decidido que: "Se a fiança foi prestada não por tempo certo, mas até efetiva devolução do imóvel locado, a garantia persiste em caso de prorrogação da locação por tempo indeterminado, não se configurando novação capaz de exonerar o fiador". (AI 627.110-00/9 - 10 Câmara, Rel. Juiz Soares Levada, j. 26.4.2000).

É curial o entendimento que a prorrogação legal do contrato de locação acarreta a prorrogação automática do contrato de fiança que lhe é acessório, mormente tendo os fiadores assumido expressamente a responsabilidade pelas obrigações daí decorrentes até a efetiva devolução do imóvel.

Nestas condições, é de se reconhecer que os argumentos contidos no recurso não são convincentes, no que toca à prorrogação do contrato - o que se verifica por força de lei - e no tocante à inexistência de comunicação escrita quanto ao prosseguimento da relação obrigacional.

De acordo com o artigo 56, parágrafo único, da Lei 8.245/91, o contrato por prazo determinado prorroga-se indeterminadamente quando, após o 
fim do prazo estipulado, o locatário permanecer no imóvel por mais de trinta dias sem oposição do locador.

Por isso, a cláusula segunda que condiciona a prorrogação do contrato à prévia anuência por escrito do locador não socorre os apelantes, já que está em desconformidade com a lei e não pode se sobrepor a ela.

A esse respeito a jurisprudência já decidiu que: "A fiança prestada em contrato de locação esgota sua força no último dia do prazo determinado especificado no contrato, salvo se o fiador expressamente assumiu aquela garantia para a hipótese de prorrogação da avença por prazo indeterminado ou até a entrega das chaves pelo afiançado." (Ap. c/ Rev. 546.261-00/0 - $4^{a}$ Câm. - Rel. Juiz Amaral Vieira - J. 15.6.99).

E também: "Existindo a clásula de garantia prevista no contrato até a entrega das chaves pelo inquilino-afiançado, não pode o fiador pretender limitá-la ao vencimento do ajuste por prazo determinado, quando houve prorrogação do contrato de locação por força de lei." (TADF - Apel. Cível $n^{\circ} 46998-2^{a}$ Turma Cível - Relatora Juíza Nancy Andrighi - J. 11.05.1998)."

No mesmo sentido do aresto transcrito, cujos precisos termos bem sintetizam a posição majoritária das Câmaras de Direito Privado do TJSP, vários outros precedentes seguem a mesma trilha:

"Acompanha o douto Juízo a corrente pretoriana pela qual extingue-se a fiança quando consumado o prazo contratual. Assim, desonerar-se-ia o fiador a partir do dia seguinte ao da prorrogação da locação a prazo indeterminado. Com a devida vênia do entendimento esposado em sentença, segue-se jurisprudência em sentido contrário, bem exposta pelo embargado em seu apelo. $\mathrm{O}$ art. $3^{\circ}$ da Lei $\mathrm{n}^{\circ} 8.245 / 91$ é explícito no sentido de que as garantias da locação, como a fiança, subsistem até a entrega das chaves, salvo estipulação em contrário.

No caso dos autos, a cláusula 20 do contrato em exame reforça aquela norma. Obrigam-se os fiadores até a efetiva entrega das chaves do imóvel, ainda que prorrogado o contrato a prazo incerto. Só não respondem, em conseqüência, pelo que ultrapassar o valor do aluguel estipulado em contrato, com as correções legais. E nada consta nos autos nesse sentido, tampouco erro de cálculo pelo credor. O contrato de fiança, em suma, encontra-se em vigor e o valor da divida permanece íntegro. Ante o exposto, dá-se provimento ao recurso, para julgar os embargos improcedentes, invertida a sucumbência., ${ }^{, 49}$

"A responsabilidade dos fiadores permanece após o término do prazo estabelecido pelo contrato de locação, circunstância que dispensa qualquer aviso ou notificação prévia, porque:

Há disposição legal: "Salvo disposição contratual em contrário, qualquer das garantias da locação se estende até a efetiva devolução do imóvel."

Há cláusula (8a) convencionando de forma expressa:

“... responsabilidades essas que perdurarão até a efetiva entrega das chaves do imóvel através de recibo assinado pela Locadora ..." (Folha 13 - Apenso).

Repousa pacífico tal entendimento nesta Corte de Justiça:

\footnotetext{
${ }^{479}$ Extinto $2^{\circ}$ TACivSP, Ap. c/ Rev. 565.748-00/2 - 11 a Câm. - Rel. Juiz JOSÉ MALERBI - J. 03.4.00.
} 
"A prorrogação do prazo contratual não caracteriza extinção da obrigação, ex vi do artigo 39 da Lei do Inquilinato, quando os fiadores assumiram a responsabilidade solidária pelos afiançados até a efetiva entrega das chaves do imóvel livre de pessoas e coisas ." "480

"2. Toda a argumentação contida no agravo parte do pressuposto de ter havido novação contratual, em face da prorrogação do termo inicial do pacto locatício, que passou a viger por tempo indeterminado.

No entanto, as longuíssimas razões e inúmeros acórdãos e doutrina citados não se aplicam, simplesmente, ao caso concreto, no qual os fiadores garantiram a locação, solidariamente, "até a entrega real e efetiva das chaves do imóvel" (fl. 44).

Aplicável, em conseqüência, o artigo 39 da Lei $\mathrm{n}^{\circ}$ 8245/91, pelo qual "Salvo disposição contratual em contrário, qualquer das garantias da locação se estende até a efetiva devolução do imóvel" (grifei). Não existe disposição em contrário e, ao invés, o que foi contratualmente previsto reforça o entendimento corretamente manifestado pela r. decisão recorrida, no sentido da subsistência das obrigações contratuais dos fiadores em caso de mera prorrogação contratual.

Ou seja, como a fiança não foi ajustada por prazo certo - caso em que, logicamente, desapareceria a garantia no termo final do contrato -, e sim por prazo indeterminado, até efetiva entrega das chaves, nenhuma aplicação tem os artigos 1483 e 1090 do Código Civil ao caso concreto, pois exonerados não se encontravam os fiadores por ocasião do termo final do contrato. (...) Ou seja, e em suma, a prorrogação do contrato não configurou novo acordo de vontades entre as partes no que se refere à fiança prestada, que o foi até devolução efetiva do imóvel locado. Logo, não tendo sido prestada por tempo certo, subsiste a fiança, para todos os efeitos legais." ${ }^{481}$

"É intuitivo, portanto, que, se o fiador desejasse fixar limite temporal expresso da garantia, deveria ter exigido a inserção dessa ressalva no instrumento contratual. No que concerne à alegação de que o pagamento de parte do débito pelo locatário teria caracterizado novação ou moratória, equivocou-se, mais uma vez, o apelante.

Cumpre ressaltar, desde logo, que novação e moratória são institutos completamente distintos, na medida em que a primeira, sem substituição dos sujeitos, ocorre quando nova dívida for contraída em substituição à original, que se extingue, como reza o art. 999, inciso I, do Código Civil, enquanto a moratória representa a concessão de prazo mais dilatado para o devedor cumprir a obrigação.

De novação, portanto, não há se cogitar, porque eventual pagamento parcial não poderia representar a extinção da obrigação primitiva, sobretudo quando ausente o chamado animus novandi, elemento essencial para a caracterização deste instituto, como observa o festejado Prof. CAIO MÁRIO DA SILVA PEREIRA (v. "Instituições de Direito Civil", Forense, vol. II, p. 191/196).

A moratória, de outro modo, sobre indemonstrada, somente provocaria a extinção da fiança quando resultasse em prejuízo para o fiador, o que não ocorre com o mero recebimento parcial do débito, como já decidiu esta Corte: "O recebimento parcial da dívida pelo credor não prejudica o

${ }^{480}$ Ap. c/ Rev. 547.420-00/6 - 10ª Câm. - Rel. Juiz IRINEU PEDROTTI - J. 26.5.99.

${ }^{481}$ AI 627.110-00/9 - 10 a Câm. - Rel. Juiz SOARES LEVADA - J. 26.4.2000. 
fiador, mas só o favorece, diminuindo-lhe a responsabilidade no tocante ao débito. Assim, não evidencia tal circunstância a caracterização de moratória, capaz de determinar a incidência do art. 1.503, inciso I do CPC, de molde a desobrigar o fiador" (EI $145.047-1^{\circ}$ Grupo - Rel. Juiz MORAES SALLES - J. 28.2.83, in JTA (Saraiva) 82/217)." "482

"3. No tema de fundo, a questão principal gira em torno da interpretação do contrato de fiança.

Objetiva a fiadora a limitação de sua responsabilidade solidária pelos encargos locatícios à data do término do contrato de locação, qual seja, dia 09/09/99.

Entretanto, a pretensão da recorrente não pode prosperar. Pela cláusula 15a da avença firmada (fls. 26), observe-se, a agravante obrigou-se, como fiadora, até a real e efetiva entrega das chaves do imóvel. Comprometeuse por todas as obrigações decorrentes do contrato de locação, compreendendo, assim, os aluguéis vencidos, desde a propositura da ação de despejo por falta de pagamento até a data efetiva da desocupação.

Ora, a par disso, a Lei do Inquilinato, estabelece, no artigo 39, que: salvo disposição contratual em contrário, qualquer das garantias da locação se estende até a efetiva devolução do imóvel.

Dessa maneira, quer pela lei, quer pelo contrato, que, expressamente, consigna o prazo de validade da fiança - até a entrega real e efetiva das chaves do imóvel locado - está obrigada a fiadora á garantia dada, pois esta é a razão de ser da fiança, conforme artigo 1.481, do Código Civil, dá-se o contrato de fiança, quando uma pessoa se obriga por outra, para com o seu credor, a satisfazer a obrigação, caso o devedor não a cumpra.

Se o fiador expressamente garante os pagamentos dos locativos até real e efetiva entrega das chaves, a eles está obrigado. A permanência do locatário no imóvel, após o término do prazo da avença locatícia, sem expressa anuência do fiador, não configura hipótese capaz de ensejar sua exoneração. Inteligência do art. 39, da Lei do Inquilinato, e art. 1.481, do Código Civil.

Assim, por qualquer àngulo que se examine, não se visualiza razão para se excluir a responsabilidade solidária da agravante sobre os encargos locatícios sub judice."

"A tese sustentada pelos embargantes, respeitante à ilegitimidade ad causam não prospera.

Com efeito, a circunstância de ter sido prorrogado o contrato de locação, fazendo-o vigorar por prazo indeterminado não afastava a responsabilidade solidária dos fiadores, ora embargantes, pois tal garantia se estende até a efetiva desocupação do imóvel pelo afiançado (cláusula $7^{\text {a }}$, fls. 09).

Confira-se, a propósito o magistério de ARNALDO MARMITT, verbis:

"Frequentemente após o término do pacto locaticio a locação prossegue $e$ os aluguéis são reajustados conforme os parâmetros da legislação especifica. Nessas hipóteses os fiadores que se vincularam até a entrega das chaves e solidariamente com os deveres assumidos pelo locatário,

${ }^{482}$ Ap. c/ Rev. 590.131-00/0 - 6 ${ }^{\mathrm{a}}$ Câm. - Rel. Juiz PAULO HUNGRIA - J. 10.10.2000.

${ }^{483}$ AI 741.926-00/3 - $11^{\mathrm{a}}$ Câm. - Rel. Juiz ARTUR MARQUES - J. 17.6.2002. 
pelo cumprimento de todas as obrigações contratuais, respondem tanto pelos locativos ajustados, como pelas correções que no curso da locação até a desocupação do imóvel foram autorizadas pela lei ou pelo contrato." (in Fiança Civil e Comercial, pág. 215, Aide Editora, $1^{a}$ ed.).

A jurisprudência não discrepa:

"Terminado o prazo do contrato de locação, mas prorrogada esta por tempo indeterminado, 'perdura a responsabilidade do fiador, se estabelecida até a entrega das chaves', inclusive quanto aos aluguéis reajustados dentro dos parâmetros legais (JTACivSP-RT 89/370, Rel. CAMARGO DA FONSECA, $2^{\circ}$ TAC5vSP,)." (GILDO DOS SANTOS, Locação e Despejo, pág. 203, Editora Revista dos Tribunais, $4^{a}$ ed.)." "484

Delimitada questão a que se refere o presente tópico, procuraremos demonstrar que a interpretação original subjacente à Súmual 214 do STJ, e que foi recentemente alterada pelo próprio Superior Tribunal de Justiça, se mostrava mais adequada à proteção das posições jurídicas dos credor e fiador, sendo certo que a nova exegese piorou a situação dos garantes e rompeu com o equlíbrio que a interpretação dantes consagrada pelo tribunal consagrava.

Não obstante, entendemos que a análise das controvérsias que cercam a Súmula 214 do Superior Tribunal de Justiça não pode ignorar aquilo que acontece na vida real, a fim de serem evitadas situações por demais onerosas aos fiadores que, além de prestarem um favor de grande valia ao afiançado, acabam por comprometer integralmente o seu próprio futuro, pois poderão arruinar todo o seu patrimônio numa operação jurídicoeconômica que nenhuma valia ou proveito material irá lhes trazer.

Segundo entendemos, essa veio a ser a razão pela qual o Superior Tribunal de Justiça, em um primeiro momento editou a Súmula 214 e consagrou uma exgese que passou a proteger a posição jurídica do fiador sem que comprometesse os interesses do locador, o que promoveu o equilíbrio da posição jurídica das partes e reforçou os princípios da boa-fé objetiva e função social do contratos no contexto da garantia fidejussória, conforme procuraremos demonstrar.

Mesmo assim, a partir da edição da súmula em comento as controvérsias e os debates que já existiam foram por demais acirrados, o que contribuiu para aumentar o clima de profunda insegurança que já cercava o tema. Tecidos os presentes esclarecimentos, passemos a analisar o sentido e alcance da Súmula 214 do Superior Tribunal de Justiça em sua exegese original.

\footnotetext{
${ }^{484}$ Ap. s/ Rev. 653.970-00/6 - 1ª Câm. - Rel. Juiz MAGNO ARAÚJO - J. 28.1.2003.
} 
Analisemos os argumentos apresentados por três doutrinadores que se debruçaram sobre o tema, tendo buscado precisar o sentido original da súmula sob enfoque.

Em comentários à Súmula 214, Heitor Vitor Mendonça Sica ${ }^{485}$ fez severas críticas à sua redação ${ }^{486}$, entendendo que a palavra aditamento teria o sentido de novação. Escreveu o referido autor:

"Por "aditamento", pode-se intuitivamente entender novação, em sua modalidade objetiva, prevista no art. 999, I, do CC de 1916 ("Art. 999. Dá-se a novação: I - Quando o devedor contrai com o credor nova dívida, para extinguir ou substituir a anterior."

A fiança, contrato acessório de garantia que é, segue a obrigação principal. Se houve novação, e a obrigação principal originalmente garantida foi extinta ou substituída, a garantia não subsiste. Trata-se de exegese dos arts. 1.003 e 1.006 da lei civil pátria ("Art. 1.003. A novação extingue os acessórios e garantias da dívida, sempre que não houver estipulação em contrário" e "Art. 1.006. Importa exoneração do fiador a novação feita sem o seu consenso com o devedor principal")."

Já Humberto Theodoro Júnior ${ }^{487}$ assim se pronunciou sobre o tema:

"Com efeito, proclama referida súmula que "o fiador na locação não responde por obrigações resultantes de aditamento ao qual não anuiu". $\mathrm{O}$ enunciado, portanto, não cogitou de prorrogação do contrato, que, às mais das vezes, não decorre de aditamento algum, mas deflui da própria lei. Nem se referiu, obviamente, a prorrogações já previstas na convenção inicial das partes." (Grifamos)

Sobre o tema, prosseguiu Humberto Theodoro ${ }^{488}$ :

"Ainda que se lavre algum documento para registrar a prorrogação, em tais circunstâncias, o efeito da extensão do vínculo contratual é simples consectário daquilo que desde a origem haviam ajustado os contratantes. A estipulação de que a fiança perduraria até a entrega das chaves, e não apenas durante o prazo certo de início avançado (sic), decorre do próprio contrato de fiança. Não se pode condicionar sua eficácia à assinatura do fiador no aditivo de prorrogação, porque já convencionado se achava que assim duararia a fiança. Impossível, destarte, exonerar automaticamente o fiador, em tais circunstâncias, por falta de anuência à prorrogação. Essa anuência já fora dada nos próprios termos da fiança em condições de validade inconteste porque autorizada por norma legal expressa (Lei do Inquilinato, art. 39).”

\footnotetext{
${ }^{485}$ In SICA, Heitor Vitor Mendonça. A penhora e o bem de família do fiador da locação. Coord. José Rogério Cruz e Tucci. Autores Clito Fornaciari Júnior et al. São Paulo: Ed. Revista dso Tribunais, 2003. p. 27.

${ }^{486}$ "Em princípio, a redação da Súmula parece bastante óbvia, malgrado sua falta de rigor termino lógico.”.

${ }^{487}$ In THEODORO JÚNIOR, Humberto. A fiança e a prorrogação do contrato de locação. Revista de Direito Privado, São Paulo, v. 5, n. 18, p. 77, abr./jun. 2004.

${ }^{488}$ Id. Ibid., p. 77 e ss.
} 
No mesmo sentido veio a ser a posição adotada por Luis Camargo Pinto de Carvalho $^{489}$ :

\begin{abstract}
"Trata-se de regra de intelecção aparentemente óbvia. O fiador, na locação, responde tão-somente pelas obrigações assumidas. Assim, por exemplo, se, no curso do contrato, locador e locatário deliberam elevar o aluguel acima do originalmente contratado, o fiador somente responderá por esse excedente se com ele houver anuído; ou, se no contrato ficou pactuado que responderia pelas obrigações até o termo final do contrato, para que continuasse a responder, no caso de prorrogação, somente com sua anuência, em aditamento sua responsabilidade prosseguiria.
\end{abstract}

Como, entretanto, em matéria de locação, o contrato se prorroga automaticamente por força de lei, o diploma inquilinário trouxe a regra expressa. como exposto, de que a responsabilidade do fiador se estende até a devolução do imóvel, ou seja, não tendo o fiador limitado sua responsabilidade, ela vai até a extinção da locação, com a devolução do prédio alugado.

Isso se nos afigura de ululante obviedade. Não há se falar em anuência com relação a prorrogação legal do contrato e extensão das responsabilidades determinadas por lei. Não há aditamento do contrato para isso ocorrer e, por via de consequiência, não há ao o que anuir. Quando se fala em aditamento, está-se falando em outro contrato, ainda que simples e complementar, com nova manifestação de vontade dos contratantes, com alteração da obrigação original. Como explicita De Plácido e Silva, aditamento significa "o aumento de cláusulas em um contrato já elaborado e mesmo registrado ou a parte acrescida ao final de um documento para alterar ou explicar algumas das condições ali exaradas, ou mesmo para corrigir omissões evidenciadas". Isso, repita-se, não existe em se tratando de prorrogação legal da locação, pois contrato prorrogado por lei não é contrato aditado." (Grifamos)

Como se vê, a doutrina entende não possuírem o mesmo significado semântico as palavras aditamento e prorrogação. Para o primeiro autor citado, aditamento seria o mesmo que novação. Já para os dois últimos, infere-se que, além de entenderem possuírem diferentes significados semânticos, o aditamento decorreria da manifestação de vontade dos contratantes, enquanto a prorrogação adviria da lei, razão por que o âmbito de incidência de ambos seria inconfundível.

Em que pesem as opiniões dos estudiosos citados, com as mesmas não podemos concordar, permissa venia.

A Súmula 214 do Superior Tribunal de Justiça é assim redigida:

"O fiador não responde por obrigações resultantes de aditamento ao qual não anuiu."

\footnotetext{
${ }^{489}$ CARVALHO, Luis Camargo Pinto de. op. cit.
} 
Por primeiro, vejamos as acepções que ambos os termos - aditamento e prorrogação - possuem na língua portuguesa, tanto na linguagem comum quanto na jurídica.

Segundo o Dicionário Eletrônico Houaiss ${ }^{490}$, a palavra aditamento teria se originado do latim additaméntum, e significaria adição, acréscimo. E uma das acepções desta palavra seria "2. aquilo que se acrescenta a (algo) a fim de se elucidar, complementar etc." (Grifamos) Portanto, este seria o significado usual da palavra aditamento.

E na linguagem jurídica, qual seria a verdadeira acepção do termo aditamento? O clássico Vocabulário Jurídico DE PLÁCIDO E SILVA ${ }^{491}$ indica que:

"Tem a mesma significação de adição. Expressa aumento, ampliação. E neste sentido, aditamento tem a significação de: Aumento de cláusulas em um contrato já elaborado e mesmo registrado. Parte acrescida ao final de um documento para alterar ou explicar alguma das condições ali exaradas, ou mesmo para corrigir omissões evidenciadas."

Portanto, conclui-se que tanto na linguagem comum quanto na jurídica a palavra aditamento expressa o significado de aumento, ampliação, a fim de se elucidar ou complementar algo. Em complemento, pode-se dizer que aditamento, no âmbito jurídico, vem a ser a modificação do conteúdo contratual supervenientemente à formação do vínculo, que tanto poderá redundar na inclusão, exclusão ou modificação de cláusulas contratuais.

E qual seria o sentido da palavra prorrogação?

A origem da palavra, conforme extrai-se do mesmo Dicionário Eletrônico Houaiss $^{492}$, seria a expressão latina prorogatio, e significaria adiar, demorar, prolongar.

Com efeito, esclarece nesse sentido o já citado Dicionário Jurídico DE PLÁCIDO ESILVA ${ }^{493}$ :

"Do latim prorogatio, de prorogare (alongar, dilatar, adiar, ampliar), exprime, originariamente, o aumento de tempo, a ampliação do prazo, o

\footnotetext{
$\overline{{ }^{490} \text { DICIONÁRIO Eletrônico Houaiss. }}$ Disponível $<$ http://houaiss.uol.com.br/busca.jhtm?verbete=aditamento\&stype=lç>.

${ }^{491}$ In SILVA, De Plácido e. Vocabulário jurídico. 2. ed. Rio de Janeiro: Forense, 1990. v. 1, p. 84.

${ }^{492}$ DICIONÁRIO Eletrônico Houaiss. $<$ http://houaiss.uol.coin.br/buseajhtm?verbete=aditamento\&stype=Iq >.

${ }^{493}$ SILVA, De Plácido e. op. cit., v. 2, p. 482.
} 
espaçamento de tempo, prestes a extinguir, para que certas coisas possam continuar, em seguimento, sem solução de continuidade.

Nesta razão, a prorrogação pressupõe prazo ou espaço de tempo, que não extinguiu nem se finou, e que é ampliado, dilatado, aumentado, antes que se fine ou se acabe.

Não se prorroga o que já se mostra terminado ou acabado, isto é, fora da vigência ou do exercício de um prazo, que não mais existe. Aí, ocorreria coisa nova, iniciar-se-ia um novo espaço de tempo, pela solução de continuidade entre o prazo antigo e o novo prazo, revelando-se, portanto, renovação, não prorrogação.

A rigor, pois, a prorrogação é a dilatação do espaço de tempo, cujo fim não ocorreu, para que se continue a fazer o que dentro dele se permitia. E, portanto, deve ser promovida antes que termine o prazo ou aquilo que se quer prorrogar, para que o tempo prefixo se dilate ou se amplie.

Na prorrogação, o antes e o depois ligam-se numa continuidade para se mostrarem como urna única e só coisa, isto é, para que se apresente como um prazo ou um espaço de tempo, em que não se registrou nem ocorreu a menor descontinuidade, o que não se registra na renovação, onde se anota a interrupção entre o passado e o novo ou presente.

A prorrogação, portanto, tem por objeto precípuo não admitir interrupção nem promover uma solução de continuidade entre o espaço de tempo, que foi insignificante para cumprimento de certo fato, e o outro, que se concedeu ou veio aumentar o passado."

Prorrogação, pois, teria o sentido de protraimento, dilação de prazo que se encontra prestes a terminar, a fim de se evitar solução de continuidade.

Portanto, prorroga-se prazo que se encontra em curso; renova-se prazo que já se extinguiu.

Tendo presente o real significado dos termos aditamento e prorrogação, agora analisemos as posições defendidas pelos doutrinadores dantes citados: Heitor Vitor Mendonça Sica, Humberto Theodoro Júnior e Luís Camargo Pinto de Carvalho.

Para o primeiro autor, aditamento e novação seriam sinônimos. Data maxima venia, aditamento não é sinônimo de novação.

A novação constitui modalidade de extinção de uma obrigação que vem ocupar o lugar da primeira. É uma forma de pagamento indireto que, ao mesmo tempo em que extingue o débito anterior, produz um novo débito, em um ato único, de modo que não apenas se assume nova dívida: se assume uma nova dívida em lugar de outra, que se extingue. Este é o mais relevante traço da novação, sem cuja compreensão é impossível a 
apreensão do instituto, da sua funcionalidade e da sua eficácia, que é a de criar e extinguir relação jurídica por efeito do mesmo ato jurídico ${ }^{494}$.

Portanto, a novação implica na assunção de nova obrigação visando a automática extinção da anterior. É, na verdade, a substituição de uma dívida por outra, substituição essa que implica na extinção da obrigação sucedida pela sucessora, a qual poderá vir a ser exigida do devedor pelo credor na data do seu vencimento. Vejamos que a obrigação sucedida desaparece, razão pela qual o único vínculo que passa a unir credor e devedor é o da obrigação nova, qual seja, a sucessora. É o que se extrai do artigo 360, inciso I, do Código Civil de 2002.

Como se vê, a finalidade da novação é obter a extinção de uma dívida, mediante a assunção de outra pelo devedor, podendo se dar de forma expressa ou tácita, mas que deve ser sempre inequívoca, ex vi do artigo 361 do Código Civil de 2002.

Assim, sendo o aditamento o meio de que se valem os contraentes para proceder a modificação do conteúdo contratual supervenientemente à formação do vínculo, que tanto poderá redundar na inclusão, exclusão ou modificação de cláusulas contratuais, o mesmo tanto poderá servir de instrumento de prova da novação quanto de mera alteração de cláusula do contrato, sem que se fale no ato de contrair-se nova dívida para extinguir e substituir a anterior.

Logo, o conteúdo do aditamento contratual tanto poderá dizer respeito à extinção de dívida presente mediante assunção de nova que a substitui (= novação), quanto a inserção/exclusão/modificação de obrigações contratuais (= aditamento), sem que haja a intenção de novar, mas sim de modificar o vínculo contratual, total ou parcialmente, tal como a inclusão de cláusula contratual referente ao dever de conservação do imóvel locado (v.g. obrigação do locatário efetuar a pintura do imóvel).

Como se pode perceber, a inserção de cláusula contratual referente à pintura do imóvel não extingue e substitui obrigação anterior do devedor, mas apenas lhe carreia novo encargo que passa a ser exigível, sendo, pois, mera alteração do conteúdo do contrato.

Dessa forma, conclui-se que poderá haver aditamento sem novação, mas jamais haverá novação sem aditamento.

Ora, parece intuitivo que aquele que cumpriu contrato de locação e decidiu manter a locação por novo período não novou, mas renovou o contrato. Neste específico caso, a

\footnotetext{
${ }^{494}$ MARTINS-COSTA, Judith. Comentários ao novo Código Civil, cit., v. 5, t. 1, p. 504.
} 
nova locação não foi estabelecida visando extinguir a anterior, mas sim manter inalterado o estado das coisas: o locador continuar a receber aluguéis, enquanto o locatário permanecer na posse do prédio locado.

Diante disso, as doutrinas de Humberto Theodoro Júnior e Luís Camargo Pinto de Carvalho, a despeito da força dos argumentos apresentados, estão a merecer alguns reparos.

Lembremos que, para os autores citados, aditamento não seria o mesmo que prorrogação porque aquele decorreria da vontade das partes, enquanto esta surgiria por força de lei.

Com efeito, como se pôde perceber pela exposição anterior, aditamento é modificação do conteúdo do contrato. E modificação, no âmbito contratual, tanto pode se dar por escrito ou verbalmente; decorrer da vontade das partes ou da lei.

Isso se dá porque vige no direito brasileiro o princípio do consensualismo, que é a liberdade da adoção da forma que revestirá os contratos e os negócios jurídicos unilaterais. Em especial quanto aos contratos, caracteriza-se o consensualismo dizendo que em regra basta o acordo entre as partes, para que estas fiquem vinculadas - consensus obligat ${ }^{495}$, ao contrário do que ocorria no direito romano, no qual dominavam o formalismo e o simbolismo que submetiam a validade de determinado contrato ao aperfeiçoamento de determinado ritual.

Assim, não havendo forma específica estabelecida em lei, nada impede que um contrato escrito venha a ser modficado por aditamento verbal. Da mesma forma, nada impede que um contrato verbal, venha a ser modificado por escrito. A dificuldade maior girará em torno da prova da modificação, não havendo qualquer influência sobre a modificação em si mesmo considerada.

Como exemplo de aditamento (= modificação) por força de lei, podemos citar as alterações impostas aos contratos das sociedades empresárias em virtude da entrada em vigor do Código Civil de 2002 que em seu artigo 2.031 determinou a adaptação dos atos e contratos sociais à nova disciplina legal imposta ao regime das fundações, associações e sociedades. Em virtude disso, algumas cláusulas tiveram de ser acrescentadas, e outras,

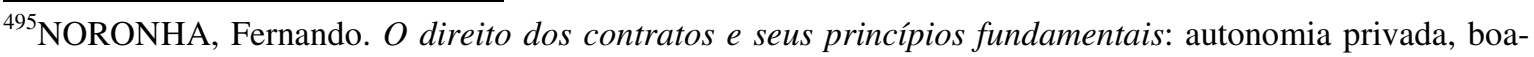
fé, justiça contratual. São Paulo: Saraiva, 1994. p. 117.
} 
eliminadas. Houve total modificação dos conteúdos dos instrumentos sociais em geral por força de lei. Aditamento contratual, pois, ainda que por força de lei.

Portanto, nada impede que a lei preveja a prorrogação ou renovação de contratos, imponha direitos e obrigações às partes, busque salvaguardar os interesses do contratante débil, dentre outros, o que se dá através de normas cogentes, as quais a vontade das partes não pode afastar.

Nesse sentir, pode-se dizer que prorrogação contratual por força de lei aditamento $e ́$, haja vista provocar a alteração da cláusula de vigência do contrato independentemente da vontade dos contraentes, ainda que apenas incida ante a omissão dos mesmos.

Logo, quando a Súmula 214 do Superior Tribunal de Justiça tratou de aditamento contratual também cuidou, ainda que de forma implícita, da "prorrogação" do vinculo por força de lei, razão pela qual a controvérsia que existia em torno do tema não encontra qualquer justificativa.

Não obstante, a questão da "prorrogação" legal do vínculo contratual está a merecer uma breve análise sob outro enfoque, o que faremos a seguir.

Com efeito, a questão da prorrogação legal do contrato de locação está a merecer uma breve análise sob outro ângulo, eis que a mesma, para as locações residenciais, vem prevista no artigo 46, e $\S$, da Lei 8.245/91:

"Art. 46 - Nas locações ajustadas por escrito e por prazo igual ou superior a trinta meses, a resolução do contrato ocorrerá findo o prazo estipulado, independentemente de notificação ou aviso.

$\S 1^{\circ}$ - Findo o prazo ajustado, se o locatário continuar na posse do imóvel alugado por mais de trinta dias sem oposição do locador, presumir-se-á prorrogada a locação por prazo indeterminado, mantidas as demais cláusulas e condições do contrato.

$\S 2^{\circ}$ - Ocorrendo a prorrogação, o locador poderá denunciar o contrato a qualquer tempo, concedido o prazo de trinta dias para desocupação." (Grifamos)

Com efeito, do ponto de vista técnico-legal com o advento do termo previsto para o término da locação opera-se a extinção do vínculo contratual existente entre locador e locatário. Todavia, por questões de política legislativa, tendo em vista que o déficit habitacional existente no país representa um grave problema social a ser enfrentado, o legislador, ao ter pensado nesse problema, procurou conciliar o interesse de ambos os contratantes: apesar da extinção do vínculo contratual, se o locatário permanecer no imóvel 
por mais de trinta dias sem oposição do locador, o contrato de locação, antes findo, estará automaticamente "prorrogado" por tempo indeterminado. Todavia, nesta hipótese o locador poderá denunciar ${ }^{496}$ o contrato a qualquer momento, concedendo ao inquilino trinta dias para a desocupação, findo o qual sem atendimento poderá ser exigido o despejo do imóvel pela via judicial.

Muito embora a lei tenha se valido do termo prorrogar, nestes casos ocorre, a bem dizer, a renovação do contrato de locação, porém por tempo indeterminado. E por que não houve prorrogação, mas sim renovação?

Porque prorrogação implica no aumento de prazo sem solução de continuidade, ou seja, apenas se prorroga o que ainda está em curso, conforme já tivemos oportunidade de expor anteriormente. Logo, extinto o contrato de locação por força do advento do termo previsto para o seu término, não se cogita mais de se prorrogar o que já acabou; neste caso, ocorre a renovação do contrato de locação por força de lei e independentemente da vontade das partes, renovação essa que se dá sem que haja tempo determinado, a fim de se permitir a retomada do imóvel mediante denúncia vazia.

Sobre o tema, doutrina Francisco Carlos Rocha de Barros:

"Regra antiga de nosso direito, o art. 1.194 do Código Civil [de 1916] afirma que a locação por tempo determinado cessa de pleno dircito, findo o prazo estipulado, independentemente de notificação ou aviso. Isso significa que a locação cessa com a expiração do prazo estipulado, sem necessidade de notificação ou aviso (...) Ao analisar tal artigo, Clóvis dizia ser princípio geral, adotado pelo Código Civil, que o prazo final opera por si a resolução do ato, a que é aposto, não se desviando dessa norma a locação." (J. M. de Carvalho Santos, Código Civil brasileiro interpretado, Freitas Bastos, 1957, v. 17, p. 81)." ${ }^{, 497}$

"Prorrogar", no caso, ressente-se de impropriedade, pois só se prorroga o que ainda vive. Se, com o término do prazo, cessou de pleno direito a locação, é impossibilidade lógica falar-se em prorrogação. Dizer que a locação se renova por declaração de vontade presumida pela lei seria mais adequado ${ }^{498}$.

Com efeito, vez mais esclarece nesse sentido o já citado Dicionário Jurídico DE PLÁCIDO E SILVA ${ }^{499}$ no verbete renovação do contrato:

\footnotetext{
${ }^{496}$ É a denominada "denúncia vazia".

${ }^{497}$ In BARROS, Francisco Carlos Rocha de. op. cit., p. 201-202.

${ }^{498}$ Id. Ibid., p. 206.

${ }^{499}$ In SILVA, De Plácido e. v. 3 e v. 4, p. 96.
} 
"Exprime o restabelecimento de um contrato, que se havia extinto ou que se tinha vencido, mantendo-se as cláusulas originais ou se acrescentando a estas novas cláusulas.

Importa a renovação do contrato numa dilatação ou aumento de prazo. Mas, difere da prorrogação porque esta somente ocorre quando o primitivo contrato não se tinha ainda vencido: a prorrogação tem que ser cumprida dentro da vigência do contrato. Em caso contrário, ocorrerá uma renovação: restabelecimento e revigoramento do contrato, cujo prazo se extinguira.

Nos contratos, civis ou comerciais, a diferença traz sua importância, pois que, na prorrogação, não havendo um novo contrato não há pagamento de novo selo, enquanto que na revogação (sic), devendo ser composto um novo instrumento, tudo se faz como se nada existisse."

E assim sendo, a Lei do Inquilinato não poderia ter prorrogado, sob um aspecto eminentemente técnico-jurídico, o que já não mais existia e, por conseguinte, ter imposto a mesma trilha ao contrato de fiança!

Portanto, não se tratando de mera prorrogação do contrato de locação, mas antes de verdadeira renovação legal da locação por tempo indeterminado, tem-se que extinto o contrato, extinta também estará a fiança, ainda que o fiador tenha se comprometido a garantir o contrato de locação até que se desse a entrega das chaves do imóvel, como vinha decidindo sistemáticamente o Superior Tribunal de Justiça.

Ora, falar em prorrogação do que já acabou revela uma insuperável contradição lógica, de modo que há, no caso, renovação do contrato de locação.

Assim, como a extinção do contrato de locação se dá automaticamente com o advento da data fixada para o seu término, uma vez extinta a locação automaticamente também extinta estaria a fiança, contrato acessório que deveria seguir a sorte do principal.

Nestes casos, ocorrida a renovação da locação ante a omissão das partes em denunciá-la, se acaso o locador pretendesse manter a garantia no período de vigência por tempo indeterminado deveria obter a anuência dos fiadores, fazendo, assim, que o contrato de locação renovado por força de lei fosse garantido durante esse período pela fiança. Está é, segundo entendemos, a melhor solução a ser dada ao destino do contrato de fiança nas situações em que ocorrer a prorrogação legal do contrato de locação, eis que se encontra de acordo com os princípios da boa-fé objetiva e da função social dos contratos.

Portanto, ante o vencimento do contrato de locação o locador depara-se com duas alternativas possíveis: a) obtém a anuência dos fiadores originários, e com isto mantém a 
garantia fidejussória, ou b) exige do inquilino a indicação de novos fiadores, sob pena de considerar resolvido o contrato por infração legal, em virtude da aplicação conjunta dos artigos 40, inciso IV e $9^{\circ}$, inciso II, da Lei do Inquilinato, sem prejuízo de poder exigir o pagamento do aluguel antecipadamente do inquilino até o sexto dia útil do mês vincendo, como previsto no artigo 42, da mesma Lei.

Dessa maneira, protegido fica o fiador, que não terá a sua obrigação extendida além do vencimento previsto para o contrato de locação, bem como salvaguardado estará o locador que poderá exigir a indicação de novo fiador, sob pena de, na omissão do inquilino, agir para obter o despejo do imóvel. Com isso, equilibra-se a posição jurídicoeconômica das partes sem que as mesmas sejam onerdas em demasia, o que foi feito pelo Superior Tribunal de Justiça com a edição da Súmula 214.

Destarte, ainda que tenhamos procurado demonstrar as razões e a conveniência da exegese originária subjacente à Súmula 214 do Superior Tribunal de Justiça, uma questão ainda exige resposta: como conciliar o princípio da interpretação restritiva do contrato de fiança previsto no artigo 819 do Código Civil de 2002, com a regra legal de vigência das garantias prestadas à locação de imóvel "até a entrega das chaves", prevista no artigo 39, da Lei do Inquilinato?

Com efeito, diz o artigo 819 do Código Civil de 2002:

"A fiança dar-se-á por escrito e não admite interpretação extensiva." (Grifamos)

Já o artigo 39 da Lei 8.245/91 assim dispõe:

"Salvo disposição contratual em contrário, qualquer das garantias da locação se estende até a efetiva devolução do imóvel" (Grifamos)

Não vemos outra alternativa que não seja a transposição, para o campo das leis ordinárias, do critério de interpretação constitucional denominado de princípio da razoabilidade, que muito embora seja utilizado na seara da interpretação constitucional para valorar os atos do Poder Público à luz dos critérios de utilidade e justiça, nada impede a sua aplicação no campo das relações interprivadas, mormente porque a chave para bem aplicar os institutos jurídicos tem sido a (re)leitura dos textos legais ordinários à luz dos valores e princípios da Constituição Federal de 1988. 
Sobre o tema, doutrina Luís Roberto Barroso ${ }^{500}$ :

"O princípio da razoabilidade é um parâmetro de valoração dos atos do Poder Público para aferir se eles estão informados pelo valor superior inerente a todo ordenamento jurídico: a justiça. Sendo mais fácil de ser sentido do que conceituado, o princípio se dilui em um conjunto de preposições que não o libertam de uma dimensão excessivamente subjetiva. É razoável o que seja conforme à razão, supondo equilíbrio, moderação e harmonia; o que não seja arbitrário ou caprichoso o que corresponda ao senso comum, aos valores vigentes em dado momento ou lugar. Há autores, mesmo, que recorrem ao direito natural como fundamento para a aplicação da regra da razoabilidade, embora possa ela radicar-se em princípios gerais da hermenêutica. Sobre este ponto em particular, veja-se a passagem, inspirada em San Thiago Dantas:

"Não é apenas a doutrina do Direito Natural que vê no Direito uma ordem normativa superior e independente da lei. Mesmo os que concebem a realidade jurídica como algo mutável e os princípios do Direito como uma síntese das normas dentro de certos limites históricos reconhecem que pode haver leis inconciliáveis com esses princípios, cuja presença no sistema positivo fere a coerência deste, e produz a sensaçao íntima do arbitrário, traduzido na idéia de lei injusta."

No campo do direito privado, pode-se considerar que o princípio da razoabilidade adota o nome de lógica do razoável.

Segundo já explicou Alípio Silveira ${ }^{501}$,

"a determinação dos conteúdos do Direito, tanto das normas gerais das normas individualizadas deve reger-se pelo logos do humano e do razoável.

O legislador opera com valorações sobre tipos de situações reais ou hipotéticas em termos genéricos e relativamente abstratos. O essencial em sua obra nunca consiste no texto da lei, mas nos juízos de valor que o legislador adotou como inspiração para sua lei.

O processo de produção do Direito continua na obra do órgão jurisdicional, o qual, em lugar de valorar. em termos gerais, certos tipos de situações, tem de valorar, em termos concretos, situações individuais. Para isso, tem que valorar a prova, valorar os fatos do caso apresentados, compreendendo seu sentido singular, qualificando-os juridicamente, e estimando qual seja a norma adequada. O conjunto dessas operações, travadas recíproca e indissoluvelmente entre si, é o plano dc solução mais justa dentro da ordem jurídica positiva."

\footnotetext{
${ }^{500}$ In BARROSO, Luís Roberto. Interpretação e aplicação da constituição. São Paulo: Saraiva, 1996. p. 204 e ss.

${ }^{501}$ In SILVEIRA, Alípio. Hermenêutica juridica: seus princípios fundamentais no direito brasileiro. São Paulo: Leia Livros, [s.d.]. v. 1, p. 174;
} 
Portanto, conclui-se caber ao intérprete da lei escolher, dentre as interpretações possíveis, aquela que se revela a mais razoável no caso concreto, a qual deve sempre conduzir à idéia básica de utilidade e justiça, reflexos estas da solidariedade e justiça social proclamadas no artigo $3^{\circ}$, inciso I, da Constituição Federal.

E no caso em análise, a visão principiológica do Direito permite a conclusão de que o princípio estatuído no artigo 819 do Código Civil, relativo à interpretação restritiva da manifestação de vontade do fiador, não poderia ter sido alterado pela regra do artigo 39 da Lei do Inquilinato, relativo à extensão da responsabilidade do fiador.

Princípio é, por definição, mandamento nuclear de um sistema, verdadeiro alicerce dele, disposição fundamental que se irradia sobre diferentes normas compondo-lhes o espírito e servindo de critério para a sua exata compreensão e inteligência, exatamente por definir a lógica e a racionalidade do sistema normativo, no que lhe confere a tônica e lhe dá sentido harmônico. É o conhecimento dos princípios que preside a intelecção das diferentes partes componentes do todo unitário que há por nome sistema jurídico positivo $^{502}$.

Os princípios jurídicos constituem a base do ordenamento jurídico, a parte permanente e eterna do Direito e, também, o fator cambiante e mutável que determina a evolução jurídica; são as idéias fundamentais e informadoras da organização jurídica da $\mathrm{Nação}^{503}$. E, precisamente por constituirem a base mesma do Ordenamento, não é concebível uma norma legal que os contravenha ${ }^{504}$. Assim, ainda que lei posterior venha a dispor contra princípio exposto em lei anterior, e desde que esse princípio disser respeito à estrutura de uma determinada área da ciência jurídica, razão por que poderia ou não ter sido positivado, não se admite a derrogação, pois, como já o disse Gustav Radbruch, "há leis que não são Direito e (...) há Direito acima das leis."

Ora, e por ser o princípio da interpretação restritiva dos negócios jurídicos benéficos o fundamento basilar desta espécie contratual (art. 114, do Código Civil), e sendo a fiança uma modalidade de contrato benéfico, em cuja disciplina o legislador entendeu por bem reforçar o princípio da interpretação restritiva (art. 819 do Código Civil),

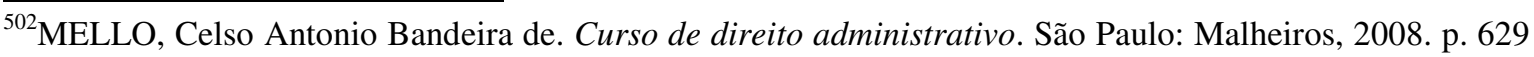
e ss.

${ }^{503}$ GONZÁLEZ PEREZ, Jesús. El principio general de la buena fé en el derecho administrativo. Madrid: Real Academia de Ciencias Morales y Politicas, 1983. p. 51-52.

${ }^{504}$ Id. Ibid., p. 52;

${ }^{505}$ In RADBRUCH, Gustav. Leis que não são direito e direito acima das leis. Justitia, São Paulo, v. 38. n. 93 , p. $159,1976$.
} 
a regral legal de extensão das garantias "até a entrega das chaves" na locação prevista no artigo 39 da Lei do Inquilinato deve ceder espaço à proteção do fiador, cuja garantia deve se entender ter sido prestada até o vencimento do contrato, porque essa seria a conclusão mais razoável se o fiador pudesse prever, no momento da apresentação da garantia, quais as graves consequências que lhe advirão se após o vencimento do contrato o inquilino deixar de pagar os aluguéis e encargos.

Esse é um princípio fundamental dos contratos benéficos, universalmente aceito pela doutrina, de modo que em não tendo havido a sua derrogação expressa pela Lei do Inquilinato, há que ser interpretado de modo a harmonizá-lo com dispositivos que porventura se entremostrem colidentes. Outrossim, não poderia a Lei do Inquilinato ter alterado o fundamento em que se funda a tipicidade do contrato de fiança construída no Código Civil sem que a sua estrutura também tivesse sido alterada naquela lei.

Ao ter comentado o artigo 39 da Lei do Inquilinato, o insígne Francisco Carlos Rocha de Barros assim escreveu:

"Por outro lado, não é dificil sustentar que este artigo de lei do inquilinato não revogou o art. 1.483 do Código Civil ${ }^{506}$. Não houve declaração expressa nesse sentido e aqui não se cuidou de regular inteiramente o contrato de fiança ( $\left(1^{\circ}\right.$ do art. $2^{\circ}$ da LICC). Resta, apenas, alegar incompatibilidade, mas sem garantia de sucesso, pela maneira genérica e ligeira como a matéria é tratada neste artigo da lei do inquilinato. Para revogar preceito tradicional do Código Civil, que, aliás, reflete opinião universal da doutrina sobre interpretação dos contratos gratuitos, é de se ter como ineficaz a norma veiculada por este artigo, até porque existe norma geral de interpretação dos contratos, consignada no art. 1.090 do Código $\mathrm{Civiv}^{507}$, afirmando que os contratos benéficos interpretar-se-ão estritamente. Ainda que se admitisse a revogação do art. 1.483 , não vemos como sustentar a revogação do art. 1.090."508

Frise-se, nesse sentido, que o fundamento, a base indestrutível dos contratos gratuitos é a de que as manifestações de vontade deles oriundas deverão ser sempre interpretadas restritivamente, pois com isto o legislador buscou proteger a posição jurídica do sujeito que, ao ter manifestado uma liberalidade, visou beneficiar a outra parte sem nada receber em troca. Assim sendo, há que se ter em mente que todo o ato de disposição patrimonial há que ser interpretado de forma restritiva, a fim de que sejam equilibradas as

\footnotetext{
${ }^{506}$ Equivalente ao art. 819 do Código Civil de 2002;

${ }^{507}$ Equivalente ao art 114 do Código Civil dc 2002;

${ }^{508}$ In BARROS, Francisco Carlos Rocha de. op. cit., p. 162.
} 
posições jurídicas das partes. E equilíbrio das posições jurídicas das partes haverá se os riscos do negócios forem atribuídos aos contratantes de forma materialmente justa.

E assim o é porque entendemos que um princípio fundamental de uma determinada área do conhecimento jurídico não pode ser alterado por lei especial sem que a própria estrutura do instituto seja também alterada, sob pena de causar uma situação perplexidade e perturbação do sistema, que mais do que proteger a pessoa do locador, acabou por gerar tremenda insegurança jurídica em face das profundas divergências que vinha provocado na doutrina e jurisprudência, o que acabou por ser agravado com a edição da Súmula 214 do Superior Tribunal de Justiça.

Com efeito, o intérprete da lei não pode ignorar a realidade das coisas, como é a dinâmica da vida, pois a imensa maioria dos fiadores não possui a menor noção da dimensão que a sua vinculação nessa condição representa: uma, porque o objetivo principal é o de ajudar um amigo ou parente próximo; duas, porque sendo o contrato de locação vínculo obrigacional de execução continuada, normalmente o inadimplemento se dá após o vencimento do contrato e durante o período de prorrogação da locação por tempo indeterminado, o que acontece muitas vezes após vários anos, sem que o fiador venha a se recordar da fiança que prestara tempos antes. Esta é a realidade da vida que não poderia ter sido ignorada pelo intérprete da lei.

\subsubsection{A Nova Exegese da Súmula $n^{\circ} 214$ do Superior Tribunal de Justiça: Violação à Segurança Jurídica}

No tópico anterior expusemos qual foi a exegese que o Superior Tribunal de Justiça prestigiou em quase oito anos de vigência da Súmula 214, o que não mais está a ocorrer tendo em vista a alteração da orientação firmada pelo tribunal nos autos dos Embargos de Divergência n. ${ }^{\circ}$ 566.633-CE; eis a provável nova redação da Súmula 214:

"Continuam os fiadores responsáveis pelos débitos locatícios posteriores à prorrogação legal do contrato se anuíram expressamente a essa possibilidade e não se exoneraram nas formas dos artigos 1.500 do $\mathrm{CC} / 16$ ou 835 do CC/02, a depender da época que firmaram o acordo."

Em face da importância do tema, e tendo em vista que o acórdão proferido pela $3^{\mathrm{a}}$ Seção do STJ nos autos dos Embargos de Divergência 566.633-CE, que foi publicada 
apenas em 12/03/2008 porque vários Ministros, apesar de terem declarado os seus votos, levaram um certo tempo para redigi-los, cumpre transcrever parte do voto-vista proferido pelo Min. Hamilton Carvalhido sobre o tema, que bem situa a nova orientação do tribunal:

"Do exposto, resulta que, a prorrogação contratual, sem a anuência dos fiadores, não os vincula, ainda que existente cláusula estendendo as obrigações até a efetiva entrega das chaves.

É que dita cláusula, costumeiramente presente nos pactos locatícios, que faz do fiador obrigado pelo cumprimento do contrato "até a efetiva entrega das chaves" refere-se às hipóteses em que o locador visava assegurar a devolução do imóvel no estado em que foi entregue e o pagamento dos débitos relativos ao curto período entre o término do prazo do contrato, diga-se, tal como originariamente pactuado, e a retransmissão da posse direta do imóvel, não obrigando, em absoluto, o fiador, no caso de haver prorrogação, se tal possibilidade não constar expressamente do contrato.

Todavia, se, para além, obriga-se o fiador, solidário, expressa e voluntariamente, não somente durante o tempo de duração do contrato por prazo determinado, mas também durante o tempo em que vier a ser prorrogado o contrato, a hipótese merece solução diversa, inexistindo lacuna obrigacional qualquer, a autorizar a integração por meio de interpretação (restritiva).

Com efeito, em hipóteses tais, não há lugar para interpretação, com a extinção da fiança, que resultaria, por certo, em equivocado dirigismo contratual pelo Poder Judiciário, mas, sim, para o estrito e literal cumprimento do contrato, em observância mesmo à liberdade de contratar, vigente no sistema pátrio civilista.

(...)

In casu, ao que se tem dos autos, o fiador livremente pactuou a garantia da locação, não somente durante o tempo de duração do contrato por prazo determinado, mas também durante o tempo de prorrogação por prazo indeterminado, como resulta da letra expressa e inequívoca da cláusula contratual que o tornou responsável pelas obrigações contratuais, "por todas as obrigações contratuais, inclusive por todos os reajustes legais e amigáveis perdurando a sua responsabilidade até a efetiva entrega das chaves, mesmo que isso venha a ocorrer após o término do presente contrato"." (Grifamos)

Com efeito, percebe-se da leitura do voto do Min. Hamilton Carvalhido que uma das razões que teria levado o STJ a modificar a sua posição sobre a questão foi a de prestigiar o princípio da liberdade de contratar, pois se o fiador se obrigou "por todas as obrigações contratuais, inclusive por todos os reajustes legais e amigáveis perdurando a sua responsabilidade até a efetiva entrega das chaves, mesmo que isso venha a ocorrer após o término do presente contrato", a hipótese não seria a de interpretação restritiva da 
avença, ante a inexistência de lacuna a ser preenchida, mas apenas de "estrito e literal cumprimento do contrato", isto é, da fiança.

Conforme já tivemos a oportunidade de apontar, o contrato de fiança é negócio jurídico de constrangimento quase absoluto para o fiador, na medida em que normalmente a garantia é prestada em favor de um parente ou amigo muito próximo, inexistindo, do ponto de vista social, qualquer possibilidade de rejeição da prestação da fiança sem a vulneração da amizade ou do parentesco. Ora, se assim o é, não há que se falar que a vontade do fiador em se obrigar nestes casos é livre e soberana, muito pelo contrário; livre e soberana não é, porque a existência de liberdade e soberania permitem a escolha do caminho a ser seguido, sendo que o fiador na presença de uma amigo ou parente não tem escolha alguma sem que a negativa em prestar a garantia lhe acarrete um prejuízo social enormíssimo.

Assim, se a posição social que o fiador normalmente ocupa no meio em que vive não lhe faculta liberdade de agir, a sua responsabilidade deveria ser limitada apenas ao período contratual durante o qual o contrato vigesse por tempo determinado.

Nesse sentido, aliás, não se deve perder de vista que um dos cuidados do legislador do Código Civil de 2002 foi o de procurar contextualizar os dispositivos da novel legislação ao "homem situado", isto é, da posição ocupada pela pessoa humana na vida social concreta, tomada em sua dinamicidade, o que representa o abandono do paradigma ultrapassado da abstração quase que absoluta das regras civis das reais necessidades sociais. Portanto, não é mais possível que o operador do direito procure justificar a imperiosa necessidade que as pessoas têm de contratar apenas sob o ângulo da liberdade porque essa, além de não ser absoluta, deve ser sempre contextualizada à luz da vida real e do comportamento social que o brasileiro típico ${ }^{509}$ de determinada região do país adota em situações semelhantes ${ }^{510}$.

Portanto, entendemos que a nova orientação que passou a dominar as decisões do Superior Tribunal de Justiça com fundamento em sua Súmula 214 não se justifica na atualidade, uma vez que lastreada em um paradigma legal ultrapassado - o da liberdade

\footnotetext{
${ }^{509}$ Devendo ser considerados os seus valores, hábitos, tradições e costumes praticados na sua vida diária;

${ }^{510}$ Preciosas são as palavras de Antonio Jeová Santos: "Há algo especioso e sedutor no Código Civil de 2002 que é o princípio da sociabilidade que impregna o seu conteúdo. É atrativa a idéia do "homem situado", em contraposição ao "sujeito isolado". Se o segredo da sobrevivência é viver insulado, a vida de relação exige que o homem se projete no mundo e dele participe não como mero espectador, mas como alguém que interfira no resultado." (In SANTOS, Antonio Jeová. Função social, lesão e onerosidade excessiva nos contratos. São Paulo: Método, 2002. p. 23).
} 
absoluta de contratar -, razão pela qual procurarei demonstrar, nas linhas que seguem, que a harmonização dos interesses dos locadores e fiadores na espécie se apresentava possível.

Conforme observamos anteriormente, o Superior Tribunal de Justiça havia pacificado um tema de vital importância aos locadores, locatários e fiadores, tanto que consolidou o seu entendimento na Súmula 214; entretanto, ocorreu uma guinada de $180^{\circ}$ graus no posicionamento da Corte: no julgamento do ERESP n ${ }^{\circ} 566.633 / \mathrm{CE}$ e por sugestão do Min. Paulo Medina, a Corte passou a adotar o entendimento segundo o qual o vencimento dum contrato de locação com a sua consequente prorrogação por tempo indeterminado não operariam mais a exoneração automática dos fiadores se os contratos contivessem cláusulas que estendessem as suas responsabilidades até que ocorresse a efetiva entrega das chaves do imóvel locado, nos termos que já eram preconizados no art. 39 da Lei $n^{\circ} 8.245 / 91$.

Todavia, a alteração da jurisprudência consolidada do STJ se deu sem que esta Corte se preocupasse em modular a eficácia da nova interpretação que passou a ser prestigiada, com isso apanhando os litigantes de surpresa no curso dos processos em andamento, muito embora por quase 10 (dez) anos a interpretação que o tribunal emprestou à Súmula 214 tivesse guiado e balizado as condutas e as legítimas expectativas da grande clientela do Poder Judiciário: advogados e pessoas comuns (locadores, locatários e fiadores).

Em face do exposto, entendemos que a guinada interpretativa do STJ não poderia ter apanhado os litigantes em processos em curso de surpresa, o que acabou por violar 2 (dois) princípios constitucionais: a) o da Segurança Jurídica (art. $1^{\circ}$, caput, da CF); b) o da Isonomia (art. $5^{\circ}$, caput, da CF).

Na realidade, a decisão do tribunal, decisão esta que tem se repetido pelo País afora, põe em risco profundo a segurança e previsibilidade que os cidadãos de bem esperam das decisões judiciais, a fim de que possam decidir quando, onde e como devem se portar e se comportar na vida de relação:

"Saber a qué antenerse concierne a la seguridad al grado de certeza y estabilidad de una determinada situación. Porque cuando hay seguridad se está en situación de prever lo que sucederá, de verlo de antemano, como si se abriera una ventana por la cual fuera posible echar una ojeda al futuro. Lo expresa así lá vieja máxima savoir c'est prévoir.

Se dice que algo brinda la seguridad cundo está dotado de las calidades de ser seguro y no presentar peligro; cuando es securus, porque está libre 
de cura, o sea, de cuidado o riesgo. Lo seguro genera confianza, puesto que confía quien tiene una esperanza firm, quien tiene fe (fides).

Lo contrario de la seguridad es la inseguridad, que trae consigo profundo disvalores. Lo inseguro genera sanciones por lo común angustiantes de incertidumbre, de intranquilidad, y de falta de protección." 511

É indiscutível que no direito brasileiro atual as Súmulas de Jurisprudência dominante têm um relevante papel sócio-jurídico: consolidam o entendimento dos tribunais sobre determinadas matérias e, com isso, passam a balizar as condutas e as legítimas expectativas dos atores jurídicos.

Atualmente é inegável que as súmulas de jurisprudência dominante possuem um caráter normativo, vale dizer, orientador de condutas. Com isto, o que queremos dizer é que as súmulas têm por finalidade manter uma moldura jurídica estável e previsível dentro da qual os indivíduos poderão planejar as suas próprias vidas ${ }^{512}$.

Portanto, o princípio da vinculatividade dos precedentes [Súmulas de jurisprudência dominante] não é uma norma que interessa apenas aos advogados, mas sim um princípio constitucional implícito que é aceito pelo Estado e pelos demais Poderes Constituídos ${ }^{513}$.

Não foi por outra razão que o então Presidente do STJ, Min. Humberto Gomes de Barros, declarou, em um discurso preciso, que a jurisprudência do tribunal deveria funcionar como um farol, pois a sua finalidade se voltava a assentar as legítimas expectativas dos atores jurídicos, verbis:

"Para o ministro Humberto Gomes de Barros, não é aceitável que o Tribunal afirme durante anos, por exemplo, que um imposto incide em determinada operação e, de repente, diga que a orientação estava errada. "Isso é brincar de 'banana boat' com o contribuinte. Depois de seguir reto em uma direção, o piloto da lancha dá uma virada brusca para derrubar todos os que estão em cima da banana. Nós temos feito isso com o contribuinte", comparou o ministro. "O STJ foi concebido como um farol e não como uma bóia à deriva. Ele precisa indicar ao navegante, ao cidadão, qual é o caminho. Mas esse caminho há que ser definitivo."

De acordo com o presidente do STJ, os magistrados precisam ter consciência de que a segurança jurídica não é apenas um princípio, mas um bem fundamental do cidadão. Para o ministro Humberto Gomes de Barros, se a sociedade e os costumes sofreram alterações ao longo do tempo, não é o Judiciário que deve mudar a interpretação da lei. Cabe ao Congresso Nacional mudar a própria lei." (Grifamos)

\footnotetext{
${ }^{511}$ ALTERINI, Atilio Anibal. La inseguridad juridica. Buenos Aires: Abeledo-Perrot, 1993. p. 16-17.

${ }^{512}$ ATIYAH, P. S. Law \& modern society. 2. ed. New York: Oxford University Press, 1995. p. 108.

${ }^{513} \mathrm{Na}$ mesma linha de Id. Ibid., p. 20.
} 
Nesse sentir, não deixa de causar espanto e perplexidade que o STJ, apesar de anos a fio ter balizado a conduta dos cidadãos tendo por norte a exegese que sempre emprestou à sua Súmula 214, tenha acabado por alterar radicalmente a sua jurisprudência dominante sem atentar às situações jurídicas que porventura se consolidaram sob o véu da interpretação original, sem ter se apercebido de que cabe ao Poder Judiciário dirimir a insegurança dos jurisdicionados, e não disseminá-la!

Enquanto o art. $1^{\circ}$, caput, da $\mathrm{CF}$ consagra o princípio da segurança jurídica, o art. $5^{\circ}$, caput, da CF consagra o princípio da isonomia; é nesse contexto que iremos analisar o porquê a nova exegese da Súmula 214 violou a Constituição Federal.

Enuncia o art. $1^{\circ}$, caput, da Constituição Federal:

"Art. $1^{\circ}$ A República Federativa do Brasil, formada pela união indissolúvel dos Estados e Municípios e do Distrito Federal, constitui-se em Estado Democrático de Direito e tem como fundamentos:"(Grifamos)

Segundo a abalizada doutrina de Gilmar Ferreira Mendes, de Inocêncio Mártires Coelho e Paulo Gustavo Gonet Branco ${ }^{514}$, tendo em vista a insuficiente proteção que o princípio do direito adquirido outorga a determinadas situações jurídicas, "a própria ordem constitucional tem-se valido de uma idéia menos precisa e, por isso mesmo, mais abrangente, que é o princípio da segurança jurídica enquanto postulado do Estado de Direito."

Com efeito, o princípio da segurança jurídica torna-se imperativo em uma sociedade pluralista e democrática como a brasileira, pois impede que situações fáticas consolidadas venham a sofrer brusca ou arbitrária alteração em flagrante violação às legítimas expectativas que a manutenção de determinado estado de coisas gerou na sociedade, pois as pessoas necessitam de estabilidade e previsibilidade para empreender e estabelecer as suas relações sociais, mormente jurídicas, uma vez que o Direito, enquanto instrumento ético, não pode deixar de servir de parâmetro ordenador de condutas, sob pena de imperar o caos, a instabilidade institucional e a insegurança social ${ }^{515}$.

\footnotetext{
${ }^{514}$ In BRANCO, Paulo Gustavo Gonet; MENDES, Gilmar Ferreira; COELHO, Inocêncio Mártires. op. cit., p. 473. (Grifamos)

515“As decisões do Poder Judiciário supervenientes, que alterarem jurisprudência do mesmo tribunal já estratificada, devem produzir efeitos para o futuro (ex nunc). Mesmo depois de adotado novo posicionamento do tribunal sobre determinado assunto, a corte deve aplicar a sua jurisprudência anterior aos casos futuros que lhe sejam apresentados, mas respeitantes a fatos ocorridos na jurisprudência anterior. Esse entendimento é coerente com o princípio da irretroatividade, que tem sede na segurança jurídica e na boa-fé, pois se o jurisdicionado praticou atos ou celebrou negócios jurídicos (privados ou
} 
São três os valores gerais acolhidos pelo princípio da segurança jurídica: a) a estabilidade; b) a certeza; e c) a previsibilidade. Destes três, o objeto do presente estudo é o terceiro. O enfoque da análise, por conseguinte, recai exclusivamente sobre a previsibilidade e o esforço que se empreende agora tem por fim isolá-la dos demais valores, para perceber-lhe os contornos, funções e conseqüências. Irrefutavelmente, a previsibilidade dos efeitos do direito conforma um dos conteúdos fundamentais do princípio da segurança jurídica. Tão fundamental, que alguns autores confundem-na com verdadeira essência daquele princípio ${ }^{516}$.

Assim, por um lado, a segurança jurídica busca propagar na sociedade um sentimento de tranqüilidade, de calma, de equilíbrio, conferindo aos destinatários das normas estabilidade em relação às consequiências dos fatos já consumados e, por outro, a previsibilidade em relação aos efeitos futuros prescritos pelo ordenamento ${ }^{517}$.

Segundo aponta J. J. Gomes Canotilho ${ }^{518}$,

"O princípio geral da segurança jurídica em sentido amplo (abrangendo, pois, a idéia de proteção da confiança) pode formular-se do seguinte modo: o indivíduo têm do direito poder confiar em que aos seus actos ou às decisões públicas incidentes sobre os seus direitos, posições ou relações jurídicas alicerçados em normas jurídicas vigentes e válidas por esses actos jurídicos deixados pelas autoridades com base nessas normas se ligam os efeitos jurídicos previstos e prescritos no ordenamento jurídico." (Grifamos)

Imaginemos, neste contexto, uma competição desportiva na qual os participantes iniciassem a disputa tendo por parâmetro determinadas regras que teriam por finalidade ordenar as suas condutas e posturas no certame; no decorrer da competição, no entanto, as

administrativos) sob a égide do entendimento anterior do tribunal, estava de boa-fé ao fazê-lo e confiou que seu procedimento estaria correto, porque respaldado em posicionamento jurisprudencial de tribunal superior. "Em resumo podemos concluir que as mudanças de entendimento jurisprudenciais devem atender as exigências constitucionais, e isso só ocorrem na medida em que resultem da proteção da confiança, segundo o art. 9. ${ }^{\circ}$ da Constituição Federal [suiça]. Decorre da boa-fé, segundo o art. 9. ${ }^{\circ}$ da Constituição Federal [suiça], que o cidadão não pode ser colocado em situação de desvantagem, se ele agiu de acordo e confiando na até então preponderante jurisprudência e nela encontrou fundamento, e que a ele não se pode atribuir desvantagem, se os tribunais posteriormente ajam contra sua legítima e justa expectativa. Não é necessário, outrossim, que o jurisdicionado ajuize ação para alegar a incidência de determinado precedente ou a afirmação sobre sobre a prevalência da jurisprudência anterior. A garantia constitucional da proteção da confiança, segundo o art. 9. ${ }^{\circ}$ da Constituição Federal [suiça], incide tanto sobre a mudança de jurisprudência em matéria processual, quanto no que tange às questões de direito material." (NERY JUNIOR, Nelson; NERY, Rosa Maria de Andrade. op. cit., p. 535-536).

${ }^{516}$ FREIRE, Fernando José de Barros. Previsibilidade dos efeitos do direito e segurança jurídica. 2007. Dissertação (Mestrado) - Pontifícia Universidade Católica, PUC. São Paulo, 2007. p. 63.

${ }^{517}$ Id. Ibid., p. 65.

${ }^{518}$ CANOTILHO, J. J. Gomes. Direito constitucional e teoria da constituição. 2. ed. Almedina: Coimbra, 1998. p. 257. 
regras da competição são alteradas e pegam a todos de surpresa: o que até um dado momento era permitido passa a ser proibido, o que era proibido passa a ser permitido; eventual pontuação obtida por um dos participantes antes da mudança de regra é-lhe subtraída, enquanto os perdedores são premiados e assim por diante.

Este singelo exemplo é ilustrativo da importância da qual se reveste a manutenção da estabilidade das regras do jogo, a fim de que as legítimas expectativas criadas às partes de um dado evento sejam respeitadas, permitindo que planejem o seu agir, as suas condutas e saibam de antemão os resultados que poderão ocorrer em determinadas situações.

Esta é a razão pela qual eventuais mudanças bruscas e repentinas nas regras de um jogo [uma demanda] já iniciado não são merecedoras de chancela ou tutela, posto serem violadoras de um dos mais comezinhos princípios: o da boa-fé. E isso porque,

“A revisão radical de determinados modelos jurídicos ou a adoção de novos sistemas ou modelos suscita indagações relevantes no contexto da segurança jurídica.

A idéia de segurança torna imperativa a adoção de cláusulas de transição nos casos de mudança radical de um dado instituto ou estatuto jurídico.

Daí porque se considera, em muitos sistemas jurídicos, que, em casos de mudança de regime jurídico, a não-adoção de cláusulas de transição poderá configurar omissão legislativa inconstitucional grave. ${ }^{519,}$

Daí porque as situações fático-jurídicas consolidadas ao longo do tempo não poderão sofrer os influxos de novos acontecimentos sem que seja ferido de morte o princípio da segurança jurídica; em caso de mudança na orientação jurisprudencial sumulada deveria o tribunal ter passado a modular a eficácia da nova interpretação sob a cláusula ex nunc, de maneira a ter evitado a aplicação retrospectiva da nova interpretação que passou a ser emprestada à Súmula 214. E isto porque na atualidade as decisões dos tribunais superiores têm caráter normativo e de ordenação de condutas.

Em precedente de grande importância o Supremo Tribunal Federal externou toda a sua preocupação com o respeito ao princípio da segurança jurídica que encontra assento no postulado do Estado de Direito previsto no art. $1^{\circ}$, caput, da CF:

"A questão pendente neste julgamento está em definir quais os contornos que a inevitável decisão do Tribunal deve assumir para que seja, na maior medida possível, menos gravosa à realidade concreta fundada sobre a nova entidade federativa.

\footnotetext{
${ }^{519}$ MENDES, Gilmar Ferreira et al. Curso de direito constitucional. São Paulo: Saraiva, 2007. p. 473.
} (Grifamos) 
A solução para o problema, a meu ver, não pode advir da simples decisão de improcedência da ação. Seria como se o Tribunal, focando toda a sua atenção na necessidade de se assegurar realidades concretas que não podem mais ser desfeitas e, portanto, reconhecendo plena aplicabilidade ao princípio da segurança jurídica, deixasse de contemplar, na devida medida, o princípio da nulidade da lei inconstitucional.

Não se pode negar a relevância do princípio da segurança jurídica neste caso. Porém, estou convicto de que é possível primar pela otimização de ambos os princípios, tentando aplicá-los, na maior medida possível, segundo as possibilidade fáticas e jurídicas que o caso concreto pode nos apresentar." (STF, Tribunal Pleno, ADI 2.240-7, Rel.-Min. EROS GRAU, v.u., 09/05/2007)

A leitura deste acórdão do STF apresentou a preocupação dos membros daquele tribunal em prestigiar a necessária segurança jurídica que deve pautar a vida de relação, sem que fosse deixada de lado a necessidade de declaração de nulidade da lei inconstitucional, tudo de modo a causar a menor instabilidade social e jurídica possível.

Ora, a Súmula 214 do STJ foi publicada pelo STJ em 2 de outubro de 1998; desde então, a despeito da sua literalidade, passou a ser diuturnamente aplicada pelo tribunal com vistas a proteger a posição jurídica dos fiadores em contrato de locação; segundo o entendimento que prevaleceu no STJ por quase 10 (dez) anos, ainda que um contrato de locação tivesse sido prorrogado por tempo indeterminado, e mesmo que este contrato contivesse uma cláusula estendendo as obrigações fidejussórias do garante até que ocorresse a entrega das chaves, o fiador estaria automaticamente exonerado da fiança desde a data em que o contrato de locação havia vencido.

Durante quase 10 (dez) anos todos os locadores, locatários e fiadores, apesar das inúmeras controvérsias, passaram a ordenar as suas condutas contratuais de acordo com o farol que passou a iluminar o contrato de fiança em virtude da exegese jurisprudencial consolidada pela e adotada na Súmula 214 do STJ.

Porém, o que parecia estar consolidado e que por quase 10 (dez) anos ordenou as condutas dos atores jurídicos sofreu uma abrupta e radical modificação que redundou em uma guinada de $180^{\circ}$ graus; no julgamento do ERESP n ${ }^{\circ} 566.633 / C E$ e por sugestão do Min. Paulo Medina, a Corte passou a adotar o entendimento segundo o qual o vencimento dum contrato de locação com a sua conseqüente prorrogação por tempo indeterminado não operariam mais a exoneração automática dos fiadores se os contratos contivessem cláusulas que estendessem as suas responsabilidades até que ocorresse a efetiva entrega das 
chaves do imóvel locado, nos termos que já eram preconizados no art. 39 da Lei $\mathrm{n}^{\circ}$ $8.245 / 91$.

A partir do citado precedente, o STJ passou a adotar a nova orientação nos processos em curso, ainda que os litigantes tivessem ordenado e balizado as suas condutas com a exegese anterior da Súmula 214 que perdurou por quase 10 (dez) anos!

Tanto isso é verdade que nos autos dos REsp 577803/SP, Rel. Ministra Jane Silva (Desembargadora Convocada do TJMG), $3^{\text {a }}$ Seção, julgado em 28/03/2008, DJ 29/05/2008), o Min. Napoleão Nunes Maia Filho, em bem elaborada declaração de voto, e apesar de ter se curvado à orientação da Corte, não deixou de consignar a sua preocupação com a segurança jurídica, pois os cidadãos comuns, repita-se, por quase 10 (dez) anos, ordenaram as suas condutas e balizaram as suas expectativas de acordo com a orientação deste STJ, verbis:

"2. Estava - e penso que ainda está - em vigor a Súmula no 214 desta Corte, afirmando o oposto que esta douta Seção tem entendido reiteradamente.

3. Como já me expressei em outras oportunidades, repetirei os meus argumentos de maneira bem breve. Admitir-se a responsabilidade do fiador por interpretação desta cláusula ou da expressão "até a entrega das chaves" é uma situação que gera insegurança para as relações locatícias, tendo em vista a existência da súmula.

4. Tal súmula dispunha expressamente - e ainda dispõe expressamente que a responsabilidade é limitada à data de vigência do contrato, salvo se, na prorrogação, o fiador anuir. Há esse ponto - digamos assim - jurídicoformal em primeiro lugar.

5. Em segundo lugar, há também outro aspecto no sentido de que as pessoas que mais precisam de fiadores são exatamente as mais pobres que não têm moradia. A moradia, sabe-se hoje, é uma garantia constitucional; é um direito fundamental. Haverá, com toda a certeza, uma retração das disponibilidades para alguém oferecer fiança mormente nos casos em que se prorroga o contrato de locação sem a ciência do fiador. Penso que, dessa forma, o fiador será surpreendido, porque a suposição que ele tinha, quando ofereceu a fiança, era a de que respondia por obrigações até a data do vencimento do contrato porque a súmula assim dispunha e não porque o contrato assim dispunha.

6. Pelo que sei, tal súmula não foi ainda revogada e, se tivesse sido revogada ou se vier a ser revogada, penso que se deverá aplicar aos contratos de locação a revogação para a frente, porque as pessoas da sociedade civil guiam-se pela orientação da jurisprudência, principalmente quando sumulada.

7. É claro que o Tribunal tem o direito de alterar os seus pré-julgados, mas, por segurança e confiança jurídica, a eficácia dessa alteração deve lavrar os seus efeitos a partir do cancelamento ou da revogação da 
súmula exatamente para que as pessoas continuem a ter confiança $e$ segurança nas súmulas.

8. Peço vênia à douta Seção, pois sei que esse entendimento é majoritário. Aliás, não há divergência, somente eu penso assim. Falei com o Senhor Ministro Felix Fischer, mais de uma vez, sobre ex nunc e ex tunc. Se revogada uma súmula, daí para frente será uma situação diferente." (Grifamos)

Diante do exposto, a nova orientação jurisprudencial adotada pelo Colendo STJ, $e$ que decorreu da mudança radical e abrupta na exegese da Súmula 214 do STJ que passou a ser adotada por aquela Corte, sem que tivesse havido alteração do seu texto, violou e está a violar o princípio da segurança jurídica (art. $1^{\circ}$, caput, da $\mathrm{CF}$ ), pois desconsiderou a orientação que vinha sendo prestigiada pelo próprio STJ ao longo de quase 10 (dez) anos, em flagrante violação das legítimas expectativas que se originaram dos precedentes jurisprudenciais adotados por aquele mesmo tribunal. E, como o devido respeito, a violação das legítimas expectativas representa violação ao princípio da boa-fé, que faz parte do núcleo essencial do postulado da segurança jurídica, pois

"Em geral, associam-se aqui elementos de variada ordem ligados à boa-fé da pessoa afetada pela medida, a confiança depositada na inalterabilidade da situação e o decurso de tempo razoável. ${ }^{, 520}$ (Grifamos)

Com o devido respeito, esta situação representa caso típico de venire contra factum proprium, pois o STJ passou a negar endosso à exegese por ele criada e que vinha sendo aplicada por quase 10 (dez) anos, sem que tivesse se preocupado com a situação dos fiadores que acreditaram na postura da Corte e confiaram na inalterabilidade da situação jurídica que estava a lhes atingir.

Conforme ainda aponta André Ramos Tavares ${ }^{521}$, um dos constitucionalistas expoentes da nova geração, em citação a Ingo Wolfgang Sarlet,

“A proteção à segurança jurídica, implícita ao Estado de Direito, exige, igualmente, uma "proteção contra medidas retrocessivas, mas que não podem ser tidas propriamente retroativas, já que não alcançam as figuras dos direitos adquiridos, do ato jurídico perfeito e da coisa julgada." (Grifamos)

\footnotetext{
${ }^{520}$ MENDES, Gilmar Ferreira et al. op. cit., p. 473.

${ }^{521}$ In TAVARES, André Ramos. Curso de direito constitucional. 5 ed. rev. e atual. São Paulo: Saraiva, 2007. p. 676 .
} 
A nova orientação adotada pelo STJ não aplicou o melhor direito à espécie, pois, com o perdão pelo trocadilho, o contrato de fiança não poderia ter se tornado em um contrato de desconfiança, o que acabou por violar o art. $1^{\circ}$, caput, da CF.

Enuncia o art. $5^{\circ}$, caput, da Constituição Federal:

“Art. $5^{\circ}$ Todos são iguais perante a lei, sem distinção de qualquer natureza, garantindo-se aos brasileiros e aos estrangeiros residentes no País a inviolabilidade do direito à vida, à liberdade, à igualdade, à segurança e à propriedade, nos termos seguintes:"(Grifamos)

Permissa venia, outro princípio constitucional que restou vulnerado pelo STJ, com o devido respeito, foi o da isonomia (art. $5^{\circ}$, caput, da CF), o qual preconiza, dentre outras acepções, que as mesmas situações fáticas devem receber o mesmo tratamento jurídico do ordenamento, bem como do Poder Judiciário.

$\mathrm{O}$ atentado à isonomia consiste em se tratar desigualmente situações iguais, ou em se tratar igualmente situações diferenciadas, de forma arbitrária e não fundamentada ${ }^{522}$.

Segundo José Afonso da Silva ${ }^{523}$, a

"doutrina como a jurisprudência já firmaram há muito a orientação de que a igualdade perante a lei tem o sentido que, no exterior, se dá à expressão igualdade na lei, ou seja: o princípio tem como destinatários tanto o legislador como os aplicadores da lei."

Desta forma, os aplicadores da lei, in casu os tribunais, não podem emprestar aos mesmos dispositivos legais uma exegese diferente a idênticas situações jurídicas sem que seja violado o princípio da isonomia (art. $5^{\circ}$, caput, da $\mathrm{CF}$ ); na hipótese em debate a Súmula 214 do STJ sempre foi aplicada da mesma forma a todo e qualquer contrato de fiança, notadamente aos que eram firmados em decorrência do estabelecimento de relações de locação; todavia, a partir do momento em que o STJ passou a adotar nova orientação jurisprudencial que emprestou uma nova interpretação à Súmula 214 sem que tivesse feito o discrímen entre as situações fático-jurídicas que surgiram e se consolidaram antes da nova orientação e aquelas que surgiram e se consolidaram a partir da nova exegese, sem dúvida violou o princípio da isonomia, pois apesar de o contrato de fiança pertencer à mesma categoria jurídica (a dos negócios jurídicos fidejussórios), todos os litigantesfiadores em processo judicial que lograram obter o trânsito em julgado das decisões que os

\footnotetext{
${ }^{522}$ Cfe. voto proferido no RE n ${ }^{\circ}$ 453.740-1-RJ, rel. Min. GILMAR MENDES, in DJU de 24.08.2007.

${ }^{523}$ In SILVA, José Afonso da. op. cit., p. 214.
} 
beneficiavam antes da mudança de orientação na jurisprudência do STJ foram beneficiados, enquanto aqueles cujos processos continuaram a tramitar após a adoção da nova exegese da Súmula 214 receberam tratamento jurídico desfavorável, não obstante tenham as situações jurídicas surgidas, no mais das vezes, em idênticos períodos de tempo.

Portanto, a mudança de exegese sobre a Súmula 214, realizada pelo STJ sem que tivesse respeitado as situações jurídicas dantes surgidas e consolidadas - o que teria sido evitado com a modulação da novel interpretação com eficácia ex nunc -, acabou por violar o princípio da isonomia, pois dezenas de milhares de contratos de fiança que foram firmados no mesmo período passaram a receber tratamento jurídico diferenciado, porquanto as mesmas situações jurídicas passaram a receber tratamento desigual sem nenhuma justificativa.

Não foi por outra razão que Cármen Lúcia Antunes Rocha ${ }^{524}$, em texto elaborado antes do seu ingresso no STF, escreveu que:

\begin{abstract}
"Igualdade constitucional é mais que uma expressão de Direito; é um modo justo de se viver em sociedade. Por isso é princípio posto como pilar de sustentação e estrela de direção interpretativa das normas jurídicas que compõem o sistema jurídico fundamental."
\end{abstract}

Assim, pois, não se revela justo tampouco jurídico que os fiadores sejam tratados de maneiras desiguais apesar das idênticas posições jurídicas que ocuparam e ocupam nas relações fidejussórias decorrentes de locações, o que acabou por disseminar uma situação de total insegurança entre os contratantes, pois apesar de terem sido guiados pela orientação jurisprudencial que prevaleceu no STJ por quase 10 (dez) anos, foram surpreendidos pela nova postura que passou a ser adotada pela Corte e que culminou por atribuir tratamento jurídico desigual a situações fáticas idênticas.

Em síntese final, era vedado ao STJ ter instituído, ainda que pela via da interpretação, tratamento desigual a fiadores que se encontravam em situação equivalente, o que ocorreu no caso da nova interpretação que fora emprestada pela Corte a Súmula 214, em ofensa ao princípio da isonomia.

\footnotetext{
${ }^{524}$ In ROCHA, Carmen Lúcia Antunes. Ação afirmativa: o conteúdo democrático do princípio da igualdade jurídica. Revista Trimestral de Direito Público, São Paulo, n. 15, p. 118, 1996.
} 


\subsection{A possibilidade de utilização da ação de despejo pelo fiador do contrato de locação}

Não obstante ser do conhecimento dos leigos e dos operadores do direito os riscos que a prestação de fiança poderá gerar, a sua utilização pelos locadores, locatários e fiadores ainda é capaz de gerar um sem-número de problemas, os quais sequer são vislumbrados pelos contratantes no momento da celebração da locação.

Com efeito, ousamos dizer que a grande maioria dos fiadores sequer tem conhecimento dos efeitos que os contratos de fiança poderão acarretar-lhes, efeitos esses que na prática têm-se demonstrado fontes infindáveis de angustia e desassossego.

Nesse contexto, é indiscutível que o fiador tem sido sempre a parte mais prejudicada da relação contratual: além de nada receber em troca da outorga da fiança são, em geral, contratos de favor ${ }^{525}$ firmados em benefício de parentes e amigos -, em caso de inadimplemento do locatário são chamados à responsabilidade para honrar os compromissos que restaram impagos.

Diante desse quadro que se avoluma dia após dia, a incômoda situação dos fiadores não pode ficar sem resposta. Daí termos resolvido tecer algumas considerações acerca de uma questão que ocorre com muita freqüência na vigência dos contratos de locação garantidos por fiança: a demora do locador em cobrar os aluguéis devidos pelo locatário.

Essa demora - na realidade negligência - na maior parte das vezes leva à ruína os fiadores, pois os locadores não se preocupam em ingressar com ação despejo contra o locatário inadimplente já que os contratos encontram-se garantidos por fiança. No final, o único prejudicado é o fiador, pois o locatário se utiliza do imóvel sem pagar, no aguardo de vir um dia a ser demandado, enquanto o locador não se preocupa em cobrá-lo pois sabe que o fiador - pessoa solvente - é quem irá responder pelos débitos em última instância.

Devido a isso o fiador paga dívida, ciente muitas das vezes de que nada receberá do locatário pelo simples fato de o mesmo não possuir patrimônio suficiente, pois se o possuísse desnecessária teria sido a outorga da garantia.

\footnotetext{
${ }^{525}$ Nesse sentido: "É também um contrato benéfico, em relação ao devedor, a quem o fiador presta, ordinàriamente, um serviço gracioso.” (BEVILÁQUA, Clóvis. Direito das obrigações. 8. ed. rev. e atual. por Achilles Bevilaqua. Rio de Janeiro: Francisco Alves, 1954. p. 321); "É um contrato, em regra, gratuito, visto que, nem o credor, nem o devedor, são obrigados a dar qualquer compensação ao fiador." (GONÇALVES, Luiz da Cunha. op. cit., v. 5, t. 1, p. 193).
} 
Por essa razão, passamos a defender que ao fiador seja outorgada legitimidade ativa extraordinária para a propositura de ação de despejo por falta de pagamento contra o inquilino ímprobo, além de outras demandas judiciais que em princípio caberiam apenas ao locador, em virtude da negligência deste - quiçá omissão dolosa -, o que entendemos ser plenamente viável à luz do ordenamento jurídico pátrio.

Para nós, tal postura servirá para prestigiar ainda mais o instituto da fiança, possibilitando ao fiador a utilização de meio expedito à resolução da locação, com vistas a pôr um fim à sua responsabilidade.

Conforme já expusemos nesta dissertação, segundo a doutrina civilista clássica a boa-fé é a intenção pura, isenta de dolo ou malícia, manifestada com lealdade e sinceridade, de modo a não induzir a outra parte ao engano ou erro ${ }^{526}$. É a chamada boa-fé subjetiva, um estado de ignorância sobre as características da situação jurídica que se apresenta, suscetível de lesionar os direitos de outrem.

Atualmente, a noção clássica de boa-fé subjetiva vem cedendo espaço à sua face objetiva, a qual leva em consideração a prática efetiva e as conseqüências de determinado ato em lugar de indagar sobre a intenção do sujeito que o praticou. A boa-fé objetiva diz respeito a elementos externos à norma de conduta, que determinam como se deve agir. $E$ um dever de agir de acordo com determinados padrões, socialmente recomendados, de correção, lisura, honestidade ${ }^{527}$.

Boa-fé objetiva significa, portanto, uma atuação "refletida", uma atuação refletindo, pensando no outro, no parceiro contratual, respeitando-o, respeitando seus interesses legítimos, suas expectativas razoáveis, seus direitos, agindo com lealdade, sem abuso, sem obstrução, sem causar lesão ou desvantagem excessiva, cooperando para atingir o bom fim das obrigações: o cumprimento do objetivo contratual e a realização do interesse das partes. $^{528}$

De acordo com Karl Larenz ${ }^{529}$,

"El principio de la "buena fe" significa que cada uno debe guardar "fidelidad" a la palabra dada y no defraudar la confianza o abusar de ella, ya que ésta forma la base indispensable de todas las relaciones humanas; suppone el conducirse como cabía esperar de cuantos con

\footnotetext{
${ }^{526}$ ALVIM, Pedro. O contrato de seguro. 3. ed. Rio de Janeiro: Forense, 1999. p. 130.

${ }^{527}$ Vede, por todos, NORONHA, Fernando. O direito dos contratos e seus princípios fundamentais: autonomia privada, boa-fé, justiça contratual, cit.

${ }^{528}$ MARQUES, Cláudia Lima. Contratos no Código de Defesa do Consumidor, cit., p. 79 e ss. (Grifamos).

${ }^{529}$ In Derecho de Obligaciones. tomo I. Madri: Editorial Revista de Derecho Privado, 1958, p. 142 e ss..
} 
pensamiento honrado intervienen en el tráfico como contratantes o participado en él en virtud de otros vínculos jurídicos. Se trata, por lo tanto, de un módulo "necesitado de concreción" que únicamente nos indica la dirección en que hemos de buscar la contestación a la cuestión de cuál sea la conducta exigible en determinadas circunstancias. No nos da una regra apta para ser simplemente "aplicada" a cada caso particular y para leer en ella la solución del caso cuando concurran determinados presupuestos. Sino que en cada supuesto se exige un juicio valorativo del cual deriva lo que el momento y el lugar exijan. Pero este juicio no se obtiene a través del criterio subjetivo del que hace la apreciación en caso de litígio, por conseguinte, del juez, sino que se tomará como módulo el pensamiento de un intérprete justo y equitativo, es decir, que la sentencia ha de ajustarse a las exigencias generalmente vigentes de la justicia, al criterio reflejado en la conciencia jurídica del pueblo o en el sector social al que correspondan los participantes (p. ej., comerciantes, artesanos, agricultores), en tanto ello no sea contrario a las exigencias y al contenido objetivo de los valores descritos en las palabras "fidelidad" y "crédito" (es decir, confianza). A este juicio cooperan los usos y concepciones ya existentes en el tráfico - habiendo de investigarse a su vez si coinciden con aquellas supremas exigencias - y de otra parte el ejemplo y modelo que la jurisprudencia ofrece en la valoración de casos análogos o equiparables." (Grifamos)

A boa-fé objetiva tem duas funções principais: cria deveres secundários de conduta (anexos ou acessórios) e impõe limites ao exercício de direitos.

Em decorrência desse princípio, são reconhecidos deveres correlatos ou laterais em todas as espécies contratuais, que se incorporam às relações negociais, exigindo aos contratantes comportamentos adequados, principalmente em vínculos que se estendem no tempo $^{530}$.

Uma das funções do princípio da boa-fé objetiva diz respeito aos chamados deveres anexos ou secundários. Vejamos.

Há, no contrato, o dever bilateral de proteção, que impede que uma das partes cause à outra algum dano, em razão da sua atividade. Existem, assim, deveres do credor, que não são deveres para consigo mesmo, mas sim deveres jurídicos. Muitos deles consistem em conduta determinada, em comunicar algo, em indicar alguma circunstância, em fornecer informações, cuja omissão pode causar dano ao outro figurante ${ }^{531}$.

O dever de proteção consiste em não causar danos ao patrimônio e à pessoa do outro contratante. $\mathrm{O}$ dever de informação tem duas acepções, uma positiva e uma negativa.

\footnotetext{
${ }^{530}$ BITTAR, Carlos Alberto. Direito dos contratos e dos atos unilaterais. 1. ed. Rio de Janeiro: Forense Universitária, 1990. p. 40.

${ }^{53}$ SILVA, Clóvis Veríssimo Couto e. A obrigação como processo. São Paulo: José Bushatsky, 1976. p. 39.
} 
A primeira importa na prestação das informações necessárias ao conhecimento da contraparte, ao passo que a segunda veda a omissão de elementos essenciais ao pleno andamento do contrato. Por sua vez, o dever de lealdade impõe que os contratantes portem-se de forma honesta e evitem comportamentos que destoem do vínculo de cooperação contratual. Este dever também tem faces positiva e negativa; no primeiro caso deve-se proceder de tal forma e, no segundo, devem-se evitar comportamentos que desvirtuem o objetivo do contrato ${ }^{532}$.

Dentro dessa nova visão oriunda da aplicação do princípio da boa-fé objetiva, os contratos passam a ser considerados não apenas como instrumentos de transferência de riquezas, mas como meios idôneos de que dispõem as partes para atingir os seus reais e socialmente legítimos interesses, uma vez que os contratos existem porque são úteis, na condição de que sejam justos ${ }^{533}$.

No transcorrer do contrato de locação, ante a inadimplência do locatário o locador dispõe da chamada ação de despejo por falta de pagamento, a qual objetiva o desfazimento do vínculo contratual em virtude do impagamento dos aluguéis, o que se encontra em consonância com a regra contida no art. 475, do Código Civil.

Apesar de dispor de ação de despejo, e até mesmo de ação de execução, não raro o locador, não obstante o impagamento dos aluguéis, deixa de cobrar o inquilino impontual por muitos meses, pois sabe que se o mesmo não pagar o fiador o fará.

Diante disso, a dívida oriunda do contrato de locação se avoluma dia após dia, acrescida de multas, juros e correção monetária, tudo isso ocorrendo sob os olhos benevolentes do locador, o qual não manifesta interesse em cobrar a dívida tão cedo pois a vantagem que por ele será auferida por vezes superará em muito as aplicações financeiras populares que remuneram o dinheiro a juros baixos. Enquanto isso, a cada novo impagamento do devedor a multa mensal poderá chegar a $20 \%$ (!), o que em parte explica o porquê da omissão de alguns locadores: tornam-se sócios do inquilino na ruína do fiador!

Em sendo assim, entendemos que a omissão do locador em cobrar os aluguéis devidos pelo inquilino dentro de prazo razoável se nos afigura abuso de direito ou demora

\footnotetext{
${ }^{532}$ SEVERO, Sérgio. Os danos extrapatrimoniais. São Paulo: Saraiva, 1996. p. 58.

${ }^{533} \mathrm{Cfe}$. NORONHA, Fernando. $O$ direito dos contratos e seus princípios fundamentais: autonomia privada, boa-fé, justiça contratual, cit., p. 96.
} 
desleal na cobrança, o que não pode ser admitido como justo ou legal à luz do ordenamento jurídico vigente ${ }^{534}$.

Em artigo lúcido a respeito do tema, advertiu Biasi Ruggiero ${ }^{535}$ :

"Nesta fase da economia nacional, a oferta de imóveis para locação é maior do que a procura. Então, alguns locadores, quando protegidos por fiança idônea, deixam, malandramente, que o inquilino permaneça em débito meses a fio, com o objetivo, indecente, de manter o imóvel ocupado e depois surpreender o fiador com astronômico débito.

Se o imóvel objeto da locação é dos vulgarmente conhecidos como "micados", ou seja os que não despertam nenhuma atração mercadológica, o fiador pode se preparar porque, mais dia menos dia, será surpreendido por tenebrosa cobrança.

Por conhecer esse abuso, as apólices de seguro, quando substituem a fiança, obrigam o locador a não aguardar mais do que um mês para mover o despejo por falta de pagamento. Os fiadores que assumem a garantia, com a intenção de honrá-la, excluídos, evidentemente, os nefastos profissionais, assinam contrato impresso em que, invariavelmente, consta a renúncia ao benefício do art. 1.500 do Código Civil. Se de um lado a ninguém é dado alegar a ignorância da lei, de outro, há princípios, como o da boa-fé e o da cognoscibilidade, resgatados explicitamente pelo Código de Defesa do Consumidor, que precisam ser respeitados. O infeliz renuncia sem saber a que está renunciando. Não tem conhecimento técnico, portanto, falta cognoscibilidade. Entra como Pilatos no Credo." (Grifamos)

Muito embora a demora desleal do locador seja há muito tempo conhecida, a mesma sempre foi tolerada pelos tribunais, pois o exercício do direito de demandar o despejo do imóvel sempre foi deixado ao exclusivo talante do locador.

\footnotetext{
534، O contrato de fiancé é benéfico e prestado em favor de alguém, na maioria das vezes, de forma graciosa. Há entre fiador e afinaçado, confiança e lealdade capazez de justificar o empenho do fiador em favor do afiançado. Tal liame de confiança, contudo, pode se esgarçar no decorrer da avença e, ao cabo da execução do contrato, vir a ser óbice para o exercício do direito do credor, cujo crédito encontra na fiança a garantia do seu cumprimento. Daí por que o CC 835 dedicou o espaço para que as partes livremente pactuassem que a exoneração não pudesse se dar enquanto não encerrados, por completo, os efeitos que $o$ negócio afiançado viesse a gerar. O que se pretendeu, evidentemente, era que o fiador não fugisse do seu compromisso, antes de satisfazer por inteiro o credor. Se, entretanto, circunstâncias peculiares da execução do negócio evidenciam que há conluio entre credor e afiançado (v.g., inquilino permanece no imóvel, apesar de não despender um níquel relativo a alugueres, sem nenhuma oposição do locador, que não lhe promove o despejo, que tolera situação que pode prejudicá-lo), não se pode impor ao fiador nenhum prejuizo, pena de mantê-lo refém de uma situação que lhe acarreta toda a sorte de desarranjo. A cláusula que o proíbe de exonerar-se da fiança, até a entrega das chaves do imóvel locado, passa a assumir o caráter de condição puramente potestativa, sujeitando o fiador ao arbítrio do fiador-garantido. Isto porque, se a obrigação do fiador só cessa quando a coisa locada venha a ser devolvida; se o inquilino não paga alugueres; se o locador não the promove o despejo; se o locador tolera o inadimplemento do inquilino e se, por isso, as chaves não são devolvidas, o fiador passa a depender, única e exclusivamente, do arbítrio do locador, o que se não pode tolerar em direito. O conteúdo moral das avenças tem tanta importância para o direito quanto todas as implicações de ordem econômica que elas encerram." (NERY JUNIOR, Nelson; NERY, Rosa Maria de Andrade. op. cit., p. 741-742). (Grifamos)

${ }^{535}$ A sina do fiador. In: Tribuna do direito. Edição de junho de 1999, p. 2.
} 
Com efeito, não se nega ao locador o direito de cobrar o inquilino ou até mesmo o fiador. Muito pelo contrário. O que se quer evitar é que o direito de cobrar seja exercido de forma irrazoável ou tardio, o que na maioria das vezes não beneficia o credor porém sempre prejudica o fiador! ${ }^{536}$ A boa-fé objetiva impede a utilização abusiva ou tardia de um direito contra um devedor, porque o credor deve colaborar ativamente para o adimplemento do seu crédito e não apenas para causar prejuízo ao fiador

Nesse sentido foi aprovado o Enunciado nº 169 na III Jornada de Direito Civil promovida pelo CEJ:

"O princípio da boa-fé objetiva deve levar o credor a evitar o agravamento do próprio prejuízo".

O direito de cobrar não pode ser tido como absoluto, razão pela qual o fiador não pode ficar à mercê do arbítrio do locador $^{537}$ que já deveria ter adotado todas as medidas necessárias ao despejo do imóvel, o que não o fez tampouco o fará por mero capricho, espírito emulativo ou até mesmo negligência.

O absolutismo do direito choca-se com a realidade dos fatos, e, por isso, sua aceitação seria força propulsora do desequilíbrio social ${ }^{538}$. Nesse contexto, não se pode deixar de considerar a relatividade do exercício dos direitos subjetivos, pois que os mesmos existem como um meio para a realização da paz social, e não como um instrumento para a satisfação de interesses puramente individuais ${ }^{539}$.

\footnotetext{
536“"Quando o proprietario, usando de sua propriedade, coloca-se fóra da lei buscando um efeito contrário ao espírito da instituição, há um abuso de direito? Para Josserand, partindo de uma concepção subjetiva, há abuso de direito, não só quando o proprietario age com intuitos maliciosos, como tambem, quando êle, prejudicando um terceiro, o faz sem interesse, causa ou motivo legítimo, ainda que agindo dentro da competência, ou melhor da esféra legal.

Saleilles, Geny e Reynaud, adoptando uma concepção objetiva da doutrina, concluem que a verdadeira fórmula é a que coloca o abuso de direito no exercicio anormal dos poderes legais, contrários ao fim econômico e social das instituições." (SODRÉ, Ruy de Azevedo. Função social da propriedade privada. São Paulo: Ed. Revista dos Tribunais, [s.d.]. p. 65) (Grfiamos)

537، Demorando o credor sem causa que justifique o seu procedimento, a execução iniciada contra o devedor, prolonga, alem do razoavel, a responsabilidade do fiador, que não se exonera pelo simples facto de se retardar essa execução (...) De facto, não pode o fiador, ou o abonador, ficar á mercê de uma responsabilidade que já se devia ter decidido, exonerando-o dos encargos da fiança. Desta forma, póde elle proprio, promover o andamento da fiança, na inercia do credor. E' um direito que a lei estabelece em favor do fiador para que não se prolongue indefinidamente a duração da sua responsabilidade." (SANTOS, J. M. Carvalho. op. cit., v. 19, p. 477).

${ }^{538}$ YASSIM, Assad Amadeo. Considerações sobre abuso de direito. Revista dos Tribunais, São Paulo, ano 69, v. 538, p. 16, ago. 1980.

${ }^{539}$ Id., loc. cit.
} 
O exercício arbitrário ou desarrazoado do direitos subjetivos colide frontalmente com a moderna noção de obrigação, a qual é tomada como o processo ${ }^{540}$ em que credor e devedor devem prestar colaboração e esforços mútuos tendo por fim o adimplemento. Em outras palavras o contrato não envolve só a obrigação de prestar, mas envolve também uma obrigação de conduta! ${ }^{541}$

Tal noção tem por base o princípio da boa-fé objetiva ${ }^{542}$, standard de comportamento leal, honesto e probo que deve viger de acordo com as expectativas da sociedade, eis que em verdade se passa é que todos os homens têm de portar-se com honestidade e lealdade, conforme os usos do tráfico, pois daí resultam relações jurídicas de confiança, e não só relações morais. ${ }^{543}$

Liberar os contratantes de cumprir seus deveres gerais de conduta, significaria afirmar que na relação contratual os indivíduos estão autorizados a agir com má-fé, a desrespeitar os direitos do parceiro contratual, a não agir lealmente, a abusar no exercício de seus direitos contratuais, a abusar de sua posição contratual preponderante, autorizando

\footnotetext{
${ }^{540}$ Doutrina Antônio Junqueira de Azevedo que a boa-fé objetiva “(...) constitui, no campo contratual sempre tomando-se o contrato como processo, ou procedimento - norma que deve ser seguida nas várias fases das relações entre as partes; o pensamento, infelizmente, ainda muito difundido, de que somente a vontade das partes conduz o processo contratual, deve ser definitivamente afastado. É preciso que, na fase pré-contratual, os candidatos a contratantes ajam, nas negociações preliminares e na declaração da oferta, com lealdade recíproca, dando as informações necessárias, evitando criar expectativas que sabem destinadas ao fracasso, impedindo a revelação de dados obtidos em confiança, não realizando rupturas abruptas e inesperadas das conversações etc. Aos vários deveres dessa fase seguem-se deveres acessórios à obrigação principal na fase contratual - quando a boa-fé serve para interpretar, completar ou corrigir o texto contratual -, e até mesmo, na fase pós-contratual, a boa-fé também cria deveres, os posteriores ao término do contrato - são os deveres post factum finitum, como o do advogado de guardar os documentos do cliente, o do fornecedor de manter a oferta de peças de reposição, o do patrão de dar informações corretas sobre ex-empregado idôneo etc." (...) Em qualquer uma das fases contratuais, a cláusula geral da boa-fé, como norma de comportamento, cria, para as partes, deveres positivos e negativos; estão, entre os primeiros, os deveres de colaboração, inclusive de informação, - ou seja, as partes, no contrato, formam como que um microcosmo, ou pequena sociedade em como já dizia Demogue, na década de 30 - e, entre os segundos, os deveres de lealdade, especialmente o de de manter sigilo." (In AZEVEDO, Antônio Junqueira de. Responsabilidade pre-contratual no Código de Defesa do Consumidor: estudo comparado com a responsabilidade pre-contratual no direito comum. Revista de Direito do Consumidor, São Paulo, n. 18, p. 25 e ss., 1996) (Grifamos)

${ }^{541}$ MARQUES, Cláudia Lima. Contratos no Código de Defesa do Consumidor, cit., p. 108. (Grifamos).

${ }^{542} \mathrm{Da}$ mesma opinião compartilha Paulo Luiz Netto Lôbo, para quem "A boa-fé objetiva é regra de conduta dos indivíduos nas relações jurídicas obrigacionais. Interessam as repercussões de certos comportamentos na confiança que as pessoas normalmente neles depositam. Confia-se no significado comum, usual, objetivo da conduta ou comportamento reconhecível no mundo social. A boa-fé objetiva importa em conduta honesta, leal, correta. É a boa-fé que podemos chamar de boa-fé de comportamento." (In LÔBO, Paulo Luiz Netto. Condições gerais dos contratos e cláusulas abusivas. São Paulo: Saraiva, 1991. p. 145). (Grifamos).

${ }^{543}$ PONTES DE MIRANDA, Francisco Cavalcanti. Tratado de direito privado. 3. ed. Rio de Janeiro: Borsoi, 1972. t. $38, \S 4.242$, p. 321. (Grifamos)
} 
a "vantagem excessiva" ou a lesão do parceiro contratual somente porque as partes firmaram um contrato 544

Outrossim, a demora desleal no ajuizamento da necessária ação de despejo que faria cessar a responsabilidade do garante também vem a ser reprimida quer pela cláusula legal do abuso de direito previsto no artigo 187, do Código Civil, quer pela cláusula legal que protege a função social do contrato.

Com efeito, enuncia o artigo 187, do Código Civil:

"Art. 187. Também comete ato ilícito o titular de um direito que, ao exercê-lo, excede manifestamente os limites impostos pelo seu fim econômico ou social, pela boa-fé ou pelos bons costumes."

De acordo com a dicção do dispositivo legal em comento, o instituto do abuso de direito é considerado ato ilícito no direito brasileiro. Como doutrina Bruno Miragem ${ }^{545}$,

"O advento da cláusula geral do artigo 187 do Código Civil, ao definir como ato ilícito o exercício de direito que viole seu fim econômico ou social, a boa-fé e os bons costumes, retirou expressamente do suporte fático da norma a exigência da culpa para a caracterização ilícito, ao mesmo tempo que previu, no art. 927, caput, o dever de indenizar os danos causados em face do exercício de direito que viole os limites previstos na tipificação prevista na parte geral."

De igual modo o princípio da função social do contrato impede que a situação de uma demora desleal no exercício de um direito por parte do credor, in casu decorrente da demora desleal em exercer o direito potestativo de pôr fim à locação que vem sendo reiteradamente descumprida pelo afiançado, possa causar o ilegal desvio da causa do contrato de locação, invertendo o papel atribuído pelo ordenamento aos figurantes do negócio.

Assim, se o credor tolera deslealmente que o locatário ocupe o seu imóvel sem que nada lhe pague, pois irá cobrar todos os aluguéis do fiador, claro está o desvio operado na causa do contrato, pois o garante que seria apenas o responsável subsidiário passou a ser, de fato, o devedor principal já que se tornou o obrigado ao pagamento dos aluguéis mensais que deveriam estar sendo pagos pelo inquilino, em uma situação completamente surreal; o inquilino que ocupa o imóvel locado não paga os aluguéis e quem deverá fazê-lo

\footnotetext{
${ }^{544}$ MARQUES, Cláudia Lima. Contratos no Código de Defesa do Consumidor, cit., p. 108. (Grifamos).

${ }^{545}$ In MIRAGEM, Bruno. Abuso do direito: proteção da confiança e limite ao exercício das prerrogativas jurídicas no direito privado. Rio de Janeiro: Forense, 2009. p. 92.
} 
é justamente o terceiro que não ocupa o imóvel e que deveria ser apenas o responsável subsidiário.

Como esta situação foi criada pelo credor que passou a tolerar e incentivar a inadimplência do inquilino, não seria razoável que o fiador tivesse de assistir e aceitar passivamente a omissão sem que nada pudesse fazer; nesta hipótese, o instrumento jurídico mais célere do sistema para resolver esta situação vem a ser a ação de despejo por falta de pagamento, pois permite a desocupação forçada com a consequente cessação da responsabilidade do fiador.

Outro fundamento também hábil a justificar a legitimidade ativa extraordinária do fiador para a propositura da ação de despejo encontra abrigo no Enunciado no 169 na III Jornada de Direito Civil promovida pelo CEJ:

"O princípio da boa-fé objetiva deve levar o credor a evitar o agravamento do próprio prejuízo".

O locador não poderá deixar de agir contra o locatário que não paga aluguéis, apenas porque o contrato está garantido por fiança. Todo credor honesto e ciente da sua responsabilidade deve necessariamente atuar efetivamente para responsabilizar o devedor principal da obrigação, procurando mitigar o próprio prejuízo para, em caso de não conseguir obter o êxito esperado, aí sim receber a prestação do fiador. O que não se admite é que o locatário passe a ocupar o imóvel do locador às custas do fiador, tornando o responsável subsidiário em devedor principal responsável pelo pagamento dos aluguéis. Como já dissemos anteriormente, não tem sentido deixar de atribuir ao credor o dever de agir para evitar, minimizar ou afastar o próprio prejuízo, eis que o direito não tolera a demora injustificável no exercício de uma posição jurídica que irá afetar substancialmente uma relação jurídica titularizada pelo omisso...

Diante dessa situação o Direito não pode omitir-se, razão pela qual deverá ser aplicada a doutrina da venire contra factum proprium (ou dos atos próprios), a fim de permitir ao fiador a utilização da ação de despejo por falta de pagamento com vistas a acionar diretamente o locatário-afiançado se acaso o locador tiver incorrido em demora desleal na cobrança de aluguéis do inquilino. 
No Brasil, Ruy Rosado de Aguiar Júnior ${ }^{546}$ bem apontara a importância que o mecanismo repressor do comportamento contraditório (venire contra factum proprium) ostenta no âmbito das relações contratuais:

"A teoria dos atos próprios, ou a proibição de venire contra factum proprium protege uma parte contra aquela que pretenda exercer uma posição jurídica em contradição com o comportamento assumido anteriormente. Depois de criar certa expectativa, em razão de conduta seguramente indicativa de determinado comportamento futuro, há quebra dos princípios de lealdade e de confiança se vier a ser praticado ato contrário ao previsto, com surpresa e prejuízo à contraparte. Aquele que vende um estabelecimento comercial e auxilia, por alguns dias, o novo comerciante, inclusive preenchendo pedidos e novas encomendas, fornecendo o seu próprio número de inscrição fiscal, não pode depois cancelar tais pedidos, sob alegação de uso indevido de sua inscrição. $\mathrm{O}$ credor que concordou, durante a execução do contrato de prestações periódicas, com o pagamento em lugar ou tempo diverso do convencionado, não pode surpreender o devedor com a exigência literal do contrato. Para o reconhecimento da proibição é preciso que haja univocidade de comportamento do credor e real consciência do devedor quanto à conduta esperada." (Grifamos)

O Professor Cunha de $S^{547}$, em comentários sobre a aplicação da doutrina do abuso de direito - venire contra factum proprium - no direito alemão, deixou assentado que:

"Julgando-se que o abuso de direito se traduz num acto antijurídico, fazse derivar dele, consoante as circunstâncias concretas da hipótese em causa, a obrigação de indemnizar, admite-se contra ele a legítima defesa, reconhece-se a legitimidade do pedido de omissão do exercício abusivo do direito, dá-se a excepção de dolo contra o que abusivamente faz valer uma pretensão e entende-se que o abuso deve ser sempre apreciado $e x$ officio, pois é ao tribunal que compete determinar os limites de exercício do direito e a ideia de abuso não é senão o retirar precisamente esses limites do conteúdo do direito.

No campo da excepção de dolo, como aplicação da proibição geral de venire contra factum proprium, um dos institutos que mais largamente tem sido objecto de elaboração pela jurisprudência alemã é o da Verwirkung, o qual entre nós foi chamado, embora sem qualquer preocupação de rigor, de <caducidade do direito > e a que prefiro, por mais expressiva e apropriada, a designação de <exercício inadmissível do direito $>$. Trata-se de proibir que, no âmbito de uma relação préexistente, o titular de um direito o venha fazer valer em contradição com a própria conduta anterior, por tal se afigurar inadmissivel com a boa fé vigentes na relação, que seriam violados por tal exercício nomeadamente, se a conduta anterior do titular, objectivamente interpretada, legitimava a convicção de que o direito já não seria exercido (o titular, por hipótese, não fazia uso dele já há muito tempo) ou nunca seria exercido por aquela forma, violadora da lei, dos bons

\footnotetext{
${ }^{546}$ In AGUIAR JÚNIOR, Ruy Rosado de. op. cit., p. 240 e ss.

${ }^{547}$ In SÁ, Cunha de. Abuso do direito. Coimbra: Livraria Almedina, 1997. p. 64 e ss.
} 
costumes ou da boa fé. Ligado ao já citado $\S 242^{\circ}$, sobre o qual se construiu, o instituto da Verwirkung tem, no entanto, esta particularidade: o facto relativamente ao qual se vem assumir uma atitude contraditória não só se situa no âmbito de uma relação pré-existente, como consiste numa inactividade, isto é, numa omissão do exercício de um certo direito por um tempo tal que torna agora inadmissível, por contrária à boa fé, a pretensão de o vir fazer valer ou de o vir fazer valer por aquele preciso modo." (Grifamos)

Igualmente a respeito da doutrina do venire contra factum proprium, também chamada de teoria dos atos próprios na América Latina, Rubén S. Stiglitz e Gabriel A. Stiglitz $^{548}$ também entenderam que o exercício contraditório de direito ou a demora desleal ou injustificada do exercício de direitos não pode ser tolerada:

"La circunstancia de que un sujeto de derecho intente verse favorecido en un proceso judicial, asumiendo una conducta que contradice outra que la precede en el tiempo, en tanto constituye un proceder injusto, es inadmisible.

A la cuestión en examen se la caracteriza como una derivación necesaria e inmediata del principio de buena fe, especialmente en la dirección que la concibe como un modelo objectivo de conduta, aceptada como arquetipo por una sociedade y que recibe su impronta ética.

Examinado el principio de buena fe, advertimos que su observancia requiere que en la relacíon jurídica la parte exhiba un comportamiento leal y adecuado a la creencia y confianza despertada en la otra, manteniendo la palabra empeñada desde el proceso formativo mismo si se trata de una relación creditoria, haciendo inadmisible la contradicción com una conducta previa y propia.

Nos parece que es un imperativo des sujeto observar un comportamiento coherente, como principio básico y en todos los órdenes de sus relaciones, no solamente las jurídicas. En este campo confluyen para su identificación, y evalución y proyecciones (consecuencias), los deberes secundarios de conducta que embretan el perfil de la línea objetiva de una lógica interior congruente que hace, al cabo, que el hombre sea - debe serlo - fiel a sus propios actos.

La declaración de inadmisibilidad de una conducta incoherente emplazada en una pretensión, requiere indeludiblemente su comparación com outra conducta precedente y propia del mismo sujeto. La inadmisibilidad será el resultado de una tarea de interpretación, relacionando para ello la conducta propia que precede al comportamiento ulterior. Y este último será el declarado inadmisible por incoherente.

El fundamento estará dado en razón de que la conducta anterior há generado - según el sentido objetivo que de ella se desprende confianza en que, qien la ha emitido, permanecerá en ella, pues lo contrario importaría incompatibilidad o contradicción de conductas

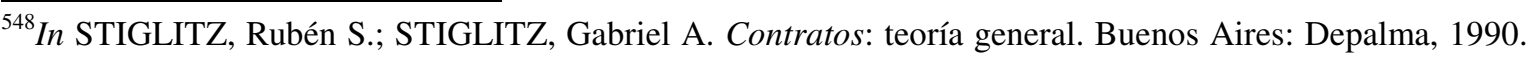
v. 1, p. 491.
} 
emanadas de un mismo sujeto, que afectan injustamente la esfera de intereses de quien suponía hallarse protegido, pues había depositado su confianza en lo que creía un comportamiento agotado en su dirección de origen. $^{549}$

La doctrina del acto próprio importa una limitación o restricción al ejercicio de una pretensión. Se trata de un impedimento de "hacer valer el derecho que en outro caso podría ejercitar.

Lo obstativo se apoya en la ilicitud de la conducta ulterior confrontada com la que le precede. La ilicitud reposa en el hecho de que la conducta incoherente contraría el ordenamiento jurídico considerado éste inescindiblemente, noción aplicable en el ámbito extracontractual o contractual - y también, y fundamentalmente, dentro del proceso judicial - y que conlleva como sanción la declaración de inadmisibilidad de la pretensión que quien intenta ponerse en contradicción com su anterior conducta deliberada, jurídicamente relevante y plenamente eficaz." (Grifamos)

Ora, se o locador deixar de pedir o despejo do imóvel locado ao devedor ante a sua inadimplência, concorrendo com a sua conduta a que o mesmo fique vários meses sem pagar aluguel, entendemos inadmissível que a sua omissão venha a beneficiá-lo, não se podendo negar ter o mesmo agido com dolo ou no mínimo de forma negligente. Daí por que ao ter assumido uma conduta contraditória com aquele que era de se esperar viesse a ter sido tomada pelo locador diligente, a postura adotada não poderá lhe aproveitar.

Em outras palavras, o credor não poderá atuar como se o fiador não existisse, de modo a permitir que a garantia subsidiária se transformasse em obrigação principal.

Segundo apontava Carvalho Santos ${ }^{551}$,

"No direito moderno, pois, já não se toleram os direitos absolutos, não faltando mesmo quem sustente, quanto ao seu exercício, que todo o direito é relativo, verificando-se o abuso sempre que se verificar a ruptura do equilíbrio dos interêsses sociais em jogo." (Grifamos)

A visão teleológica e atual do Direito deve ser sempre presidida por uma lógica de solidariedade $^{552}$ e lealdade entre os parceiros contratuais, baseando-se na boa-fé e

\footnotetext{
${ }^{549}$ STIGLITZ, Rubén S.; STIGLITZ, Gabriel A. op. cit., p. 492.

${ }^{550}$ In Id. Ibid., p. 493.

${ }^{551}$ In SANTOS, Carvalho. Código Civil brasileiro interpretado. 4. ed. Rio de Janeiro: Freitas Bastos, 1950. v. 3 , p. 340 e ss.

${ }^{552}$ Segundo Rubén S. Stiglitz, "Pero de lo que no cabe duda es de que al hallarse el contrato inserto en el contexto social, y ser un instrumento de convivencia, debemos privilegiar a la solidariedad, y a los principios y valores que la sustentam, como cláusula abierta, flexible, pura y oxigenante, que ineludibelmente debe hacer campamento, e integrarse conceptualmente, en la relacíon de equivalencia.

Ello motiva la necessidad de que sea el ordenamiento jurídico quien, para preservar un mínimo de "justicia contratual", derogue o declare inaplicables disposiciones que, errónea e injustificadamente, fundadas en el
} 
equidade, o que certamente não ocorrerá se ao fiador forem imputadas todas as consequências do inadimplemento do locatário, eis que os riscos contratuais deverão ser partilhados de forma justa, e não demasiadamente excessiva para um dos contraentes em prejuízo dos demais.

Os tempos são outros e a sociedade já não mais tolera o abuso de direito, o agir de forma desarrazoada, pois o direito não pode caminhar divorciado dos princípios morais que imperam na sociedade e que norteiam as consciências a conceberem os relacionamentos dentro de um mínimo de decência e pudor econômico, sob pena de se converterem estes em instrumento de pura especulação e destruição, ao invés de se tornarem fatores construtivos da riqueza nacional ${ }^{553}$.

Para o Direito, essencial é o justo, o devido ao outro, o que sustenta o direito da liberdade, declarador e preservador dos valores humanos. Repousa assim, sobre a noção do justo, toda a construção jurídica. A justiça é, no entanto, valor moral por excelência, que só se perfazendo no certo e no seguro, não prescinde da materialidade objetiva, da funcionalidade desses dois outros conceitos. O ser humano, a quem é inato o senso de justiça, aspira também à segurança e à certeza na realização de seu direito ${ }^{554}$.

Diante de tais casos, haja vista a existência de nítido interesse jurídico do fiador em pôr cobro à locação - tutela preventiva, pensamos - a ação de despejo deverá ser outorgada ao garante da locação, interpretação essa que deverá ser feita em conjunto com os artigos 834, do Código Civil, 62 e seguintes, da Lei do Inquilinato, e à luz dos princípios da boa-fé objetiva, função social do contrato, vedação ao abuso de direito, inafastabilidade do controle jurisdicional e da instrumentalidade do processo.

Diz o artigo 834, do Código Civil:

“Art. 834. Quando o credor, sem justa causa, demorar a execução iniciada contra o devedor, poderá o fiador promover-lhe o andamento."

orden público, no sean útiles a la paz social sino a la agresión, a la hostilad y a la desconfianza. Y especialmente provechosas en punto al estímulo de la litigiosidad. El contrato debe ser concebido con una mínima dosis de sensibilidad, o, si se prefiere, de humanidad, pues si aceptamos que no se trata de un fonómeno factible de ser reducido a una operación económica, también habremos de coincidir en que su función, predominantemente, consiste en satisfacer y tutelar necessidades e intereses humanos legítimos." (In STIGLITZ, Rubén S. Autonomía de la voluntad y revisón del contrato. Buenos Aires: Depalma, 1992. p. 69).

${ }^{553}$ RIZZARDO, Arnaldo. Da ineficácia dos atos jurídicos e da lesão no direito. Rio de Janeiro: Forense, 1983. p. 96.

${ }^{554}$ SÁ, Djanira Maria Radamés de. O duplo grau de jurisdição como garantia constitucional. In: WAMBIER, Teresa Arruda Alvim; NERY JUNIOR, Nelson (Coords.). Aspectos polêmicos e atuais dos recursos cíveis de acordo com a Lei 9.756/98. 1. ed. 2. tir. São Paulo: Ed. Revista dos Tribunais, 1999. p. 185. 
Segundo pensamos, é caso típico de substituição processual ou de legitimação ativa extraordinária. Há claro interesse processual do fiador, ainda que ele não tenha despendido importância alguma ${ }^{555}$, pois o sentido finalístico da lei é o de evitar (= escopo preventivo) ou pelo menos minorar o sacrifício do fiador, máxime por negligência do credor no retardamento da execução. Muitas vezes o credor, confiando na solvabilidade do devedor, pode descuidar-se do andamento da execução contra o fiador ${ }^{556,557 .}$

Por idêntica razão, entendemos que o termo "demorar a execução iniciada contra o devedor" poderá ser tomado como sinônimo de "demorar a execução do despejo do imóvel iniciada contra o devedor", porque ao se deferir ao fiador a legitimidade para pleitear o desfazimento da locação estar-se-á evitando que a demora do locador em adotar as medidas necessárias à punição do locatário inadimplente venha a redundar em prejuízo ao fiador, o que certamente poderá vir a ser evitado ou até mesmo minorado com o desfazimento oportuno da locação.

Com efeito, o interesse jurídico do fiador é iminente, pois se a execução contra o devedor tiver no mínimo sucesso parcial, diminuirá sua obrigação diante do credor $^{558}$.

Com efeito, o aplicador da lei, seja o administrador, seja o juiz, não pode desligarse do resultado de sua ação e considerar cumprido seu dever com a mera e simples aplicação racional da norma aos fatos. Sua tarefa deve ir além: é criativa por natureza, pois que com ela deve integrar a ordem jurídica ${ }^{559}$.

E sendo criativa a atividade do intérprete do direito, com vistas a alcançar resultados justos e socialmente úteis, essas são as considerações que nos permitem defender a outorga de legitimação ativa extraordinária a permitir a propositura da ação de despejo por falta de pagamento ao fiador ante a demora desleal da cobrança da dívida pelo locador.

\footnotetext{
${ }_{555}^{55}$ OLIVEIRA, Lauro Laertes de. op. cit., p. 67.

${ }_{557}^{55}$ Id., loc. cit.

${ }^{557}$ Doutrinava Pontes de Miranda: "A ratio legis do art. 1.498 está em evitar-se que o fiador tenha de vir a pagar o que o credor teria recebido se fôsse diligente." (PONTES DE MIRANDA, Francisco Cavalcanti. op. cit., t. 44, § 4.788, 11, p. 161).

${ }^{558}$ Conforme OLIVEIRA, Lauro Laertes de. op. cit., p. 67.

${ }^{559}$ MOREIRA NETO, Diogo de Figueiredo. Legitimidade e discricionariedade. 3. ed. rev. e atual. Rio de Janeiro: Forense, 1998. p. 56.
} 


\section{8. É admissível que o devedor principal também figure como fiador do contrato?}

Este tópico da dissertação foi motivado pelo fato de termos encontrado vários contratos de locação nos quais uma das partes figurou como locatário e fiador ao mesmo tempo, sendo que em todos eles a situação fático-jurídica era idêntica: o locatárioinquilino era titular de um único bem imóvel, de maneira que em tese seria admissível a penhora do imóvel do garante.

Diante da hipótese apresentada, indaga-se: é admissível que o devedor principal também figure como fiador do contrato de locação? Vejamos.

Em um dos poucos precedentes sobre o tema, o Superior Tribunal de Justiça, nos autos do recurso especial 62198-SP (leading case), julgado em 16/05/1997, tendo sido relator o Ministro Adhemar Maciel, da 2. ${ }^{\text {a }}$ Turma, decidiu que nula seria a fiança em que a mesma pessoa figurasse no contrato na condição de fiador e fiadora:

"CIVEL E PROCESSUAL CIVIL. EXECUÇÃO FISCAL. FIANÇA BANCARIA. MESMA PESSOA FIGURANDO COMO DEVEDORAFIANÇADO E FIADOR: IMPOSSIBILIDADE. RECURSO NÃO CONHECIDO.

I - A fiança bancária, como toda fiança, pressupõe três pessoas distintas: o credor, o devedor-afiançado e o banco-fiador.

Não é juridicamente possível que uma pessoa (in casu, a Caixa Econômica Federal) seja simultaneamente devedora-afiançada e fiadora.

II - Inteligência do art. 1.481 DO CC e do art.. 9..$^{\circ}$ II, da lei.$^{\circ}$ $6.830 / 1980$.

III - Recurso especial não conhecido." (REsp 62198/SP, Rel. Ministro ADHEMAR MACIEL, 2. ${ }^{\mathrm{a}}$ Turma, julgado em 16/05/1997, DJ 09/06/1997 p. 25497)

Neste caso julgado pelo Superior Tribunal de Justiça, o voto-condutor do relator considerou que a estrutura do contrato de fiança exigiria, pelo menos, a presença de três pessoas distintas: (a) a do credor, (b) do devedor-afiançado e a (c) do terceiro-fiador.

Dessa forma, o tribunal decidiu que "Não é juridicamente possível que uma mesma pessoa seja simultaneamente devedor-afiançado e fiador, pois contraria a lógica e especialmente o art. 1.481 do CC ("Dá-se o contrato de fiança quando uma pessoa se obriga por outra, para com o seu credor, a satisfazer a obrigação, caso o devedor não a cumpra”)- que uma pessoa garanta a si própria, seja fiadora de si mesma.” (Grifamos) 
Em outras oportunidades posteriores e a partir do precedente citado, o Superior Tribunal de Justiça manteve o entendimento de que a prestação de fiança pelo próprio devedor seria inadmissível:

\begin{abstract}
"EXECUÇÃO FISCAL. FIANÇA BANCÁRIA. Trata-se de possibilidade da fiança bancária ser prestada pelo próprio devedor afiançado, e não por terceiro. A fiança sempre pressupõe que seja ofertada por terceiro, uma vez que se destina a assegurar o cumprimento de obrigação de outrem. Na fiança bancária há três figuras distintas: o credor, o devedor-afiançado (ou executado) e o banco-fiador (ou garante), não se confundindo o garante e o executado. Sendo assim, incabível a prestação de fiança bancária para garantia do processo de execução fiscal pela própria CEF devedora. Precedente citado: REsp 62.198-SP, DJ 9/6/1997. REsp 183.648-SP, Rel. Min. Franciulli Netto, julgado em 26/3/2002."
\end{abstract}

Ao compararmos as redações dos artigos 1.481 do Código Civil de 1916 e a que foi adotada no artigo 818 do Código Civil de 2002, perceberemos que foi mantida a mesma estrutura do contrato em ambas as codificações:

\begin{tabular}{|c|c|}
\hline \multicolumn{1}{|c|}{ Código Civil de 1916 “Art. 1.481. Dá-se o contrato de fiança } & Código Civil de 2002 \\
\hline $\begin{array}{l}\text { "Art.818. Pelo contrato de fiança, uma } \\
\text { quando, uma pessoa se obriga por outra, para com } \\
\text { seu credor, a satisfazer a obrigação, caso o devedor } \\
\text { não a cumpra." }\end{array}$ & $\begin{array}{c}\text { pessoa garante satisfazer ao credor uma obrigação } \\
\text { assumida pelo devedor, caso este não a cumpra." }\end{array}$ \\
\hline
\end{tabular}

A melhora redacional do artigo 818 do Código Civil de 2002 comparada a do artigo 1.481 do Código Civil de 1916 não foi capaz de alterar a estrutura negocial da fiança, de maneira que a feição legal do contrato exige a presença de pelo menos dois sujeitos distintos: credor e fiador, uma vez que o afiançado, conforme já expusemos no item 4.4.1., não participa do contrato de garantia, até porque o mesmo poderá ser firmado contra a sua vontade.

Diante dos precedentes citados, entendemos que a estrutura atual do contrato de fiança deverá ser modificada, a fim de torná-lo mais efetivo e consoante a sua função social, que é a de garantir eficazmente uma obrigação, quer seja alheia quer seja própria. Expliquemos.

Segundo se extrai dos julgados citados, o Superior Tribunal de Justiça manifestou o entendimento de que as figuras do devedor e do fiador não poderiam ser reunidas na 
mesma pessoa; portanto, o fiador seria sempre um terceiro, terceira pessoa que se responsabiliza pelo adimplemento alheio.

Nesse sentido a doutrina de António Menezes Cordeiro ${ }^{560}$ :

"Naturalmente, as suas obrigações têm, como sujeitos passivos, pessoas diferentes, de tal forma que, em última análise, pelo esquema da garantia geral, vamos encontrar, assegurando a obrigação garantida, dois patrimónios: a do devedor e o da pessoa adstrita à garantia." (Grifamos)

No entanto, a estrutura legal do contrato de fiança não se apresenta a mais adequada na atualidade, especialmente porque a intromissão de um terceiro em dada relação contratual tem se mostrado fator de insegurança e propulsor de litígios, pois inúmeras são as demandas de garantes que postulam a extinção do vínculo fidejussório tão-logo ocorra a mora do afiançado, que é justamente a situação em que o credor se encontra mais vulnerável; outrossim, como já expusemos anteriormente, a redação atual do artigo 835, do Código Civil deixa dúvidas sobre ser ou não possível a manifestação de exoneração de fiança quando o afiançado já se encontrar em mora.

Posta a questão nestes termos, entendemos que a melhor opção seria a de se permitir que o afiançado pudesse também figurar como fiador, especialmente porque nesta hipótese não haveria os mesmos problemas que a sub-rogação acarreta nas posições jurídicas do garante e do devedor, já que aquele poderá sofrer a perda do seu único bem imóvel, porém em regresso não poderá atingir o único bem imóvel porventura existente no patrimônio do afiançado.

Em sendo assim, se o próprio devedor também pudesse figurar em um contrato como fiador, especialmente nos contratos de locação de imóveis urbanos, a impenhorabilidade do bem de família não poderia por ele ser alegada por força da exceção prevista no artigo $3 .^{\circ}$, inciso VII, da Lei n. ${ }^{\circ}$ 8.009/90, razão pela qual seria eliminado um dos fatores de perturbação do vínculo que é o da ação regressiva do fiador que pagou a dívida contra o devedor-afiaçado objetivando o seu ressarcimento.

Na atualidade, o fiador não recebe a proteção legal dispensada ao bem de família dos devedores em geral, pois poderá ter o seu único imóvel penhorado, enquanto o devedor-afiançado terá o seu único imóvel blindado e posto a salvo do fiador que não poderá atingi-lo, situação esta que demonstra a ilogicidade do mecanismo sub-rogatório

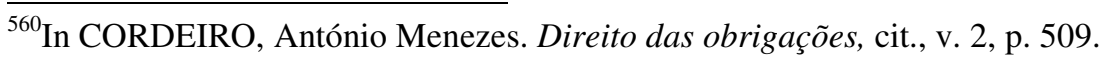


atual, pois como o credor originário não possuía qualquer privilégio legal que lhe permitia acessar o bem de família do devedor, o fiador que pagou a dívida e se sub-rogou em seu lugar assumirá o crédito originário com "todos os direitos, ações, privilégios e garantias do primitivo, em relação à dívida, contra o devedor principal e os fiadores", a teor do artigo 349 do Código Civil. 


\section{A REFORMA DA LEI DO INQUILINATO: LEI N.$^{\circ}$ 12.112, DE 9 DE DEZEMBRO DE 2009}

Após longos 18 (dezoito) anos de vigência a Lei n. ${ }^{\circ}$ 8.245/91, mais conhecida como Lei do Inquilinato, sofreu uma profunda reforma pela Lei n. ${ }^{\circ} 12.112$, de 9 de dezembro de 2009 que entrará em vigor em 24 de janeiro de 2009 em razão do veto presidencial $^{561}$ aposto ao artigo $3 .^{\circ}$ da Lei que previa a sua imediata entrada em vigor.

Nos termos da justificação do projeto do Deputado José Carlos Araújo, depois de mais de 18 anos de vigência da Lei 8.245/90, de 18 de outubro de 1991, verificou-se "a necessidade de se promover aperfeiçoamentos neste diploma legal. Isto se justifica em função das modificações advindas como o Código Civil que entrou em vigor em 2003, das mudanças nas regras processuais que foram aprovadas nesse período e da alentada jurisprudência acumulada com as interpretações decorrentes dos conflitos jurídicos estabelecidos entre as partes"

Na presente dissertação abordaremos apenas as alterações legislativas que afetaram o contrato de fiança à locação, dado o escopo do trabalho; assim, os dispositivos legais a serem comentados serão os artigos 12, 39, 40 incisos II e X, que dizem respeito aos aspectos materiais da fiança, não tendo sido objeto de comentários os artigos relativos aos aspectos processuais da garantia fidejussória.

\footnotetext{
${ }^{561}$ Eis as razões expostas no veto presidencial: "Razões do veto

"Nos termos do art. 8ㅜ caput, da Lei Complementar nํ 95, e 26 de fevereiro de 1998, a entrada em vigor imediata somente deve ser adotada em se tratando de normas de pequena repercussão, o que não é o caso do presente projeto de lei.

Assim, de modo a garantir tempo hábil para que os destinatários da norma examinem o seu conteúdo e estudem os seus efeitos, propor-se que a cláusula de vigência seja vetada, fazendo-se com que o ato entre em vigor em quarenta e cinco dias, nos termos do art. $1^{\circ}$-do Decreto-Lei ${ }^{\circ}$ - 4.657, de 4 de setembro de 1942 - Lei de Introdução ao Código Civil Brasileiro.”

${ }^{562}$ SCAVONE JUNIOR, Luiz Antonio. Apresentação. In: Reforma da lei do inquilinato. São Paulo:
} Ed. Revista dos Tribunais, 2009. 
Lei $.^{\circ} 8.245 / 91$

\begin{tabular}{|c|c|}
\hline o Antiga & Nova Redação \\
\hline $\begin{array}{l}\text { Art. 12. Em casos de separação de fato, } \\
\text { separação judicial, divórcio ou dissolução da } \\
\text { sociedade concubinária, a locação prosseguirá } \\
\text { automaticamente com o cônjuge ou companheiro } \\
\text { que permanecer no imóvel. } \\
\text { Parágrafo único. Nas hipóteses previstas } \\
\text { neste artigo, a sub - rogação será comunicada por } \\
\text { escrito ao locador, o qual terá o direito de exigir, no } \\
\text { prazo de trinta dias, a substituição do fiador ou o } \\
\text { oferecimento de qualquer das garantias previstas } \\
\text { nesta lei. }\end{array}$ & $\begin{array}{l}\text { “Art. 12. Em casos de separação de fato, } \\
\text { separação judicial, divórcio ou dissolução da união } \\
\text { estável, a locação residencial prosseguirá } \\
\text { automaticamente com o cônjuge ou companheiro } \\
\text { que permanecer no imóvel. } \\
\quad \& 1^{o} \text { Nas hipóteses previstas neste artigo e } \\
\text { no art. } 11 \text {, a sub-rogação será comunicada por } \\
\text { escrito ao locador e ao fiador, se esta for a } \\
\text { modalidade de garantia locatícia. } \\
\quad \& 2^{-} \text {O fiador poderá exonerar-se das suas } \\
\text { responsabilidades no prazo de } 30 \text { (trinta) dias } \\
\text { contado do recebimento da comunicação oferecida } \\
\text { pelo sub-rogado, ficando responsável pelos efeitos } \\
\text { da fiança durante } 120 \text { (cento e vinte) dias após a } \\
\text { notificação ao locador." }\end{array}$ \\
\hline
\end{tabular}

O artigo 12, da Lei do Inquilinato, já previa hipóteses em que ocorreria a subrogação legal do contratos de locação; nas situações indicadas há a substituição do locatário por pessoa diversa da que figurou no vínculo independentemente da vontade do locador.

Agora, pela novel redação do caput, a substituição automática do locatário se circunscreve às locações residenciais, em consonância com o disposto no art. 11, I, que trata da sub-rogação legal nessa hipótese. Demonstra a lei a intenção de proteção à dignidade da pessoa e prestigia o direito constitucional à moradia, do art. $6 .^{\circ}$ da Constituição Federal de $1988^{563}$.

Nas hipóteses enumeradas era muito comum a ocorrência de substituição do locatário, sem que o locador ou o fiador tivessem tomado conhecimento da alteração; assim, o locador se via surpreendido com a ocupação do imóvel locado por pessoa estranha ao vínculo originário, o que ocorria em prejuízo da própria garantia fidejussória eventualmente prestada, dado o seu caráter intuitu personae.

Segundo entendemos, a alteração legislativa se apresentou benéfica, pois passou a privilegiar a boa-fé objetiva das partes em atenção ao princípio da informação.

${ }^{563}$ SCAVONE JUNIOR, Luiz Antonio. op. cit., p. 14-15. 
A primeira alteração havida no artigo 12 da Lei do Inquilinato foi a substituição da expressão "sociedade concubinária” pela da "união estável”, colocando a lei das locações em harmonia com o Código Civil de 2002.

A segunda alteração ocorreu no $\S 1 .^{\circ}$, do artigo 12 , pois o legislador estendeu ao fiador o direito de ser notificado da sub-rogação operada. E tratando-se de um direito, a bem dizer direito a ser informado, impõe ao "cônjuge ou companheiro que permanecer no imóvel" o dever de veicular a notificação ao garante sob pena de suportarem a ineficácia da garantia.

Ao nosso sentir, não se trata de nulidade porque pelo sistema do Código Civil de 2002 somente haverá tal espécie de invalidade nas hipóteses subsumíveis ao elenco do artigo 166, incisos I a VII. Também não se trata de invalidade de outra ordem porque a ausência de notificação ao fiador afeta apenas os efeitos da garantia em relação ao cônjuge ou companheiro que permanecer no imóvel, não invalidando o contrato firmado entre fiador e credor.

Assim, se acaso não ocorrer a notificação prevista no reformado $\S 1 .^{\circ}$, do artigo 12 , da lei do inquilinato, a fiança permanecerá válida, porém ineficaz em face do cônjuge ou companheiro que permaneceram no imóvel, de modo que a situação será equiparável à inexistência de garantia, pois uma fiança que não surte efeitos prático-jurídicos é análoga a uma situação de inexistência fidejussória. A ausência de notificação, pois, não acarretará a exoneração automática do fiador, como à primeira vista poderia parecer $^{564}$, pois a omissão do afiançado legal não poderia, com suporte na boa-fé objetiva, protegê-lo em detrimento do locador.

Posta a questão nestes termos, duas situações possíveis se apresentarão:

a) ou se permite ao locador notificar o inquilino para que apresente nova garantia no prazo de trinta dias, sob pena de desfazimento da locação, nos termos do reformado artigo 40, inciso X, parágrafo único, da Lei do Lnquilinato, pois garantia ineficaz é equiparável à garantia inexistente;

b) ou se permite ao locador proceder a notificação do fiador, ante a omissão do afiançado legal, de maneira a manter hígida a fiança até que o garante promova, se o caso, a exoneração prevista no reformado $\S 22^{\circ}$, do artigo 12 , da lei do inquilinato, que será

\footnotetext{
$\overline{{ }^{564} \text { No mesmo sentido: Id. Ibid., p. } 15-16 .}$
} 
comentado a seguir, posto que a notificação tem também a finalidade de permitir que o fiador possa vir a exercer o direito de exoneração, se assim o quiser.

Por sua vez, o $\S 2 .^{\circ}$, do reformado artigo 12 , da Lei do Inquilinato, outorgou ao fiador o direito à exoneração ${ }^{565}$ nos casos de sub-rogação legal da locação, em nítido prestígio ao caráter intuitu personae da fiança. A partir da entrada em vigor das alterações legislativas, o fiador terá o direito potestativo de pleitear a exoneração da fiança, porém, diferentemente do prazo de 60 (sessenta) dias previsto no artigo 835 do Código Civil, o fiador permanecerá vinculado à garantia durante 120 (cento e vinte) dias a contar da efetiva ${ }^{566}$ notificação do locador comunicando a exoneração.

A bem dizer, o legislador concedeu o direito de exoneração ao fiador, porém estendeu no tempo a responsabilidade, procurando manter um equilíbrio mínimo nas posições jurídicas do locador e do fiador.

Questão que ainda permanecerá em aberto, vem a ser a da admissibilidade ou não da renúncia ao direito de exoneração. Será admissível ao fiador renunciar previamente ao direito de exoneração previsto no $§ 2 .^{\circ}$, do reformado artigo 12, da Lei do Inquilinato? Em nossa opinião a resposta é negativa, ante os mesmos fundamentos já exposto no item 4.7.2.1 da presente dissertação.

Lei $.^{\circ} 8.245 / 91$

\begin{tabular}{|c|c|}
\hline Redação Antiga & Nova Redação \\
\hline $\begin{array}{l}\text { Art. 39. Salvo disposição contratual em } \\
\text { contrário, qualquer das garantias da locação se } \\
\text { estende até a efetiva devolução do imóvel. }\end{array}$ & $\begin{array}{l}\text { Art. 39. Salvo disposição contratual em } \\
\text { contrário, qualquer das garantias da locação se } \\
\text { estende até a efetiva devolução do imóvel, ainda que } \\
\text { prorrogada a locação por prazo indeterminado, por } \\
\text { força desta Lei }\end{array}$ \\
\hline
\end{tabular}

\footnotetext{
${ }^{565}$ Segundo aponta SCAVONE JUNIOR, Luiz Antonio, haveria uma faculdade outorgada ao locador que seria a de promover a respesctiva ação de despejo por falta de pagamento com fundamento no artigo 40, inciso IV, parágrafo único, da lei do inquilinato: "Cumpre esclarecer que, no caso de sub-rogação e exoneração do fiador comunicado, deixou a lei de prever neste artigo a possibilidade antes existente de o locador "exigir, no prazo de trinta dias, a subsituição do fiador ou o oferecimento de qualquer das garantias previstas nesta lei". Isto porque a hipótese já está prevista, a título de exoneração do fiador, no art. 40, IV, que possibilita a exigência do novo fiador no prazo de trinta dias, sob pena de infração legal e despejo." (In Reforma da lei do inquilinato, cit., p. 18).

${ }^{566}$ Manifestação de vontade receptícia.
} 
O artigo 39 da Lei do Inquilinato sempre enunciou uma regra clara: a de que as garantias da locação estender-se-iam, salvo estipulação contratual contrária, até a efetiva devolução do imóvel locado.

Nesta hipótese, no que pertine à fiança, a prorrogação legal da locação provocava também a prorrogação da garantia fidejussória, regra esta que não gerava maiores dúvidas.

Todavia, desde a edição da Súmula 214 do Superior Tribunal de Justiça, as decisões do tribunal passaram a ser tomadas no sentido de que a prorrogação legal da locação provocaria a extinção automática da fiança, porque " $O$ contrato acessório de fiança obedece à forma escrita, é consensual, deve ser interpretado restritivamente e no sentido mais favorável ao fiador. Desse modo, a prorrogação do pacto locatício por tempo indeterminado, compulsória ou voluntariamente, desobriga o garante que a ela não anuiu." 567

E em razão do entendimento que passou a predominar no âmbito do Superior Tribunal de Justiça, o Congresso Nacional procurou suplantar a jurisprudência com a inclusão do artigo 819 -A, do Código Civil, pela Lei n. ${ }^{\circ} 10.931$, de 2 de agosto de 2004, que assim dispunha:

“Art. 819-A. A fiança na locação de imóvel urbano submete-se à disciplina e extensão temporal da lei específica, somente se aplicando as disposições deste Código naquilo que não for incompatível com a legislação especial."

O referido dispositivo legal sequer chegou a entrar em vigor por ter sido vetado pelo Senhor Presidente da República sob as seguintes justificativas:

"Razões do veto

"Não está clara a conseqüência prática do dispositivo. Aventou-se a possibilidade de o dispositivo ser uma tentativa de afastar a aplicação do art. 835 do novo Código Civil, o qual dispõe:

'Art. 835. O fiador poderá exonerar-se da fiança que tiver assinado sem limitação de tempo, sempre que lhe convier, ficando obrigado por todos os efeitos da fiança, durante sessenta dias após a notificação do credor.'

Contudo, não se pode afirmar que o dispositivo inserto seria causa de afastamento da aplicação do art. 835 do Código Civil. Primeiro, porquanto não há afirmação expressa de que o art. 835 seja incompatível com a lei de locações. Segundo, porque, se o dispositivo fosse incompatível com a lei de locações, o afastamento se daria

\footnotetext{
${ }^{567}$ In AgRg no REsp 832.271/SP, Rel. Ministra LAURITA VAZ, 5. ${ }^{\text {a }}$ Turma, julgado em 19/10/2006, DJ 20/11/2006 p. 359.
} 
independentemente de previsão legal expressa, mas apenas com base nas regras normais de hermenêutica.

Ademais, tornando mais obscura a conseqüência material do dispositivo, tem-se o disposto no art. 2.036 do Código Civil:

'Art. 2.036. A locação de prédio urbano, que esteja sujeita à lei especial, por esta continua a ser regida.'

Por fim, a jurisprudência do Superior Tribunal de Justiça, examinando disposição do Código Civil antigo, análoga ao atual art. 835, admitiu a renúncia do direito de exoneração da fiança, como se observa do seguinte precedente:

'CIVIL. LOCAÇÃO. EXONERAÇÃO DA FIANÇA. RENÚNCIA EXPRESSA. CÓDIGO DE DEFESA DO CONSUMIDOR. INAPLICABILIDADE. ARTIGO 1500 DO CÓDIGO CIVIL. PRORROGAÇÃO DO CONTRATO. POSSIBILIDADE. (...)

- A Jurisprudência assentada nesta Corte construiu o pensamento de que é válida a renúncia expressa ao direito de exoneração da fiança, mesmo que o contrato de locação tenha sido prorrogado por tempo indefinido, vez que a faculdade prevista no artigo 1500 do Código Civil trata de direito puramente privado.

- Recurso especial não conhecido.' (RESP 280577/SP; DJ de 24 de abril de 2001. Min. Rel. Vicente Leal. Data de decisão 26 de março de 2001. $6^{\text {a }}$ Turma)

Portanto, querendo, o locador pode exigir que o fiador renuncie à possibilidade de exoneração da fiança. Neste ponto, por conseguinte, não há elemento de insegurança jurídica.

Assim, não é possível compreender os efeitos materiais exatos da norma proposta, o que gerará insegurança jurídica no ambiente dos negócios de locação imobiliária e torna conveniente o veto por contrariedade ao interesse público."

$\mathrm{O}$ artigo dantes vetado retornou ao cenário legal através da Lei n. ${ }^{\circ} 12.112$, de 9 de dezembro de 2009, que alterou a redação do artigo 39 da Lei do Inquilinato. Comparemos as redações do vetado artigo 819-A, do Código Civil e a novel redação do artigo 39 da Lei n. ${ }^{\circ} 8.245 / 90$ :

\begin{tabular}{|c|c|}
\hline Artigo Vetado que seria Incluído no Código Civil & Nova Redação da Lei $n .^{\circ} 8.245 / 91$ \\
\hline $\begin{array}{l}\text { "Art. 819-A. A fiança na locação de imóvel } \\
\text { urbano submete-se à disciplina e extensão temporal } \\
\text { da lei específica, somente se aplicando as } \\
\text { disposições deste Código naquilo que não for } \\
\text { incompatível com a legislação especial." }\end{array}$ & $\begin{array}{l}\text { Art. 39. Salvo disposição contratual em } \\
\text { contrário, qualquer das garantias da locação se } \\
\text { estende até a efetiva devolução do imóvel, ainda que } \\
\text { prorrogada a locação por prazo indeterminado, por } \\
\text { força desta Lei }\end{array}$ \\
\hline
\end{tabular}


Apesar das diferentes redações, a finalidade da nova redação emprestada ao artigo 39 da Lei do Inquilinato foi a de evitar que os tribunais pudessem novamente desconsiderar a letra da lei para considerar extinta a fiança ainda que o contrato de locação tivesse sido prorrogado por tempo indeterminado.

Não obstante, a nova redação do dispositivo que ainda se encontra no período de vacatio legis é muito superior ao da regra vetada, pois com rara felicidade acrescentou a regra de que a prorrogação da locação por força da Lei do Inquilinato não acarretará a extinção de qualquer uma das garantias locatícias, especialmente a fidejussória.

Todavia, modificando radicalmente a jurisprudência que se firmou no Superior Tribunal de Justiça a partir de 2007, o inciso X e o parágrafo único acrescidos ao artigo 40 da Lei do Inquilinato estabelecem a possibilidade de o fiador se exonerar da fiança no termo final do contrato, independentemente de sua prorrogação por tempo indeterminado. Em outras palavras, só se estenderá até a efetiva entrega das chaves caso o fiador não tome a providência de pedir exoneração, nos termos do inciso X, da Lei $n .^{\circ} 8.245 / 91^{568}$, hipótese esta que iremos abordar a seguir.

Lei $n .^{\circ} 8.245 / 91$

\begin{tabular}{|c|c|}
\hline Redação Antiga & Nova Redação \\
\hline $\begin{array}{l}\text { Art. } 40 \text {. O locador poderá exigir novo fiador } \\
\text { ou a substituição da modalidade de garantia, nos } \\
\text { seguintes casos: } \\
\text { (...) }\end{array}$ & $\begin{array}{l}\text { Art. } 40 \text {. O locador poderá exigir novo } \\
\text { fiador ou a substituição da modalidade de garantia, } \\
\text { nos seguintes casos: }\end{array}$ \\
\hline $\begin{array}{c}\text { II - ausência, interdição, falência ou } \\
\text { insolvência do fiador, declaradas judicialmente; }\end{array}$ & $\begin{array}{l}\text { II - ausência, interdição, recuperação } \\
\text { judicial, falência ou insolvência do fiador, } \\
\text { declaradas judicialmente; } \\
\text { (...) } \\
\text { X - prorrogação da locação por prazo } \\
\text { indeterminado uma vez notificado o locador pelo } \\
\text { fiador de sua intenção de desoneração, ficando } \\
\text { obrigado por todos os efeitos da fiança, durante } 120 \\
\text { (cento e vinte) dias após a notificação ao locador. } \\
\text { Parágrafo único. O locador poderá } \\
\text { notificar o locatário para apresentar nova garantia } \\
\text { locatícia no prazo de } 30 \text { (trinta) dias, sob pena de } \\
\text { desfazimento da locação." }\end{array}$ \\
\hline
\end{tabular}

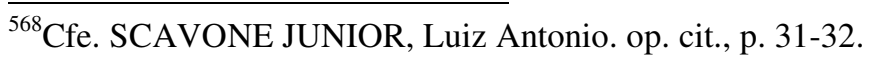


A Lei n. ${ }^{\circ} 12.112$, de 9 de dezembro de 2009, provocou duas alterações no artigo 40, da Lei do Inquilinato:

a) a primeira visou a adaptação do seu inciso II à Lei de Falências (Lei n. ${ }^{\circ}$ 11.101/2005) com a introdução da hipótese de recuperação judicial como hábil a permitir ao locador que postule a substituição do fiador que tiver se valido do favor legal, pois a recuperação judicial do garante diminuiria a segurança do credor porque a fiança é caução pessoal sem qualquer privilégio, de modo que não garantiria o recebimento do seu crédito em caso de incumprimento do contrato de locação pelo afiançado.

b) a segunda e mais importante alteração legislativa foi a introdução do inciso $\mathrm{X}$ e parágrafo único no artigo 40 da Lei n. ${ }^{\circ}$ 8.245/91, com a veiculação do direito potestativo à exoneração da fiança locatícia em favor do garante.

A partir da entrada em vigor da lei de reforma das locações de imóveis urbanos, a Lei do Inquilinato contará com regra específica sobre a exoneração da fiança, em tudo semelhante a do artigo 835, do Código Civil. Assim, uma vez prorrogado o contrato de locação por tempo indeterminado poderá o fiador exonerar-se da garantia fidejussória independentemente da vontade do locador mediante o exercício do seu direito potestativo através de simples notificação que, à míngua de disposição legal, não precisará obedecer forma ou figura de juízo, podendo ser exercitada extrajudicialmente.

Pelo princípio da simetria das formas e por questões de segurança jurídica, não haverá de ser admitida a notificação verbal da exoneração, porque como o contrato de fiança se dá somente por escrito, também por escrito deverá ser formulada a notificação dirigida ao credor.

Sobre o tema doutrina Luiz Antonio Scavone Junior ${ }^{569}$ :

"Em outras palavras, ao término do prazo contratado para a locação, ou o locador cuida de obter a anuência expressa do fiador com a prorrogação legal ou o fiador poderá notificar o locador, ficando responsável por cento e vinte dias após a efetiva notificação, ou até antes, se novo fiador for apresentado pelo locatário e aceito pelo locador previamente ao termo final de cento e vinte dias.

Poder-se-ia redargüir, afirmando que o inciso $\mathrm{X}$ só se aplica ao caso de prorrogação convencional do contrato.

Não é o que pensamos. A uma, porque a lei não distinguiu, e, a duas, porque não haveria a menor necessidade de alteração legislativa para tal mister, posto que a prorrogação convencional sem a anuência expressa do fiador o exonera, por força dos arts. 365 e 366 do Código Civil.

\footnotetext{
${ }^{569}$ In SCAVONE JUNIOR, Luiz Antonio. op. cit., p. 43-44.
} 
Portanto, entendemos que a subsistência das garantias até a devolução das chaves do art. 39 se aplica indistintamente às outras modalidades de garantia.

Todavia, no caso de garantia fidejussória, a teor do novel inciso $\mathrm{X}$ do art. 40, a subsistência da garantia fica condicionada à hipótese de o fiador deixar de notificar o locador, comunicando sua intenção de não permanecer como garantidor das obrigações contratuais do locatário, obrigando-se pelas obrigações do afiançado decorrentes do contrato de locação pelo prazo de cento e vinte dias."

E em razão da redação dos novos inciso X e parágrafo único do artigo 40 da Lei n. ${ }^{\circ}$ 8.245/91, ocorrida a exoneração do fiador poderá o locador exigir nova garantia contratual do locatário, sob pena incorrer em infração legal autorizadora do desfazimento da locação mediante despejo, o que por certo fará com que o locatário-afiançado se apresse em restabelecer a garantia.

Por fim, outra questão que poderá surgir diante dos novos inciso $\mathrm{X}$ e parágrafo único do artigo 40 da Lei n. ${ }^{\circ} 8.245 / 91$, será a de se saber se o fiador poderá promover a notificação exoneratória da garantia "antes do término do contrato, para que a sua responsabilidade cesse juntamente com o prazo originariamente fixado. „570

De acordo com o entendimento esposado por Luiz Antonio Scavone Junior ${ }^{571}$, esta possibilidade não existiria pela razões que expõe:

"Entendemos que essa possibilidade não existe.

A uma, em função de o inciso $X$ mencionar expressamente a possibilidade somente quando da prorrogação legal do contrato. A duas, por ser este um sucedâneo da exoneração antes tratada pela regra geral do art. 835 do Código Civil, que exige fiança prestada sem limitação de tempo, o que só ocorre com a prorrogação legal, tendo a Lei do Inquilinato apenas optado, no caso de fiança concedida em contrato de locação, por estender de sessenta para cento e vinte dias contados da notificação o prazo de responsabilidade do fiador que pede exoneração."

Em remate, à semelhança do que escrevemos no item anterior, questão que ainda que permanecerá em aberto vem a ser a da admissibilidade ou não da renúncia ao direito de exoneração na hipótese de prorrogação legal da locação. Será admissível ao fiador renunciar previamente ao direito de exoneração previsto no $\S 2 .^{\circ}$, do reformado artigo 12 , da Lei do Inquilinato? Em nossa opinião a resposta é negativa, ante os mesmos fundamentos já exposto no item 4.7.2.1 da presente dissertação.

\footnotetext{
${ }^{570}$ SCAVONE JUNIOR, Luiz Antonio. op. cit., 45. (Grifamos)

${ }^{571}$ In Id., loc. cit.
} 


\section{PROPOSTA DE ALTERAÇÃO LEGISLATATIVA DO INSTITUTO DA FIANÇA}

Neste capítulo apresentaremos uma proposta de alteração do regramento legal do contrato de fiança, de acordo com o pensamento que temos construído há certo tempo e que é fruto das nossas reflexões e perplexidades sobre o tema, especialmente pelas dificuldades práticas que têm rondado a garantia, por força dos rumos que a jurisprudência brasileira tem emprestado ao instituto.

Por primeiro, apresentaremos uma proposta de alteração do regramento do contrato de fiança tal como previsto no Código Civil atual. Vejamos.

\section{CAPÍTULO XVIII \\ DA FIANÇA \\ Seção I \\ Disposições Gerais}

\begin{tabular}{|c|c|}
\hline $\begin{array}{l}\text { Art. } 818 \text {. Pelo contrato de fiança, uma } \\
\text { pessoa garante satisfazer ao credor uma obrigação } \\
\text { assumida pelo devedor, caso este não a cumpra. }\end{array}$ & $\begin{array}{l}\text { Art. 818. Pelo contrato de fiança, uma } \\
\text { pessoa promete o adimplemento do devedor, se } \\
\text { responsabilizando pelo débito caso o afiançado não } \\
\text { o cumpra. } \\
\text { Parágrafo primeiro. É permitida a fiança } \\
\text { prestada pelo devedor em seu próprio benefício. } \\
\text { Parágrafo segundo. Ao fiador e ao } \\
\text { devedor não se aplica a hipótese de } \\
\text { impenhorabilidade prevista na Lei 8.009/90. }\end{array}$ \\
\hline
\end{tabular}

O objetivo da alteração legislativa proposta é o de permitir que o próprio devedor que possua bens suficientes à garantia de uma dívida por ele contraída possa ser fiador de si mesmo, o que contribuirá para a diminuição dos litígios envolvendo terceiros; outrossim, a partir da alteração proposta a situação jurídica do fiador e do devedor-afiançado terá sido nivelada, pois a impenhorabilidade do bem de família prevista na Lei n. ${ }^{\circ} 8.009 / 90$, que já não era mais aplicável ao fiador passará a ser também inaplicável ao devedor principal, o que acreditamos que tornará a fiança uma garantia efetiva e razoavelmente segura para o credor e também para o fiador, pois se este vier a sub-rogar-se nos direitos do credor 
originário por ter pago a dívida do afiançado, poderá executar o único bem imóvel deste para se ressarcir.

\begin{tabular}{|l|l|}
\hline Artigo não existente no Código Civil. & $\begin{array}{c}\text { Art. 818-A. Qualquer que seja o regime de } \\
\text { bens, tanto o marido quanto a mulher só poderão } \\
\text { prestar fiança em conjunto, sob pena de nulidade. } \\
\text { Parágrafo primeiro. O caput deste artigo } \\
\text { será aplicável aos companheiros que viverem em } \\
\text { união estável. } \\
\text { Parágrafo segundo. Se o fiador omitir a } \\
\text { sua situação ao credor, o outro cônjuge ou } \\
\text { companheiro será subsidiariamente responsável } \\
\text { pela garantia em caso de insuficiência patrimonial, } \\
\text { cabendo neste caso o exercício do direito de } \\
\text { regresso, sem prejuízo das perdas e danos. } \\
\text { Parágrafo terceiro. Aplica-se este artigo às } \\
\text { pessoas que estiverem separadas de fato. }\end{array}$ \\
\hline
\end{tabular}

Um novo artigo foi acrescentado à dogmática da fiança, a fim de se tentar resolver uma polêmica situação: a fiança prestada por pessoas casadas ou que vivam em união estável.

Nestas hipóteses, optamos por indicar que a fiança de pessoas casadas ou que vivam em união estável somente poderá ser subscrita por ambos os cônjuges ou companheiros, a fim de se evitar a polêmica sobre se a simples outorga prevista no art. 1.647, III, do Código Civil acarretaria a responsabilidade patrimonial do cônjuge-anuente. A fiança passará a ser do casal. O mesmo regime jurídico foi estendido às uniões estáveis porque ambas compõem entidades familiares de igual envergadura.

Optamos também por estabelecer uma modalidade de responsabilidade civil subsidiária por fato de outrem ao termos redigido o parágrafo segundo do dispositivo sugerido, pois a sonegação de corretas informações ao credor constitui-se ato ilícito e põe em risco a higidez da garantia. E o princípio da boa-fé objetiva não se coaduna com situações desse jaez. Dessa forma, no caso específico da fiança um dos cônjuges ou companheiros será responsabilizado pelo ato praticado pelo outro, contra o qual poderá voltar-se posteriormente e exigir perdas e danos.

Também estendemos as disposições do artigo às pessoas que estejam separadas de fatos, na tentativa de evitar mais uma polêmica porque muitas vezes estas situações de fato são de impossível comprovação, o que contribui para mais uma foco de conflito. 
Ainda que o dispositivo se apresente polêmico à primeira vista, optamos por dar início ao debate visando resolver problema prático-jurídico bastante sensível.

\begin{tabular}{|l|l|}
\hline $\begin{array}{l}\text { Art. 819. A fiança dar-se-á por escrito, e } \\
\text { não admite interpretação extensiva. }\end{array}$ & Regra a ser mantida. \\
\hline
\end{tabular}

A regra será mantida com a mesma redação atual, porque é clara e não deixa dúvidas sobre o caráter benéfico da garantia, de maneira que o fiador somente poderá ser responsabilizado pelas obrigações que expressamente fizeram parte da fiança.

\begin{tabular}{|l|l|}
\hline $\begin{array}{l}\text { Art. 820. Pode-se estipular a fiança, ainda } \\
\text { que sem consentimento do devedor ou contra a sua } \\
\text { vontade. }\end{array}$ & Regra a ser mantida. \\
\hline
\end{tabular}

A regra será mantida com a mesma redação atual, porquanto a fiança é contrato de garantia que interessa ao credor e ao fiador, em princípio, sendo despicienda a participação do devedor. Assim, a regra reforça a idéia de que o consentimento do devedor ou a sua vontade fidejussória não são elementos do suporte fático de existência do contrato.

\begin{tabular}{|l|l}
\hline $\begin{array}{l}\text { Art. 822. Não sendo limitada, a fiança } \\
\text { compreenderá todos os acessórios da dívida } \\
\text { principal, inclusive as despesas judiciais, desde a } \\
\text { citação do fiador. }\end{array}$ & $\begin{array}{l}\text { Art. 822. A fiança importará } \\
\text { na } \\
\text { responsabilidade solidária dos fiadores e do }\end{array}$ \\
devedor principal e compreenderá todos os \\
acessórios da dívida principal, inclusive as \\
despesas judiciais, desde a mora do devedor \\
principal.
\end{tabular}

Foi conferida nova redação ao art. 822 do Código Civil, a fim de que fosse estipulada a solidariedade da responsabilidade do fiador e do devedor principal, a qual passaria a decorrer da lei e não mais de estipulação contratual. Com a referida alteração, entendemos que a imposição da solidariedade legal permitirá ao credor optar, sem a necessidade de estipulação contratual, quem será demandado para o cumprimento da obrigação desde a mora do devedor principal, e não mais a partir da sua citação, porquanto o fiador há que ser o responsável pela dívida desde o momento em que esta se tornou exigível. 
Art. 823. A fiança pode ser de valor inferior ao da obrigação principal e contraída em condições menos onerosas, e, quando exceder o valor da dívida, ou for mais onerosa que ela, não valerá senão até ao limite da obrigação afiançada.
Art. 823. A fiança pode ser de valor inferior ao da obrigação principal e contraída em condições menos onerosas, e, quando exceder o valor da dívida, ou for mais onerosa que ela, não será exigível senão até ao limite da obrigação afiançada.

A locução "não valerá" prevista na redação atual foi alterada para "não será exigível", a qual entendemos mais adequada porque não trata o dispositivo de uma hipótese de invalidade, mas sim de ineficácia, de inexigibilidade. A parte que exceder à dívida principal não será inválida, posto não enquadrável nas hipóteses previstas no art. 104 do Código Civil, mas apenas não poderá ser cobrada do fiador.

\begin{tabular}{|l|l|}
\hline $\begin{array}{l}\text { Art. 824. As obrigações nulas não são } \\
\text { suscetíveis de fiança, exceto se a nulidade resultar } \\
\text { apenas de incapacidade pessoal do devedor. }\end{array}$ & $\begin{array}{l}\text { Art. 824. As obrigações inexistentes ou } \\
\text { nulas não são suscetíveis de fiança, exceto se o } \\
\text { defeito resultar apenas de incapacidade pessoal do } \\
\text { devedor. }\end{array}$ \\
$\begin{array}{l}\text { Parágrafo único. A exceção estabelecida } \\
\text { neste artigo não abrange o caso de mútuo feito a } \\
\text { menor. }\end{array}$ & \\
\hline
\end{tabular}

$\mathrm{Na}$ nova redação proposta foi excluído o parágrafo único do dispositivo, que continha a seguinte redação: “A exceção estabelecida neste artigo não abrange o caso de mútuo feito a menor."

Com efeito, raramente se litiga em juízo tendo por fundamento a hipótese de mútuo feito a menor, o que demonstra que a redação do artigo 824 do Código Civil - que adotou com alterações a do art. 1.488 do Código Civil de 1916 - na atualidade carece de qualquer efetividade.

Dessa forma, acrescentamos na nova redação que as obrigações inexistentes e as nulas não serão suscetíveis de fiança, de acordo com o princípio da acessoriedade da fiança, segundo o qual a garantia estaria atrelada à sorte do contrato de fiança, de maneira que se acaso inexistente ou nulo for o contrato sobrejacente à fiança, inexistente ou nula também será a fiança. 
Art. 825. Quando alguém houver de oferecer fiador, o credor não pode ser obrigado a aceitá-lo se não for pessoa idônea, domiciliada no município onde tenha de prestar a fiança, e não possua bens suficientes para cumprir a obrigação.
Art. 825. O contrato preliminar de fiança ou a promessa de dar fiador dar-se-ão por escrito.

Parágrafo primeiro. Quando alguém houver prometido dar fiador, o credor ficará sujeito a aceitá-lo se for pessoa financeiramente idônea, domiciliada no município onde tenha de prestar a fiança, e possua bens suficientes para cumprir a sua responsabilidade.

O caput do artigo 825 foi transformado no parágrafo único do referido dispositivo em sua nova redação. Destarte, na nova redação foram admitidas expressamente as figuras do contrato preliminar de fiança e da promessa de dar fiador, a primeira regida pelos artigos 462 a 466 do Código Civil, e, a segunda, pelos artigos 439 e 440 da mesma lei.

O caput do artigo 825 foi transformado em parágrafo único do novo dispositivo e sofreu alteração em sua redação, de modo a ficar claro que na hipótese da promessa de dar fiador o devedor titularizará um direito potestativo a ser exercido contra o credor, de maneira que este não poderá recusar o garante se ficar demonstrado em eventual demanda judicial ex arts. 826 a 838 do Código de Processo Civil, que o fiador é financeiramente idônea, domiciliada no município onde tenha de prestar a fiança e possua bens suficientes para cumprir a sua responsabilidade.

A nova redação sugerida teve por finalidade deixar claro que o sistema admite as figuras do contrato preliminar de fiança e da promessa de dar fiador, tão comuns que são nas atividades empresárias, principalmente nas de pequeno porte, nas quais as sucessivas cessões do quotas sociais ocorrem com a obrigação expressa de que novos fiadores sejam apresentados, hipótese esta que raramente ocorre de acordo com o regramento legal e é causa de nulidade ou ineficácia do pacto.

\begin{tabular}{|c|c|}
\hline $\begin{array}{l}\text { Art. 826. Se o fiador se tornar insolvente } \\
\text { ou incapaz, poderá o credor exigir que seja } \\
\text { substituído. }\end{array}$ & $\begin{array}{l}\text { Art. 826. Se o fiador se tornar insolvente, } \\
\text { incapaz ou tiver reduzido o seu patrimônio de } \\
\text { modo a comprometer a garantia, poderá o credor } \\
\text { exigir que seja substituído, no prazo de } 60 \\
\text { (sessenta) dias a contar da notificação do devedor, } \\
\text { sob pena de poder ser exercida a resolução do } \\
\text { contrato garantido, nos termos do artigo } 475 \text { deste } \\
\text { Código. }\end{array}$ \\
\hline
\end{tabular}


A nova redação sugerida ao artigo 826 do Código Civil teve por finalidade esclarecer que o credor titulariza um direito potestativo contra o afiançado, a fim de que este, nos casos de insolvência, incapacidade ou redução do patrimônio do fiador de modo a comprometer a garantia, promova a substituição do garante, apresentando novo fiador, nos termos do artigo 825 do Código Civil, o que deverá ocorrer no prazo de 60 (sessenta) dias a contar da notificação do afiançado. Decorrido o prazo fixado na lei, poderá o credor conceder mais tempo ao devedor ou desde logo exercer o direito potestativo de resolução do contrato garantido, tendo a nova redação considerado a ausência de garantia fidejussória uma das causas possíveis do pleito de extinção do contrato garantido.

Seção II

Dos Efeitos da Fiança

Art. 827. O fiador demandado pelo pagamento da dívida tem direito a exigir, até a contestação da lide, que sejam primeiro executados os bens do devedor.

Parágrafo único. O fiador que alegar o benefício de ordem, a que se refere este artigo, deve nomear bens do devedor, sitos no mesmo município, livres e desembargados, quantos bastem para solver o débito.

\begin{tabular}{|l|l|}
\hline Art. 828. Não aproveita este benefício ao fiador: & Artigo a ser revogado. \\
I - se ele o renunciou expressamente; & \\
II - se se obrigou como principal pagador, ou & \\
devedor solidário; & \\
III - se o devedor for insolvente, ou falido. & \\
\hline
\end{tabular}

$\begin{aligned} & \text { Art. 829. A fiança conjuntamente prestada um } \\ & \text { só débito por mais de uma pessoa importa }\end{aligned}$
compromisso de solidariedade entre elas, se
declaradamente não se reservarem o benefício de
divisão.
Parágrafo único. Estipulado este benefício, cada
fiador responde unicamente pela parte que, em
proporção, lhe couber no pagamento.

Art. 830. Cada fiador pode fixar no contrato a parte da dívida que toma sob sua responsabilidade, caso em que não será por mais obrigado.

\section{Artigo a ser revogado.}


Os artigos 827 a 829 do Código Civil regulam as hipóteses relativas ao exercício do benefício de excussão (arts. 827 e 828) do benefício da divisão (arts. 829 a 830). A nossa sugestão é no sentido de serem revogados os dispositivos relativos aos benefícios, pois apesar da sua tradição no direito brasileiro as práticas contratuais consagraram as exclusões expressas de ambos em todo e qualquer instrumento contratual elaborado, razão por que a sua previsão legal somente é justificada pela tradição romana.

$\mathrm{Na}$ verdade, o novo regime legal da fiança por nós sugerido consagra a solidariedade fidejussória por força de lei, de maneira que o art. 829 se mostra inoperante. Já o benefício da divisão, por se turno, poderá ser convencionado pelos próprios fiadores em outro instrumento contratual que não o da fiança, pois terá apenas eficácia interna à garantia. Como a prestação de fiança será sempre solidária, os fiadores serão responsabilizados pela integralidade da dívidas, quer isolada quer conjuntamente.

Com relação ao benefício da excusão, o próprio regime da solidariedade pré-exclui a sua eficácia, razão pela qual optamos pela sua expressa revogação.

\begin{tabular}{|c|c|}
\hline $\begin{array}{l}\text { Art. 831. O fiador que pagar integralmente a } \\
\text { dívida fica sub-rogado nos direitos do credor; mas só } \\
\text { poderá demandar a cada um dos outros fiadores pela } \\
\text { respectiva quota. } \\
\text { Parágrafo único. A parte do fiador insolvente } \\
\text { distribuir-se-á pelos outros. }\end{array}$ & Artigo a ser mantido. \\
\hline
\end{tabular}

Este artigo será mantido em nossa proposta porque perante o credor os fiadores sempre responderão, isolada ou conjuntamente, pela totalidade da dívida, ao passo que entre os garantes a responsabilidade de cada um será proporcional ou por cabeça, salvo instrumento no qual tiverem estabelecido divisão distinta.

Em nossa opinião, permitir que os fiador estipulem perante o credor $o$ fracionamento da garantia é causa de enfraquecimento da fiança, razão pela qual a responsabilidade dos garantes deverá ser integral. 


\begin{tabular}{|c|c|}
\hline $\begin{array}{l}\text { Art. 832. O devedor responde também } \\
\text { perante o fiador por todas as perdas e danos que } \\
\text { este pagar, e pelos que sofrer em razão da fiança. }\end{array}$ & Artigo a ser mantido. \\
\hline $\begin{array}{l}\text { Art. 833. O fiador que paga a dívida ou } \\
\text { sofre perdas e danos tem direito aos juros do } \\
\text { desembolso pela taxa estipulada na obrigação } \\
\text { principal ou aos juros legais da mora. }\end{array}$ & $\begin{array}{l}\text { Artigo a ser transformado em parágrafo } \\
\text { Parágrafo único. O fiador que paga a } \\
\text { dívida ou sofre perdas e danos em razão da garantia } \\
\text { tem direito aos juros do desembolso pela taxa } \\
\text { estipulada na obrigação principal ou aos juros } \\
\text { legais da mora, caso aquela não tenha sido } \\
\text { convencionada. }\end{array}$ \\
\hline
\end{tabular}

Este artigoss serão mantidos em nossa proposta porque sendo a fiança um negócio benéfico e firmado com caráter intuitu personae, o devedor-afiançado deverá ser responsabilizado civilmente, a fim de reparar os danos que a sua conduta porventura causou ao garante, notadamente em razão de demora em desocupar imóvel locado, mesmo encontrando-se em mora, dentre outras situações possíveis.

O artigo 833 foi transformado em parágrafo único do artigo 832, e sofreu uma mudança em sua redação, porque ambos mantém íntima conexão, o que não justifica a existência de dois dispositivos distintos. Ademais, o mesmo dispositivo passou a contemplar as hipóteses de pagamento realizado pelo fiador e das perdas e danos por ele sofridas em razão da fiança.

Art. 834. Quando o credor, sem justa causa, demorar a execução iniciada contra o devedor, poderá o fiador promover-lhe o andamento.
Art. 834. Quando o credor deixar de iniciar ou retardar o ajuizamento de qualquer medida judicial contra o devedor, o fiador poderá promover-lhe o andamento, atuando como substituto processual do credor.

$\mathrm{O}$ artigo em comento teve a sua redação alterada, a fim de adequá-lo ao princípio da boa-fé objetiva, especialmente porque o Enunciado n ${ }^{\circ} 169$ na III Jornada de Direito Civil promovida pelo CEJ enuncia:

"O princípio da boa-fé objetiva deve levar o credor a evitar o agravamento do próprio prejuízo

Assim sendo, a nova redação sugerida respousa apenas no aspecto objetivo da omissão ou retardamento na promoção de medida que deveria ter sido realizada pelo 
credor; caberá aos juízes a fixação casuística daquilo que seria ou não abuso do credor, a fim de evitar que este agrave o seu próprio prejuízo em detrimento do fiador, que será responsabilizado pelo incumprimento do contrato, porém sem que o credor desvie a função sócio-econômica do contrato em seu favor, tornando o garante co-devedor em lugar de responsável.

\begin{tabular}{|c|c|}
\hline $\begin{array}{l}\text { Art. 835. O fiador poderá exonerar-se da fiança } \\
\text { que tiver assinado sem limitação de tempo, sempre que } \\
\text { lhe convier, ficando obrigado por todos os efeitos da } \\
\text { fiança, durante sessenta dias após a notificação do } \\
\text { credor. }\end{array}$ & $\begin{array}{l}\text { Art. 835. O fiador poderá exonerar- } \\
\text { se da fiança que tiver assinado sem limitação } \\
\text { de tempo, sempre que lhe convier, ficando } \\
\text { obrigado por todos os efeitos da fiança, } \\
\text { durante cento e vinte dias após a notificação } \\
\text { do credor. } \\
\text { Parágrafo primeiro. É vedada a } \\
\text { renúncia ao direito de exoneração previsto no } \\
\text { caput. } \\
\text { parágrafo segundo. É ineficaz } \\
\text { perante o credor o exercício do direito de } \\
\text { exoneração se no momento da recepção da } \\
\text { notificação pelo credor o devedor já estiver } \\
\text { em mora. } \\
\text { Parágrafo terceiro. Aplica-se o } \\
\text { presente dispositivo aos contratos regidos na } \\
\text { Lei n. } 8.245 / 91 \text {. }\end{array}$ \\
\hline
\end{tabular}

O artigo 835 passará a ter uma nova redação com o aumento do prazo de vinculação do fiador de sessenta para cento e vinte dias, a fim de harmonizá-lo com a recente reforma da lei do inquilinato, além de a nossa proposta ter previsto a inclusão de três parágrafos ao seu caput.

O parágrafo primeiro tem por finalidade colocar um ponto final à discussão sobre se o direito de exoneração é ou não passível de renúncia, tendo sido expressamente vedada esta, uma vez que representa a única via pela qual o fiador poderá pôr fím à fiança se o contrato garantido estiver a viger por tempo indeterminado.

O parágrafo segundo tem por finalidade evitar o esvaziamento da fiança, porque na prática temos visto que tão-logo vem a ocorrer a mora do devedor-afiançado o fiador corre para se exonerar com fundamento neste artigo 835, pois logo no momento em que o credor se encontra vulnerável o garante pretende despir-se da garantia. Portanto, o objetivo do parágrafo vem a ser a sua harmonização à regra geral do artigo 475, do Código Civil, segundo a qual o mecanismo resolutório é deferido apenas ao lesado pelo inadimplemento 
de uma obrigação e não ao devedor que estiver em mora ou ao responsável pelo adimplemento daquele que é responsável pelas ações e omissões do afiançado.

Já o parágrafo terceiro visa evitar discussões sobre se o novo mecanismo seria ou não aplicável às relações jurídicas regidas pela Lei n. ${ }^{\circ}$ 8.245/91, sendo certo que optamos por sua aplicação aos contratos de locação de imóveis urbanos, os quais representarão os campo da sua maior aplicação.

\begin{tabular}{|l|l|}
\hline Art. 836. A obrigação do fiador passa aos & Artigo a ser mantido. \\
herdeiros; mas a responsabilidade da fiança se & \\
limita ao tempo decorrido até a morte do fiador, e & \\
não pode ultrapassar as forças da herança. & \\
\hline
\end{tabular}

O presente dispositivo será mantido na proposta que formulamos, porquanto reforça o caráter intuitu personae da garantia: a morte do garante extingue a fiança, mas os herdeiros ficam responsáveis pelas obrigações porventura existentes até a morte do fiador.

Seção III

Da Extinção da Fiança

Art. 837. O fiador pode opor ao credor as exceções que lhe forem pessoais, e as extintivas da obrigação que competem ao devedor principal, se não provierem simplesmente de incapacidade pessoal, salvo o caso do mútuo feito a pessoa menor.
Art. 837. O fiador pode opor ao credor as exceções que lhe forem pessoais, e as extintivas da obrigação que competem ao devedor principal, se não provierem simplesmente de incapacidade pessoal.

O presente dispositivo foi mantido na proposta que formulamos com a exclusão da cláusula legal "salvo o caso do mútuo feito a pessoa menor", que na atualidade só se mantém no Código Civil por reverência à tradição. Não obstante, dada a íntima conexão entre o contrato garantido e a fiança, o fiador continuará a titularizar legitimidade para opor as exceções pessoais ou as relativas ao devedor principal, as quais poderão até mesmo provocar a dilação ou extinção da fiança. 
Art. 838. O fiador, ainda que solidário, ficará desobrigado:

I - se, sem consentimento seu, o credor conceder moratória ao devedor;

II - se, por fato do credor, for impossível a sub-rogação nos seus direitos e preferências;

III - se o credor, em pagamento da dívida, aceitar amigavelmente do devedor objeto diverso do que este era obrigado a lhe dar, ainda que depois venha a perdê-lo por evicção.
Art. 838. O fiador ficará desobrigado:

I - se, sem consentimento seu, o credor conceder moratória ao devedor, verbal ou por escrito;

II - se, por fato do credor, for impossível a sub-rogação nos seus direitos e preferências;

III - se o credor, em pagamento da dívida, aceitar amigavelmente do devedor objeto diverso do que este era obrigado a lhe dar, ainda que depois venha a perdê-lo por evicção.

IV - se a fiança tiver sido prestada à pessoa jurídica e esta tiver sido extinta ou tiver sofrido alteração em seu contrato social com a exclusão do sócio ou dos sócios que constavam à época da prestação da fiança.

$\mathrm{V}$ - se a mora ou inadimplemento do devedor não forem comunicadas ao fiador, desde o momento que ocorrer a falta do devedor.

Parágrafo único. Na hipóteses dos incisos IV e V, deste artigo, a notificação deverá ser realizada, respectivamente, pelo fiador e pelo credor, nos termos do artigo 835 deste Código.

O presente dispositivo foi mantido na proposta que formulamos, porém com exclusão e acréscimos. Tendo em vista que o regime legal da fiança por nós formulado ostentará a solidariedade ex vi legis, propusemos a exclusão da cláusula lega "ainda que solidário”, que não fará mais sentido.

A mudança operada no inciso I teve por finalidade esclarecer que a moratória tanto poderá ser concedida por escrito ou verbalmente, de modo a transformar esta hipótese em uma questão de fato para permitir ao fiador a comprovação em juízo da sua ocorrência.

Nesse sentir, foi acrescentado o inciso IV que passou a contemplar expressamente uma hipótese de desobrigação da fiança, consistente na extinção ou alteração do quadro social da pessoa jurídica afiançada, especialmente porque nestas hipóteses a garantia é manifestada tendo em vista a pessoa dos sócios que em determinada época figuravam no seu quadro social, o que reforça o caráter intuitu personae da fiança.

No entanto, a fim de evitar polêmicas optamos por introduzir um parágrafo único ao dispositivo, a fim de que os fiadores ostentassem o ônus de comunicar ao credor a 
alteração do quadro social da pessoa jurídica e a sua intenção de desobrigarem-se (rectius, exonerarem-se passivamente), sob pena de manutenção da garantia.

Outrossim, a fim de evitar que o credor fosse surpreendido com a extinção da garantia, seguimos o regime geral de que a manifestação da notificação exoneratória $e x$ art. 835 do Código Civil seguirá o seu procedimento, de modo que o fiador permanecerá atrelado à garantia pelo prazo de cento e vinte dias a contar do recebimento da comunicação pelo credor, e mesmo assim submetendo-se às vicissitudes do respectivo parágrafo segundo que foi por nós proposto com a seguinte redação:

"Parágrafo segundo. É ineficaz perante o credor o exercício o exercício do direito de exoneração se no momento da recepção da notificação o devedor já estiver em mora."

Nesta hipótese, procuramos conciliar os interesses do credor e do fiador, a fim de aquele não fosse surpreendido com a abrupta extinção da garantia, porém prestigiando a fiança como negócio jurídico desinteressado, mas nem por isso carente de seriedade. Com efeito, o fiador que presta garantia à pessoa jurídica deverá estar efetivamente ciente e consciente do risco assumido, pois só assim o instituto voltará a ser revalorizado.

Outrossim, foi incluído o inciso V com fundamento na boa-fé objetiva, a fim de obrigar que o credor dê conhecimento ao fiador da postura adotada pelo afiançado no decorrer da relação contratual e que lhe possa ser prejudicial; destarte, se o fiador tomar conhecimento de que o inquilino passou a não pagar os aluguéis e o contrato garantido estiver a viger por tempo indeterminado, poderá optar por pagar o débito e postular a exoneração da garantia. Acreditamos que a hipótese em comento irá dinamizar as relações contratuais porquanto a postura leal do credor, devedor e fiador serão necessárias para que a fiança cumpra a sua natural missão e função para a qual foi criada, razão pela qual cada um dos interessados na garantia não mais poderá omitir-se sob o fundamento de que estaria a agir em exercício regular de direito.

\begin{tabular}{|r|l|}
\hline Art. 839. Se for invocado o benefício da & Artigo a ser revogado. \\
excussão e o devedor, retardando-se a execução, cair em \\
insolvência, ficará exonerado o fiador que o invocou, se \\
provar que os bens por ele indicados eram, ao tempo da \\
penhora, suficientes para a solução da dívida afiançada.
\end{tabular}


O presente artigo não será contemplado na nossa proposta, tendo em vista que optamos por excluir os benefícios da excussão e da divisão do regime legal da fiança, tal como eram expostos nos artigos 827 a 829 do Código Civil.

Por fim, tendo em vista a função social da fiança e a sua grande utilização na sociedade brasileira, mormente em contratos de locação, por amor ao debate trazemos mais uma proposta que alterará o perfil do instituto à luz do princípio da relatividade dos efeitos dos contratos, valorizando a denominada tutela externa do crédito.

Por primeiro, entendemos não ser razoável que a fiança contemple apenas eficácia inter partes na sua feição clássica, porque muitas vezes o fiador despe-se do seu patrimônio e esvazia a garantia, contando com a complacência ou não de terceiros, e prejudica sobremaneira o credor que no momento da execução da fiança não encontra patrimônio suficiente do garante.

Assim sendo, propomos que seja formado um Cadastro Nacional de Fiadores a ser mantido no e administrado pelo Colégio Notarial do Brasil, por exemplo, à semelhança do que já ocorre com os testamentos. Desta forma, todo e qualquer contrato de fiança e aquele que tiver contemplado esta modalidade de garantia deverão ser levados a registro para conhecimento da sociedade, sob pena de nulidade, sendo que aquele que se apresentar como fiador deverá apresentar a respectiva certidão positiva/negativa da sua condição de garante, a fim de que o credor possa mensurar o risco de uma nova fiança à luz da situação patrimonial do fiador.

E adotamos a nulidade como sanção, pois esta modalidade de invalidade fará com que o primeiro credor em favor de quem foi prestada a primeira fiança tenha interesse próprio em registrar o contrato e o pacto adjecto de fiança, pois do contrário a nulidade lhe imporá o prejuízo de não poder executar a garantia em caso de incumprimento do contrato garantido, em face da sua ineficácia.

Desta forma, acreditamos ser possível acabar de vez com o ilegal mercado de fiadores profissionais, cujos anúncios pululam nos jornais e em placas de grandes centros urbanos, porquanto toda e qualquer pessoa teria condições de saber se aquele com quem estivesse a contratar seria ou não fiadora de outros negócios, a fim de que pudesse ser mensurado o risco a ser assumido pelo credor, o que estará conforme aos princípios da boa-fé objetiva e da função social do contrato de fiança. 
Além de acreditarmos que a nossa proposta contribuirá para a extinção do mercado de fiadores profissionais, ela revalorizará mais ainda o contrato de fiança porque quem assume o risco fidejussório deverá fazê-lo com seriedade, de modo que a garantia possa vir a ser efetivamente executada em caso de incumprimento da obrigação garantida.

Outrossim, este cadastro poderia ser disponibilizado a qualquer interessado na rede mundial de computadores (internet), a fim de que indexação do sistema fosse realizada a partir do nome do fiador e de outros dados pessoais, permitindo a qualquer pessoa o acesso ao cadastro sem burocracia e perda de tempo, valorizando sobremaneira a função social do contrato de fiança. 


\section{REFERÊNCIAS BIBLIOGRÁFICAS}

AGUIAR JÚNIOR, Ruy Rosado de. A extinção dos contratos por incumprimento do devedor. 1. ed. Rio de Janeiro: Aide, 1991.

ALTERINI, Atilio Aníbal. Contratos civilis - comerciales - de consumo: teoría general. Buenos Aires: Abeledo-Perrot, 1999.

La inseguridad juridica. Buenos Aires: Abeledo-Perrot, 1993.

ALTERINI, Atilio A.; LÓPEZ CABANA, Roberto M. La autonomía de la voluntad en el contrato moderno. Buenos Aires: Abeledo-Perrot, 1989.

ALVES, João Luiz. Código Civil da República dos Estados Unidos do Brasil anotado. 3. ed. Rio de Janeiro: Borsoi, 1958. v. 5.

ALVES, Jones Figueirêdo. Novo Código Civil comentado. Coord. Ricardo Fiuza. 3. ed. atual. São Paulo: Saraiva, 2004.

ALVIM, Agostinho. Da inexecução das obrigações e suas conseqüências. 2. ed. São Paulo: Saraiva, 1955.

ALVIM, Pedro. O contrato de seguro. 3. ed. Rio de Janeiro: Forense, 1999.

AMARAL, Francisco. Direito civil: introdução. 6. ed. rev. atual. e aum. Rio de Janeiro: Renovar, 2006.

ANDRADE, Fábio Siebeneicheler de. Da codificação: crônica de um conceito. Porto Alegre: Livr. do Advogado, 1997.

ANDRIGHI, Nancy et al. Comentários ao novo Código Civil. Coord. Sálvio de Figueiredo Teixeira. Rio de Janeiro: Forense, 2008. v. 9.

ASSIS, Araken de. Resolução do contrato por inadimplemento. 3. ed. rev. e atual. São Paulo: Ed. Revista dos Tribunais, 1999.

ATIYAH, P. S. Law \& modern society. 2. ed. New York: Oxford University Press, 1995.

AZEVEDO, Álvaro Villaça. Bem de família: penhora em fiança locatícia e direito à moradia. In: NERY, Rosa Maria de Andrade. DONNINI, Rogério (Coords.). Responsabilidade civil: estudos em homenagem ao professor Rui Geraldo Camargo Viana. São Paulo: Ed. Revista dos Tribunais, 2009.

. Contratos: disposições gerais, princípios e extinção. In: AZEVEDO, Antonio Junqueira; TÔRRES, Heleno Taveira; CARBONE, Paolo (Coords.). Princípios do novo Código Civil brasileiro e outras temas em homenagem a Tullio Ascarelli. São Paulo: Quartier Latin, 2008. 
AZEVEDO, Álvaro Villaça. Teoria geral dos contratos típicos e atípicos. 2. ed. São Paulo: Atlas, 2004.

. Teoria geral das obrigações. 10. ed. São Paulo: Atlas, 2004.

AZEVEDO, Antônio Junqueira de. Estudos e pareceres de direito privado. São Paulo: Saraiva, 2004.

Negócio jurídico e declaração negocial: noções gerais e formação da declaração negocial. São Paulo: Saraiva, 1986.

2002 .

Negócio jurídico: existência, validade e eficácia. 4. ed. atual. São Paulo: Saraiva, 2002.

Responsabilidade pre-contratual no Código de Defesa do Consumidor: estudo comparado com a responsabilidade pre-contratual no direito comum. Revista de Direito do Consumidor, São Paulo, n. 18, p. 23-31, 1996.

AZEVEDO, Noé de. Abuso do direito no exercício da demanda. São Paulo: Ed. Revista dos Tribunais, 1929.

BARROS, Francisco Carlos Rocha de. Comentários à lei do inquilinato. São Paulo: Saraiva, 1995.

BARROSO, Luís Roberto. Curso de direito constitucional contemporâneo. São Paulo: Saraiva, 2009. . Interpretação e aplicação da constituição. São Paulo: Saraiva, 1996.

BAUMAN, Zygmunt. Modernidade líquida. Rio de Janeiro: Zahar, 2000.

BDINE JR., Hamid Charaf. Código civil comentado: doutrina e jurisprudência. Coord. Cezar Peluso. 3. ed. rev. e atual. Barueri: Manole, 2009.

BERGEL, Jean-Louis. Teoria geral do direito. São Paulo: Martins Fontes, 2006.

BERGER, Adolf. Encyclopedic dictionary of roman law. Philadelphia: The American Philosophical Society, 1953.

BESSONE, Darcy. Do contrato: teoria geral. São Paulo: Saraiva, 1997.

BETTI, Emilio. Teoria geral do negócio jurídico. Trad. de Fernando Miranda. Coimbra: Coimbra Ed., 1970. t. 3.

BEVILÁQUA, Clovis. Código Civil dos Estados Unidos do Brasil comentado. Rio de Janeiro: Francisco Alves, 1917.

Código Civil dos Estados Unidos do Brasil. Rio de Janeiro: Francisco Alves, 1919. v. 5, t. 2. 
BEVILÁQUA, Clóvis. Direito das obrigações. 8. ed. rev. e atual. por Achilles Bevilaqua. Rio de Janeiro: Francisco Alves, 1954.

BIANCA, Massimo C. Diritto civile: il contratto. 2. ed. Milano: Giuffrè, 2000. v. 3.

BITTAR, Carlos Alberto. Direito dos contratos e dos atos unilaterais. 1. ed. Rio de Janeiro: Forense Universitária, 1990.

BOBBIO, Norberto. A era dos direitos. 4. tir. São Paulo: Ed. Campus, 2004. Teoria do ordenamento jurídico. Brasília: UnB, 1997.

BONFANTE, Pietro. Instituzioni di diritto romano. 10. ed. Milano: G. Giappichelli, 1949.

BORDA, Alejandro. El contrato de fianza: límites de la responsabilidad del fiador. Buenos Aires: La Ley, 2009.

BORGES, João Eunápio. Títulos de crédito. 2. ed. Rio de Janeiro: Forense, 1975.

BRANCO, Paulo Gustavo Gonet; MENDES, Gilmar Ferreira; COELHO, Inocêncio Mártires. Curso de direito constitucional. 4. ed. rev. e atual. São Paulo: Saraiva, 2009.

BULOS, Uadi Lammêgo. Curso de direito constitucional. 2. ed. São Paulo: Saraiva, 2008.

CÂMARA DOS DEPUTADOS. Projeto de Lei 6.960/2002. Disponível em: <http://www2.camara.gov.br/proposicoes>. Acesso em: 17 ago. 2008.

CANEZIN, Claude. Arte jurídica. Curitiba: Juruá, 2005. v. 2.

CANOtilho, J. J. Gomes. Direito constitucional e teoria da constituição. 2. ed. Almedina: Coimbra, 1998.

CARVALHO, Luís Camargo Pinto de. Da extinção da responsabilidade do fiadores em contrato de locação. Disponível em: <http\l:www.saraivajur.com.br>.Acesso em: 21 jun. 2005.

CARVALHO FILHO, Milton Paulo de. Código Civil comentado: doutrina e jurisprudência. Coord. Cezar Peluso. 3. ed. rev. e atual. Barueri: Manole, 2009.

CASADO, Márcio Mello. O leasing e a variação cambial. Revista dos Tribunais, São Paulo, n. 763,1999.

CAVALCANTI, José Paulo. Da renúncia no direito civil. Rio de Janeiro: Forense, 1958.

CAVALIERI FILHO, Sergio. Programa de responsabilidade civil. 8. ed. rev. e ampl. São Paulo: Atlas, 2008.

CHAMOUN, Ebert. Instituições de direito romano. 3. ed. rev. e aum. Rio de Janeiro: Forense, 1957. 
CHAVES, Antônio. Tratado de direito civil. São Paulo: Ed. Revista dos Tribunais, 1982, v. 2 , t. 2.

CHINELATO, Silmara Juny. Comentários ao código civil. Coord. Antônio Junqueira de Azevedo. São Paulo: Saraiva, 2004. v. 18.

COELHO, Fábio Ulhoa. Curso de direito civil. São Paulo: Saraiva, 2003. v. 1.

Curso de direito comercial. 6. ed. rev. e atual. São Paulo, 2003. v. 2, v. 6.

COELHO, José Fernando Lutz. Locação: questões atuais e polêmicas. Curitiba: Juruá, 2005 .

CORDEIRO, António Menezes. Da boa fé no direito civil. Coimbra: Almedina, 1997.

Direito das obrigações. Lisboa: A.F.D.L., 2001. v. 2.

Tratado de direito civil português. 3. ed. rev. e aum. Coimbra: Almedina, 2007. v.

1, t. 1 .

DALL'AGNOL JUNIOR, Antonio Janyr. Direito do consumidor e serviços bancários e fnanceiros - aplicação do CDC nas atividades bancárias - Revista de Direito do Consumidor, São Paulo, n. 17, p. 12, 1998.

DANTAS, San Tiago. Programa de direito civil II: os contratos. Rio de Janeiro: Rio, 1978.

DE MATTIA, Fábio Maria. Aparência de representação. São Paulo: Ed. CID, 1999.

DEL NERO, João Alberto Schützer. Conversão do negócio jurídico. Rio de Janeiro: Renovar, 2001.

DELGADO, José Augusto. Comentários ao novo Código Civil. Coord. Sálvio de Figueiredo Teixeira. Rio de Janeiro: Forense, 2004. v. 11, t. 2.

- Princípio da instrumentalidade, do contraditório, da ampla defesa e modernização do processo civil. Trabalho apresentado ao Congresso Mundial de Direito Processual em data de 19 a 22 de maio de 1999, na cidade do Recife, Pernambuco. Inédito.

DERNBURG, Arrigo. Diritto delle obbligazioni. 6. ed. Tradução de Francesco Bernardino Cicala. Torino, Fratelli Bocca, 1903.

DIAS, Maria Berenice. Manual de direito das famílias. 5. ed. rev. atual. e ampl. São Paulo: Ed. Revista dso Tribunais, 2009.

DICIONÁRIO Eletrônico Houaiss. Disponível em:

$<$ http://houaiss.uol.com.br/busca.jhtm?verbete=aditamento\&stype=lç>.

DÍEZ-PICAZO, Luis. Fundamentos del derecho civil patrimonial. 5. ed. Madrid: Tecnos, 1996. v. 1. 
DÍEZ-PICAZO, Luis; GULLON, Antonio. Sistema de derecho civil. 6. ed. Madrid: Tecnos, 1992. v. 2.

DINAMARCO, Cândido Rangel. Instituições de direito processual civil. São Paulo: Malheiros Ed., 2001. v. 3. . A reforma da reforma. 2. ed. São Paulo: Malheiros Ed., 2002.

DINIZ, Maria Helena. Código civil anotado. São Paulo: Saraiva, 1995. . Curso de direito civil brasileiro. 17. ed. São Paulo: Saraiva, 2002. v. 3.

- Curso de direito civil brasileiro: teoria das obrigações contratuais e extracontratuais. 17. ed. atual. São Paulo: Saraiva, 2002. v. 3.

. Dicionário jurídico. 3. ed. rev. atual. e aum. São Paulo: Saraiva, 2007.

DOWER, Nelson Godoy Bassil. Curso moderno de direito civil. 4. ed. São Paulo: Nelpa, 2009.

EHRLICH, Eugen. Fundamental principals of the sociology of law. New Jersey: Transactions Publishers, 2002.

FARIA, Cristiano Chaves de; ROSENVALD, Nelson. Direito das famílias. Rio de Janeiro: Lumen Juris, 2008.

FARIA, José Eduardo. Ideologia e função do modelo liberal de direito e Estado. Lua Nova, São Paulo, v. 4, n. 14, p. 82-92, abr./jun. 1988.

FREIRE, Fernando José de Barros. Previsibilidade dos efeitos do direito e segurança jurídica. 2007. Dissertação (Mestrado) - Pontifícia Universidade Católica, PUC. São Paulo, 2007.

FROTA, Pablo Malheiros da Cunha; SILVEIRA, Fábio Viana Fernandes da. Famílias no direito contemporâneo: estudos em homenagem à Paulo Luiz Netto Lôbo. Salvador: Juspodivm, 2010.

GAGLIANO, Pablo Stolze; PAMPLONA FILHO, Rodolfo. Novo curso de direito civil: parte geral. 8. ed. rev., atual. e reform. São Paulo: Saraiva, 2006. v. 1.

GALGANO, Francesco. Diritto privato. 6. ed. Pádova: Cedam, 1990.

GILISSEN, John. Introdução histórica ao direito (Introduction historique au droit). 2. ed. Trad. A. M. Hespanha e L. M. Macaísta Malheiros. Lisboa: Fundação Calouste Gulbenkian, 1995.

GODOY, Claudio Luiz Bueno de. Código civil comentado: doutrina e jurisprudência. Ccoord. Cezar Peluso. 3. ed. rev. e atual. Barueri: Manole, 2009. 
GOMES, Manuel Januário da Costa. Assunção fidejussória de divida: sobre o sentido e o âmbito da vinculação como fiador. Coimbra: Almedina, 2000.

GOMES, Orlando. Contrato de adesão: condições gerais dos contratos. São Paulo: Ed. Revista dos Tribunais, 1972.

. Contratos. 18. ed. Rio de Janeiro: Forense, 1998.

Introdução ao direito civil. 10. ed. Rio de Janeiro: Forense, 1993.

Raizes históricas e sociológicas do Código Civil brasileiro. Salvador: Livraria Progresso, 1958.

. Transformações gerais dos direitos das obrigações. Decadência do voluntarismo jurídico e novas figuras jurídicas. São Paulo: Ed. Revista dos Tribunais, 1980.

GONÇALVES, Carlos Roberto. Direito civil brasileiro: parte geral. São Paulo: Saraiva, 2003. v. 1.

Direito civil brasileiro. São Paulo: Saraiva, 2004. v. 3.

GONÇALVES, Luiz da Cunha. Tratado de direito civil. 2. ed. portuguesa, atual. e aum. e 1. ed. brasileira, anotada por Dimas Rodrigues de Alckmin. 1. ed. São Paulo: Max Limonad, 1955. v. 5, t. 1.

GONZÁLEZ PEREZ, Jesús. El principio general de la buena fé en el derecho administrativo. Madrid: Real Academia de Ciencias Morales y Politicas, 1983.

LADEAUR, Karl-Heinz. The theory of autopoiesis as an approach to a better understanding of postmodern law: from the hierarchy of norms to the heterarchy of changing patterns of legal inter-relationships, Fiesole, European University Institute, EUI Working Paper on Lau n. 99/3.

LARENZ, Karl. Derecho justo: fundamentos de etica jurídica. Tradução de Luis DíezPicazo. Madrid: Civitas, 1993.

Derecho de obligaciones. Madrid: Ed. Revista de Derecho Privado, 1958. t. 1.

LISBOA, Roberto Senise. Manual de direito civil. 3. ed. rev., atual. e ampl. São Paulo: Ed. Revista dos Tribunais, 2004. v. 2.

. Manual de direito civil. 4. ed. reform. São Paulo: Saraiva, 2009. v. 3.

LÔBO, Paulo Luiz Netto. Comentários ao Código Civil. Coord. Antonio Junqueira de Azevedo. São Paulo: Saraiva, 2003. v. 6.

. Condições gerais dos contratos e cláusulas abusivas. São Paulo: Saraiva, 1991.

. O contrato: exigências e concepções atuais. São Paulo: Saraiva, 1986. 
LÔBO, Paulo Luiz Netto. Direito civil: famílias. São Paulo: Saraiva, 2008.

. Direito civil: parte geral. São Paulo: Saraiva, 2009.

. Teoria geral das obrigações. São Paulo: Saraiva, 2005.

LOPES, Miguel Maria de Serpa. Curso de direito civil. 4. ed. Rio de Janeiro: Freitas Bastos, 1993. v. 4.

. Exceções substanciais: exceção de contrato não cumprido. Rio de Janeiro: Freitas Bastos, 1959.

LORENZETTI, Ricardo Luis. Fundamentos de direito privado. Tradução de Vera Maria Jacob Fradera. São Paulo: Ed. Revista dos Tribunais, 1998.

. Tratado de los contratos. Santa Fe: Rubinzal-Culzoni, 2000. t. 3.

LUCENA, José Waldecy. Das sociedades limitadas. 6. ed. atual. Rio de Janeiro: Renovar, 2005.

MALUF, Carlos Alberto Dabus. Comentários à lei de locação de imóveis urbanos. Coord. Juarez de Oliveira. São Paulo: Saraiva, 1992.

A transação no direito civil e no processo civil. 2. ed. rev. e aum. São Paulo: Saraiva, 1999.

MARINO, Francisco Paulo De Crescenzo. Contratos coligados no direito brasileiro. São Paulo: Saraiva, 2009.

MARIONI, Luiz Guilherme. Tutela específica. São Paulo: Ed. Revista dos Tribunais, 2000.

MARKY, Thomas. Curso elementar de direito romano. 8. ed. São Paulo: Saraiva, 1995.

MARMELSTEIN, George. Análise econômica dos direitos fundamentais. Disponível em: $<$ http://direitosfundamentais.net/2007/12/14/>. Acesso em: 22 set. 2007.

Curso de direitos fundamentais. São Paulo: Atlas, 2008.

MARQUES, Claudia Lima. Apresentação. In: LORENZETTI, Ricardo Luis. Fundamentos do direito privado. São Paulo: Ed. Revista dos Tribunais, 1998.

Confiança no comércio eletrônico e a proteção do consumidor. São Paulo: Ed. Revista dos Tribunais, 2004.

Contratos no Código de Defesa do Consumidor. 2. ed. São Paulo: Ed. Revista dos Tribunais, 1995.

Contratos no Código de Defesa do Consumidor. 3. ed. São Paulo: Ed. Revista dos Tribunais, 1998. 
MARQUES, Cláudia Lima. Contratos no Código de Defesa do Consumidor. 5. ed. rev. atual. e ampl. São Paulo: Ed. Revista dos Tribunais, 2005.

. Manual de direito do consumidor. São Paulo: Ed.Revista dos Tribunais, 2008.

MARTINS, Fran. Títulos de crédito. 9. ed. Rio de Janeiro: Forense, 1994. v. 1.

MARTINS-COSTA, Judith. A boa-fé no direito privado. São Paulo: Ed. Revista dos Tribunais, 1999.

Comentários ao novo Código Civil. Coord. Sálvio de Figueiredo Teixeira. Rio de Janeiro: Forense, 2003. v. 5, t. 1.

. O método de concreção e a interpretação dos contratos: primeiras notas de uma leitura suscitada pelo Código Civil. In: DELGADO, Mário Luiz; ALVES, Jones Figueirêdo (Coords.). Questões controvertidas no direito das obrigações e dos contratos. São Paulo: Método, 2005. v. 4.

MAXIMILIANO, Carlos. Hermenêutica e aplicação do direito. 15. ed. Rio de Janeiro: Forense, 1995.

MEIRELES, Rose Melo Venceslau. Autonomia privada e dignidade humana. Rio de Janeiro: Renovar, 2009.

MELlo, Celso Antonio Bandeira de. Curso de direito administrativo. São Paulo: Malheiros, 2008.

MELLO, Marcos Bernardes de. Teoria do fato jurídico: plano da existência. 12. ed. São Paulo: Saraiva, 2003.

. Teoria do fato jurídico: plano da validade. 7. ed. rev. e atual. São Paulo: Saraiva, 2006.

MENDES, Gilmar Ferreira et al. Curso de direito constitucional. São Paulo: Saraiva, 2007.

MIRAGEM, Bruno. Abuso do direito: proteção da confiança e limite ao exercício das prerrogativas jurídicas no direito privado. Rio de Janeiro: Forense, 2009.

Diretrizes interpretativas da função social do contrato. Revista de Direito do Consumidor, São Paulo, v. 56, 2005.

MIRANDA, Custódio da Piedade Ubaldino. Teoria geral do negócio jurídico. São Paulo: Atlas, 1991.

MIRANDA, Francisco Cavalcanti Pontes de. Comentários à Constituição de 1967. São Paulo: Ed. Revista dos Tribunais, 1968. t. 6.

Fontes e evolução do direito civil brasileiro. 2. ed. Rio de Janeiro: Forense, 1981. 
MIRANDA, Francisco Cavalcanti Pontes de. Tratado de direito privado. 3. ed. reimpr. Rio de Janeiro: Borsoi, 1971. v. 1.

Tratado de direito privado. 3. ed. 2. reimpr. São Paulo: Ed. Revista dos Tribunais, 1984. t. 1.

. Tratado de direito privado. 3. ed. Rio de Janeiro: Borsoi, 1972. t. 3.

Tratado de direito privado. 3. ed. Rio de Janeiro: Borsoi, 1972. t. 4.

Tratado de direito privado. 3. ed. 2. reimp. São Paulo: Ed. Revista dos Tribunais, 1983. t. 5 .

. Tratado de direito privado. 4. ed. São Paulo: Ed. Revista dos Tribunais, 1983. t. 6.

Tratado de direito privado. 3. ed. 2. reimp. São Paulo: Ed. Revista dos Tribunais, 1984. t. 22.

. Tratado de direito privado. 3. ed. Rio de Janeiro: Borsoi, 1972. t. 38.

. Tratado de direito privado. 3. ed. Rio de Janeiro: Borsoi, 1972. t. 44.

. Tratado de direito privado. 2. ed. 3. reimpr. São Paulo: Ed. Revista dos Tribunais, 1984. t. 44.

Tratado de direito privado. 3. ed. 2. reimpr. São Paulo: Ed. Revista dos Tribunais, 1984. t. 44.

Tratado de direito privado. São Paulo: Ed. Revista dos Tribunais, 1984. t. 47.

MONTEIRO, Washington de Barros et al. Curso de direito civil. 36. ed. São Paulo: Saraiva, 2009.

; MALUF, Carlos Alberto Dabus; SILVA, Regina Beatriz Tavares da. Direito das obrigações: 1. parte. 34. ed. São Paulo: Saraiva, 2009.

$\frac{}{2009 .} ;$ _ _ Direito das obrigações. 2. parte. 36. ed. São Paulo: Saraiva,

MORAES, Maria Celina Bodin de. A causa dos contratos. Revista Trimestral de Direito Civil, Rio de Janeiro, v. 21, p. 98, jan./mar 2005.

Princípios do direito civil contemporâneo. In: (Coord.). Rio de Janeiro: Renovar, 2006.

MOREIRA ALVES, José Carlos. A parte geral do projeto de Código Civil brasileiro. 2. ed. aum. São Paulo: Saraiva, 2003.

Direito romano. 6. ed. rev. e acresc. Rio de Janeiro: Forense, 1997. v. 2. 
MOREIRA NETO, Diogo de Figueiredo. Legitimidade e discricionariedade. 3. ed. rev. e atual. Rio de Janeiro: Forense, 1998.

MOSSET ITURRASPE, Jorge Mosset. Como contratar en una economia de mercado. Santa Fe: Rubnizal-Culzoni Editores, 1996.

NEGREIROS, Teresa. Teoria do contrato: novos paradigmas. Rio de Janeiro: Renovar, 2003.

NERY JUNIOR, Nelson. Código brasileiro de defesa do consumidor. 6. ed. rev. atual. e ampl. Rio de Janeiro: Forense Universitária, 1999.

; NERY, Rosa Maria de Andrade. Código Civil comentado. 7. ed. rev. atual. e ampl. São Paulo: Ed. Revista dos Tribunais, 2009.

NETO, Soriano. Pareceres. Separata da: Revista Acadêmica da Faculdade de Direito do Recife, Recife, v. 2, 1947.

NEVES, José Roberto de Castro. Direito das obrigações. Rio de Janeiro: GZ Ed., 2009.

NICOLAS, Barry. An introduction to roman law. New York: Oxford University Press, 1996.

NORONHA, Fernando. O direito dos contratos e seus princípios fundamentais: autonomia privada, boa-fé, justiça contratual. São Paulo: Saraiva, 1994.

. Direito das obrigações. São Paulo: Saraiva, 2003. v. 1.

NOVAIS, Alline Arquette Leite. A teoria contratual e o código de defesa do consumidor. São Paulo: Ed. Revista dos Tribunais, 2001.

NUNES, Castro. Do mandado de segurança. 9. ed., atual. por José de Aguiar Dias. Rio de Janeiro: Forense, 1998.

OLIVEIRA, Eduardo Ribeiro de. Comentários ao novo Código Civil. Coord. Sálvio de Figueiredo Teixeira. Rio de Janeiro: Forense, 2008. v. 2.

. União estável: do concubinato ao casamento. 6. ed. atual. e ampl. São Paulo: Método, 2003.

OLIVEIRA, Euclides de. União estável: do concubinato ao casamento. 6. ed. atual. e ampl. São Paulo: Método, 2003.

OLIVEIRA, Lauro Laertes de. Da fiança. São Paulo: Saraiva, 1981.

PASQUALOTTO, Adalberto. Contratos nominados III. Coord. Miguel Reale e Judith Martins-Costa. São Paulo: Ed. Revista dso Tribunais, 2008.

PEIXOTO, Carlos Fulgêncio da Cunha. A sociedade por cotas de responsabilidade limitada. Rio de Janeiro: Forense, 1958. 
PEREIRA, Caio Mário da Silva. Direito civil: alguns aspectos de sua evolução. Rio de Janeiro: Forense, 2001. Instituições de direito civil. 10. ed. Rio de Janeiro: Forense, 1995. v. 3. Instituições de direito civil. 11. ed. Rio de Janeiro: Forense, 2003. v. 3.

PESQUISA mensal de locação. Disponível em: $<$ http://www.secovi.com.br/empty.php?local=/pesquisa/locacao/index.htm>. Acesso em: 30 nov. 2008.

PINHEIRO, Rosalice Fidalgo; ISAGUIRRE, Katya. O direito à moradia e o STF: um estudo de caso acerca da impenhorabilidade do bem de família do fiador. In: TEPEDINO, Gustavo; FACHIN, Luiz Edson (Orgs.). Diálogos sobre direito civil. Rio de Janeiro: Renovar, 2008, v. 2.

RADBRUCH, Gustav. Leis que não são direito e direito acima das leis. Justitia, São Paulo, v. 38. n. 93, 1976.

REALE, Miguel. O projeto do Código Civil: situação atual e seus problemas fundamentais. São Paulo: Saraiva, 1986.

- Visão geral do projeto de Código Civil. Disponível em: <http://www.miguelreale.com.br/artigos>. Acesso em: $03 \mathrm{dez} 2008$.

RENTERÍA, Pablo. Considerações acerca do atual debate sobre o princípio da função social do contrato. In: MORAES, Maria Celina Bodin de (Coord.). Princípios do direito civil contemporâneo. Rio de Janeiro: Renovar, 2006.

REZZÓNICO, Juan Carlos. Principios fundamentales de los contratos. Buenos Aires: Astrea, 1999.

RIZZARDO, Arnaldo. Da ineficácia dos atos jurídicos e da lesão no direito. Rio de Janeiro: Forense, 1983.

ROCHA, Carmen Lúcia Antunes. Ação afirmativa: o conteúdo democrático do princípio da igualdade jurídica. Revista Trimestral de Direito Público, São Paulo, n. 15, p. 85-99, 1996.

RODRIGUES, Silvio. Direito civil: dos contratos e das declarações unilaterais de vontade. 30. ed. rev. São Paulo: Saraiva, 2007. v. 3.

Direito civil: parte geral. 34. ed. atual. 6. tir. São Paulo: Saraiva, 2007.

ROPPO, Enzo. O contrato. Trad. de Ana Coimbra e M. Januário C. Gomes. Coimbra: Almedina, 1988.

RUGGIERO, Biasi. A sina do fiador. Tribuna do direito, São Paulo, jun. 1999.

SÁ, Cunha de. Abuso do direito. Coimbra: Livraria Almedina, 1997. 
SÁ, Djanira Maria Radamés de. O duplo grau de jurisdição como garantia constitucional. In: WAMBIER, Teresa Arruda Alvim; NERY JUNIOR, Nelson (Coords.). Aspectos polêmicos e atuais dos recursos cíveis de acordo com a Lei 9.756/98. 1. ed. 2. tir. São Paulo: Ed. Revista dos Tribunais, 1999.

SANSEVERINO, Milton. Renunciabilidade do direito à exoneração da fiança. Disponível em: <http://bdjur.stj.gov.br/>. Acesso em: 25 maio 2009.

SANTOS, Antonio Jeová. Função social, lesão e onerosidade excessiva nos contratos. São Paulo: Método, 2002.

SANTOS, Carvalho. Código Civil brasileiro interpretado. 4. ed. Rio de Janeiro: Freitas Bastos, 1950. v. 3.

SANTOS, Gildo dos. Fiança. São Paulo: Ed. Revista dos Tribunais, 2006.

SANTOS, J. M. Carvalho. Código Civil brasileiro interpretado. 2. ed. Rio de Janeiro: Freitas Bastos, 1938. v. 19.

SANTOS, Moacir Amaral. Da fiança e de alguns dos benefícios do fiador. Revista dos Tribunais, São Paulo, n. 238.

SCAVONE JUNIOR, Luiz Antonio. Apresentação. In: Reforma da lei do inquilinato. São Paulo: Ed. Revista dos Tribunais, 2009.

Reforma da lei do inquilinato. São Paulo: Ed. Revista dos Tribunais, 2010.

SCHREIBER, Anderson. A proibição de comportamento contraditório: tutela da confiança e venire contra factum proprium. Rio de Janeiro: Renovar, 2005.

SCHULZ, Fritz. Derecho romano clásico. Trad. José Santa Cruz Teigeiro. Barcelona: Bosch, 1960.

SEGALLA, Alessandro Schirrmeister. Da possibilidade de utilização da ação de despejo pelo fiador do contrato de locação. Revista Jurídica, Porto Alegre, v. 48, n. 279, p. 22-41, jan. 2001.

- Legimitação extraordinária e relações de locação. Disponível em: <http://www.tex.pro.br/>. Acesso em: 24 ago. 2009.

SEVERO, Sérgio. Os danos extrapatrimoniais. São Paulo: Saraiva, 1996.

SICA, Heitor Vitor Mendonça. A penhora e o bem de família do fiador da locação. Coord. José Rogério Cruz e Tucci. Autores Clito Fornaciari Júnior et al. São Paulo: Ed. Revista dso Tribunais, 2003.

SILVA, Clóvis Veríssimo Couto e. A obrigação como processo. São Paulo: José Bushatsky, 1976. 
SILVA, De Plácido e. Vocabulário jurídico. 2. ed. Rio de Janeiro: Forense, 1990. 4 v.

SILVA, João Calvão da. Cumprimento e sanção pecuniária compulsória. 2. ed. Coimbra: Almedina, 1995.

SILVA, José Afonso da. Comentário contextual à constituição. 2. ed. São Paulo: Malheiros Ed., 2006.

Curso de direito constitucional positivo. 20. ed. rev. e atual. São Paulo: Malheiros Ed., 2002.

SILVA FILHO, Artur Marques da. Direito à moradia e fiança locatícia. In: NANNI, Giovanni Ettore (Coord.). Temas relevantes de direito civil contemporâneo. São Paulo: Atlas, 2008.

SILVEIRA, Alípio. Hermenêutica no direito brasileiro. São Paulo: Ed. Revista dos Tribunais, 1968.

Hermenêutica juridica: seus princípios fundamentais no direito brasileiro. São Paulo: Leia Livros, [s.d.]. v. 1.

SIMÃO, José Fernando. Crônica de uma morte anunciada: a fiança locatícia. Disponível em: <http://www.flaviotartuce.adv.br/secoes/verartigoc.asp?art=162>. Acesso em: 17 ago. 2009.

SOCIEDADE BIBLICA DO BRASIL Disponível em: $<$ http://www.sbb.org.br/interna.asp?areaID=71>. Acesso em: 19 set. 2009.

SODRÉ, Ruy de Azevedo. Função social da propriedade privada. São Paulo: Ed. Revista dos Tribunais, [s.d.].

STIGLITZ, Rubén S. Autonomía de la voluntad y revisón del contrato. Buenos Aires: Depalma, 1992.

; STIGLITZ, Gabriel A. Contratos: teoría general. Buenos Aires: Depalma, 1990. v. 1.

SWEDBERG, Richard. Max Weber and the idea of economic sociology. New Jersey: Princeton University.

TARTUCE, Flávio. Função social dos contratos: do Código do Consumidor ao Código Civil de 2002. 2. ed. São Paulo: Método, 2007.

TAVARES, André Ramos. Curso de direito constitucional. 5 ed. rev. e atual. São Paulo: Saraiva, 2007.

TEIXEIRA, Sálvio de (Coord). Comentários ao novo Código Civil. Rio de Janeiro: Forense, 2004. v. 11, t. 2. 
TELLES, Inocêncio Galvão. Manual dos contratos em geral. 4. ed. Coimbra: Coimbra Ed., 2002.

TEPEDINO, Gustavo. O Código Civil, os chamados microssistemas e a Constituição: premissas para uma reforma legislativa. In: TEPEDINO, Gustavo (Coord.). Problemas de direito civil-constitucional. Rio de Janeiro: Renovar, 2000.

; BARBOZA, Heloisa Helena; MORAES, Maria Celina Bodin de. Código Civil interpretado. Rio de Janeiro: Renovar, 2006. v. 2.

; SCHREIBER, Anderson. A boa-fé objetiva no Código de Defesa do Consumidor e no novo Código Civil. In: FARIAS, Cristiano Chaves (Org.). Leituras complementares de direito civil: o direito civil-constitucional em concreto. Salvador: Podivm, 2007.

; SCHREIBER, Anderson. Código Civil comentado. Coord. Álvaro Villaça Azevedo. São Paulo: Atlas, 2008. v. 4.

THEODORO JÚNIOR, Humberto. Comentários ao novo Código Civil. Coord. Sálvio de Figueiredo Teixeira. 3. ed. Rio de Janeiro: Forense, 2005.

Comentários ao novo Código Civil. Coord. Sálvio de Figueiredo Teixeira. Rio de Janeiro: Forense, 2008. v. 3, t. 2.

A fiança e a prorrogação do contrato de locação. Revista de Direito Privado, São Paulo, v. 5, n. 18, p. 66-83, abr./jun. 2004.

VARELLA, João de Matos Antunes. Das obrigações em geral. 8. ed. Coimbra: Almedina, v. 1.

VENOSA, Sílvio de Salvo Direito civil. 2. ed. São Paulo: Atlas, 2002. v. 3.

Direito civil: contratos em espécie. 8. ed. São Paulo: Atlas, 2008. v. 3.

. Direito civil: teoria geral das obrigações e teoria geral dos contratos. 8. ed. São Paulo: Atlas, 2008. v. 2.

VIANA, Rui Geraldo Camargo. A novação. São Paulo: Ed. Revista dos Tribunais, 1979.

WALD, Arnoldo. Comentários ao novo Código Civil. Rio de Janeiro: Forense, 2005. v. 14.

WAMBIER, Teresa Arruda Alvim. Controle das decisões judiciais por meio de recursos de estrito direito e de ação rescisória: o que é uma decisão contrária à lei? São Paulo: Ed. Revista dos Tribunais, 2001.

YASSIM, Assad Amadeo. Considerações sobre abuso de direito. Revista dos Tribunais, São Paulo, ano 69, v. 538, ago. 1980.

ZAVASCKI, Teori Albino. Comentários ao código de processo civil. Coord. Ovídio Araújo Baptista da Silva. São Paulo: Ed. Revista dos Tribunais, 2000. v. 8. 